Fall 1961

\title{
1961 Miracle Yearbook
}

\section{Cedarville College}

Follow this and additional works at: https://digitalcommons.cedarville.edu/yearbooks

Part of the Higher Education Commons, Organizational Communication Commons, and the Public Relations and Advertising Commons

\section{Recommended Citation}

Cedarville College, "1961 Miracle Yearbook" (1961). Yearbooks. 43.

https://digitalcommons.cedarville.edu/yearbooks/43

This Book is brought to you for free and open access by DigitalCommons@Cedarville, a service of the Centennial Library. It has been accepted for inclusion in Yearbooks by an authorized administrator of DigitalCommons@Cedarville. For more information, please contact digitalcommons@cedarville.edu. 
378.7714

C. 389

1961

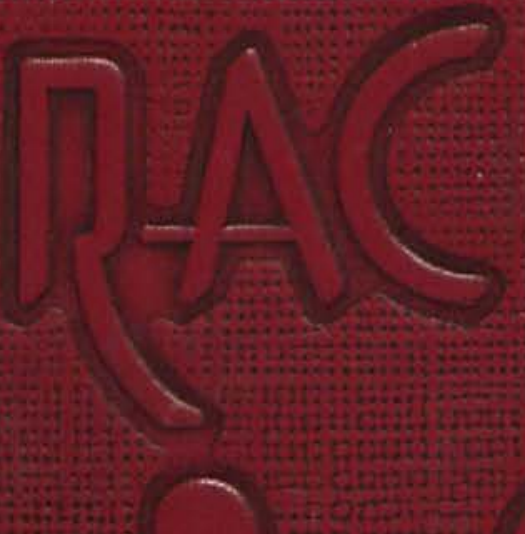

$-$

-
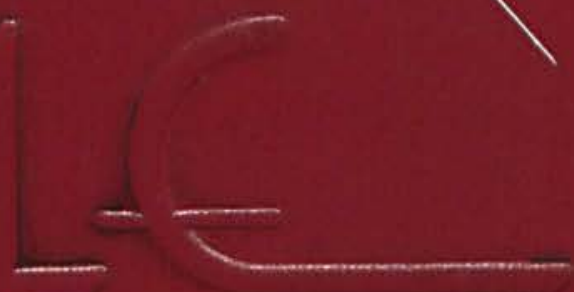
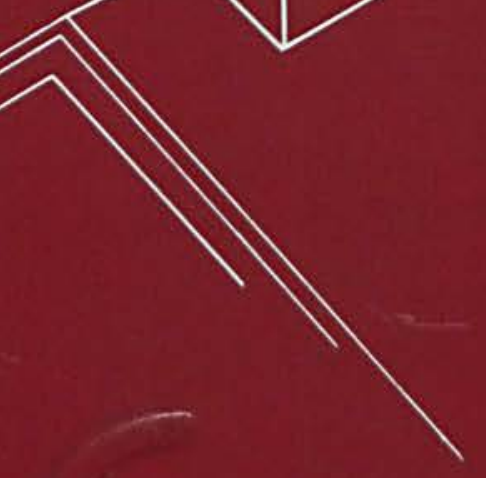


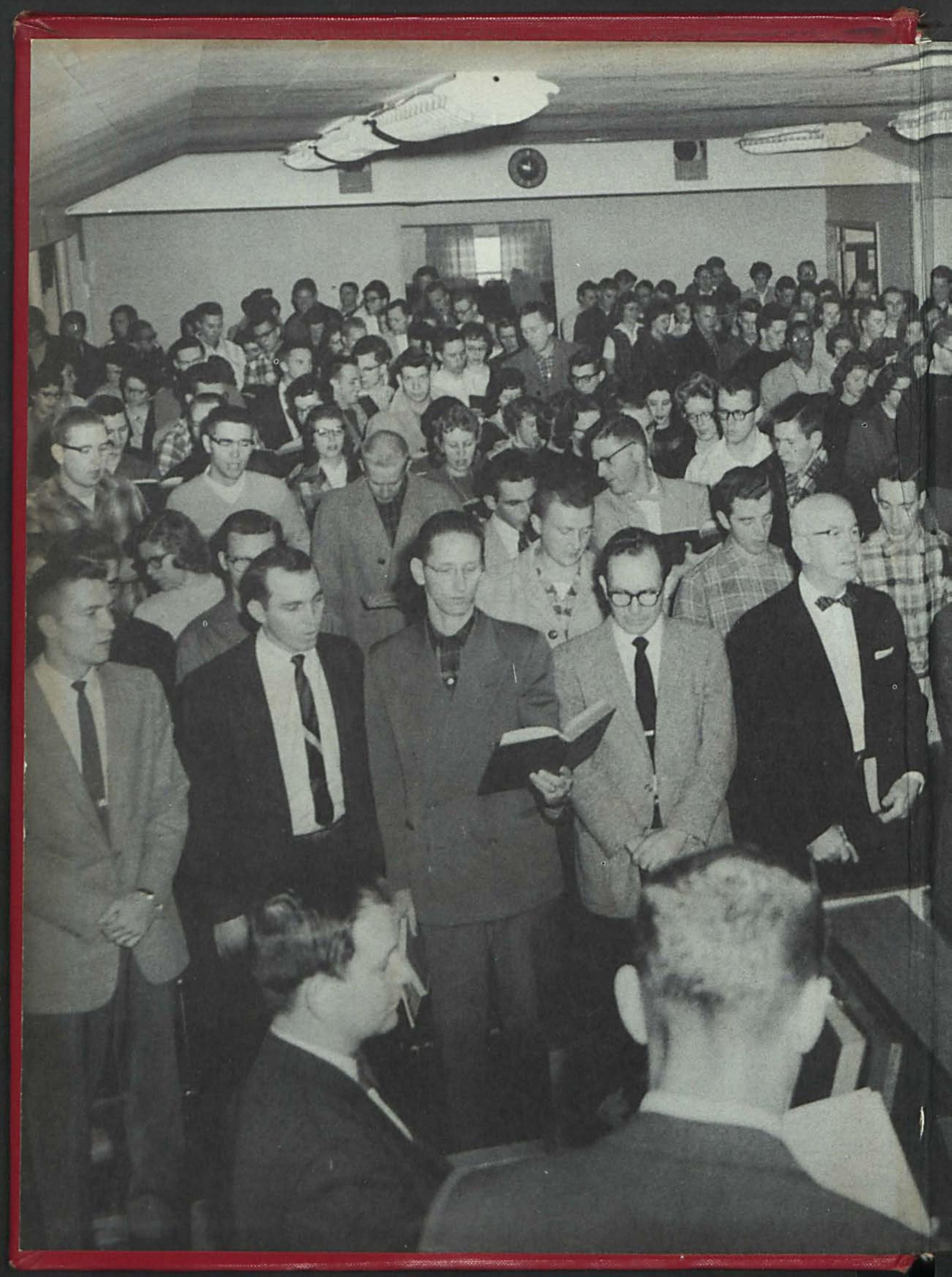





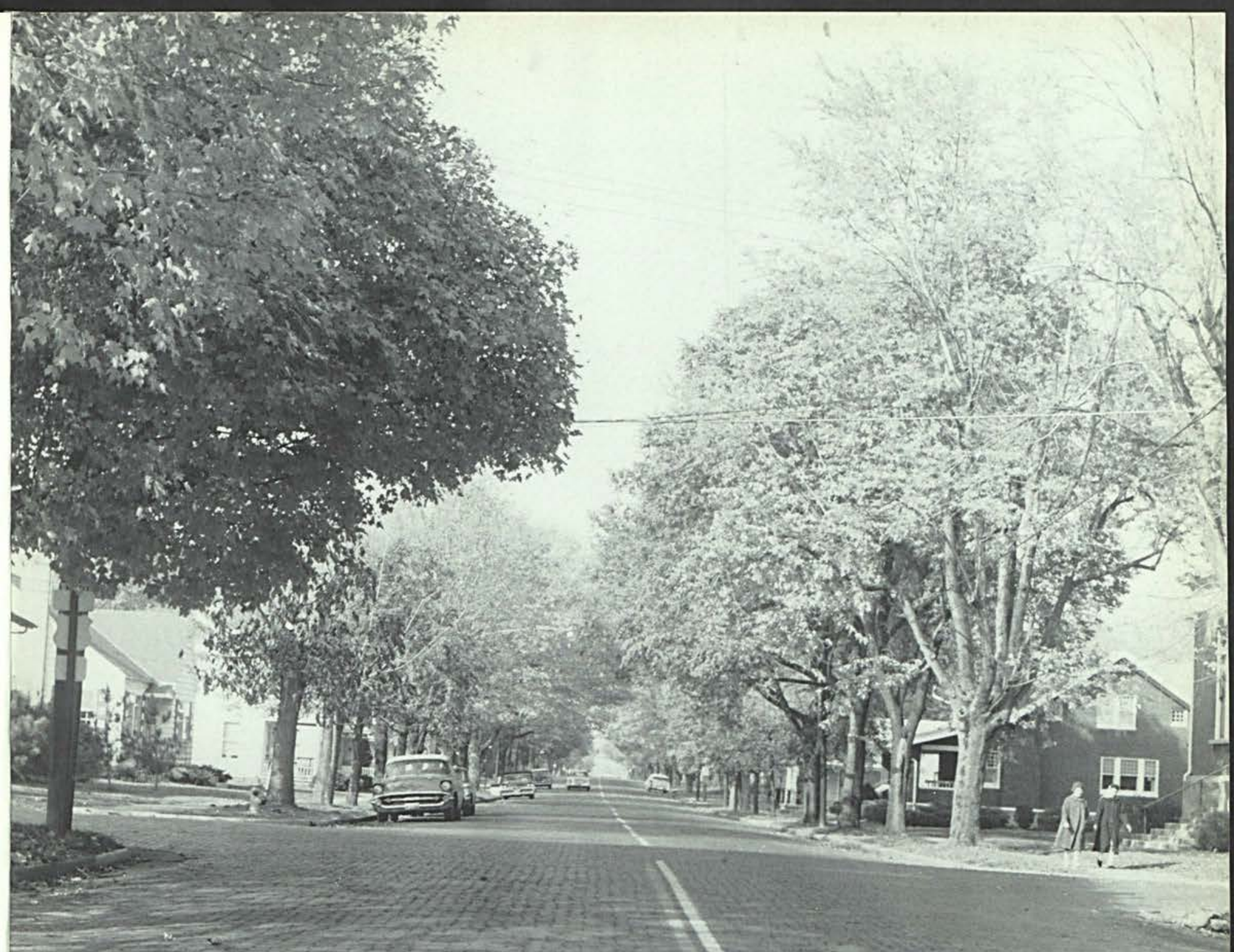

Our first view

"Our paths have led to Cedarville" where the early inviting scenes soon become familiar ones. But perhaps the very first view we had of our college town was this scene looking up Main Street past the library. 


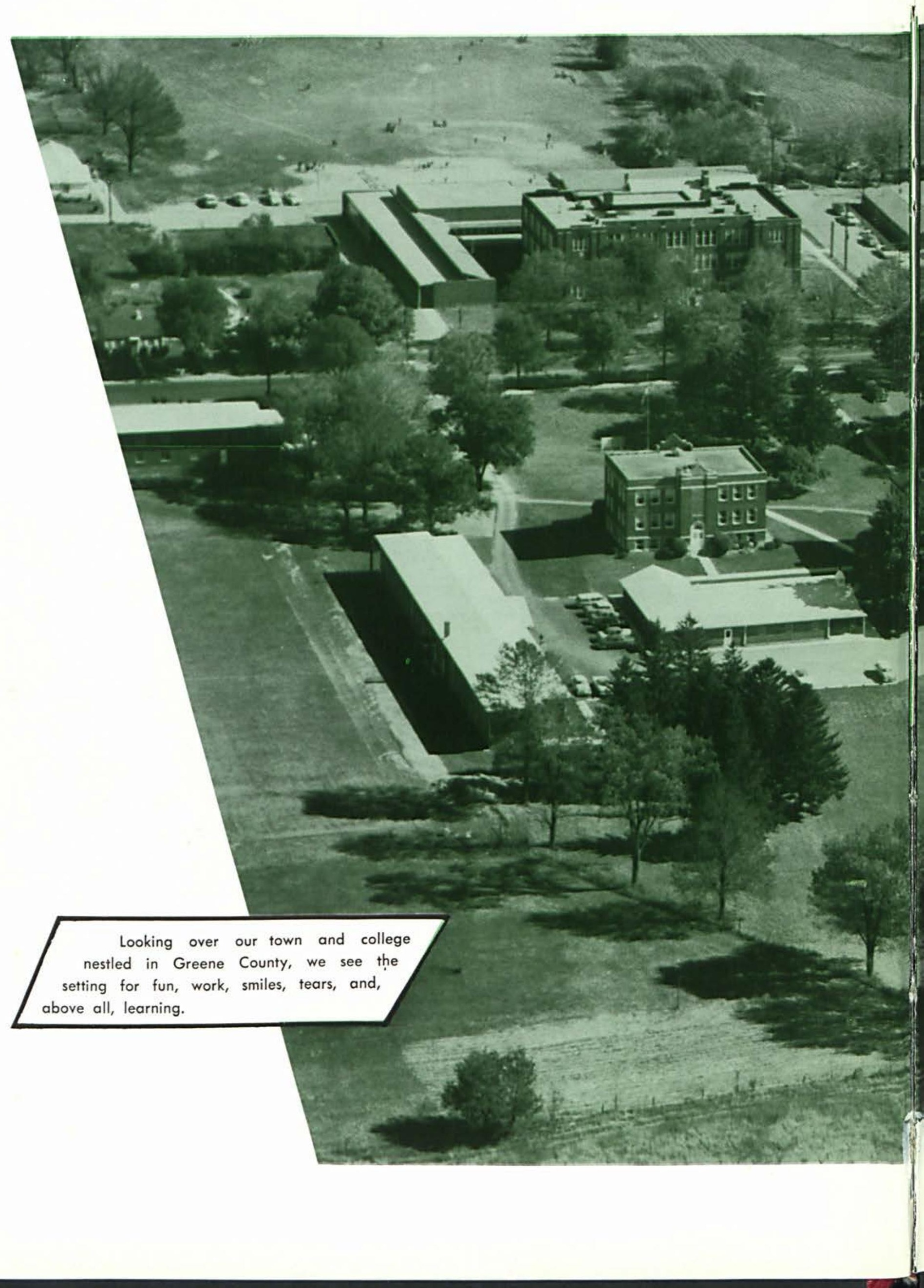




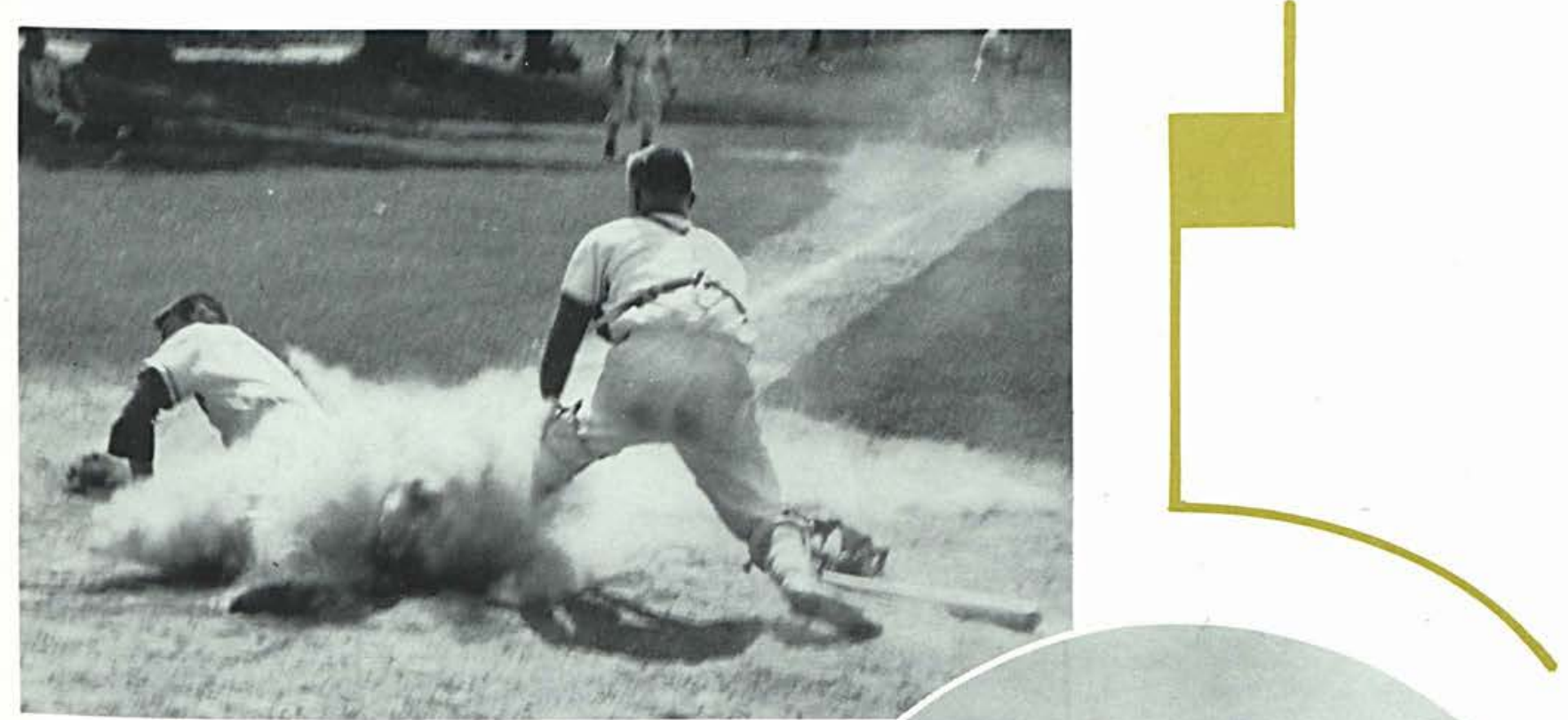

Senior Jim Entner is at the catcher's box in one of the two major sports at CC.

Norm Getty as the professor is a popular guy in the 1960 Prospective Students' Day play, "Professor, How Could You?"

\section{in the Spring}

Graduates march across the compus from the administration building to the gymnasium where the graduation service is held.
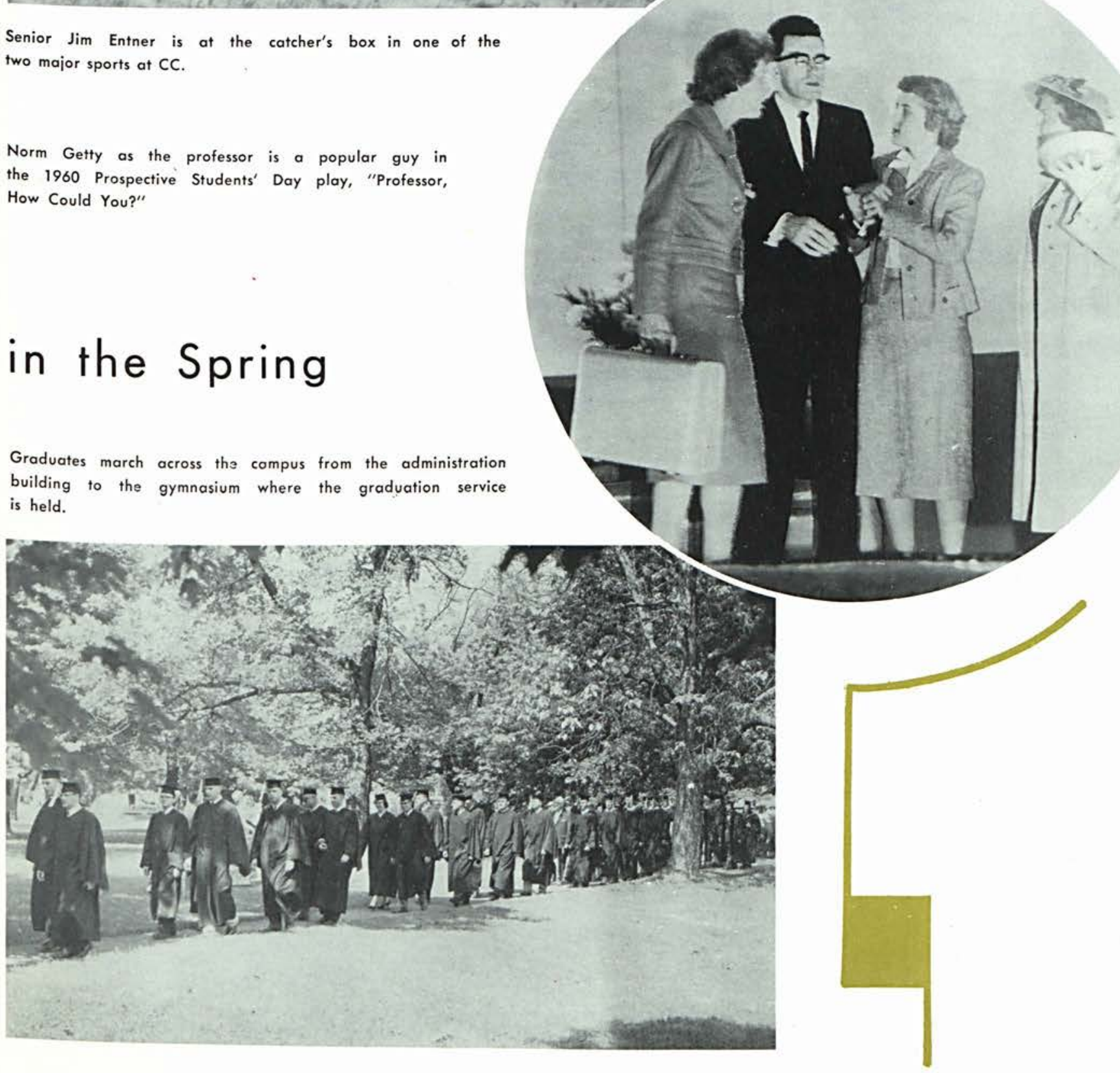


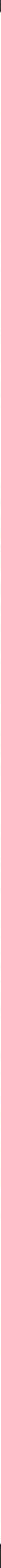




\section{Christian service at Cedarville}

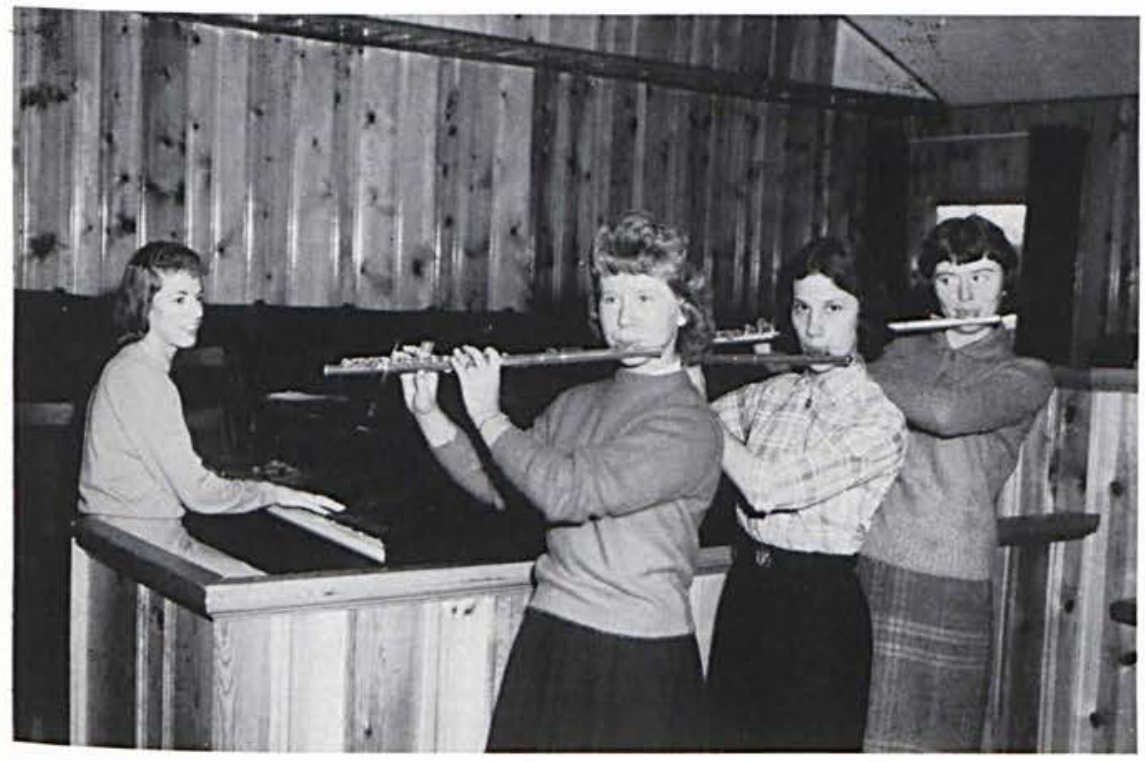

The tower of Milner Chapel is an inspiring symbol on our campus. Every Sunday morning a Christian service group conducts services in the Springfield Jail. The flute trio is only one of many small musical groups which represent the college in Christian service assignments. For the College Choir, the annual spring tour highlights the year. One of their favorite selections this year was "I Want Jesus to Walk With Me."

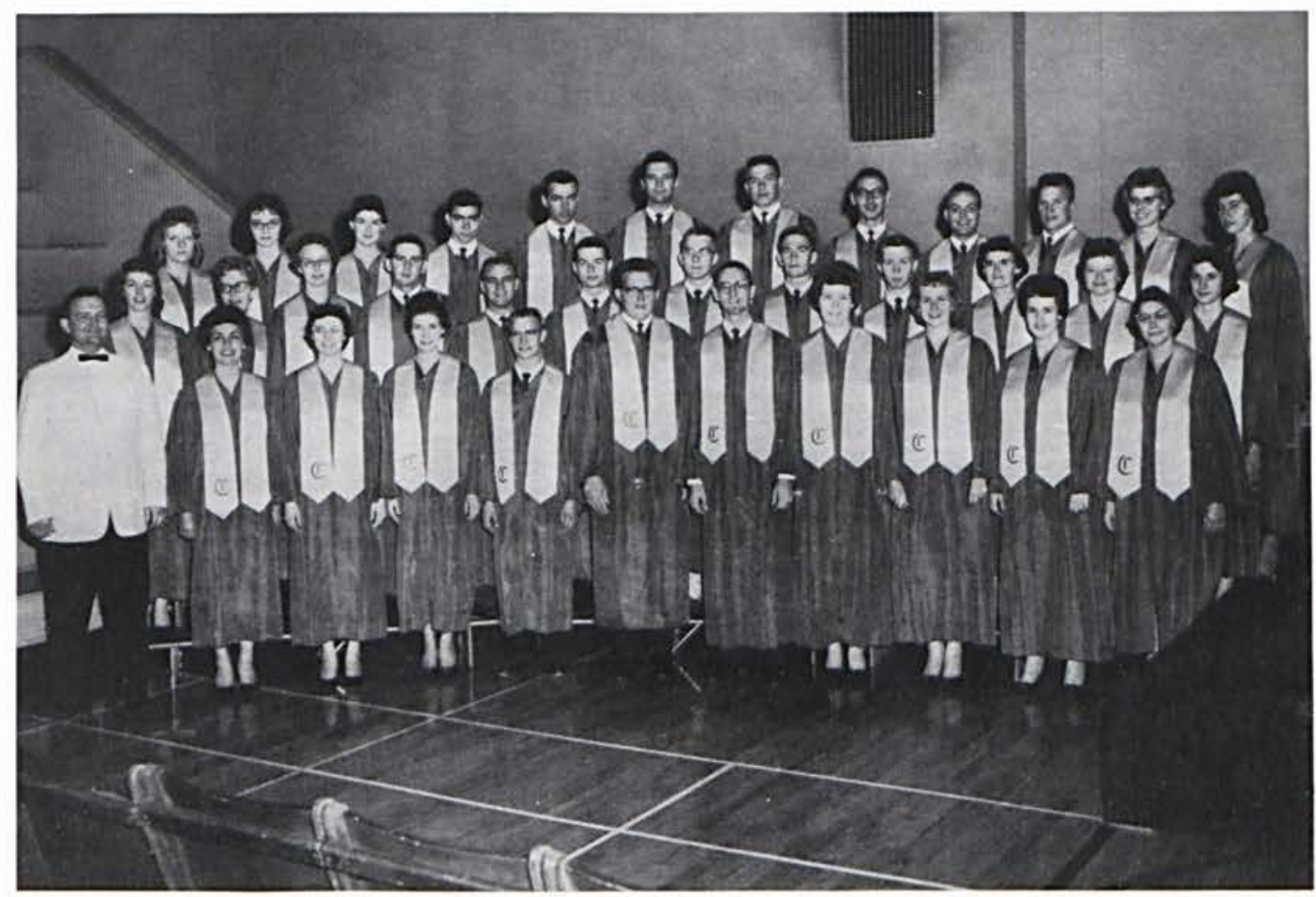




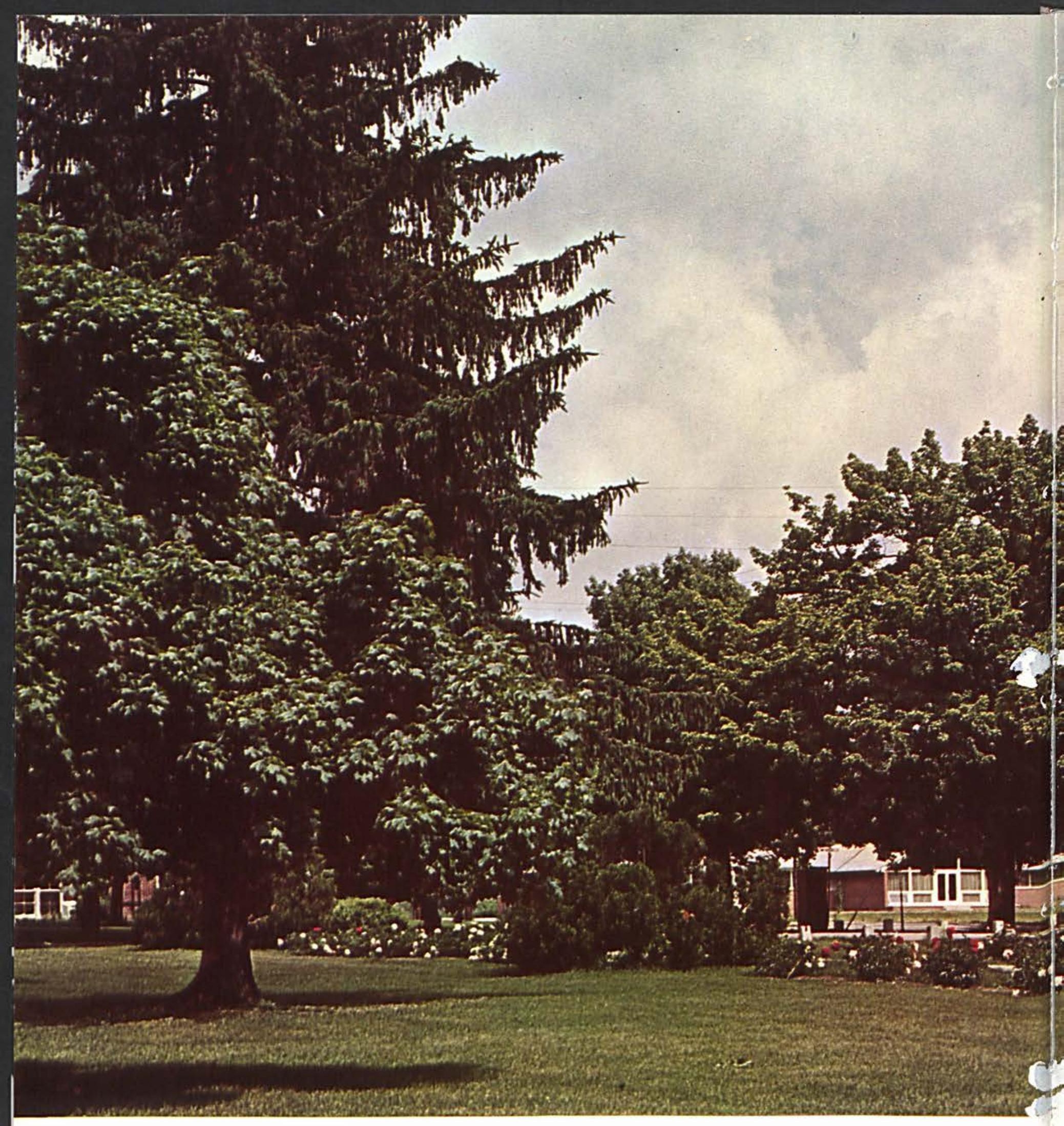





\section{Let's look}

together

at

Cedarville

College

\section{Cedarville, Ohio}

in the year

1960-61

aro

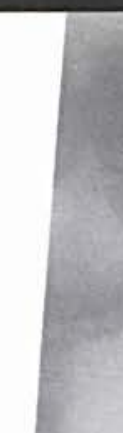




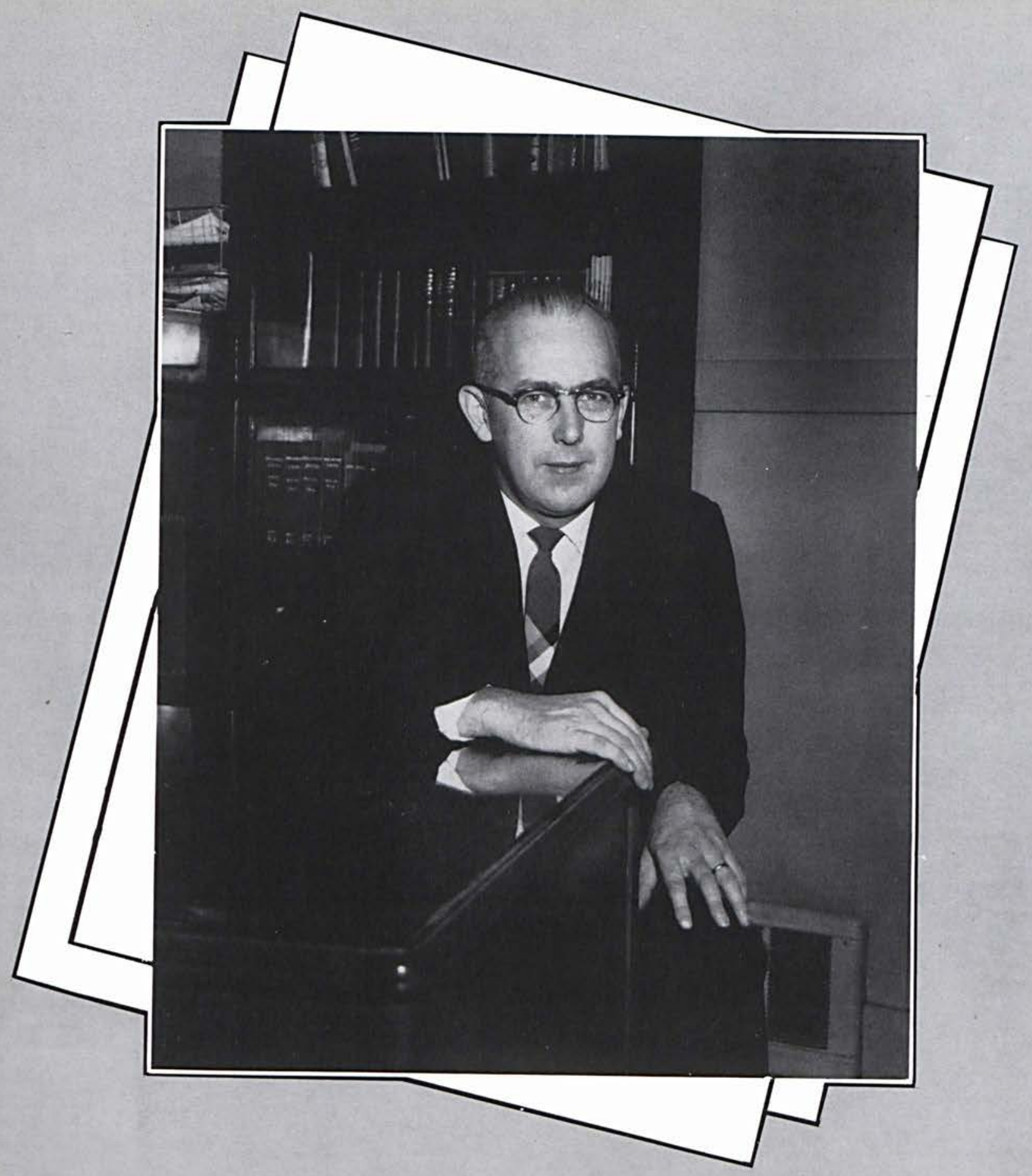

\section{President's Message}

Following the crucifixion of Christ two disciples on the road to Emmaus had a transforming experience with the risen Savior. His presence dispelled all doubts in the hearts of the disciples, brought them together in a fellowship of eternal realities, and gave them an insight into the Scriptures which they had not herefofore knowri.

With the Bible as the center of the curriculum, the Cedarville College faculty and students look together to the same living Savior and experience the "burning heart" as through His word he talks with them "by the way" (Luke 24:32). May this personal relationship with the eternal Christ ever make Cedarville a college where faith in the Bible and its Author is strengthened and never lost. 


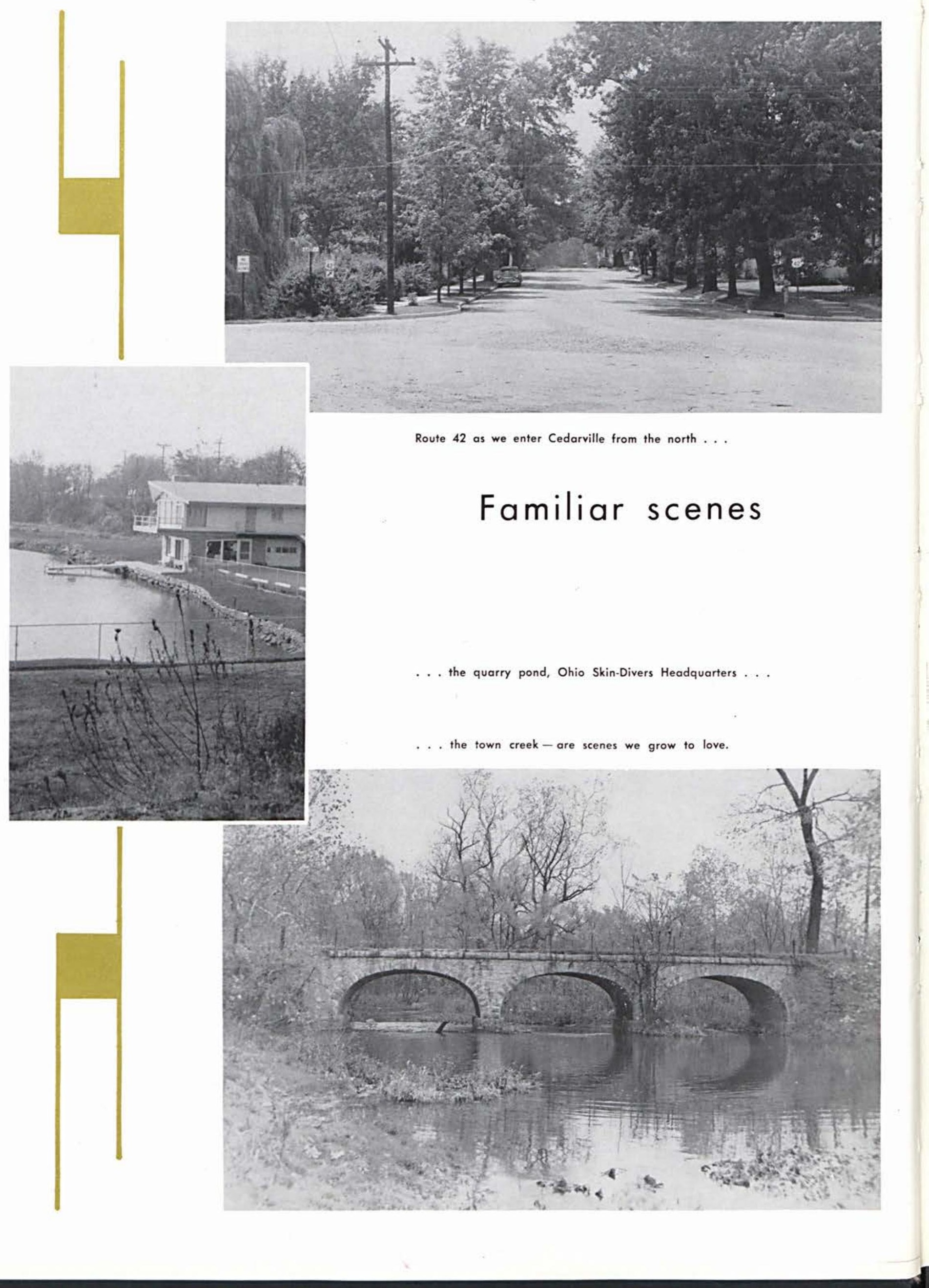



2.

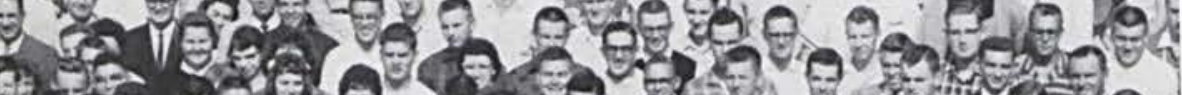

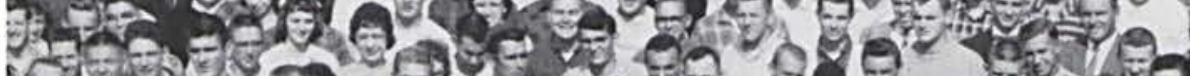

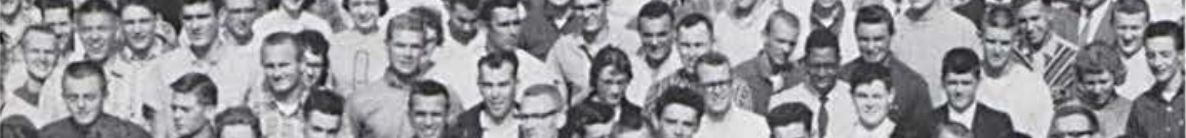

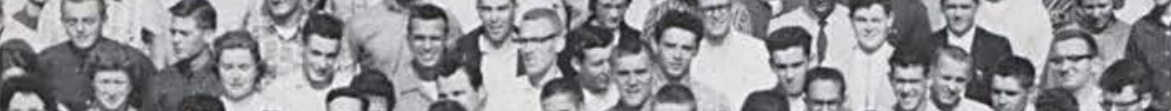

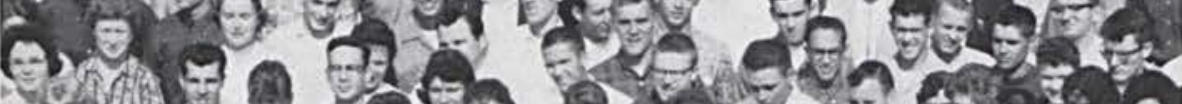
प.

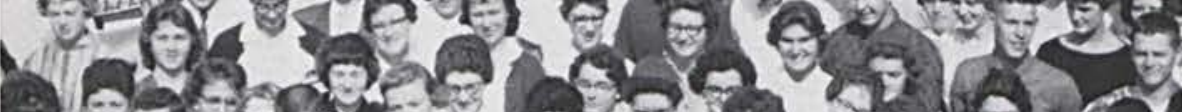

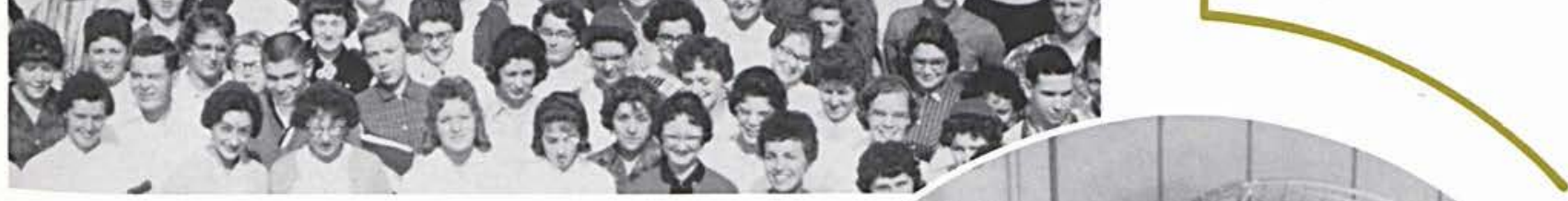

The new face in September... .

in the fall

. . the hilarious Varsity " $\mathrm{C}$ " initiation ...

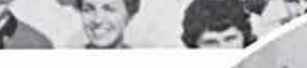

- the College float at the Firemen's Parade - recall times we had fun.
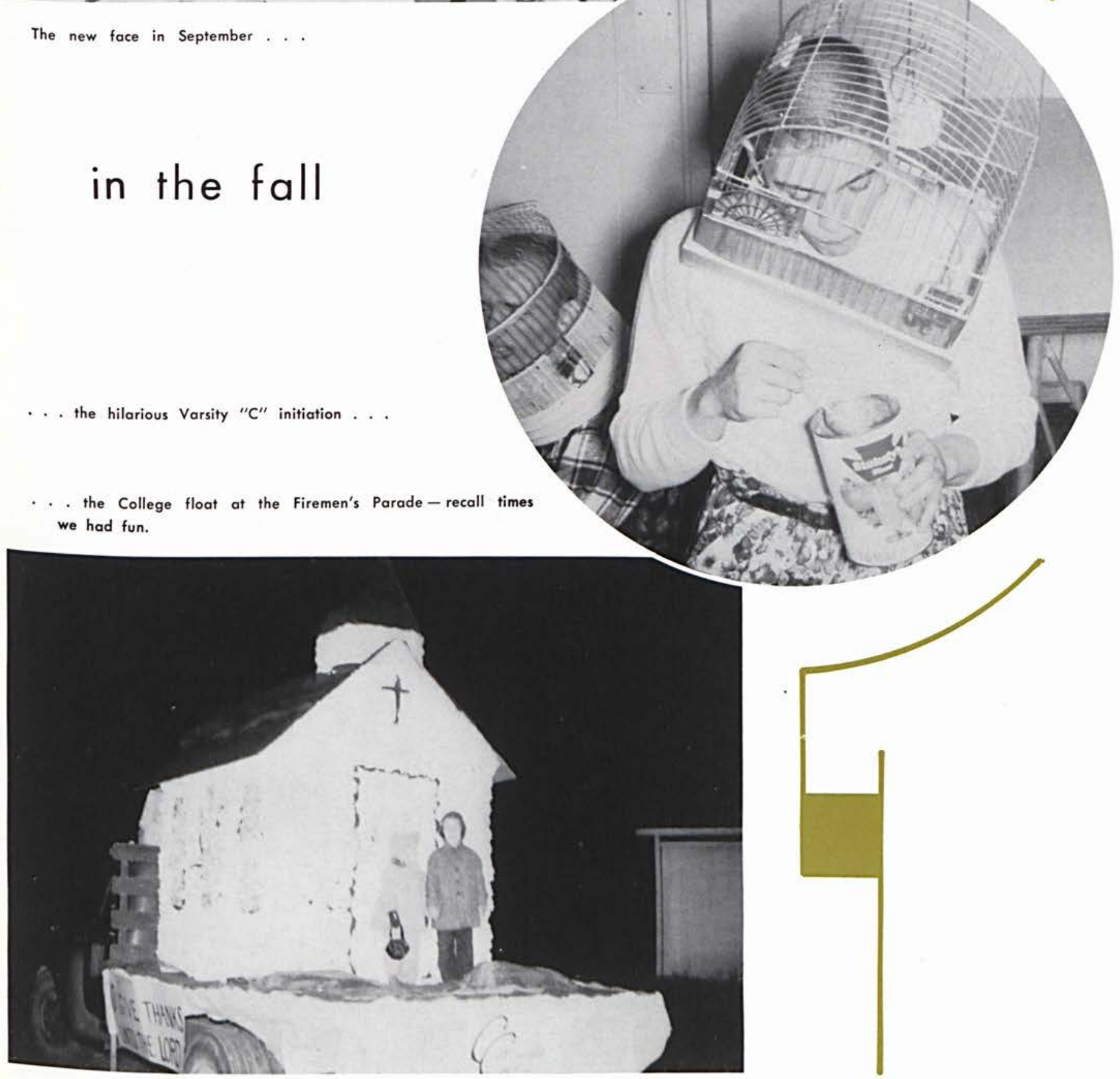


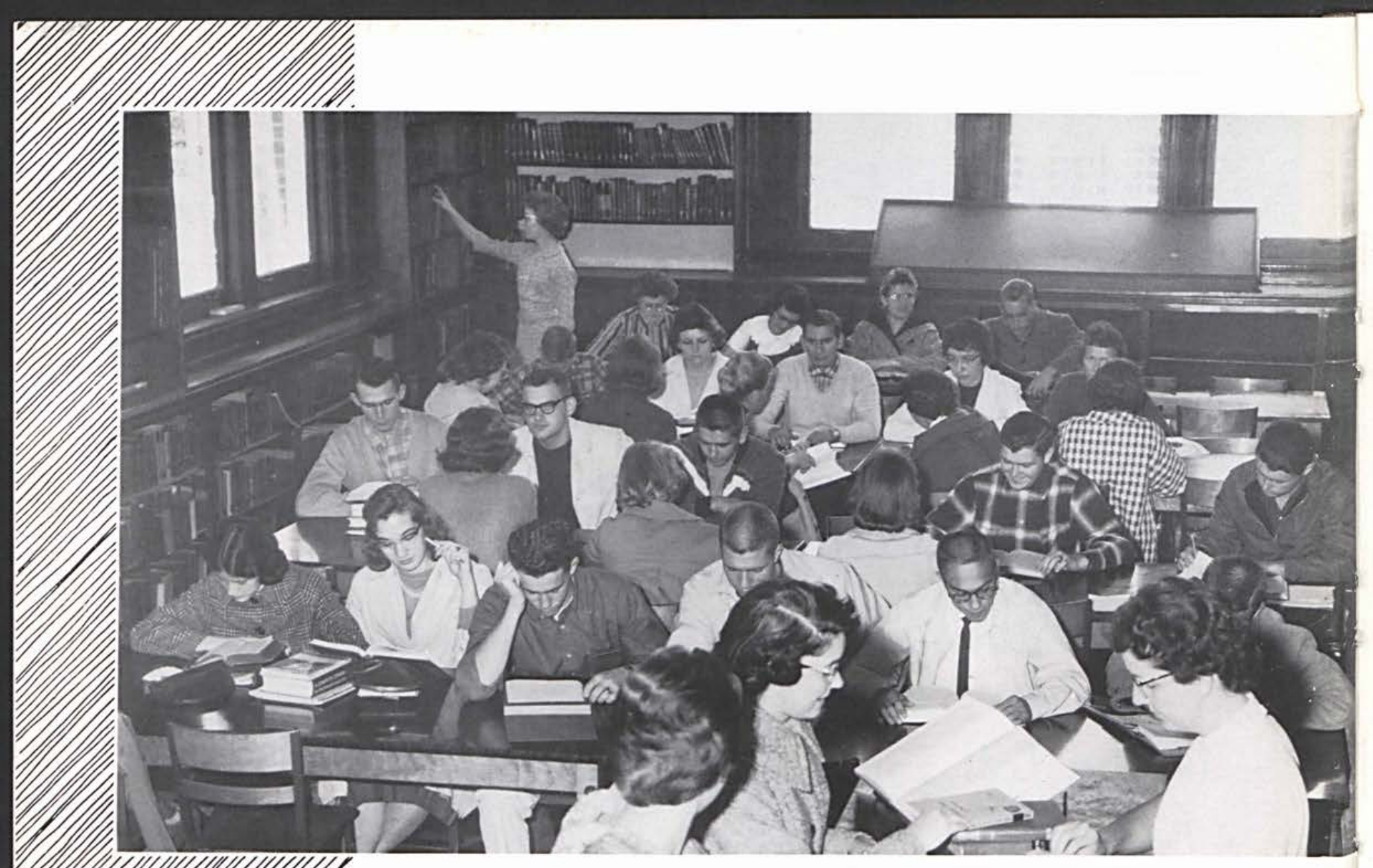

A posed picture ... o oh nol This is a typical scene every evening (except Sunday) in every room at the college library. One of many college libraries built by Carnegie in 1906, it is overflowing in 1960.

One corner of the chemistry lab on the second floor of Science Hall.

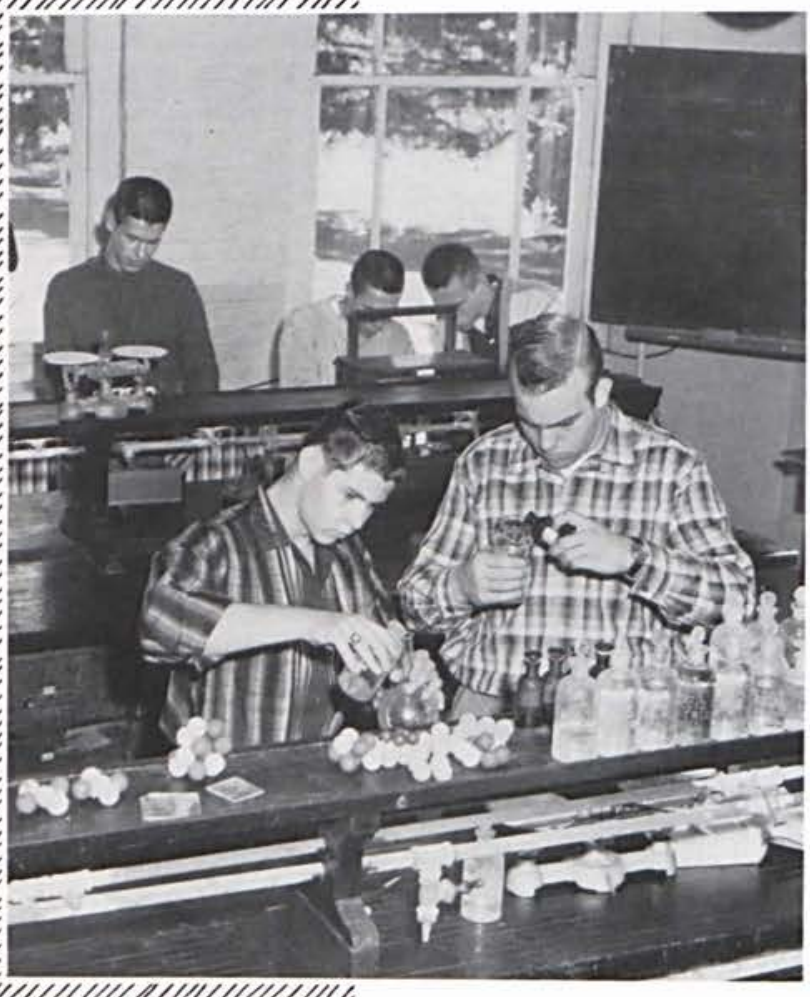

Mr. Bergen uses the laboratory method in classes in French, German, and Spanish.

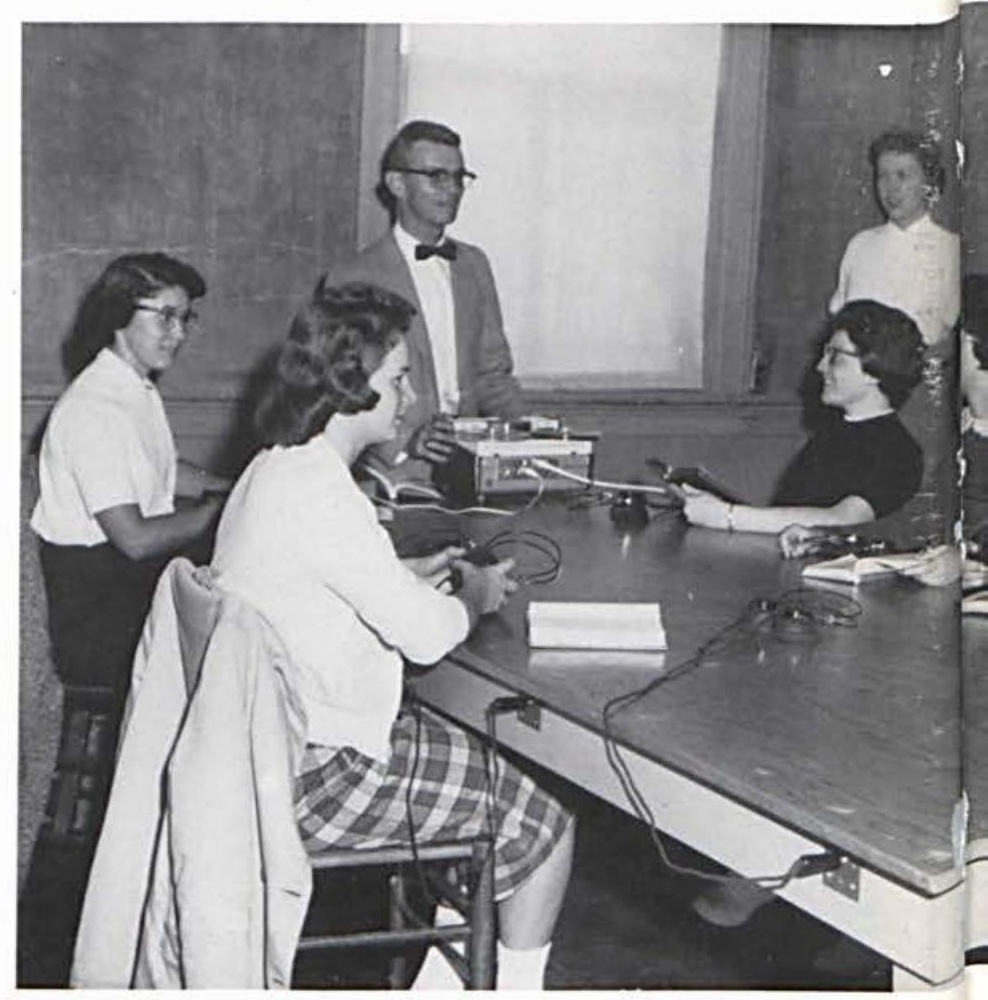


You have just had an introduction to our college. But it will take many more pages to tell the whole story, and we will have to go LOOKING TOGETHER. Our "theme" cannot be expressed in a single word or phrase, but it is that feeling of WARMTH and BEAUTY that FRIENDS have when they GET TO KNOW and UNDERSTAND one another. It is this feeling that we want to have as we LOOK TOGETHER at our college life through the pages of our annual.
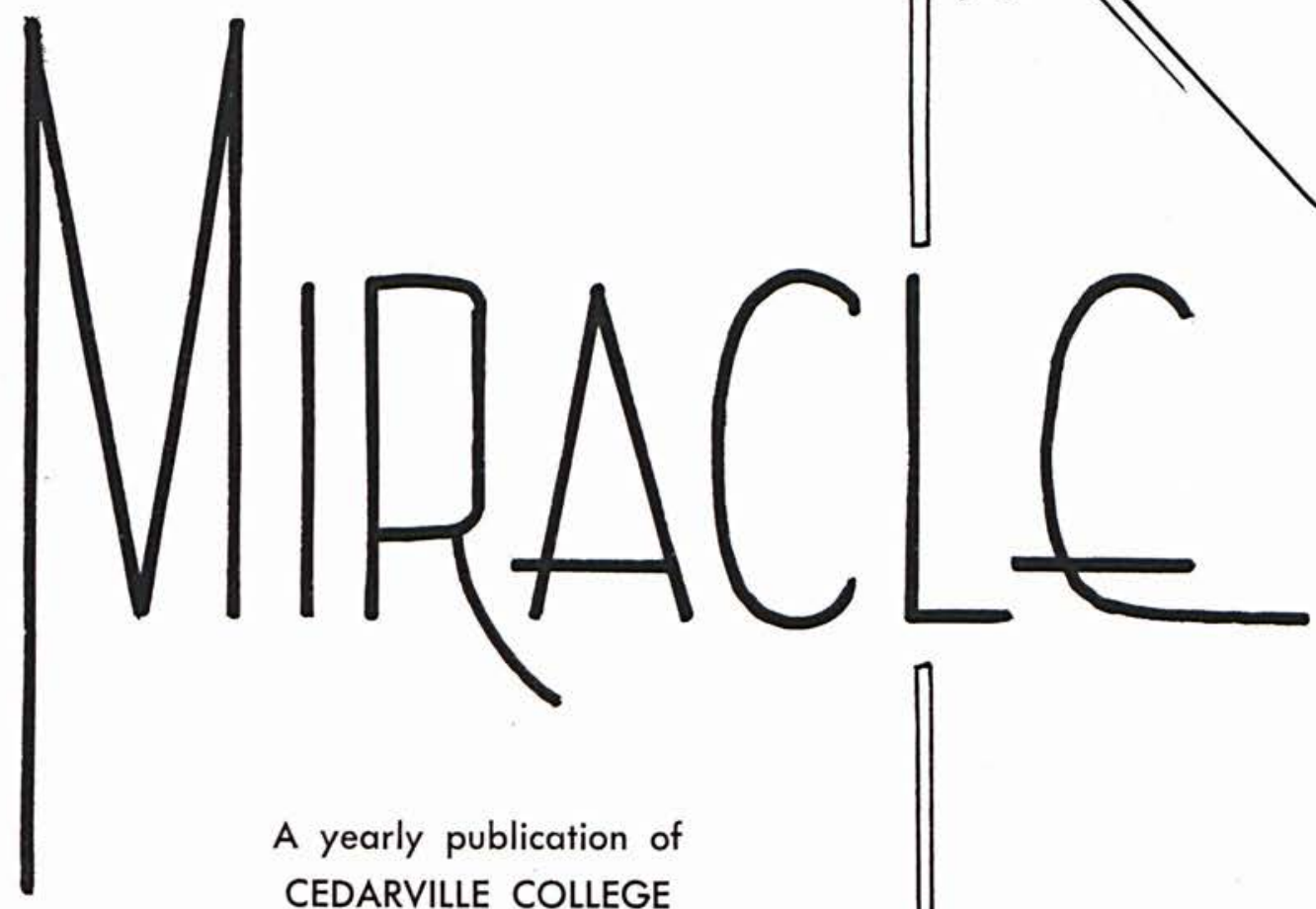

A yearly publication of CEDARVILLE COLLEGE CEDARVILLE, OHIO 

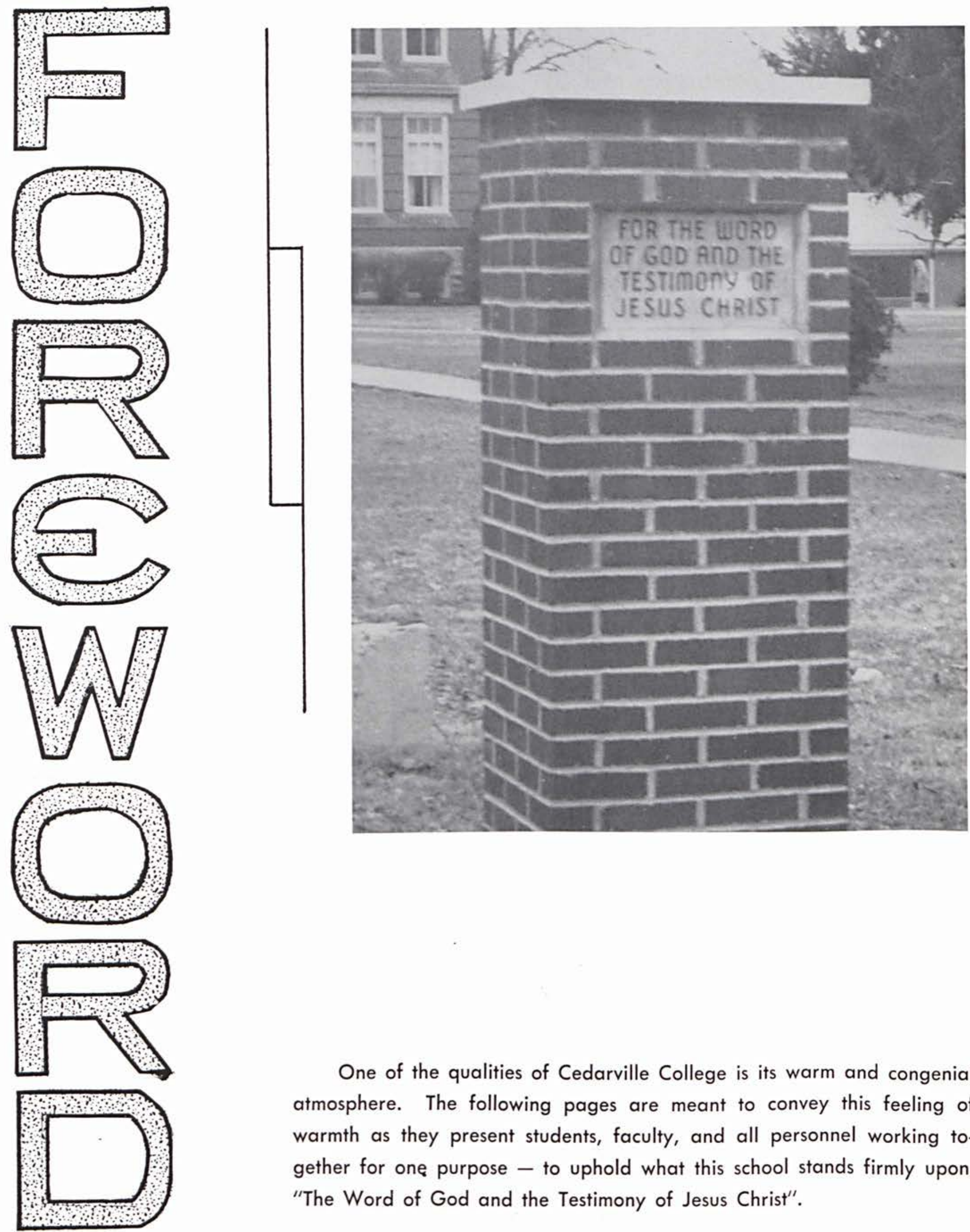

One of the qualities of Cedarville College is its warm and congenial atmosphere. The following pages are meant to convey this feeling of warmth as they present students, faculty, and all personnel working together for one purpose - to uphold what this school stands firmly upon, "The Word of God and the Testimony of Jesus Christ". 


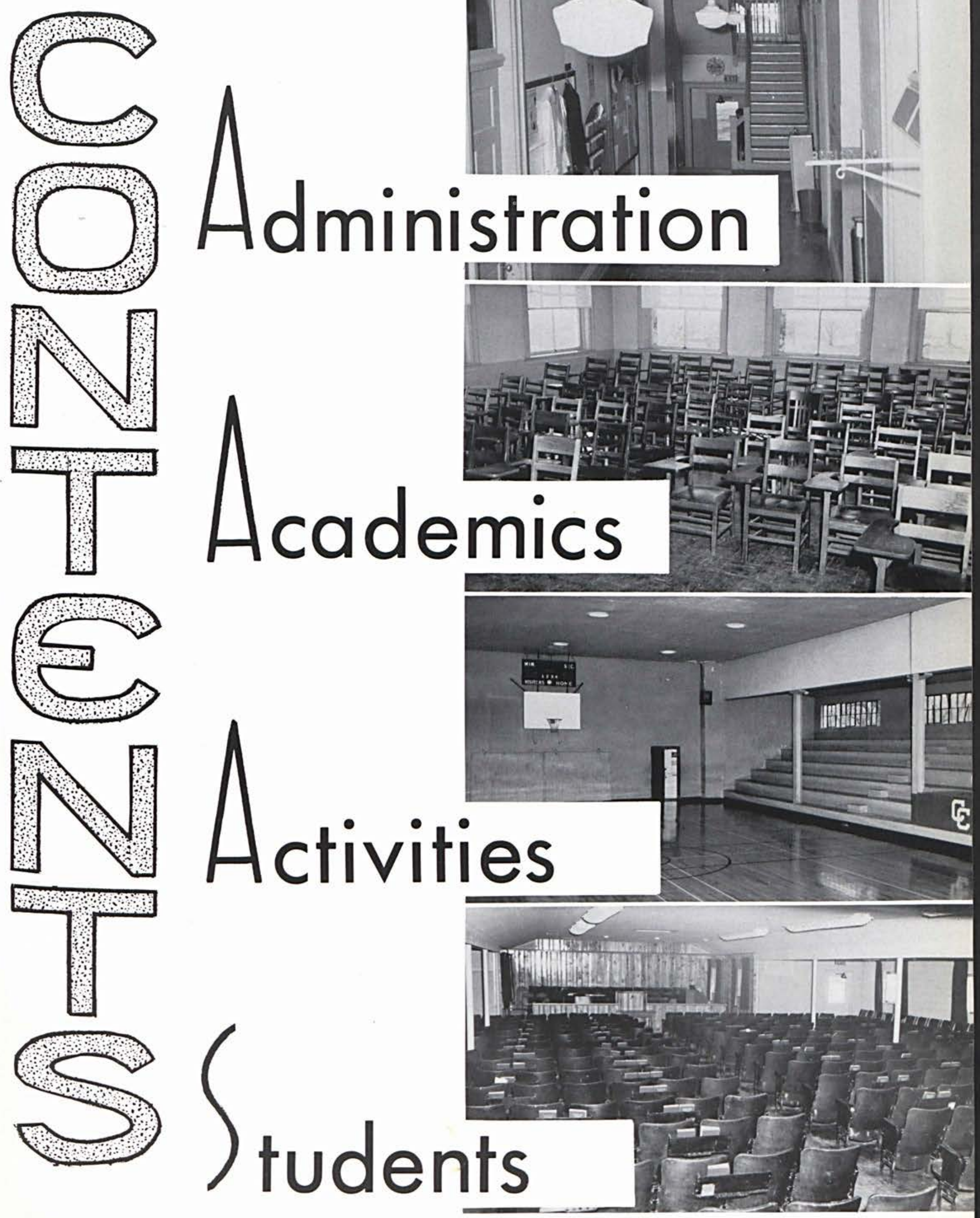




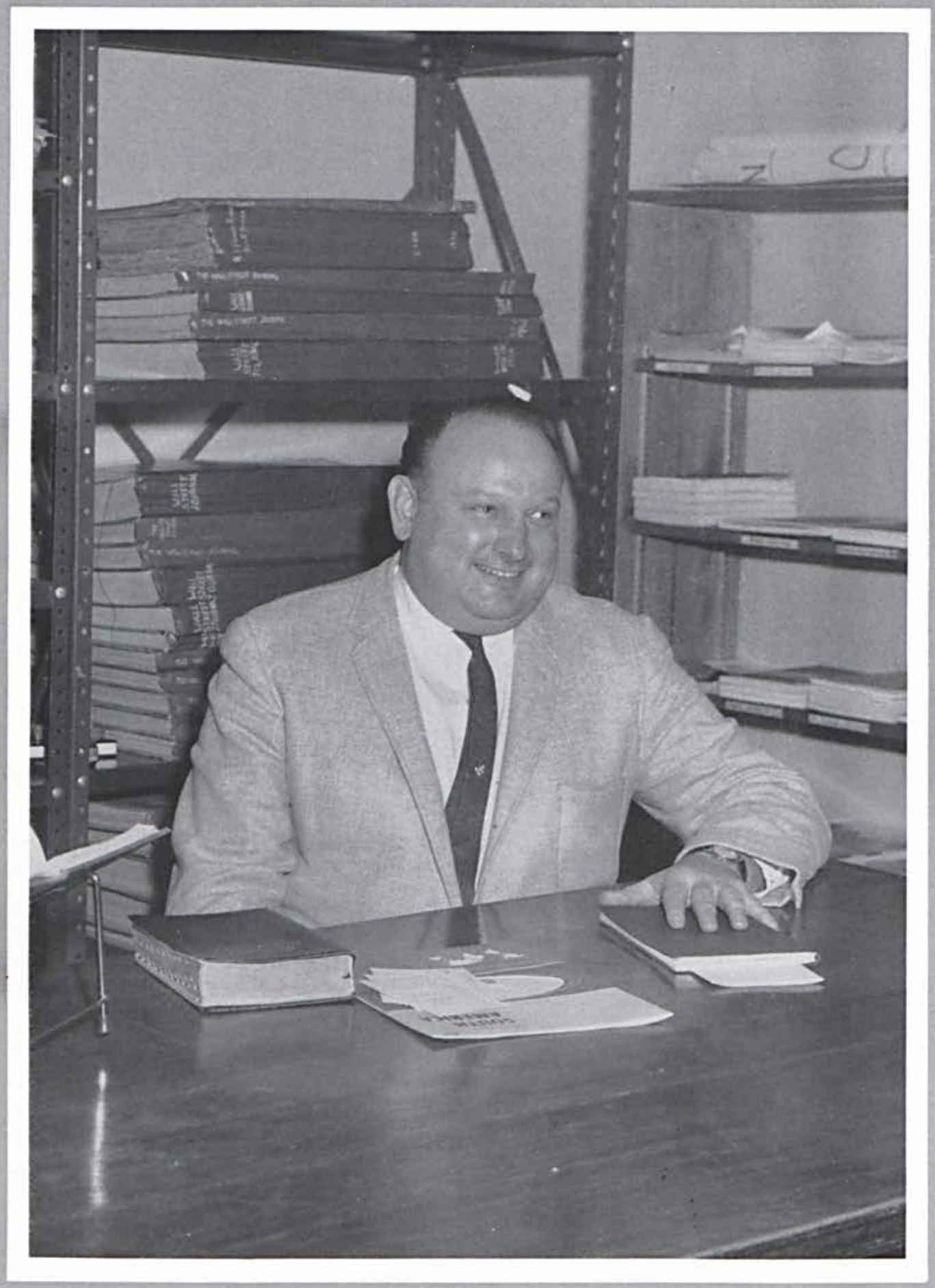





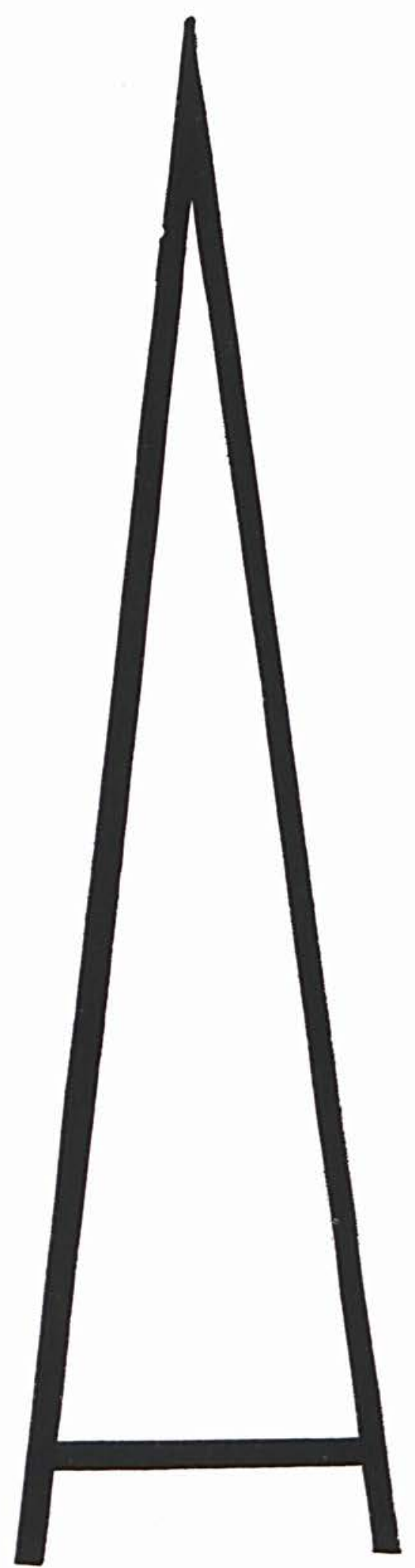

A glance down this empty corridor where our administrative offices are located will remind us that signs and stairways do not make administration. People do. And these people are the nicest we know. They have helped us in GETTING TO KNOW our way around.

\section{CONTENTS}

\section{Trustees}

and Administration

Office Staff

Maintenance Staff

Cafeteria Staff

Bookstore Staff

Residence Staff

Library Staff

Tribute to

Miss Williamson
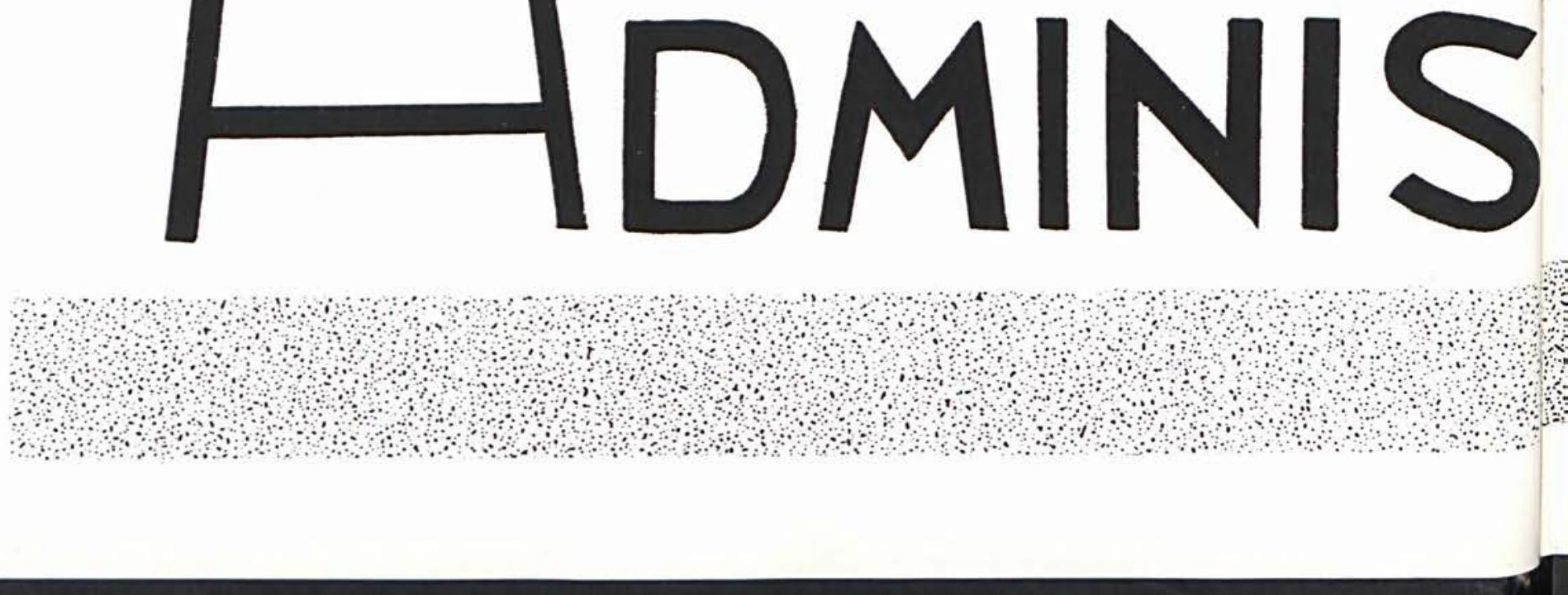

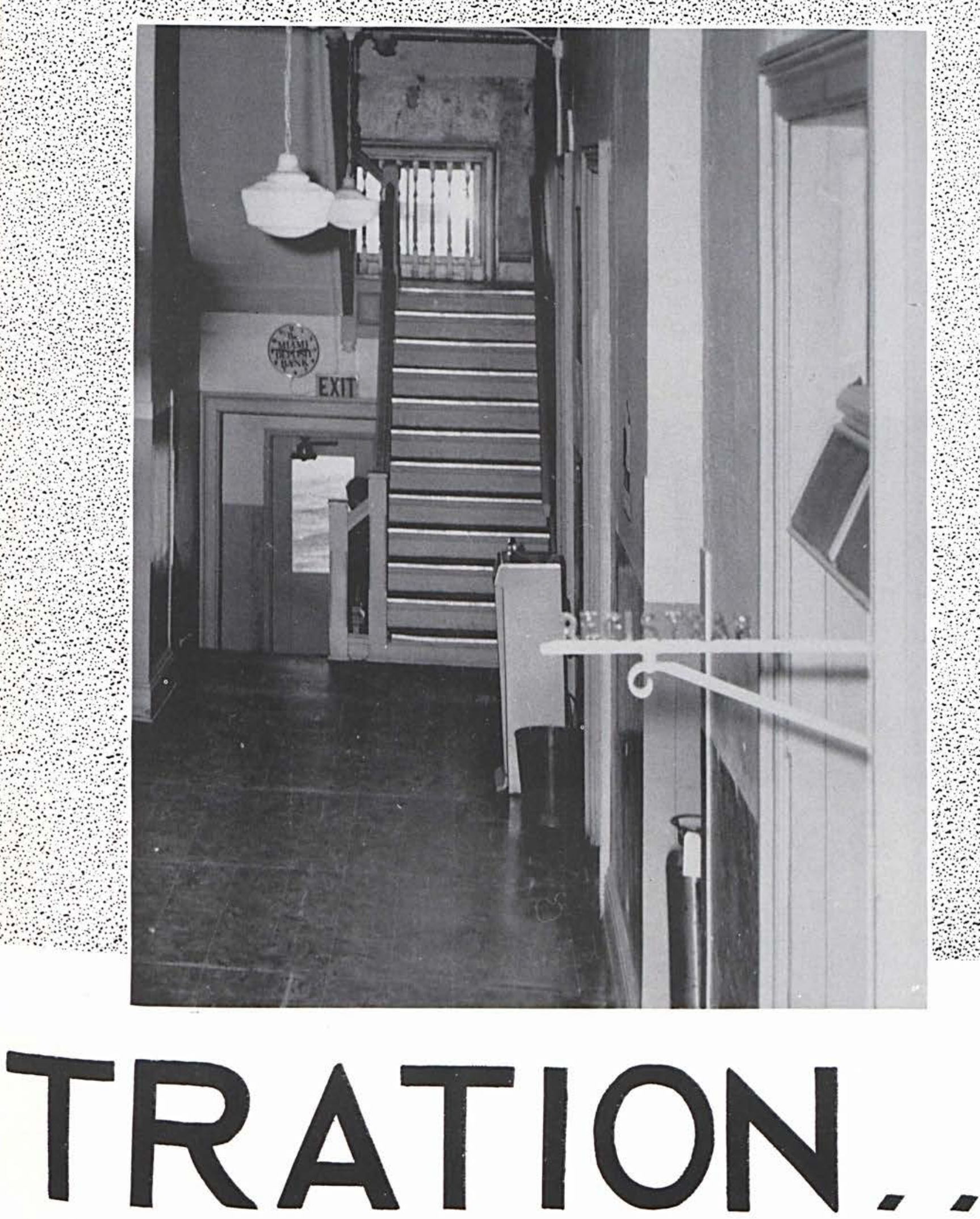


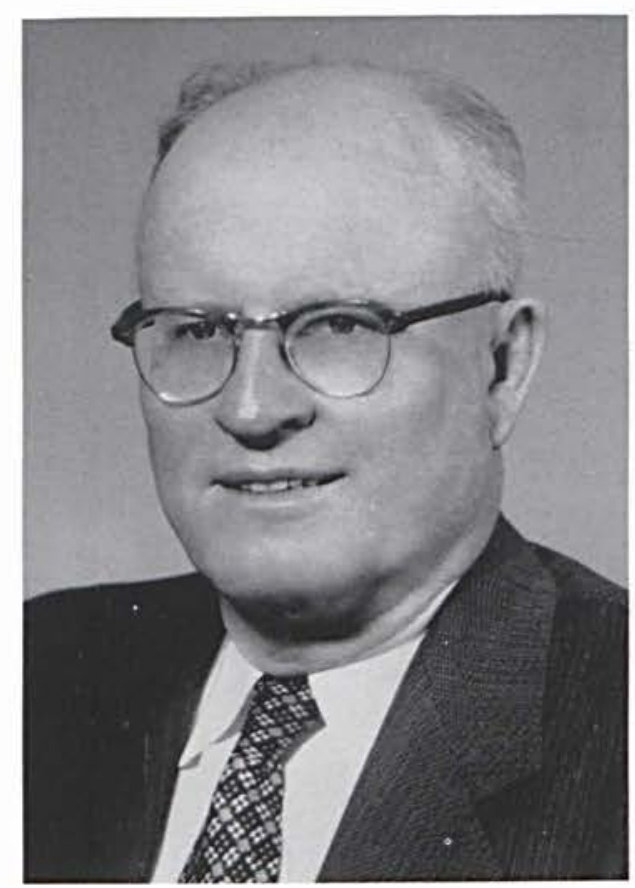

DR. CLIFFORD R. MADDOX Academic Dean

\section{Administration}

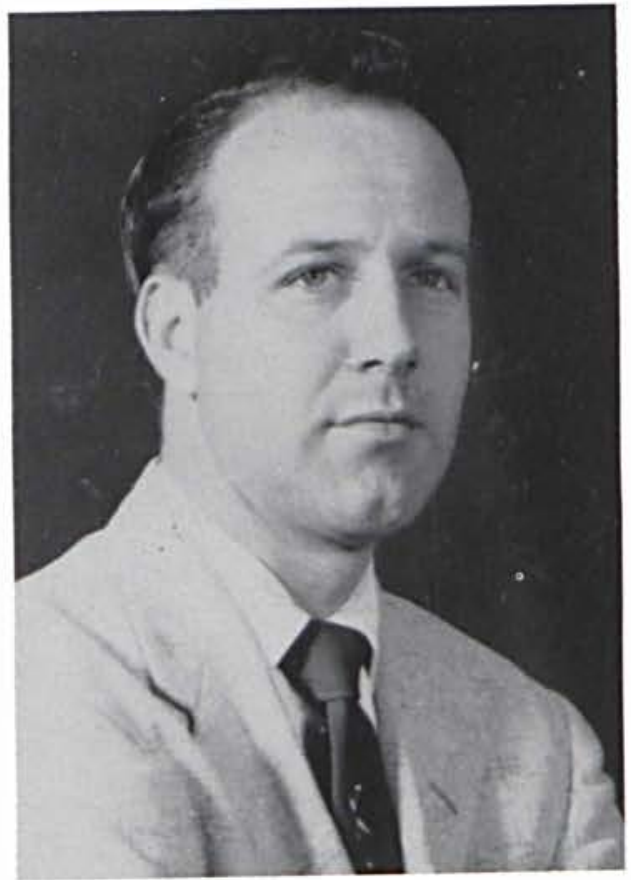

MR. ROBERT UNDERWOOD

Registrar

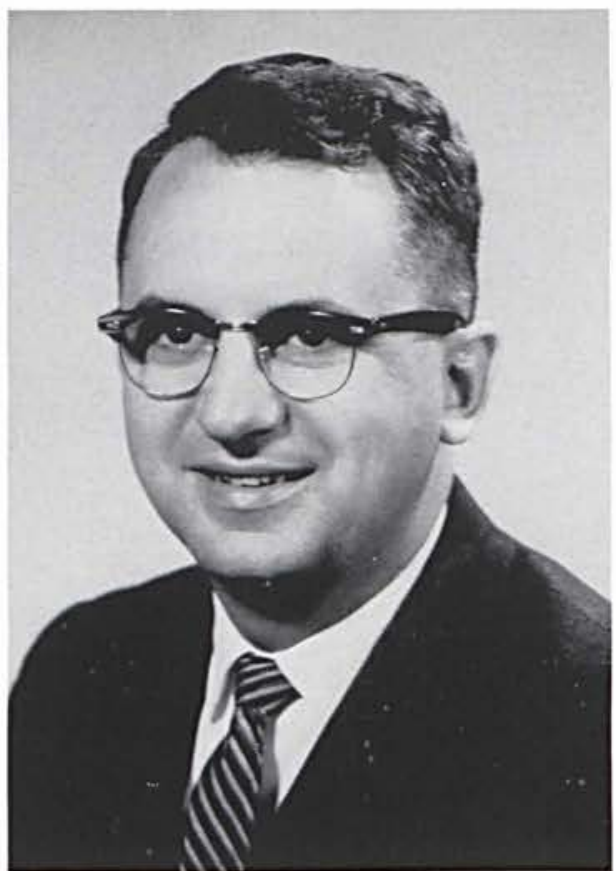

MR. RICHARD MC INTOSH Dean of Students

\section{EXECUTIVE COMMITTEE}

George S. Milner, Chairman

Clifford R. Maddox William A. Brock

Thomas Younger

George L. Boyd

James T. Jeremiah

William Patterson

Robert Underwood

Earl V. Willetts

Arthur F. Williams

\section{BOARD OF TRUSTEES \\ CEDARVILLE COLLEGE}

Mr. Charles Barth

Rev. George A. Bates

Mr. George L. Boyd

Rev. William A. Brock

Mr. Norman B. Chappell

Dr. Jack Cline

Rev. Alfred Colwell

Rev. Glenn H. Davis

Mr. John A. Draxler

Mr. Arthur Dyke

Mr. Roy Guenin

Dr. Frederick E. Milkie
Mr. George S. Milner, Sr. Mr. E. A. Morton

Rev. Kenneth A. Muck Mr. J. Dale Murphy Mr. William Patterson, Sr. Mr. James G. Richardson

Rev. Wilbur Rooke

Rev. Gerald Smelser Mr. Eugene Smith Mr. Charles D. Wallace Rev. Earl Willetts Rev. Donald Woodby

Rev. Thomas Younger 


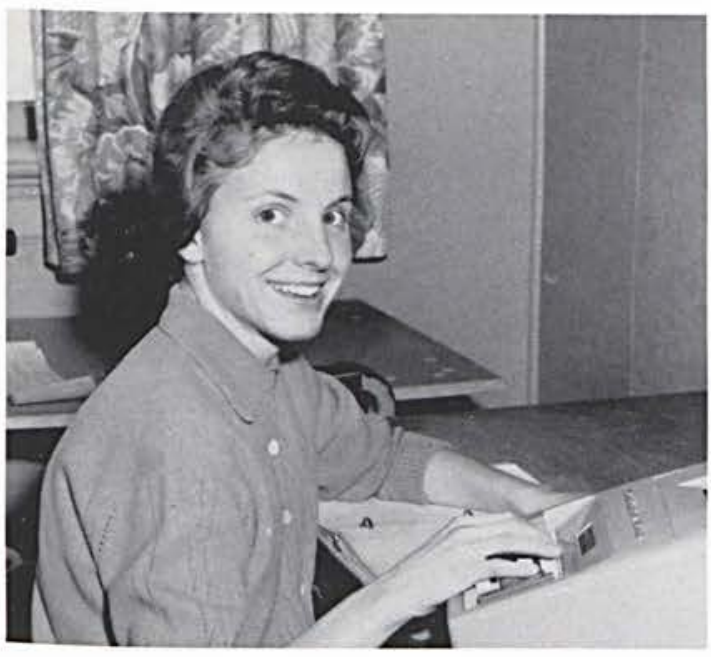

Miss Eleanor Keeter

Bookkeeper

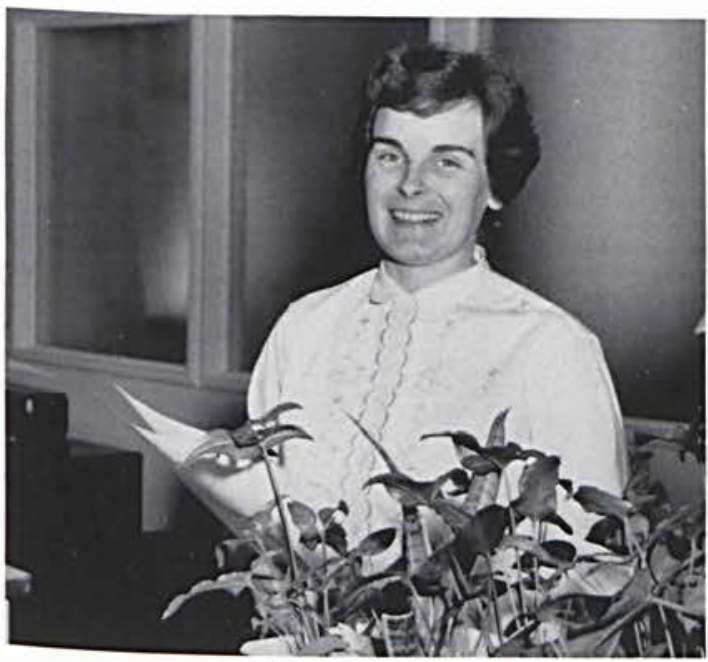

Miss Gerry White

Secretary to the Registrat

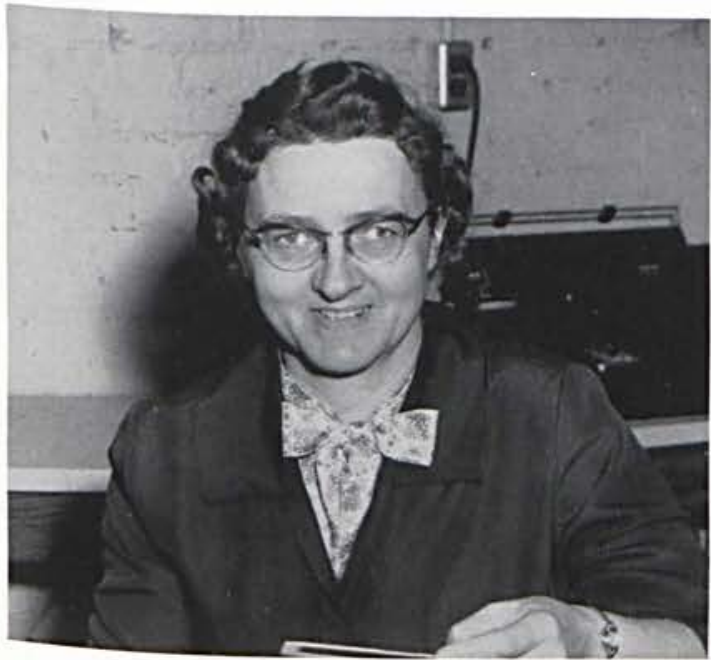

Mrs. Jeremiah

Publications

Office

\section{Staff}

All business transactions take place in the Business Office. Mrs. Jeremiah keeps busy with the publication of a monthly Cedarville College Bulletin plus many other items for the College.

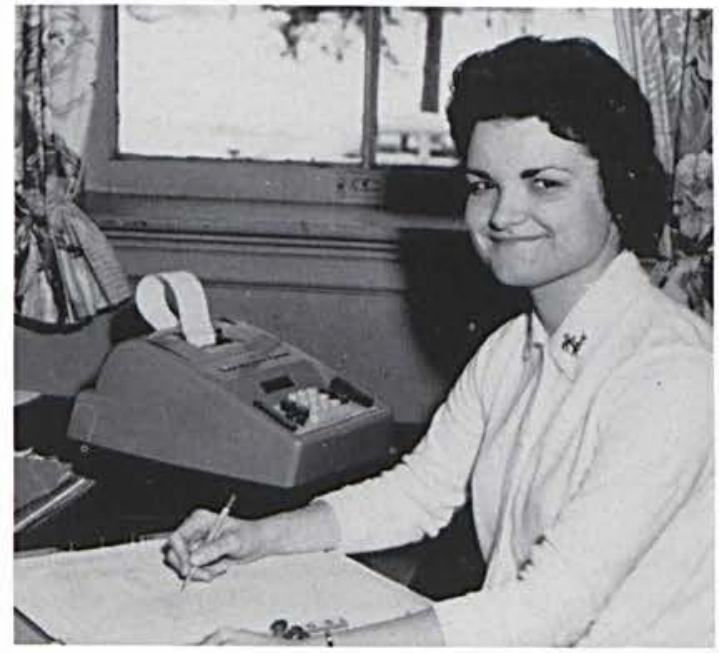

Miss Mariorie Hes

Cashier

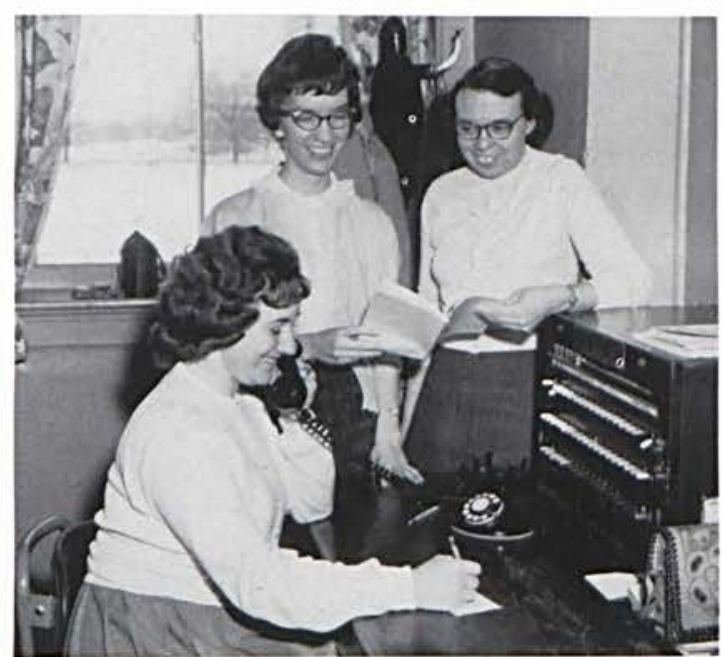

Left to Right: Juanita Allford, Peggy Howard Jean Hartsell. 


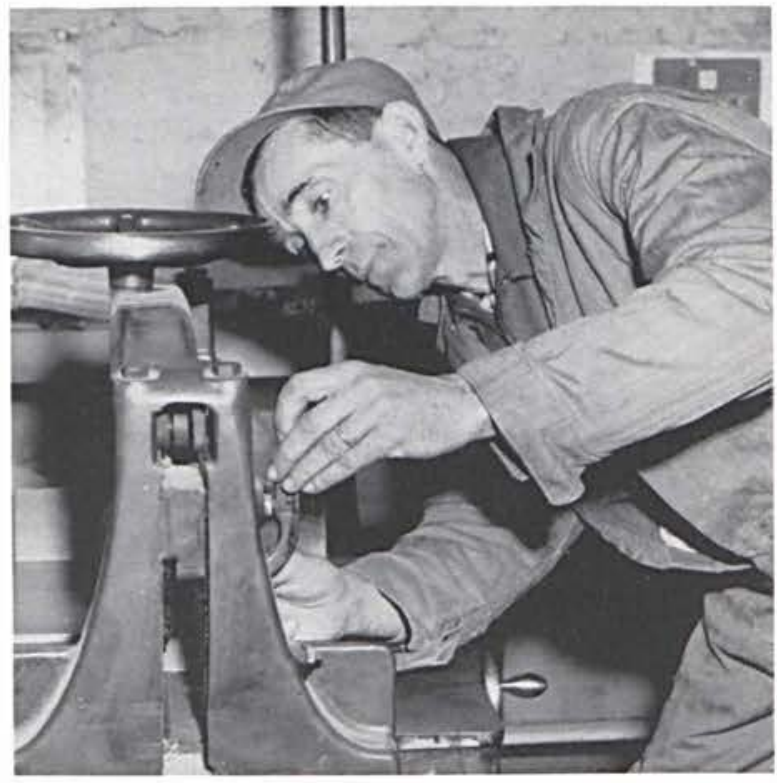

Gerald "Pop" Marshall

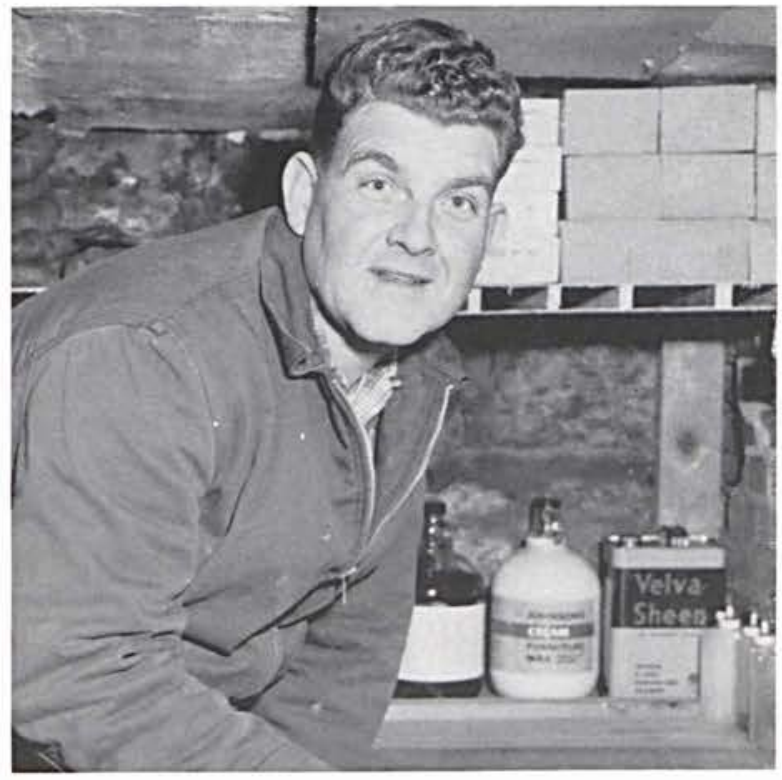

Charles Tarter

\section{Maintenance Staff}

The never ceasing job of keeping an entire campus clean and in good working order falls to the Maintenance Department.

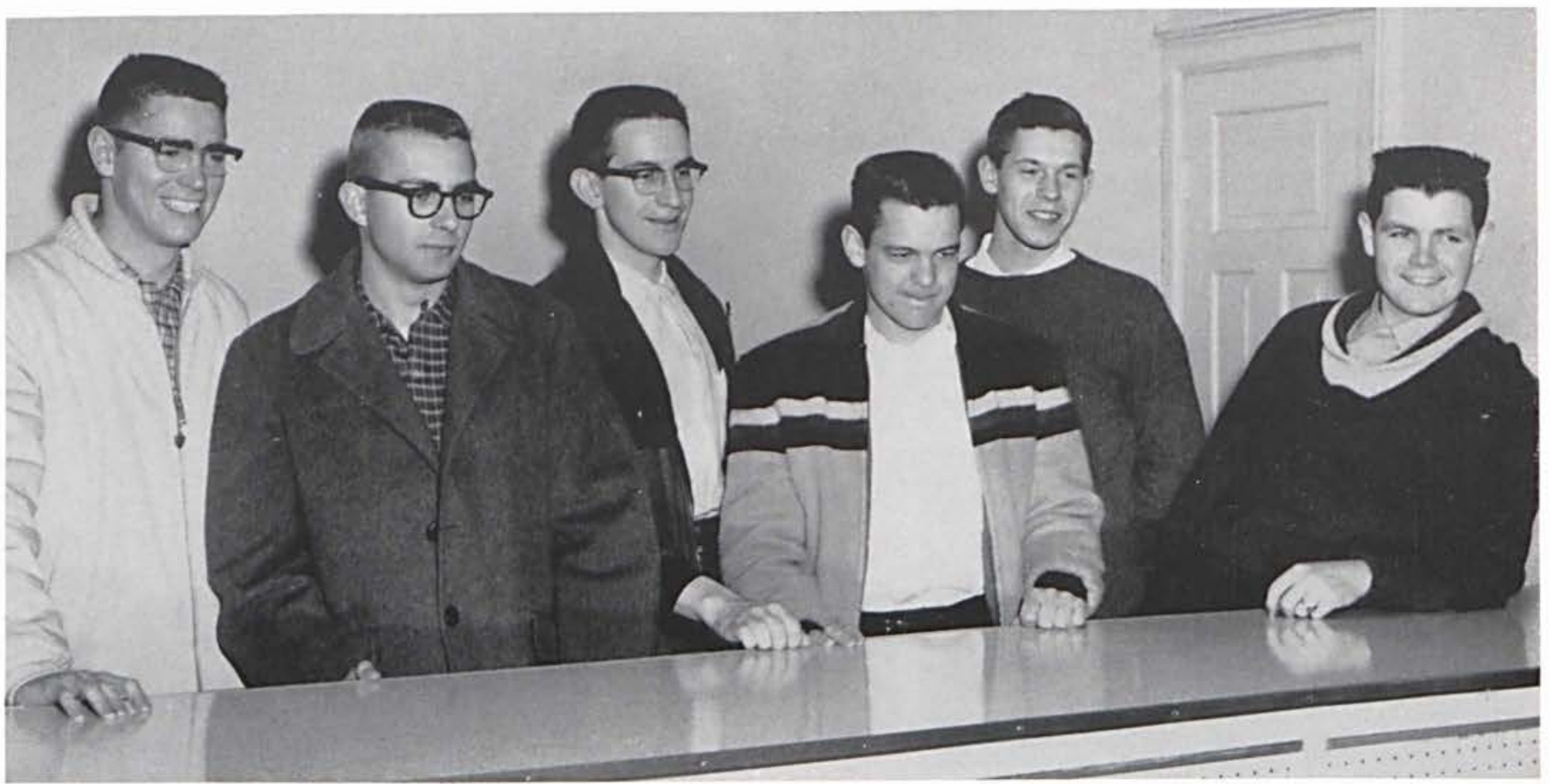

STUDENT ASSISTANTS - Lovis Schramm, Gene Wright, Dave Rifenberick, Jay Moore, Dave Taylor, Dave Woodman. 


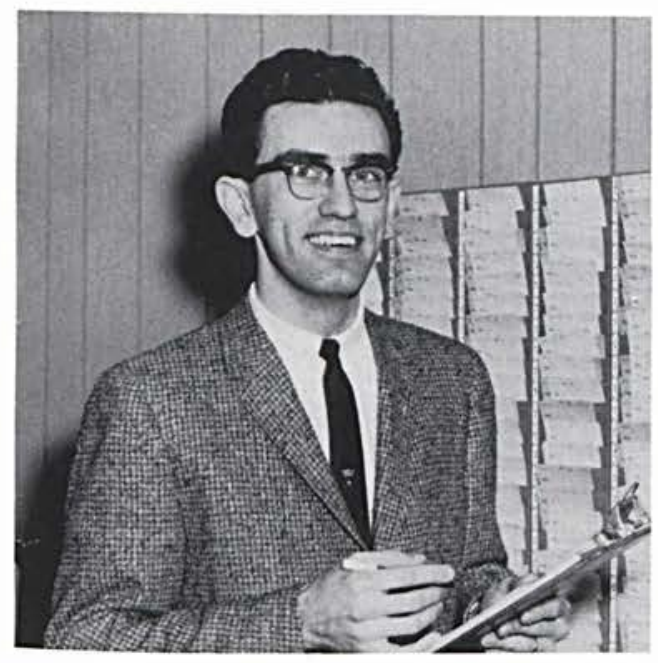

Norm Getty

Manager

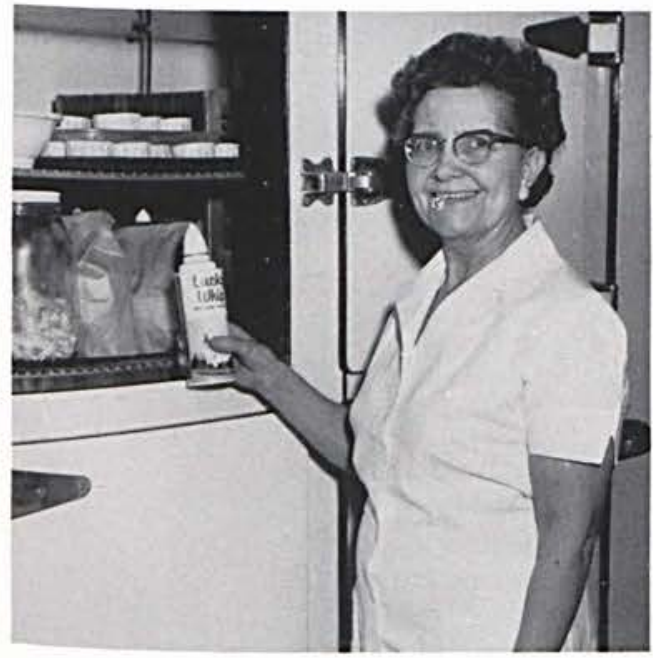

Mrs. Shirley

Head Cook

\section{Cafeteria Staff}

The College Cafeteria serves "three squares" to hungry students. One new addition to the cafeteria this year is the high-fidelity set which makes each meal more enjoyable. The cafeteria provides many job opportunities for students.

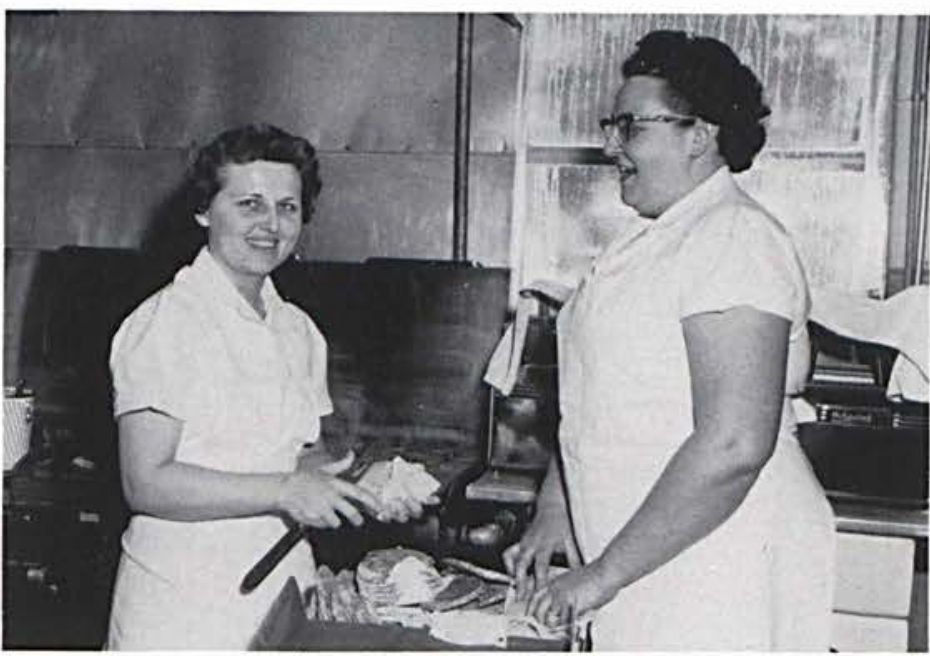

Mrs. Wyland, Mrs. Tarter Assistant Cooks

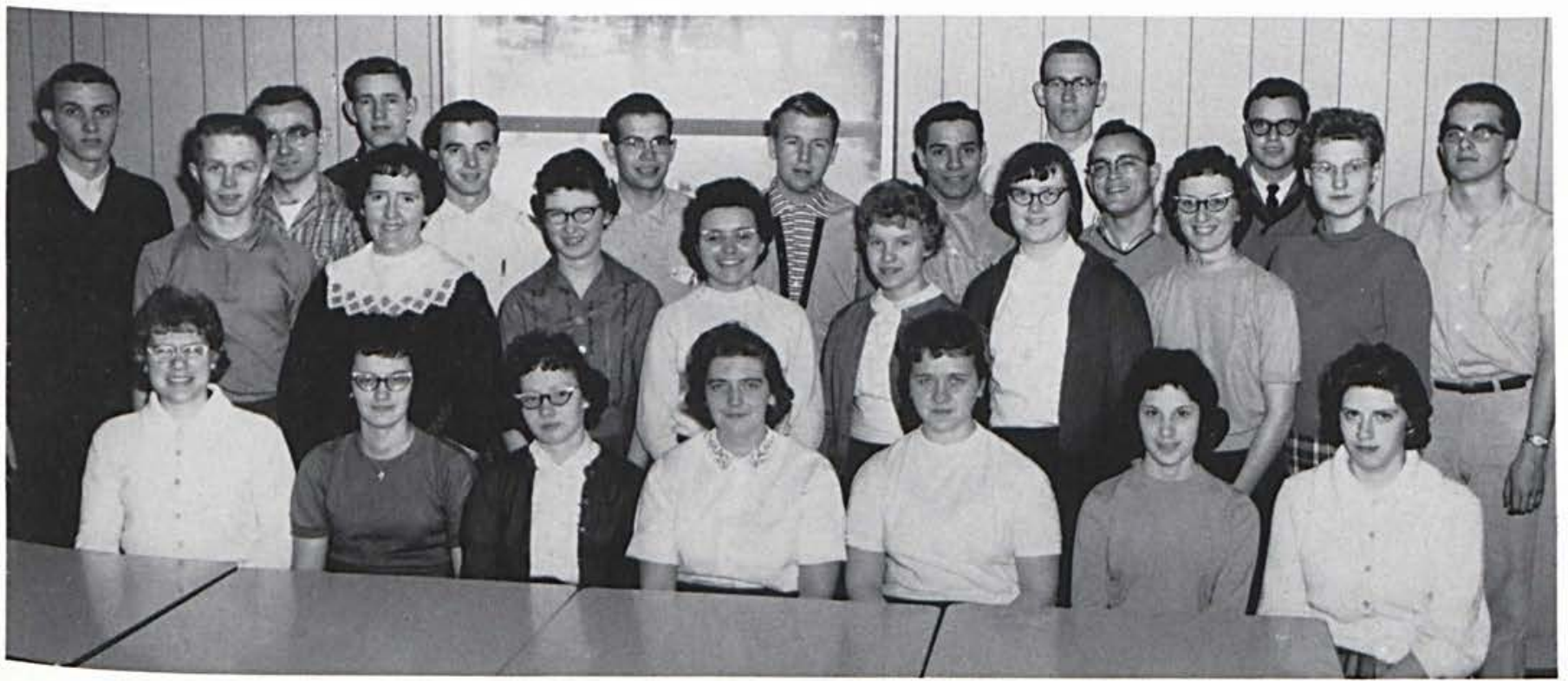

Student Assistants - Seated: Hope Marie Willie, Diane Hunter, Sharon Addleman, Loretta Cushey, Esther Spieth, Pat Adams, Elaine Adams. Second Row: Dan Park, Betty McKeehan, Beverly Woods, Pat Schonscheck, Sue Addleman, Judy Smith,
Pauline Lowe, Sue Geyser. Third Row: Dave Warren, John Coons, Steve Nimmo, Tony Nicklas, Ken Hamilton, Phil Grant, Ed Villaba, Bill Warfield, Lyle Rose, Ken Atkins, Ralph Werner. 


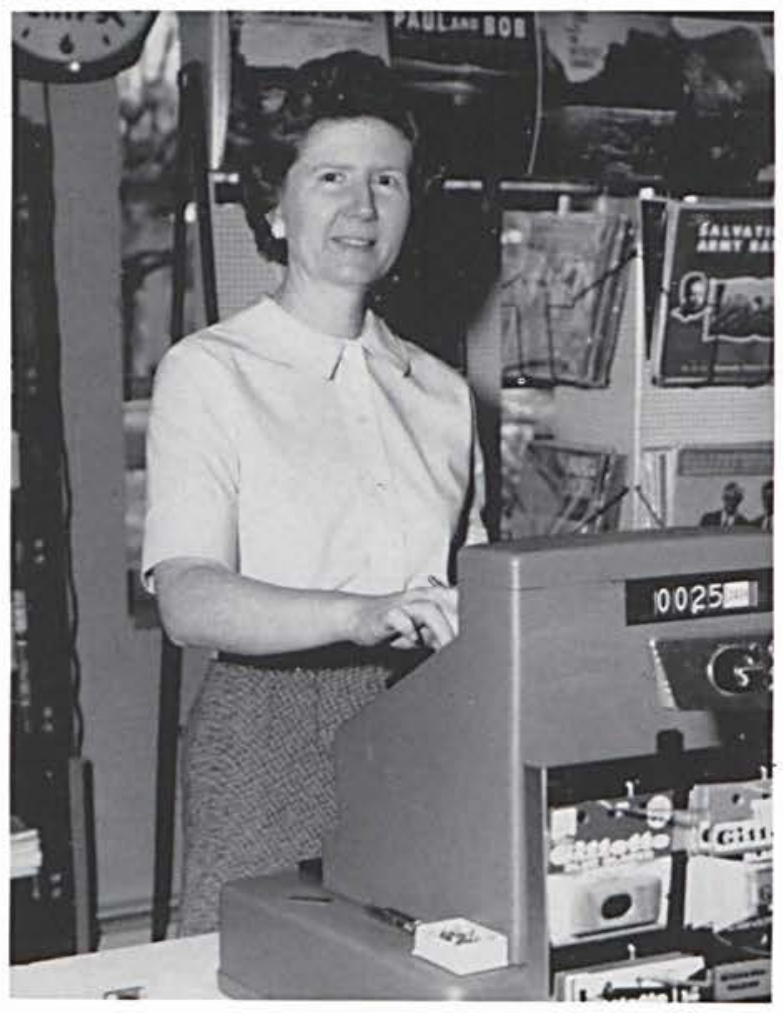

Miss Bernice Mick Bookstore Manager

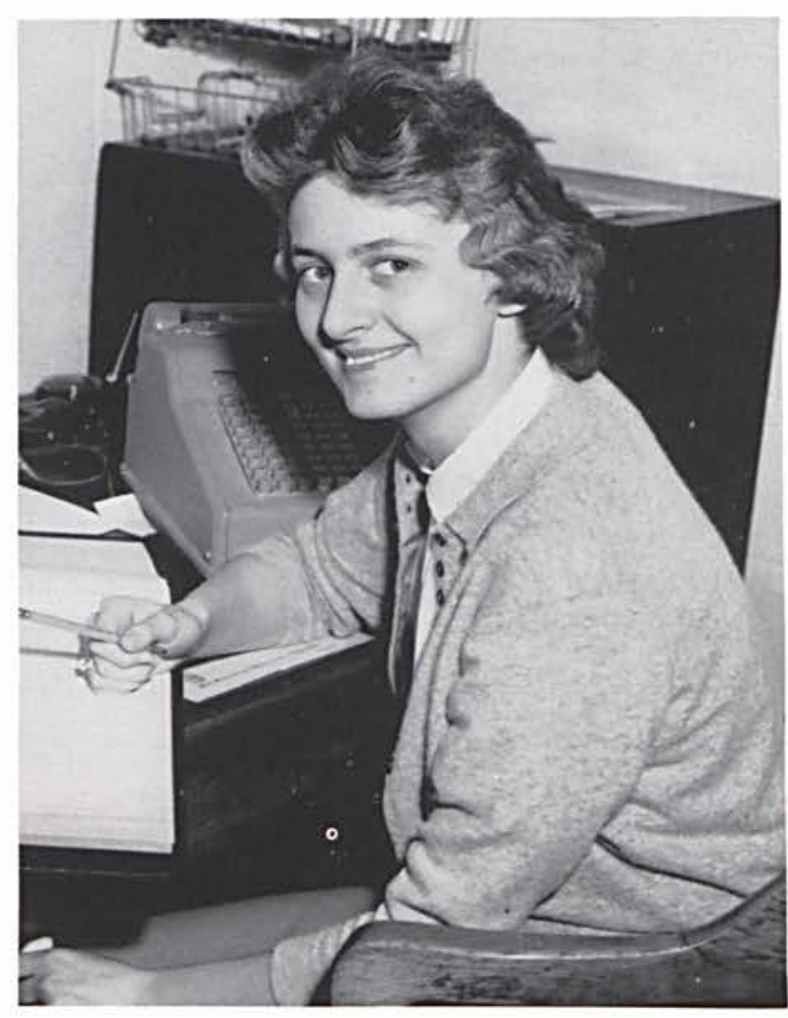

Miss Lois Jeremiah Assistant

\section{Bookstore Staff}

An ever popular place on campus is the College Bookstore. Bernice Mick, along with student help and part-time assistants, Mrs. Bergen and Lois Jeremiah, handles well the steady flow of customers.

This year the record selection has been increased and more cosmetics and drugs have been added.

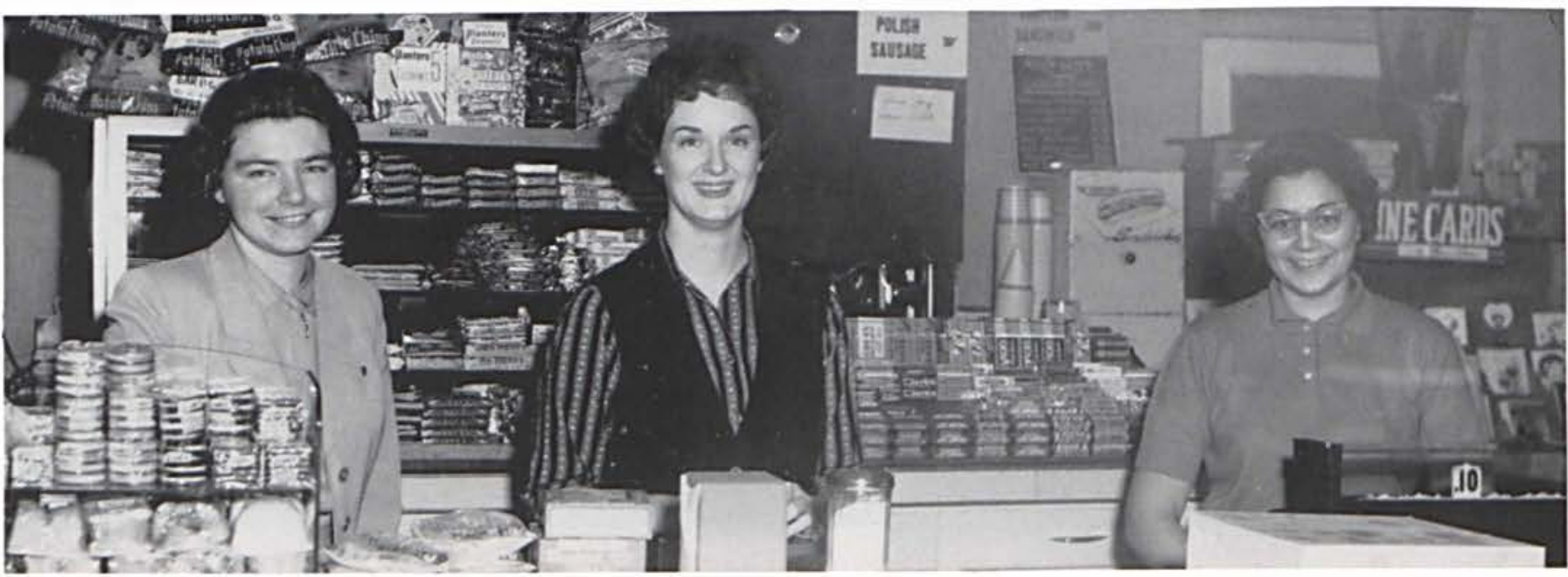

Left to Right: Charlene Ressler, Carole Lanius, Donna Finley. 


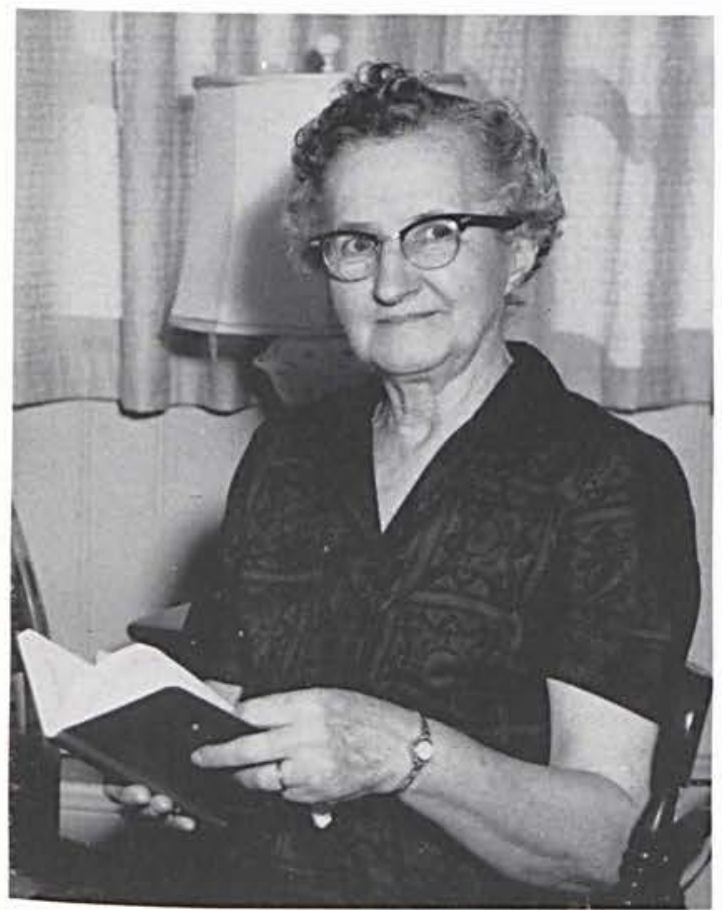

Mrs. Ruth Underwood Dorm Mother

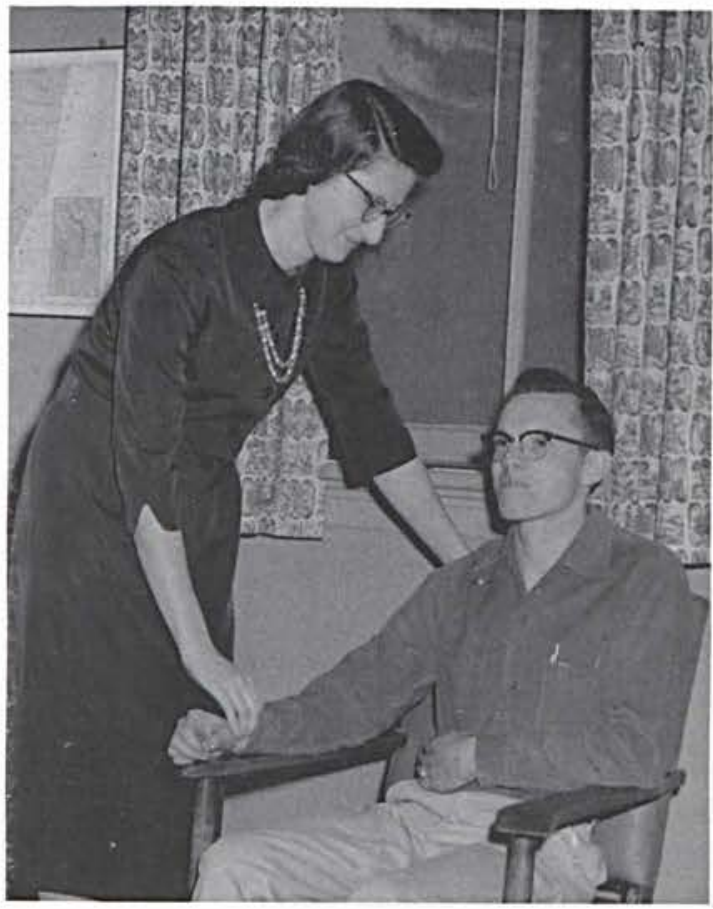

Miss Jean Fisher College Nurse

\section{Residence Staff}

Mrs. Underwood moved to her apartment in the new girls' dorm this fall where she is house-mother to the 110 girls there in addition to overseeing the dorm conduct of all the girls and serving on the college discipline committee. All the other dormitories on campus are governed by counselors and monitors.

Medical care is given to the students by the school nurse, Miss Fisher.

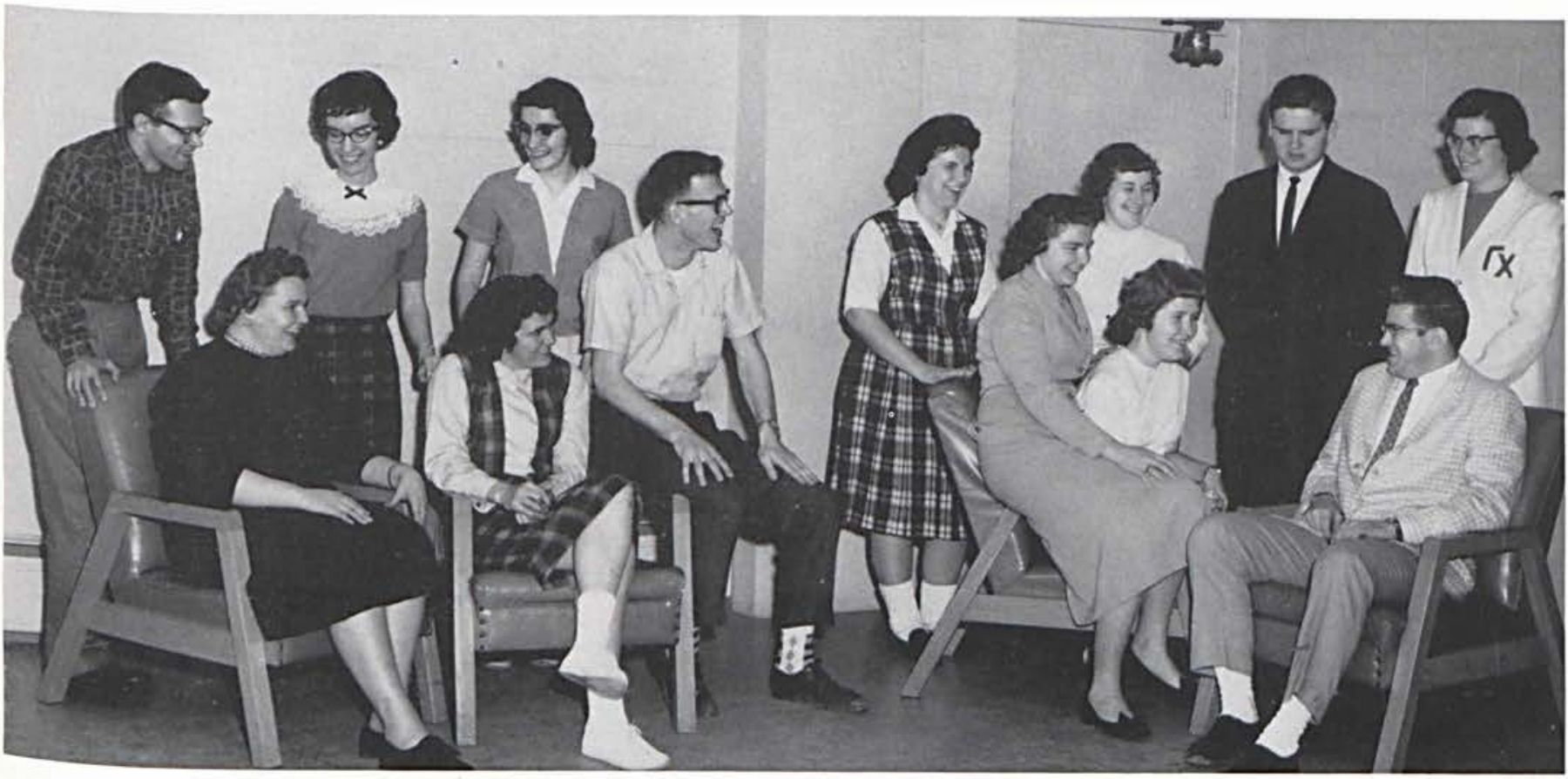

Seated, Left to Right: Delores Osborn, Nancy McDivitt, John Butler, Charlene Ressler, Shirley Harrington, Robert Domokos.
Standing: Keith Webster, Peggy Howard, Judy Bird, Barbara

Swertfager, Juanita Allford, Charles Hartzell, Jane Ginz. 


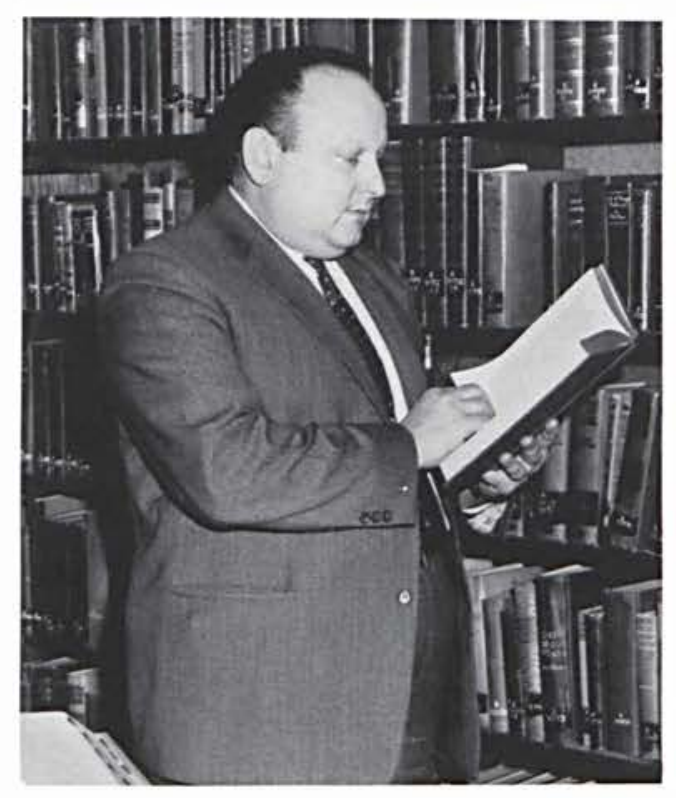

Mr. Paul Wyland

Director of Library

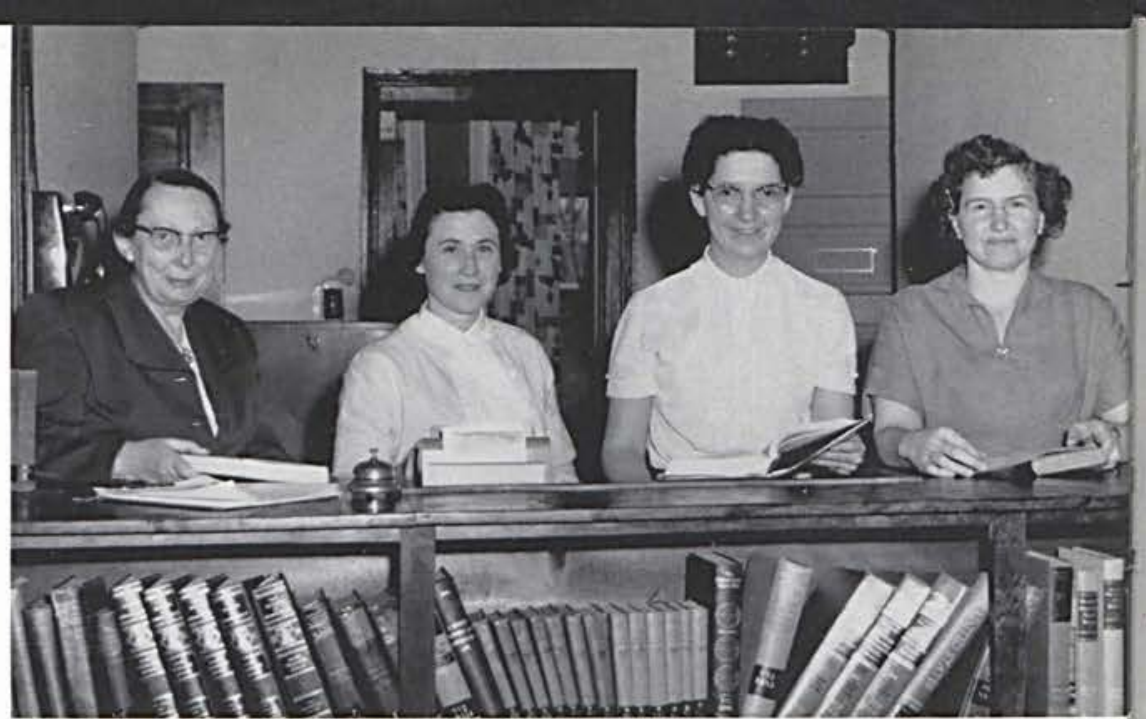

ASSISTANTS - Left to Right: Mrs. Esther Ruder, Mrs. Patricia Thornton, Mrs. Ida St. Clair, Mrs. Bonnie Alexander.

\section{Library Staff}

There have been several improvements in the library this past year. The student project and the faculty project of the previous year helped make possible the metal stacks for the periodical room. We also have new chairs and tables in the library.

Left to Right: Jim Keim, John Ingram, Jeri Wickell, Elaine Jordan, Peggy

Buerer, Beth Elmore.

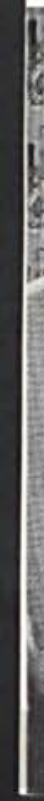

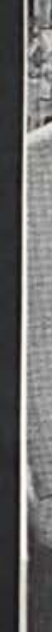

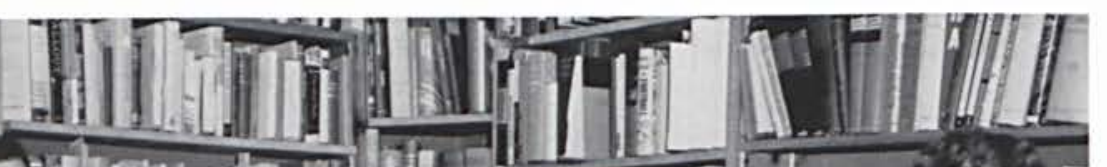

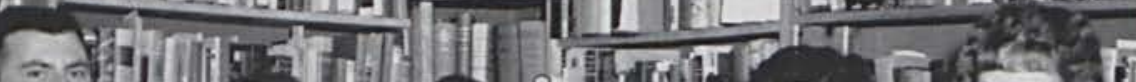

Mrs. Alberta Chaffe Head Librarian 


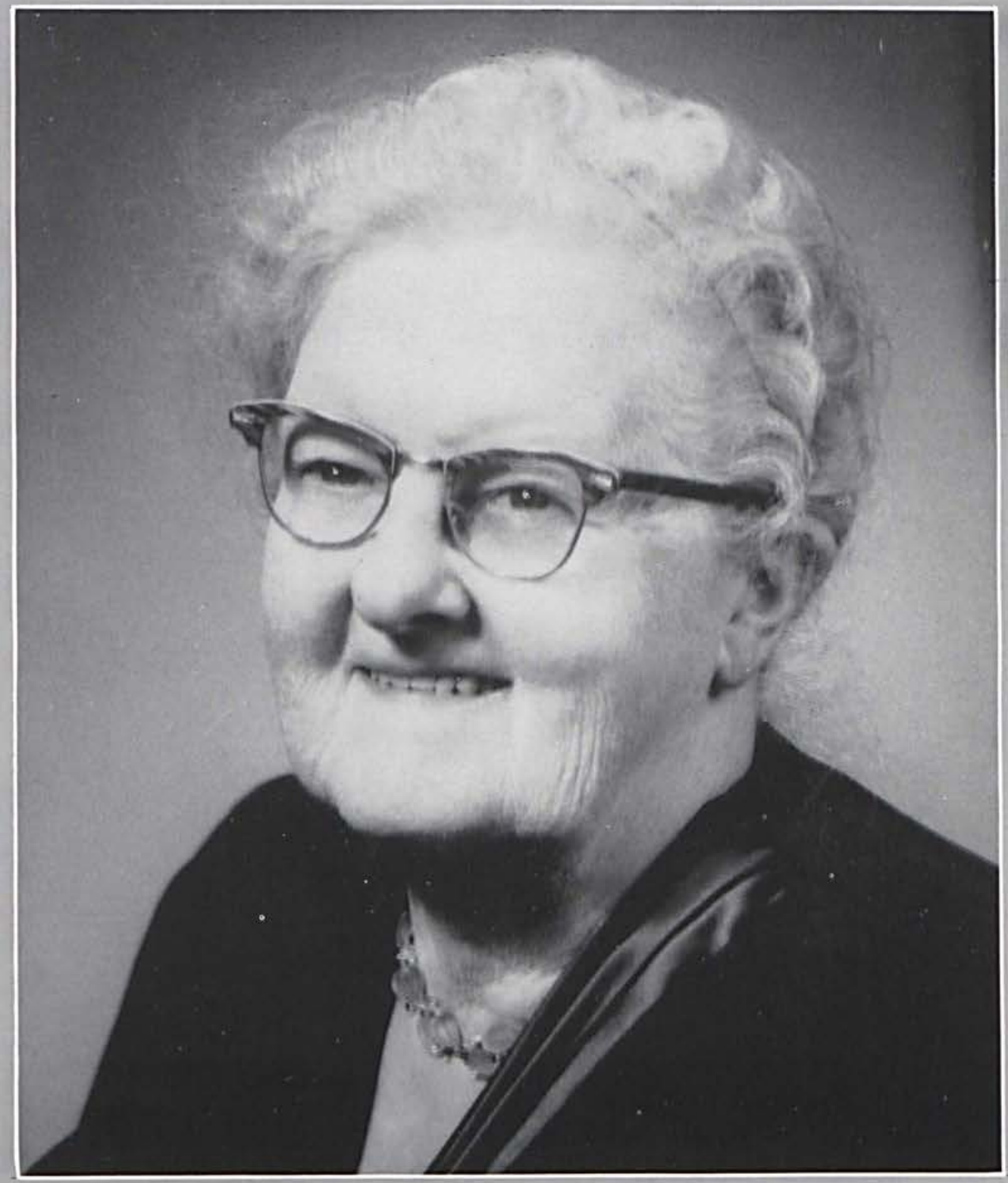

An oil portrait of Miss Mary Irwin Williamson, who served as librarian of Cedarville College for 37 years, from 1921 to 1957, is on display in the main reading room of the College Library. Special tribute was paid to Miss Williamson at the College Commencement exercises on May 28, 1960. The oil portrait will be hung permanently in a special reading room in the College Library to be known as the Mary Williamson Room. 


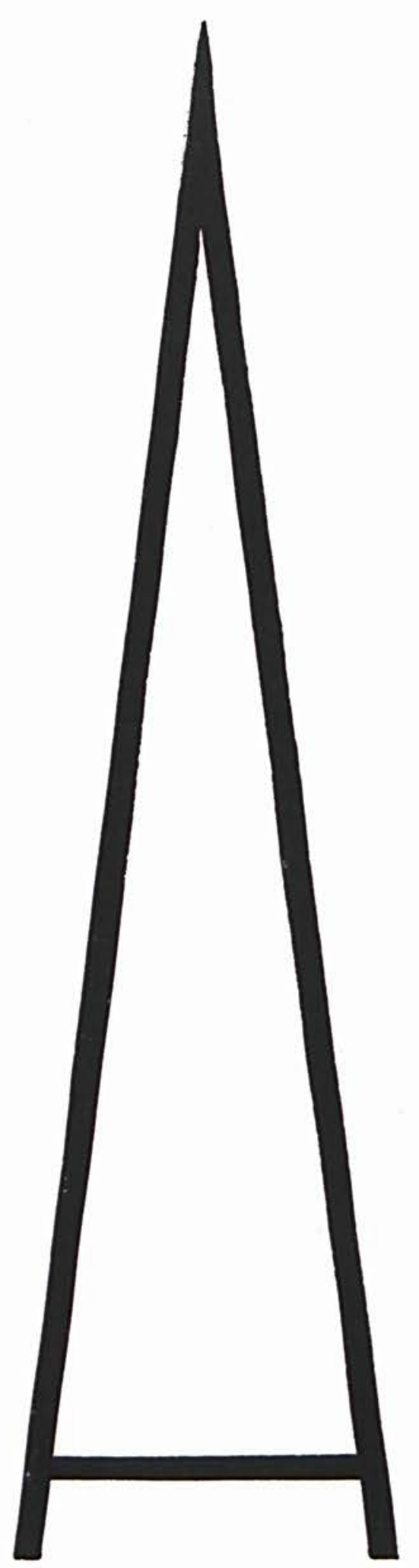

The silence of the empty classroom brings back the memory of lectures, class notes, exams, and term papers. The patience and UNDERSTANDING of our Christian instructors make these experiences happy ones.

\section{CONTENTS}

Biblical Education

Educational Psychology

Health and

Physical Education 39

Music

Language and Literature 44

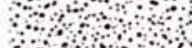

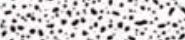

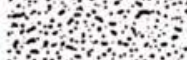

Science 47

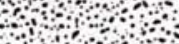

40

Social Science 50
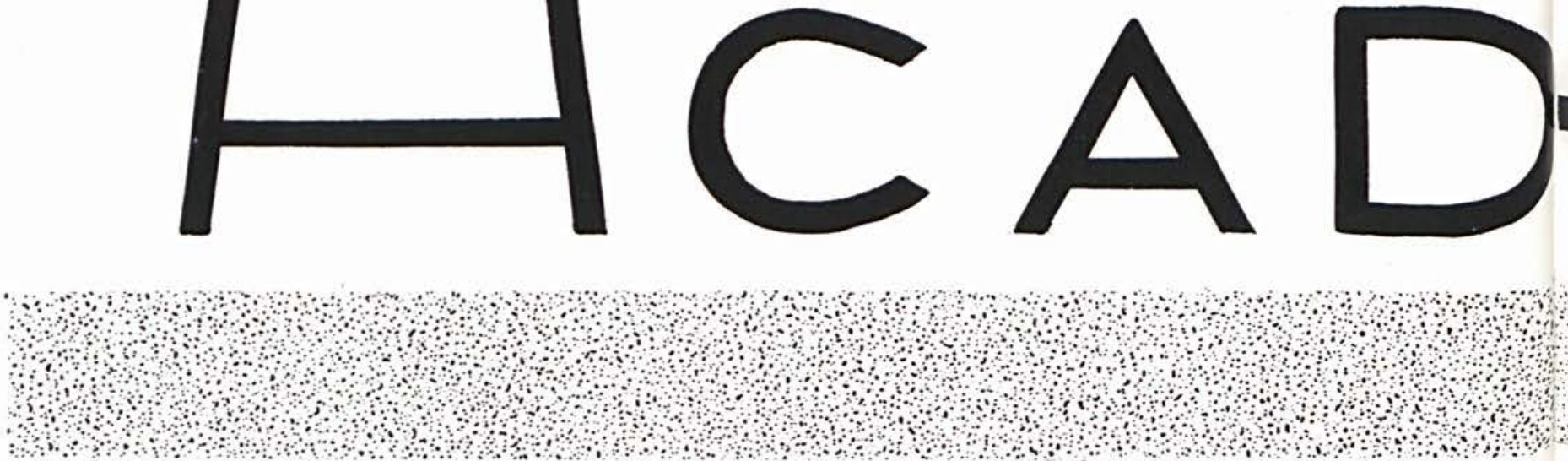

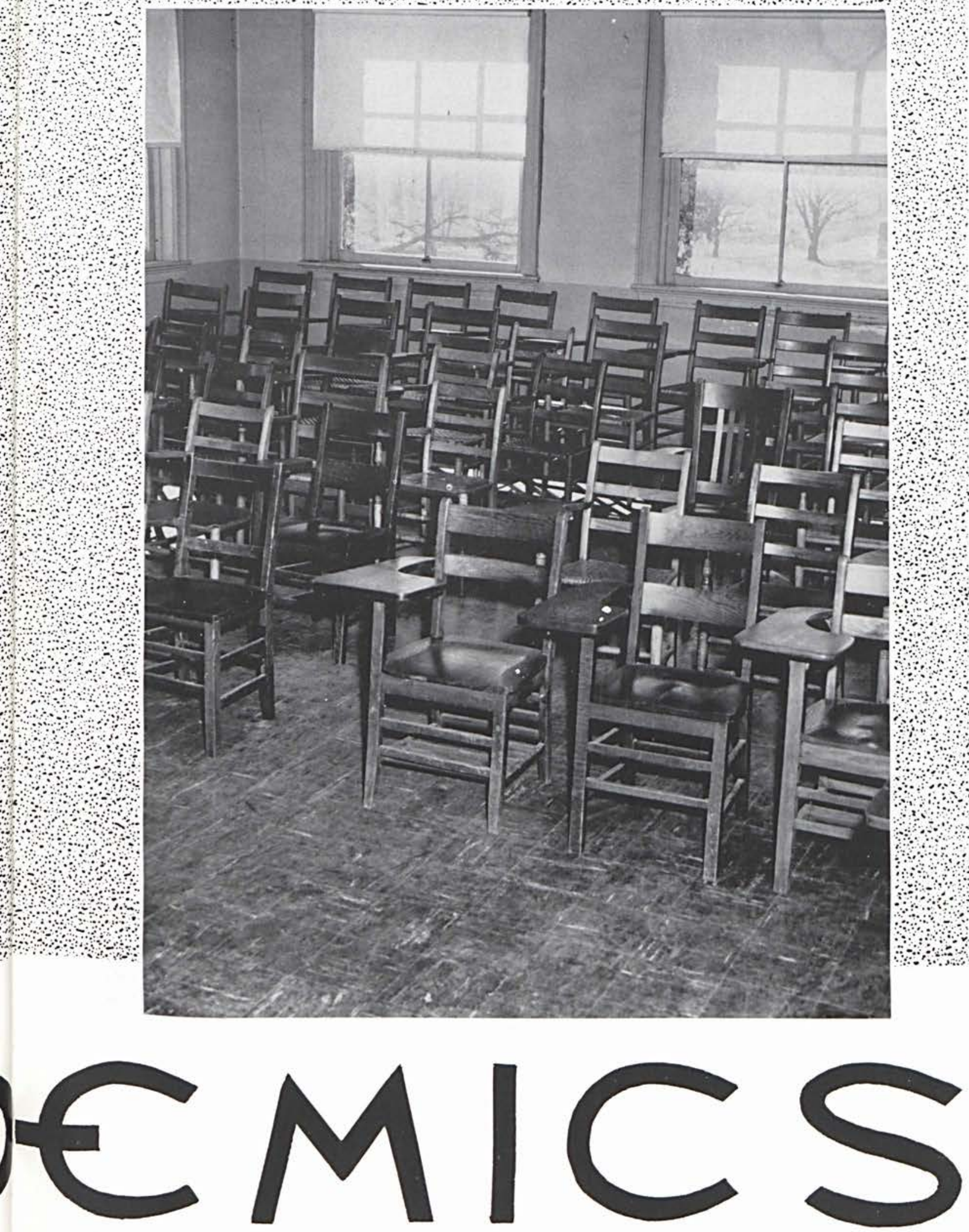


\section{Division of Biblical Education}

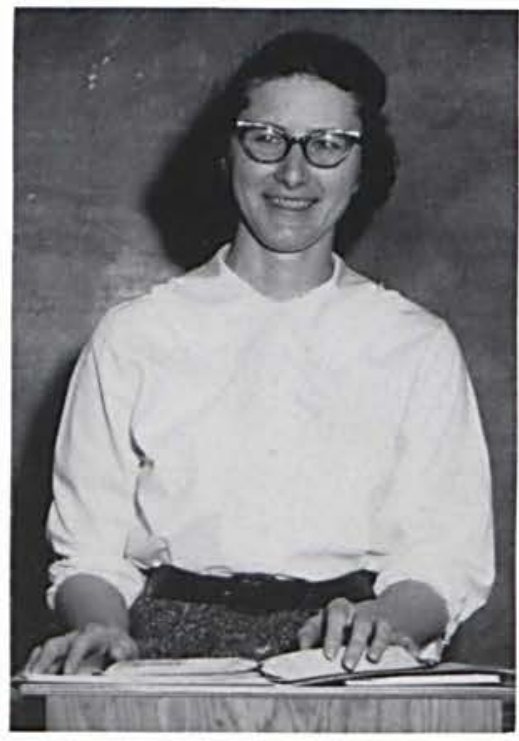

Jean Fisher, B.R.E.

Christian Education

\section{Faculty}

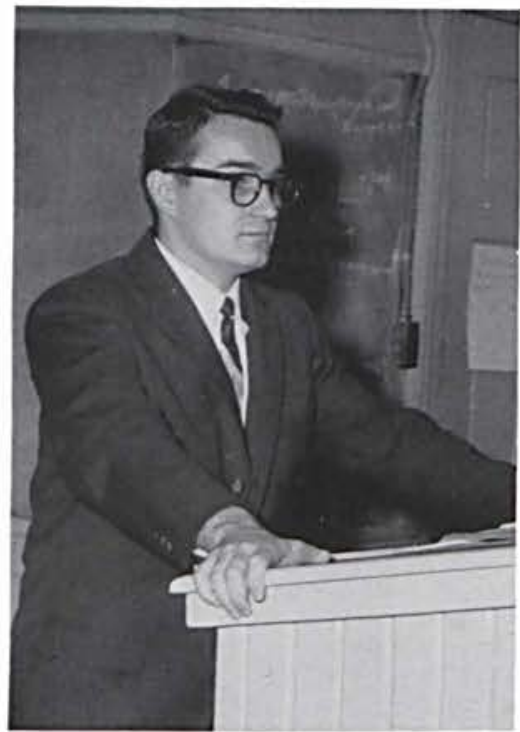

Robert Gromacki, Th.B., Th.M. Bible

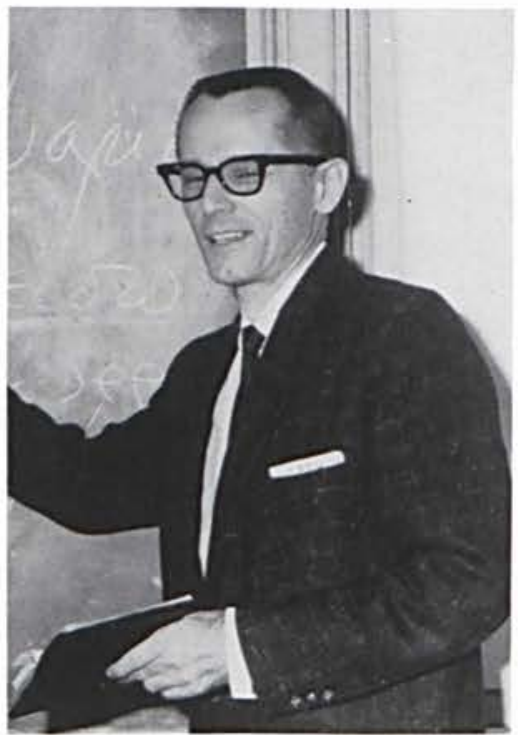

George Lawlor, B.D., Th.M. Bible, Greek
All students benefit by the Division of Biblical Education. It may be divided into two main divisions ... the general Bible course for the student not preparing for full time service and the specific Bible course for the student wishing to serve his Lord as a pastor, missionary, or other specialized fields. In either case, godly professors carefully and helpfully instruct a thorough, systematic study of the Bible. This year Mr. Gromacki has joined the teaching staff in this department.

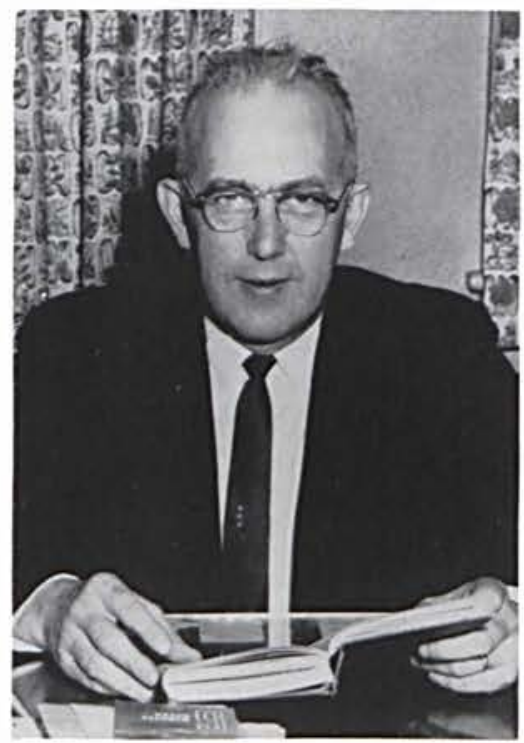

James Jeremiah, Th.B., A.B. Bible Doctrine 


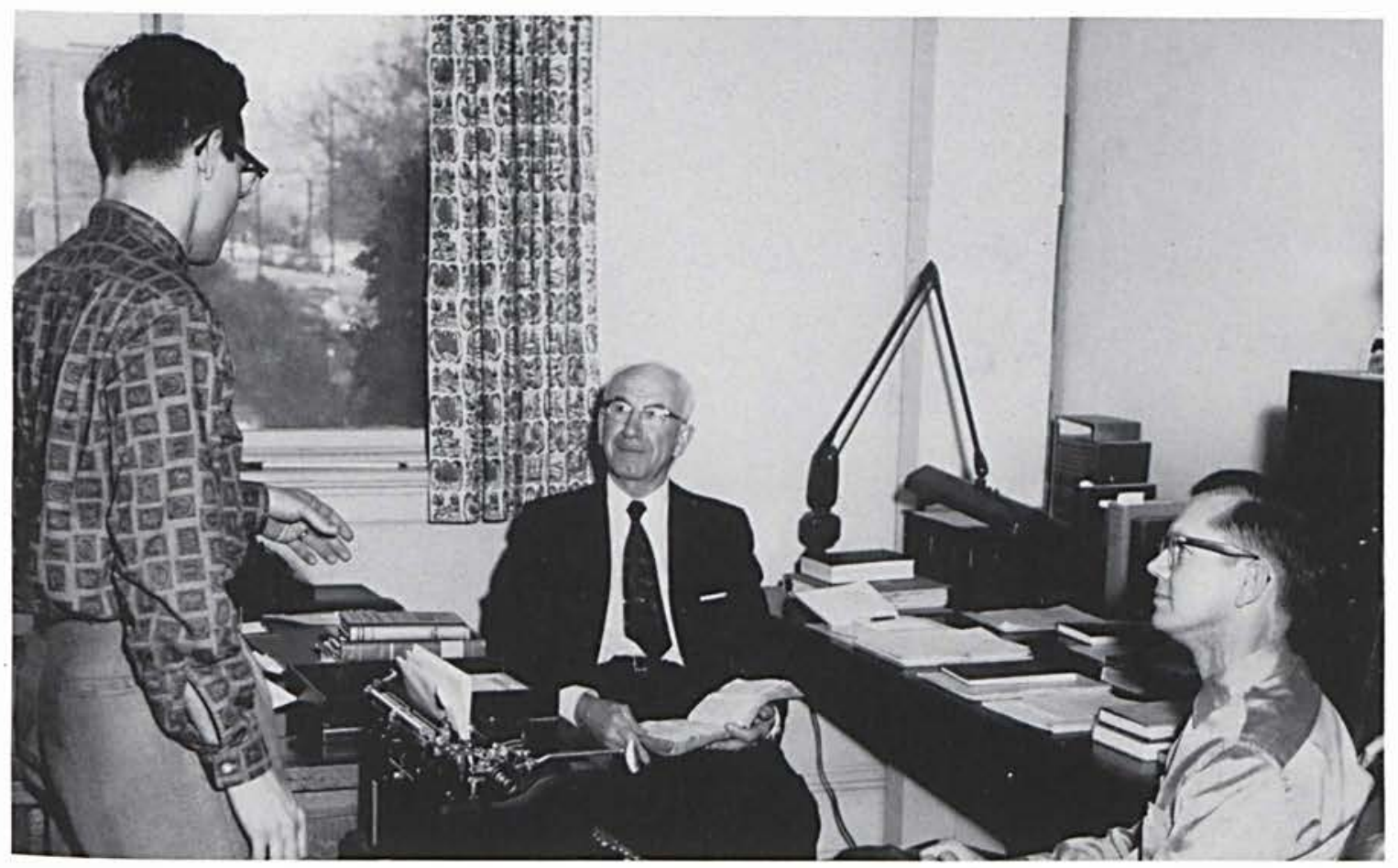

Dr. Williams gives some advice to Keith Webster and Rush Frazier about Pastoral Theology class.

The main purpose of this course of study is to give us a sound background so that we can then be more effective witnesses for the Lord Jesus Christ in whatever field God directs us.

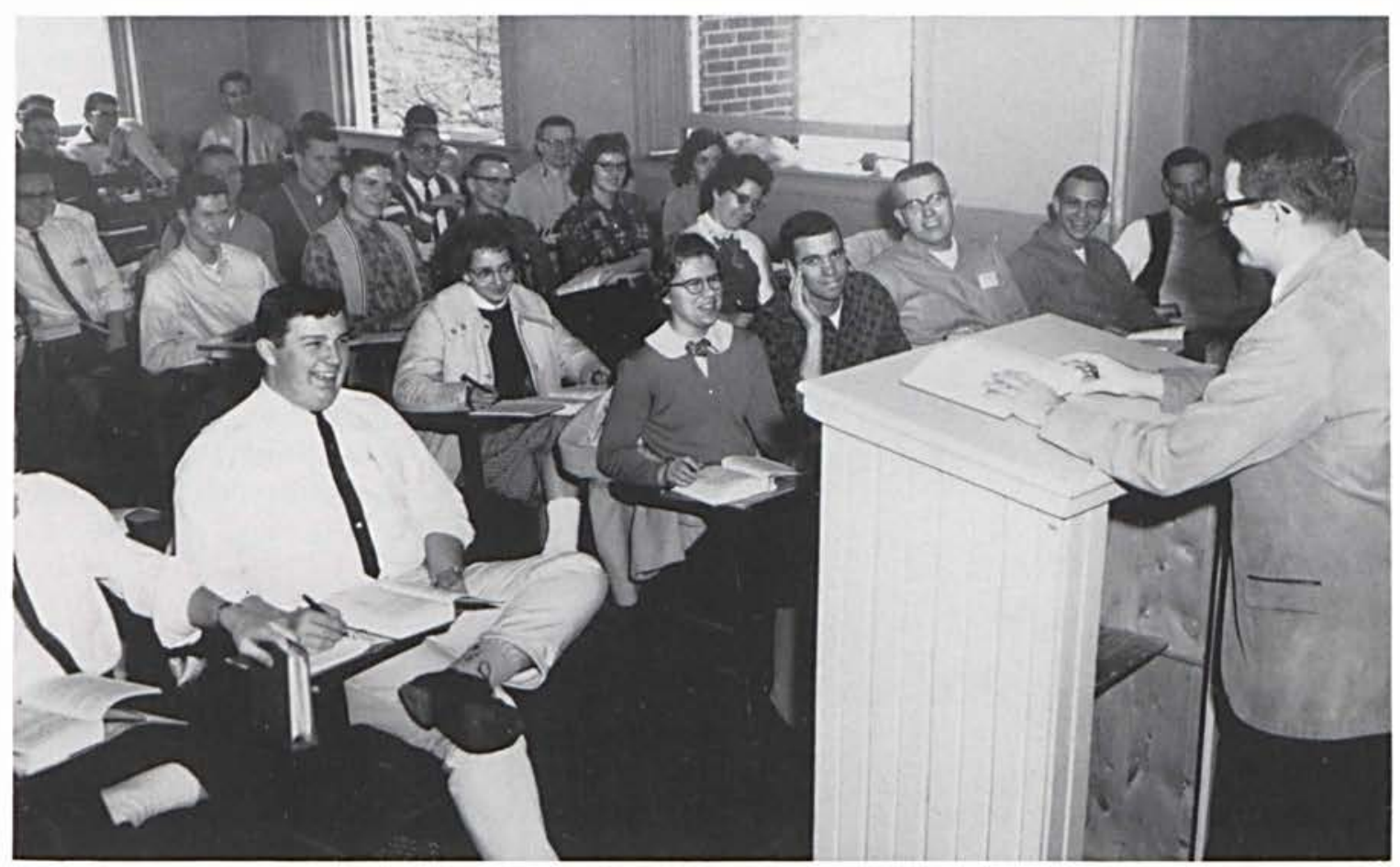

Students find New Testament Survey interesting under the instruction of Mr. Gromacki. 


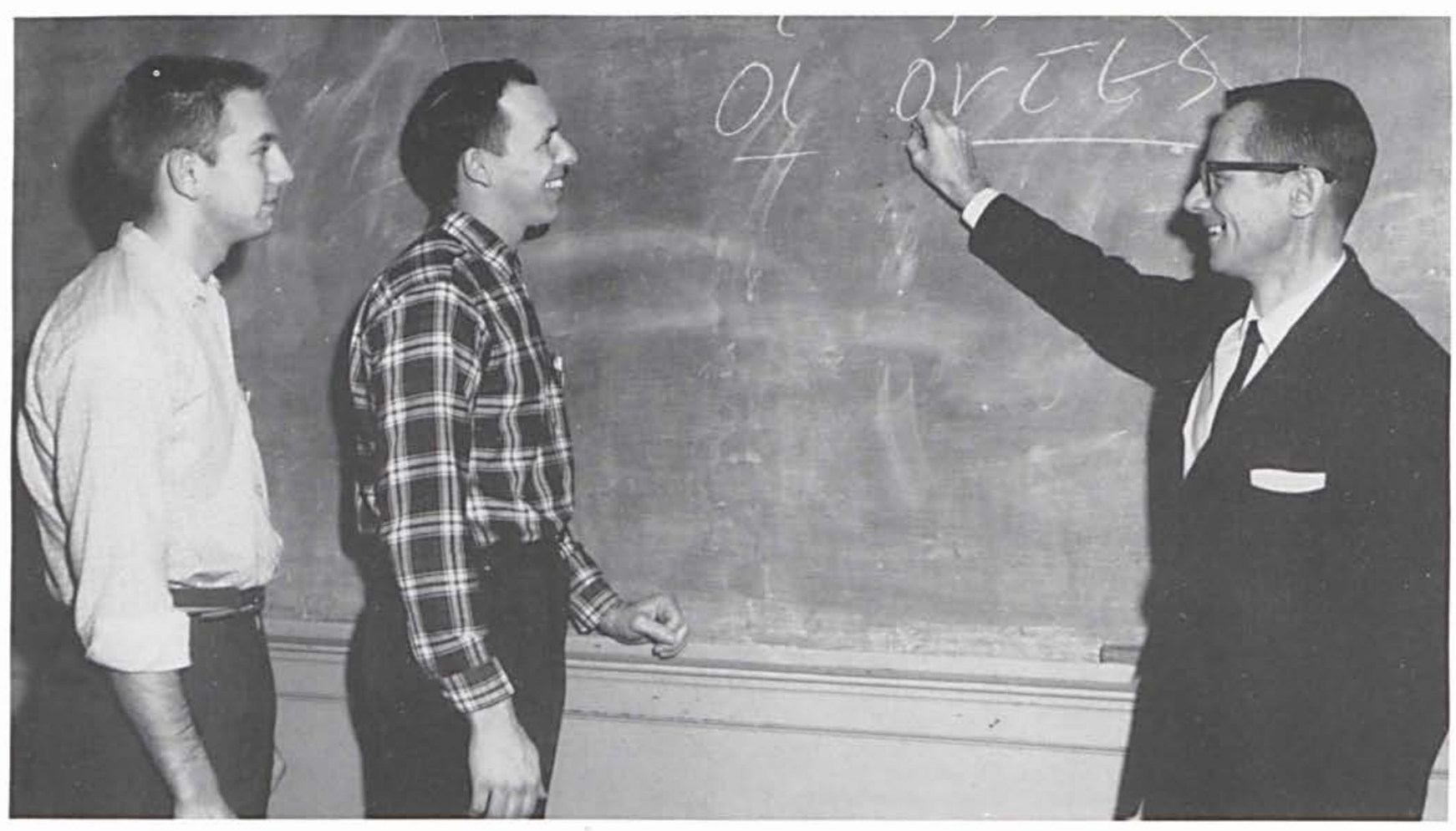

Paul Gathanay and Art Hicks receive an explanation in the study of Greek from Mr. Lawlor.

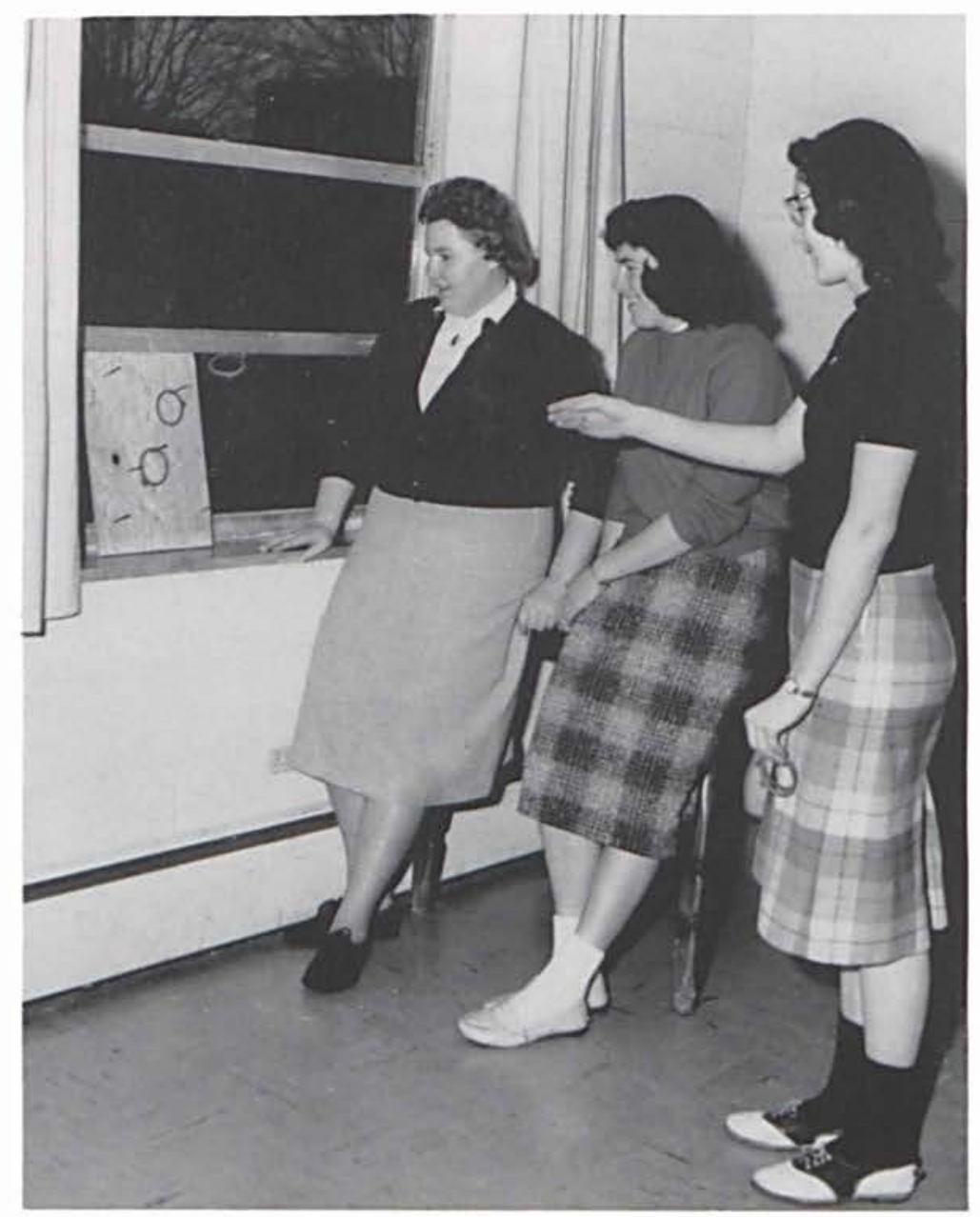

Mr. Lawlor's Greek classes had a speciai treat during this school year. Rev. Spiros Zodiathes, the outstanding radio speaker of the American Missions to Greece, was on campus. He spoke to the Greek classes showing them that the Bible in the original text is so very necessary to proper interpretation.

Our Christian education department uses both theory and practice to prepare us for Christian service. In addition to course work in Education Work of the Church, students are required to put theory to practice by teaching children's groups under the supervision of the Christian Education instructor, Miss Fisher.

Dee Osborn, Nancy McDivitt, and Judy Bird play at "ring toss" at the April Fool's Party which climaxed the semester of Christian Education of Youth. 


\section{Division of Psychology and Education}

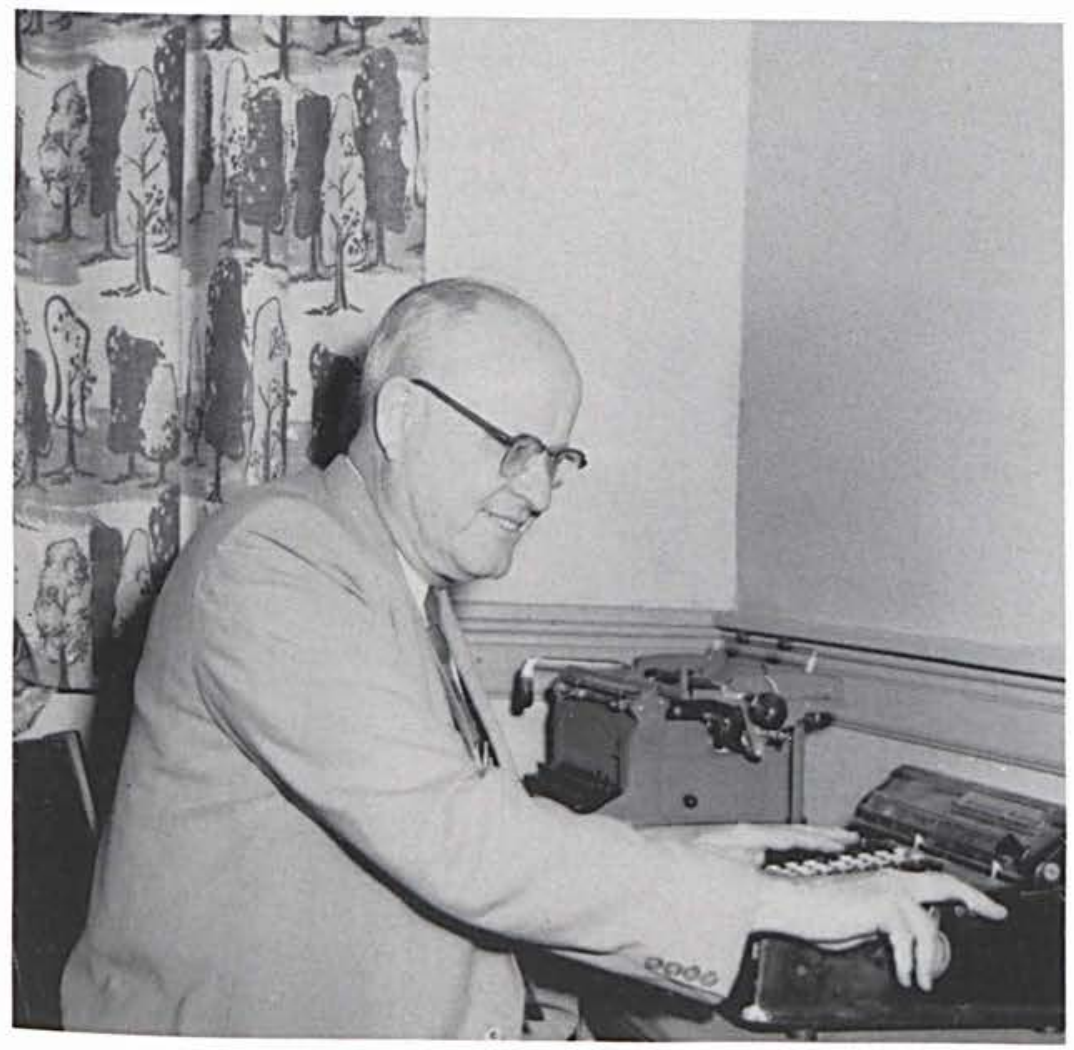

\section{Faculty}

Clifford R. Maddox, Ph.D. Psychology

Teaching is only part of the duties of Mr. Underwood and Dr. Maddox in this department. Much time is spent in counseling and in aiding the students in finding employment after graduation. This year eight seniors plan to enter the teaching profession after graduation in June.

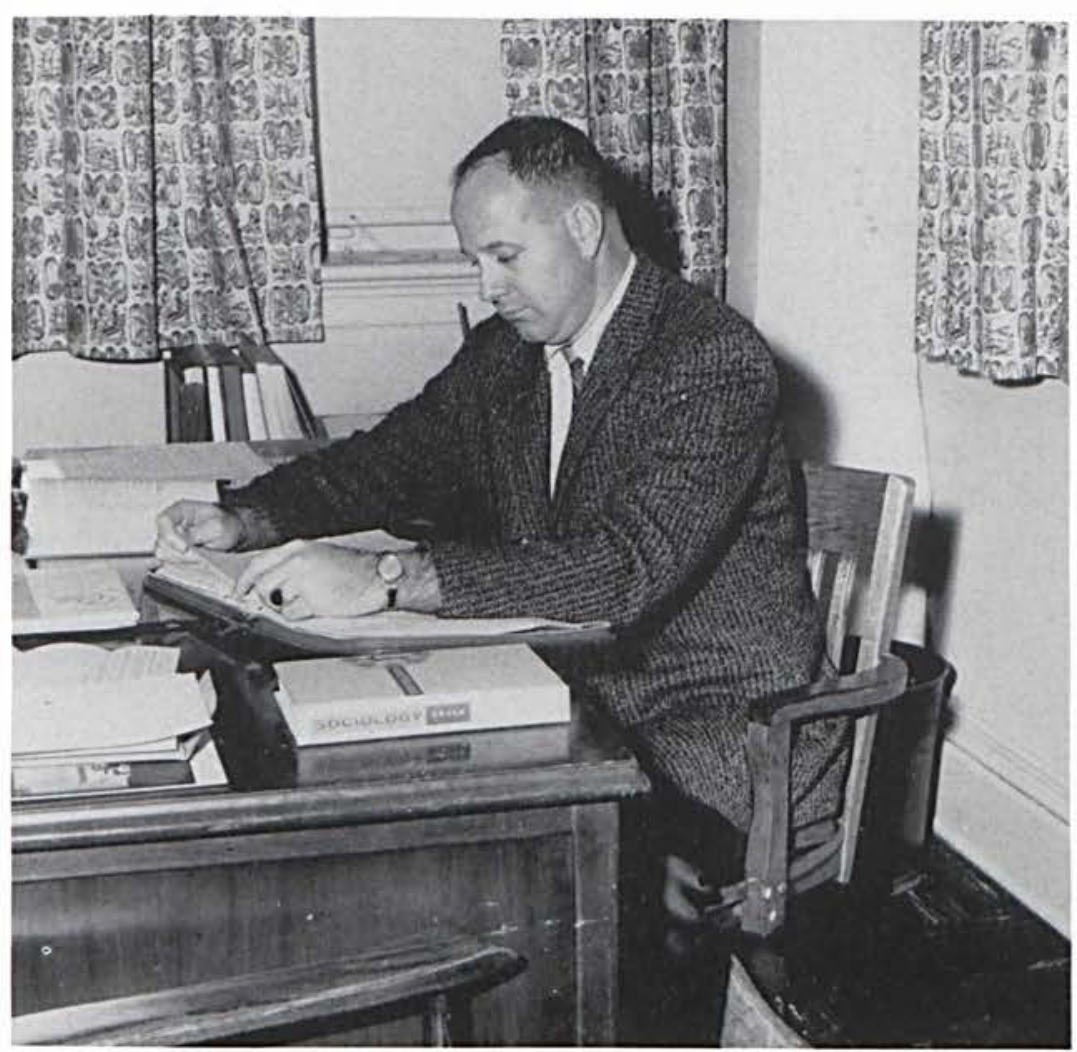

Robert Underwood, M.A.

Education 


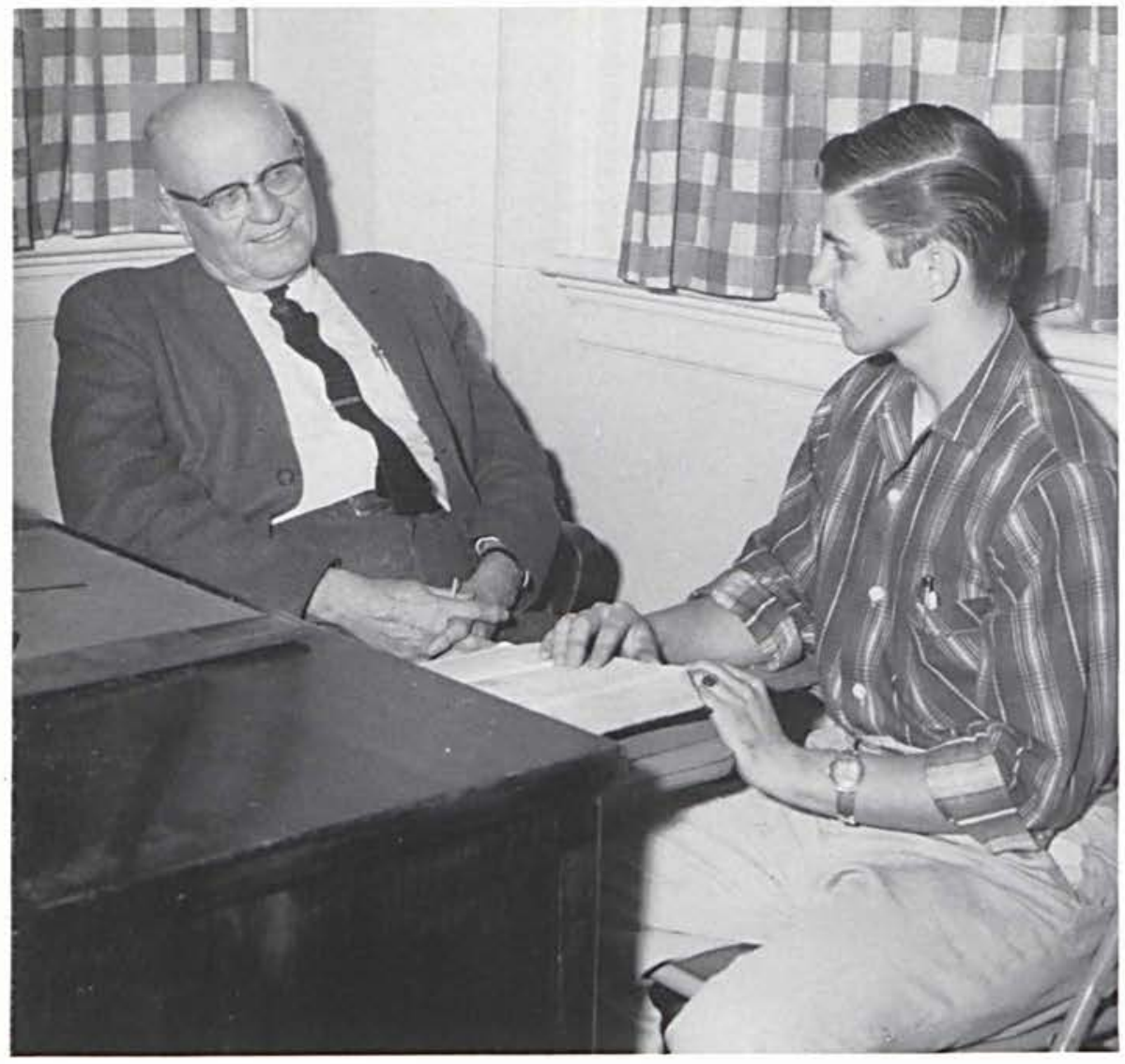

We students who wish to teach in the public or private education systems are greatly interested in this department. The 175 majors and minors now in this division are enrolled in courses ranging from Introduction to Education to Applied Psychology. Our agreement with Central State College allows students to pursue part of their education program on their campus which is just four miles away.

We find guidance through many trips to the office of Dr. Maddox. At the end of our years at college, we will have learned that "college is different."

Dr. Maddox counsels with Gary Hogard.

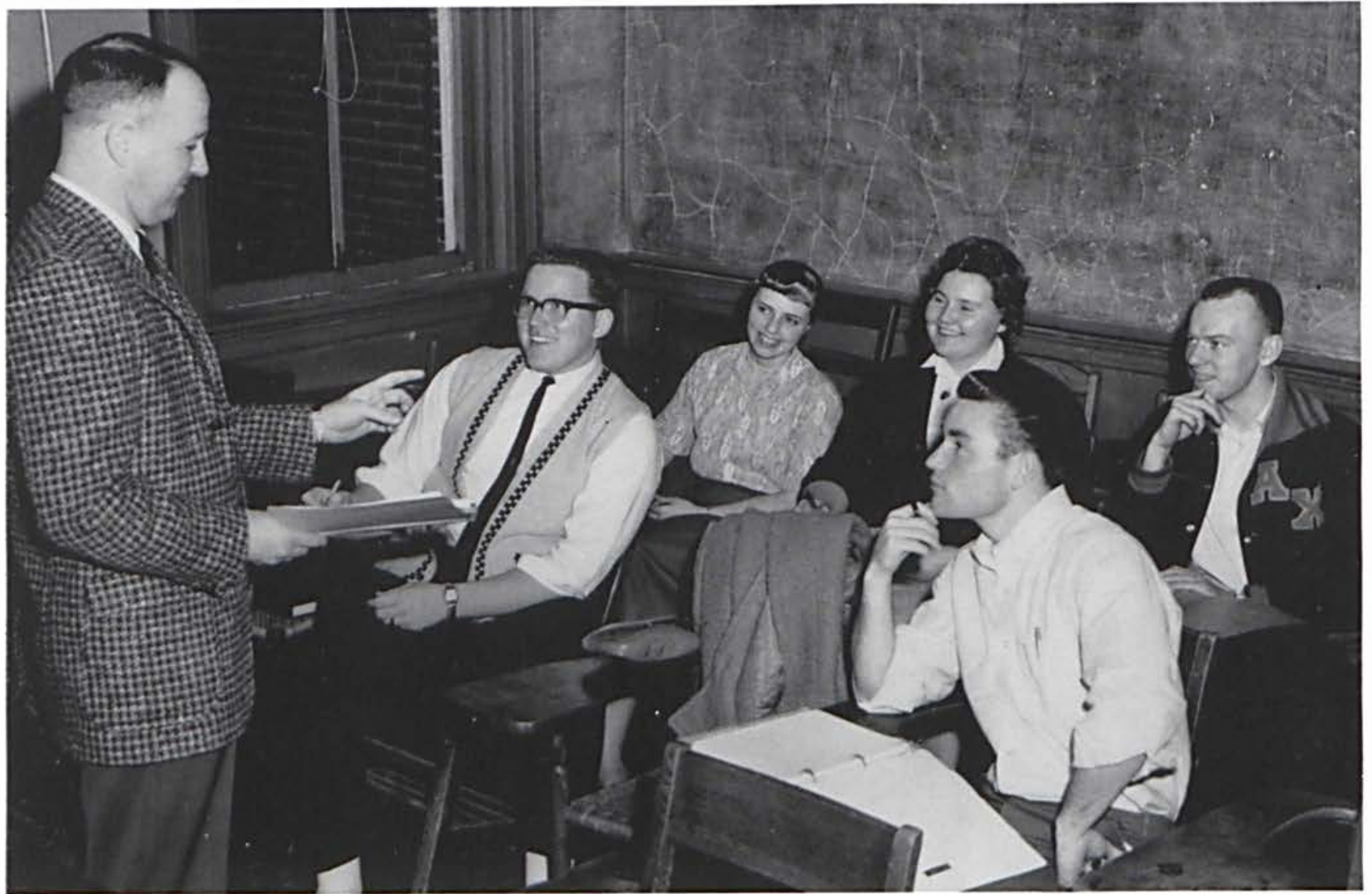

Students receive a new concept in Philosophy of Education under the teaching of Mr. Underwood. 


\section{Division of Health and Physical Education}

\section{Faculty}
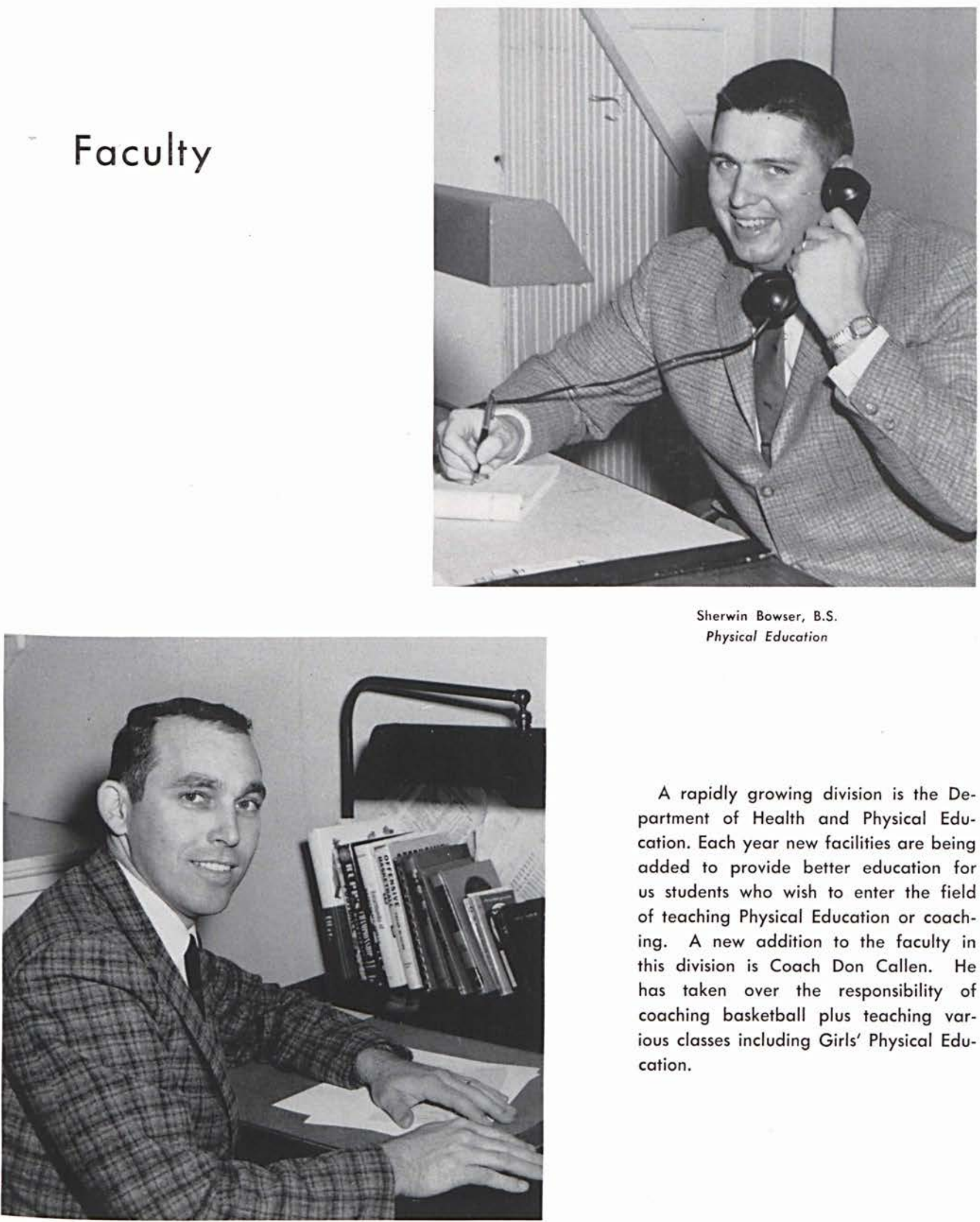

Sherwin Bowser, B.S

Physical Education

A rapidly growing division is the Department of Health and Physical Education. Each year new facilities are being added to provide better education for us students who wish to enter the field of teaching Physical Education or coaching. A new addition to the faculty in this division is Coach Don Callen. He has taken over the responsibility of coaching basketball plus teaching various classes including Girls' Physical Education. 


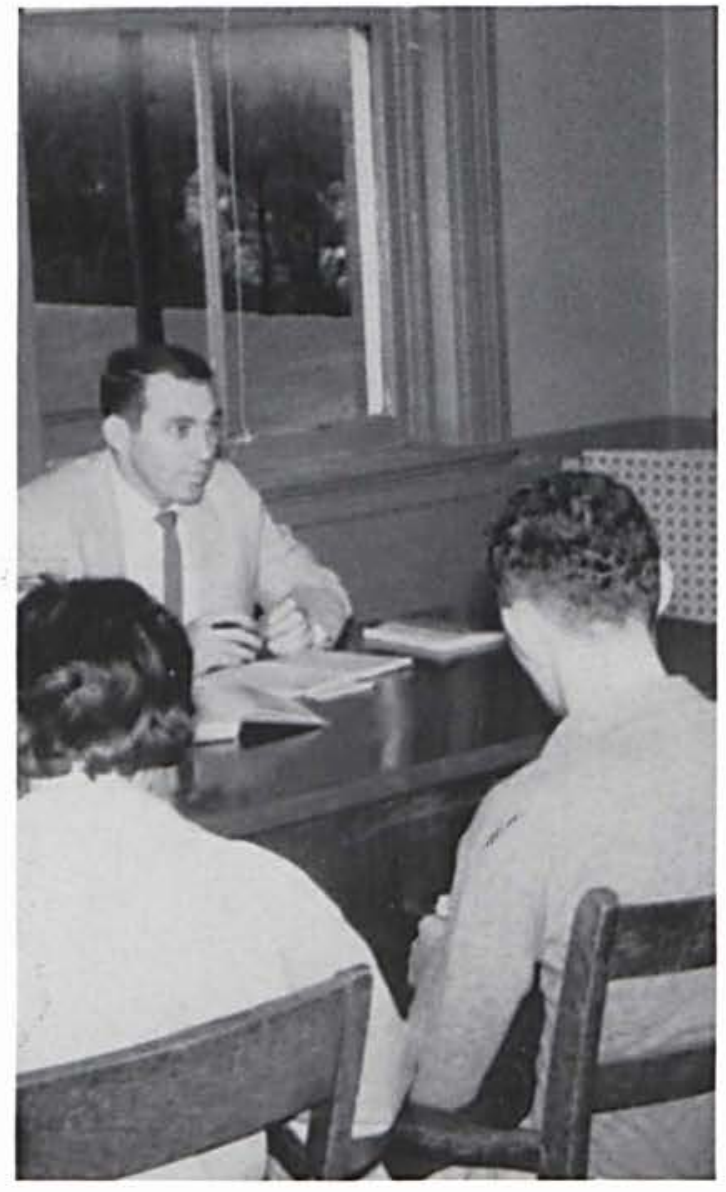

This division not only trains us to teach in public schools, but it also trains us for church youth work. This year we will be using not only our gymnasium and baseball field, but also the quarter mile track which surrounds the gridiron.

A big project of this year was the plan of building a recreation center. This will provide a gymnasium, recreational facilities, snack shop, and student lounge. The Student Project this year will be applied to the fund for this project.

Mr. Callan presents methods of safety to his First Aid class.

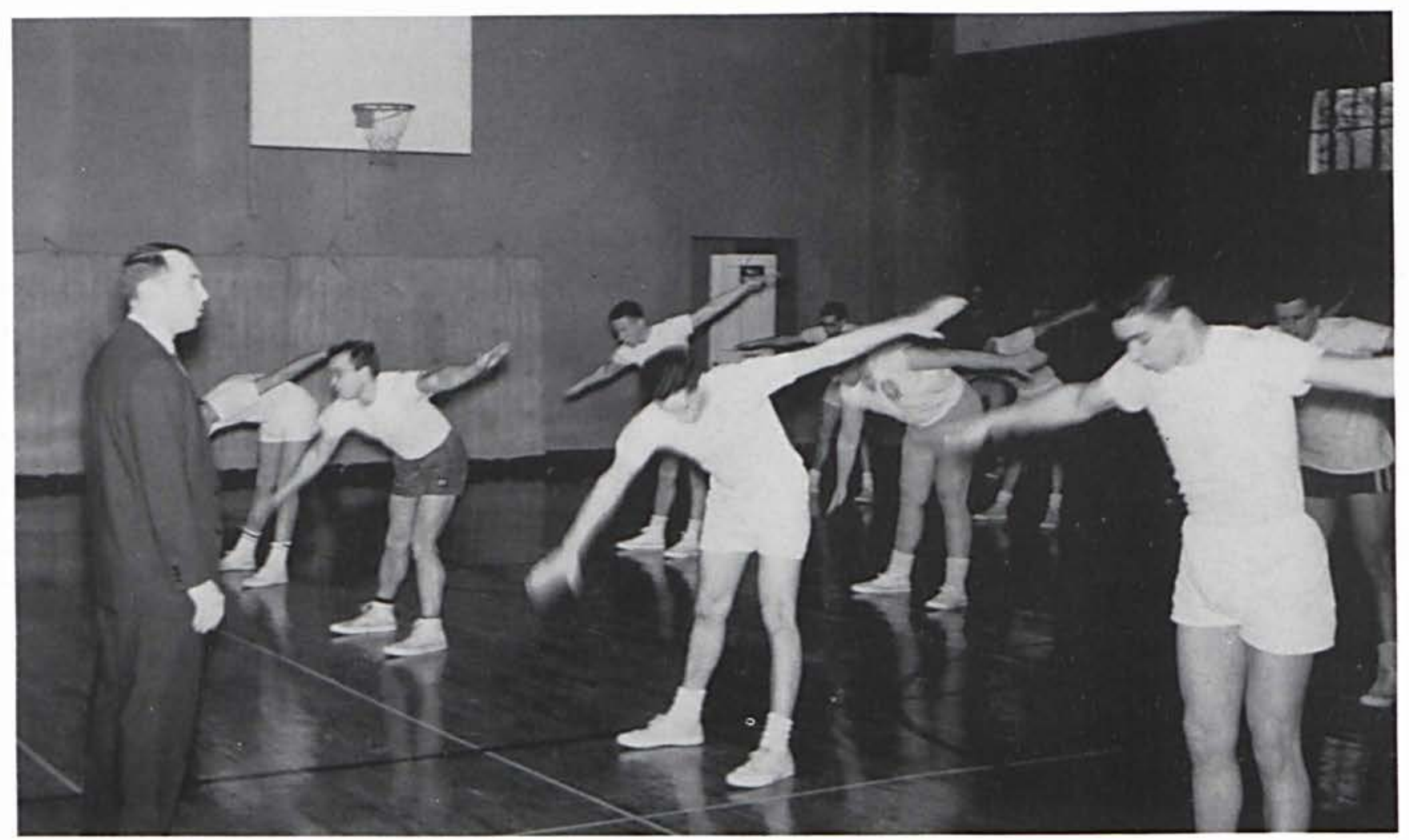

One of the Freshman men's Physical Education classes exercise before beginning an hour of activity. 


\section{Division of Music}

\section{Faculty}

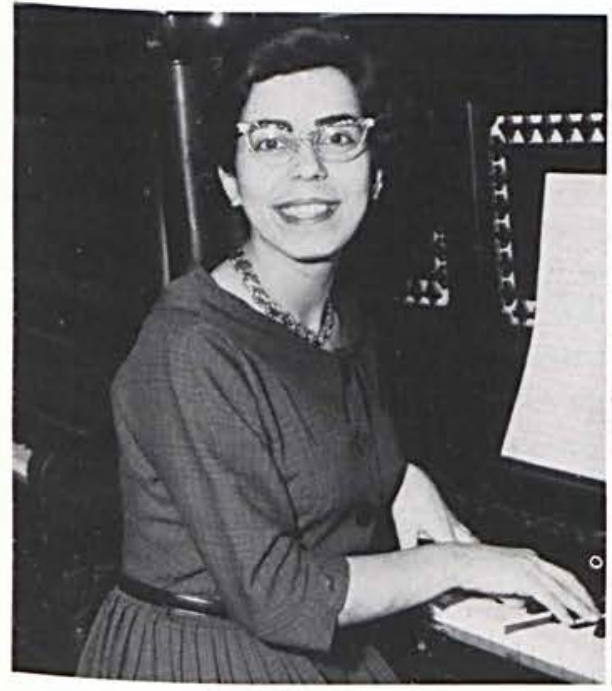

Rebecca Cooke, B.S.

Piano and Voice

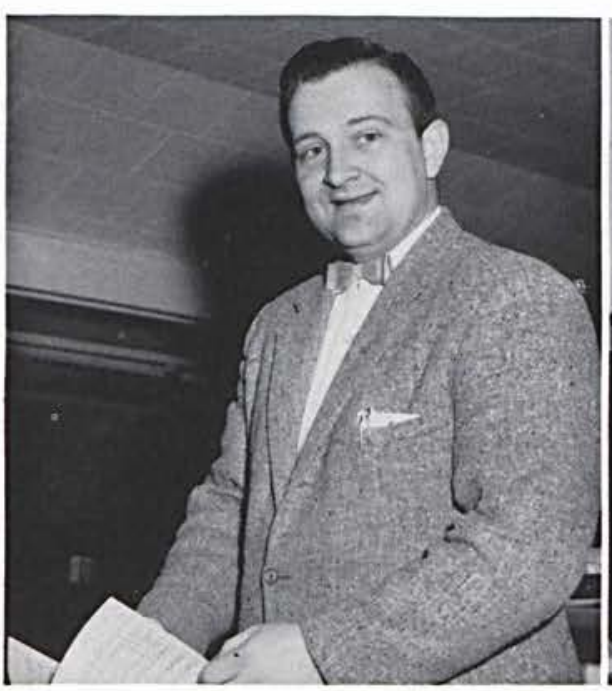

Richard Cooke, M.S.

Vocal Music

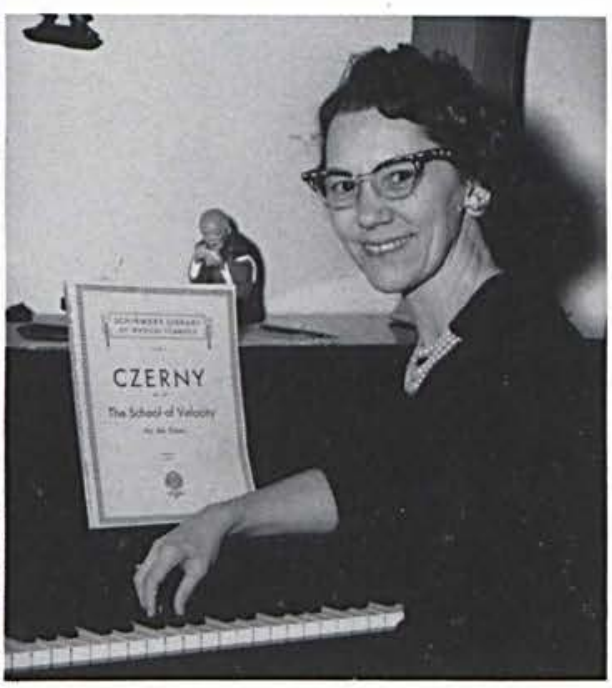

Lois Moffat

Piano

Young people with musical talent come to Cedarville to find advanced training in the Music Division of the College. Here we find musical direction under skilled and competent faculty. The course of study may include courses from Conducting to Counterpoint. New to the department this year is Mr. Thornton.

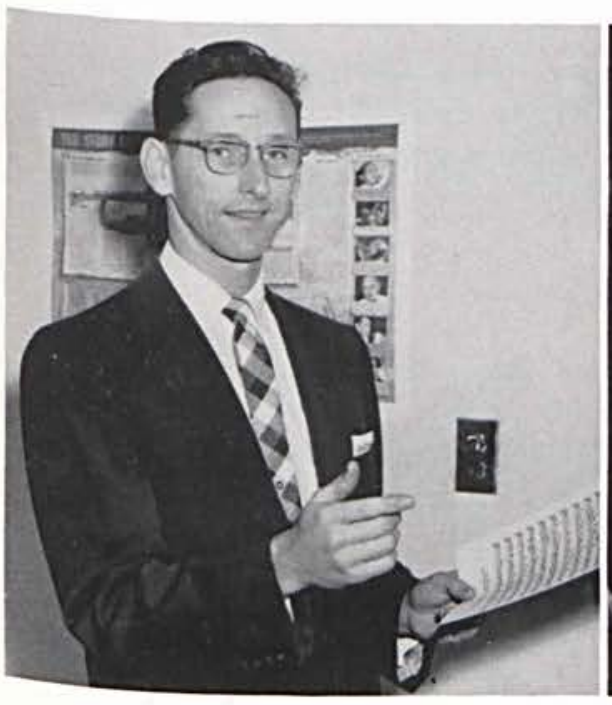

William Thornton, B.S., M.S. Instrumental Music

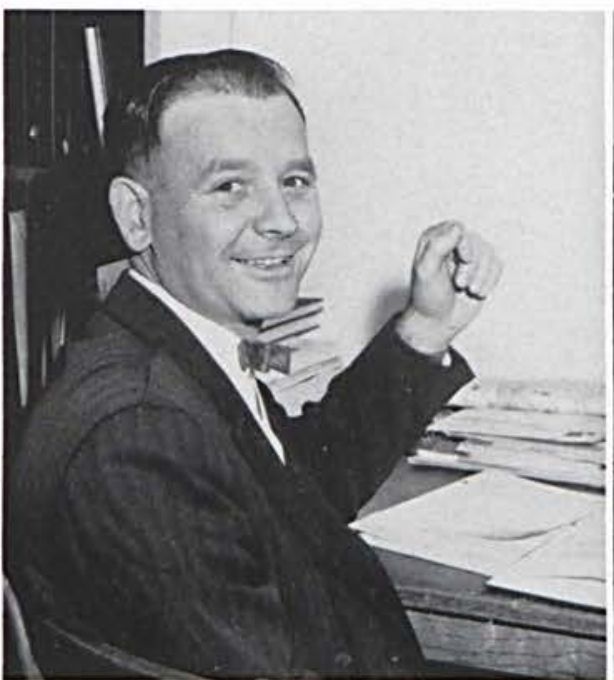

Warren Webber, M.Mus.Ed. Instrumental Music

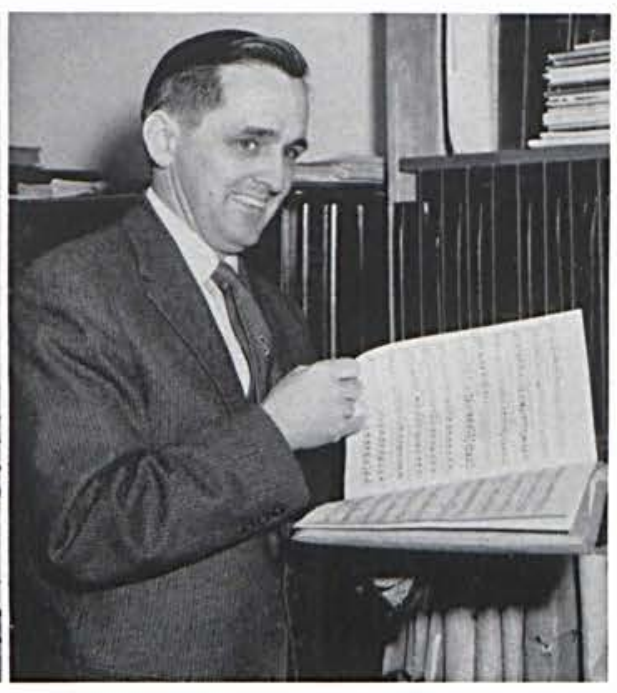

George Zinn

Vocal Music 
Virginia Jackson spends a long hour in one of the six practice rooms located in Milner Chapel.

Both Mr. Thornton and Sam Canine seem to enioy this trumpet lesson.

From the Music Department the school selects various musical groups to represent the College in churches throughout the mid-west. This summer a Girls' Trio and a Men's Quartet will act as ambassadors for the entire college as they sing at camps and church groups throughout the United States.
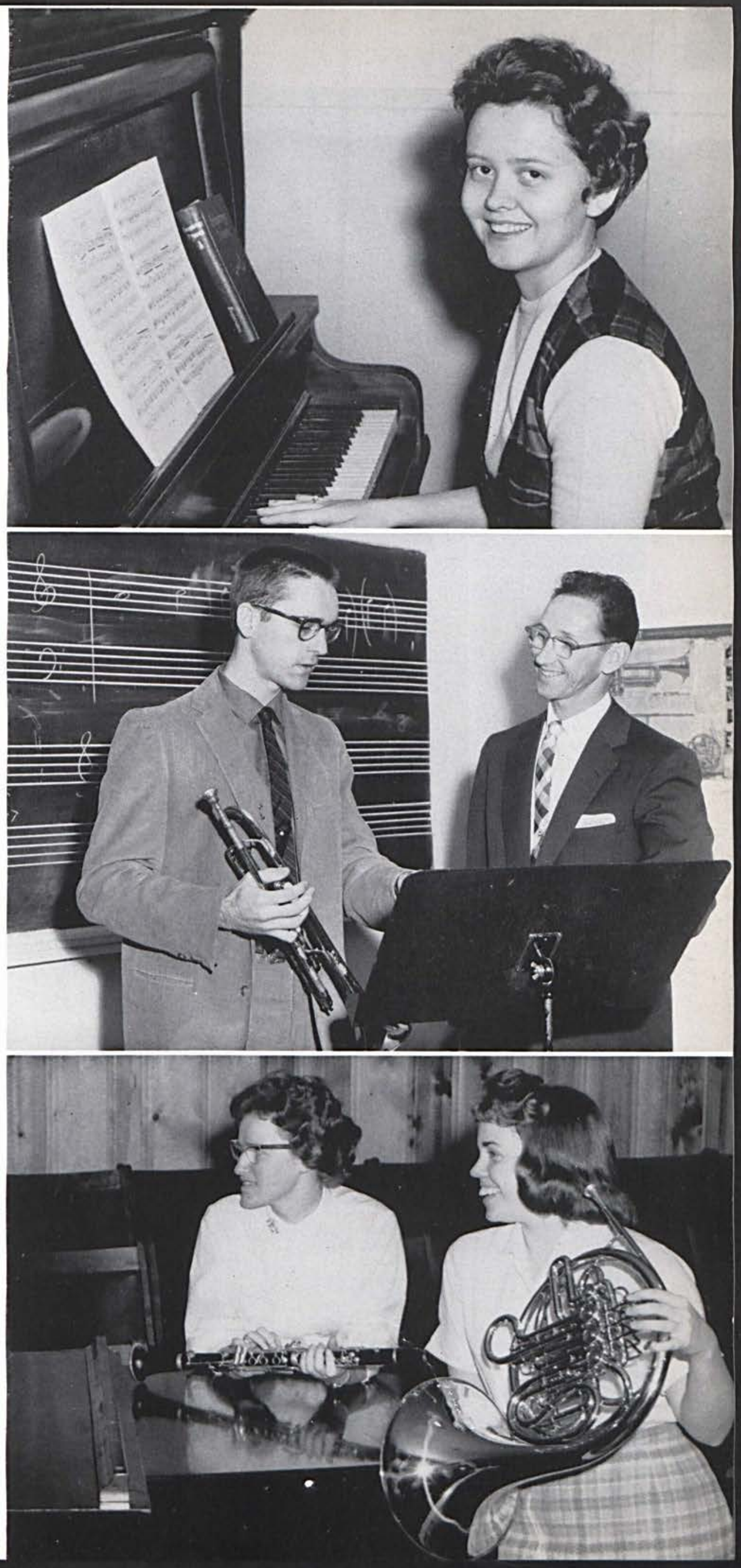

Sally Bender and Joyce Walker listen to a portion of band music. 


\section{Division of Language and Literature}

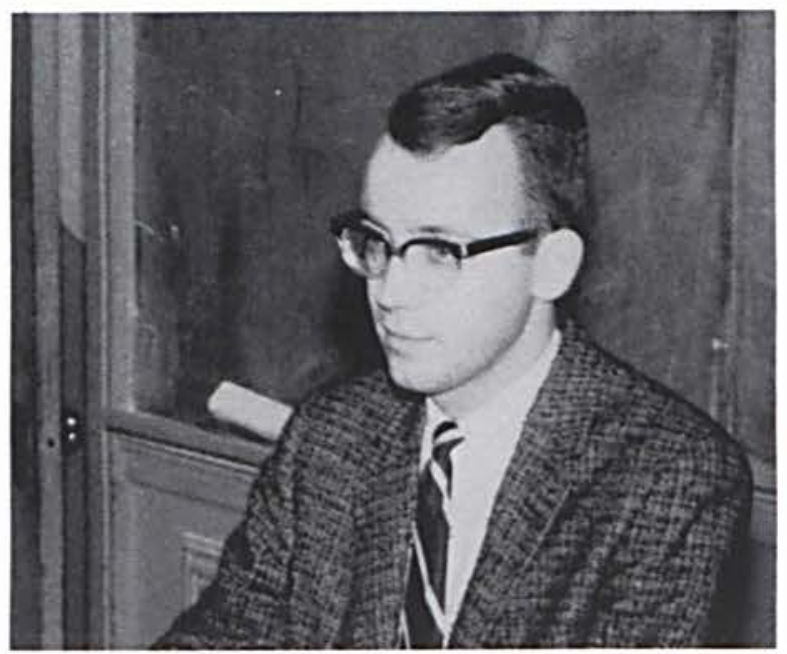

Raymond Bartholomew, M.A. English

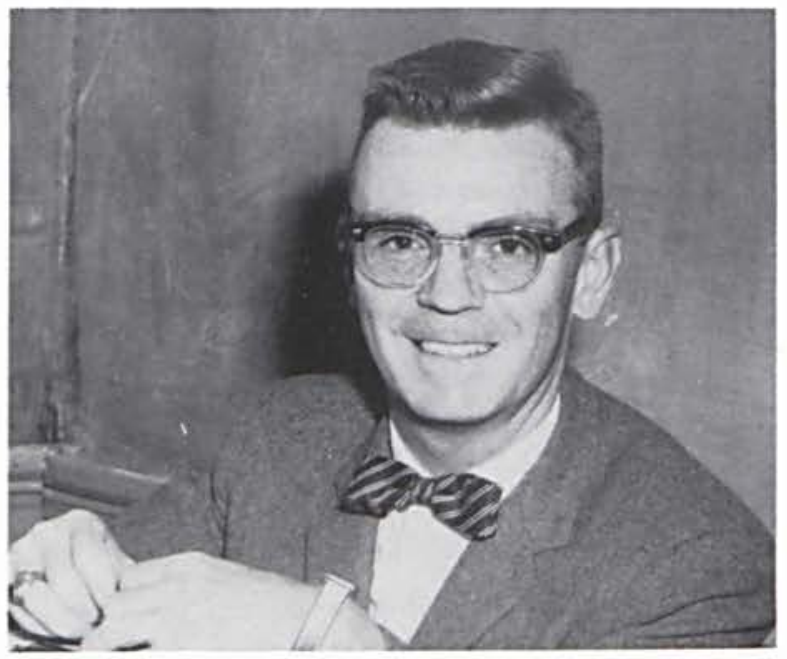

Harmon Bergen, B.A.

Foreign Languages

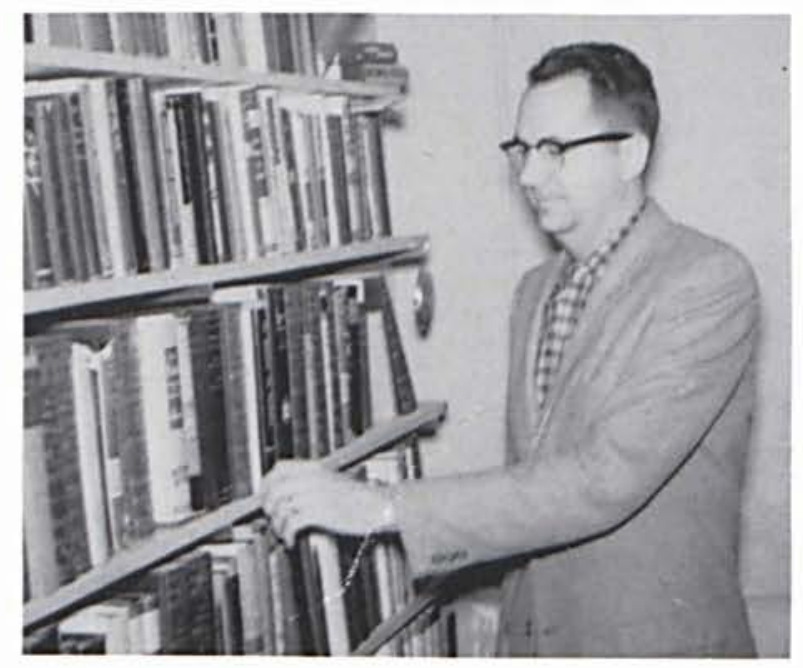

Richard McIntosh, A.B., B.D.

\section{Faculty}

This department offers excellent training for us who wish to enter the fields of foreign language, speech, or English. Mr. McIntosh is a new member of the teaching staff in this area.

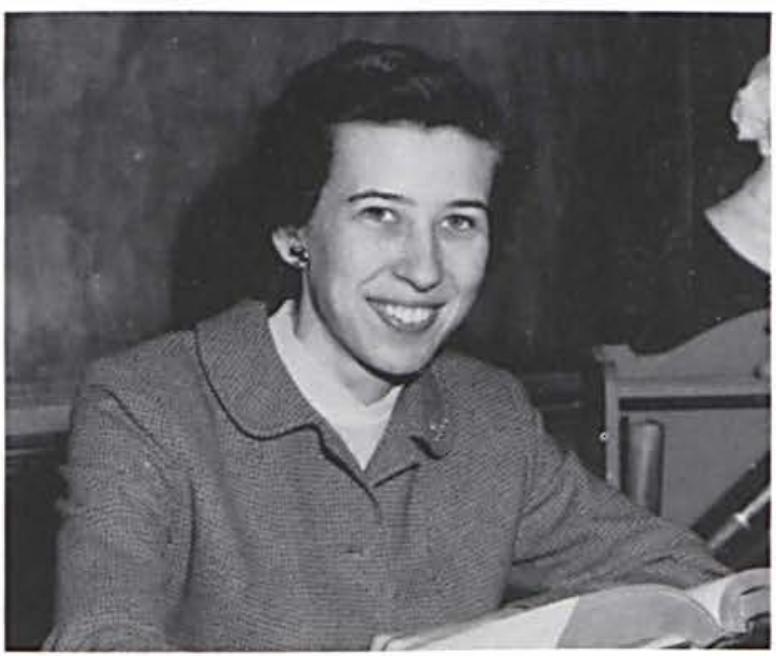

Ruth Kantzer, A.B.

English

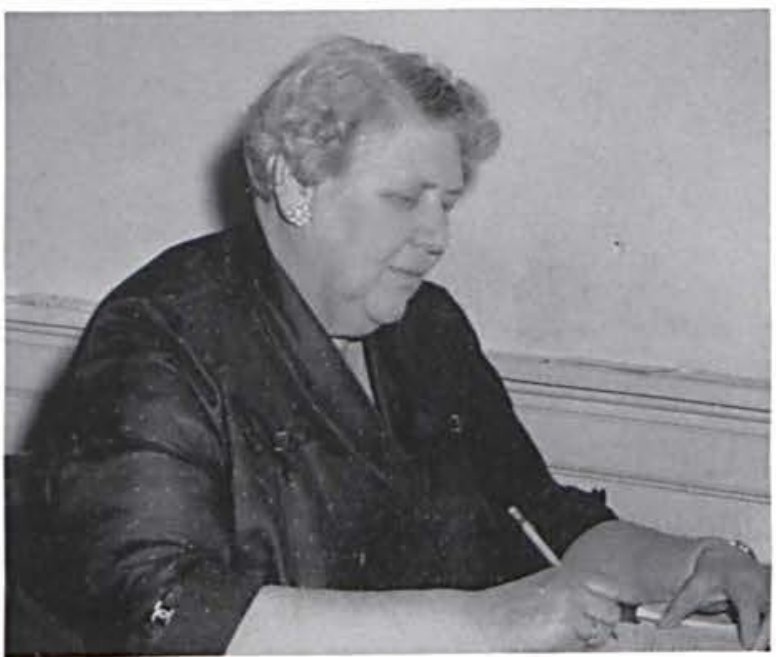

Miriam Maddox, M.A.

Speech 


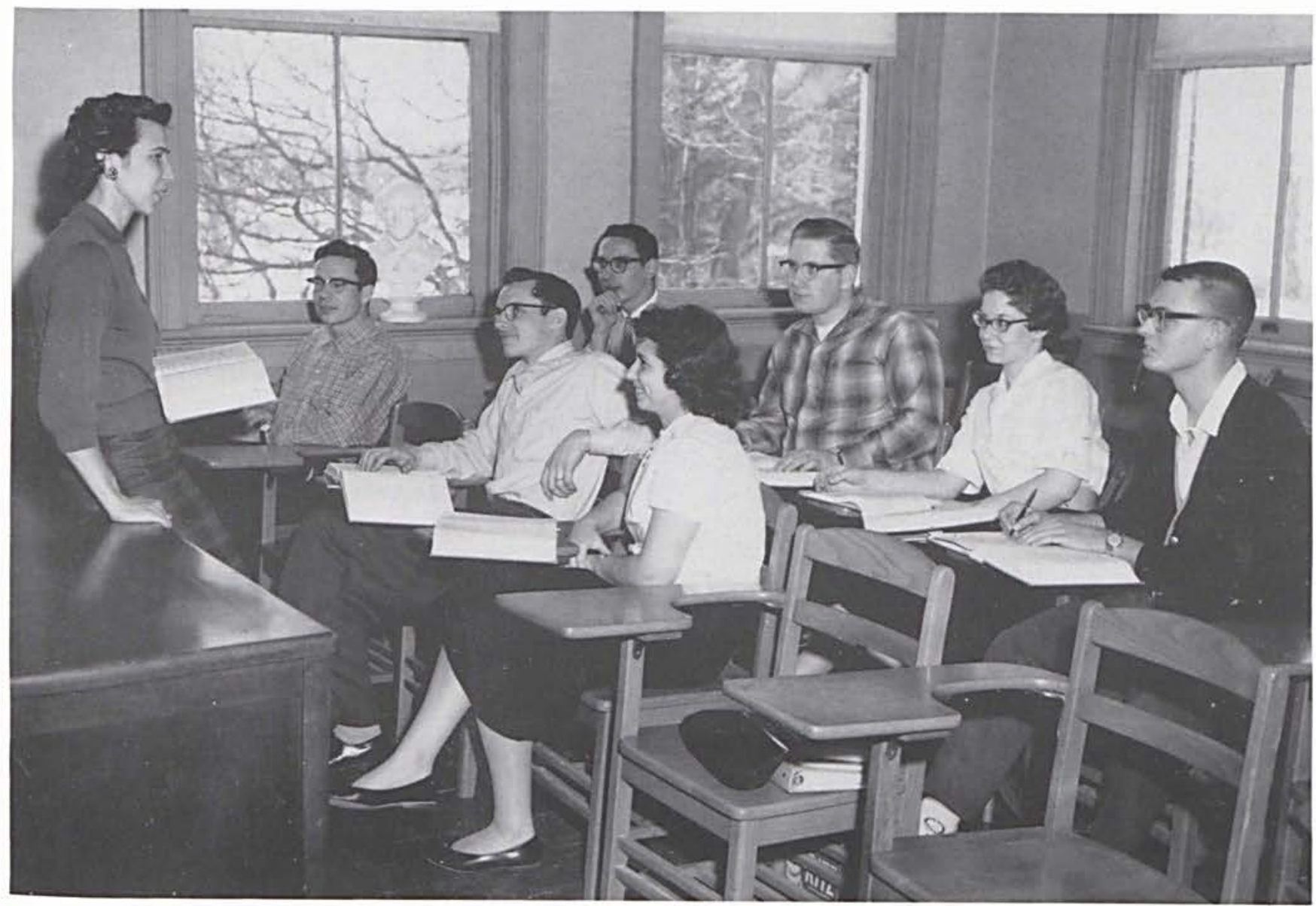

Students discuss with Miss Kantzer the problems of Shakespearean drama.

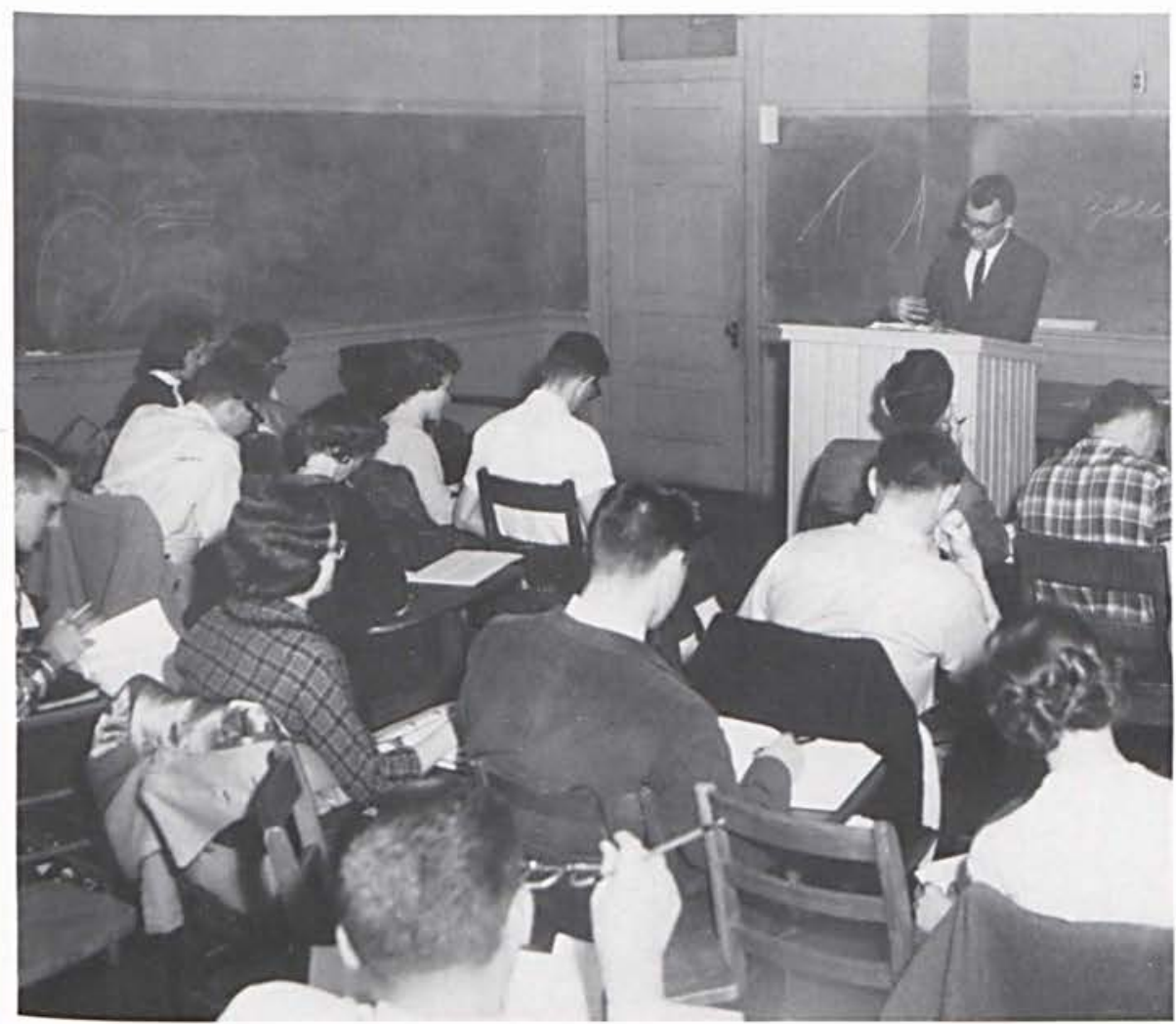

We students who wish to major in the field of English Language and Literature find a very good selection of courses with a very well qualified $s t a f f$ instructing. Such classes as Shakespeare and American Fiction are offered. Each student must take English Composition and English or American Literature which gives a good general knowledge of the field.

Mr. Bartholomew explains difficult portions of English literature. 


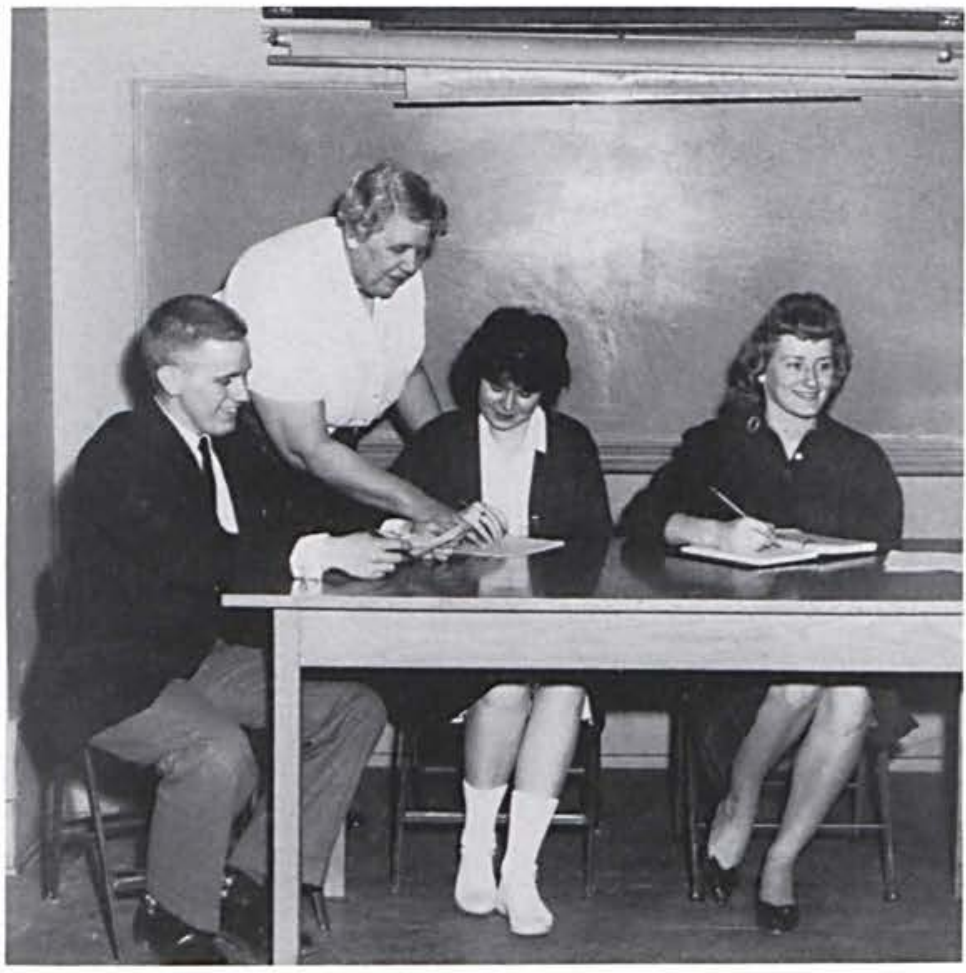

The seven basic principles of Speech are learned under the direction of Mrs. Maddox.
The foreign language department uses the technique of using tape recordings to learn the language. We hear the language on tapes, and we also record lessons in the language on the tapes. This method has been proved very effective on many college campuses.

The emphasis in the Speech department is primarily on every kind of oral communication. After a speech course with Mrs. Maddox, every student knows the seven basic principles of Speech.

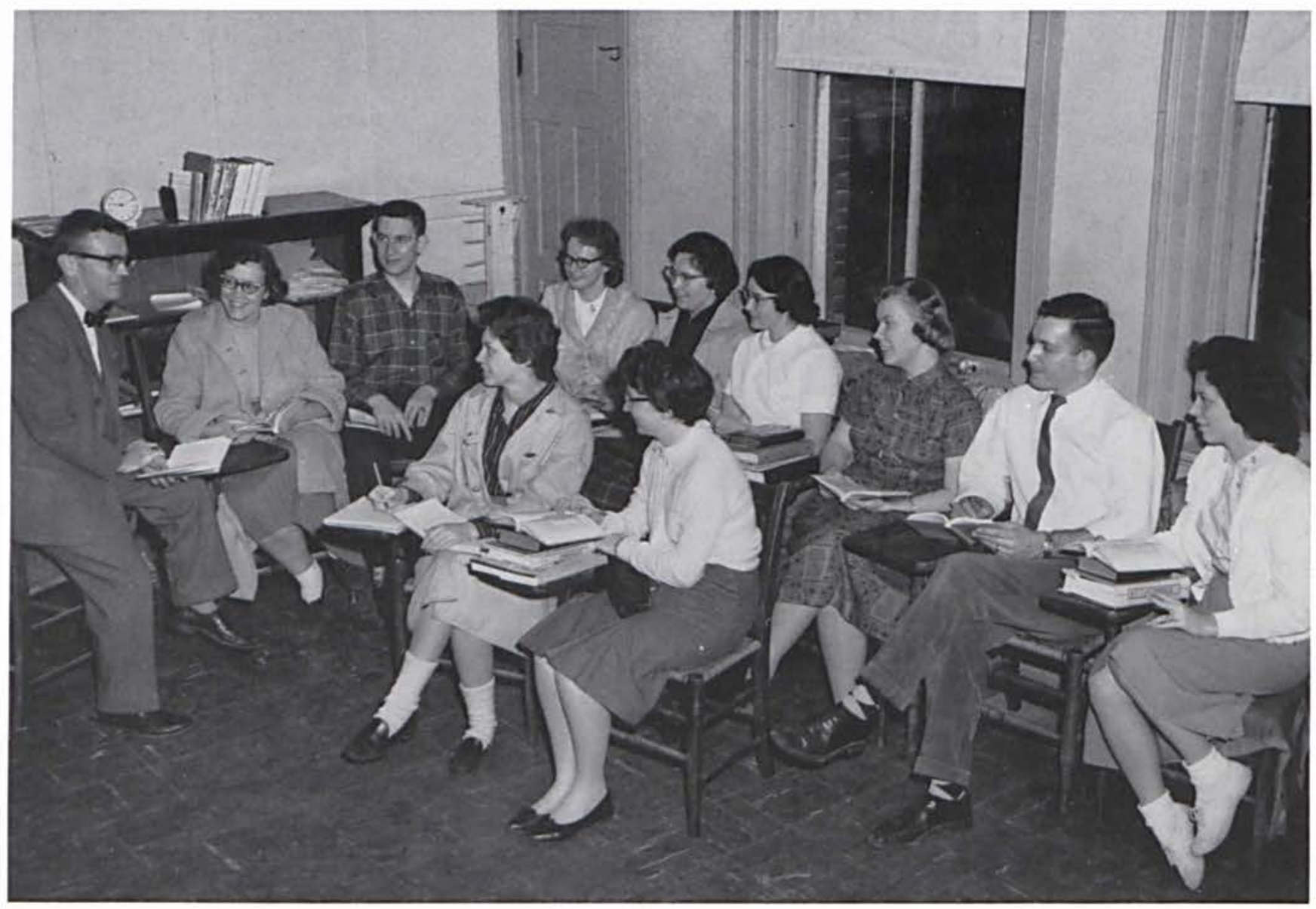




\section{Division of Science}

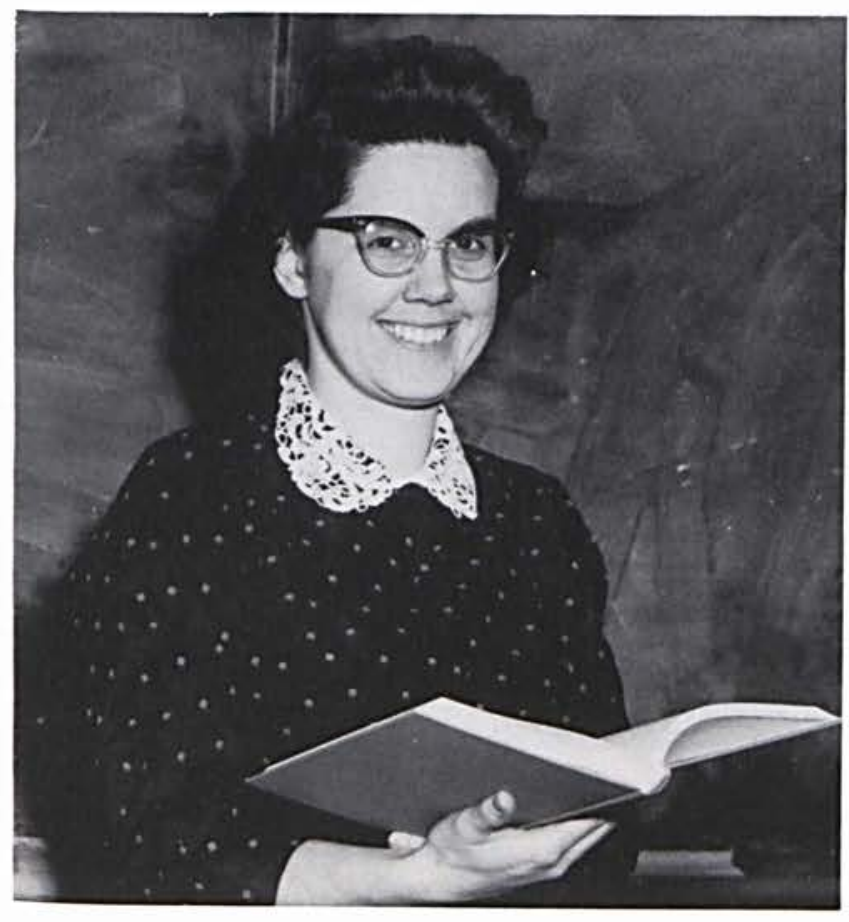

Barbara Mcintosh

Mathematics

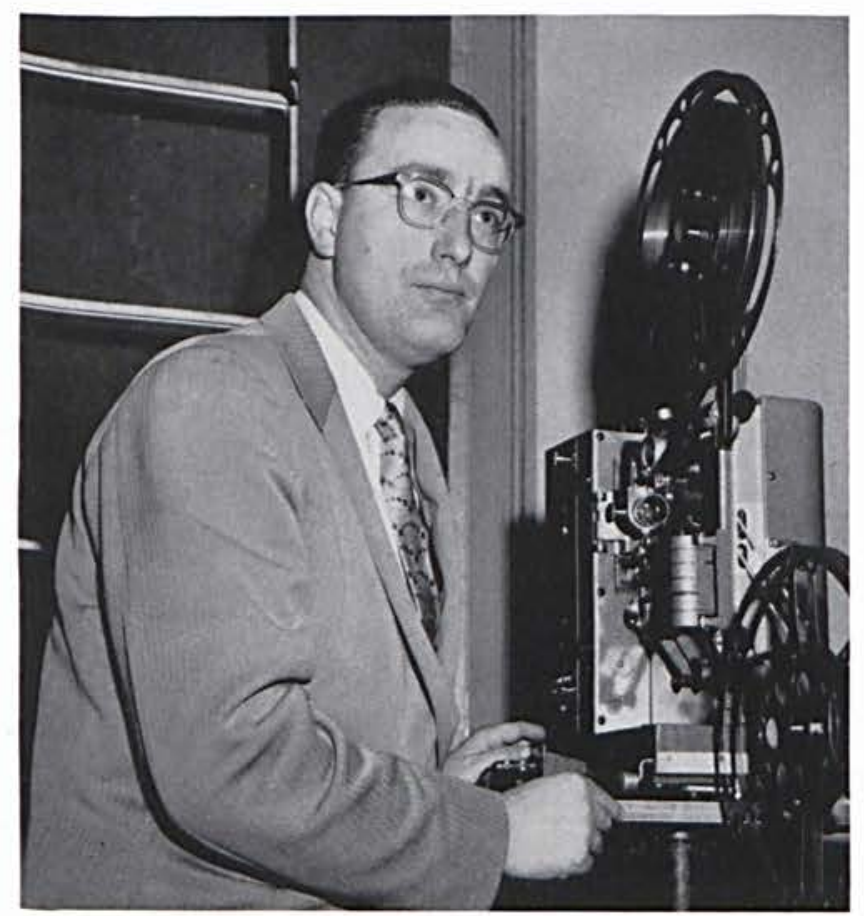

Bruce Turnbull, B.D., M.S.

Physical Science

\section{Faculty}

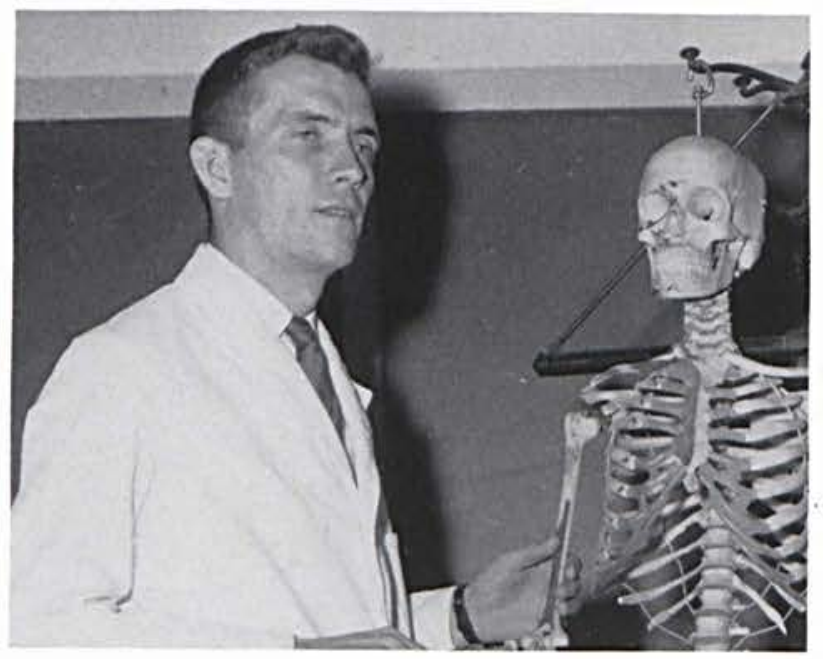

Dale Thomson, B.A.

Biological Science

There have been several interesting events in the Science Department this year. Mr. Turnbull has returned after a leave of absence to continue his studies, and Mrs. Mclntosh has taken over the duties of instructing students in Principles of Mathematics. Although our college does not offer a special pre-medical course, the science department was pleased this year when one of our students was accepted at Indiana State Medical College. 


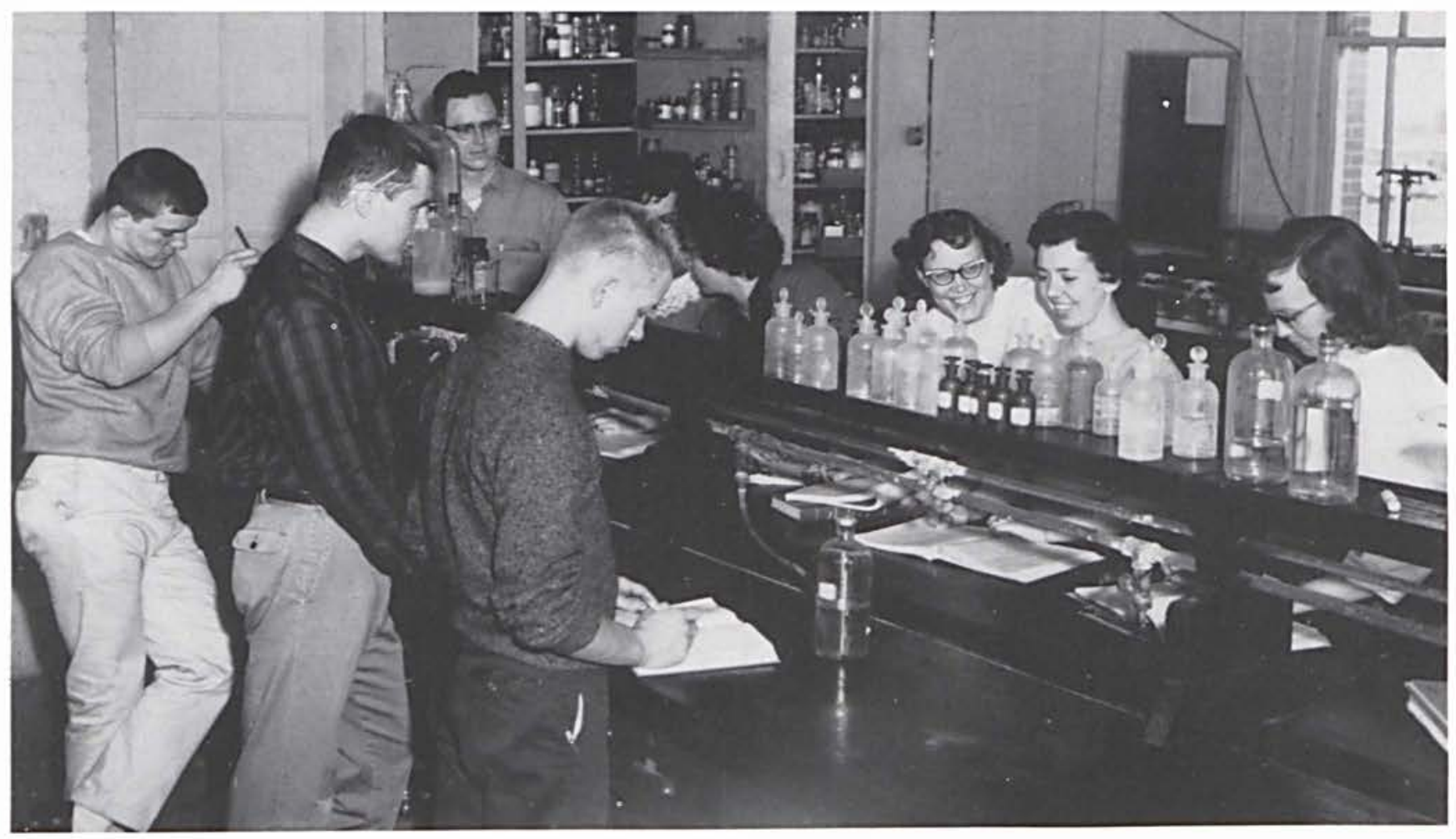

The principles of chemistry are applied in experimentation in the chemistry lab.

Students who study in this field may study such courses as Comparative Embryology and College Algebra. Science majors are prepared to teach or to furthur their training in the medical field as a doctor or a nurse.

Under the qualified instruction of Mrs. Mclntosh, students review the basic principles of Mathematics.

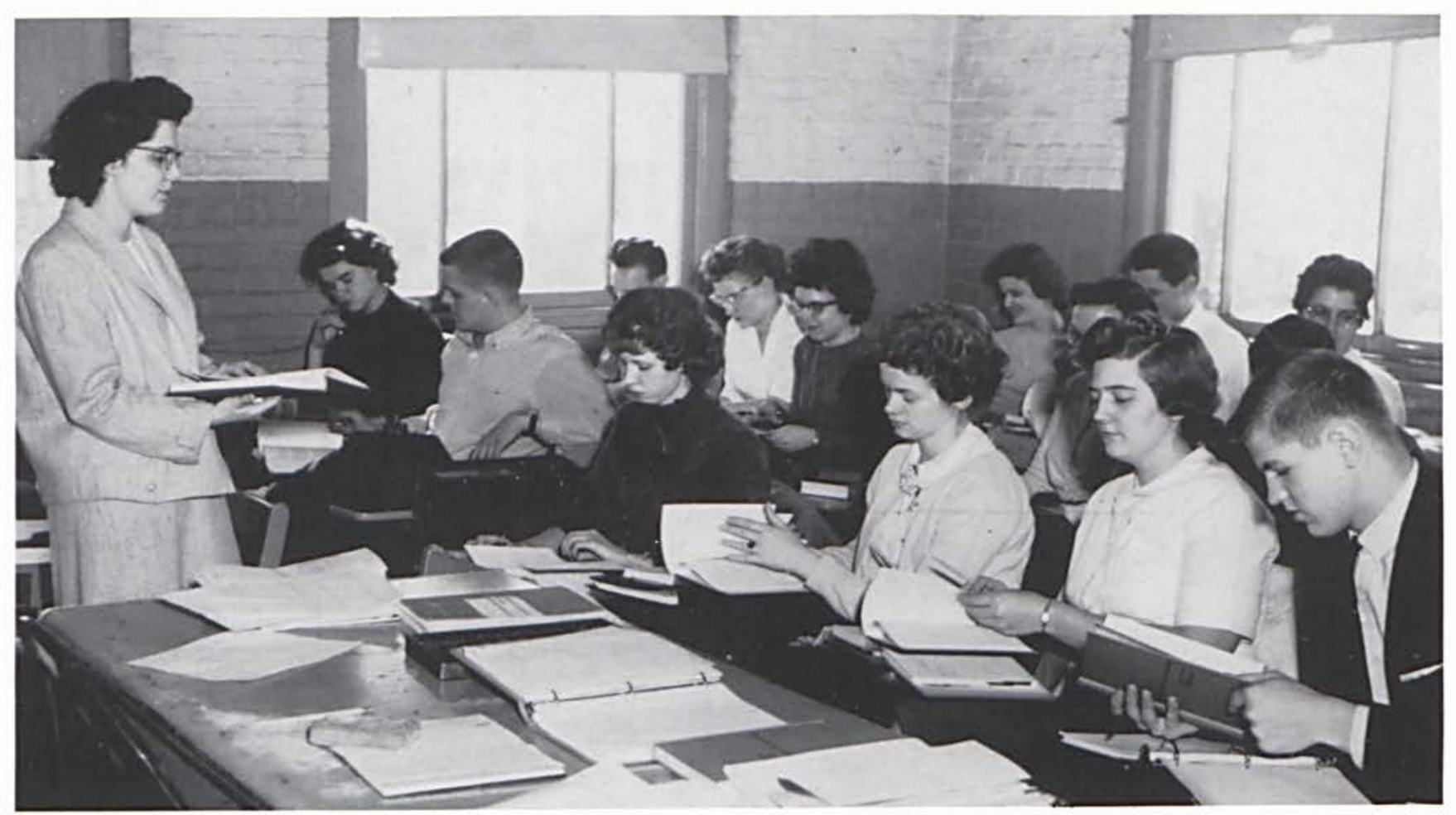




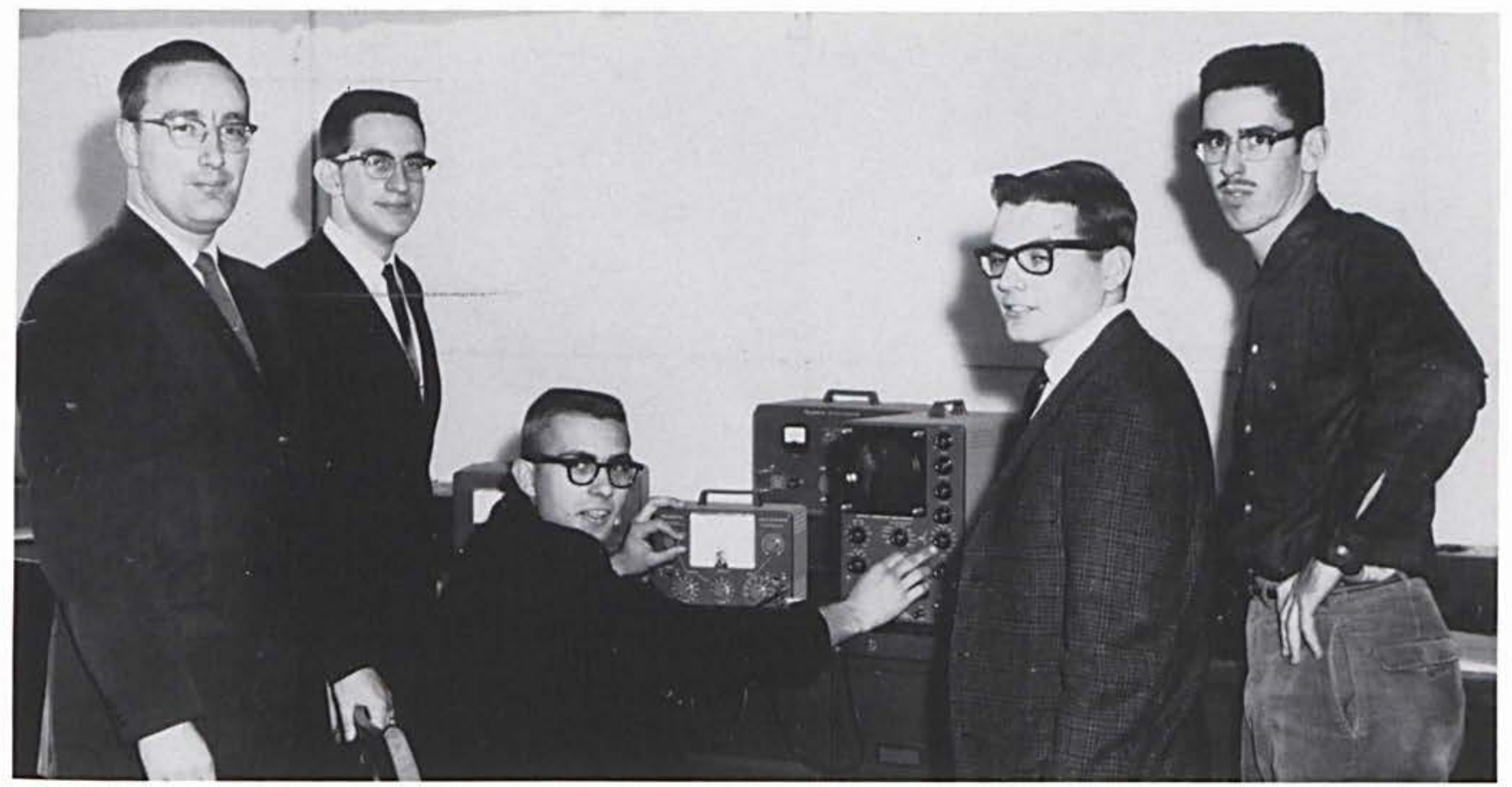

Mr. Turnbull's physics class demonstrate this oscillo. scope which they constructed.

Last summer the labs were painted and redone in various ways to help make it more pleasant for us who spend so much of our time dissecting perch.

Many organisms are studied in zoology lab. under

the supervision of Mr. Thomson.

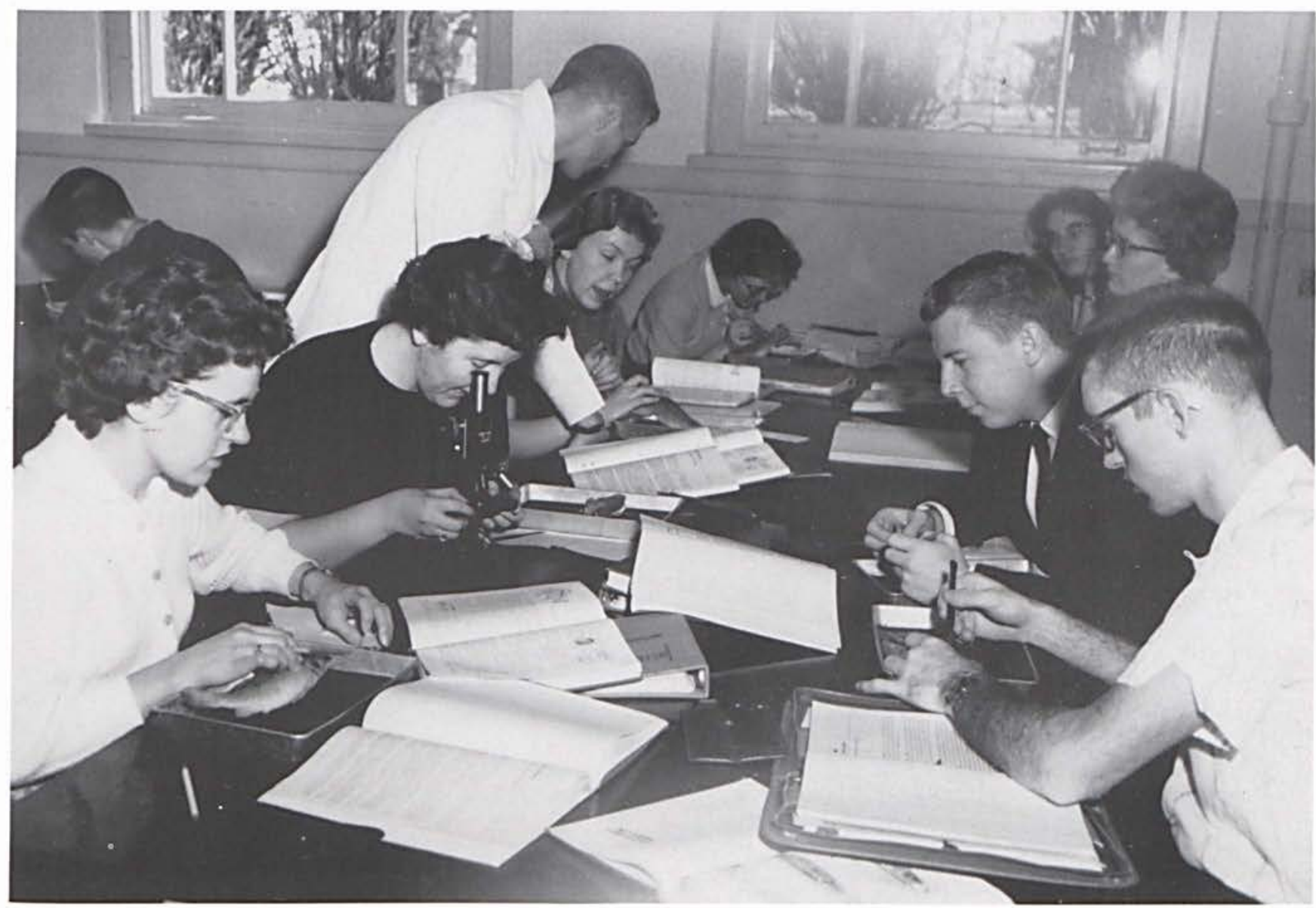




\section{Division of Social Science}

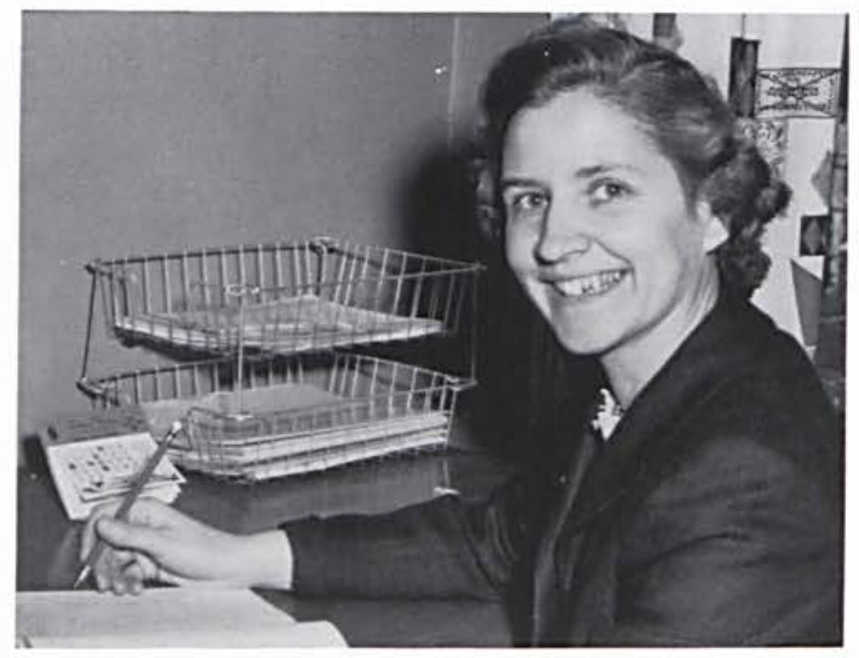

Alberta Chaffe, B.A.

Library Science

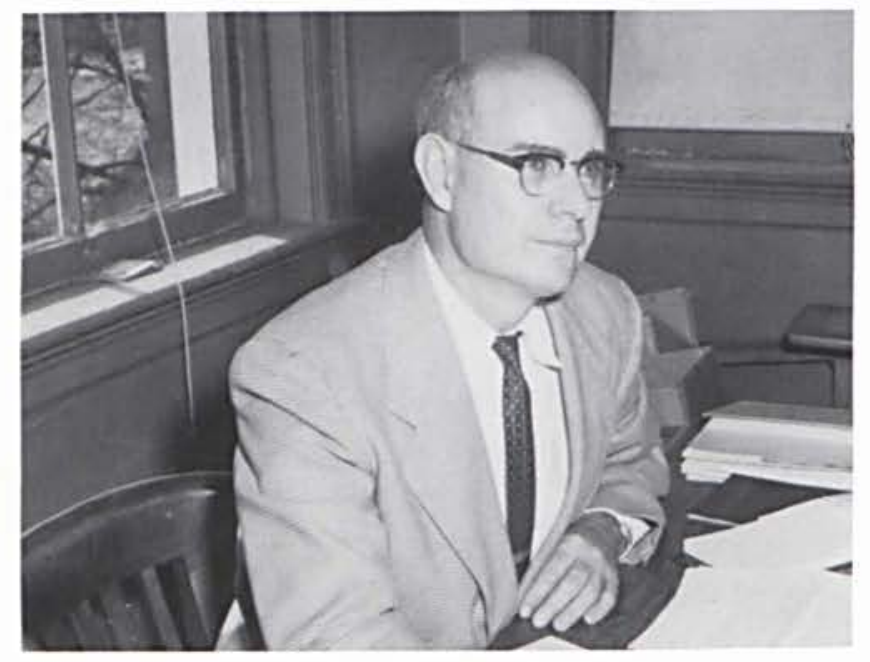

Cleveland McDonald, M.Litt. Sociology

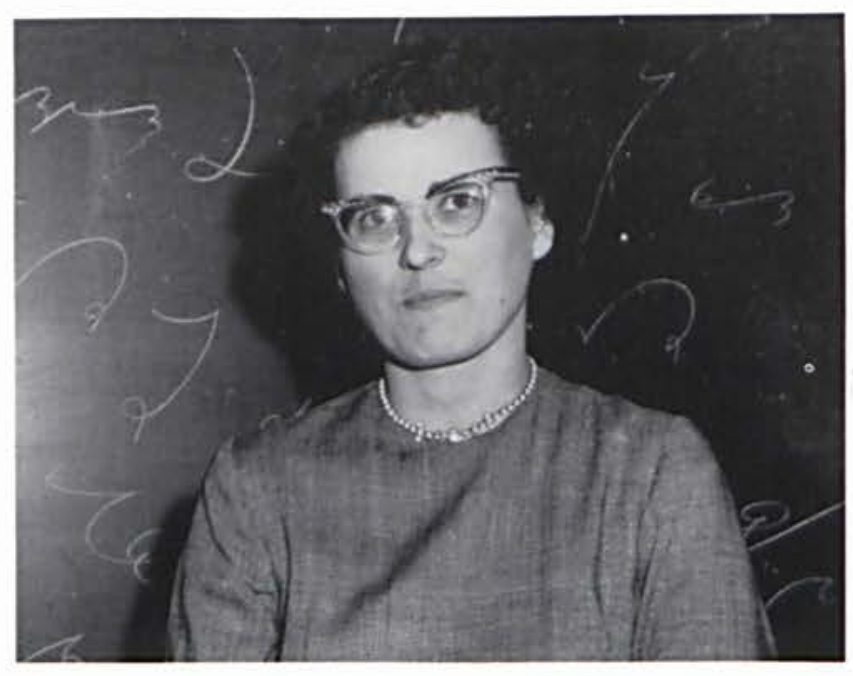

Ardeth Webber, A.B.

\section{Faculty}

This too is a growing department on campus. More and more of our students are seeing the need for Christians in social work, government, and teaching.

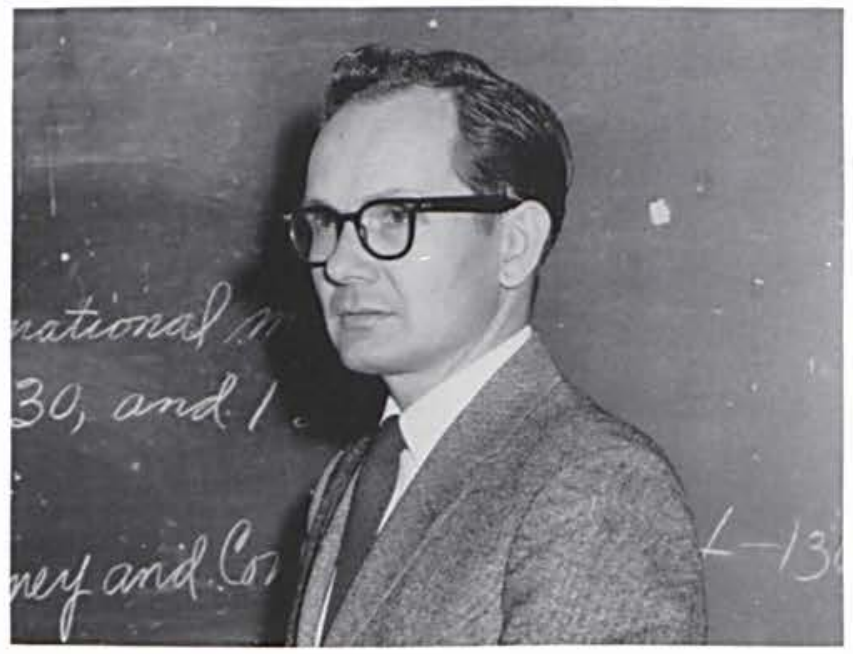

Kenneth St. Clair, B.S.

Business

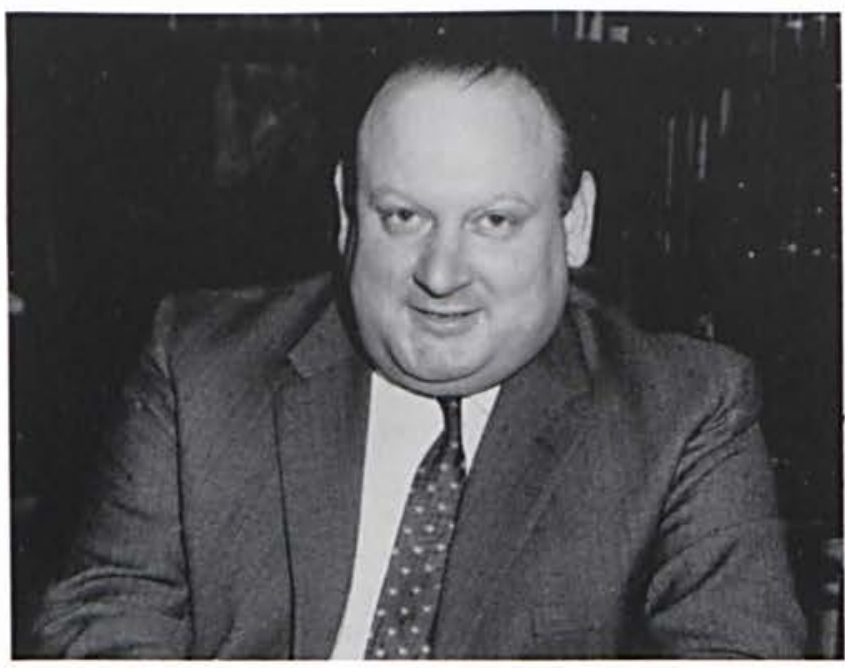

G. Paul Wyland, M.A. History 


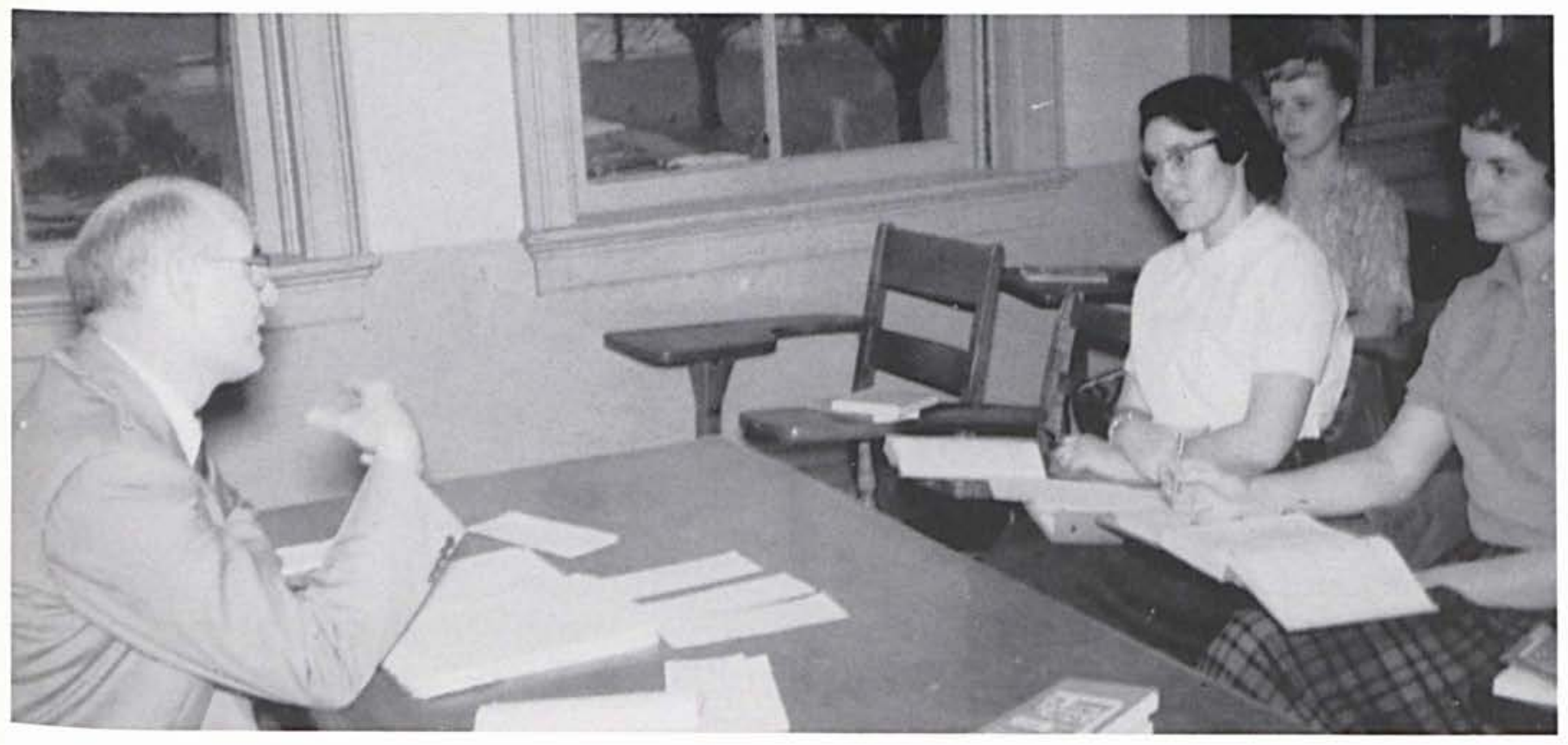

Mr. McDonald's Urban Sociology class study the various issues related to city life.

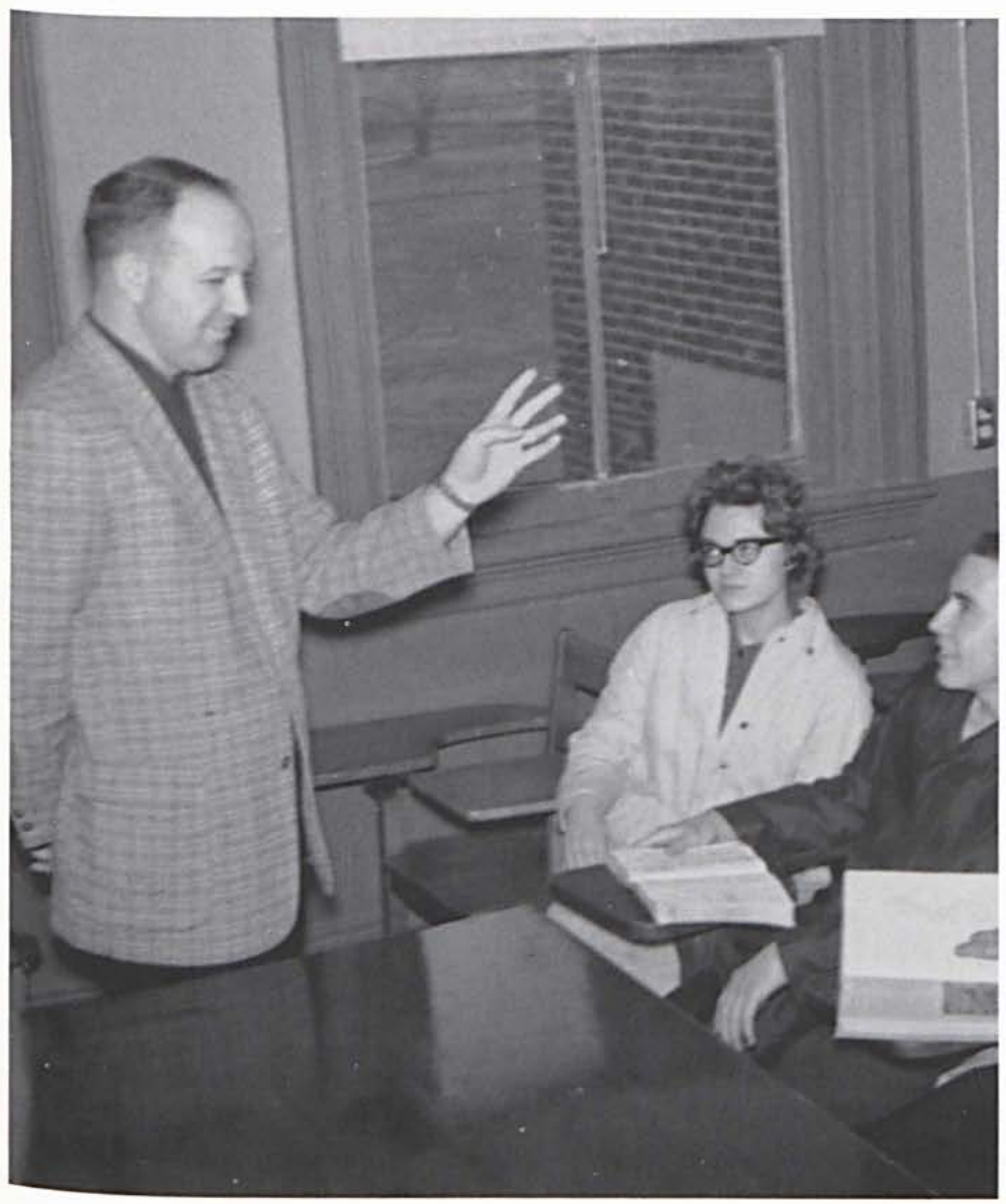

This year a new course of study has been introduced in this department. Mrs. Chaffe, a former C.C. student, instructs courses in Library Science. Another new addition to this department is Mrs. Mclntosh who teaches Business Mathematics. During the first semester of the school year when Mr. McDonald was absent from the campus, Mr. Underwood took over the classes in Sociology and American Government.

Mr. Underwood's Sociology class discuss many problems of our modern society. 


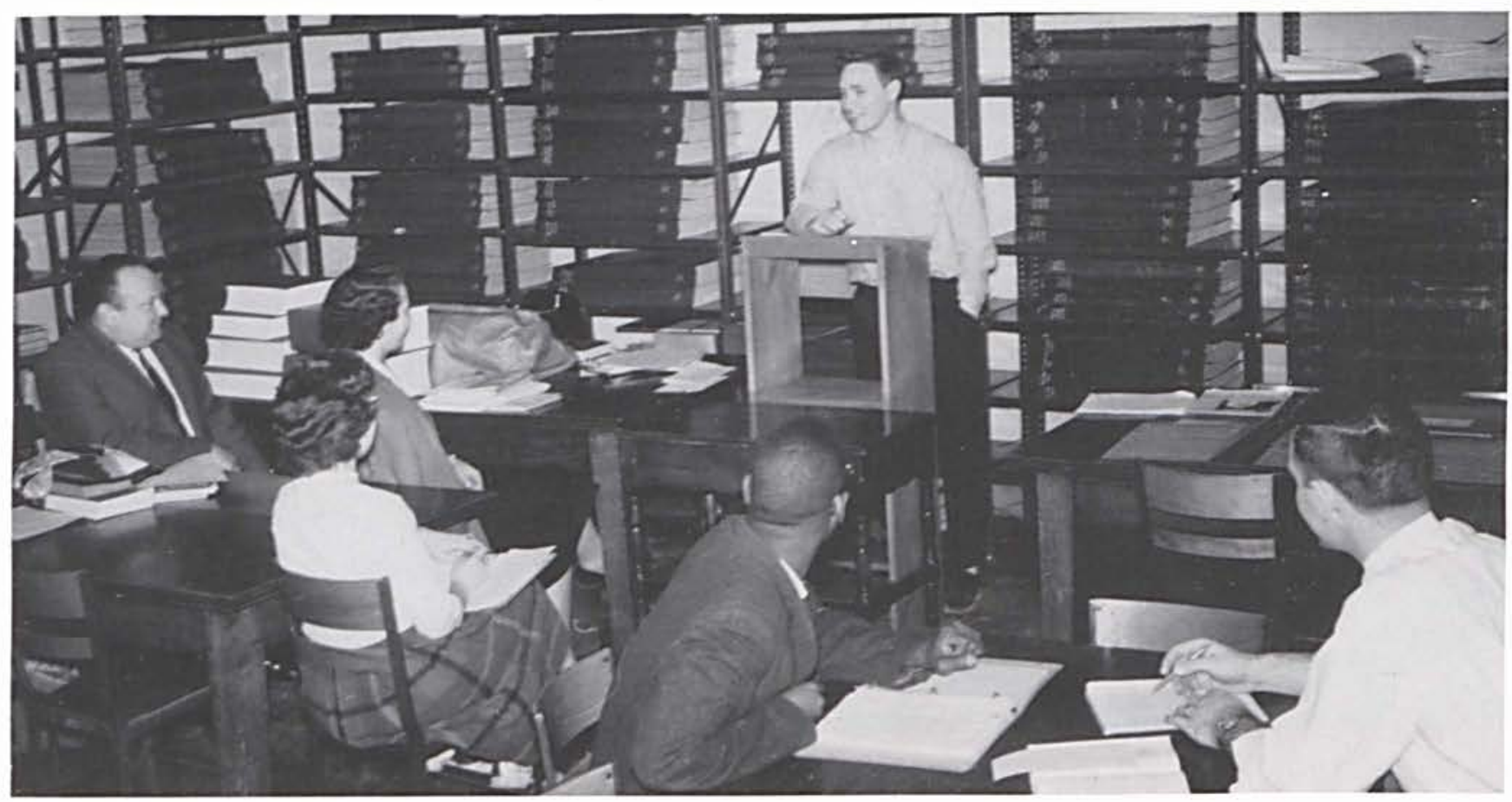

Student teaching is an important part of Mr. Wyland's advanced history courses.

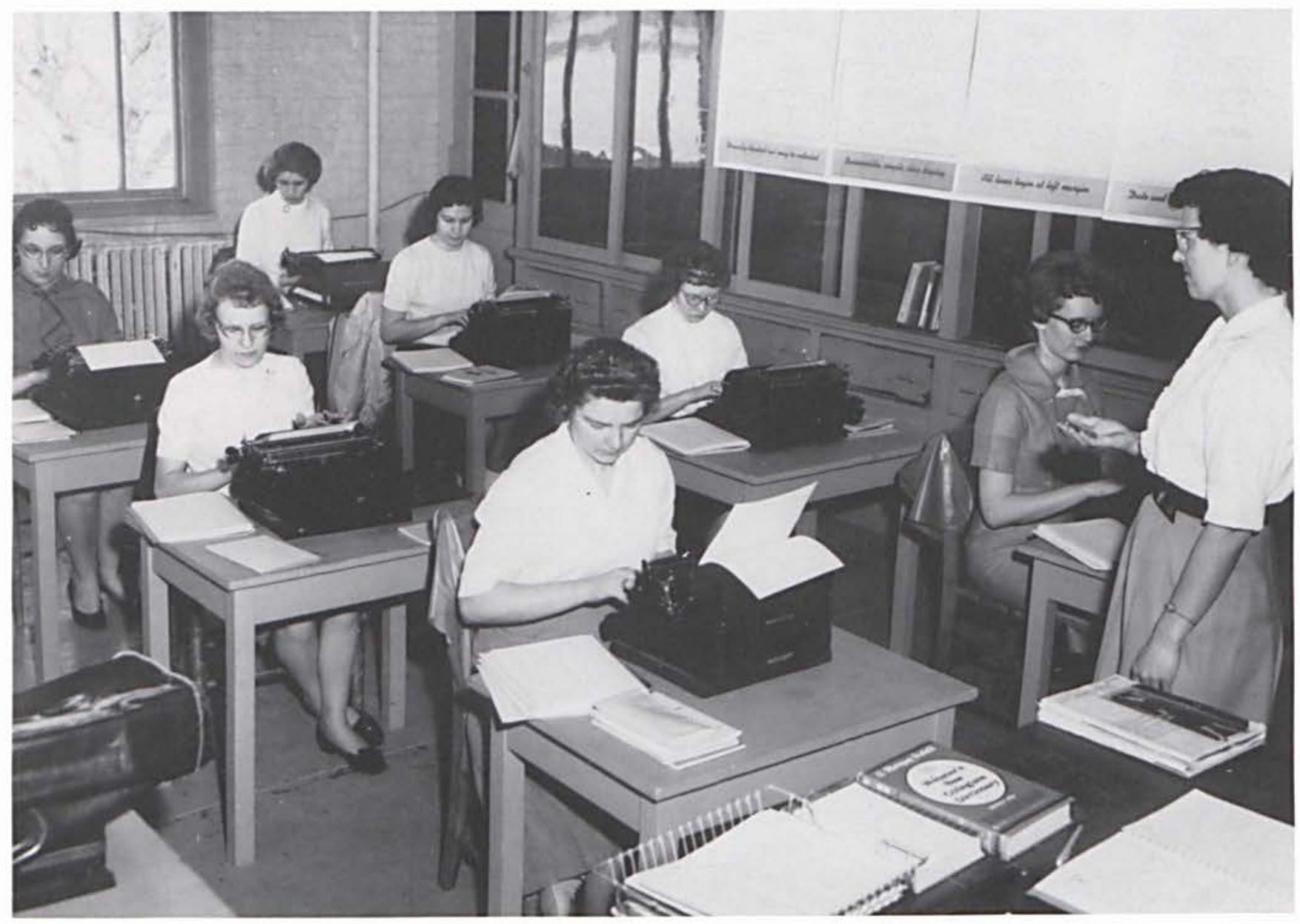




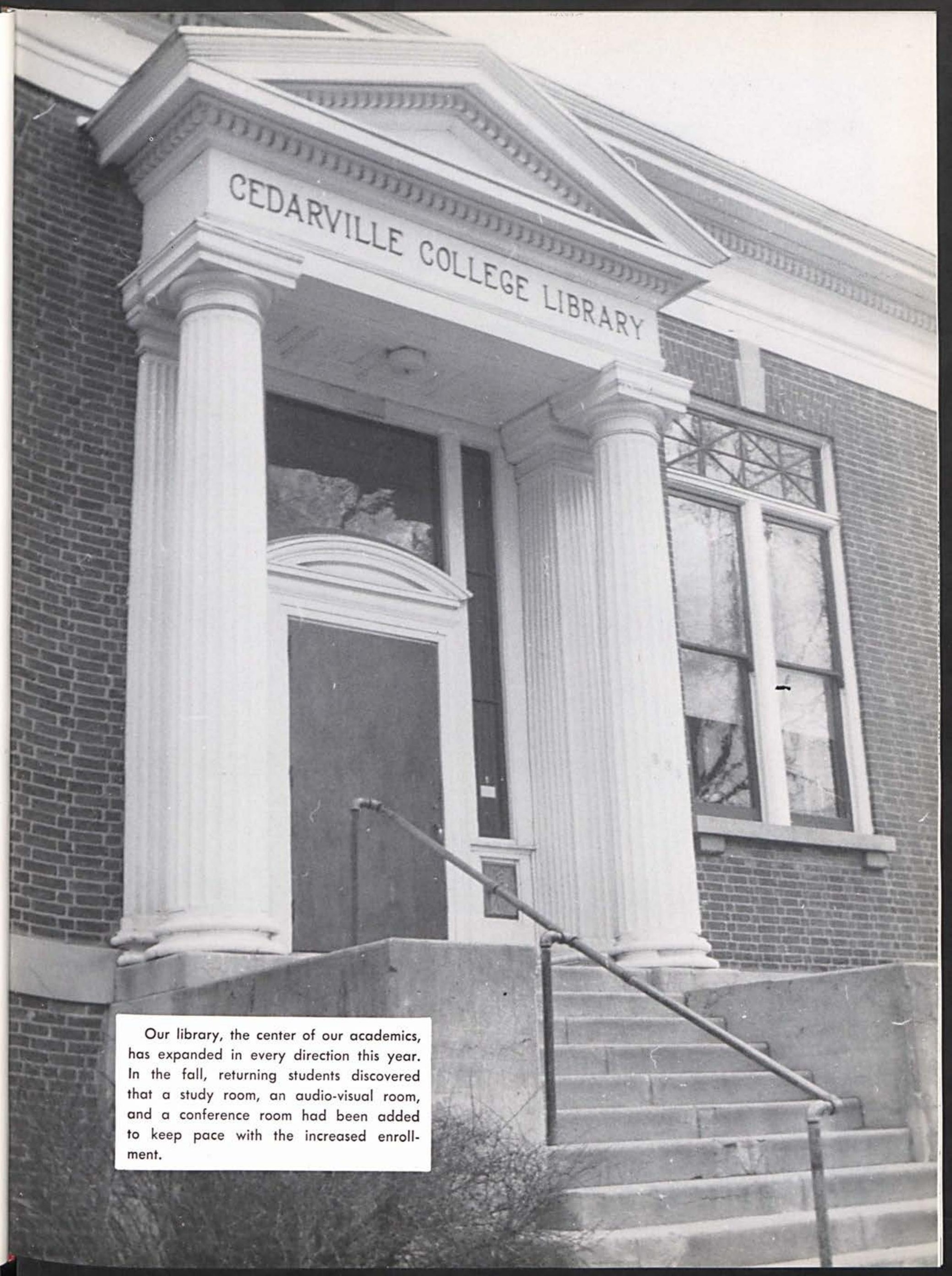




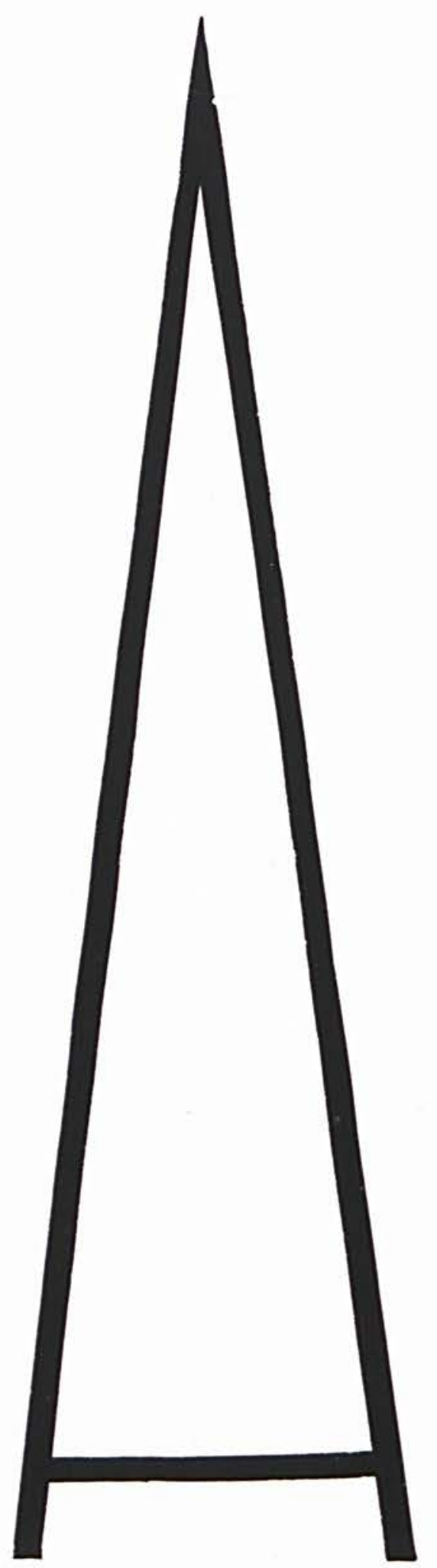

Looking across the glistening floor of our empty gym we can recall many of our college activities. In September we came here to register; later we returned for basketball games, classes in physical education, and class parties. In May the seniors among us will receive their diplomas here. The cheer, applause, and laughter of our friends fill this place, and our whole college life, with WARMTH and BEAUTY.

\section{CONTENTS}

Christian Service 56

Organizations 63

Music 76

Athletics

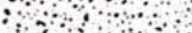

Social Life 99

Snapshot Contest
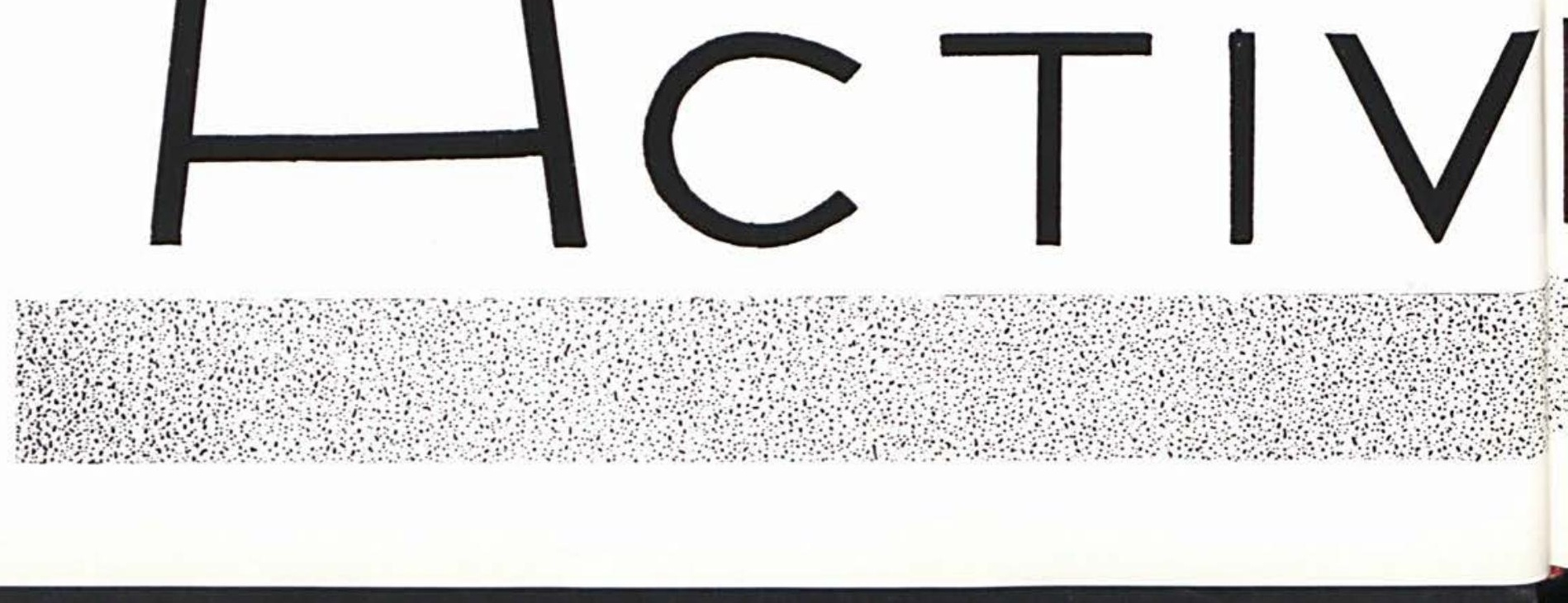


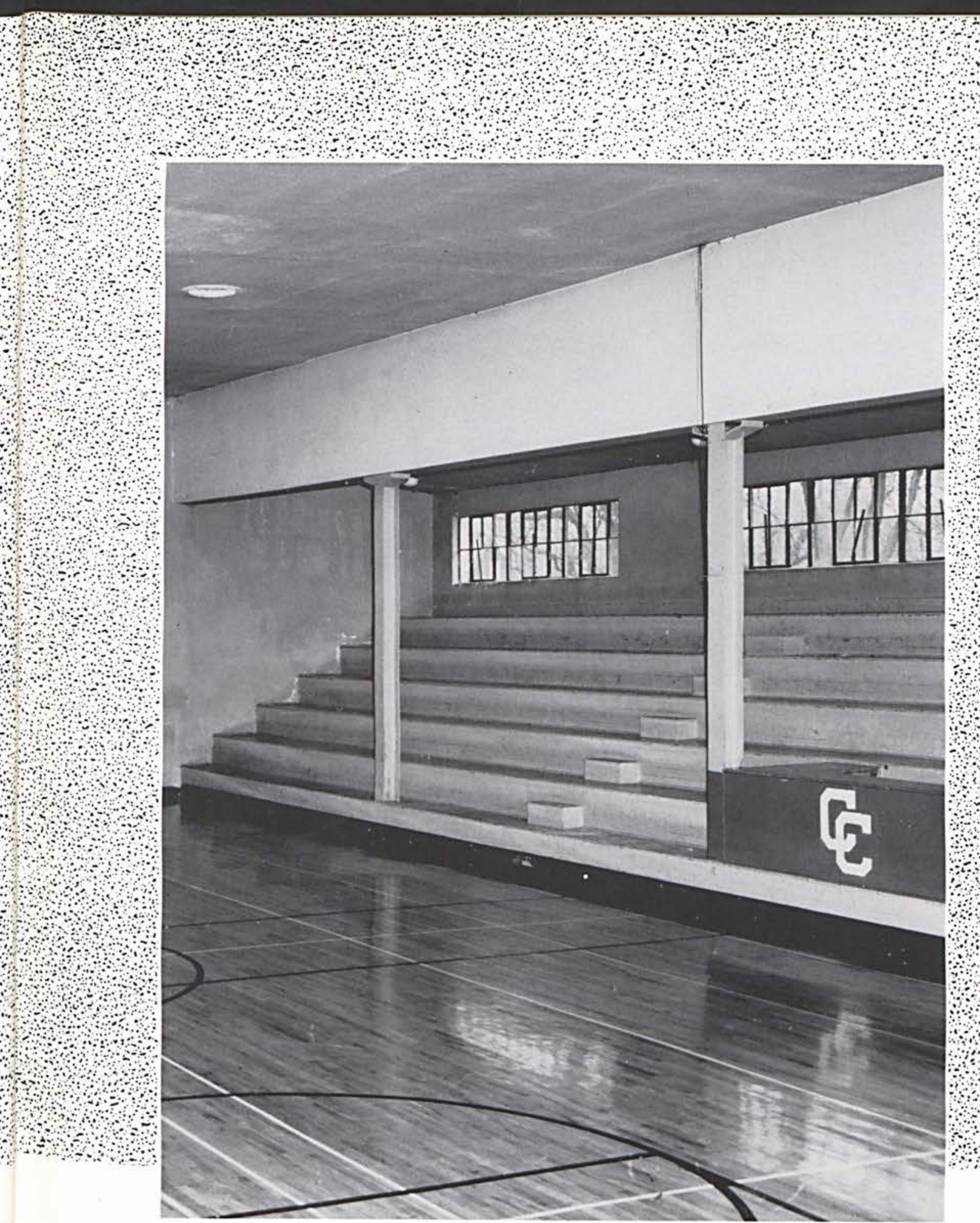

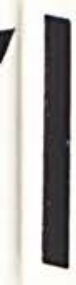
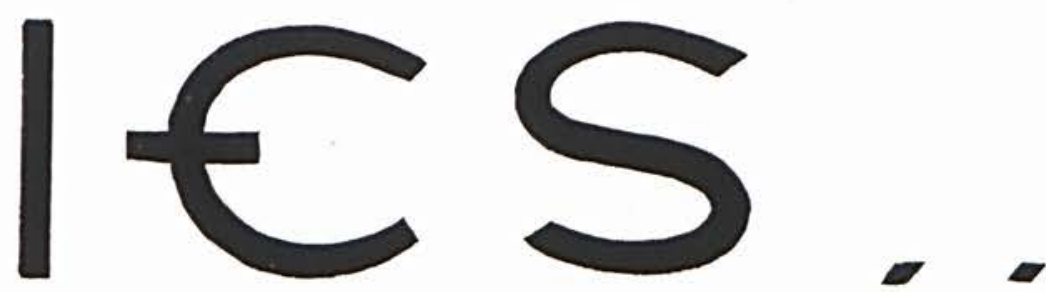


\section{Christian Service ...}

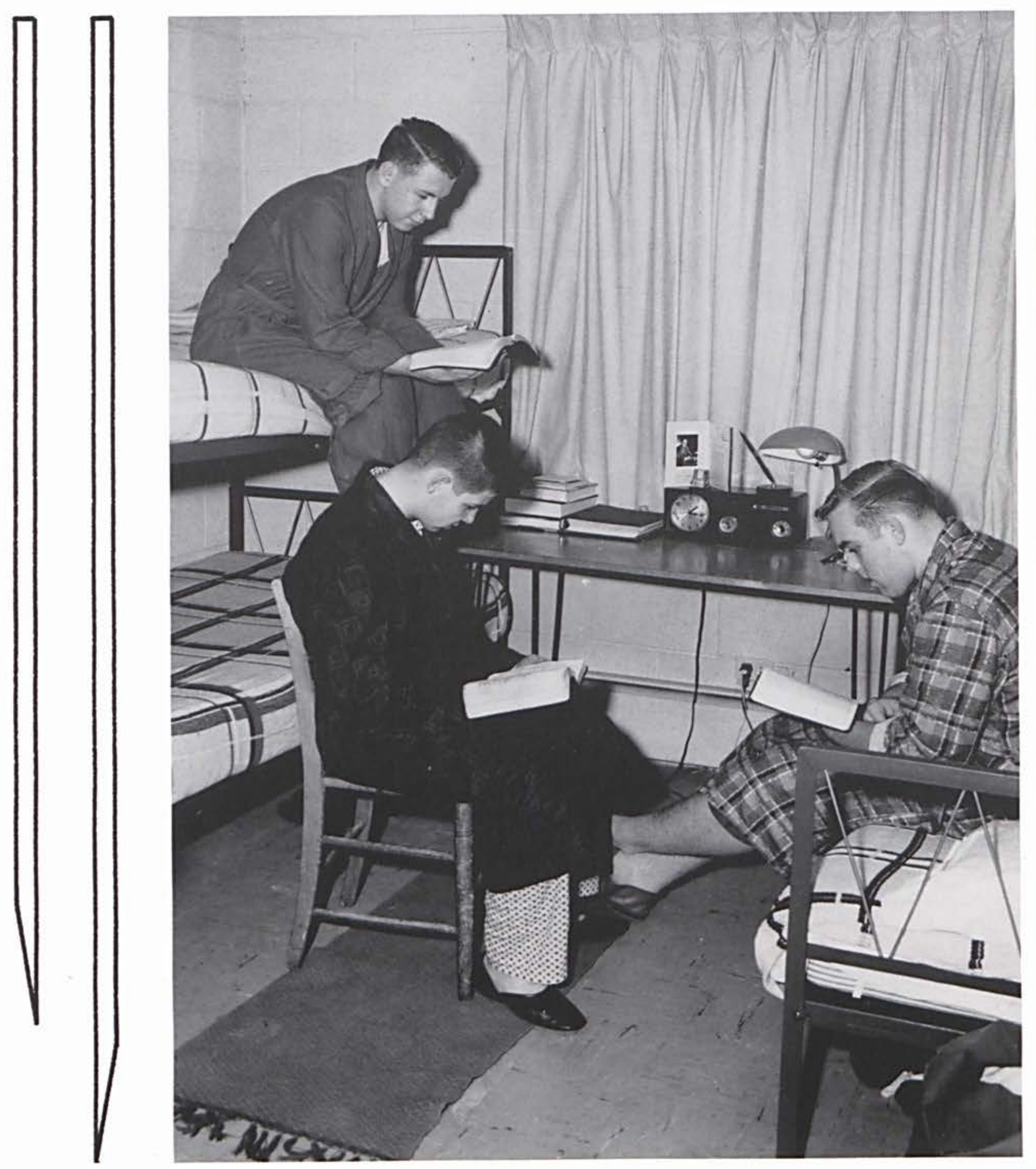




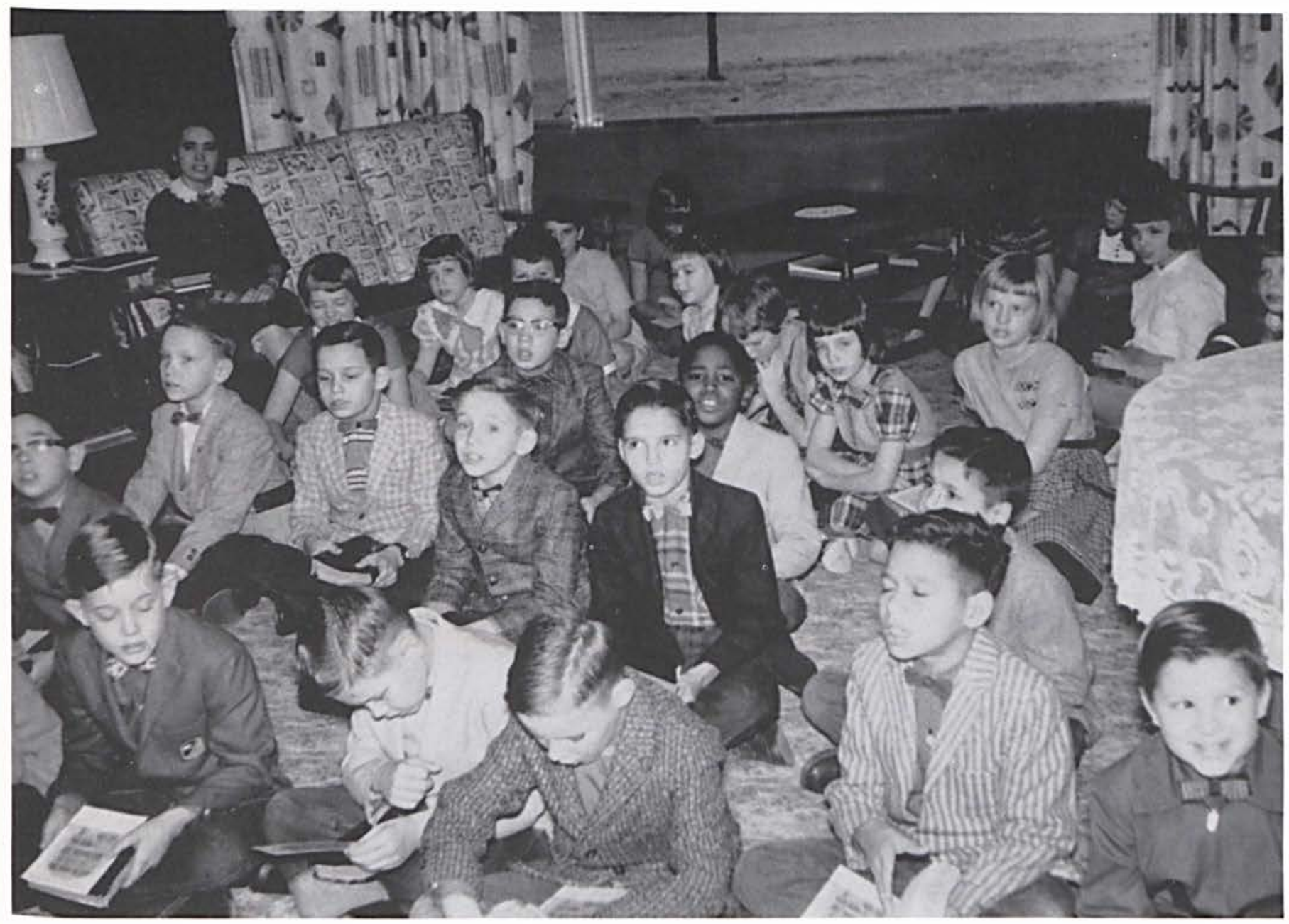

"How then shall they call on him in whom they have not believed? and how shall they believe in him whom they have not heard? and how shall they hear without a preacher?" Romans 10:14

Keeping in mind these words of the apostle Paul we are made to ask ourselves "How shall these children hear unless someone tells them?" It has been the mission of the Christian Service Department to enable the people of the surrounding area to hear the good news of the Gospel. A wide range of ministry is carried on, from the youngest child in the junior church to the oldest person in the rest home.

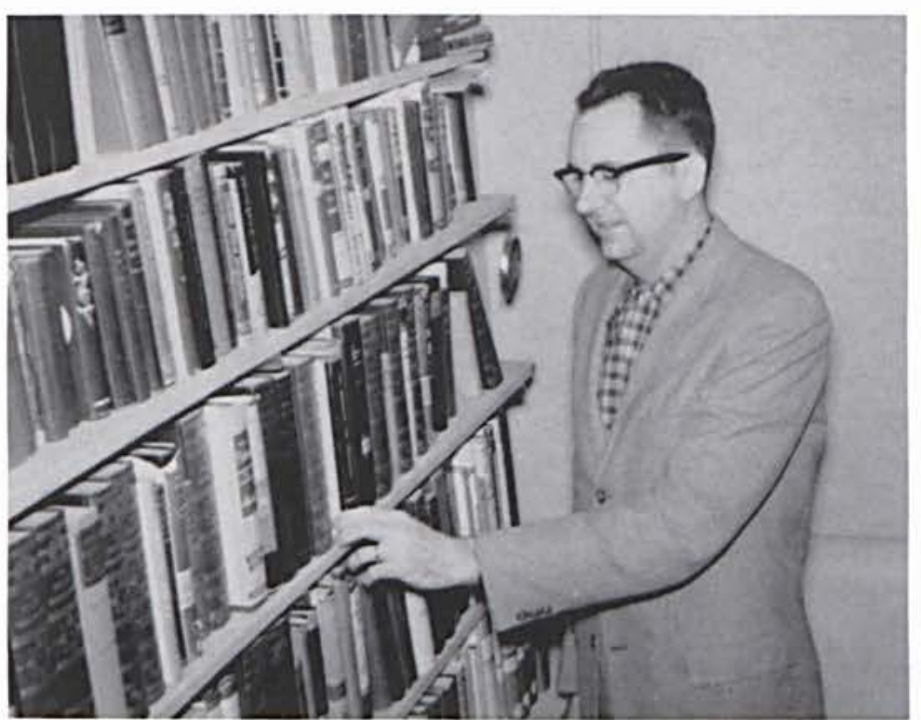

Mr. McIntosh, Director of Christian Service. 
mory

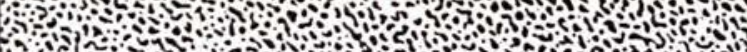

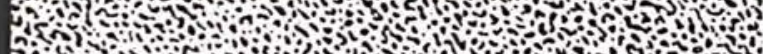

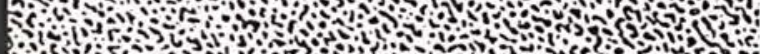
H.

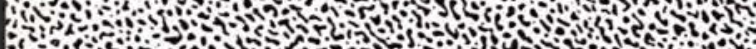
H.

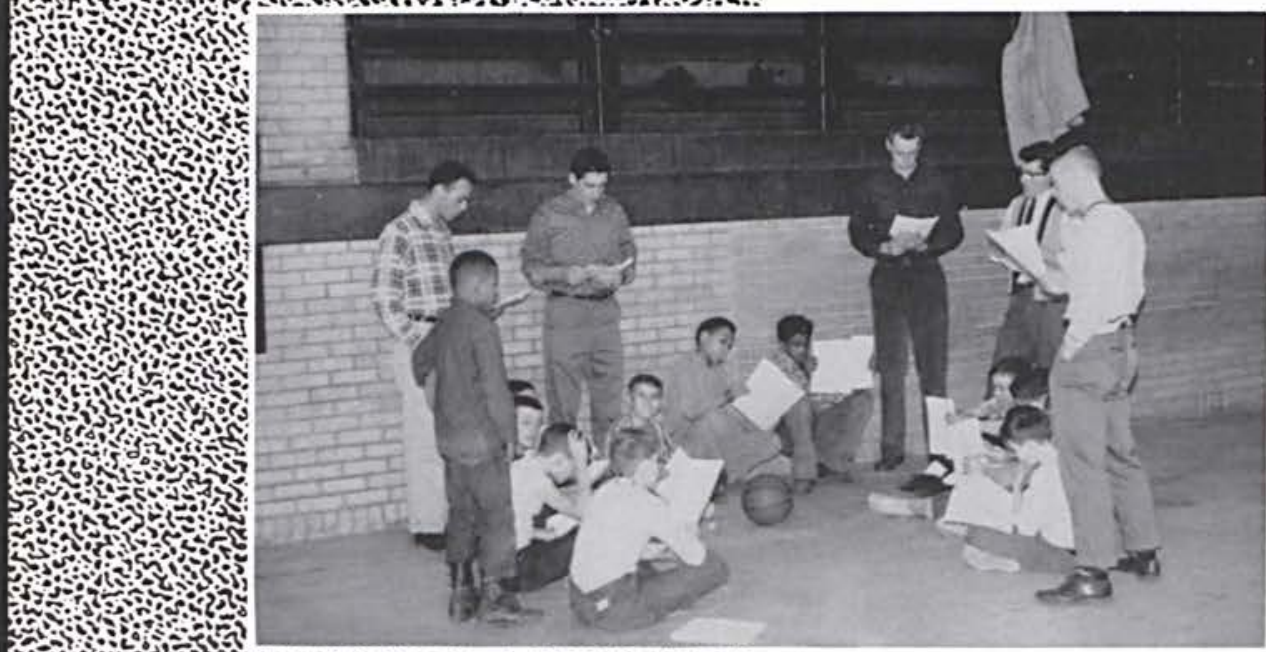

"Train up a child in the way he should go and when he is old he will not depart from it." One of the most important ministries of the Christian Service department is the work among the young people. Our students are engaged in youth work in various ways in Cedarville, Xenia, and Springfield.
Dave Searles, Ken Swigart, Norman Emery, Jim Maple and leader Jim Grafton instruct some fellows in the Boys' Brigade.
H.

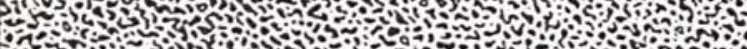 - 2 - (N)

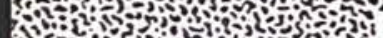

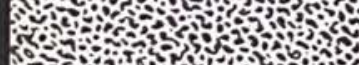
(1)

(5)

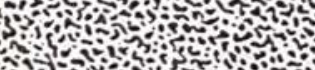

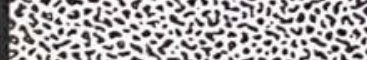
S.4. P Bs. Pand

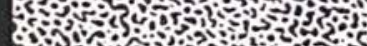
Sis

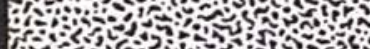
Fis: 6.

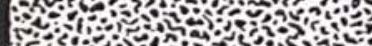
Find

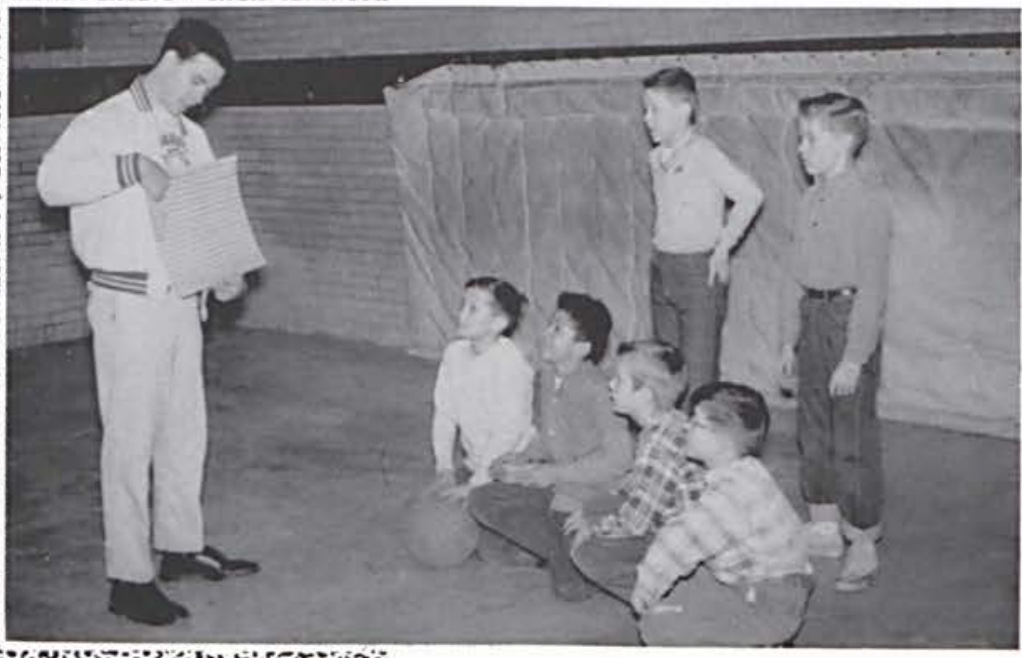

sion 3.

Larry Helmick explains an achievement chart to a group of Boys' Stockade members. o ( 17 . P A in:

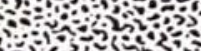
Fin

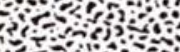

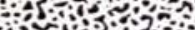
i.. 0

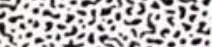
tojs

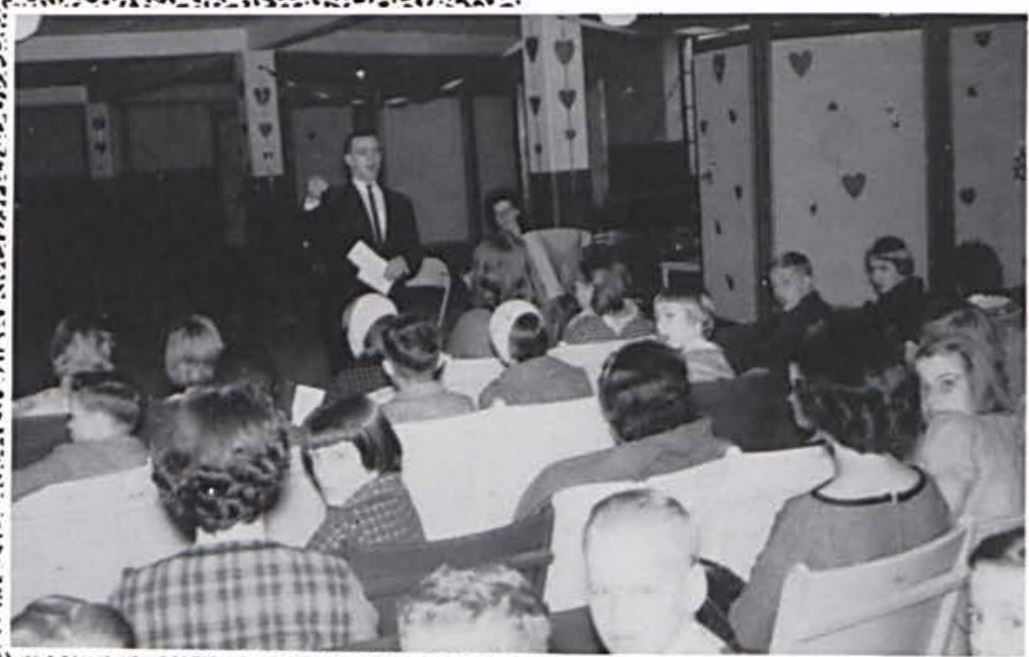
Q Hof

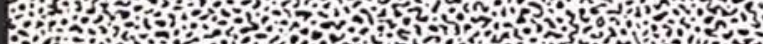
And S. Eor

Phil Jewett leads a group of children at the O.S.S.O. home in a favorite chorus. 
An important service is held every Sunday morning for those who have been taken into the custody of the law. Cedarville students have branched out into the Clark County jail in Springfield, the Xenia jail, and the detention home in Springfield.
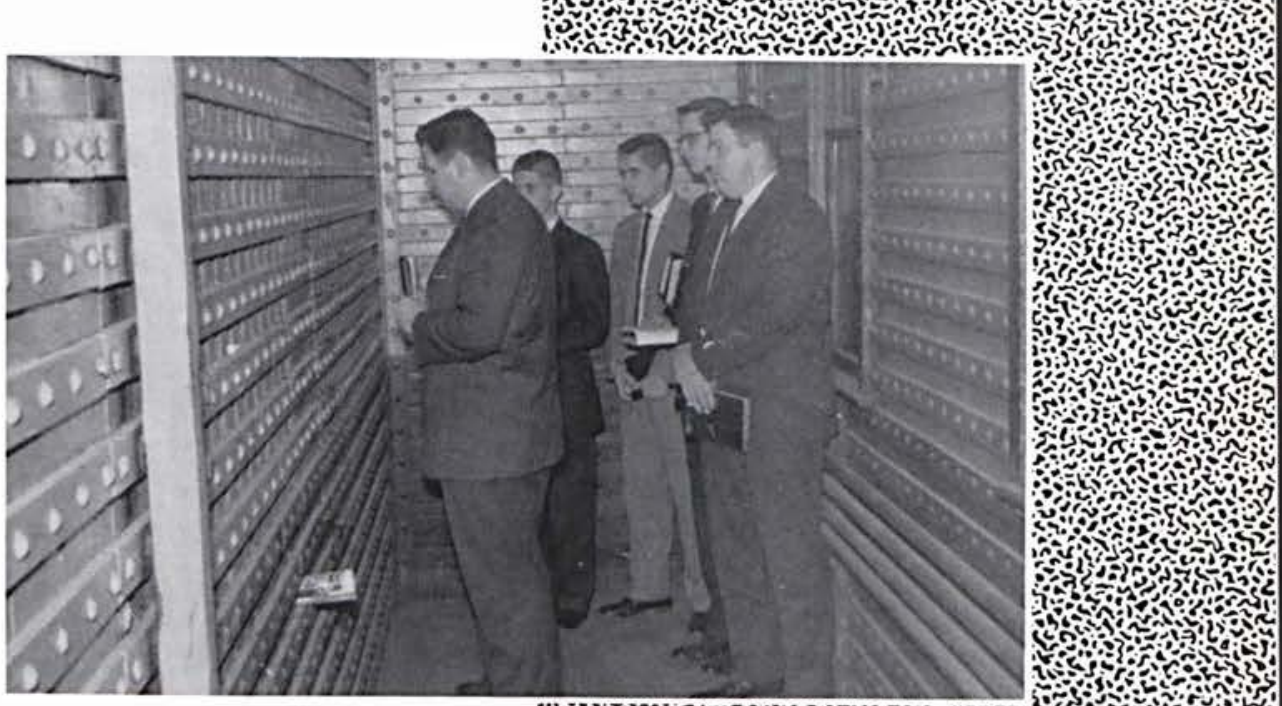

A group of fellows held a service in one section of the Springfield Jail.
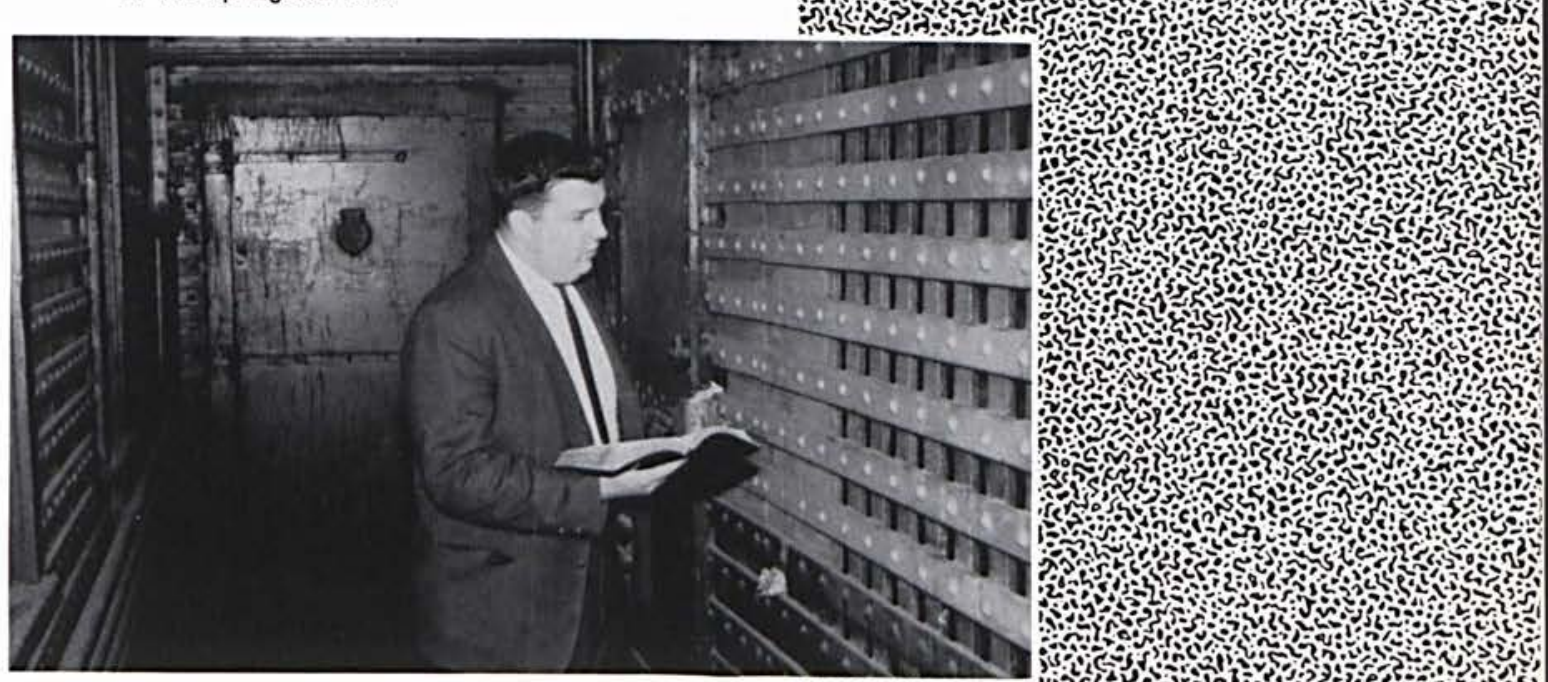

Doug Smith presents the good news of salvation to the lost.

A 2. (2) sito

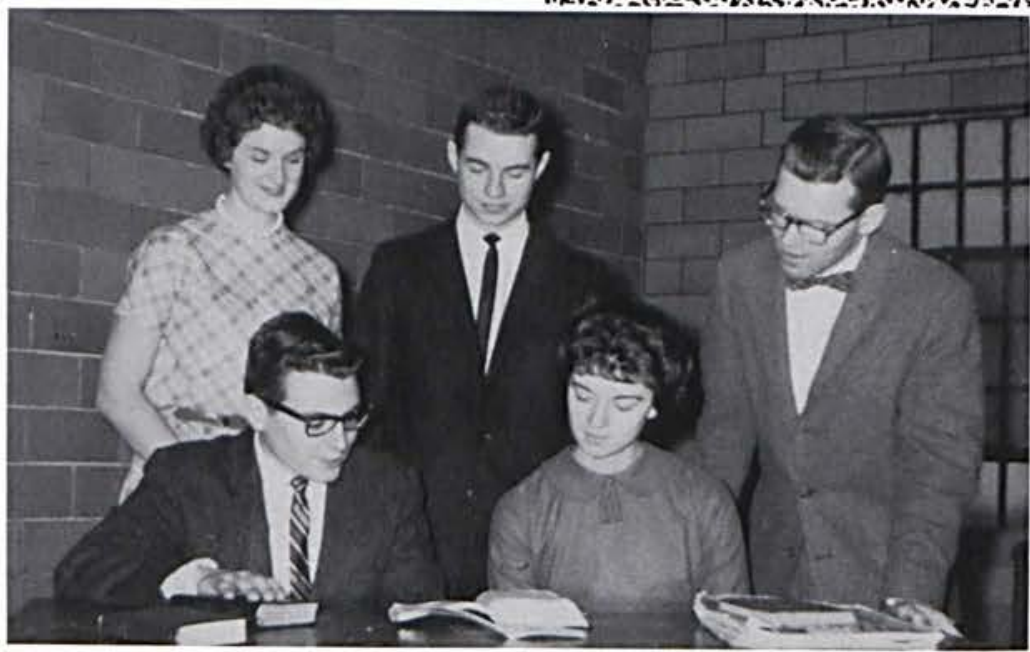

等

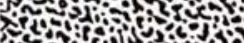

The Springfield detention home group has devotions together after arriving at the home.

23?

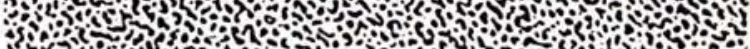

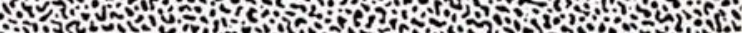
: An PS

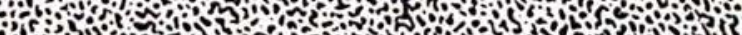
1.0. 


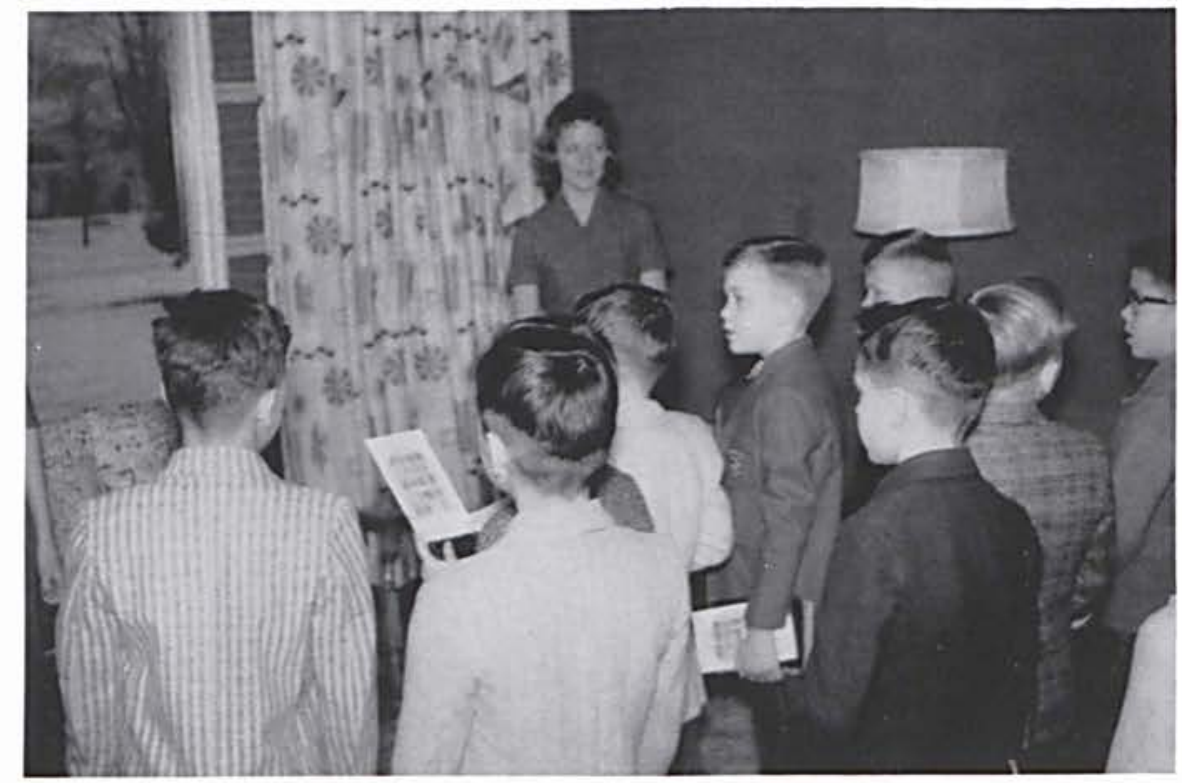

Carol Henson listens as the children at the Taylor home on the O.S.S.O. campus sing a hymn.

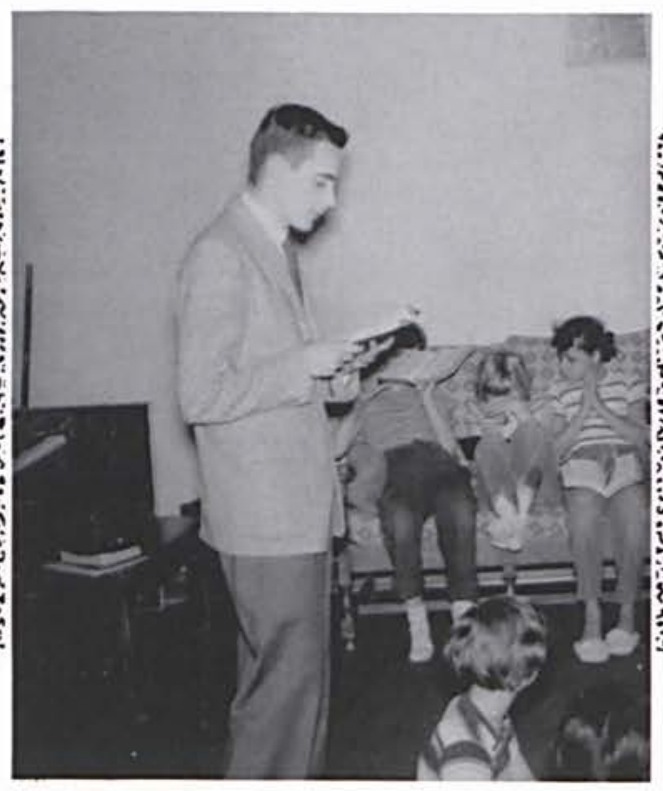

Wrow and Another opportunity for 30. ind to children in junior

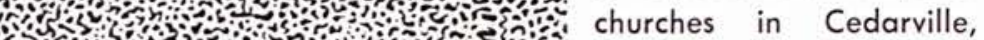

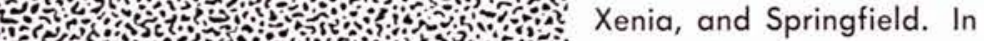

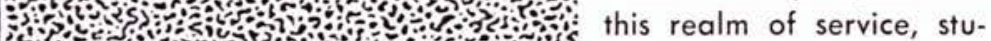
S.

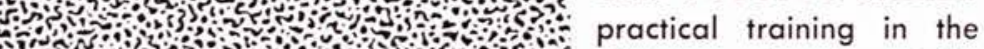
(n) Christian education of the .

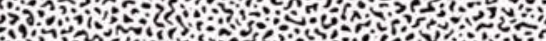

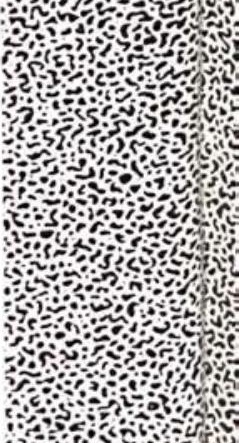
on ons

Don Middleton reads a passage of Scripture to a group of children at the Peter Pan house at the O.S.S.O.

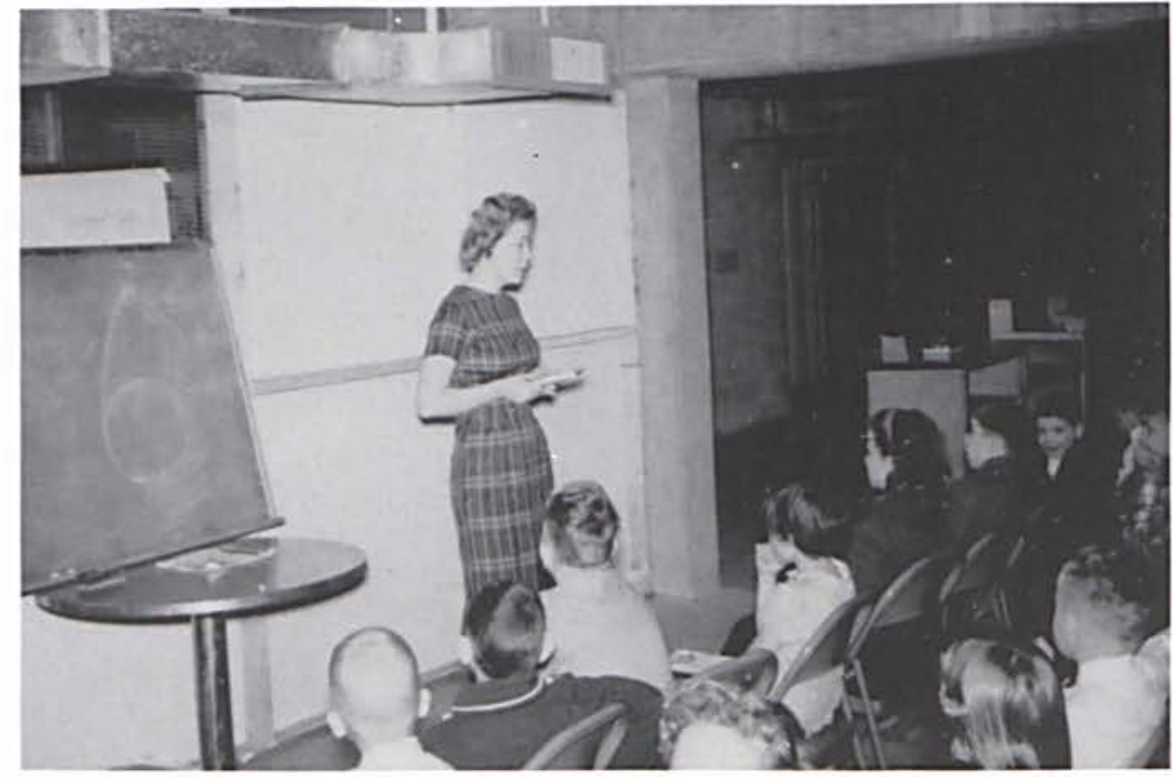

Children in junior church at Xenia Emmanuel Baptist listen to a story given by Irene Benson. 


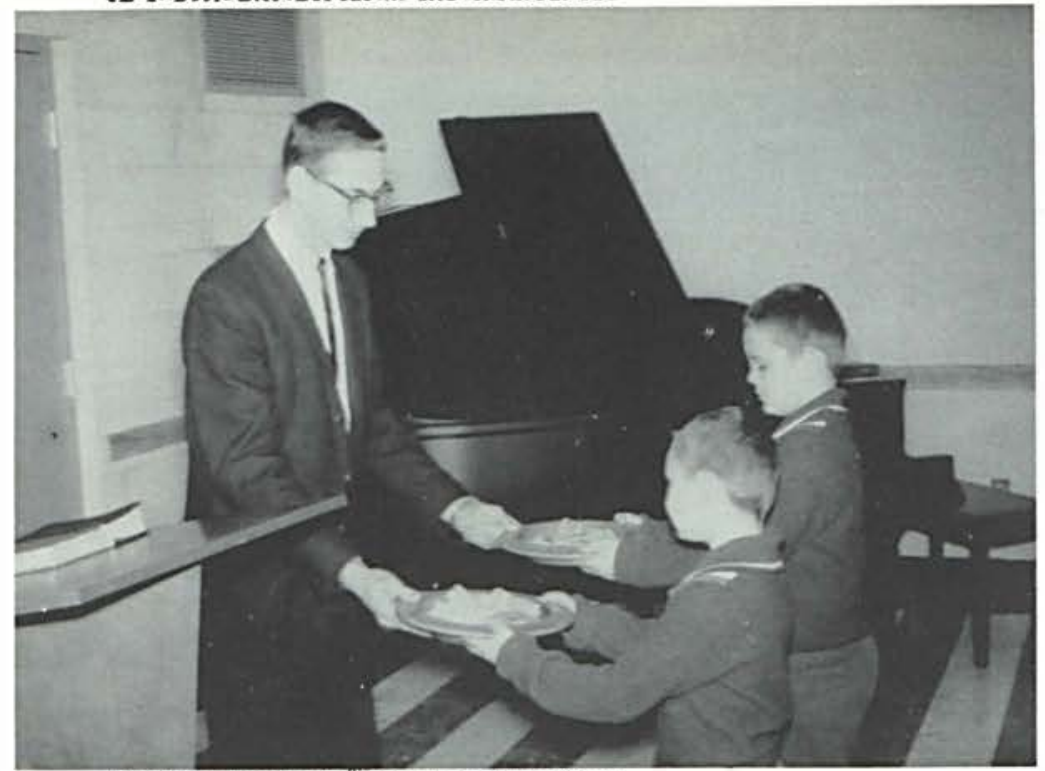

f A

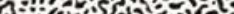

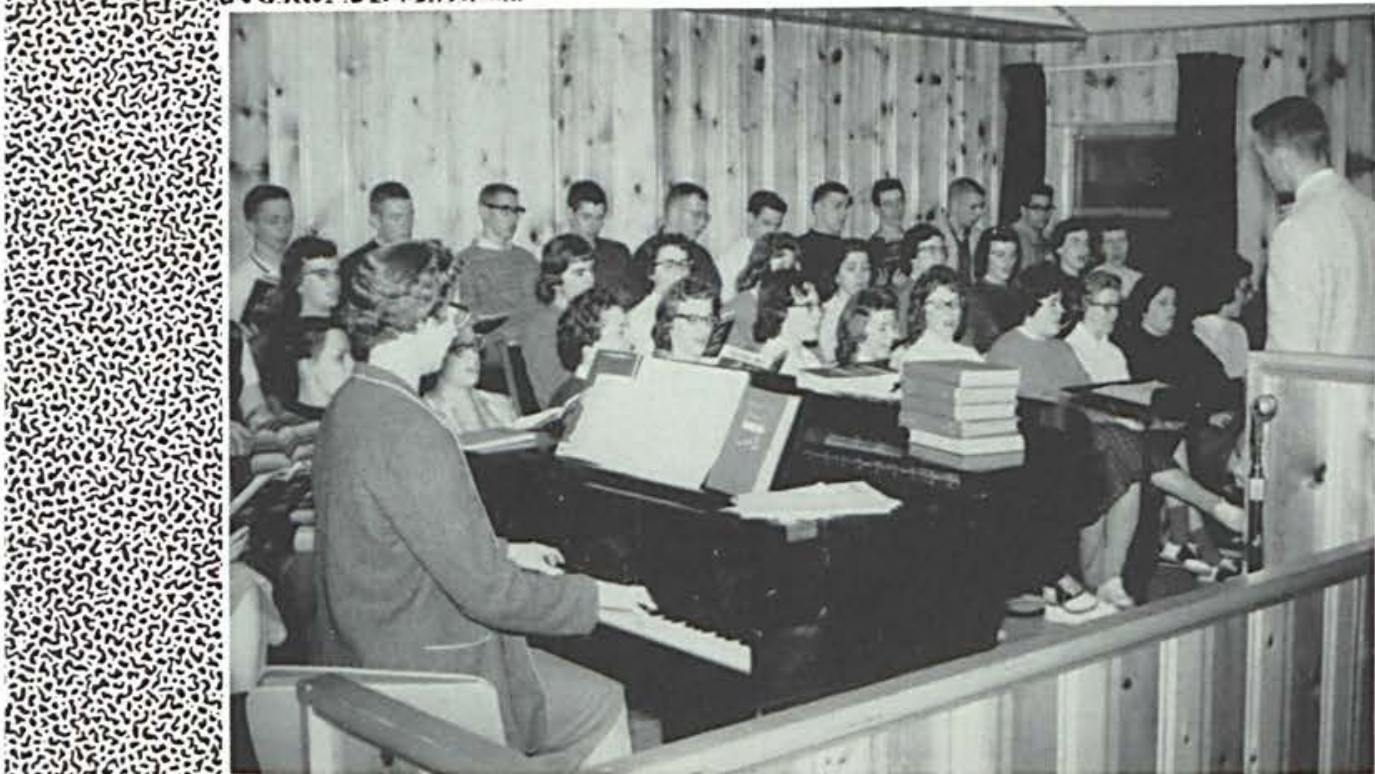

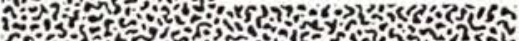

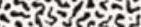
An a 340 H 2. 3 . In? \$5 5 ; Not only are our students engaged in such services as mentioned on Pi services as mentioned on the preceding pages; but also as student pastors, Sunday School superintendents, and music directors, etc. Surely, we can say that it is a great privilege to give service unto the Lord.

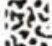
onsise

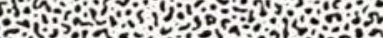

As Sunday School superintendent at Xenia Emmanuel Baptist Church, Dave Earnhart receives the tithes and offerings.

The Grace Baptist Church choir of Cedarville serves as a medium for Christian service for numerous students. 


\section{Organizations .....}

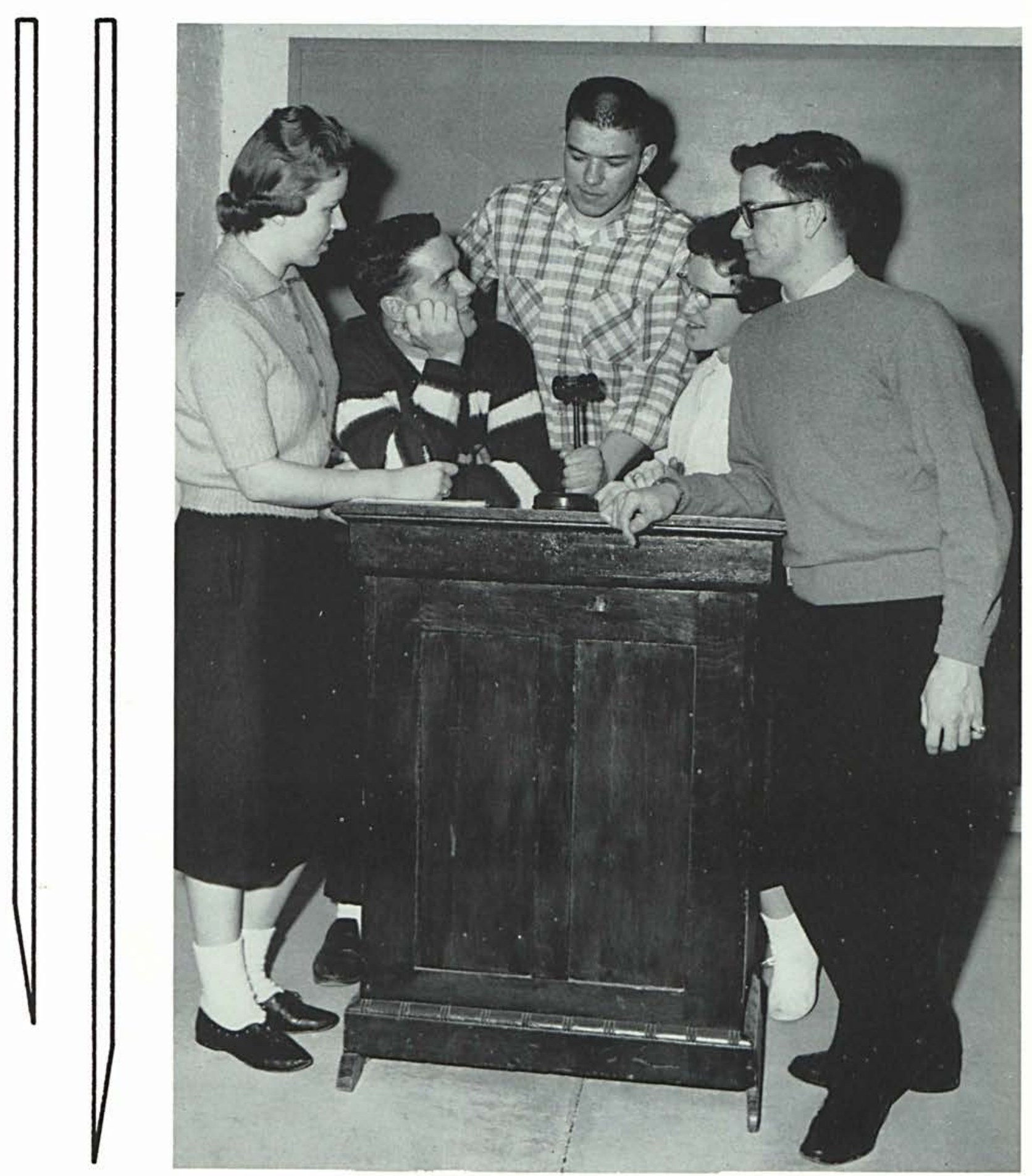




\section{Student Council}

Student leaders, with the advice of a faculty member, plan and carry out many campus activities. One responsibility of the Council is to enforce the traffic rules on campus. A court is set up to administer this. Last year the Council started an annual Student Body Project and each year it nominates four co-chairmen, two of whom are to be chosen by the student body to carry out the project. The goal this year is $\$ 1000.00$.

\begin{tabular}{|l|r|}
\hline \multicolumn{1}{|c|}{ OFFICERS } \\
President & \\
Vice-President & Terry Goodrich \\
Secretary & Esther Weiss \\
Treasurer & Shirley Harrington \\
Advisor & Mr. R. Mclntosh \\
\hline
\end{tabular}

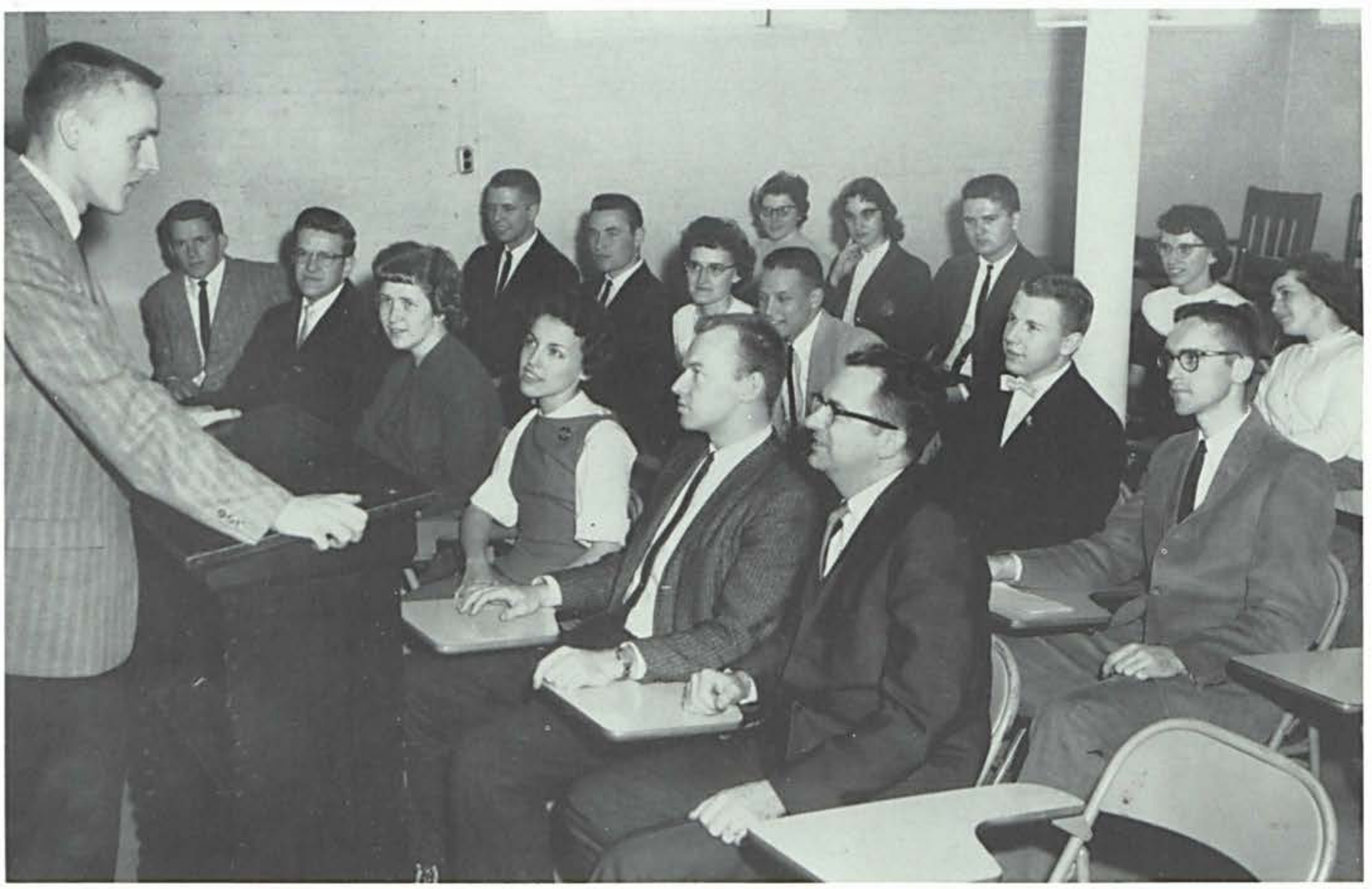

Standing: Jim Entner. Seated, First Row, Left to Right: Bill Jennings, Bob Domokos, Shirley Harrington, Esther Weiss, Terry Goodrich, Mr. Maclntosh. Second Row: Ron Mooney, Dan Brower, Jean Lockerbie, John Lawlor, Phil Grant, Sam Canine. Third Row: Rosalee Albrecht, Nancy Shimits, Chuck Hartzell, Peg Getty, Juanita Allford. 


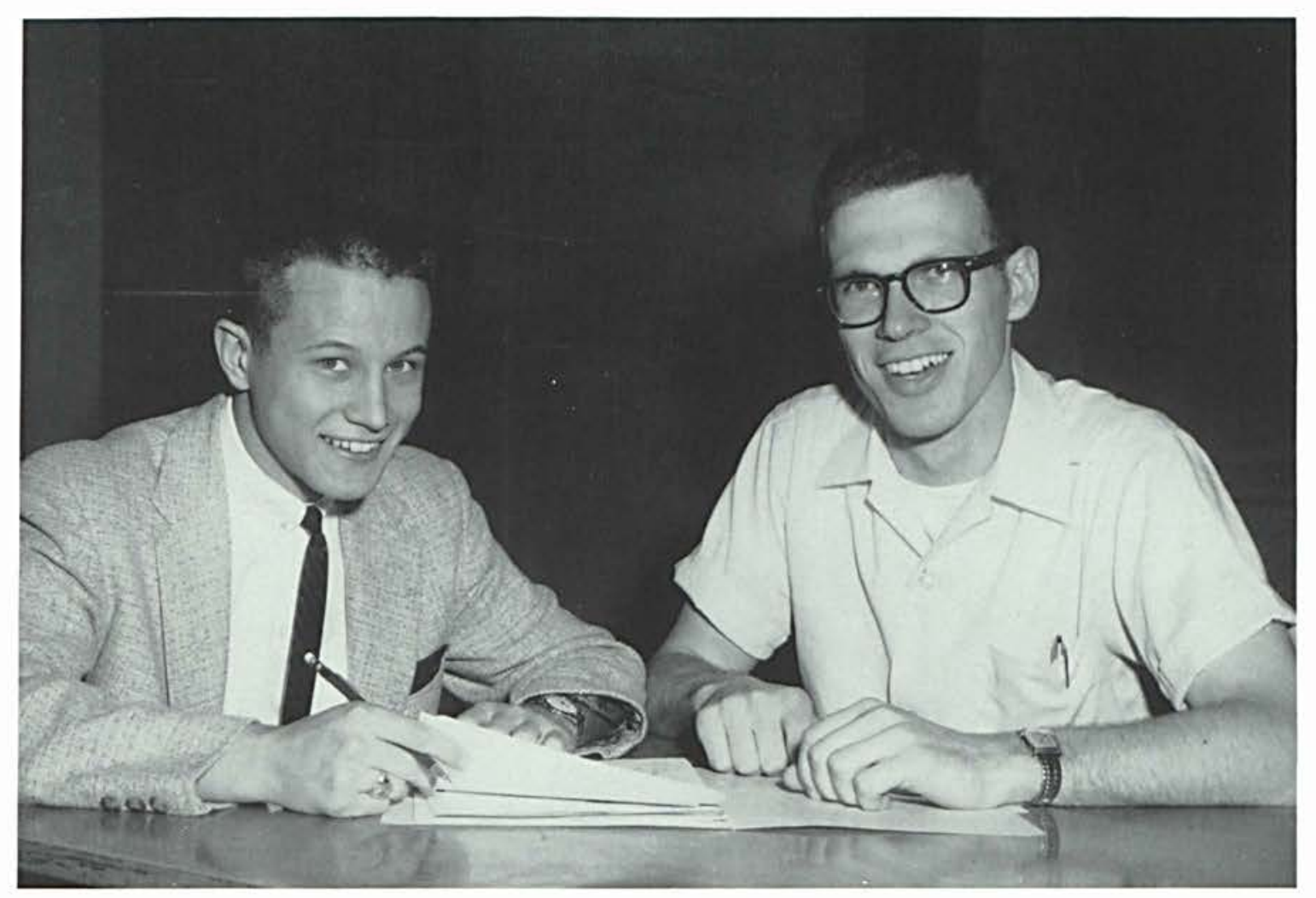

Student Body Project Co-Chairmen John Lawlor and John Butler.

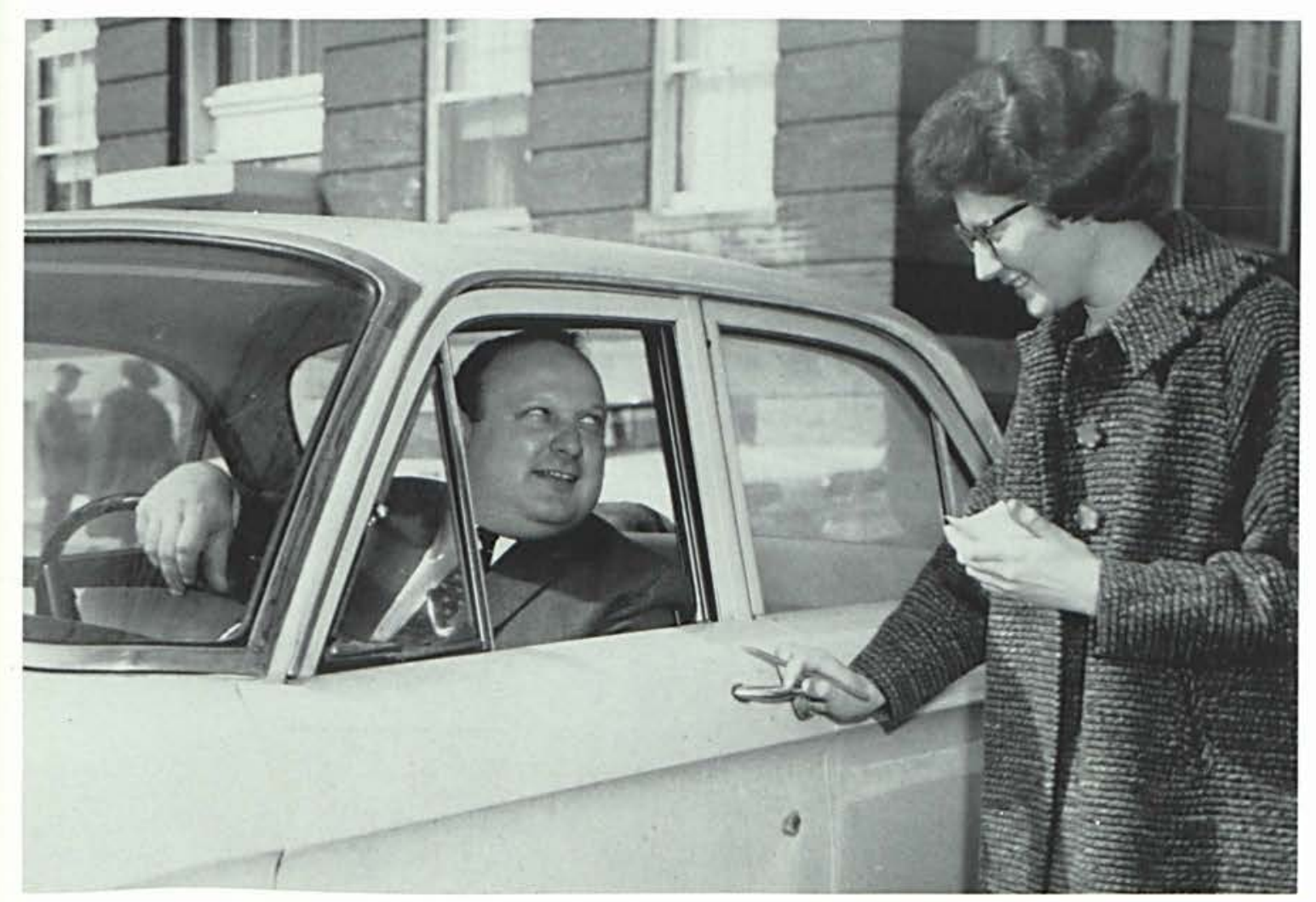

Representative Rosalee Albrecht gives a traffic ticket to an offender! 


\section{Alpha Chi}

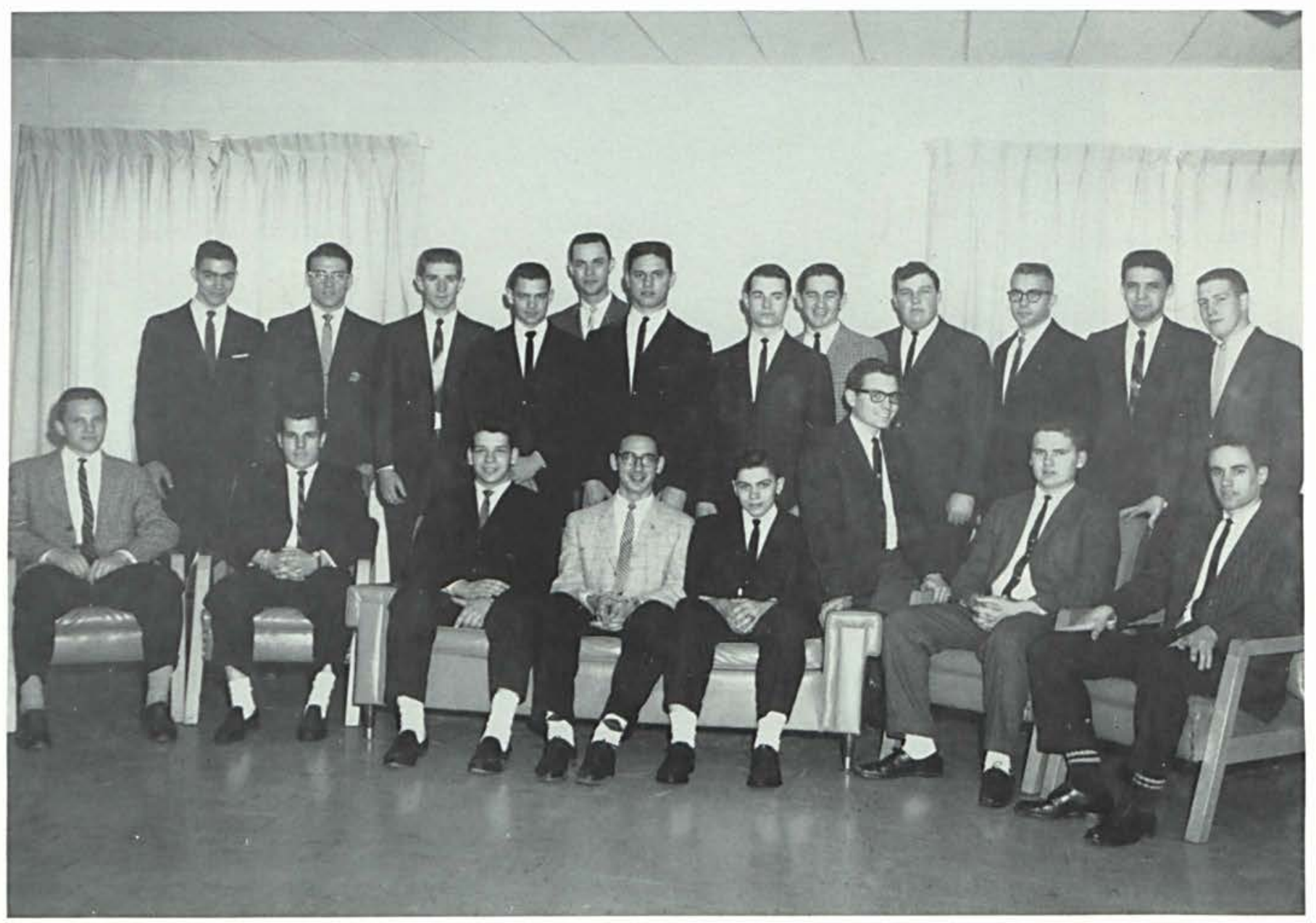

Seated, Left to Right: Ellis Howard, Tony Rotondi, Rich Blumenstock, Dave Earnhart, Mark Hazeltine, Tom Cetas, Chuck Hartzell, Otis Stone. Standing: Gordon Finley, Allen Biddle, Elvin
King, Jay Moore, Al Mumford, Don Tennant, Ed Bensinger, Ken Swigert, Doug Smith, Gene Wright, Darius Nutt, Cliff Kingsland.
Alpha Chi - these Greek words mean Men for Christ and form the name of the men's literary society. The primary purpose is the cultivation of Christian personality and leadership. Alpha Chi is in charge of the annual Thanksgiving Banquet, this year it was held at the Springfield South High School.

\begin{tabular}{|l|}
\hline \multicolumn{2}{|c|}{ OFFICERS } \\
President _ \\
Vice-President \\
Secretary-Treasurer \\
Advisor $\ldots$ Rave Earnhart
\end{tabular}


This group of students, interested in foreign and home missions, meets each day in morning prayer bands. FWM frequently sponsors missionary speakers in chapel. Last year they began an annual Missionary Conference in cooperation with Grace Baptist Church. Officers are: President, Bob Domokos; Vice-President, Art Hicks; Secretary-Treasurer, Marlene Davis.

\section{Fellowship for}

\section{World Missions}

Missionary Conference Committee. Left to Right: Lauren Schenk, Bob Domokos, Charlene Ressler, Pastor Moffat, Jim Entner.

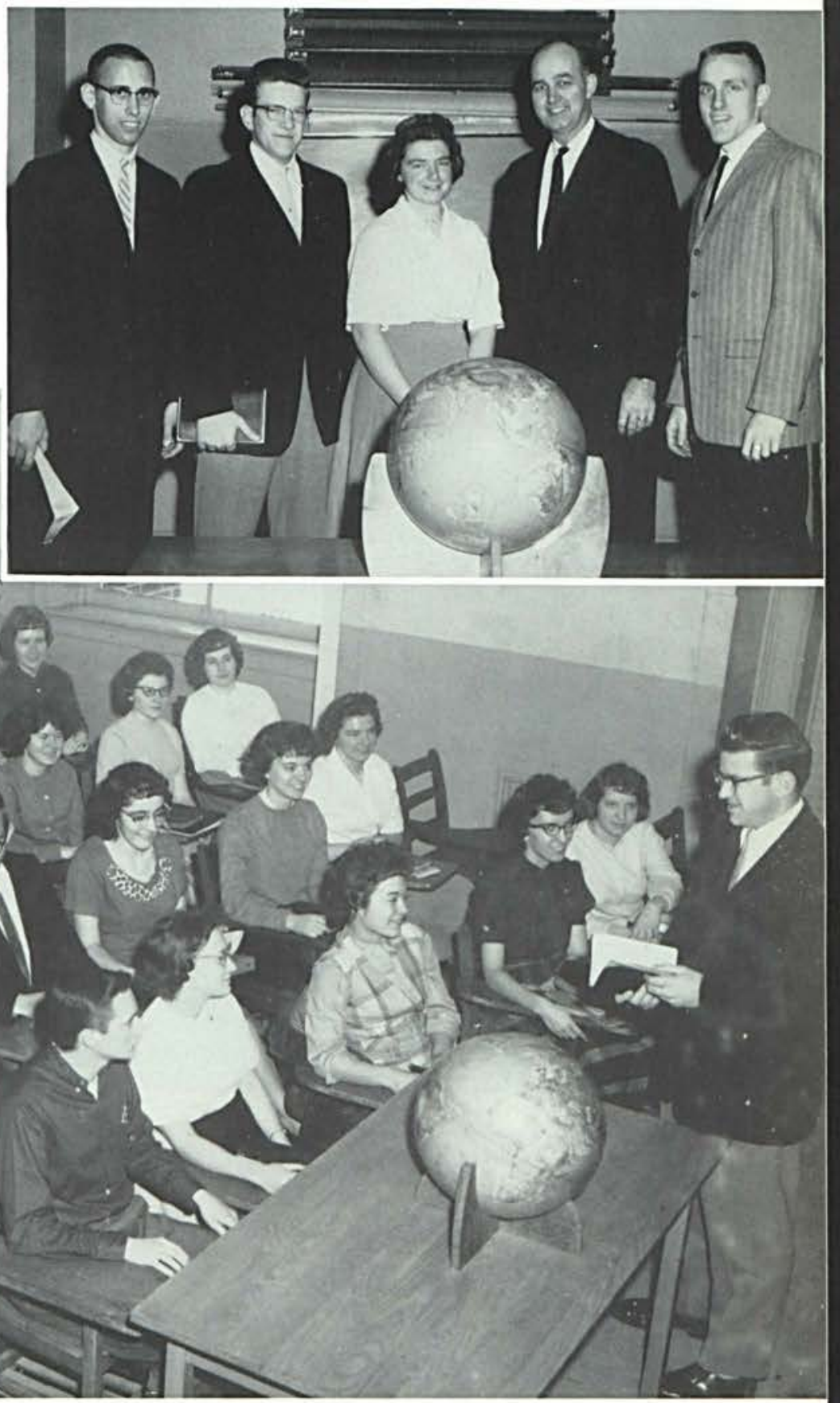

Standing: Bob Domokos. First Row, Left to Right: Don Middleton, Carol Brown, Jeannie Du Pre, Peggy Howard, Donna Everett. Second Row: Lauren Schenk, Gene Wright, Julia Bird, Cathy Shelton, Charlene Ressler. Third Row: Peggy Buerer, Lyle Rose, Lois Bayless, Mary Blann, Rosalee Albrecht, Juanita Allford. Fourth Row: Chuck Hartsell, Betty Rose, Sharon
Addleman, Bonnie Nash, Shirley Harringtc.l. Fifth Row: Peg Getty, Irene Benson, Barb Slavins, Bev Lyon, Keith Webster, Barney Farnsworth. Sixth Row: Betty Smith, Hazel Brovont, Esther Weiss, Jim Entner, Tony Nicklas. Seventh Row: Gordon Finley, Mark Hazeltine. 


\section{Varsity "C"}

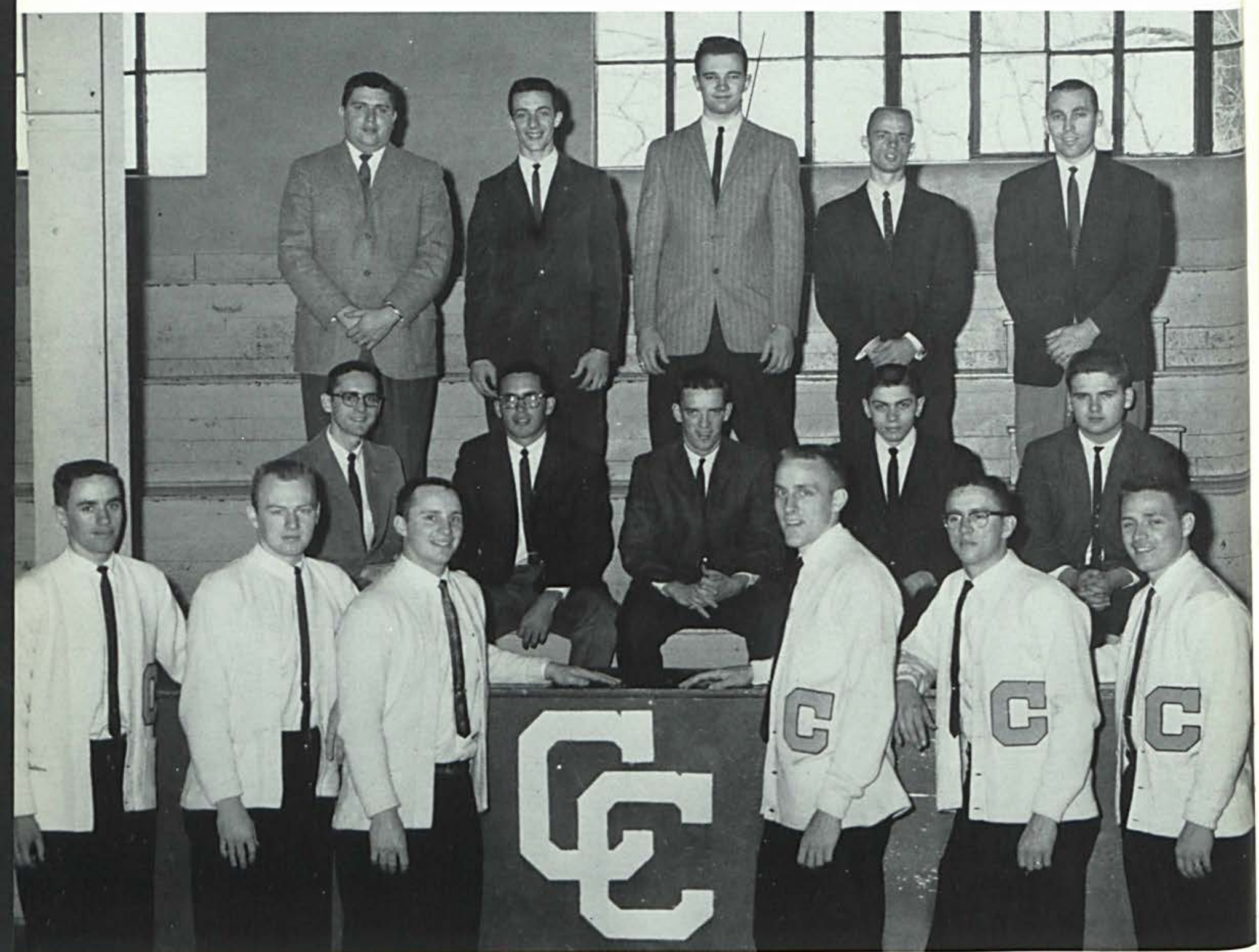

First Row, Left to Right: Otis Stone, Terry Goodrich, Dave Cochran,

Elder, Tim Grafton, Mark Hazeltine, Chuck Hartzell. Third Row: Coach Jim Entner, Terry Zerby, Dave Lewis. Second Row: Sam Canine, Bill

The purpose of Varsity " $C$ " is to promote leadership among the fellows who have earned their letters in varsity athletics. Varsity athletics at CC includes basketball, baseball, and tennis. The accomplishments of the year were the purchase of varsity sweaters, a pitching machine, and basketball seasonal programs.

Officers of the club are: President, Dave Cochran; Vice-President, Jim Entner; Secretary, Terry Goodrich; Treasurer, Norris Smith. The advisors are Coaches Bowser and Callan. 
Sock ' $n$ ' Buskin provides the opportunity for dramatic talent and interest to be displayed on campus. Students may earn points toward membership in the organization by participating in the various plays pre- sented throughout the school year. This club sponsored an outstanding film, Hamlet during the first semester. They were also responsible for the homecoming play.

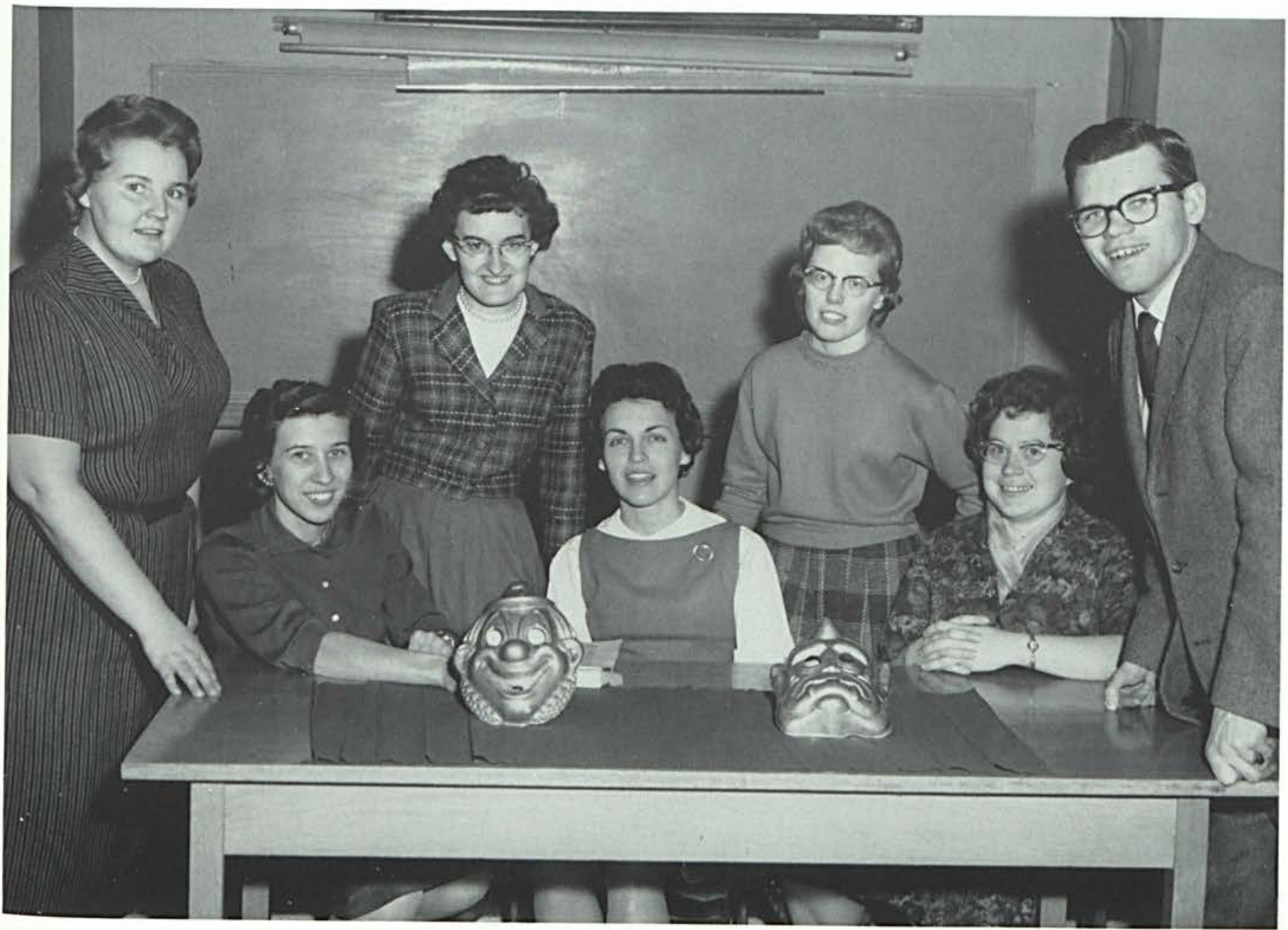

Seated, Left to Right: Miss Kantzer, Esther Weiss, Neva Claypool. Standing: Delores Osborn, Jean Lockerbie, Phyllis Dobbs, Keith Webster.

\begin{tabular}{|lr|}
\hline & OFFICERS \\
President & \\
Vice-President & Keith Webster \\
Secretary & Esther Weiss \\
Treasurer & Phyllis Dobbs \\
Advisor & Miss Webster \\
\hline
\end{tabular}

\section{Sock}

'n'

Buskin 


\begin{tabular}{|c|}
\hline STAFF \\
Co-Editors \\
Reporters \\
Allford, Hazel Brovont, Donna Everett, Betty Mc- \\
Keehan, Margaret Stowell, Hope Marie Willie, \\
Bev Woods. \\
Advisor
\end{tabular}

\section{Whispering}

\section{Cedars}

Whispering Cedars, a bi-weekly paper, is published by and for the students under the supervision of Mr. Ray Bartholomew.

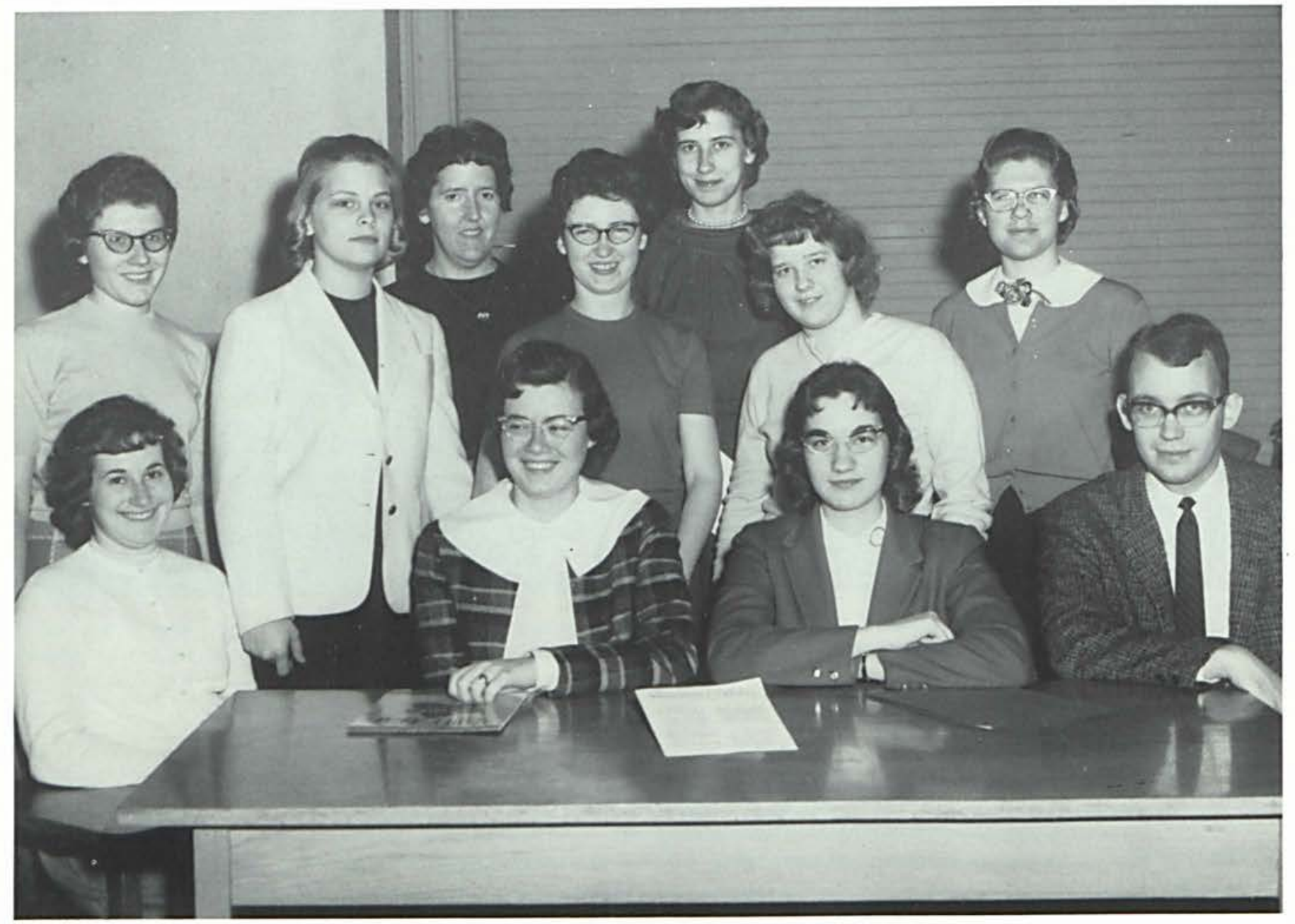

Seated, Left to Right: Juanita Allford, Jane Ginz, Nancy Shimits, Mr. Bartholomew. Standing: Rosalee Albrecht, Mar- garet Stowell, Betty McKeehan, Bev Woods, Hazel Brovont, Donna Everett, Hope Marie Willie. 


\section{Future Pastors' Fellowship}

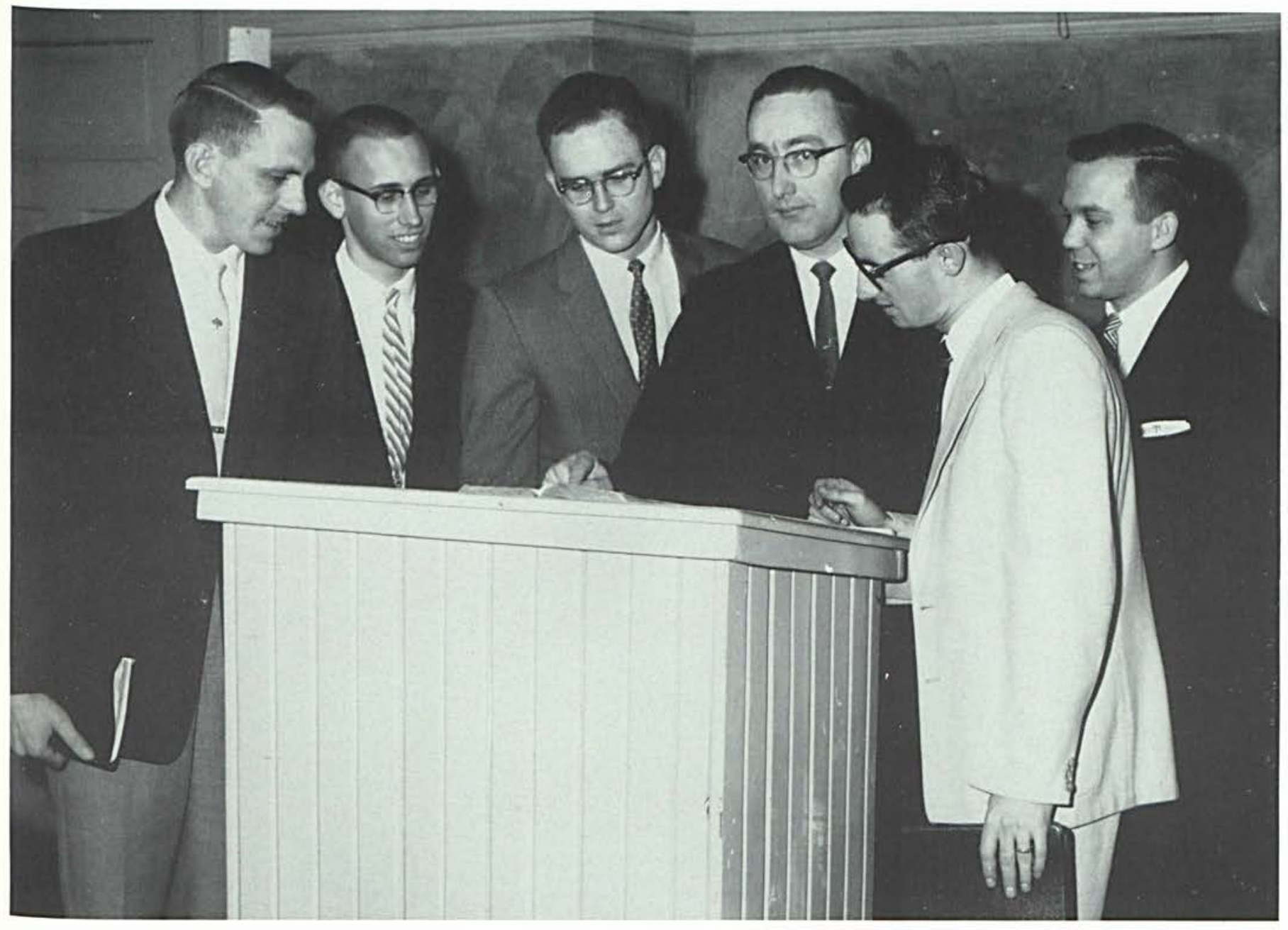

Left to Right: Jerry Wagnitz, Lauren Schenck, Lon Reising, Mr. Turnbull, Leon Rowland, Marv Troyer.

The Future Pastors' Fellowship was organized this year by some of the ministerial students. The purpose is to discuss important theological issues, to seek helpful information in the areas of the Pastor's personal life and the life of his church, and to make his ministry for Christ more effective. Mr. Turnbull is the advisor. 


\section{Miracle Staff}

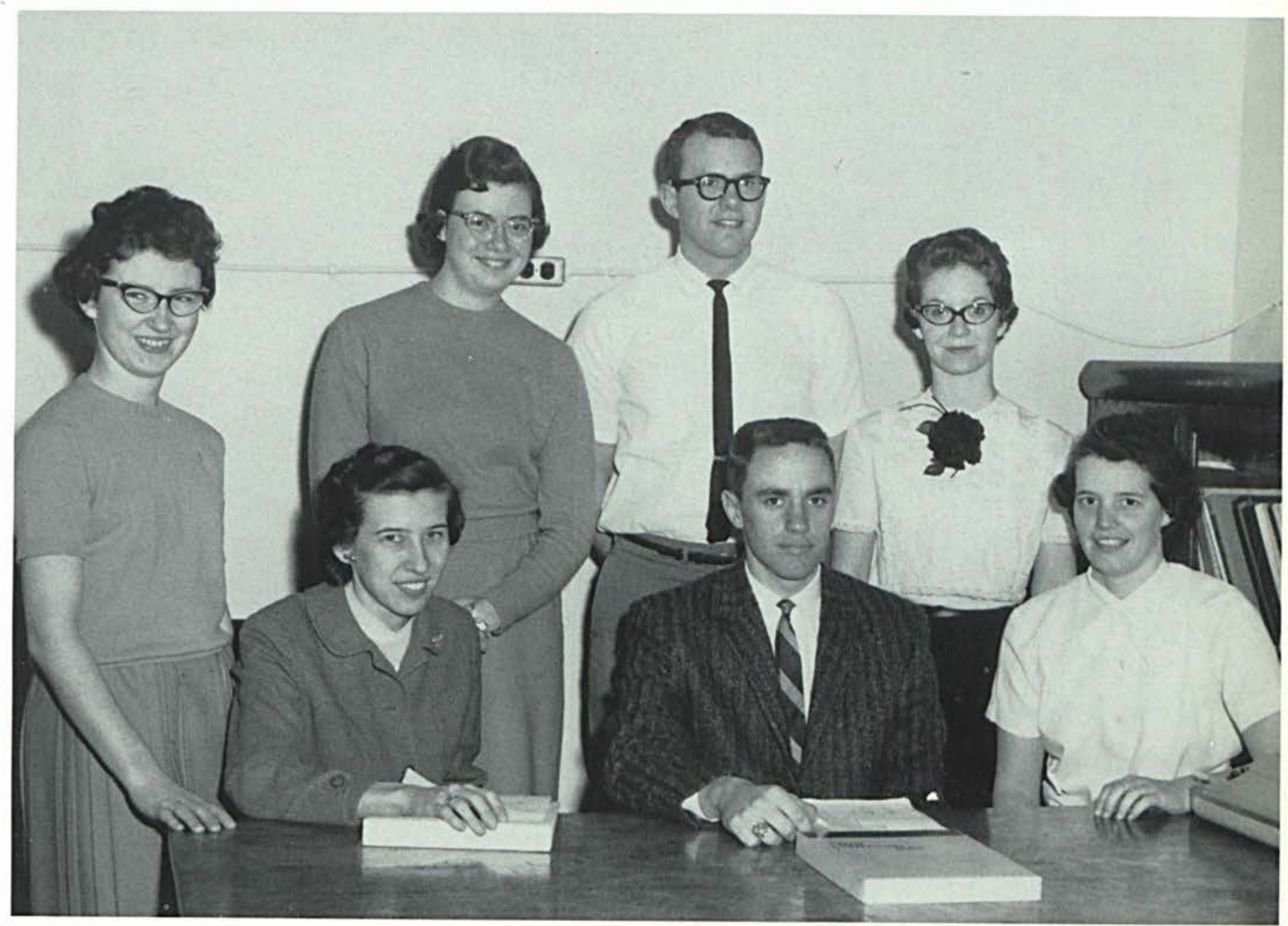

Seated, Left to Right: Miss Kantzer, Otis Stone, Eleanor Taylor. Standing: Bev Woods, Jane Ginz, Jerry Peifer, Betty Smith.

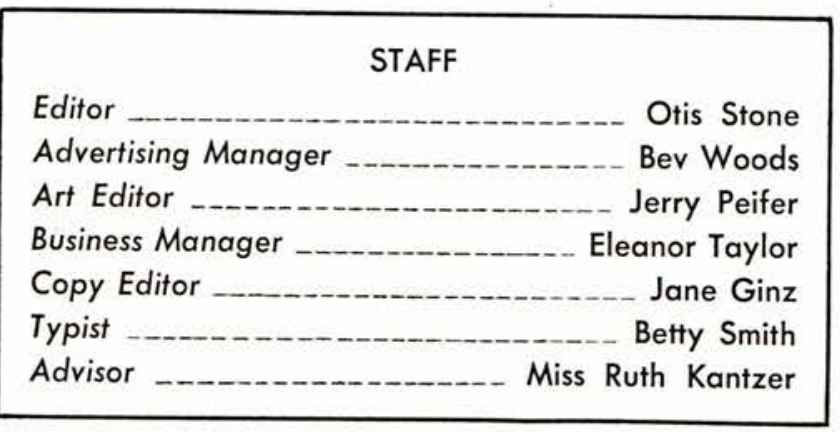

The Miracle is an annual publication of Cedarville College. The Junior class, supervised by a Faculty Advisor is responsible for editing, publishing, and distributing it. 


\section{Music .....}
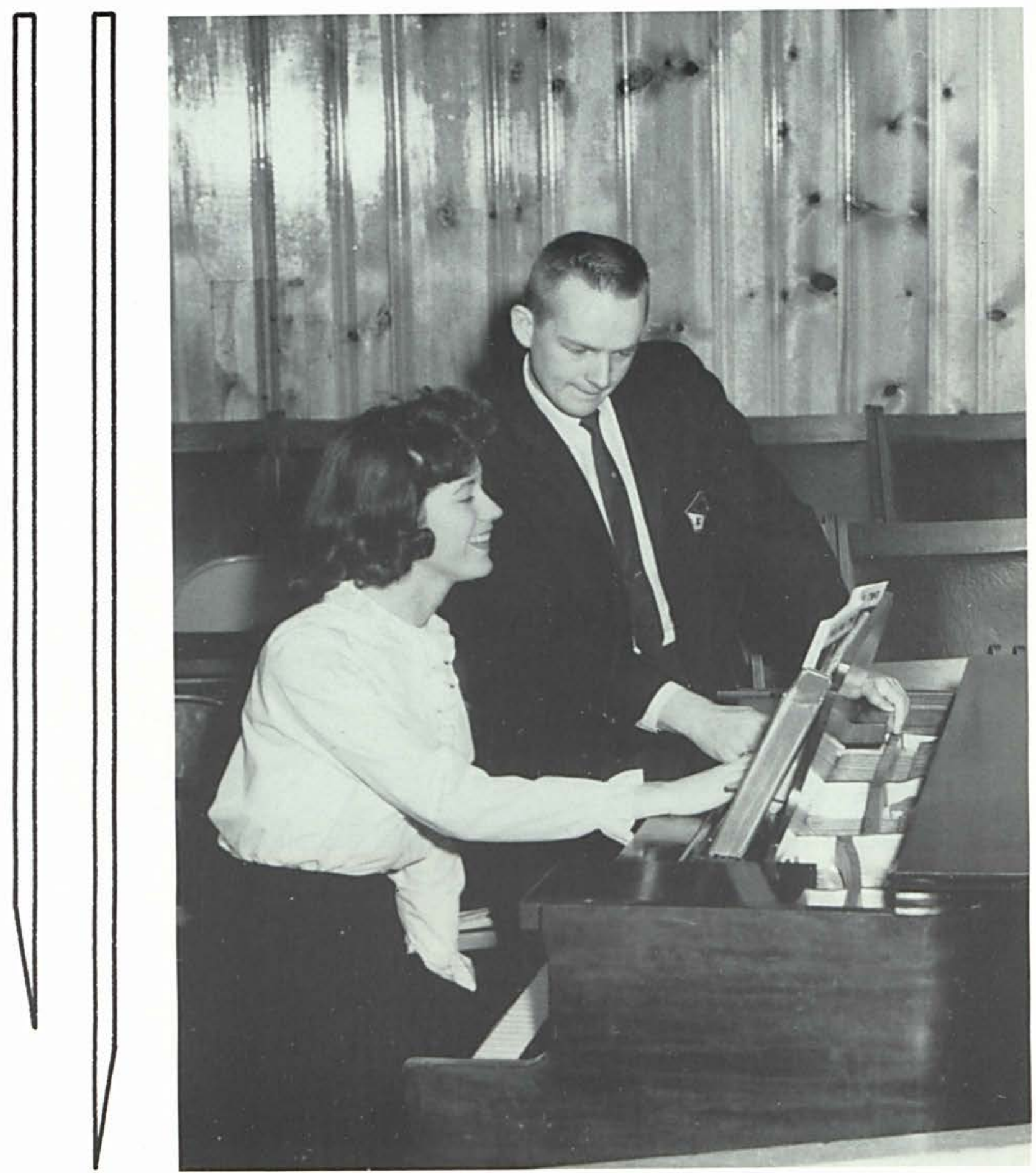


\section{Chamber Band}

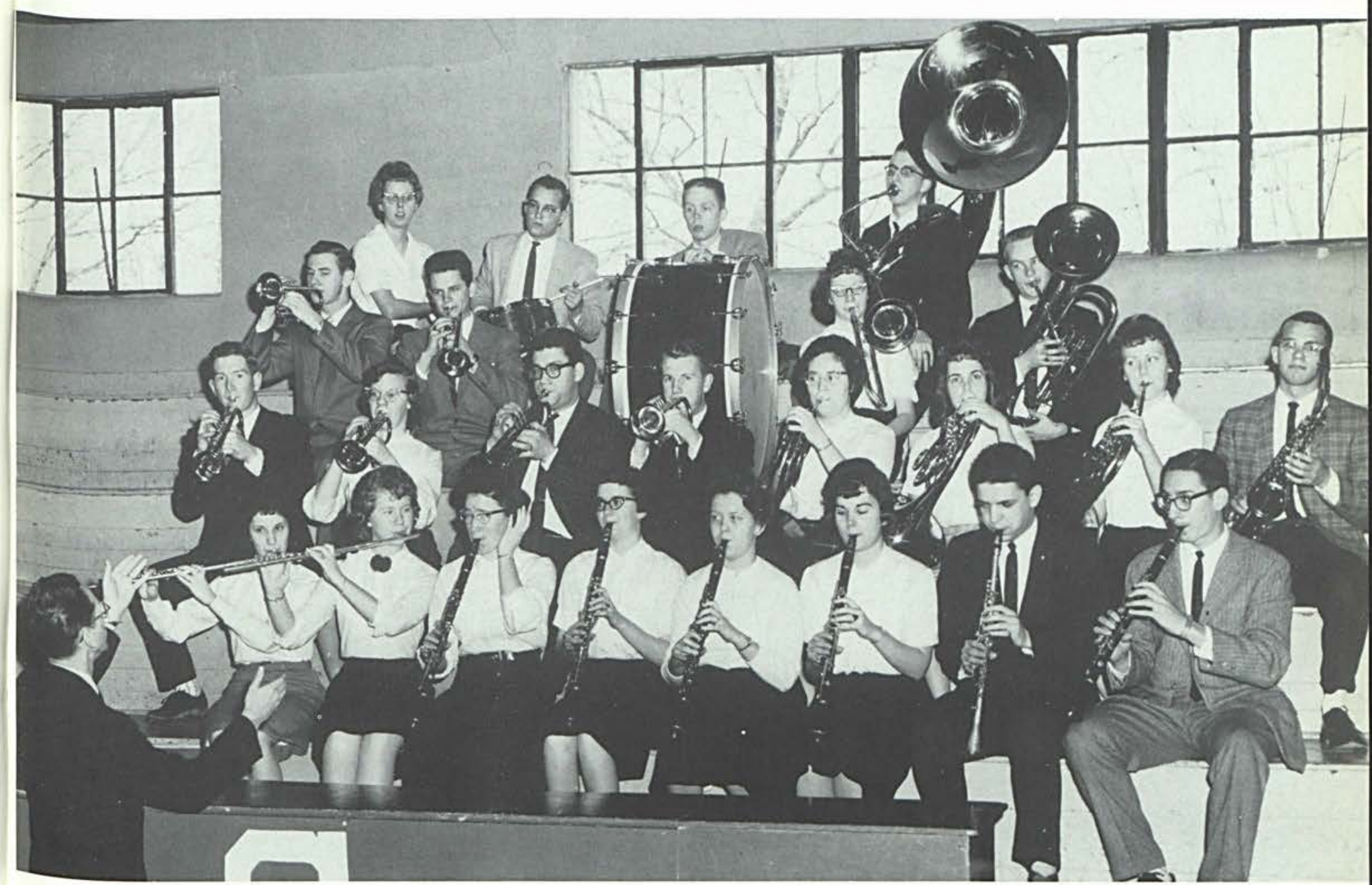

First Row, Left to Right: Pat Adams, Faye Haas, Joyce Walker, Carole Boren, Virginia Jackson, Carole Kuney, Darius Nutt, Dave Earnhart. Second Row: John Morgan, Nancy Smith, Steve Boalt, Phil Grant, Joyce Grant, Sally Bender, Lois Jacobson, Bill Riter. Third Row: Dale
Whiting, Jim Walker, Sharon Addleman, Bill Washburn. Fourth Row: Carol Zoellner, Lyle Rose, Dan Park, Ralph Werner. Director, Mr. Thornton.

In its second year, the Chamber Band greatly increased in number. Under the direction of Mr. Webber, the band participated in the annual Christmas Concert. The Pep Band, which played at all home basketball games, was comprised of various members of the Chamber Band. During the second semester, Mr. Thornton took over the responsibilities of directing the band. 


\section{College}

\section{Choir}

The College Choir gives opportunity for students to receive excellent training and experience in choral singing. In addition to the annual Spring Tour of about two weeks, the choir takes part in services in many churches throughout the area presenting sermons in song for the glory of the Lord. Assistant Professor Richard Cooke directs the choir. 


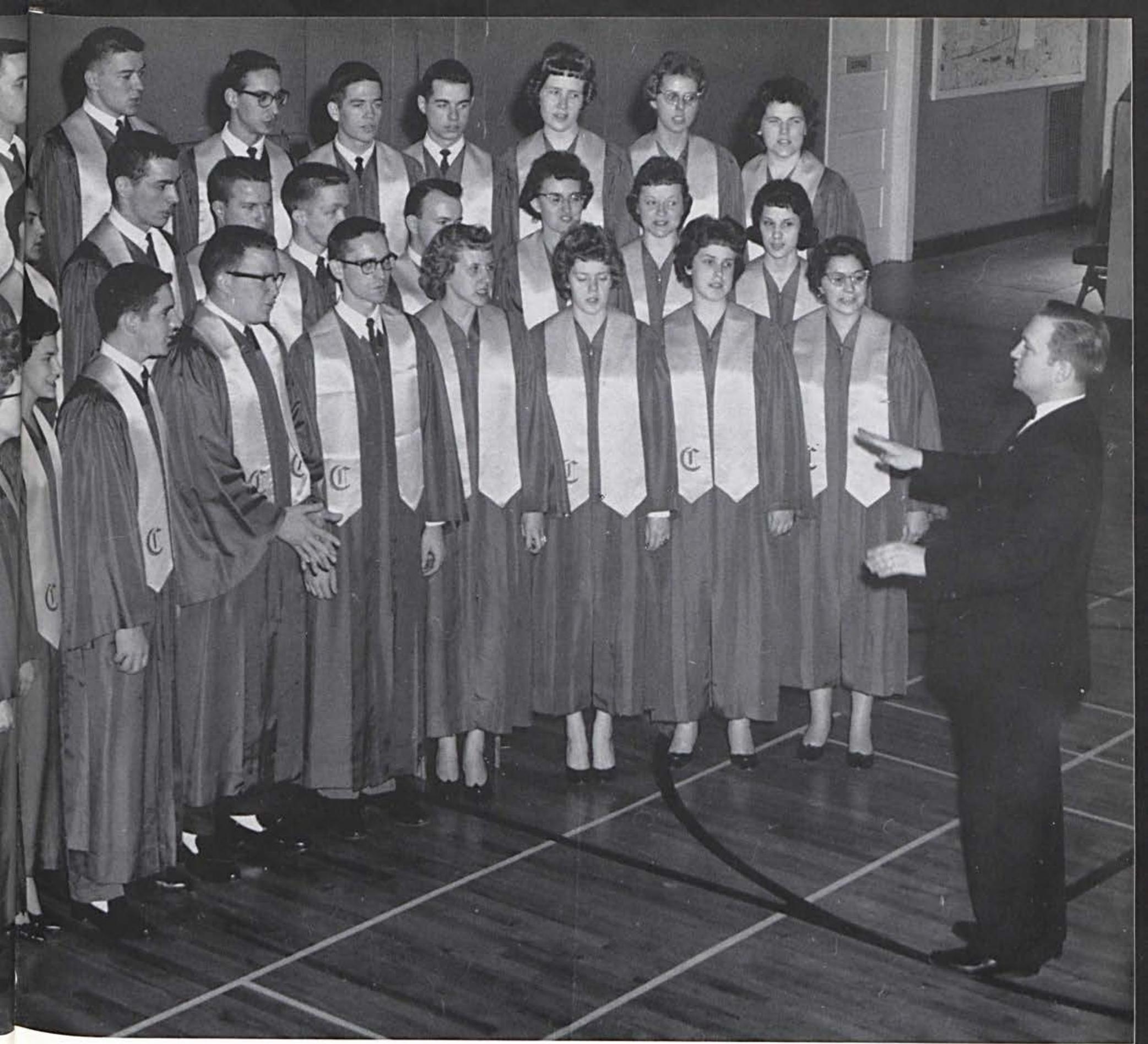

First Row, Left to Right: Esther Weiss, Carol Brown, June Golden, Rita Millikin, Donna Thompson, Ken Swigart, Rich Davidson, Sam Canine, Judy Lachman, Vicki Wooster, Elayne Howard, Donna Finley. Second Row: Bonnie Nash, Sharon Addleman, Jim Keim, Gordon Finley, Dave Searles, Dave Jeremiah, Lynn Jefson, Dan Park, John

Ingram, Jean Lockerbie, Pat Petry, Pat Adams. Third Row: Eleanor Smelser, Carole Lanius, Ralph Werner, John Morgan, Al Mumford, Dave Blossom, Dave Earnhart, Roger O'Bryan, Ed Bensinger, Shirley Harrington, Carol Zoellner, Barbara Swertfager. Director, Mr. Cooke. 



\section{Sports .....}

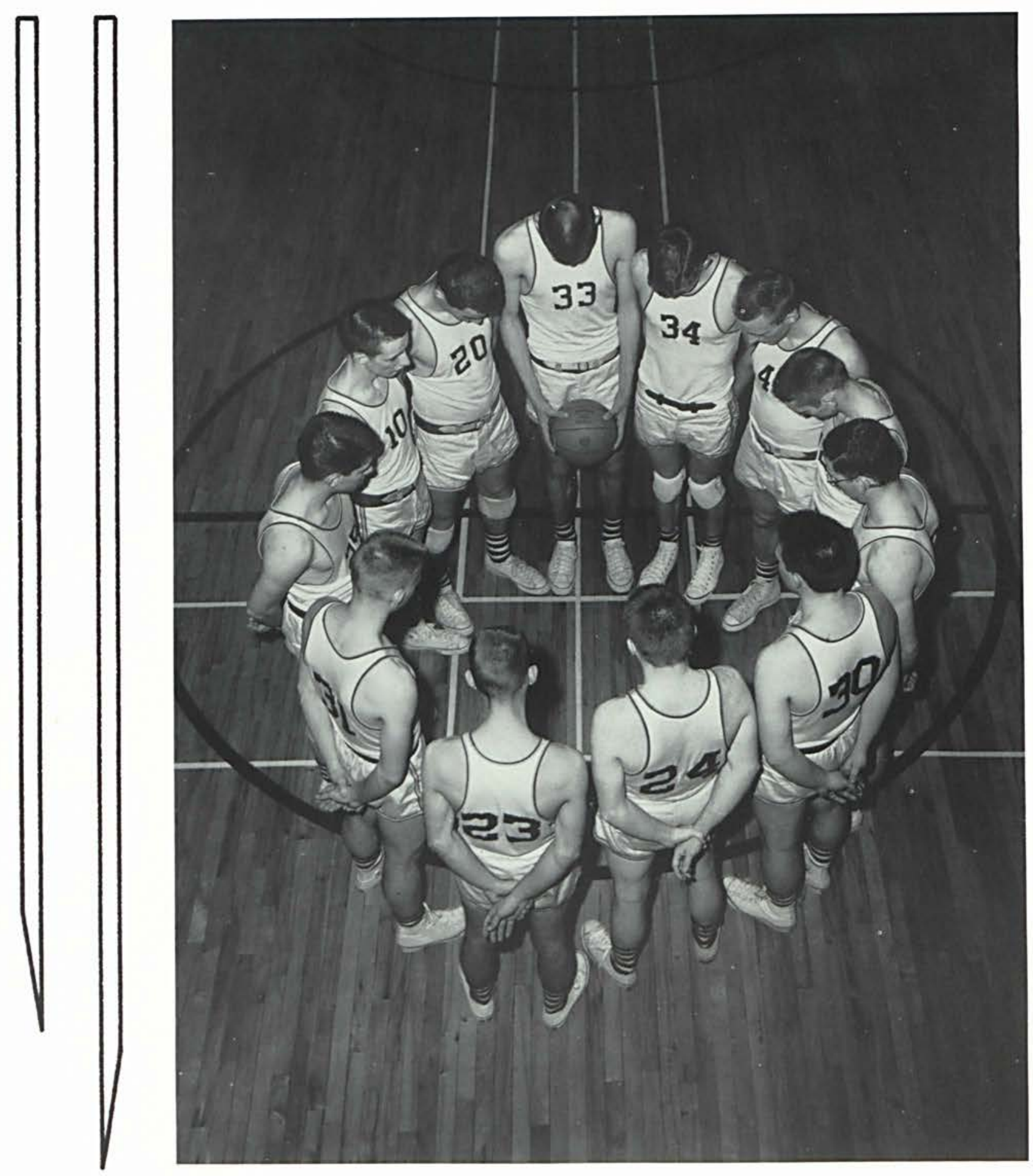


Coach Bowser and Most Valuable Player Norris Smith discuss the problems encountered during the last season.

\section{Baseball}

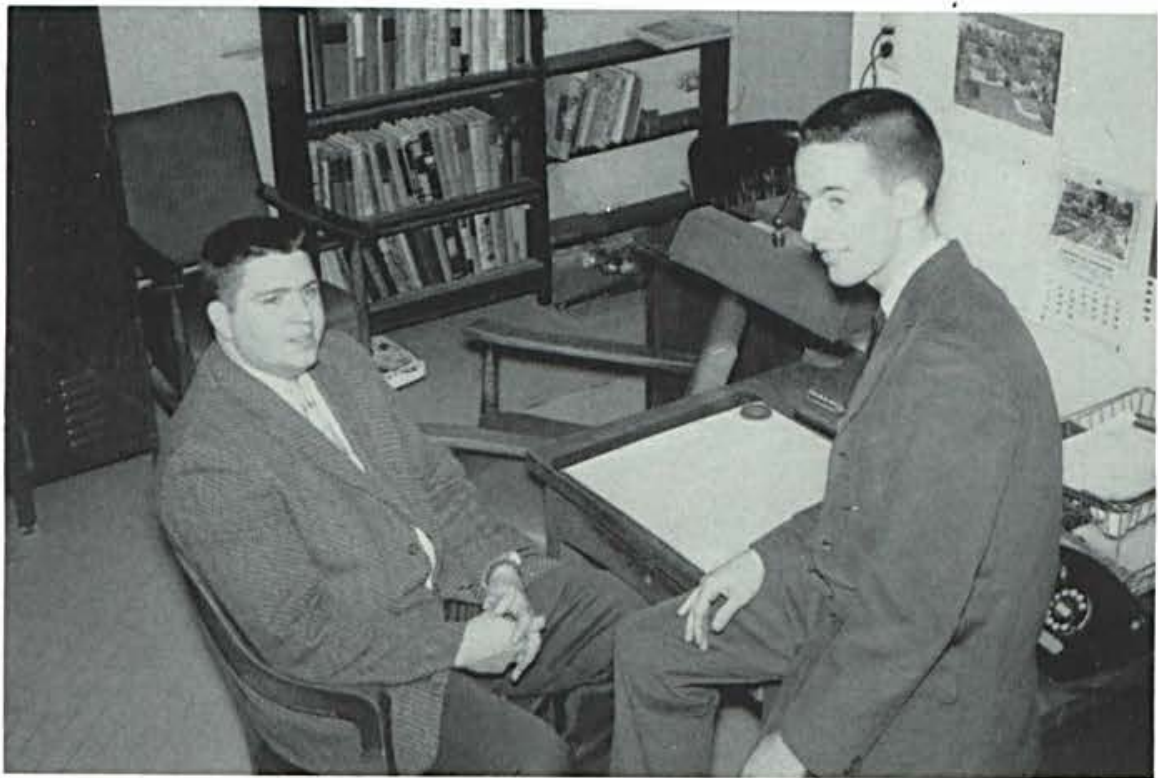

The coming of another baseball season brought a new, rich source of talent which, when mingled with the veteran ability of the years before, brought a spark of hope in Cedarville College baseball followers. The hustling Yellowjackets, playing one of its roughest schedules ever, developed gradually during the course of the season and finished strong with two victories over Findlay and Wright-Patterson. Although it was not a winning season, the team can boast of a couple of accomplishments - two wins over a strong WrightPatterson Air Force Base Team and their first win ever over Findlay. The most valuable player trophy went to Norris Smith for his fine pitching performances and all around play. With a .311 batting average, Dave Dautel copped the batting title. His excellent defensive play around first base aided the team, also. Coach Sherwin Bowser can lock optimistically to next season expecting further improvement.

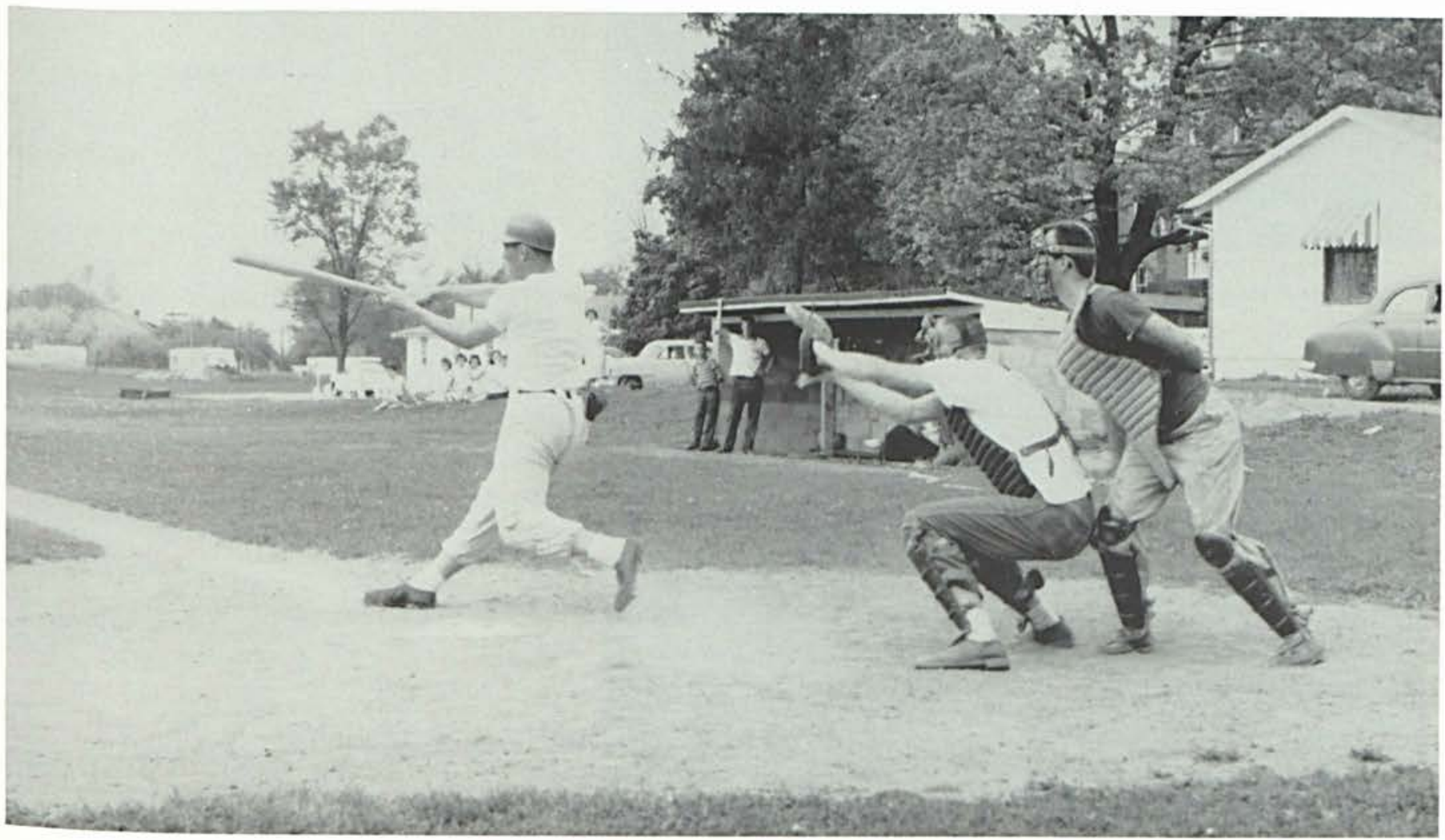




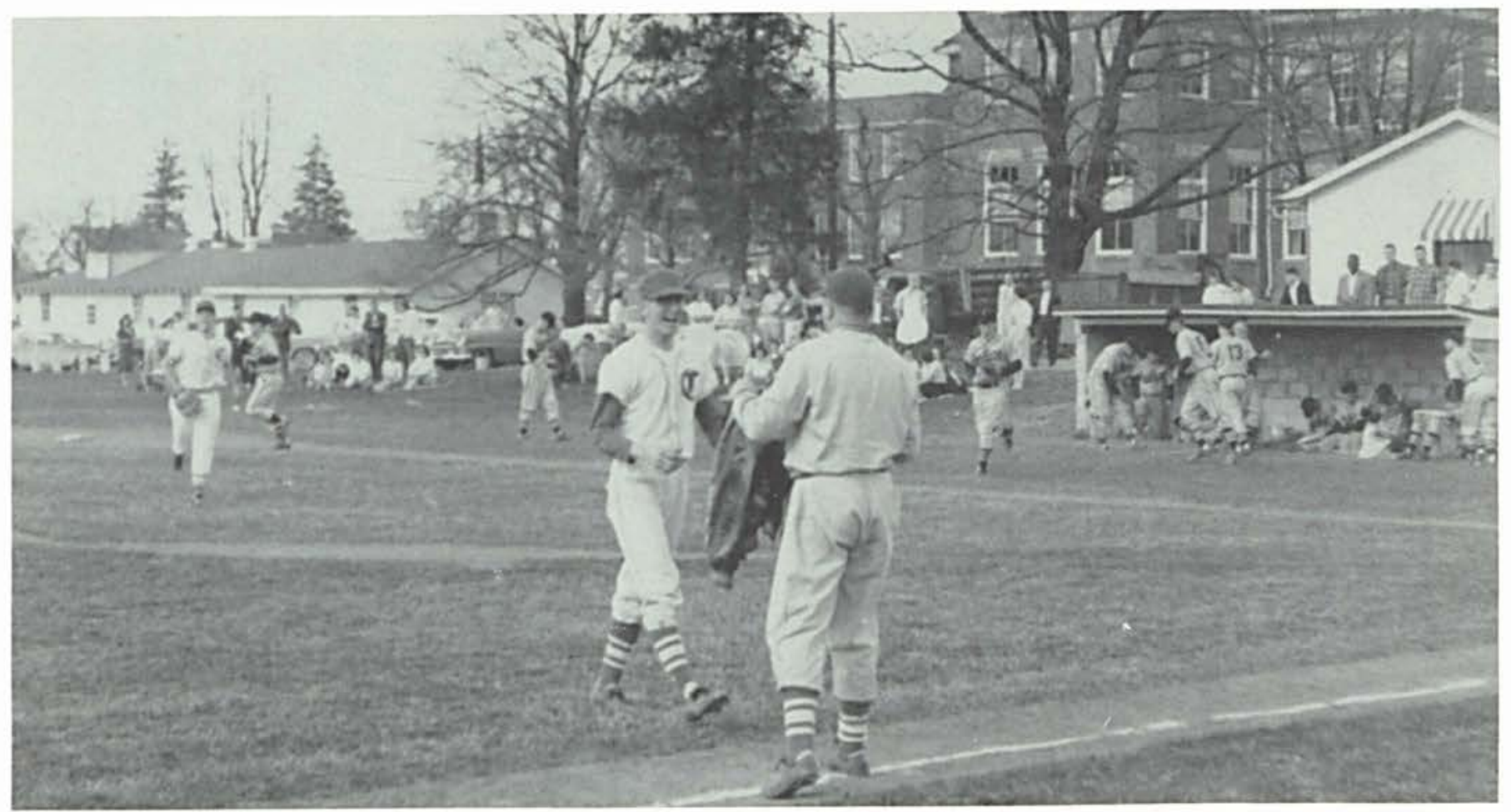

Coach Bowser meets pitcher Vance Ashley as he walks from the mound after a successful inning in a game played on the home field.

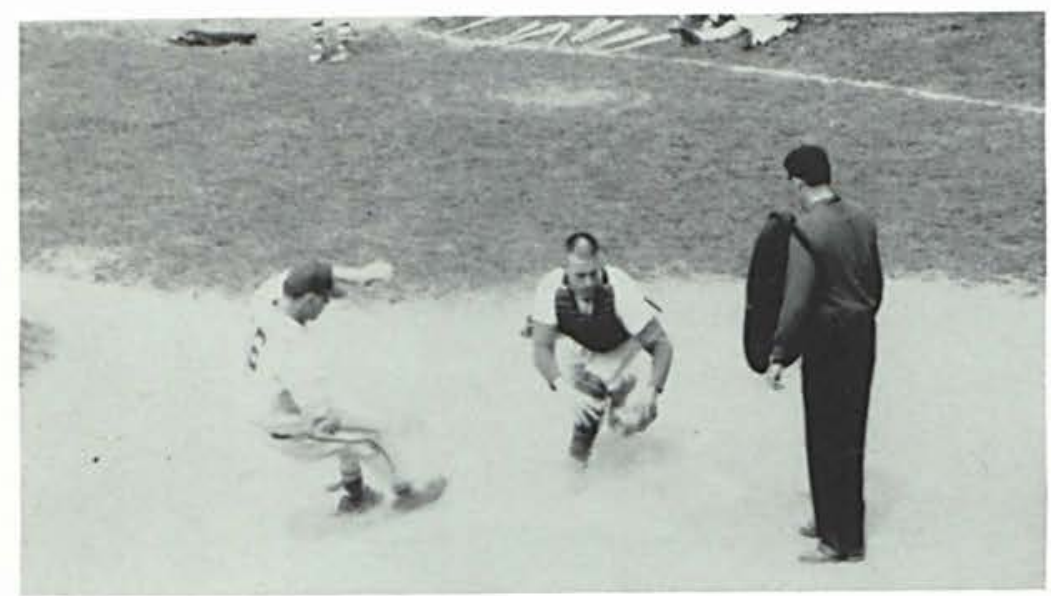

Catcher Jim Entner scrambles for the ball in a close play at home plate.

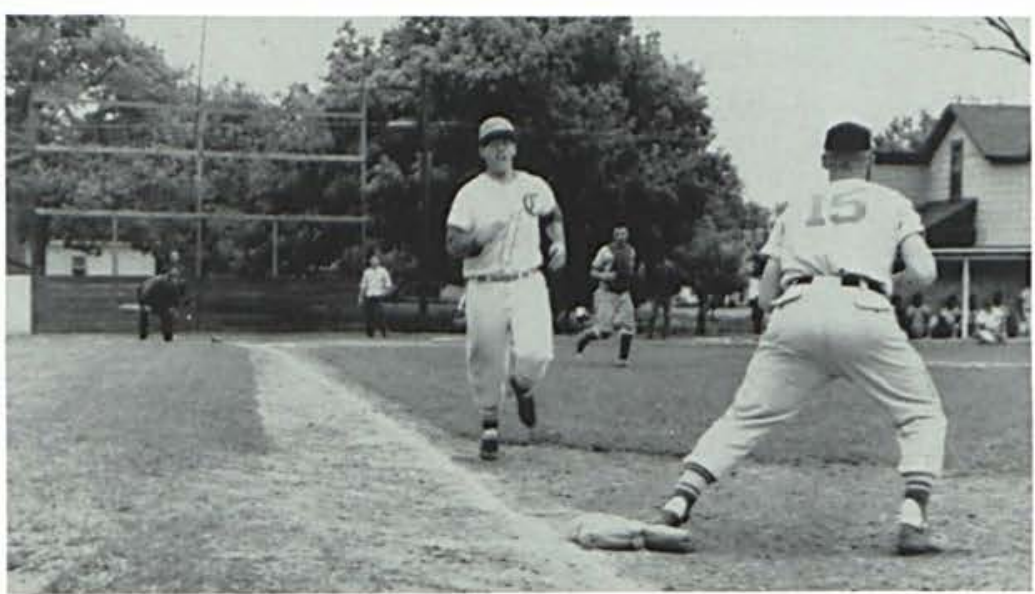

\section{SEASON RECORD}

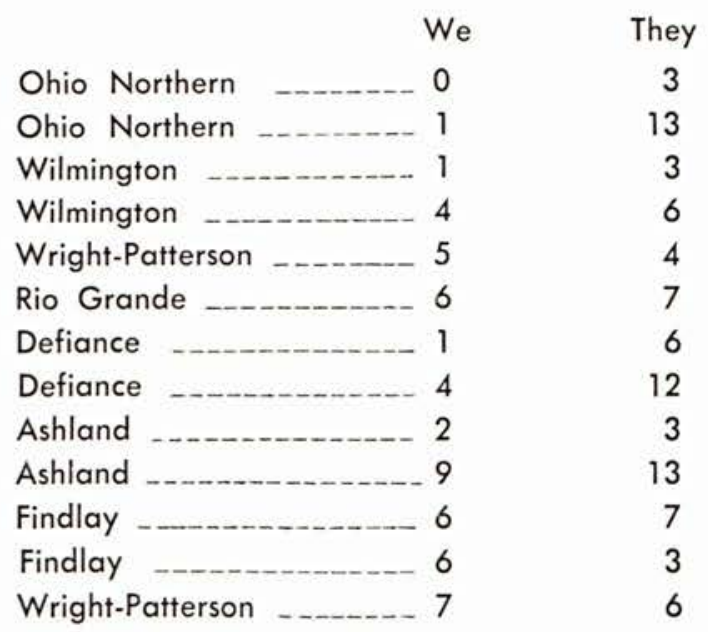




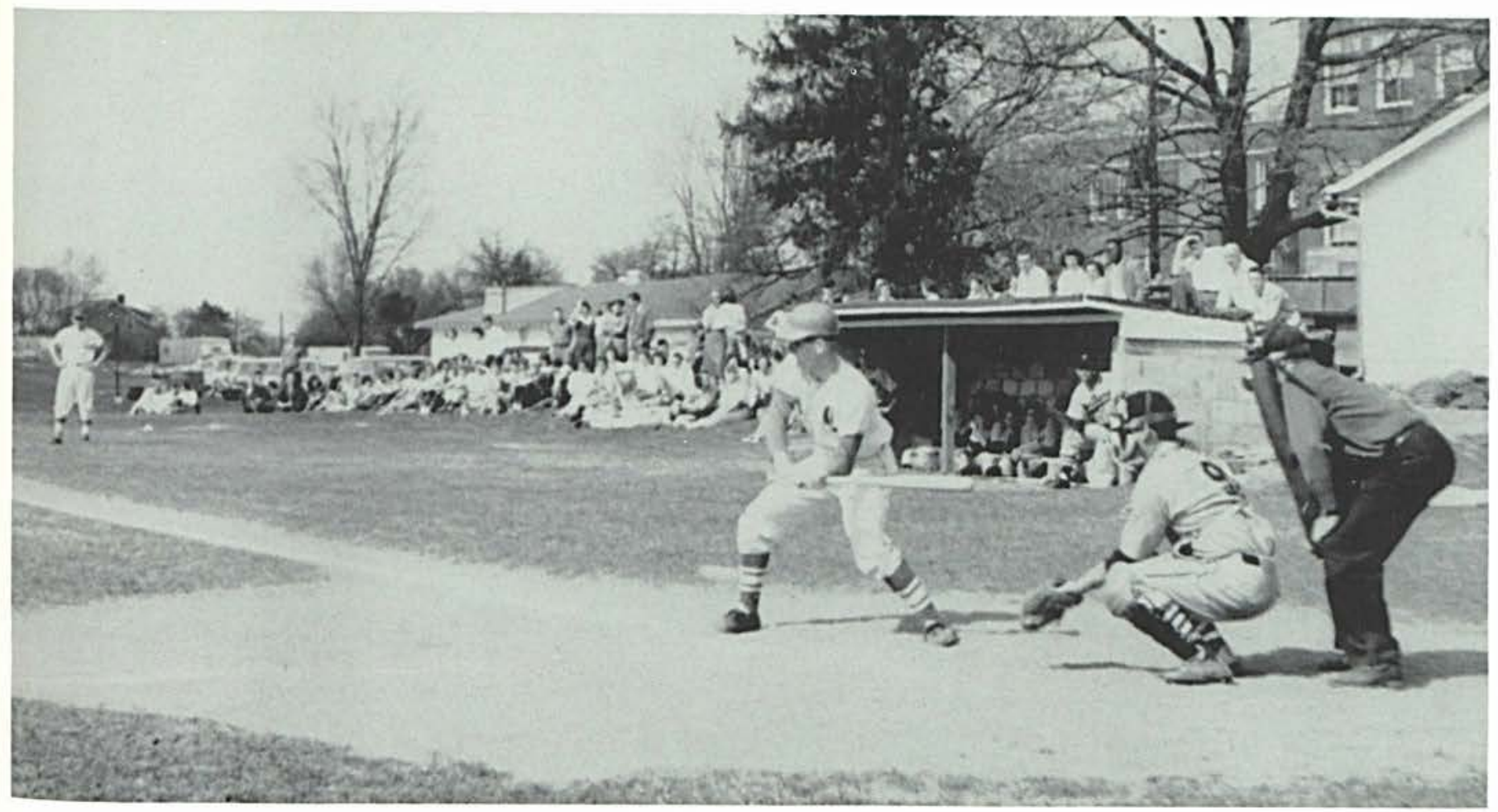

Vance Ashley, in that familiar batting stance of his, prepares to hit a knee-high pitch.

\section{BATTING AVERAGES}

Dave Dautel 311

Norris Smith .256

Vance Ashley .238

Ted Ocheltree .227

Chuck Taylor .224

Mark Hazeltine

.214

Bill Elder

.200

Jim Entner

.177

Jim Grafton

.166

Roy Carr

.147

Pete McFann .117

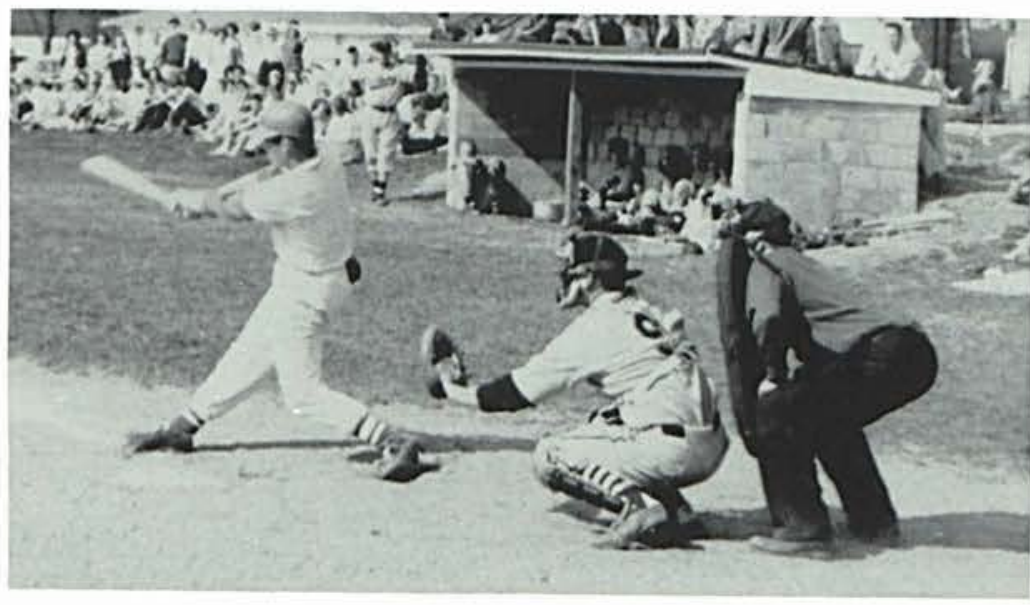

With a good, healthy cut, Chuck Taylor belts one down the first base line.

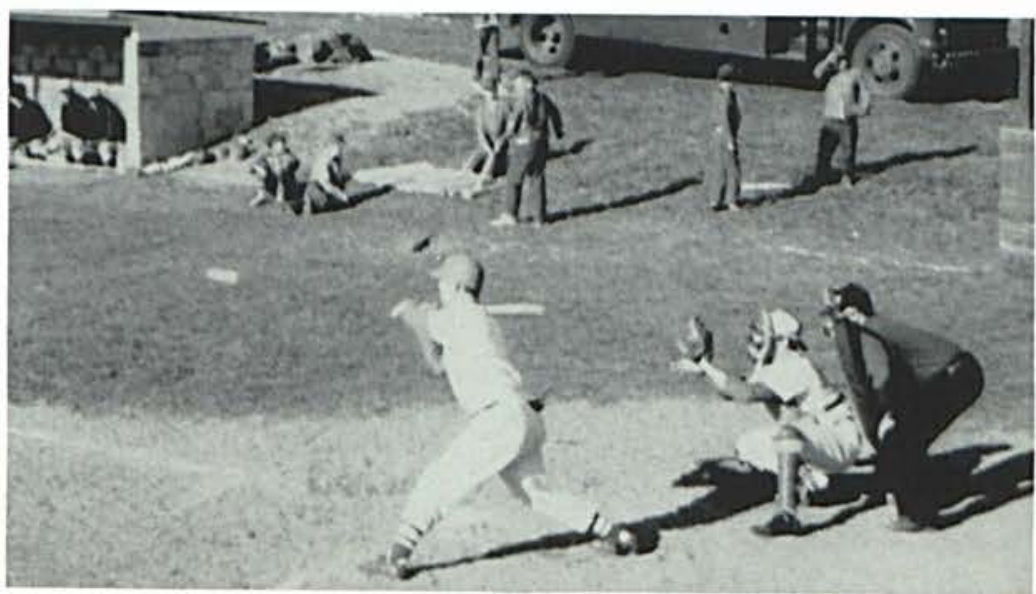




\section{Tennis}

After a year of inactivity in tennis, the 1960 version of Cedarville College tennis players pictured below did creditably well in holding their own against the tough competition in the Mid-Ohio League. Highlighting the season was a double win over Bluffton College as well as a smashing victory over Wilmington. Playing his usual fine caliber of tennis, John Entner did much in holding the team together long enough to bring five victories to the Cedarville camp.

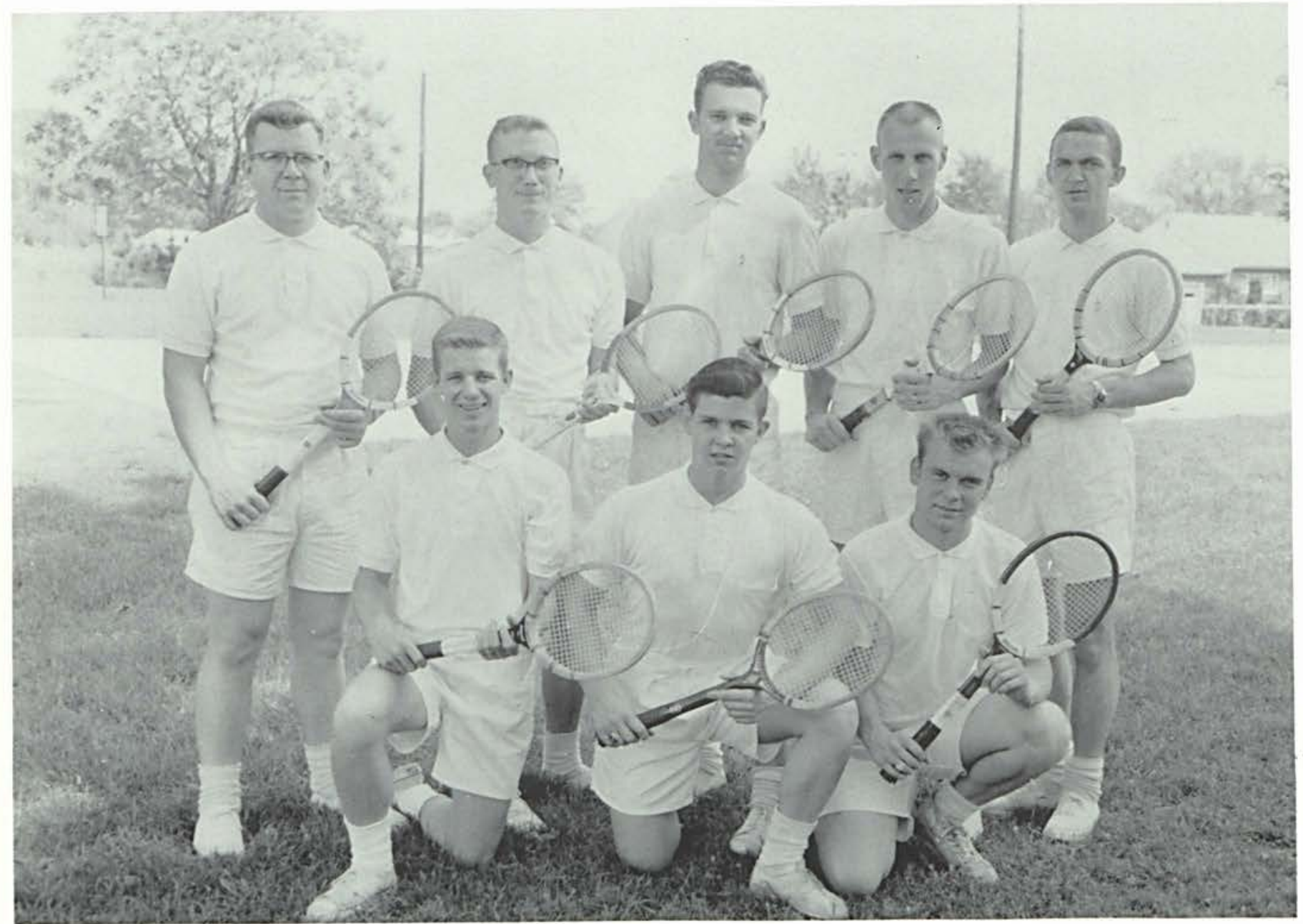

Kneeling: Keith Collett, Gary Hogard, Bob Bell. Standing: Bob Humphreys, Chuck Horn, Jack Moffatt, John Entner, Dick Minier.

SEASON RECORD

$\begin{array}{llc} & \text { We } & \text { They } \\ \text { Central State } & 2 & 5 \\ \text { Bluffton } & 6 & 1 \\ \text { Bluffton } & 6 & 3 \\ \text { Wilmington } & 2 & 1 \\ \text { Defiance } & 1 & 7 \\ \text { Central State } & 2 & 5 \\ \text { Wilmington } & 4 & 3 \\ \text { Ohio Northern } & 5 & 2 \\ \text { Defiance } & 2 & 5\end{array}$




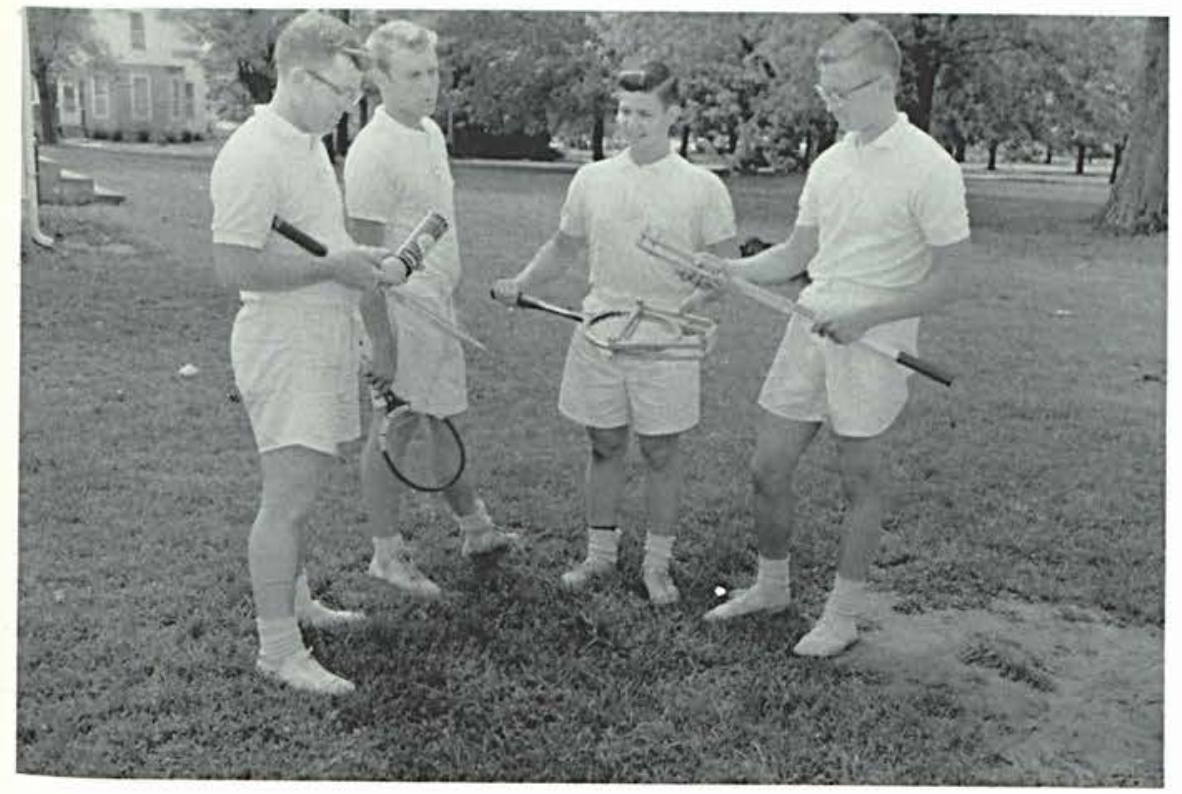

Bob Humphreys, Bob Bell, Gary Hogard, and Chuck Horn inspect their rackets before a practice session.

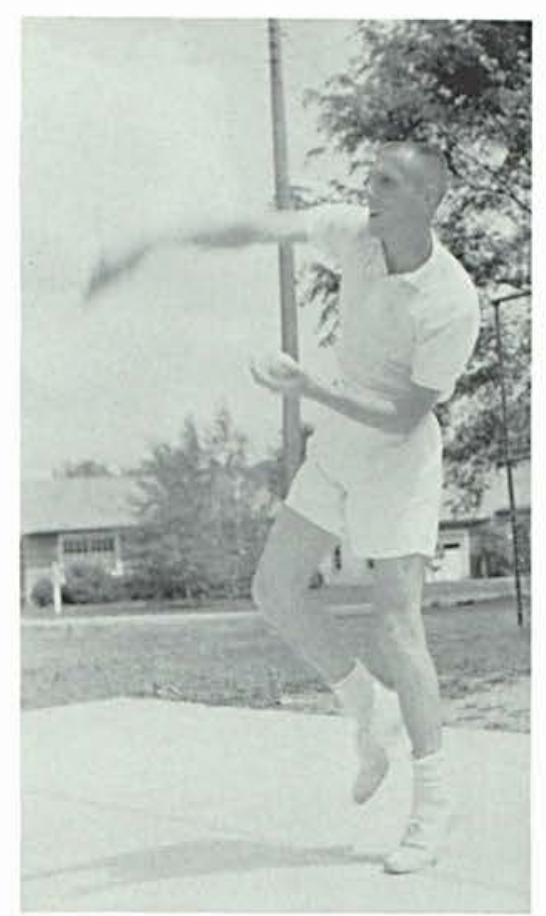

Captain John Entner

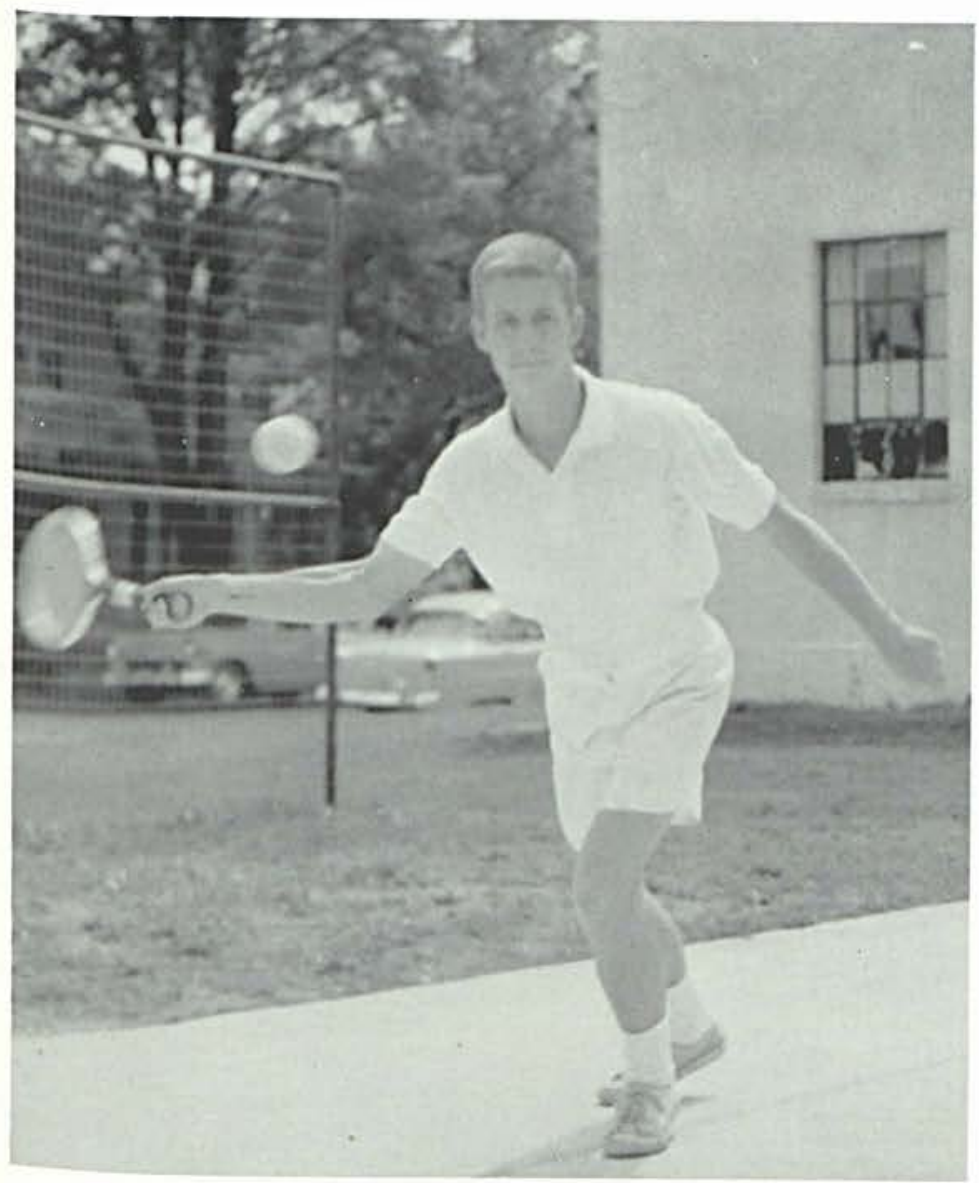

Keith Collett shows his form as he hits the ball to....

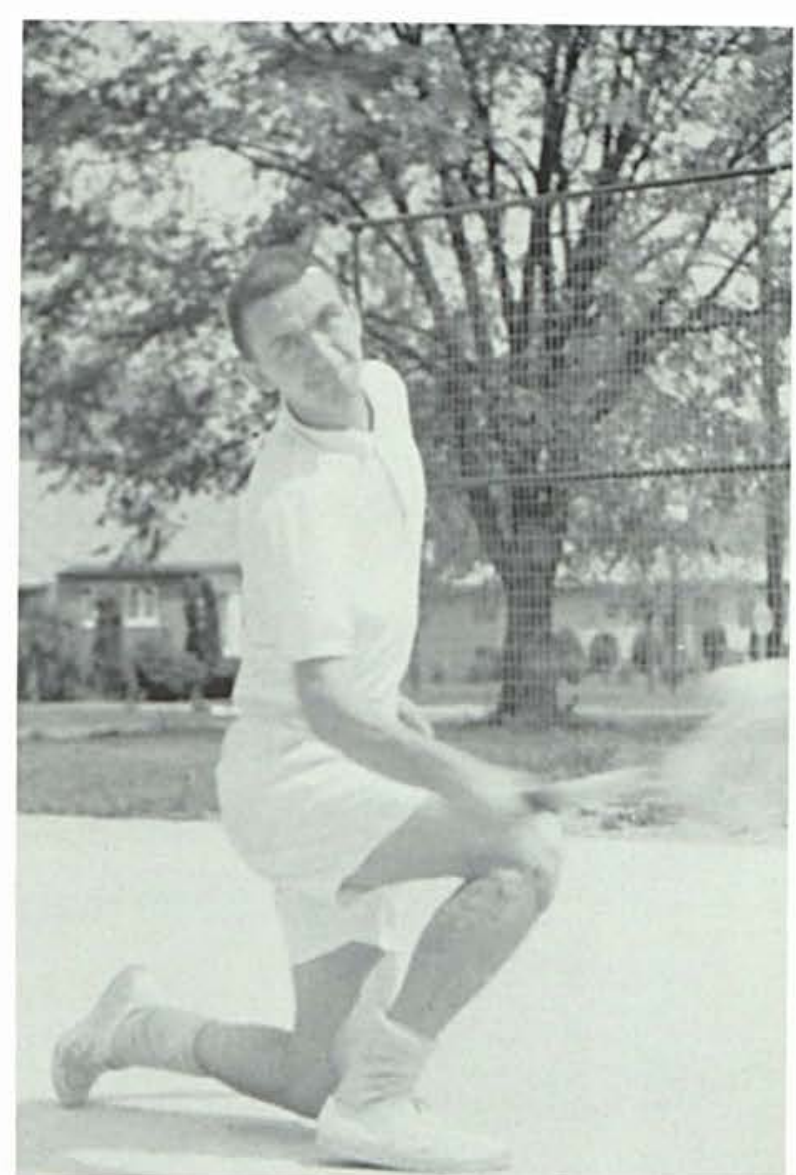

... Dick Minier who returns it. 


\section{Basketball}

\section{The Varsity Team}

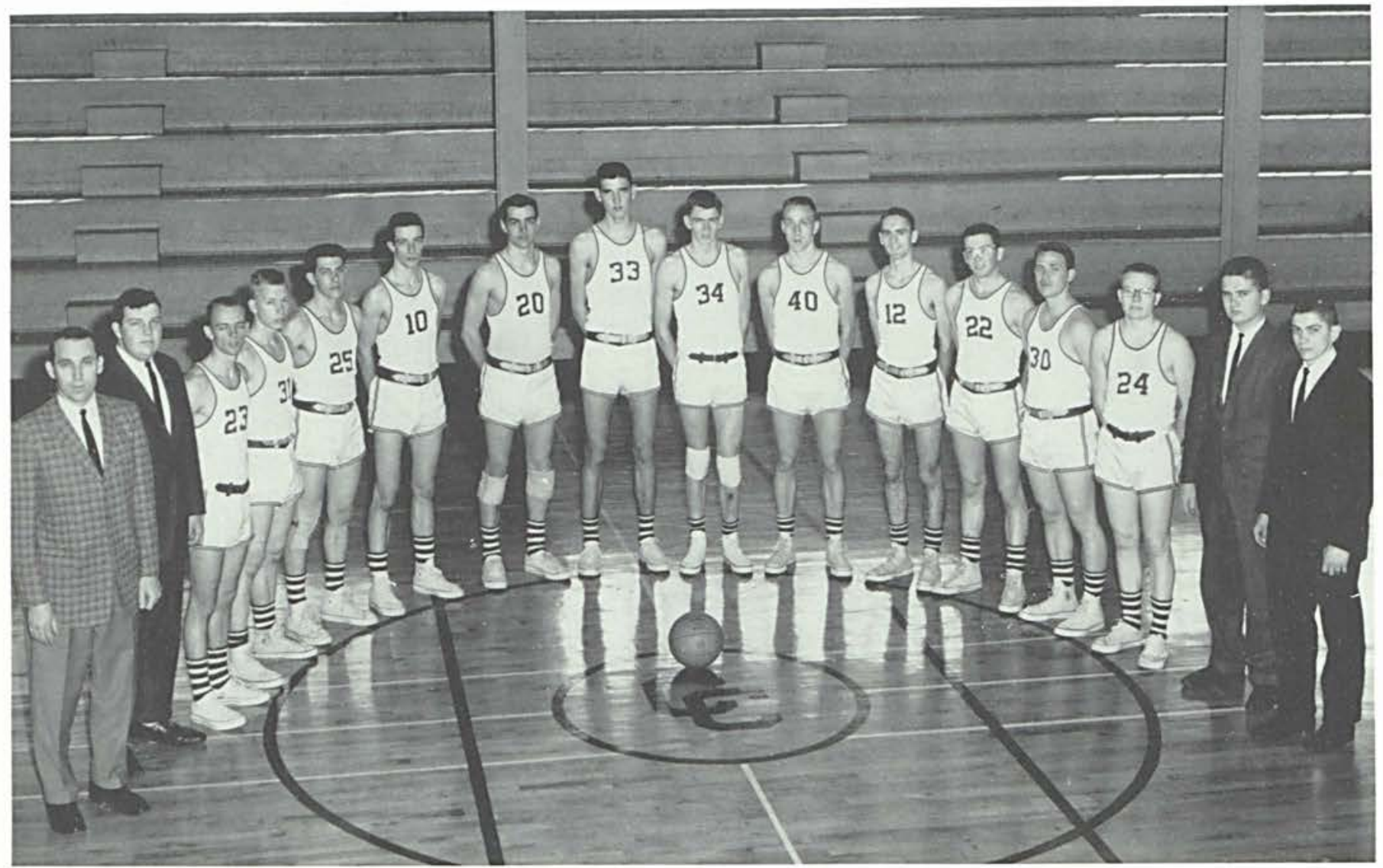

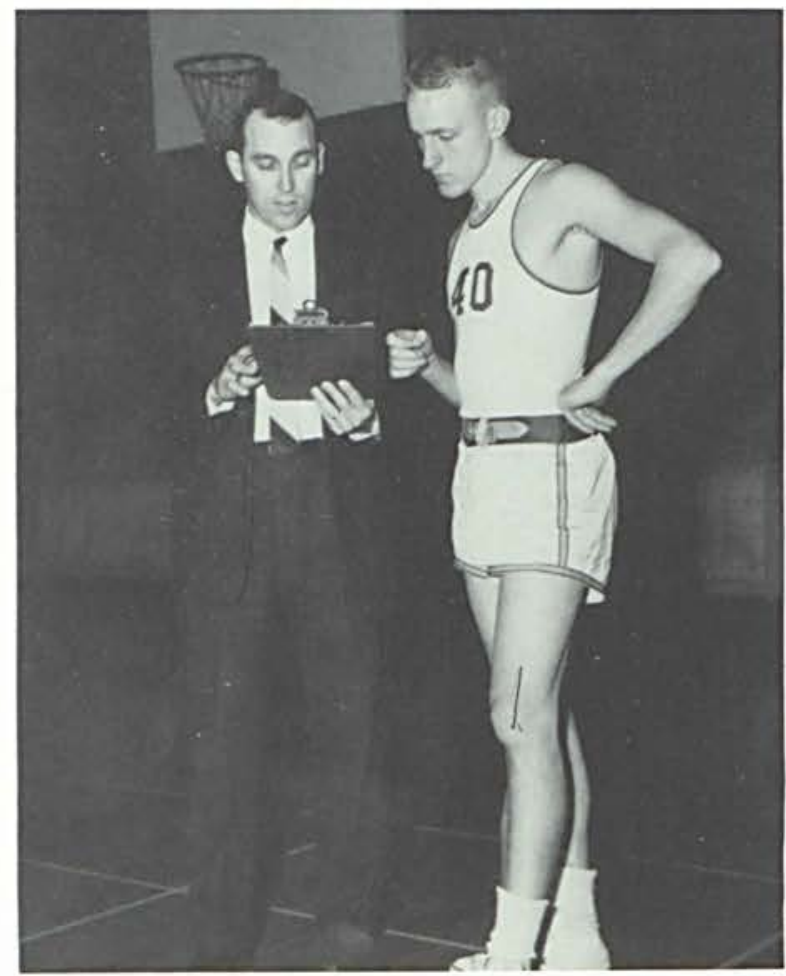

Coach Don Callan converses with captain Jim Entner
Left to Right: Coach Callan, Doug Smith, Manager; Ted Ocheltree, John Justice, Dave Morganti, Norris Smith, Dave Jeremiah, Gary Walthal, Rod Lane, Jim Entner, Sam Canine, Ed Norris, Dave Lewis, Tom Evans, Chuck Hartzell, Statistician; Mark Hazeltine, Manager.

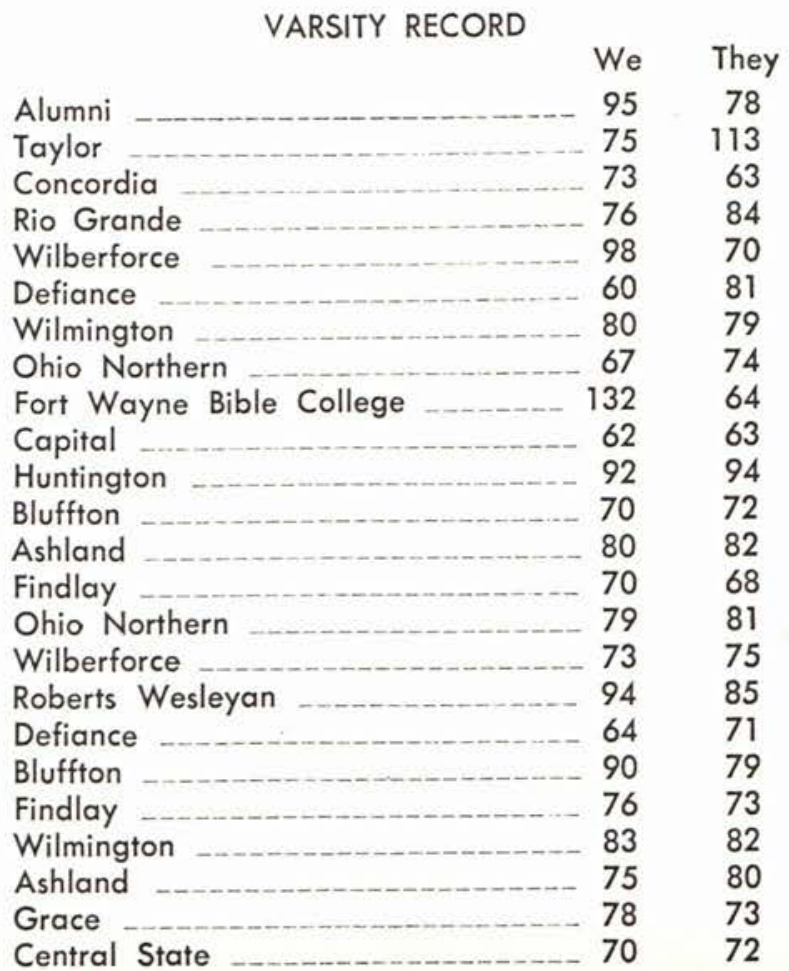




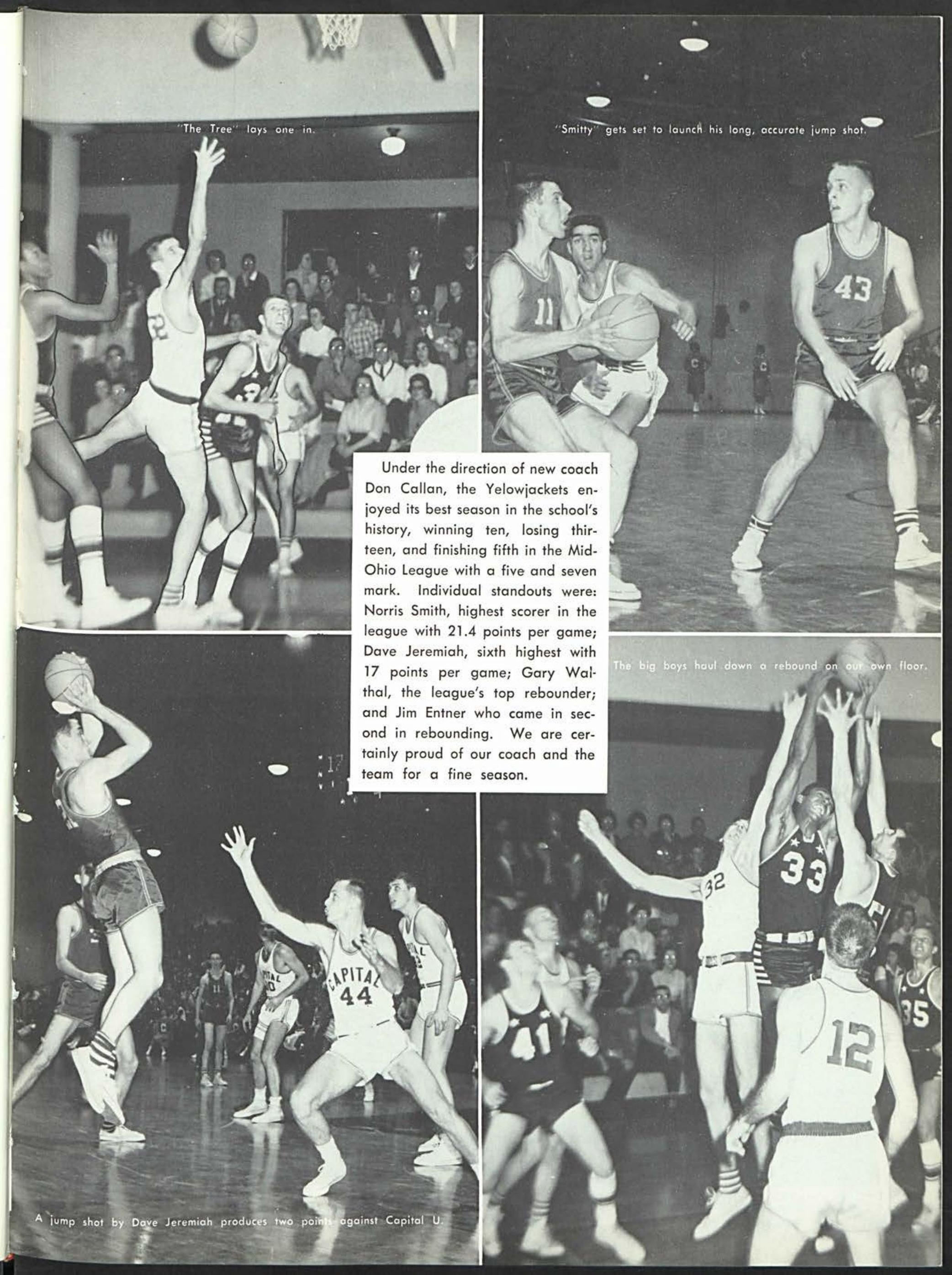




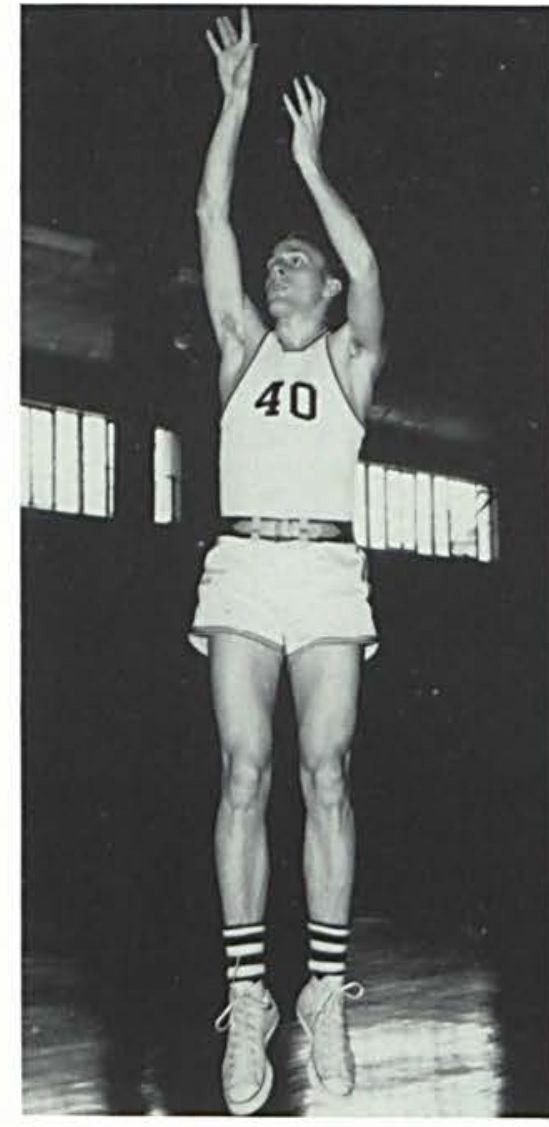

Jim Entner, 6 $6^{\prime \prime}$

Senior, captain, forward

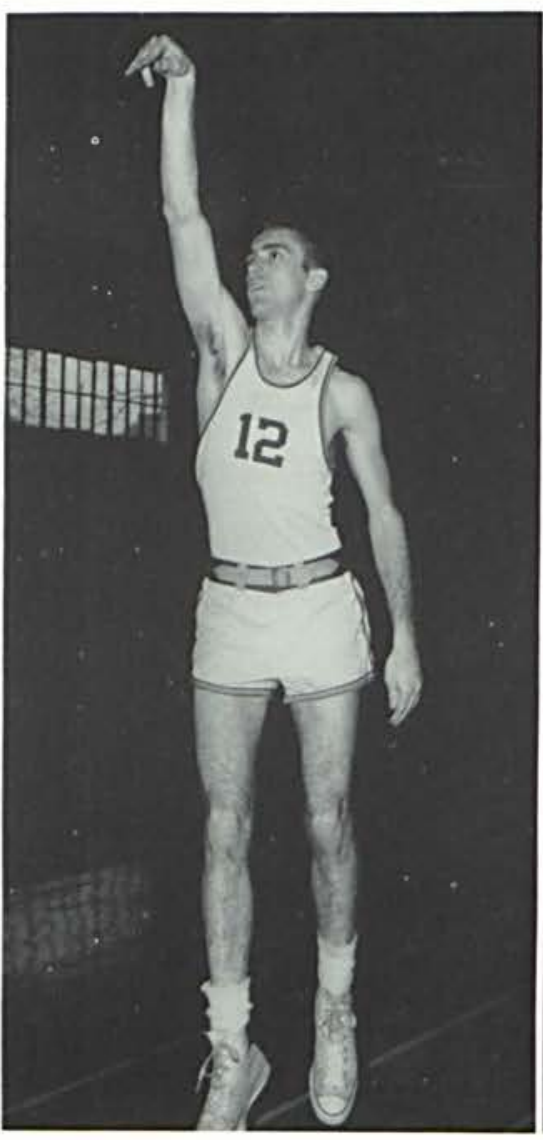

Sam Canine, 6'0"

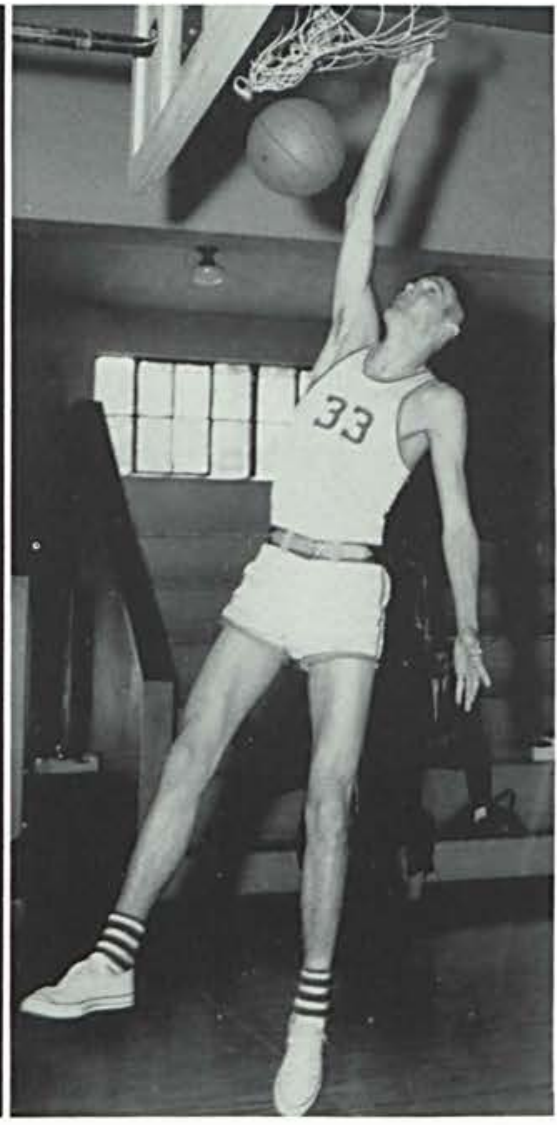

Gary Walthal, 6'7"

Freshman, center

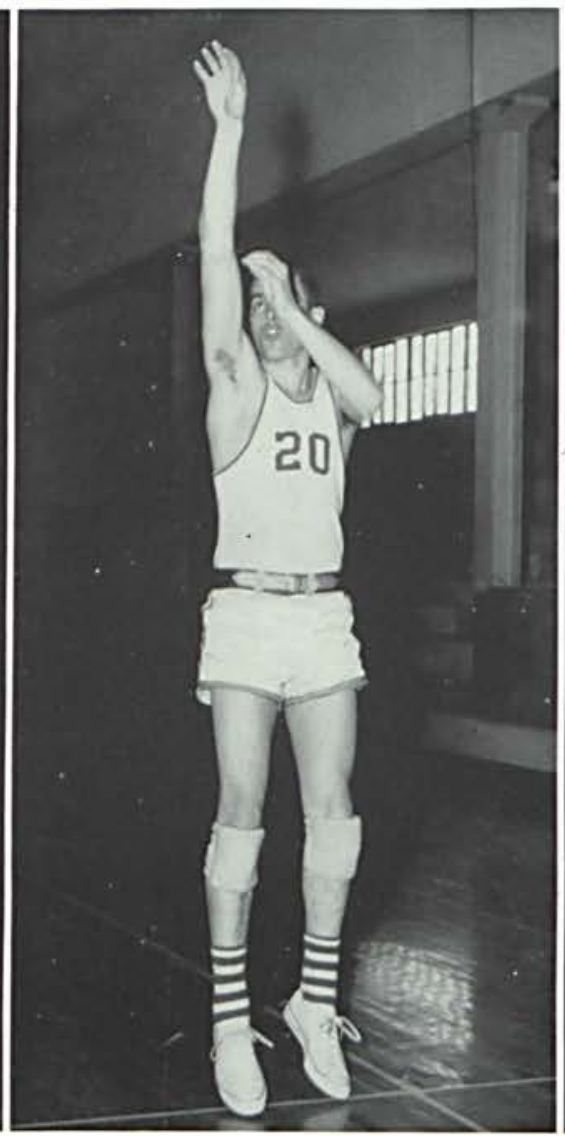

Dave Jeremiah, 6' $2^{\prime \prime}$

Sophomore, forward

Norris Smith, 6'0

Sophomore, guard 


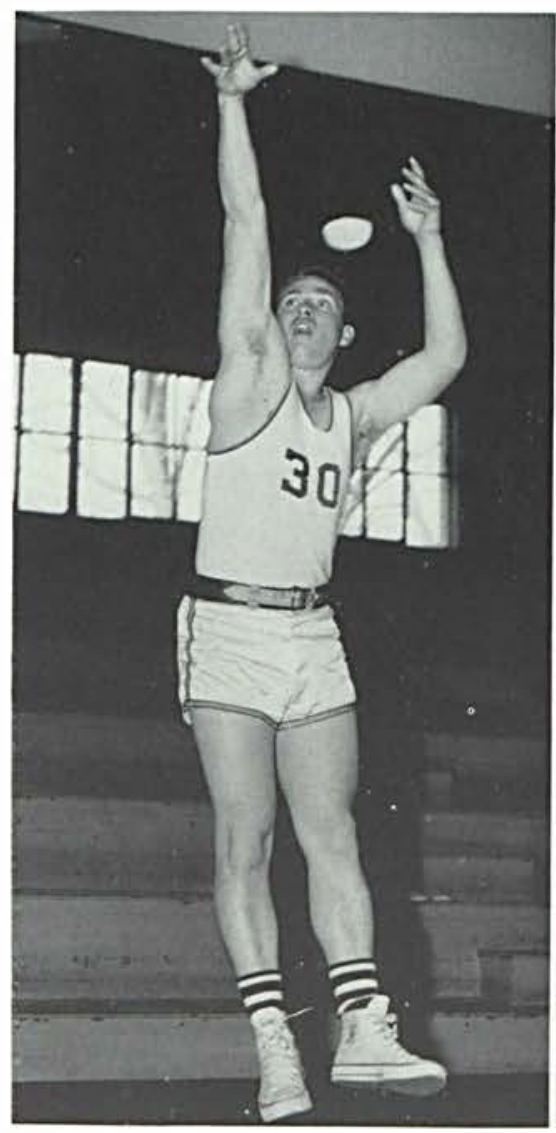

Dave Lewis, 5'10"

Junior, guard

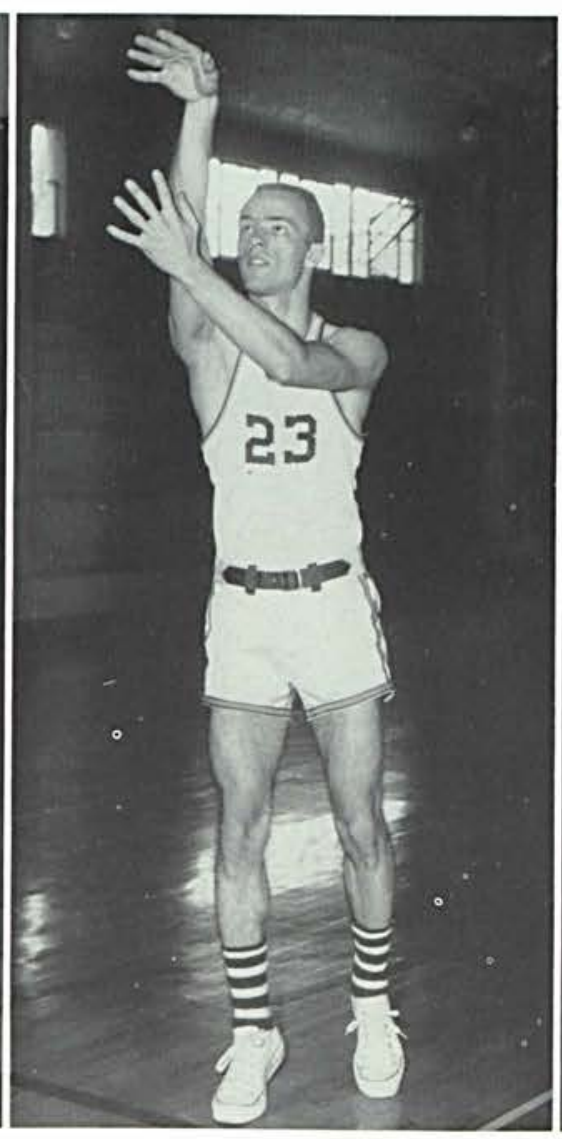

Ted Ocheltree, 5'5"

Sophomore, guard

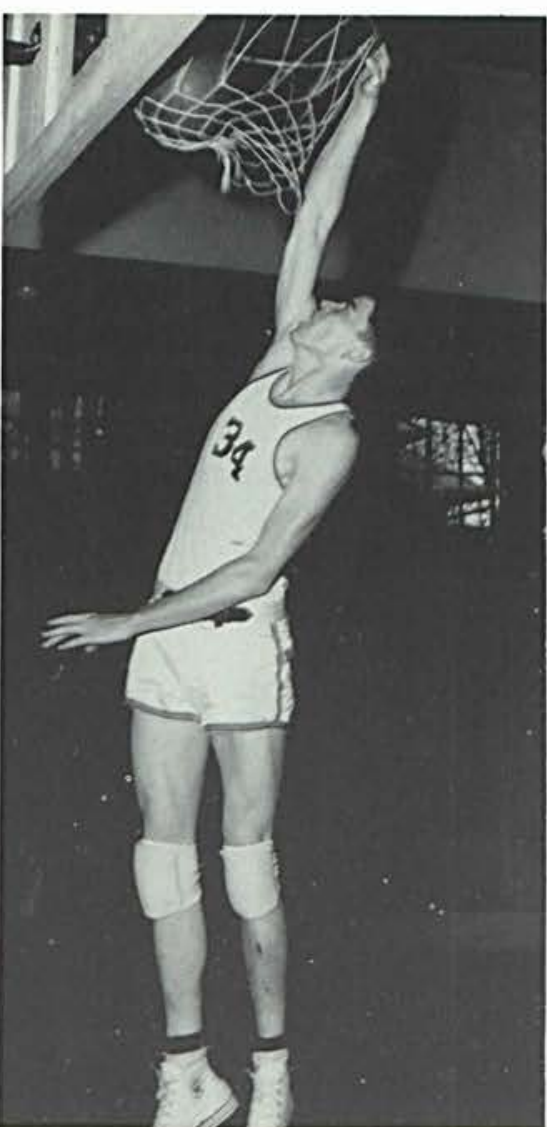

Rod Lane, 6'2"

Freshman, center

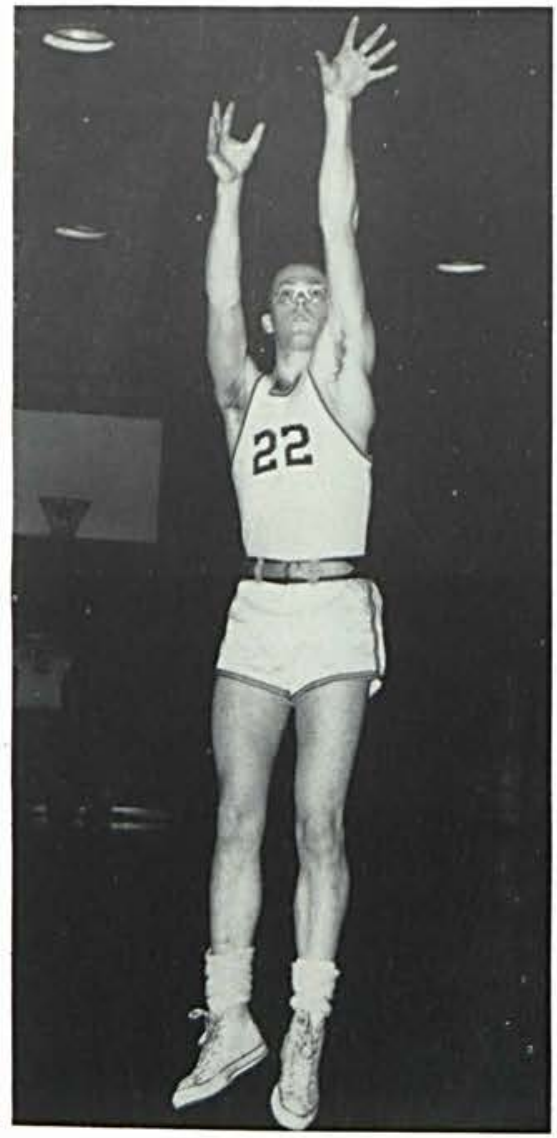

Ed Norris, 5'10"

Freshman, forward

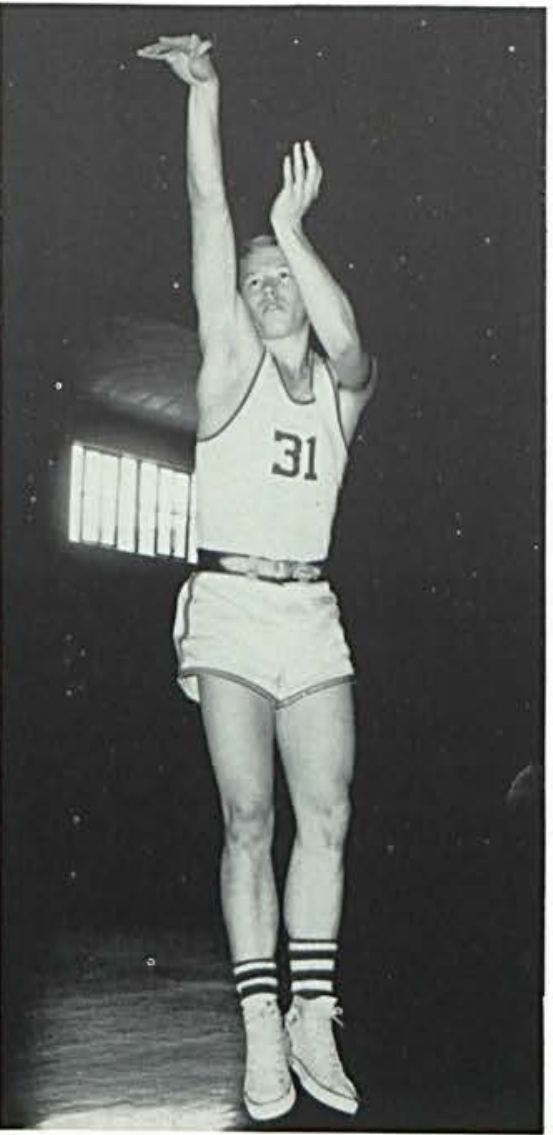

John Justice, 5'9"

Freshman, guard 


\section{Junior Varsity Team}

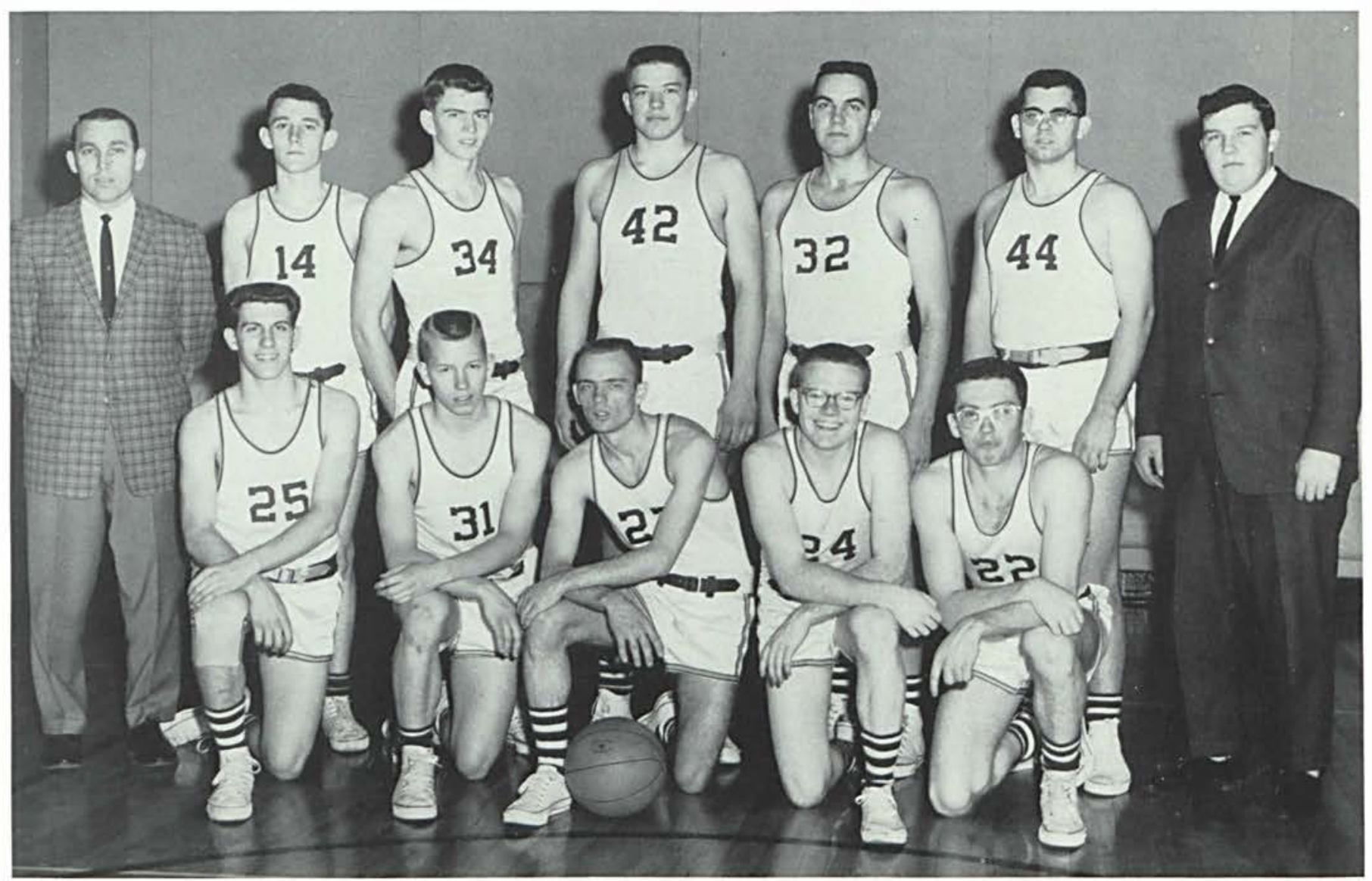

Front Row: Dave Morganti, John Justice, Ted Ocheltree, Tom Evans, Ed Norris. Back Row: Coach

Callan, Jim Sprague, Rod Lane, Dave Blossom, Rich White, John Bigelow, Doug Smith, Manager.

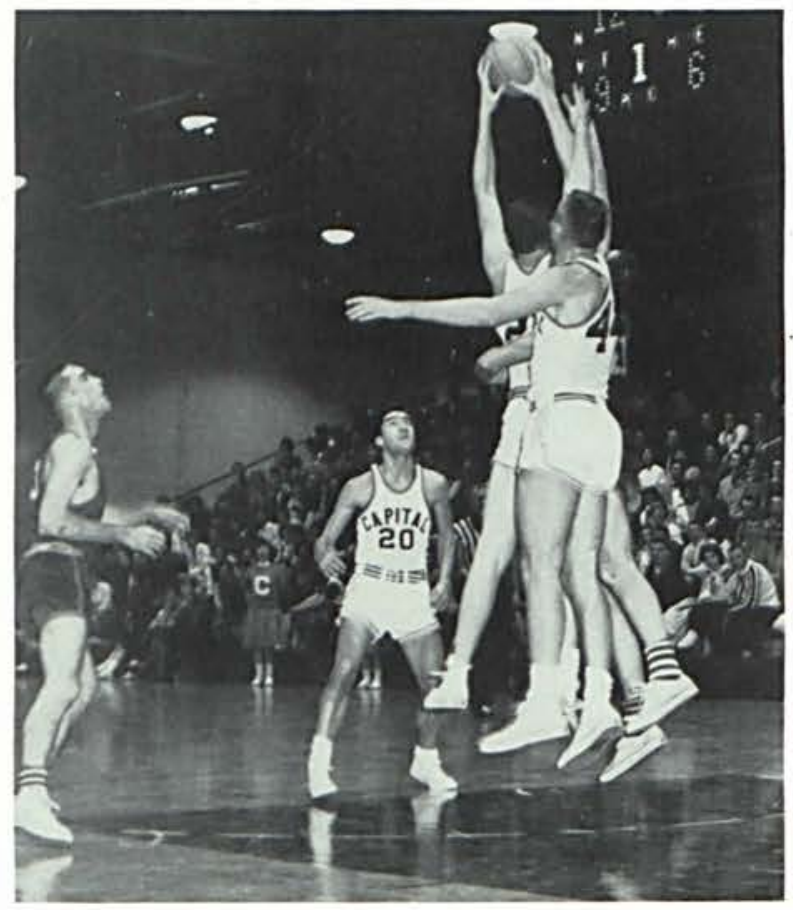

JUNIOR VARSITY RECORD

$\begin{array}{lcc} & \text { We } & \text { They } \\ \text { Defiance } & 54 & 93 \\ \text { Wilmington } & 53 & 75 \\ \text { Ohio Northern } & 60 & 94 \\ \text { Varsity "C' Club } & 59 & 60 \\ \text { Capital } & 59 & 90 \\ \text { Bluffton } & 65 & 50 \\ \text { Intramural All-Stars } & 57 & 54 \\ \text { Findlay } & 98 & 110 \\ \text { Miami-Jacobs } & 81 & 101 \\ \text { Defiance } & 63 & 89 \\ \text { Bluffton } & 58 & 70 \\ \text { Findlay } & 61 & 69 \\ \text { Wilmington } & 64 & 70 \\ \text { Central State } & & \end{array}$

The boys from Capital pull down a rebound. 


\section{Varsity Cheerleaders}

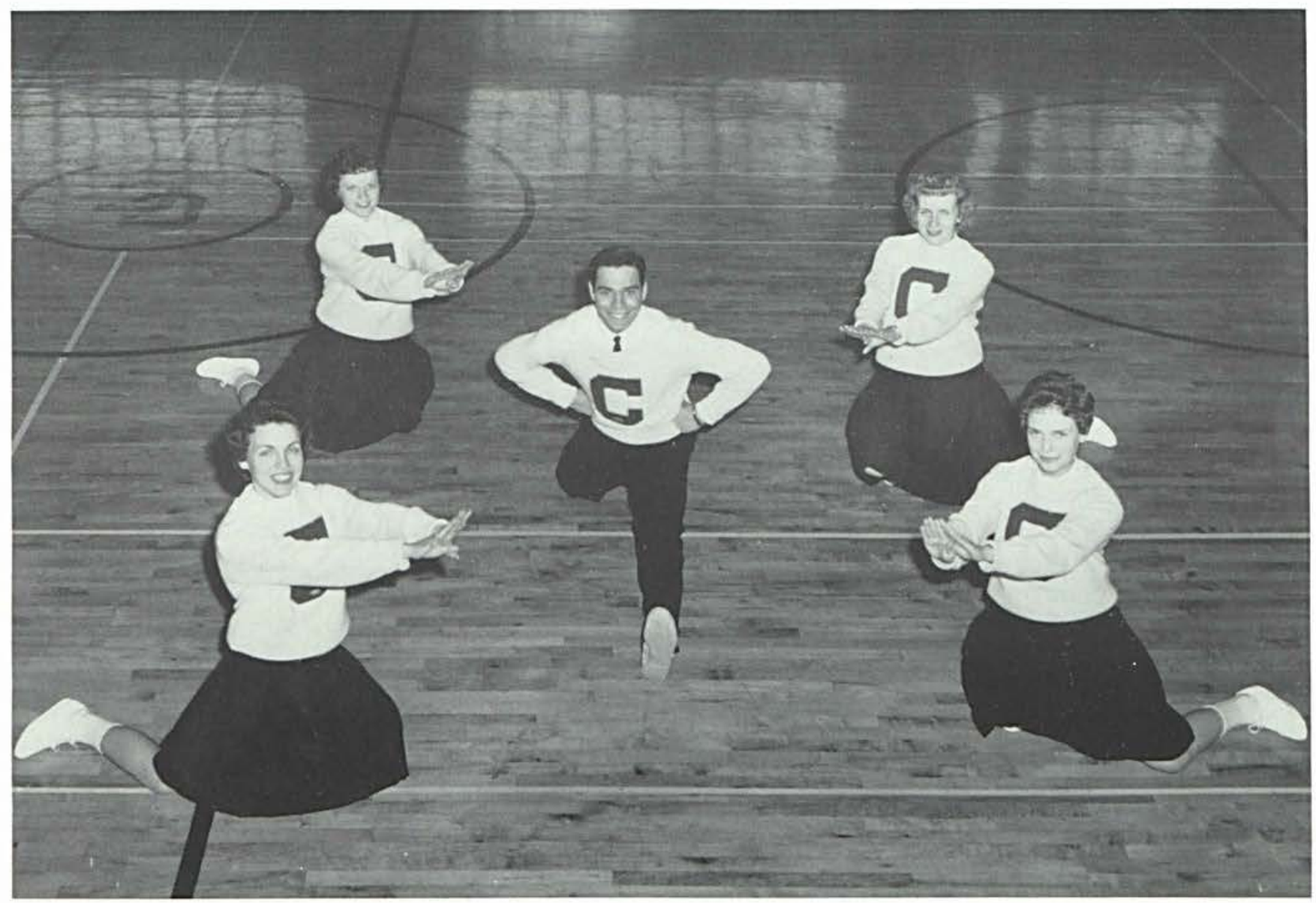

Back: Pat Petry, Judy Lachman. Center: Ed Villalba. Front: Esther Weiss, Donna Thompson.

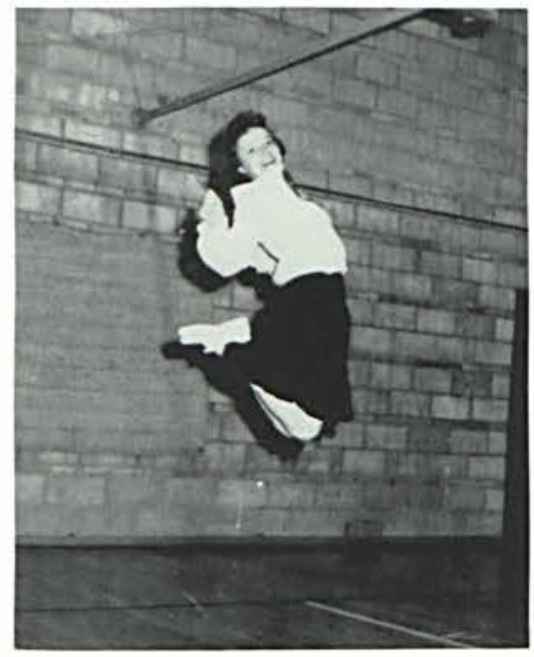

Pat Petry
A great part of the relative success of the 1960-61 Yellowjackets was due to the enthusiastic backing on the part of student body. Spearheading this enthusiasm were the varsity and junior varsity cheerleaders. Going to all of the away games and learning several new cheers were just a couple of their functions.

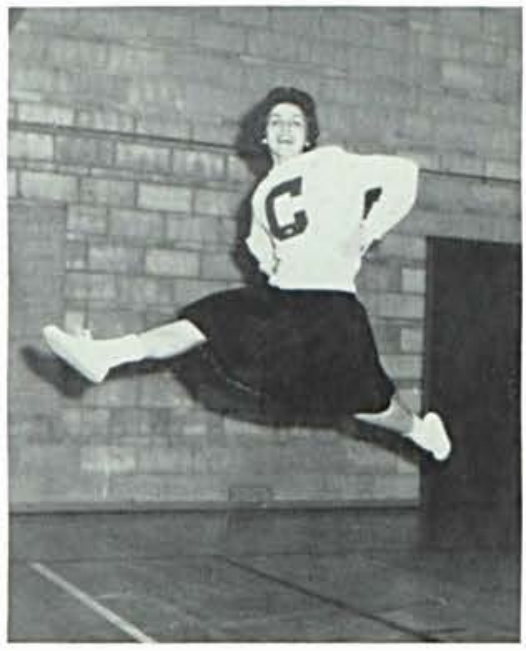

Esther Weiss 


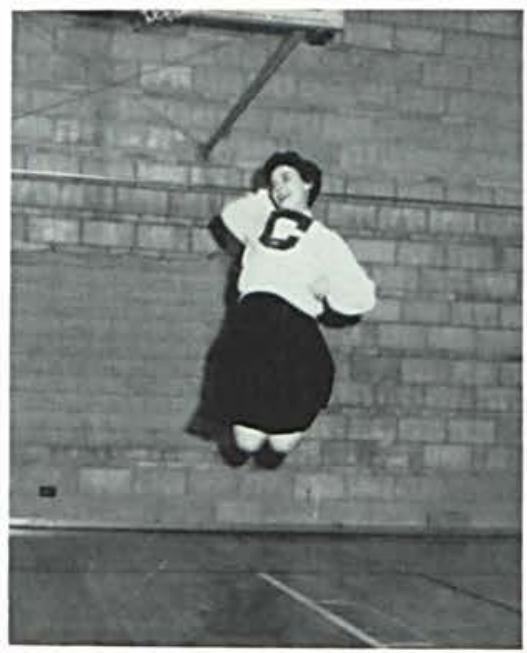

Donna Thompson

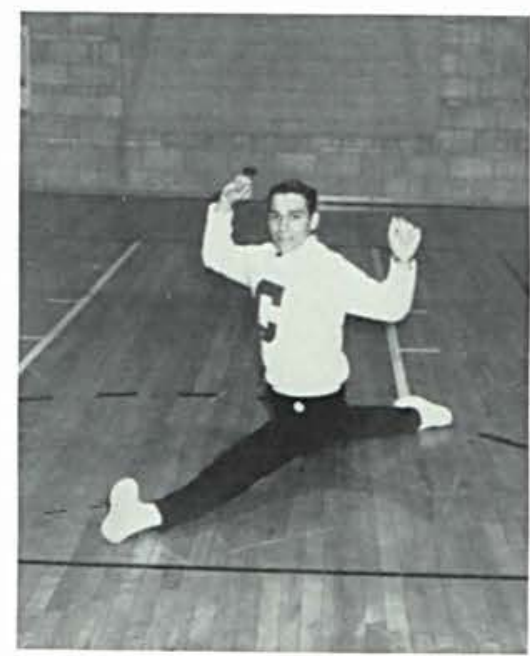

Ed Villalba

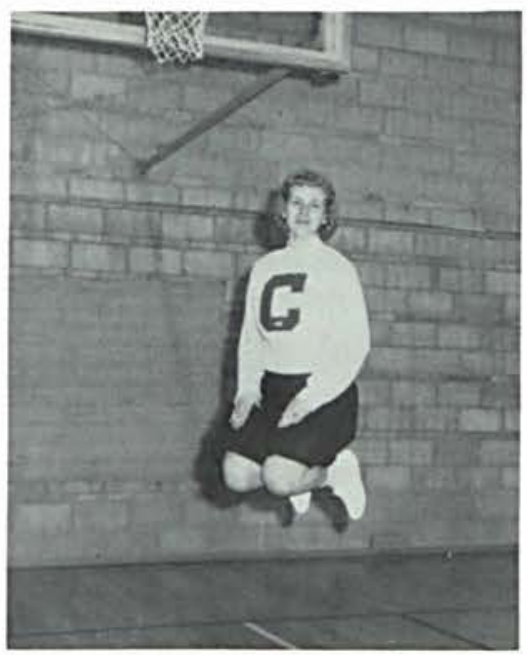

Judy Lachman

\section{Junior Varsity Cheerleaders}

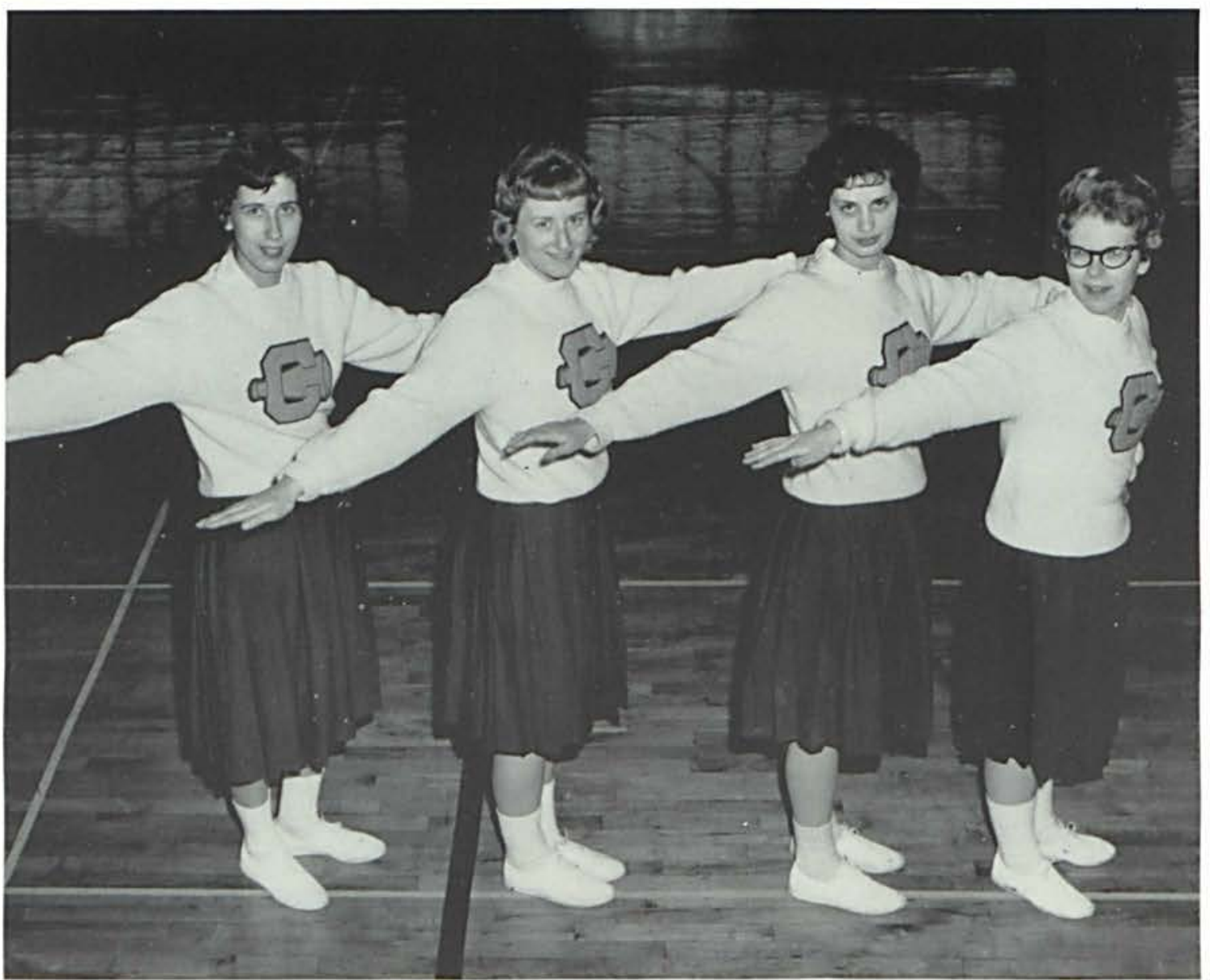




\section{Intramurals}

\section{Football}

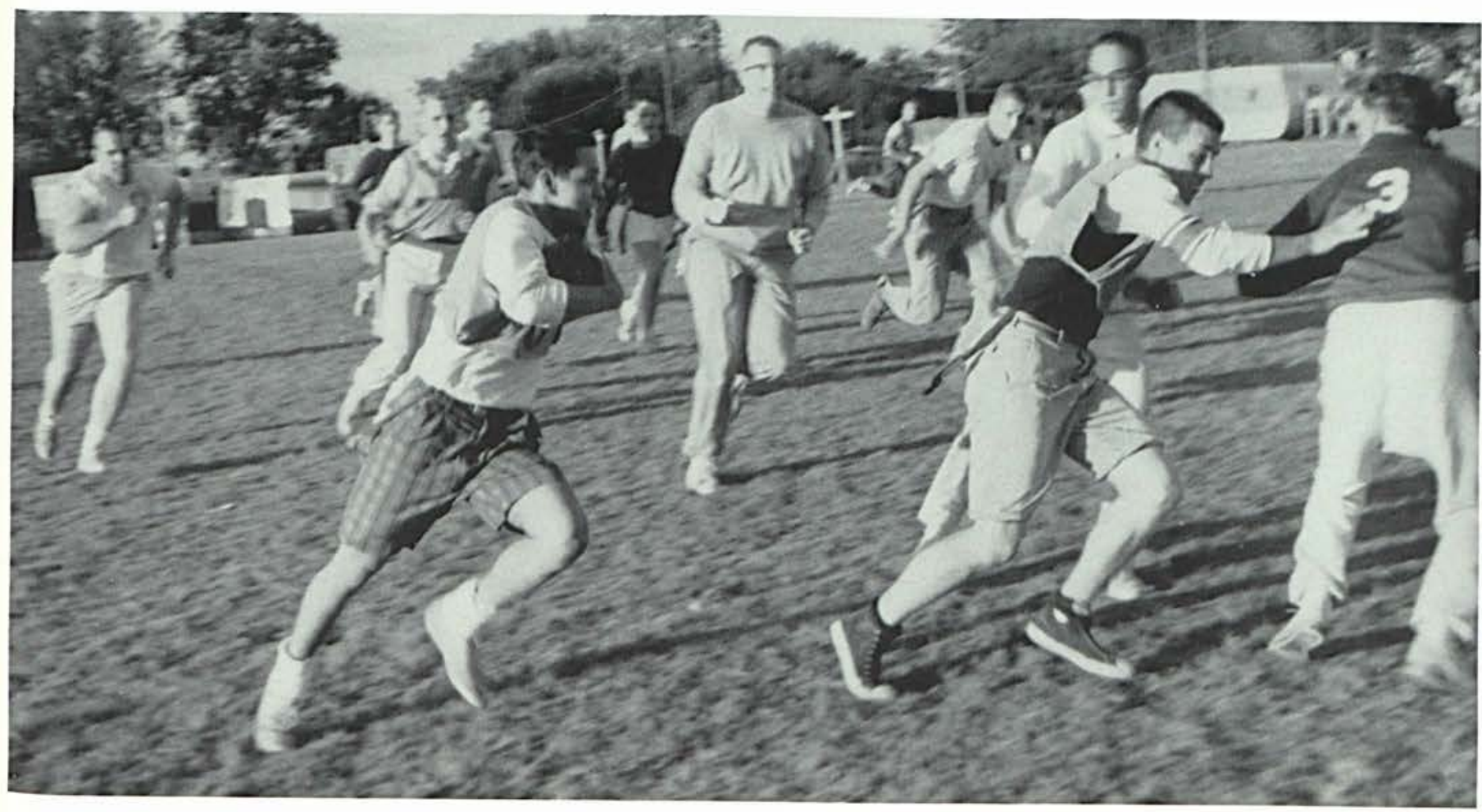

Scatback Ed Villalba churns around right end behind Allen Biddle's interference.

SEASON STANDINGS

$\begin{array}{llllc} & \text { W } & \text { L } & \text { Pts. } & \text { Opp. Pts. } \\ \text { Piper Cubs } & 7 & 2 & 224 & 150 \\ \text { Earnhart Kangaroos } & 6 & 3 & 236 & 158 \\ \text { Biddle Bears } & 4 & 5 & 130 & 190 \\ \text { Kilbourn Weightlifters } & 1 & 8 & 46 & 138\end{array}$

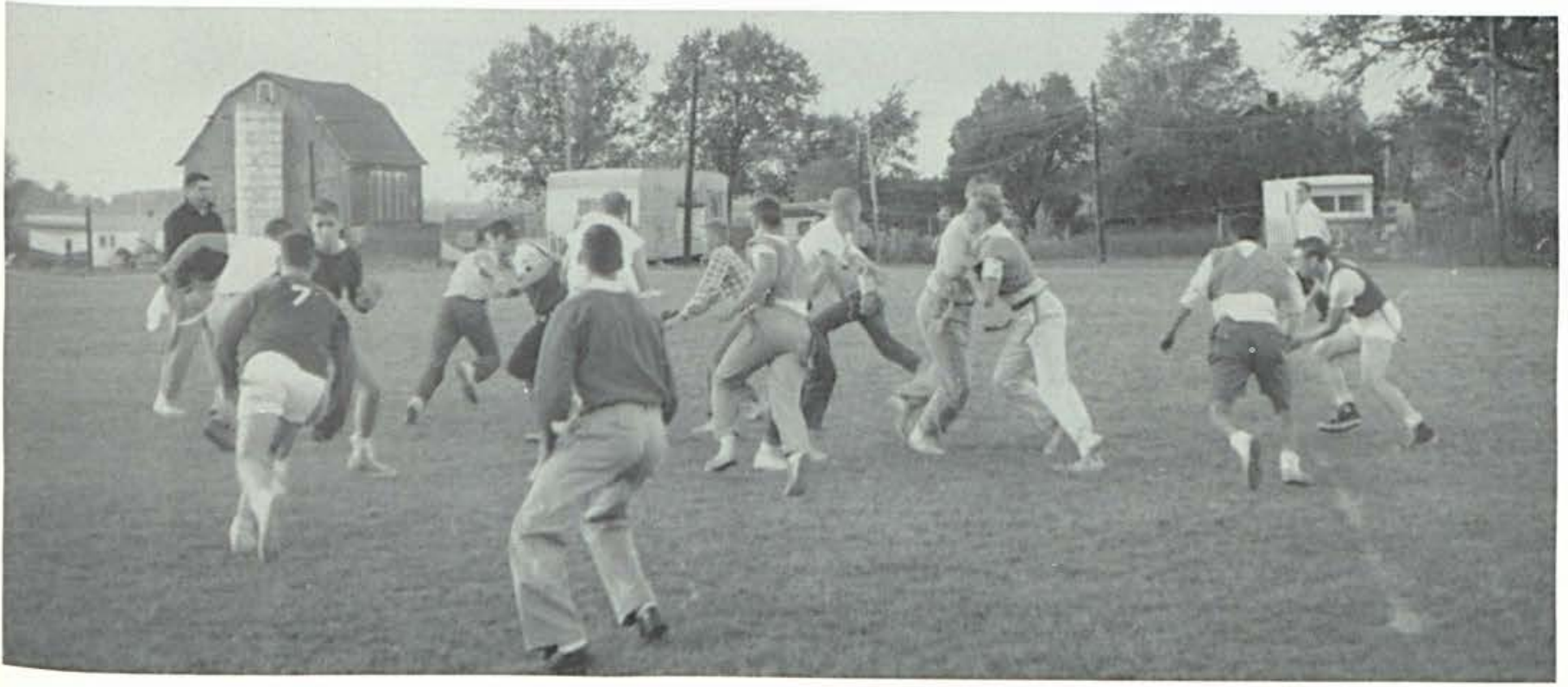




\section{Womens' Basketball}

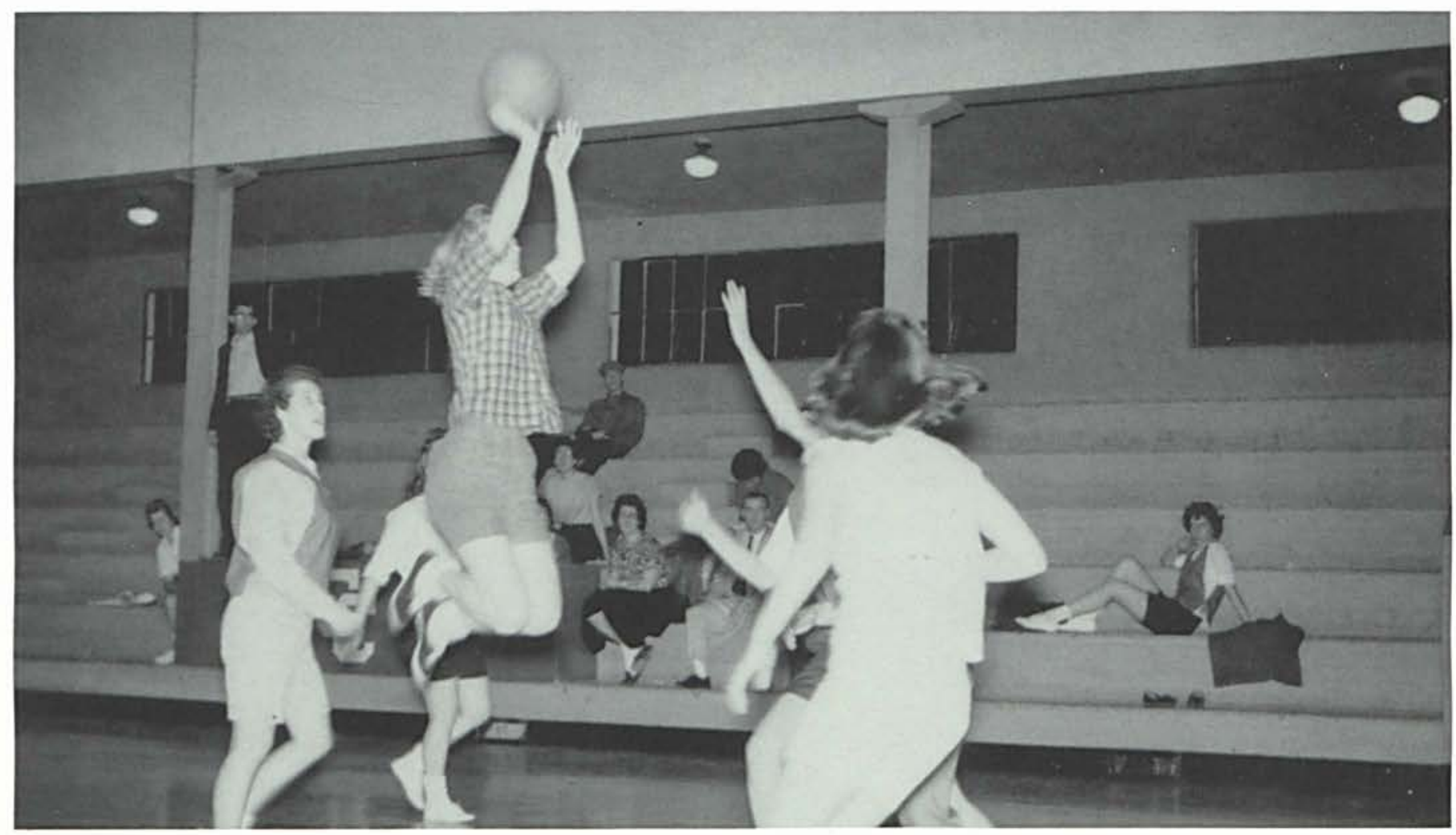

Bette Adamson jumps high to bag a two-pointer.

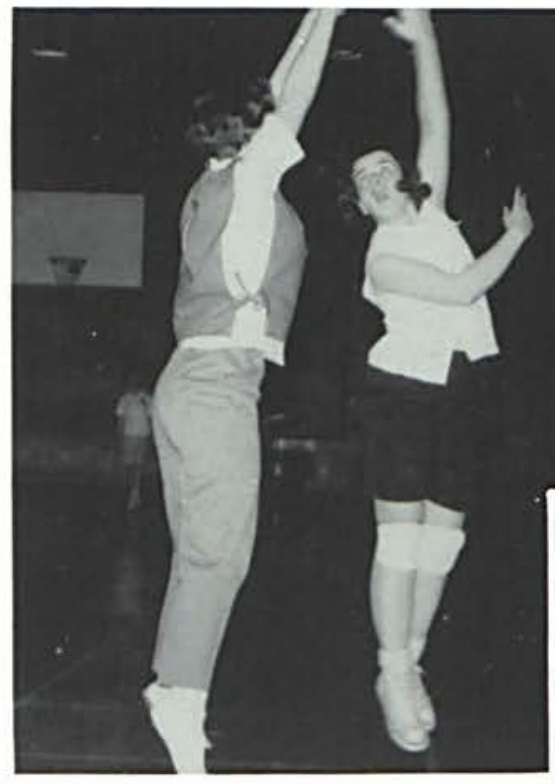

Janet McClish is guarded closely by Cathy Shelton as she shoots a hook shot.

WOMEN'S BASKETBALL STANDINGS

Won Lost

New Dorm (B) _ _ 61

Faith Hall _..._. 2

New Dorm (A) 2 


\section{Mens' Basketball}

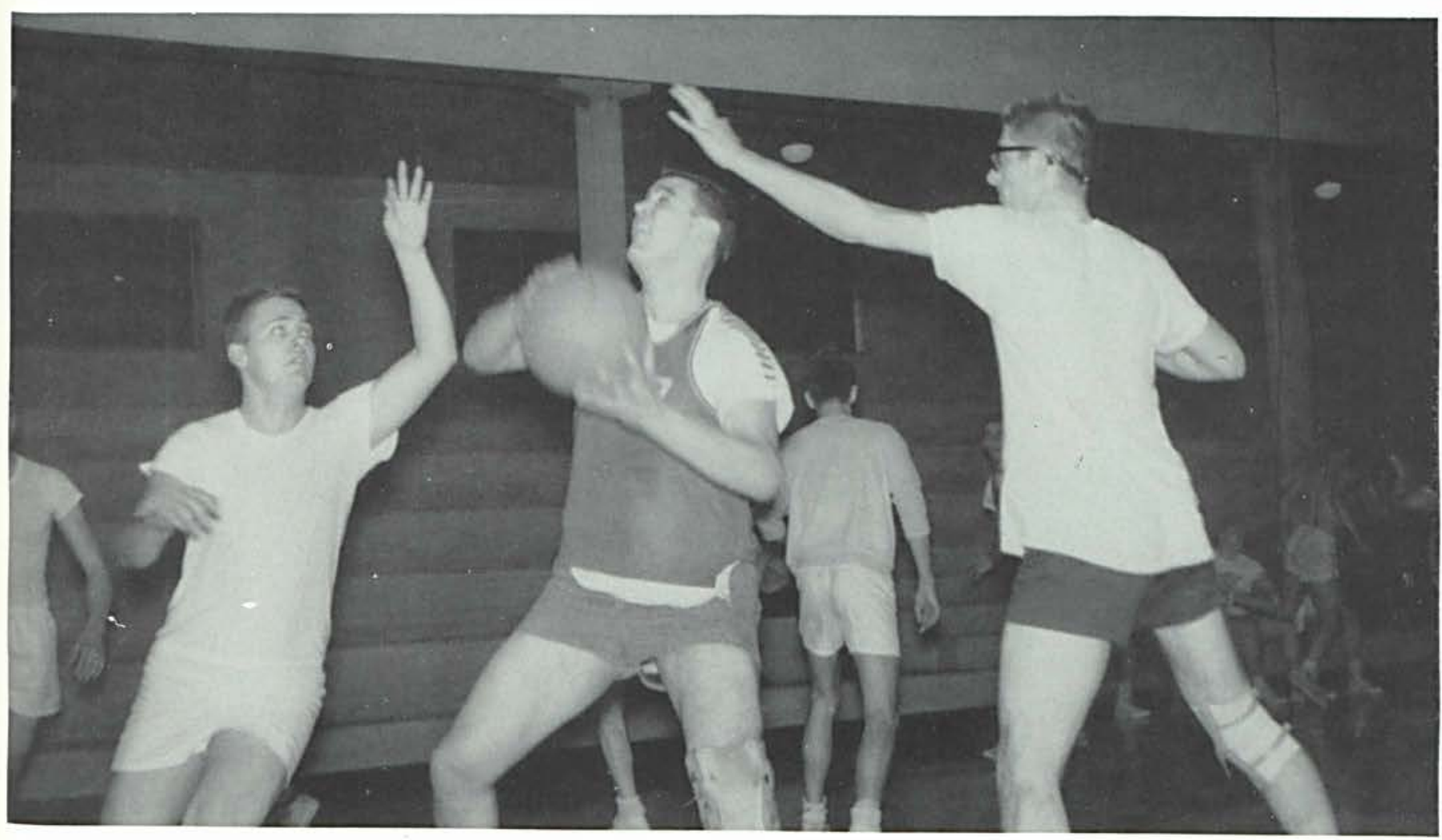

Phil Brower is guarded closely by Chuck Hartzell and Vance Ashley.

MEN'S BASKETBALL STANDINGS

$\begin{array}{lrr} & \text { Won } & \text { Los } \\ \text { Bethel Hall } & 9 & 1 \\ \text { Cedar Hall } & 8 & 2 \\ \text { Off Campus } & 5 & 5 \\ \text { Bookstore Dorm } & 5 & 5 \\ \text { Harriman Hall } & 4 & 6 \\ \text { Rife Hall } & 0 & 10\end{array}$

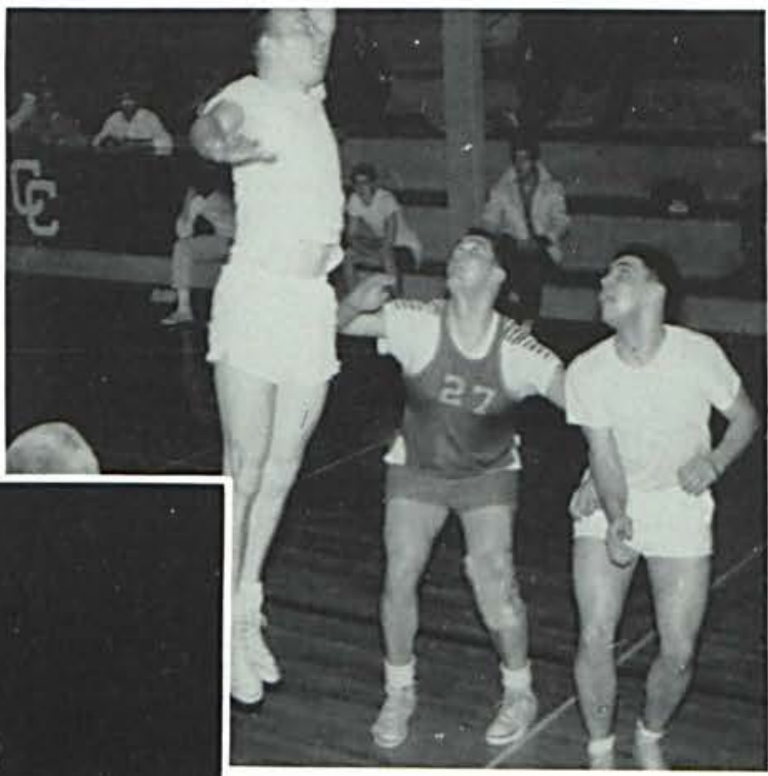

Rife Hall's Terry Goodrich leaps to get a rebound against the Bookstore team. 


\section{Volleyball}

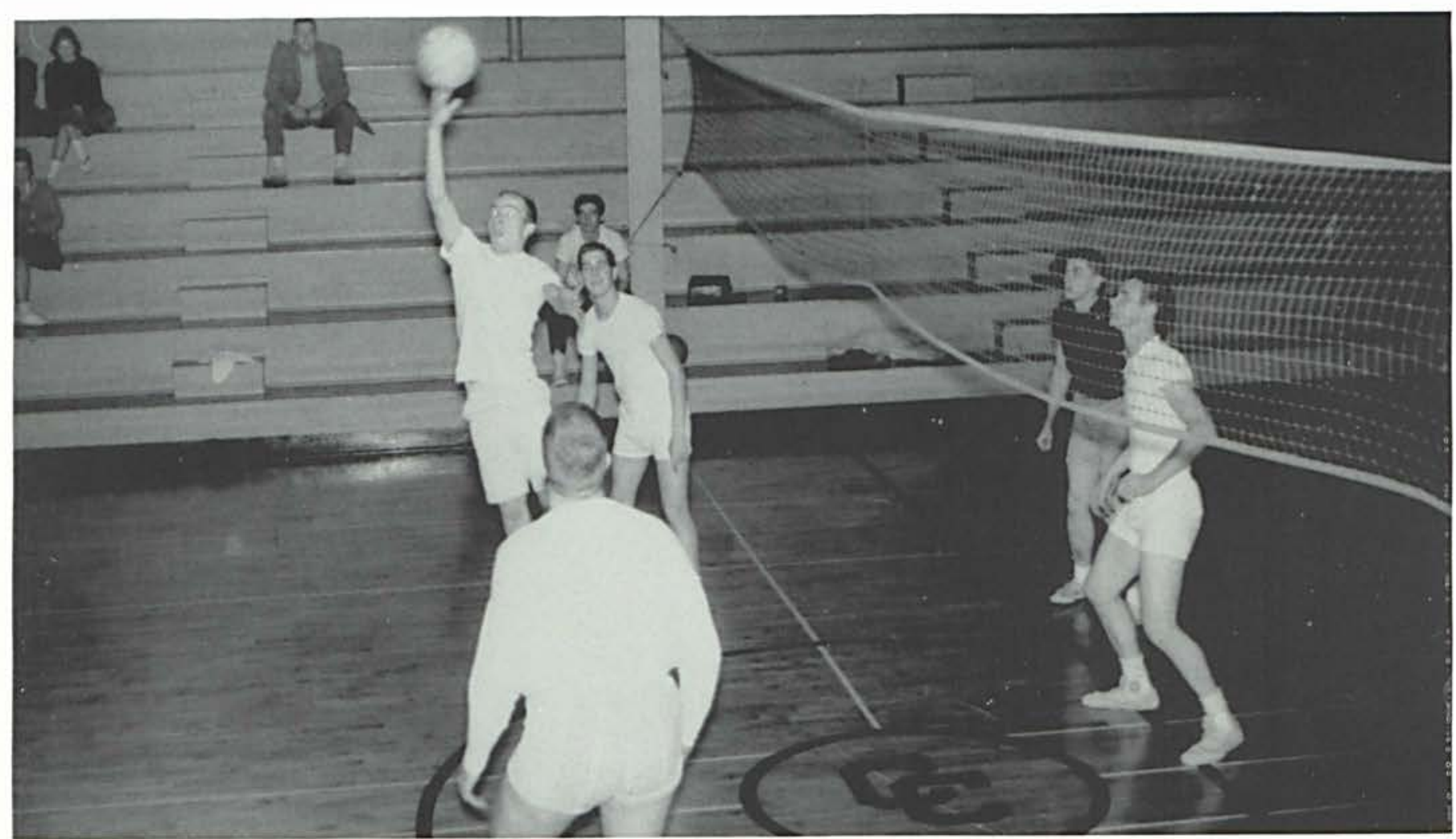

Ted Ocheltree leaps high to tap one over for the champion Bookstore team.

MEN'S STANDINGS

\section{WOMEN'S STANDING}

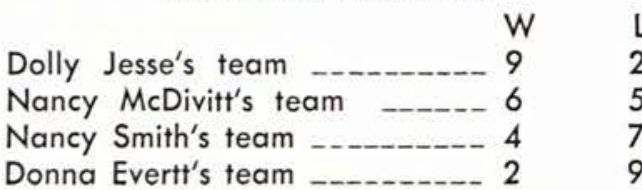

$\begin{array}{lll} & \text { W } & \text { L } \\ \text { Bookstore } & 6 & 0 \\ \text { Bethel East } & 4 & 2 \\ \text { Off-Campus } & 3 & 2 \\ \text { Cedar Hall } & 3 & 4 \\ \text { Harriman Hall } & \\ \text { Rife Hall } & & 4 \\ \text { Bethel West } & 1 & 5\end{array}$

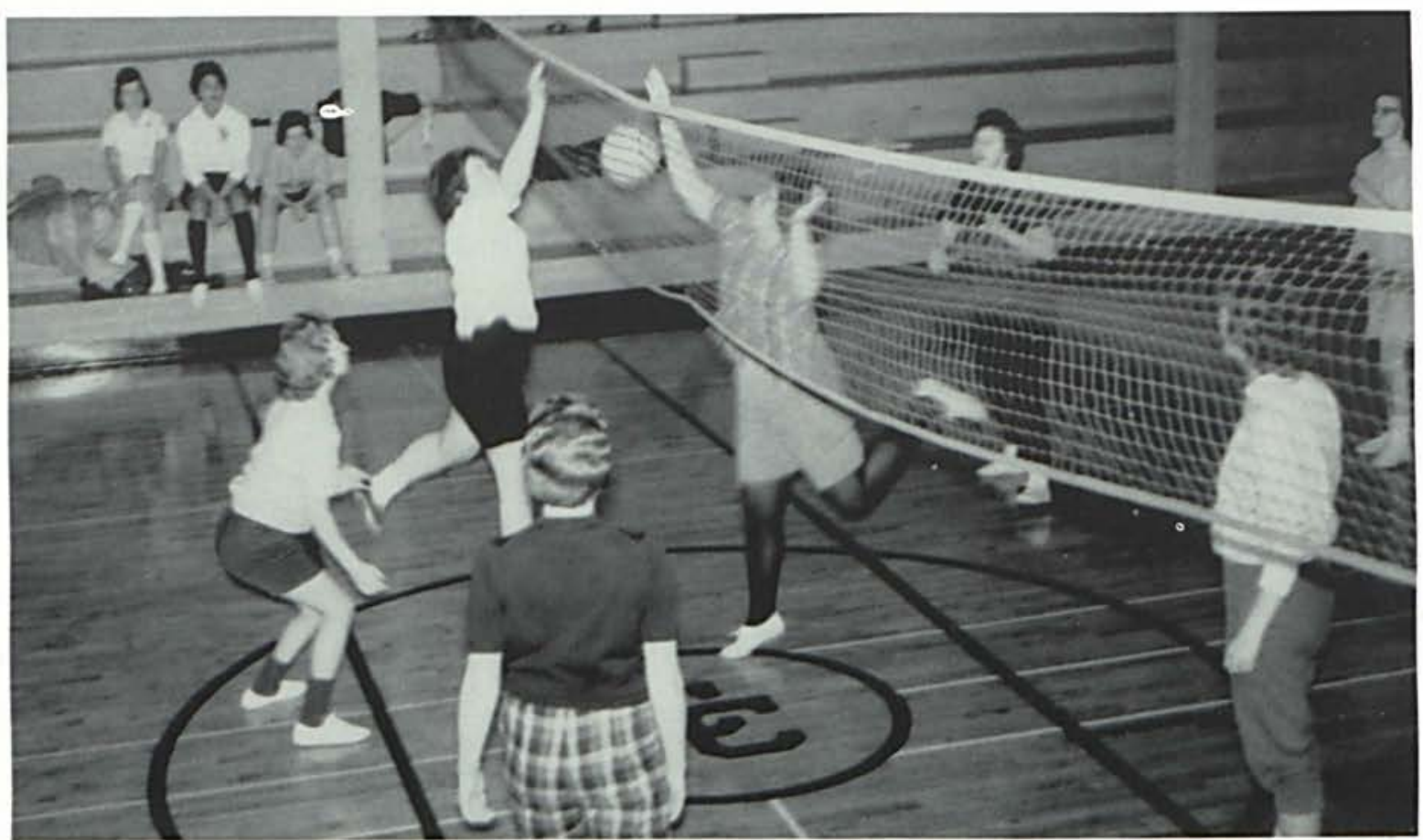




$$
\text { Social Life ...... }
$$

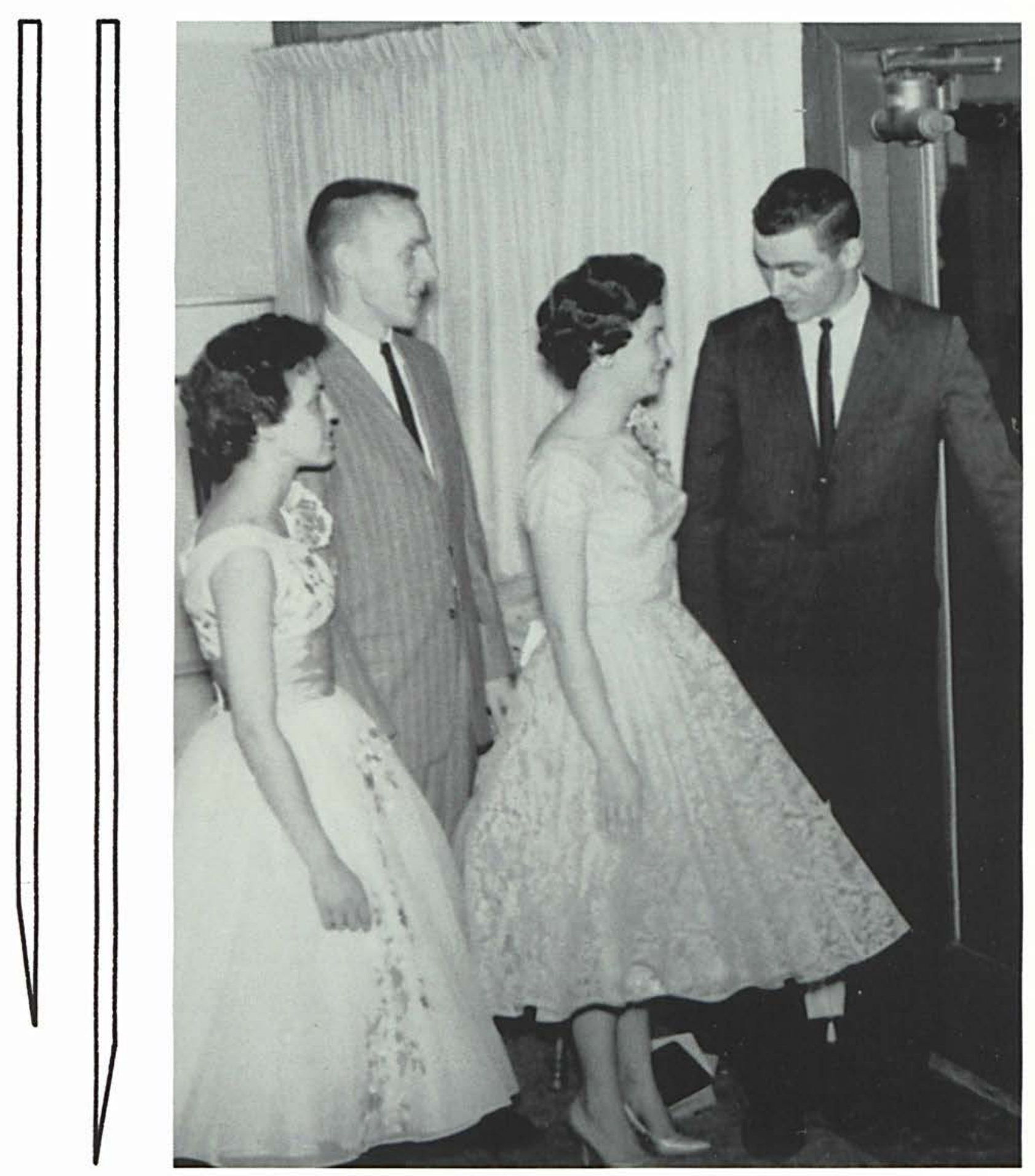




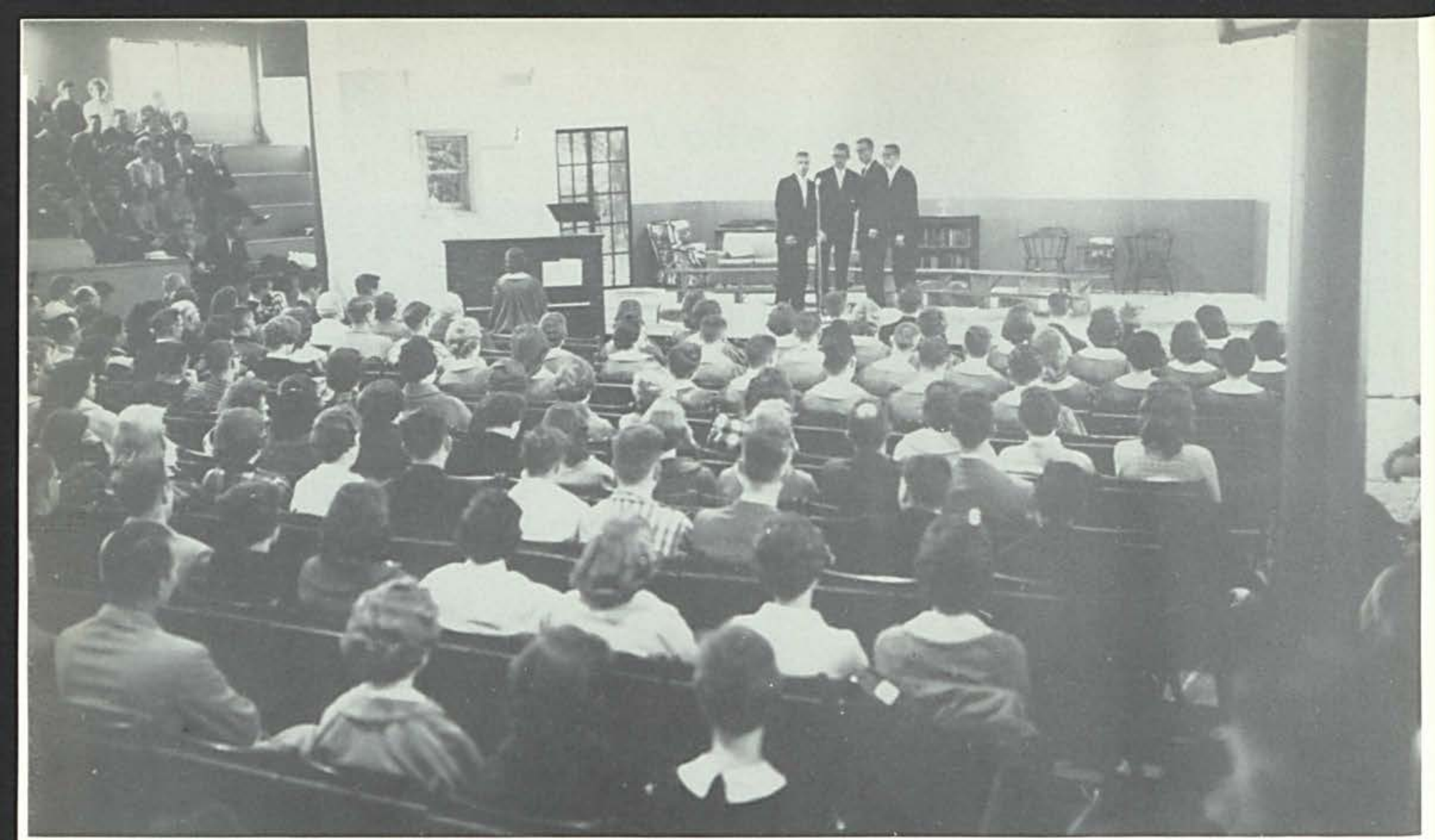

Visitors enjoy C.C. men's quartet.

\section{Prospective}

\section{Students'}

\section{Day}
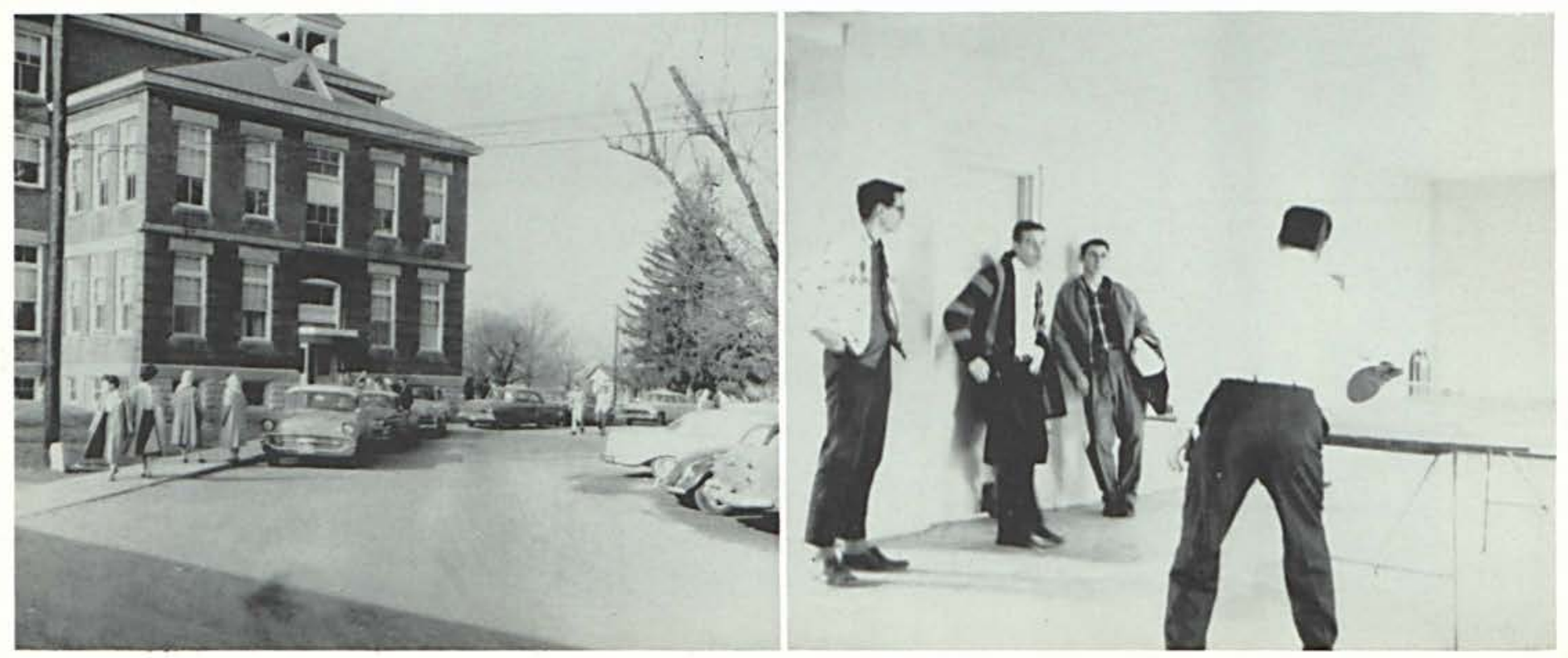


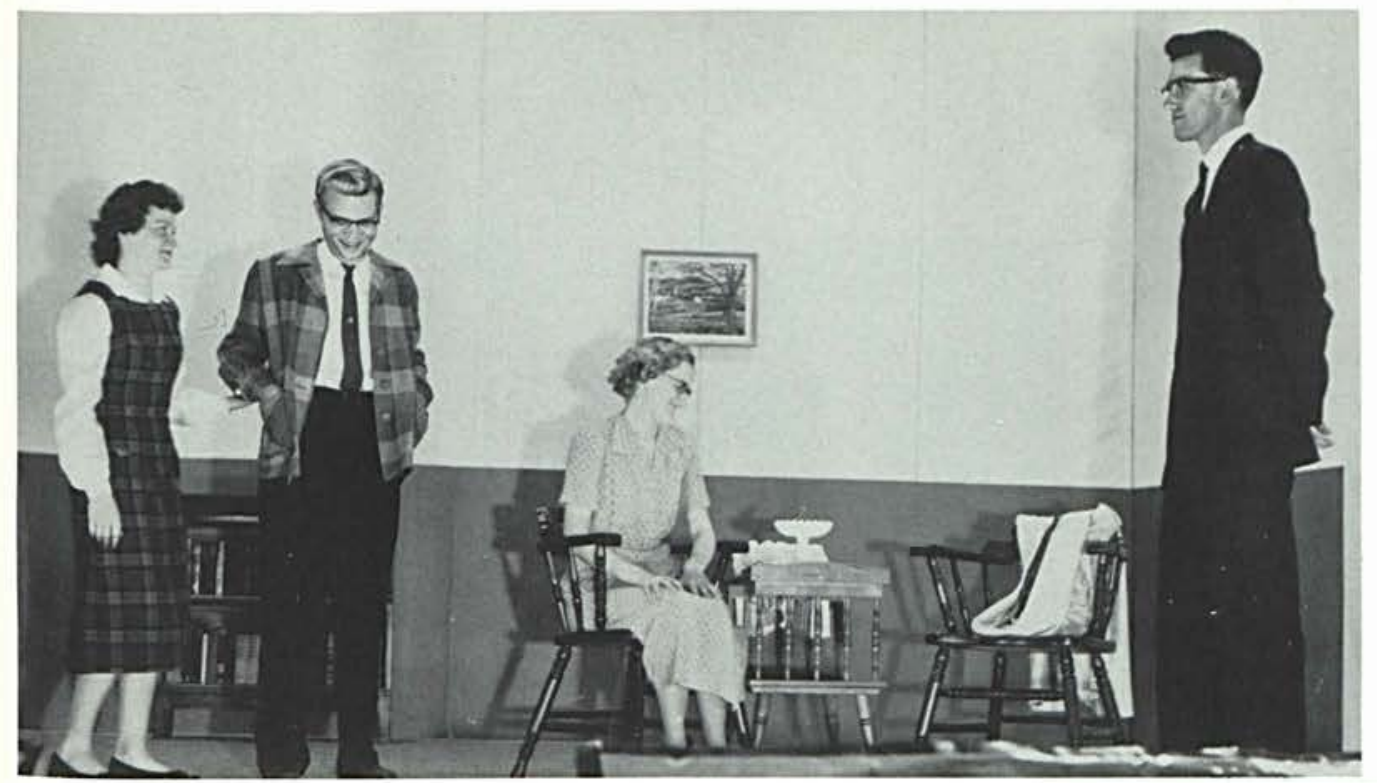

Pat Petry makes a hit with the family.

Professor Norm GettyStudent Pat Petry.

\section{Professor,}

How

\section{Could}

You?
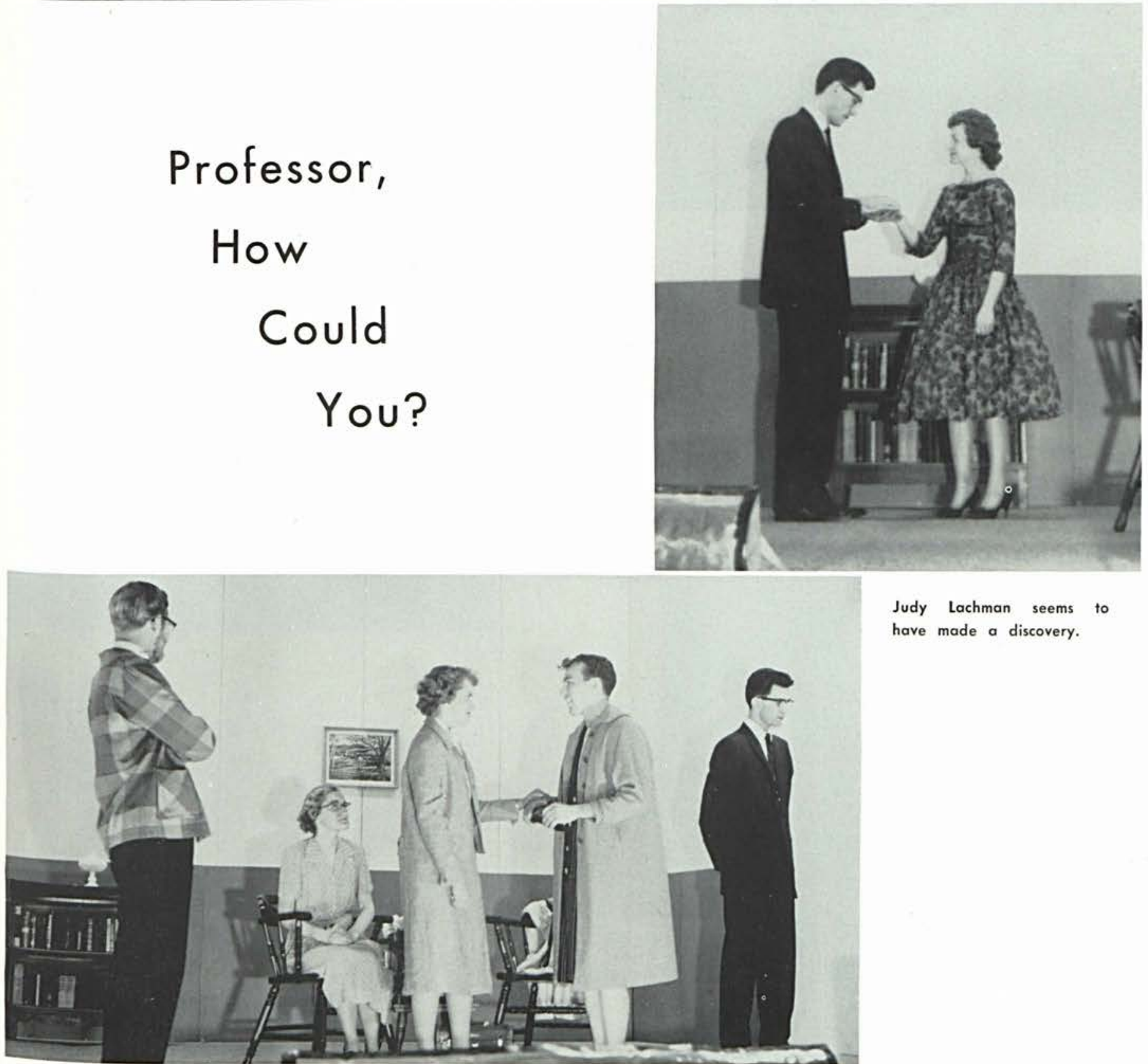

Judy Lachman seems to

have made a discovery. 


\section{Choir Tour}

Our College Choir, making its annual spring tour, travelled 2,500 miles to present sixteen concerts. These many miles were travelled in thirteen days and in six different states and the District of Columbia.

Choir members enjoyed sight-seeing in such places as Washington, New York, West Point, and Niagara Falls. But most important, the opportunity to serve the Lord through music was a joy to all.

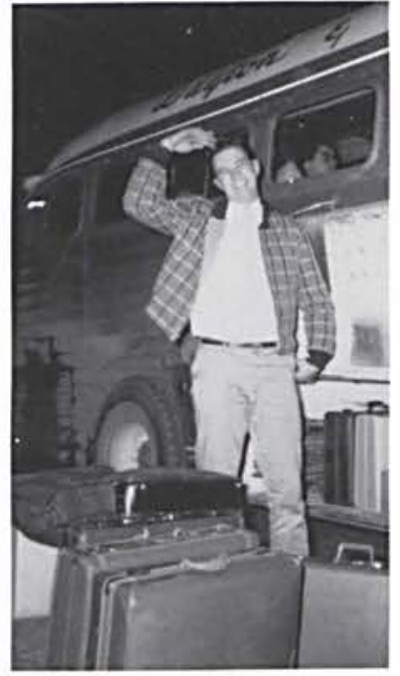

"Hey Brownie, need some help?"

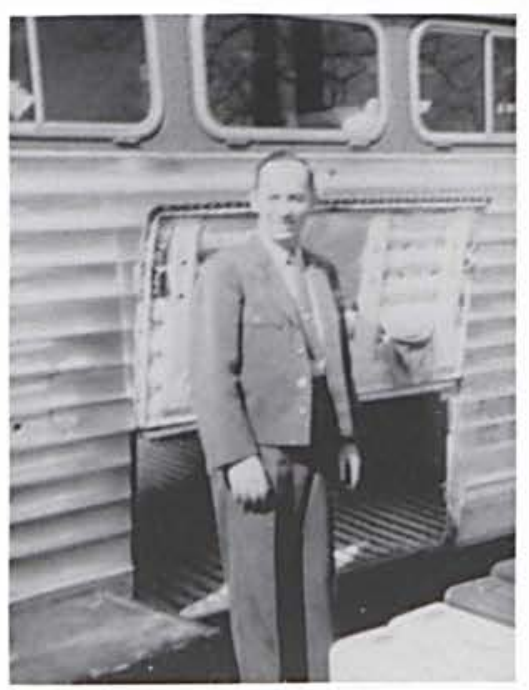

Our favorite bus driver, Brownie.

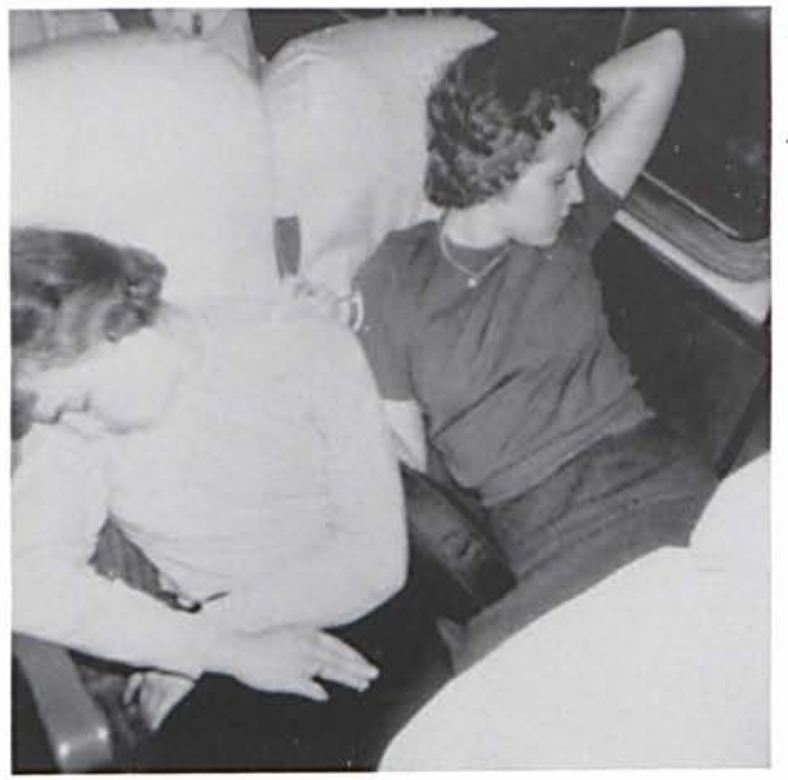

Sleeping beauties. 


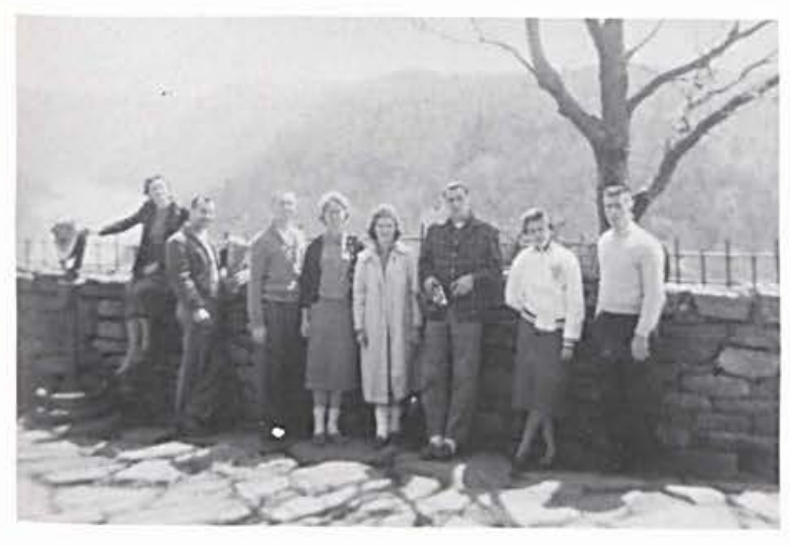

The part of Hawk's Nest, W. Va., known as Lover's Leap.

The skyline of New York City.
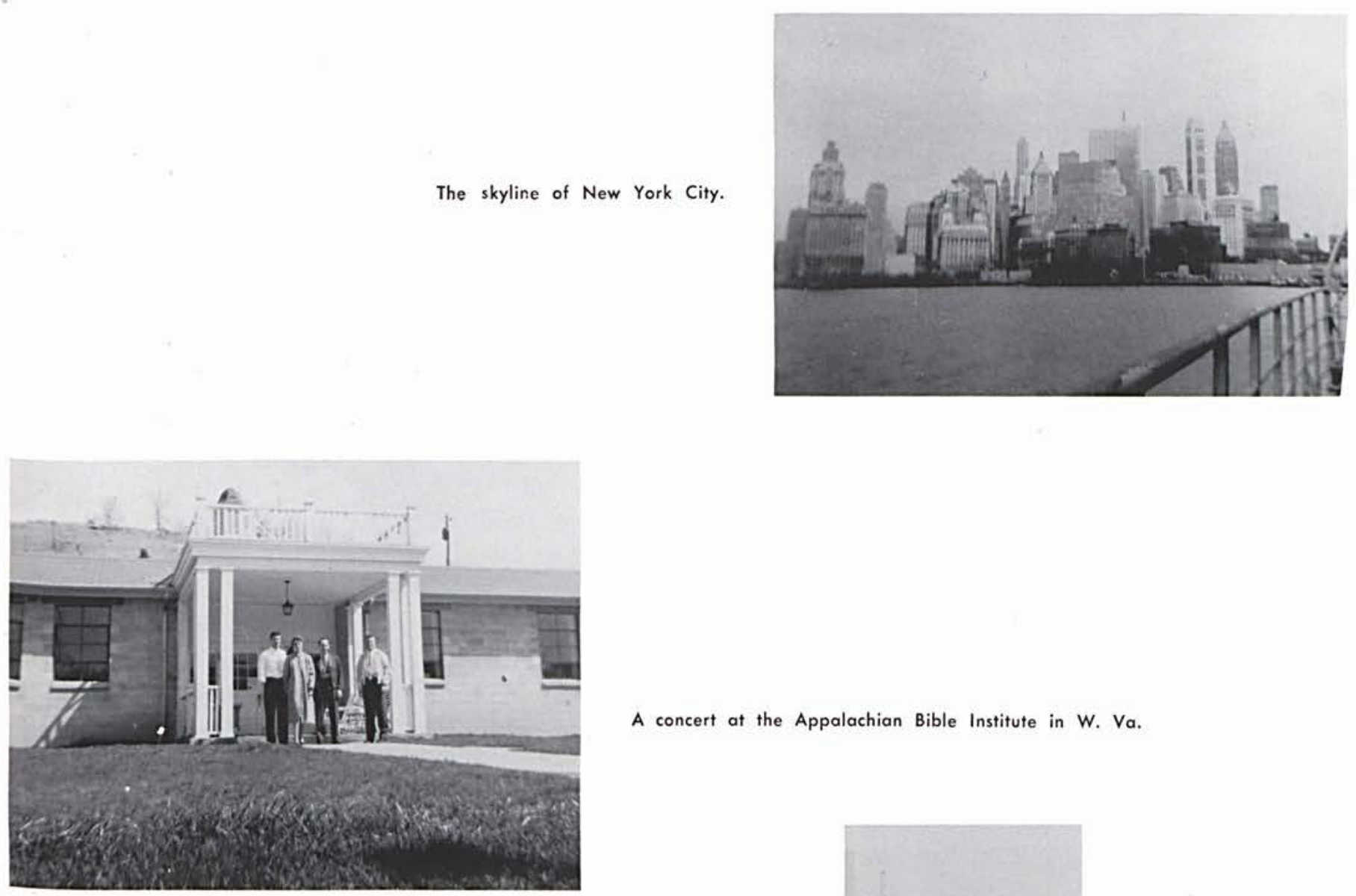

A concert at the Appalachian Bible Institute in W. Va.

At last, I get the hang of this choir tourl

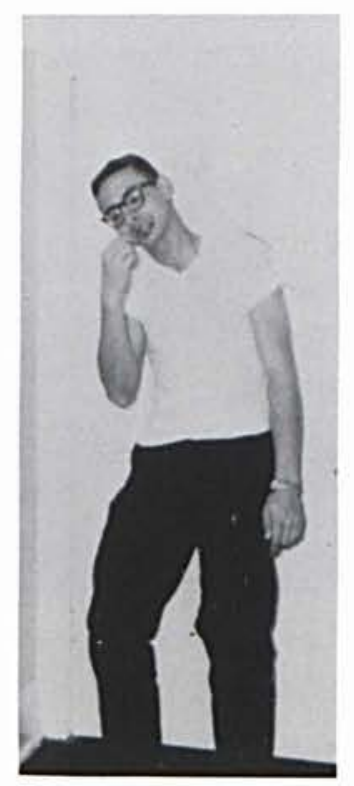




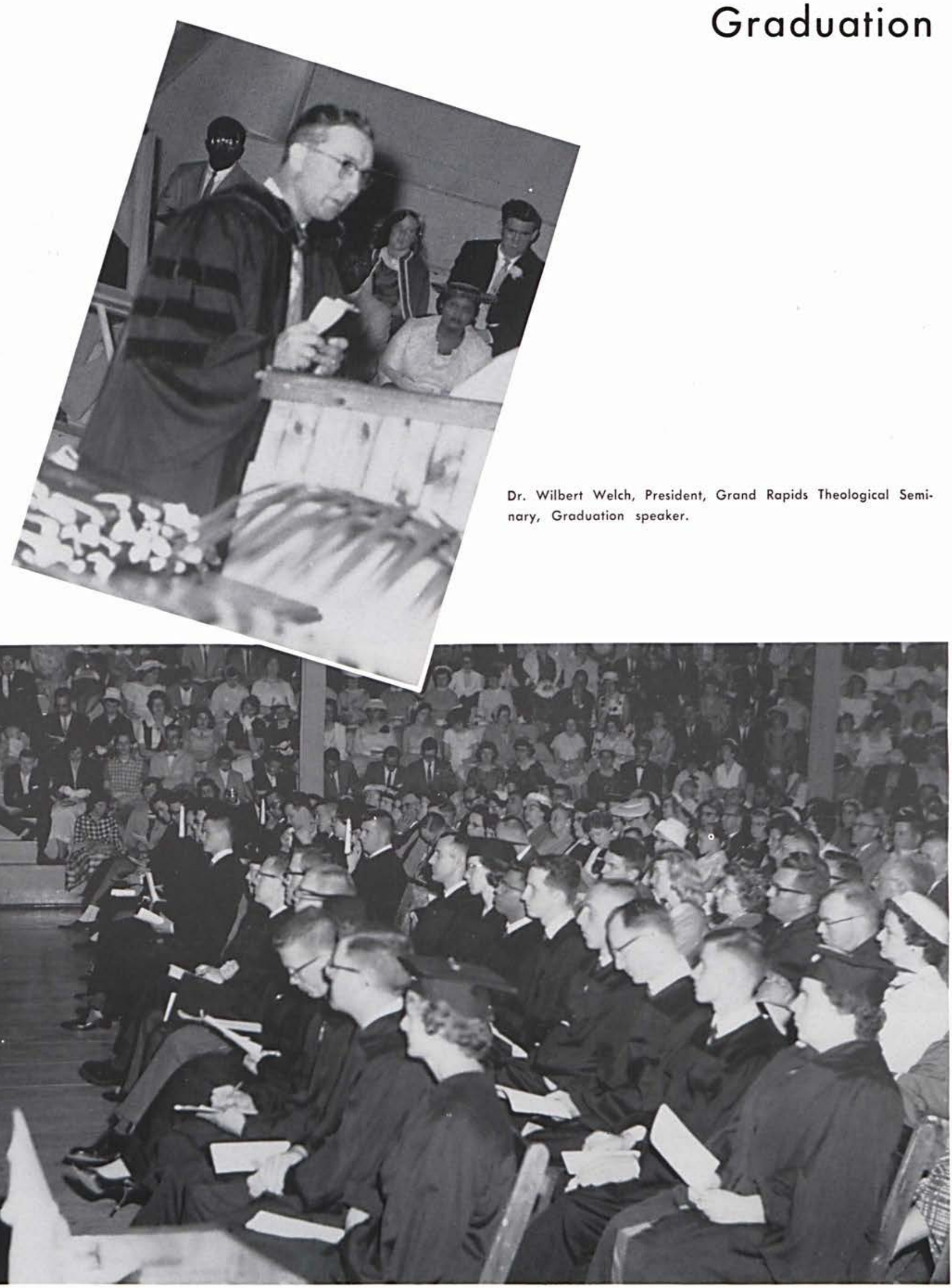

The end of four hard years! 


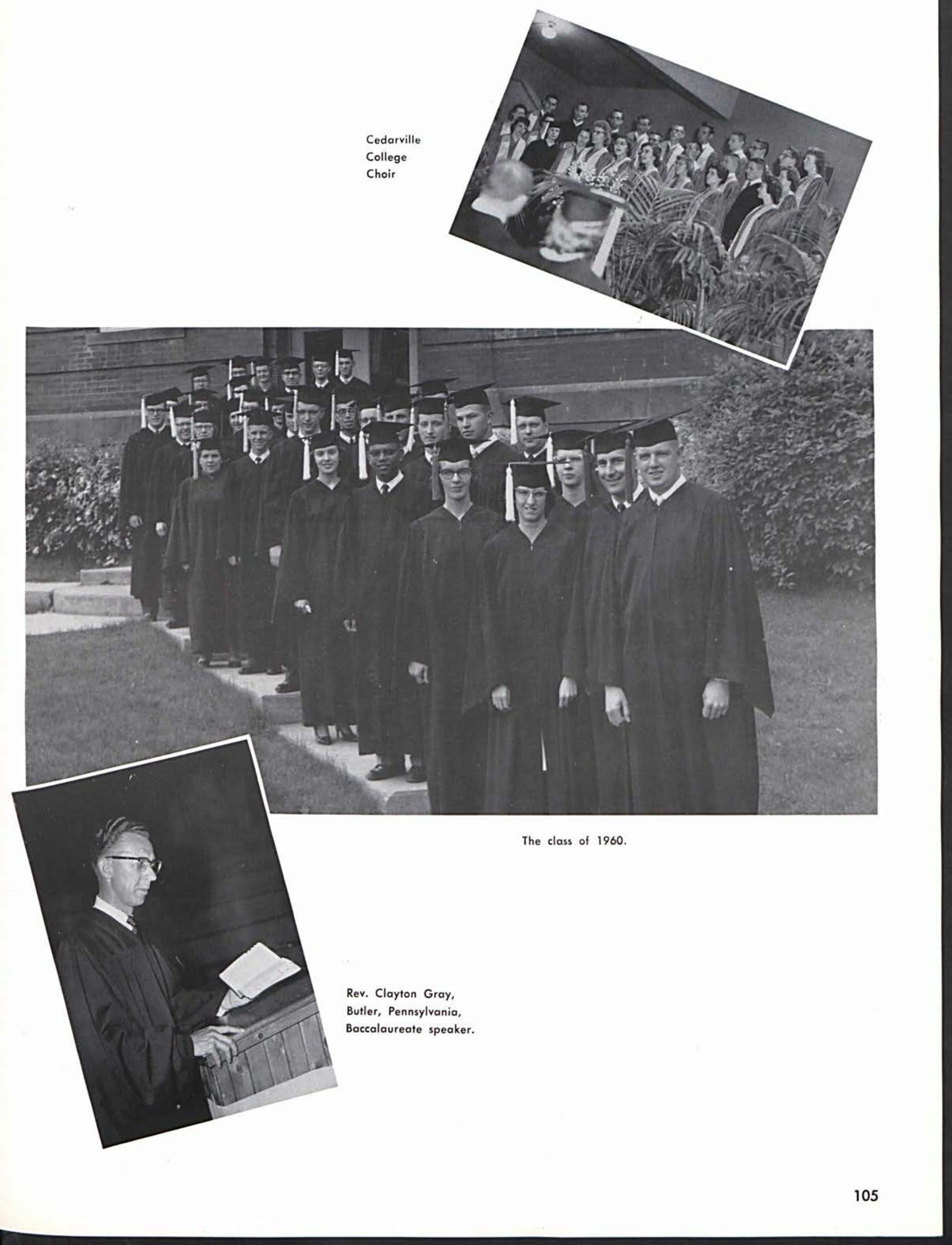



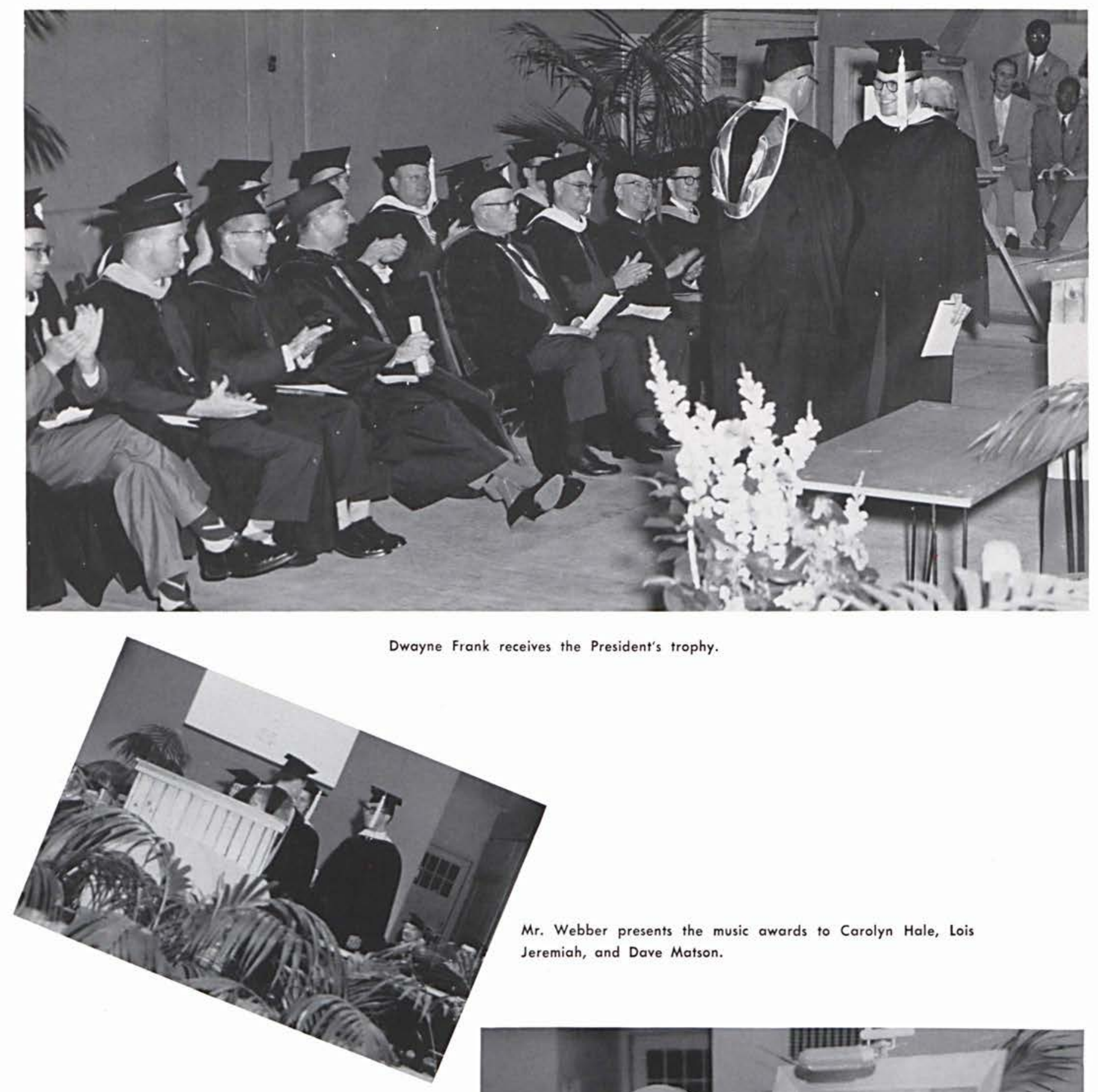

Miss Mary Williamson, thirty-seven faithful years of service to the library.

Mr. Webber presents the music awards to Carolyn Hale, Lois Jeremiah, and Dave Matson.

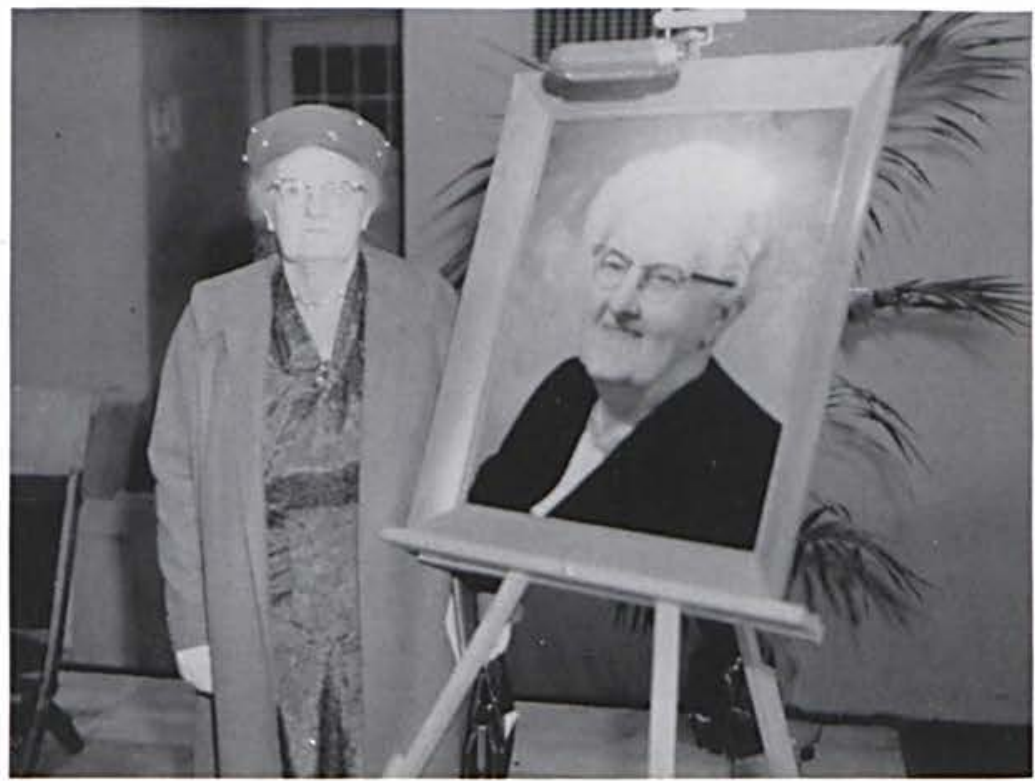


Presidents Jeremiah and Welch exchange comments after the ceremonies.
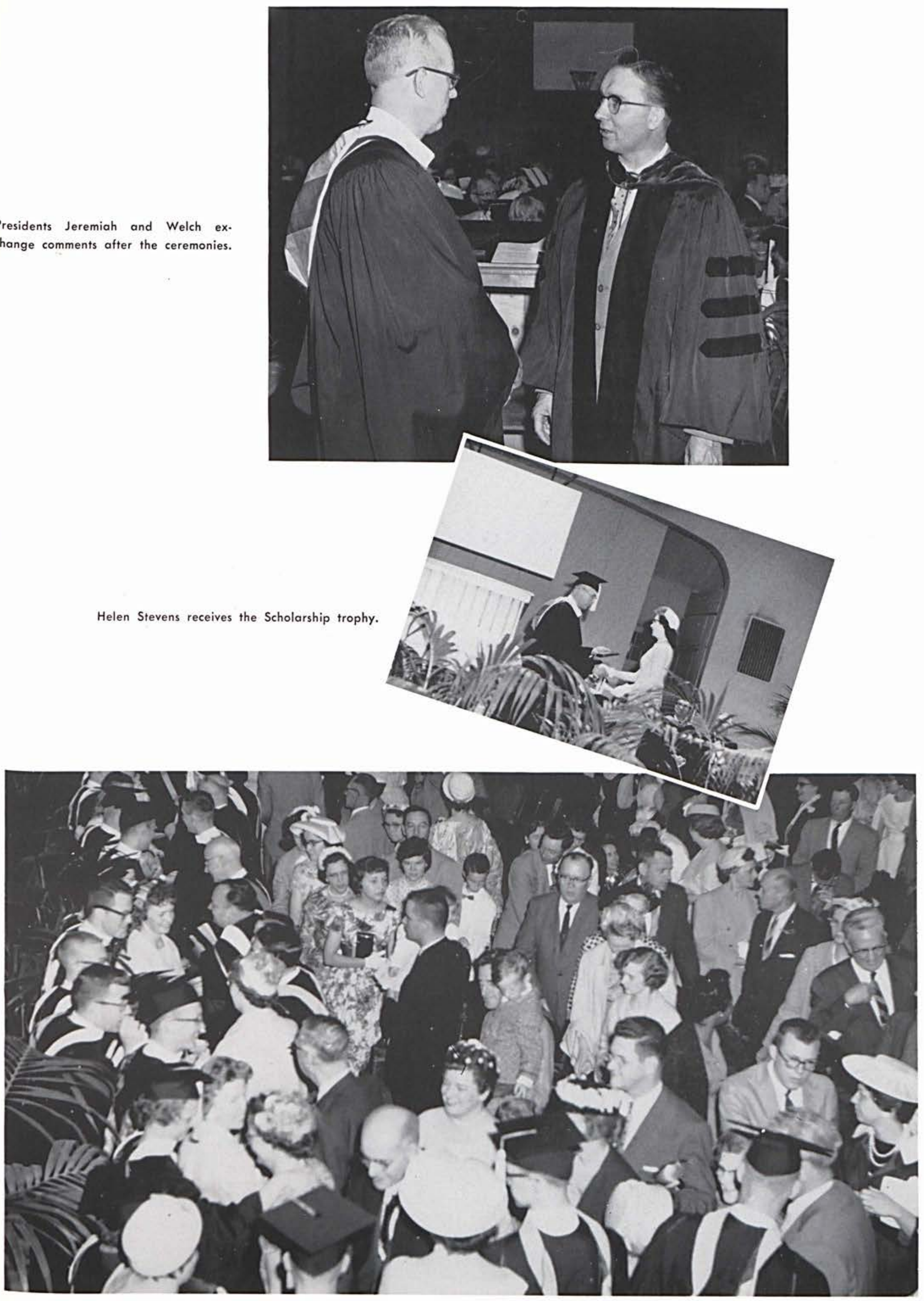

The aftermath. 


\section{School}

\section{Picnic}

Ted Ocheltree has finally reached the top.

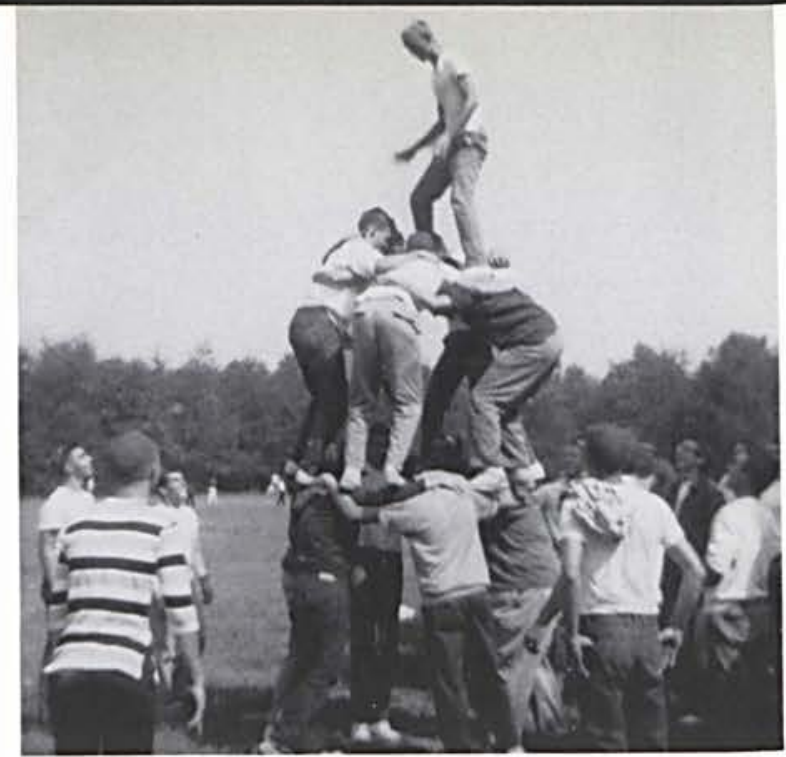

We'd leave - but we're all tied

up.
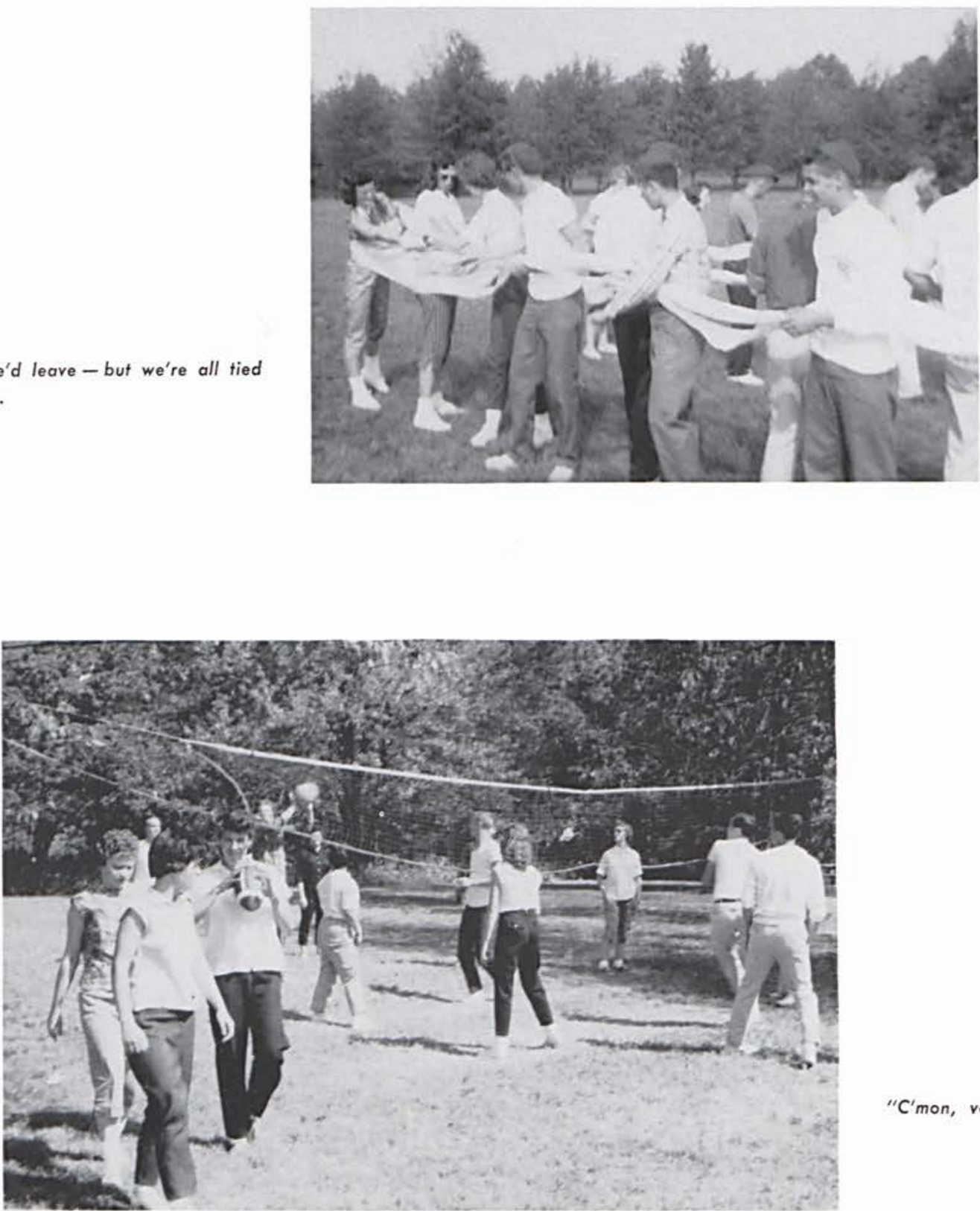

"C'mon, volleyball's not tough enough for us!" 


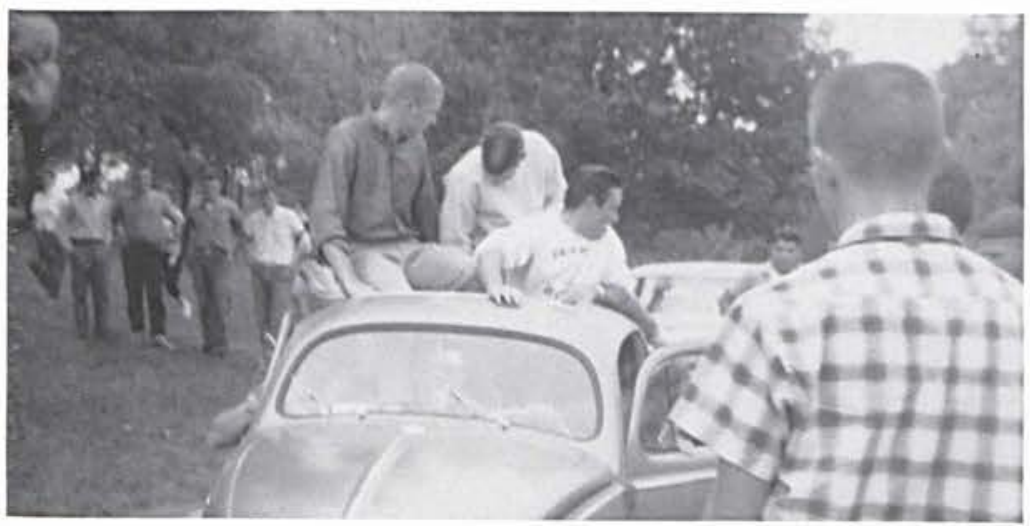

Somebody go get Tony Kilbourn.

Hey fellows, come back!
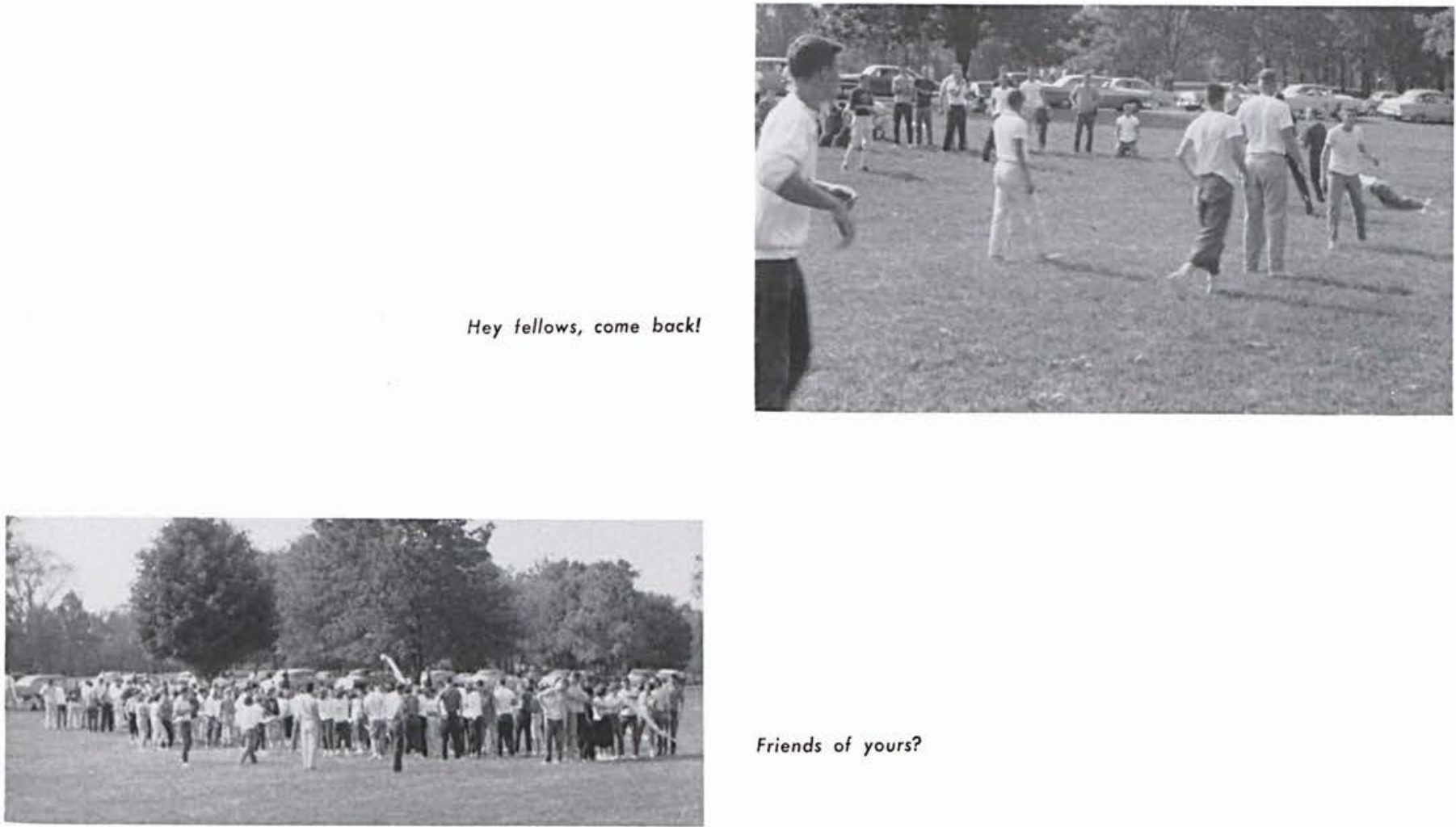

Friends of yours?

Now if the rope hadn't broken..

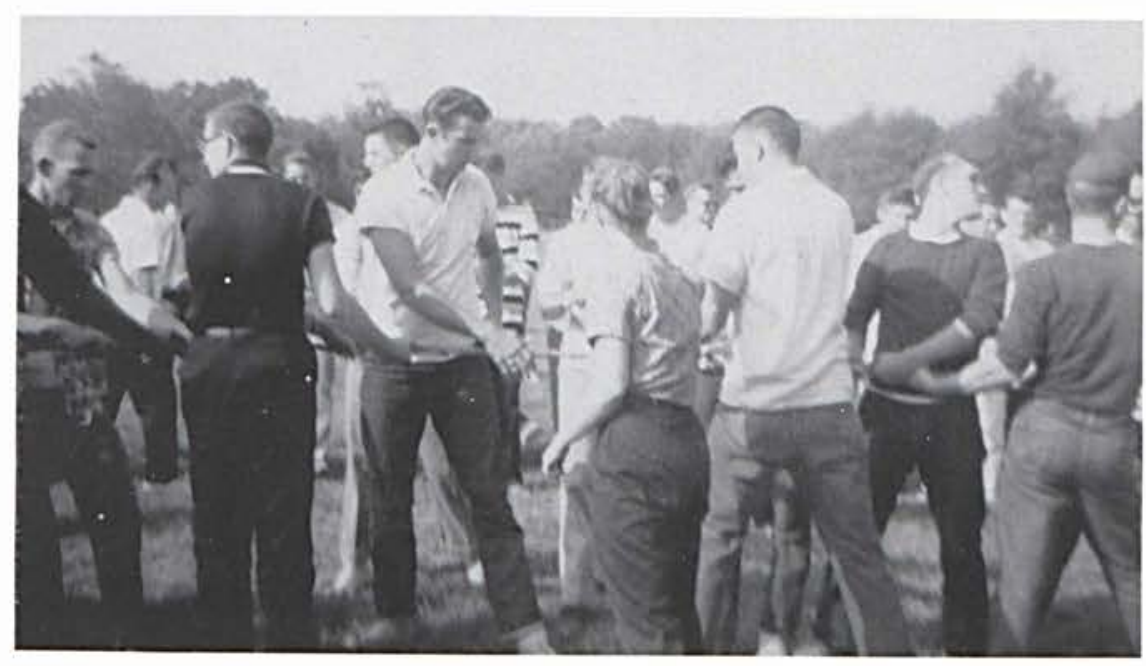




\section{Freshman Initiation}

Carmen Witt and June Willmington prepare for the big day.

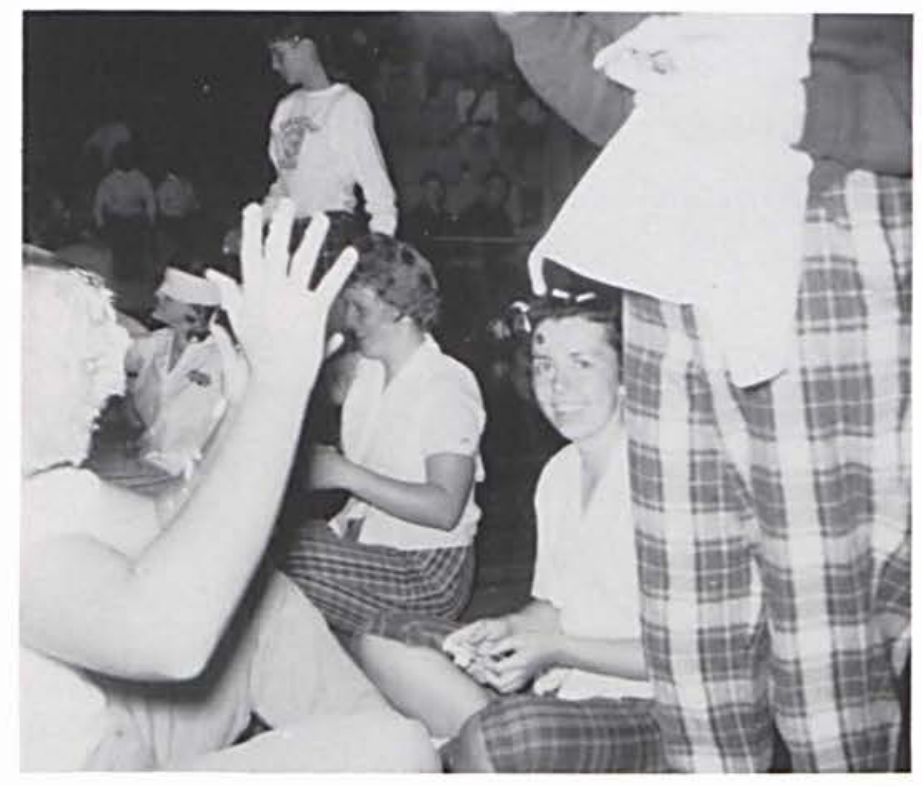

Freshmen humbled - Sophomores rule againl
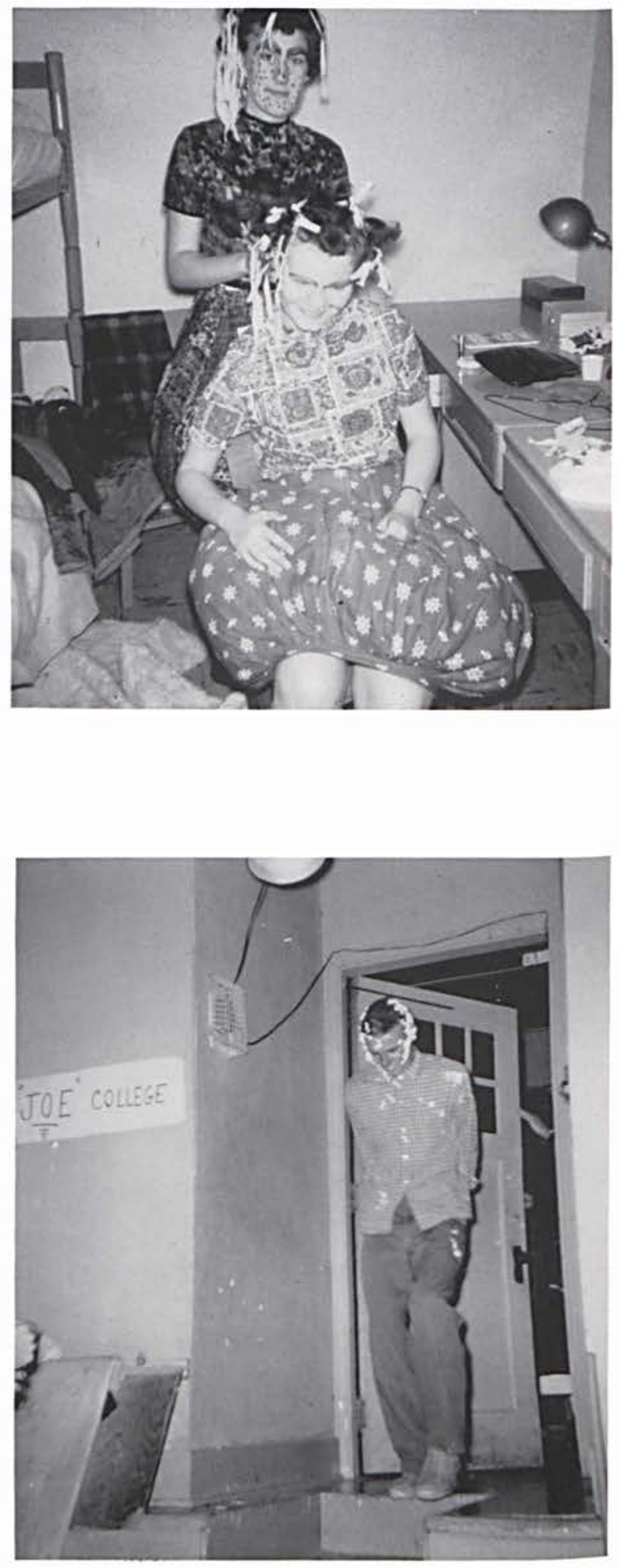

A full-fledged college student. 


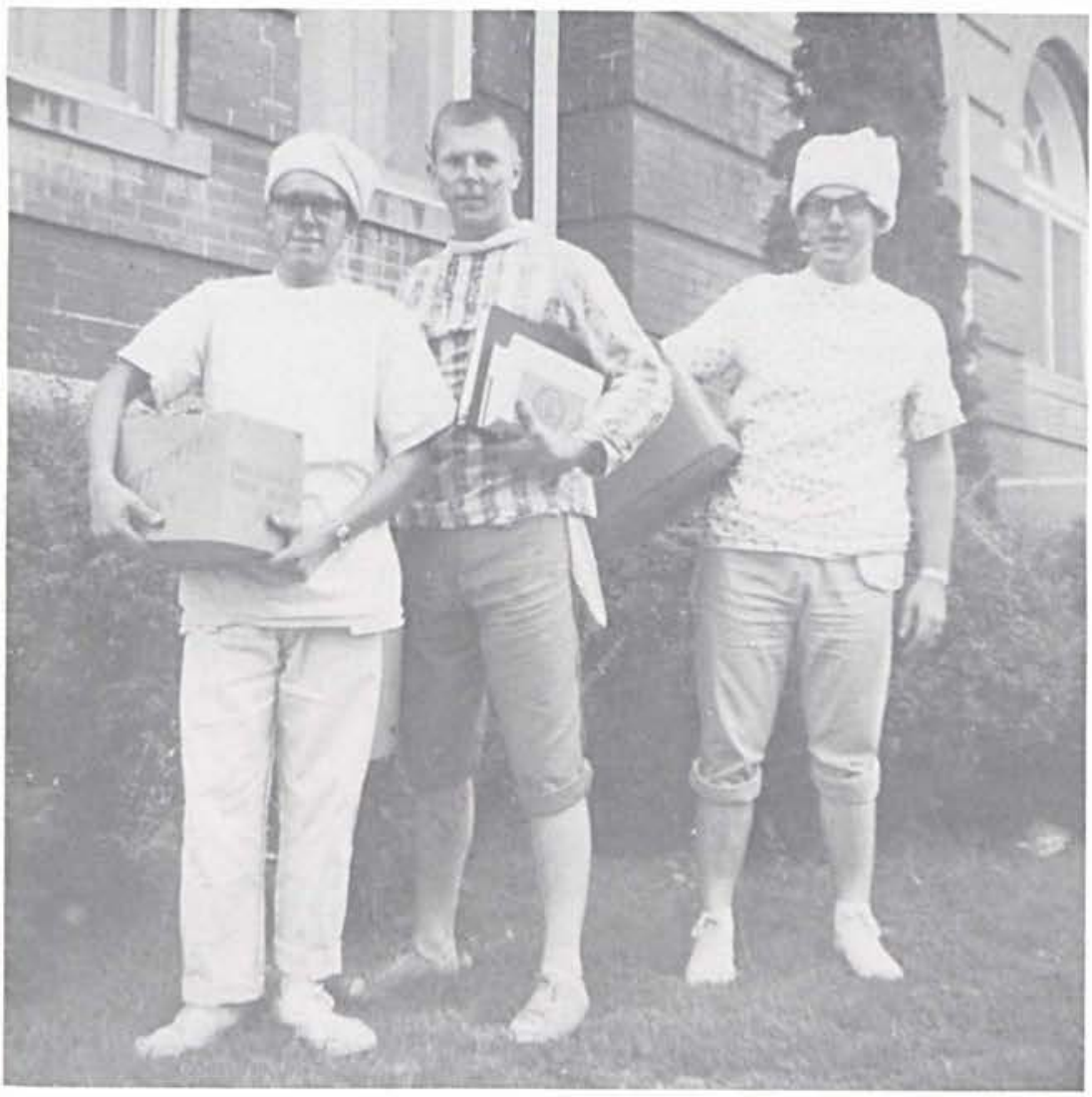

Green beanies . . Early morning awakening ... Strange wearing apparel, , , Knives as eating utensils... Campus clean-up... Episodes in Davey's Locker. . . These will be remembered by the Freshmen for many a day to come.

All dressed up and no place to go.

Pat Barrett begins the day with a smile.

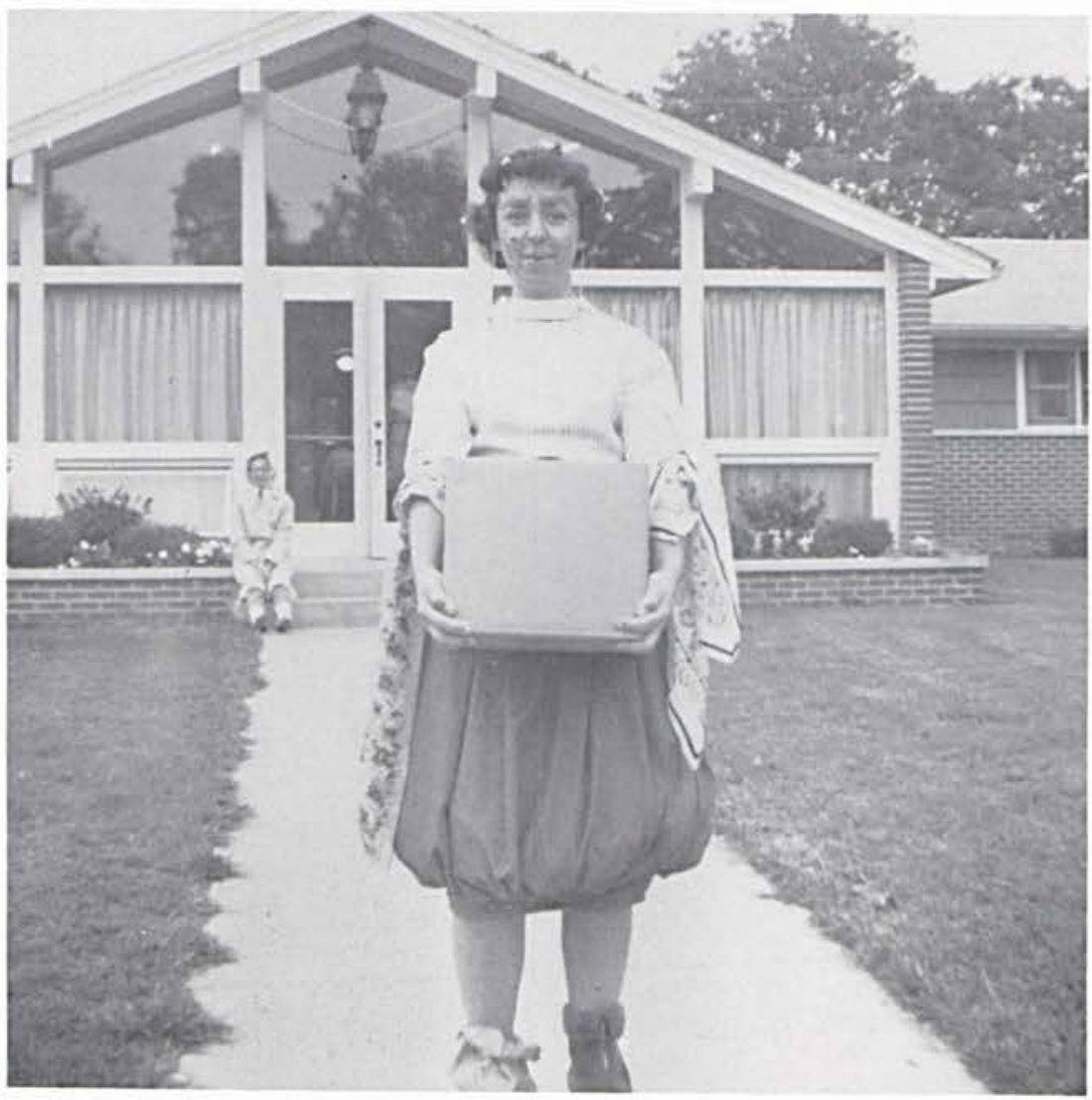




\section{Open}

\section{House}

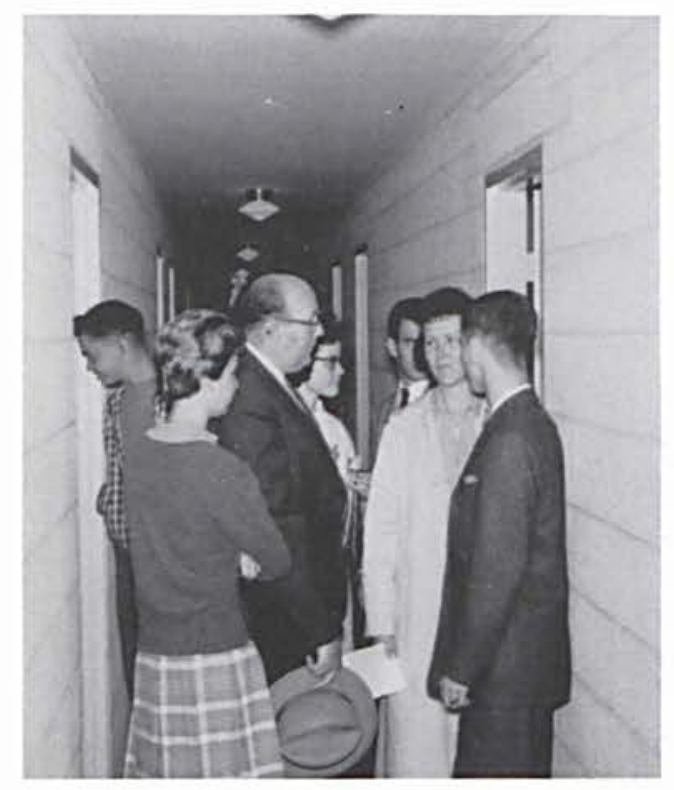

A tour through the dorm...

or

around the table.

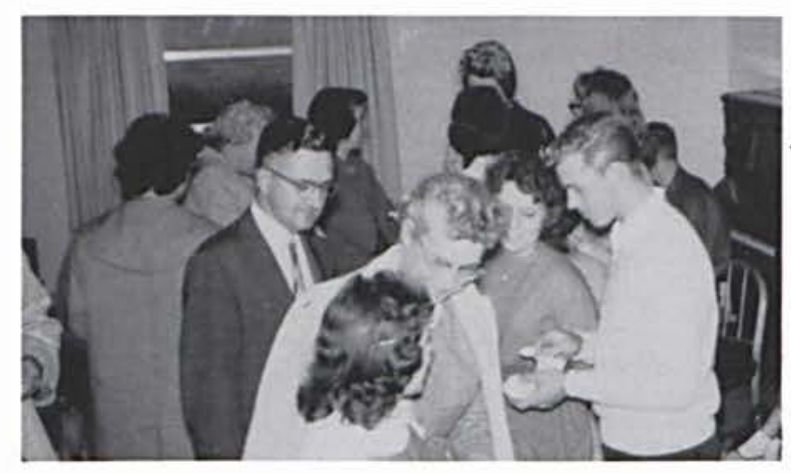

Time to chat.
The theme of our Open House, held on October 8, 1960, was: Cedarville College is Moving Forward.

Various phases of our college were represented throughout the day ... Cedarville's Heritage ... Cedarville's Growth ... and Cedarville's Potential.

During the day there were guided tours throughout the entire campus. The highlight of the day was the meeting held in Alford Memorial Gymnasium. Many distinguished guests spoke to the large audience. The main speaker of the afternoon was Dr. Joseph M. Stowell of Hackensack, New Jersey.

The day gave a good indication that Cedarville College has a tremendous future.

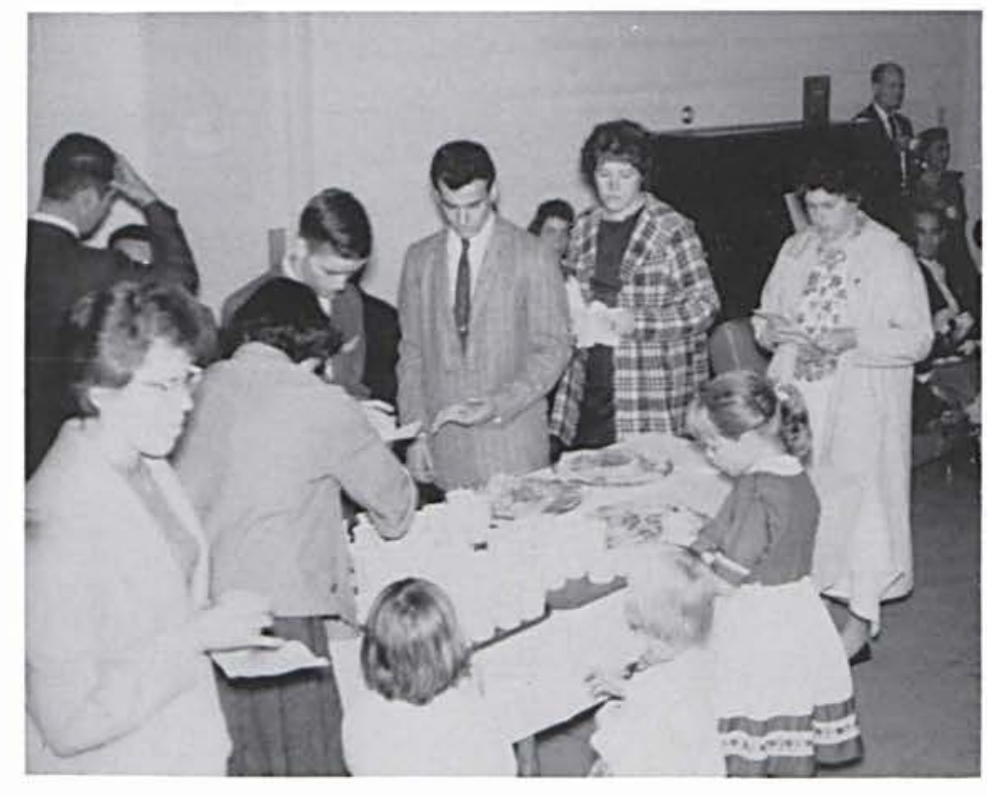

Time to rest.

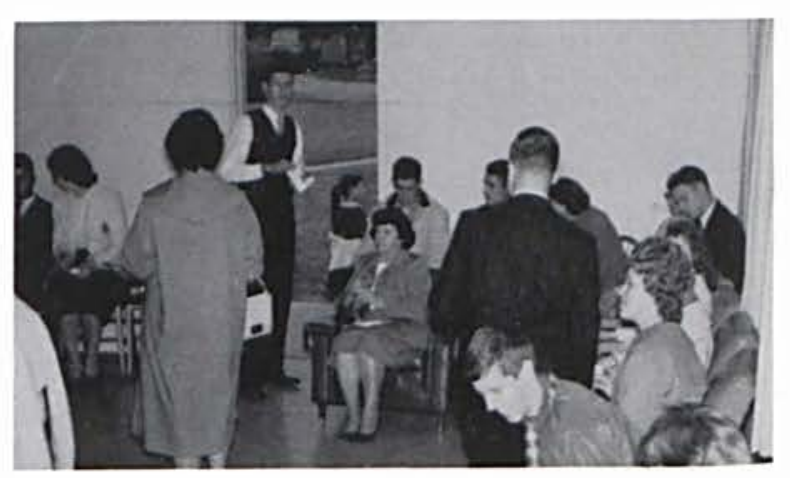




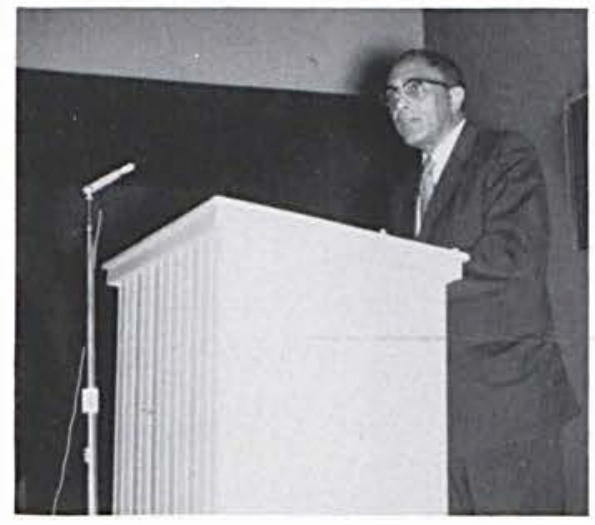

Dr. Charles Wesley

President

Central State College

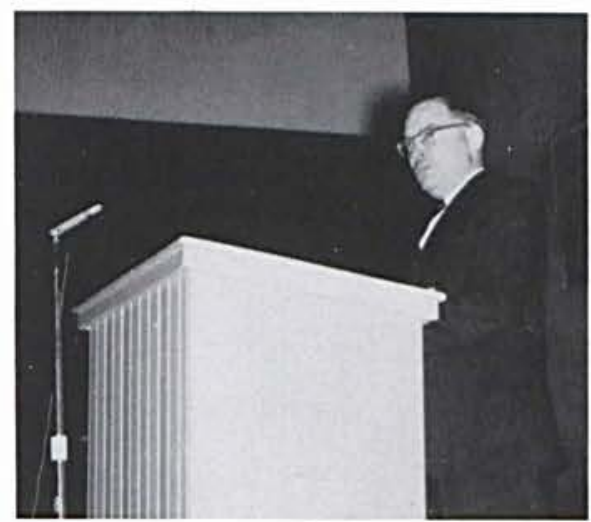

Dr. Joseph Stowell

Pastor

First Baptist Church

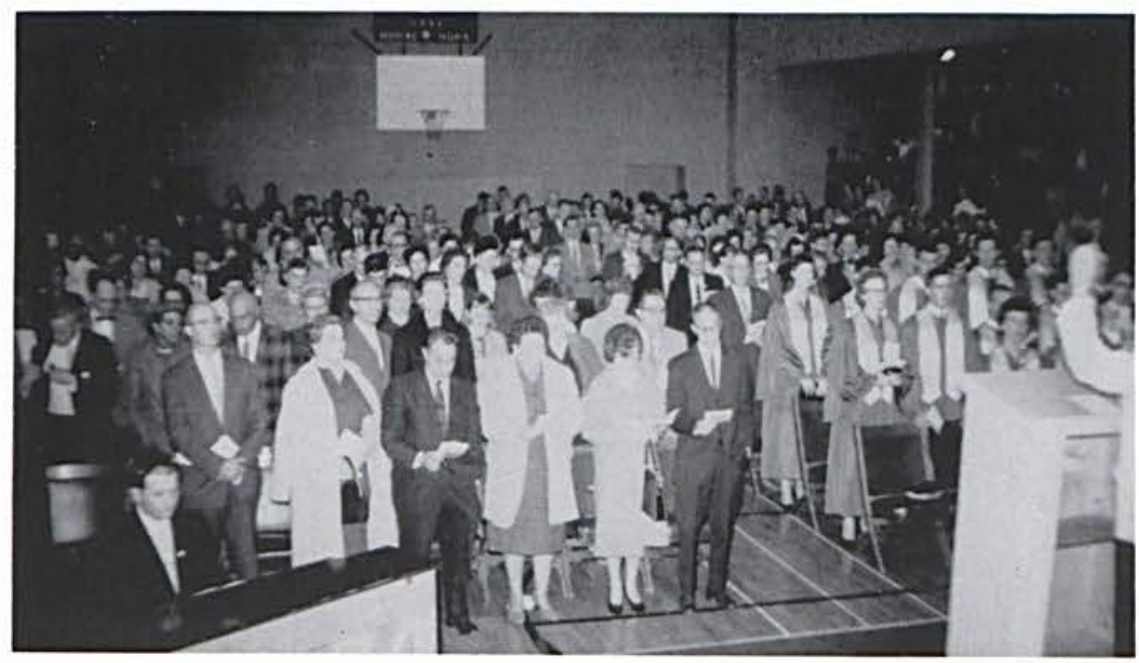

". . it is good to sing praises unto our God ..."

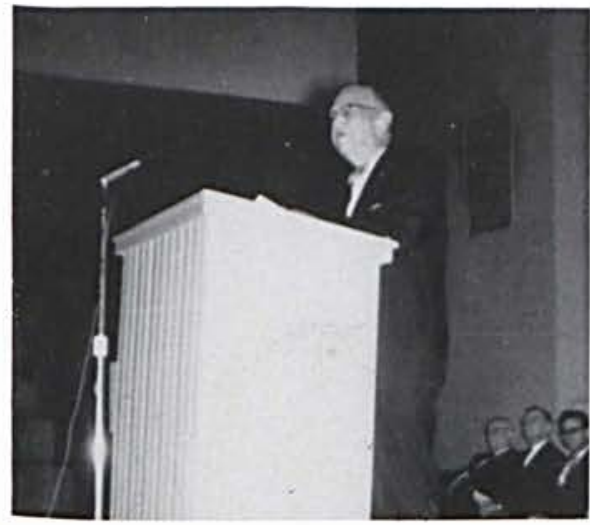

Mr. George Milner

Chairman, Board of Trustees

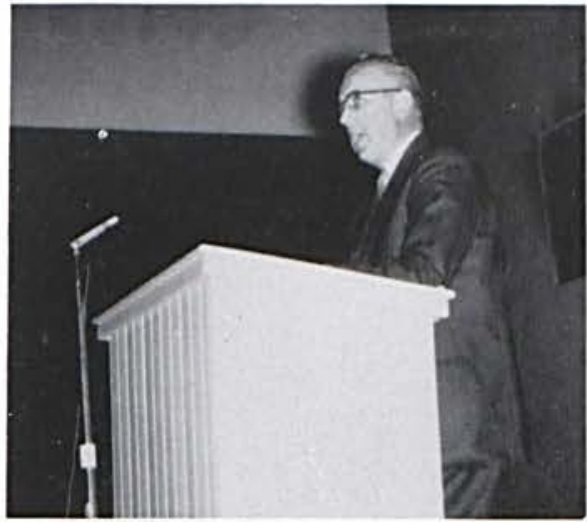

President Jeremiah 


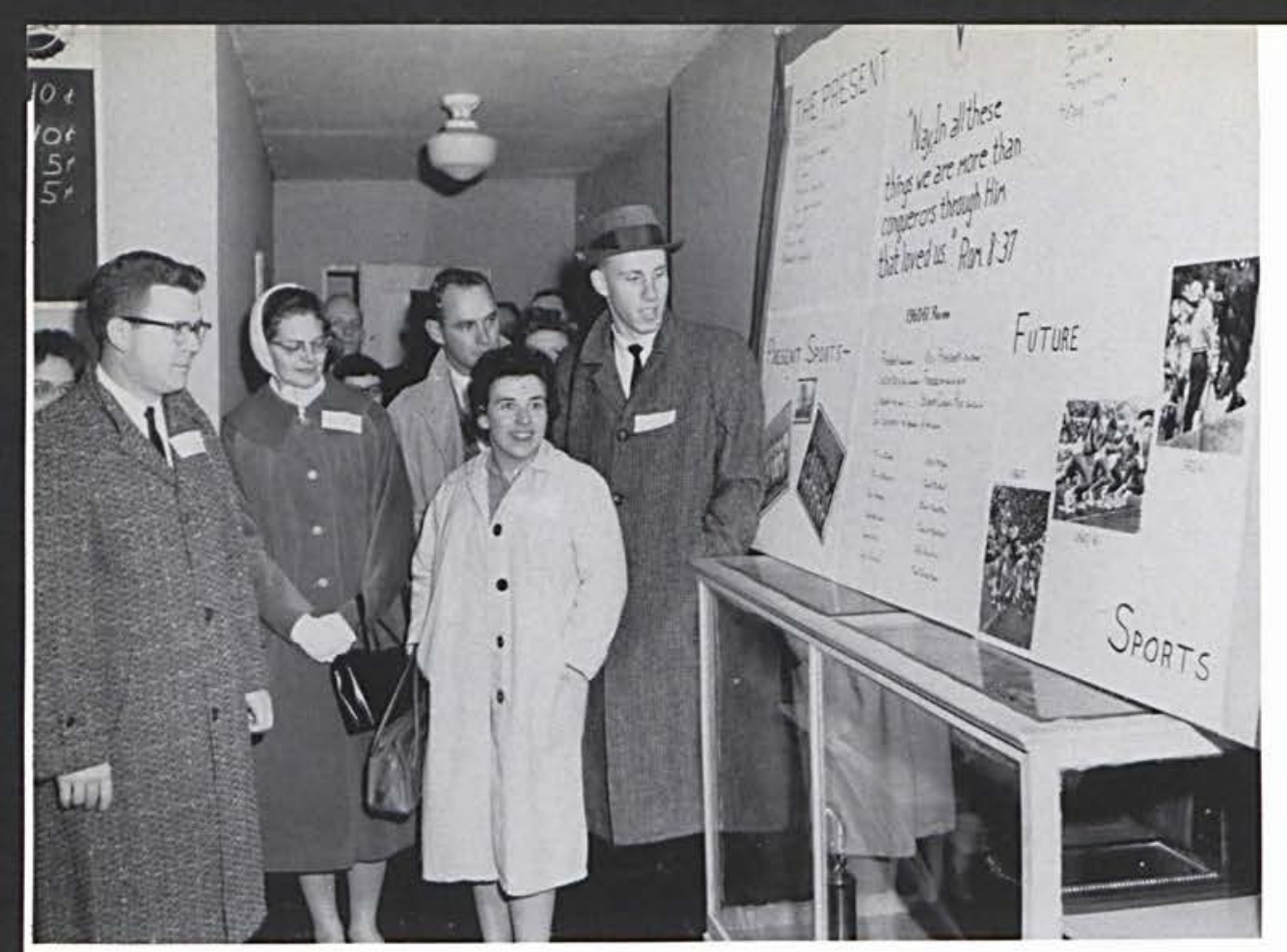

Alumni view Varsity C. display.

\section{Homecoming}

This is one of our alumnus?

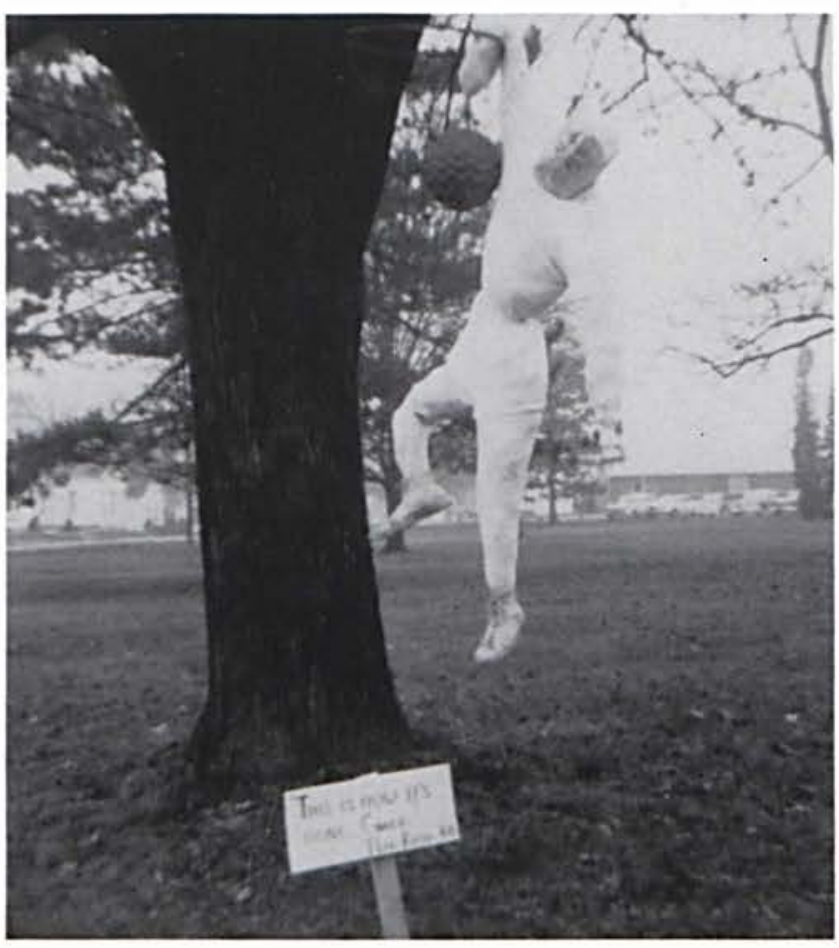

The Alumni seem to enjoy their return to the Cedarville campus.

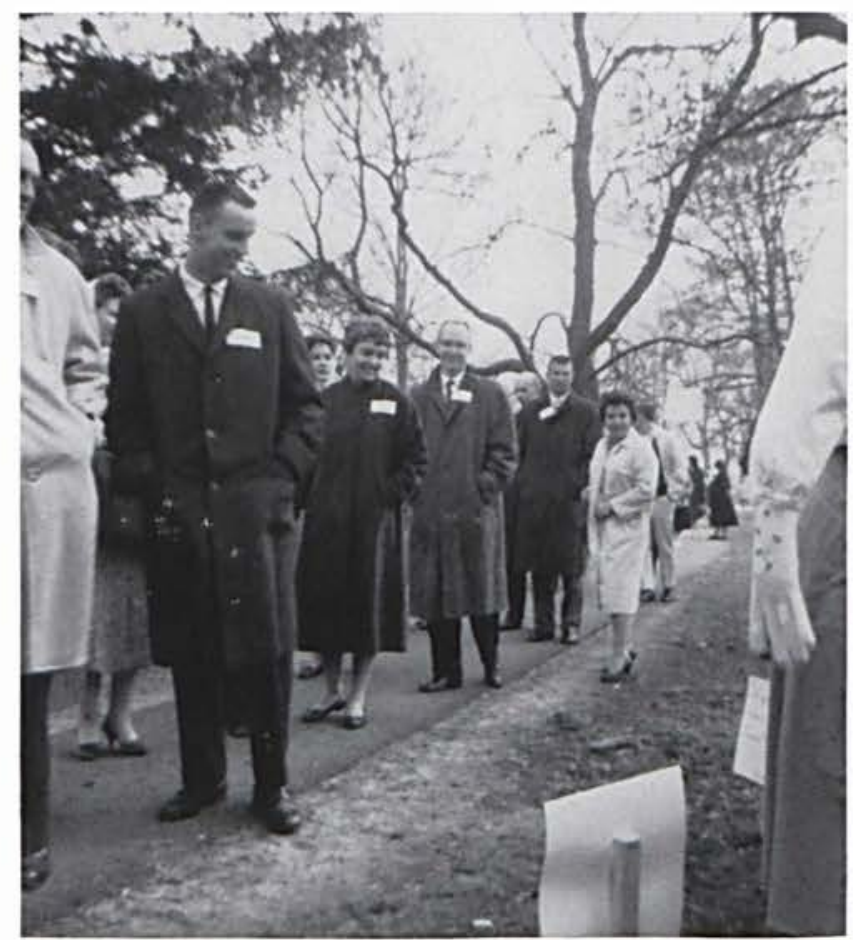



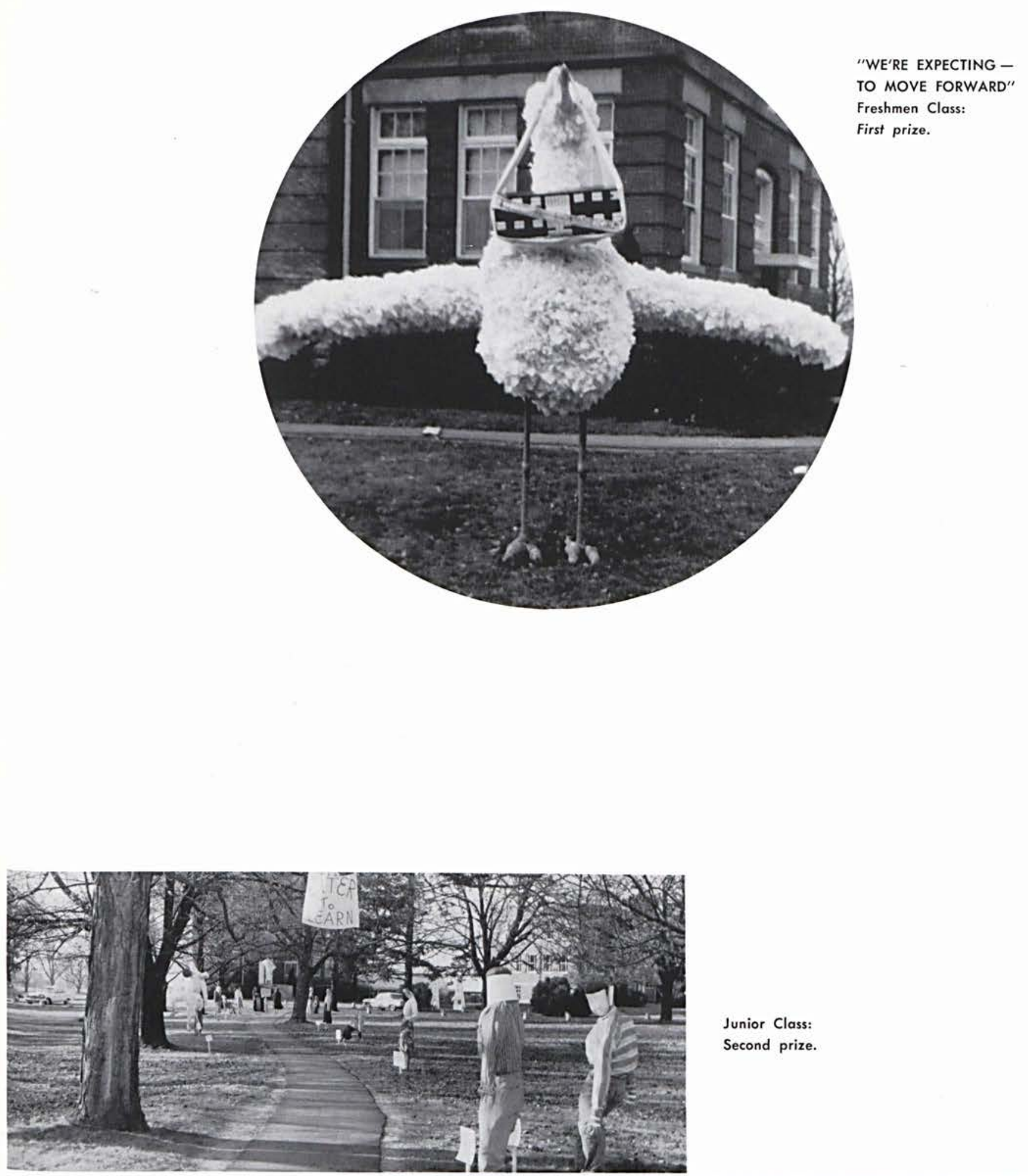

Second prize.

Faith Hall:

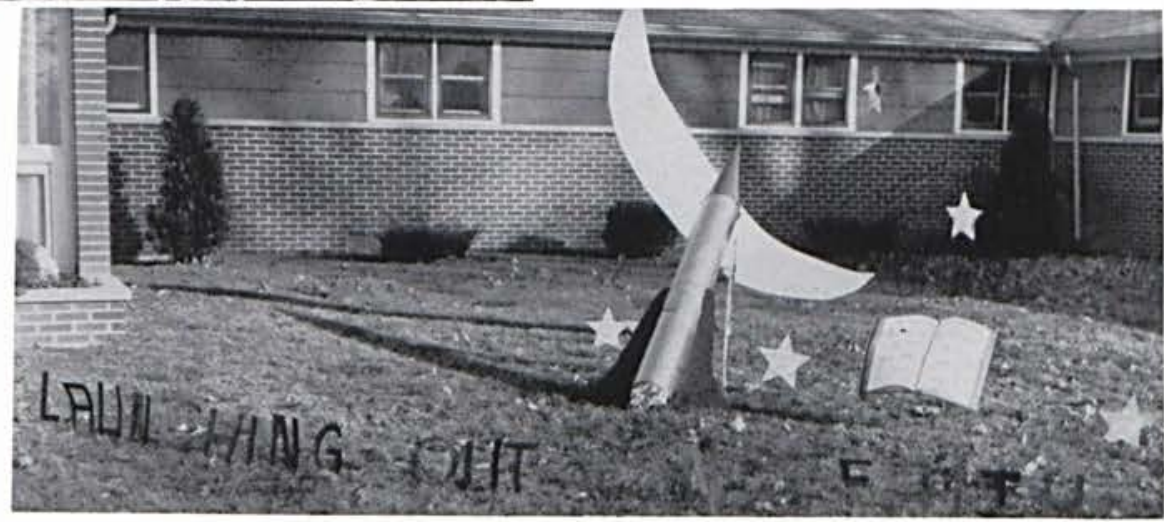


The highlight of the Homecoming weekend is the annual Alumni Game. The Varsity was the victor95-78. Little All--American, Pete Reese, scored 39 points for the Alumni.

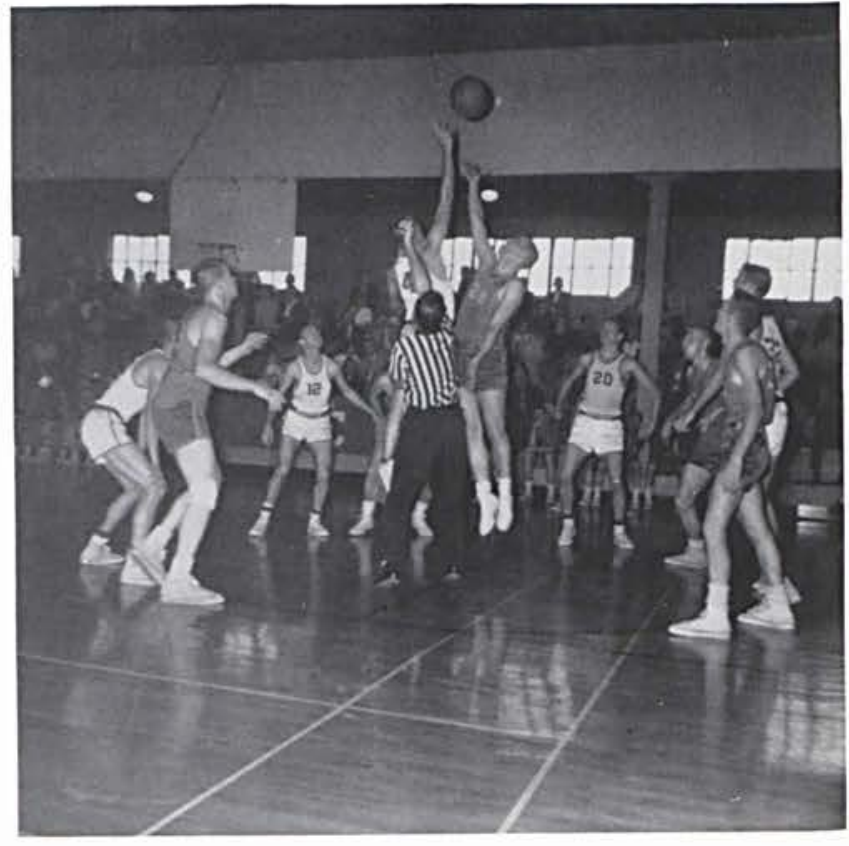

You almost made it, Jerry.

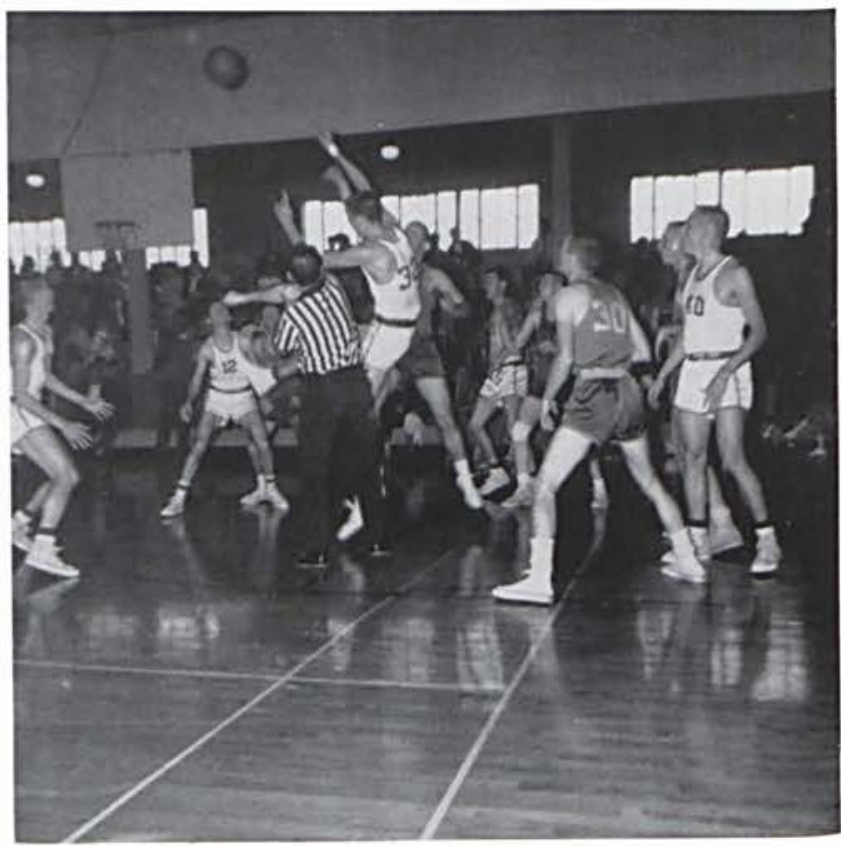

Walthal tips the ball to the Varsity. 

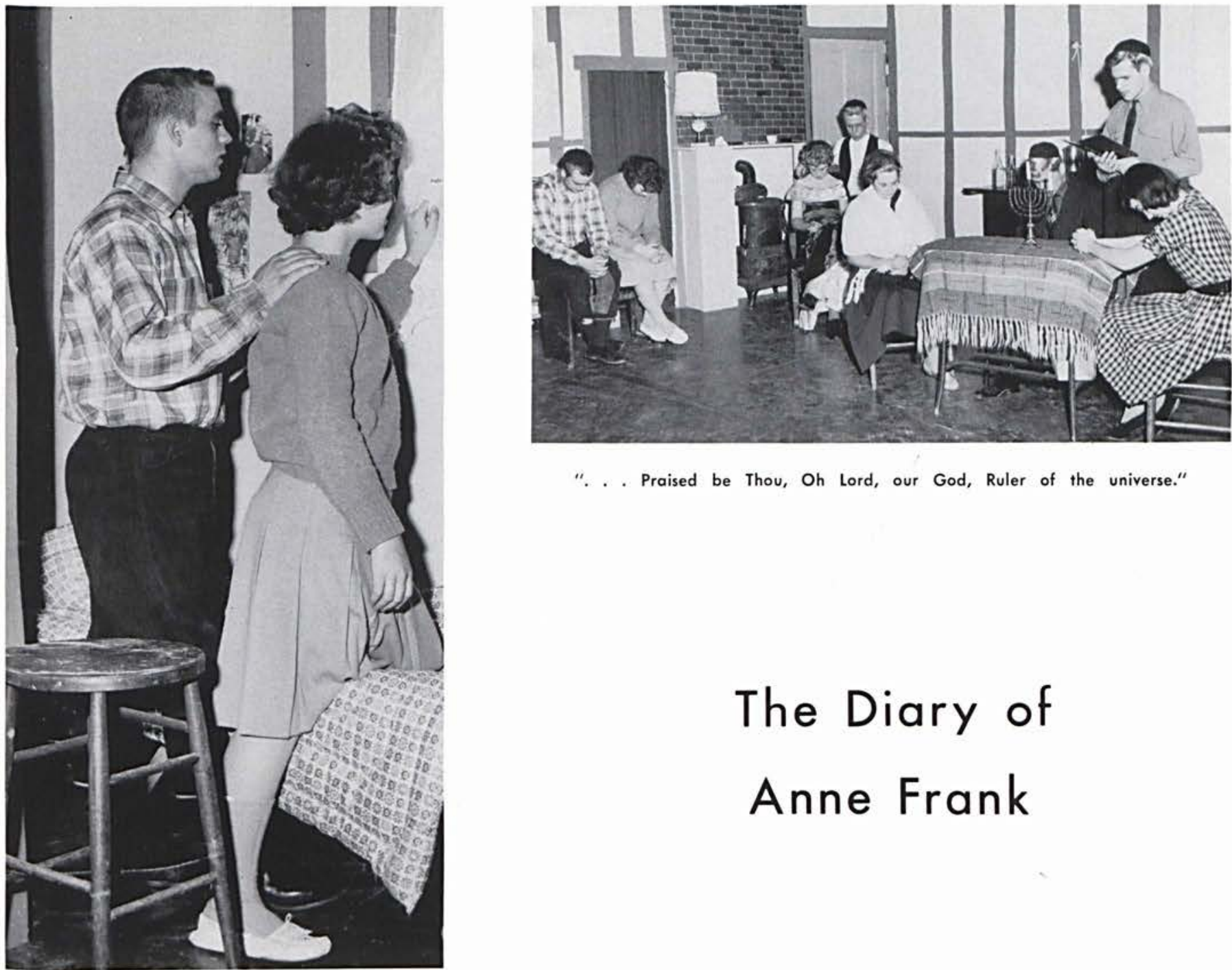

". . . Praised be Thou, Oh Lord, our God, Ruler of the universe."

\section{The Diary of} Anne Frank

Jeannie DuPre' and Phil Jewett make a

very convincing Anne and Peter.

Eighteen reasons for a successful play.

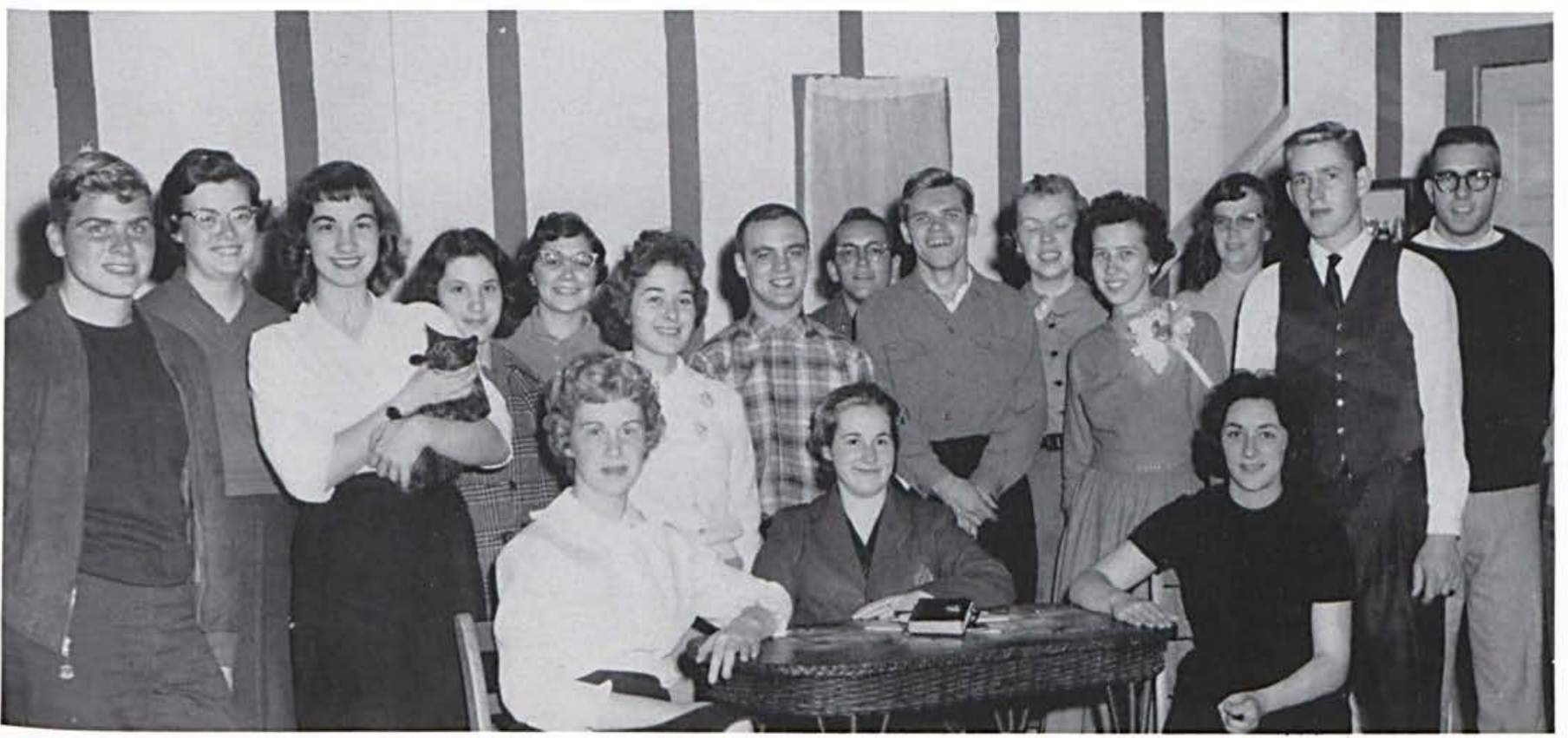




\section{Christmas Concert}

The annual Christmas Concert was presented by the Music Department on December 13th and 14th. Included in the program was Mr. Webber's clarinet arrangement of "A Sprig of Holly." The main feature of the program was "The Song of Christmas," a cantata by Roy Ringwald with a special instrumental score arranged by Mr. Cooke.

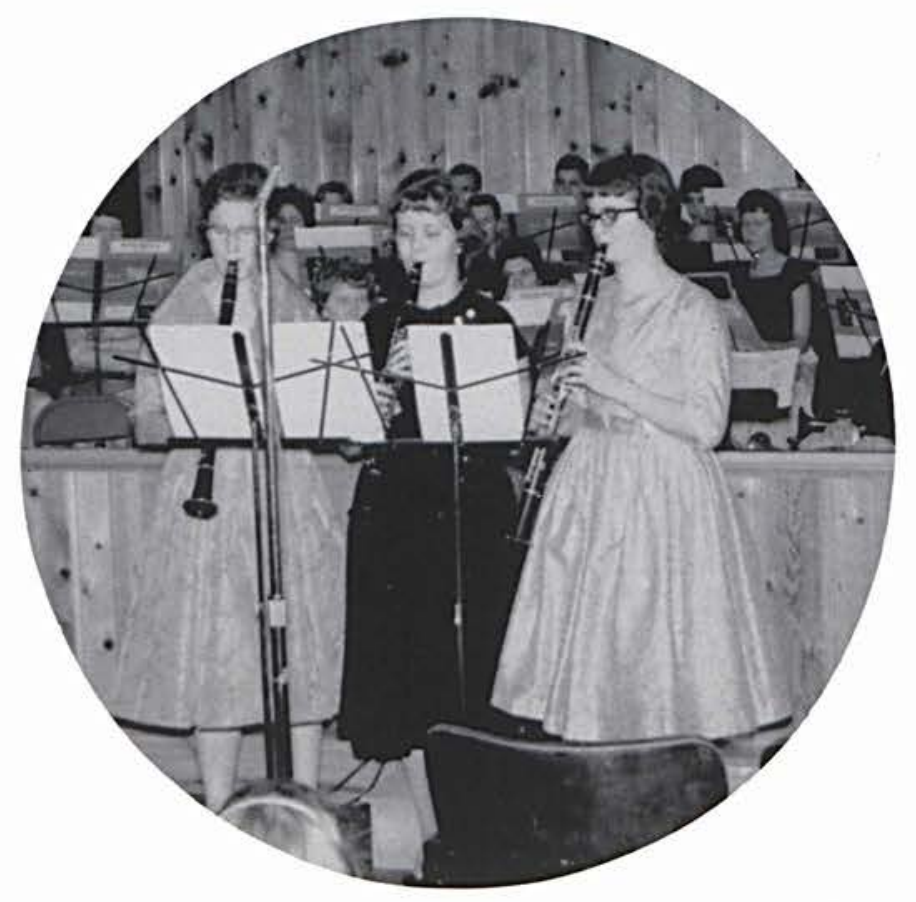

Joyce Walker, Virginia Jackson. and Carole Boren play Mr. Webber's special arrangement of "A Sprig of Holly."

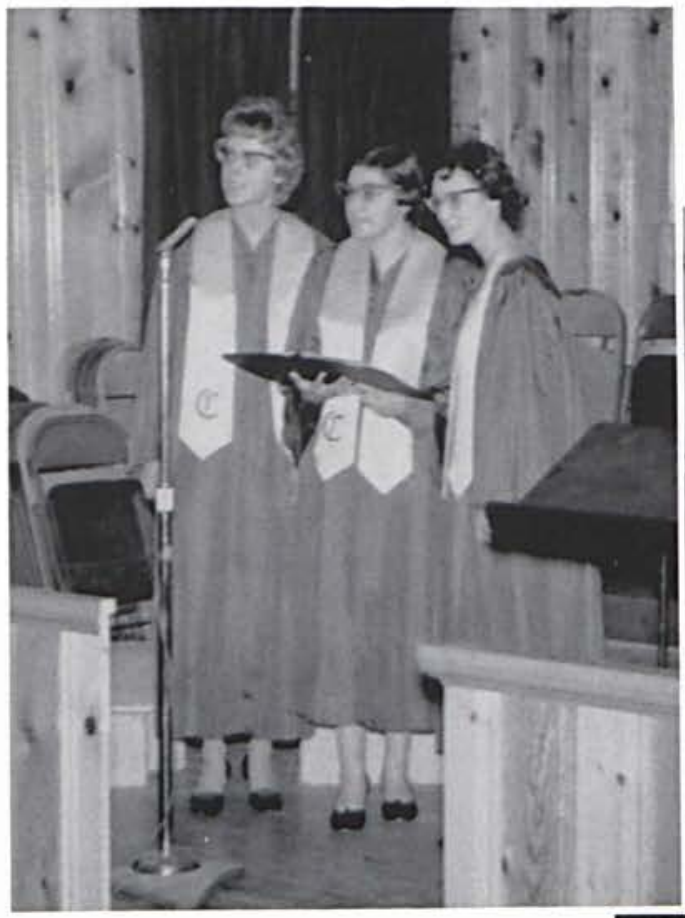

The girls trio composed of Carol Zoellner, Donna Finley, and Carol Mr. Zinn directs the Chapel Choir as they sing "King, All Glorious." Brown sing "A Christmas Star." 


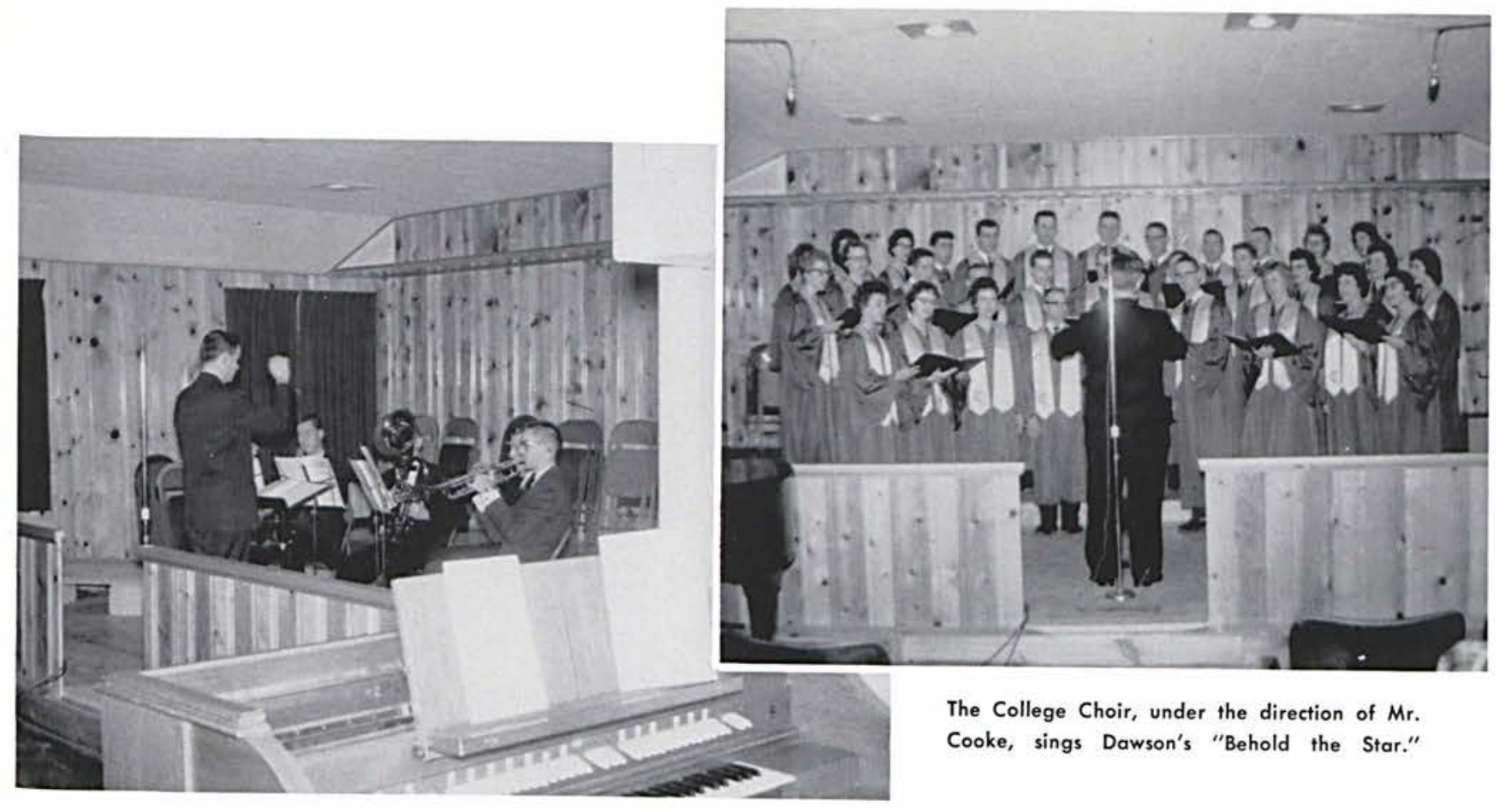

Gordon Chitty, Bill Washburn, Phil Grant, and Sam Canine play selections from Kemp's "Four Brass for Christmas."

All music groups combine to present Roy Ringwald's cantata "The Song of Christmas."

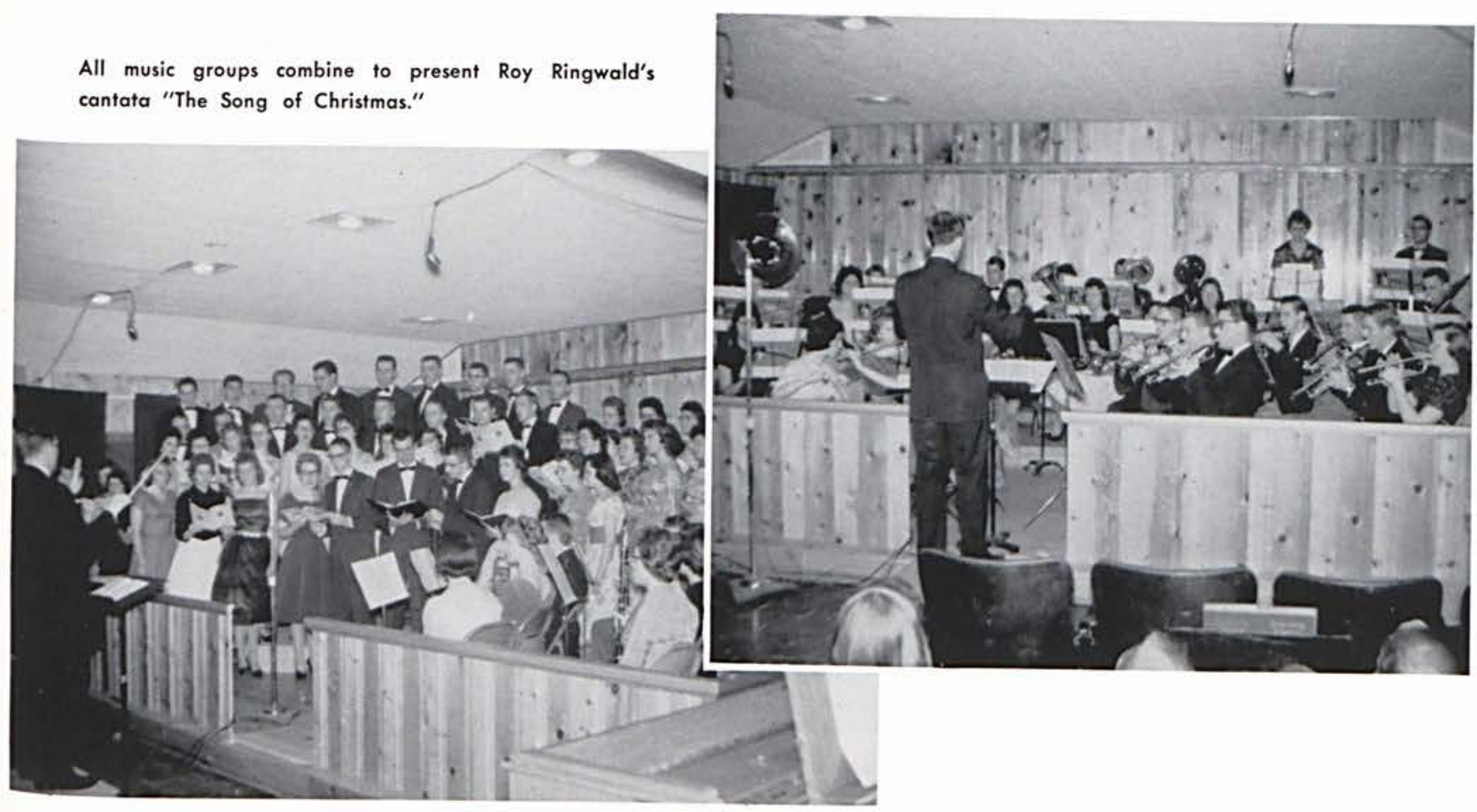

Under the direction of Mr. Webber, the Concert Band presents DeLamater's "Christmastide Overture." 


\section{Valentine}

\section{Banquet}

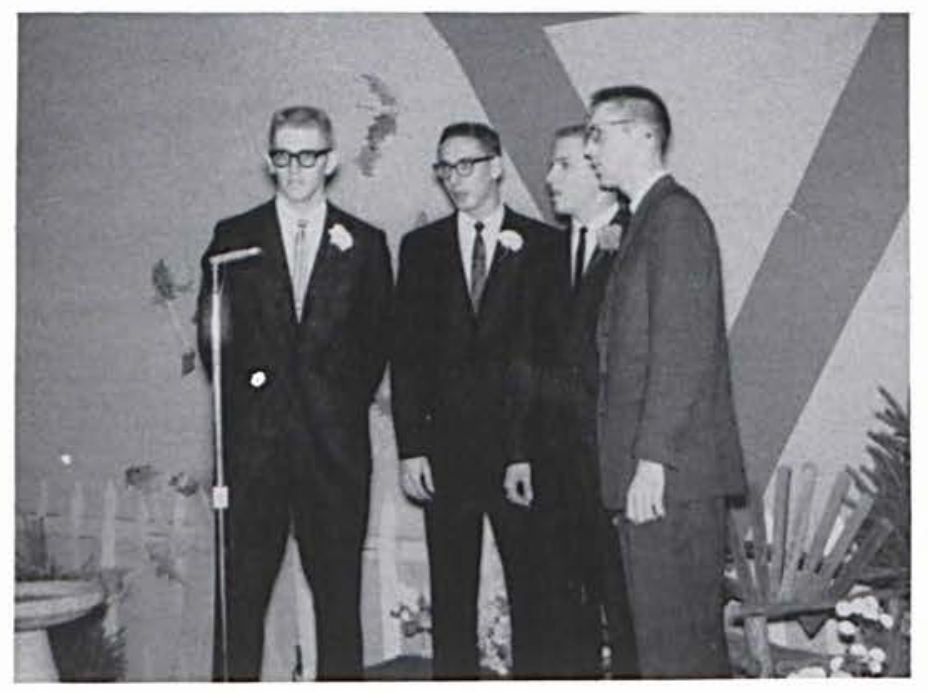

Vance Ashley, Dave Earnhart, Lynn Jefson, and Sam Canine sing "Autumn Leaves."

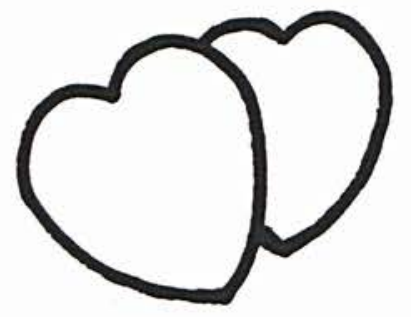

The theme of the annual Valentine's Banquet, sponsored by Gamma Chi, was "Cupid's Garden." The musical program which provided the entertainment for the evening portrayed the many devices of Cupid in bringing two people together.

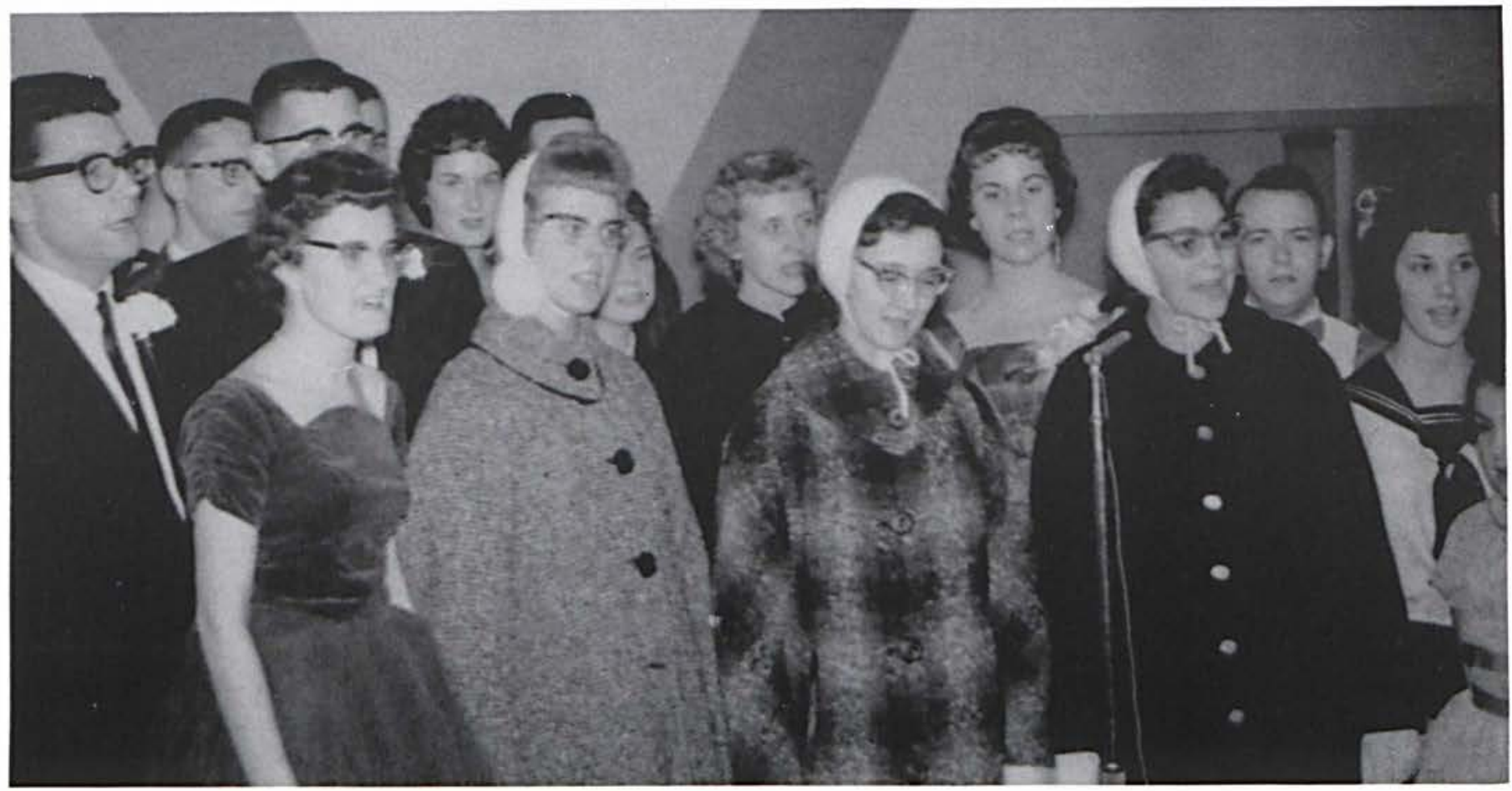




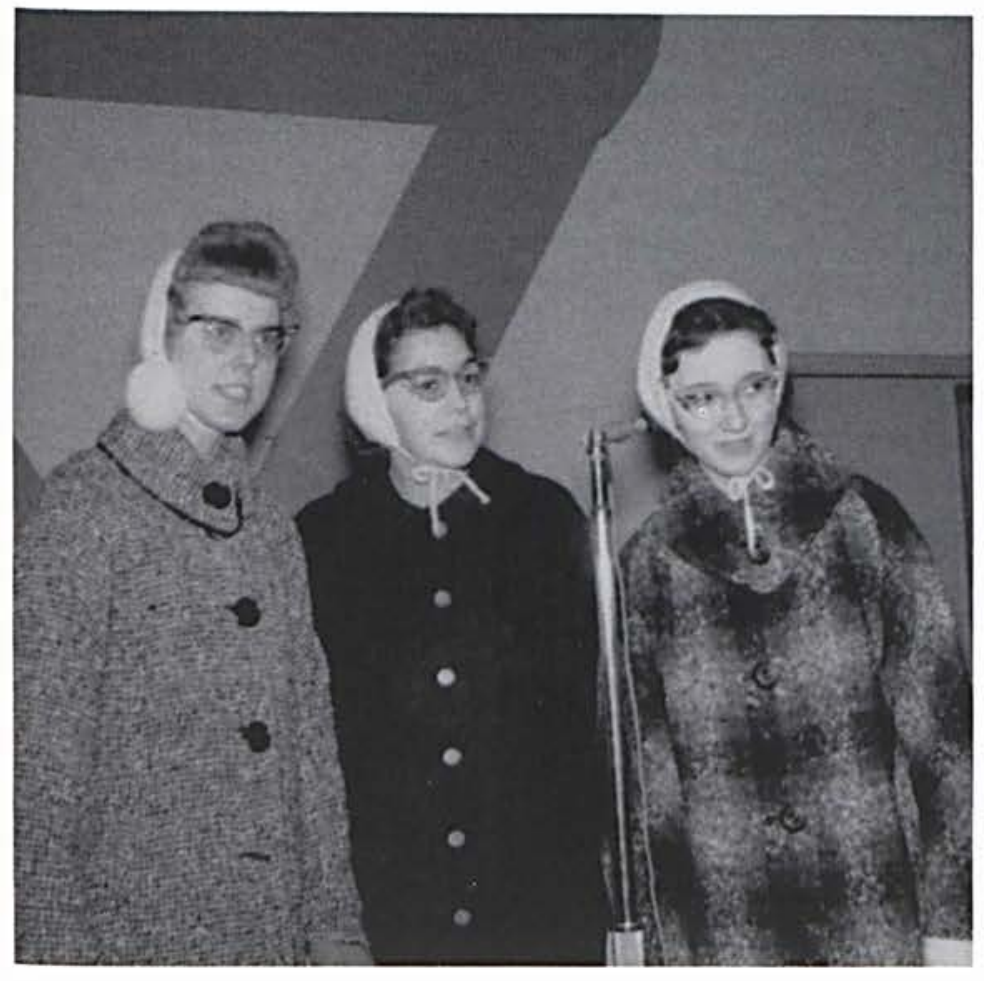

The Girls' trio puts us in a wintry mood by singing "Winter Wonderland."

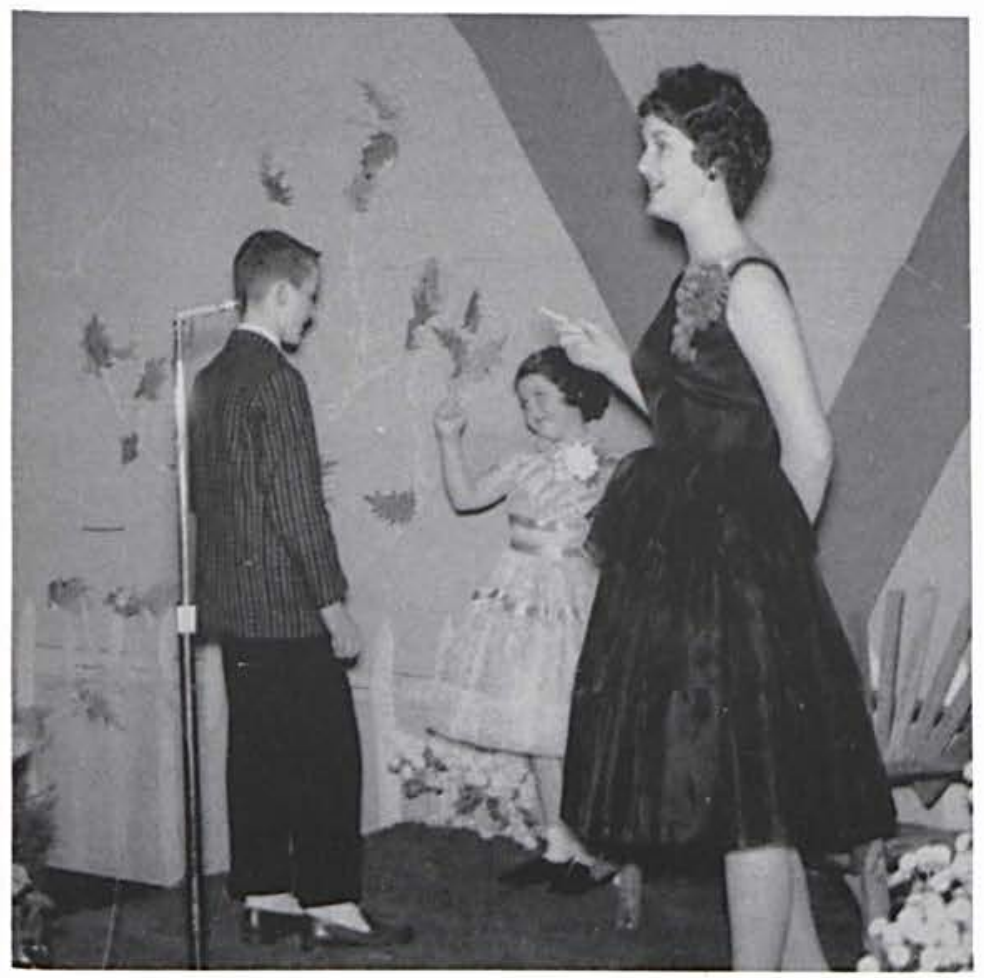

Carole Lanius sings "The Lilac Tree" as Jimmy D. Jeremiah and Linda St. Clair portray young sweethearts.
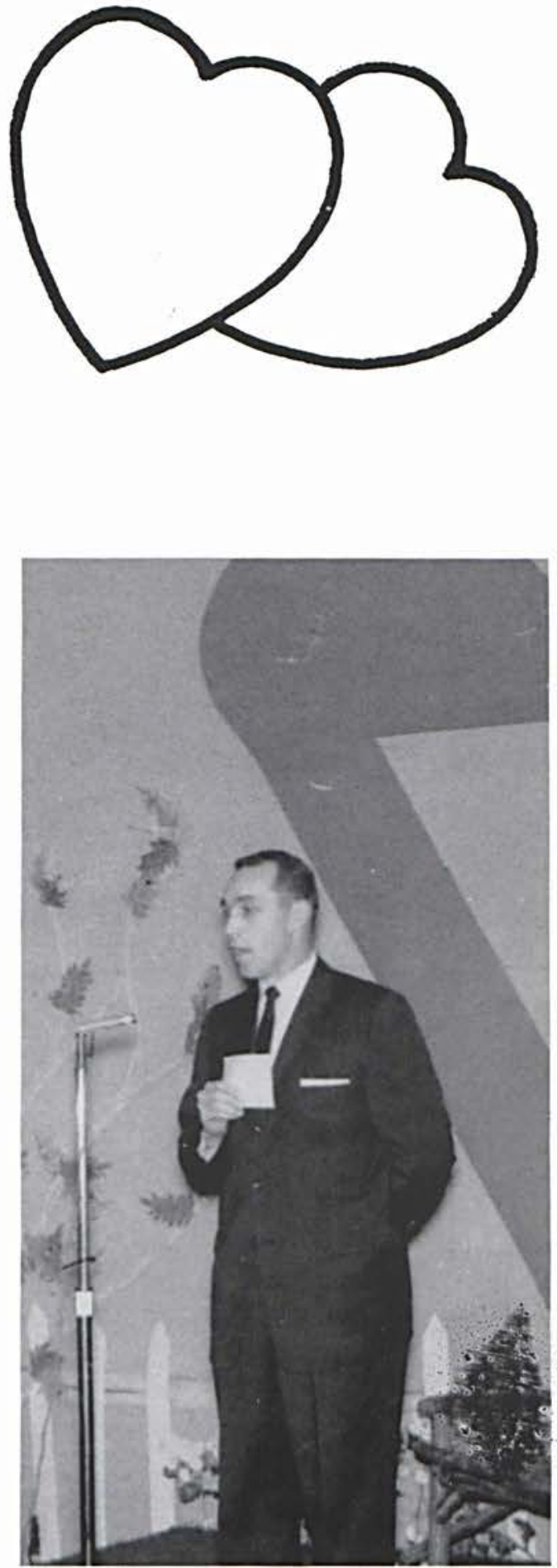

Mr. Don Callan serves as Master of Ceremonies for this occasion. 


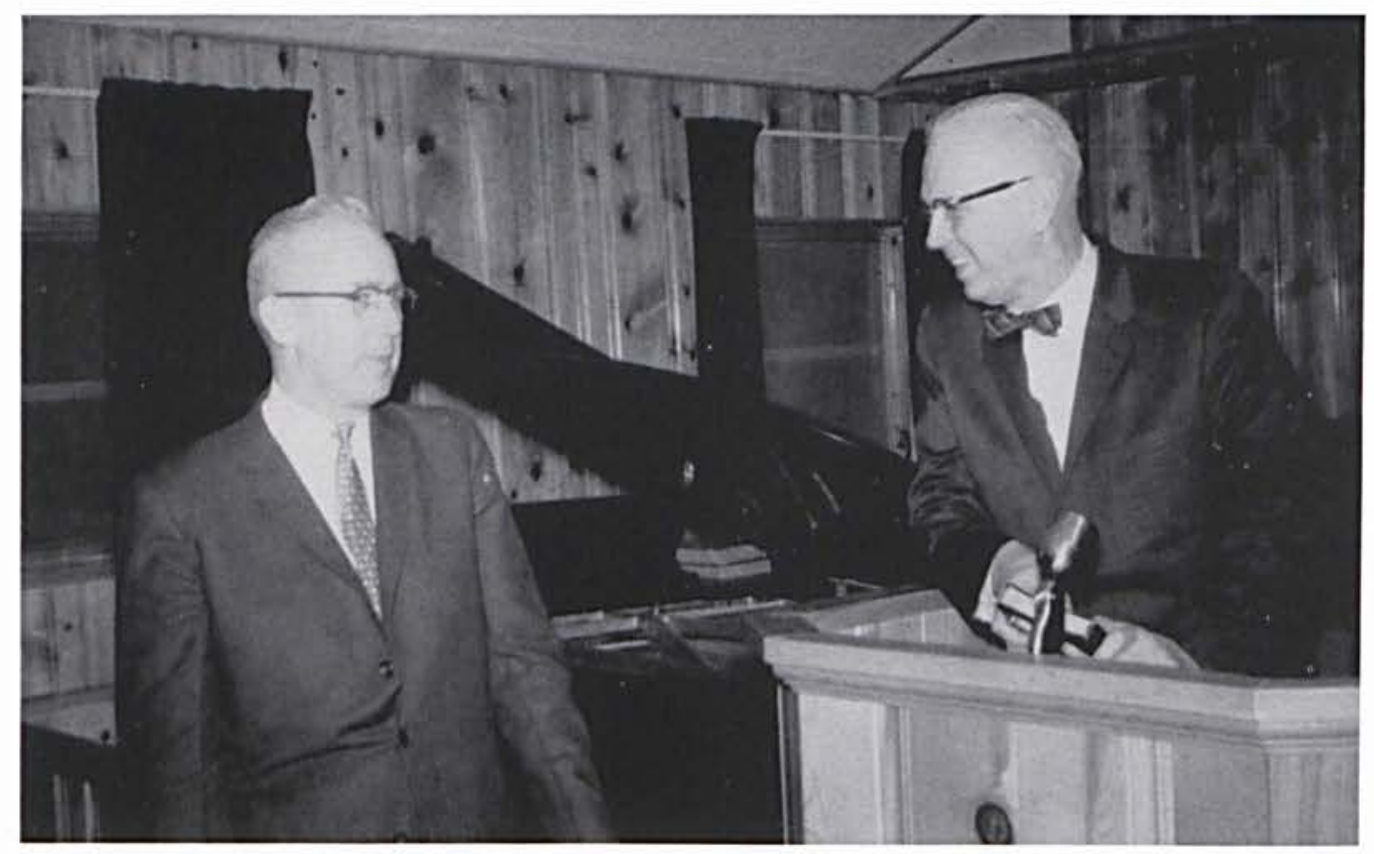

President James Jeremiah and Dr. Paul Jackson.

\section{Special Meetings}

Dr. William Kuhnle

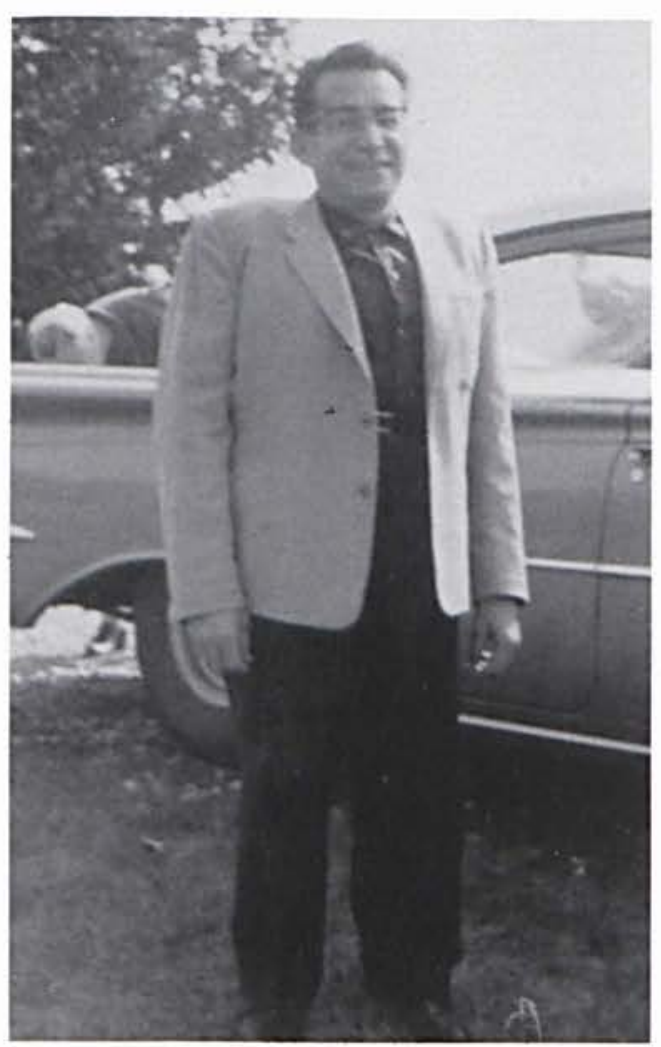

The special Bible Lectures which are held both in the spring and in the fall serve as an uplift for the entire student body. This year Dr. William Kuhnle from Milwaukee, Wisconsin, spoke in the fall. For the spring series we were privileged to have Dr. Paul Jackson - National Representative of the G.A.R.B.C.

Along with these special meetings, each year two days are set aside for special days of prayer. In October, 1960; and again during the second semester on February 22, 1961, we observed the days when the individual campus groups met for prayer.

Each day we attend daily chapel periods which stress praise, prayer, worship, and practical Christian living and service.

To encourage missions, FWM sponsored our annual Missionary Conference the week of April 5, 1961. 


\section{Snapshot Contest}

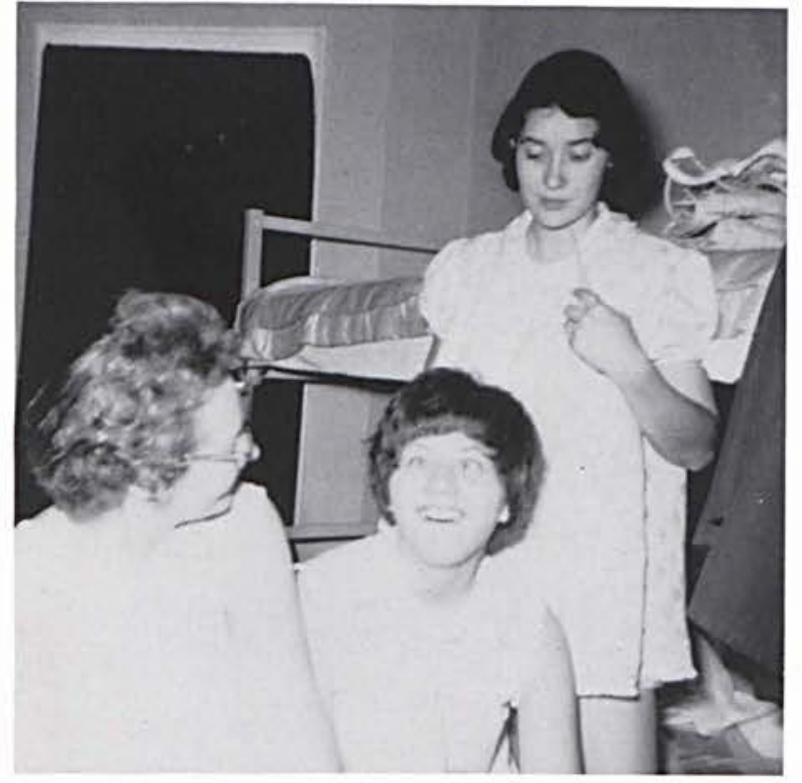

"Meanwhile, back at Harriman Cave." submitted by Virginia Lowe

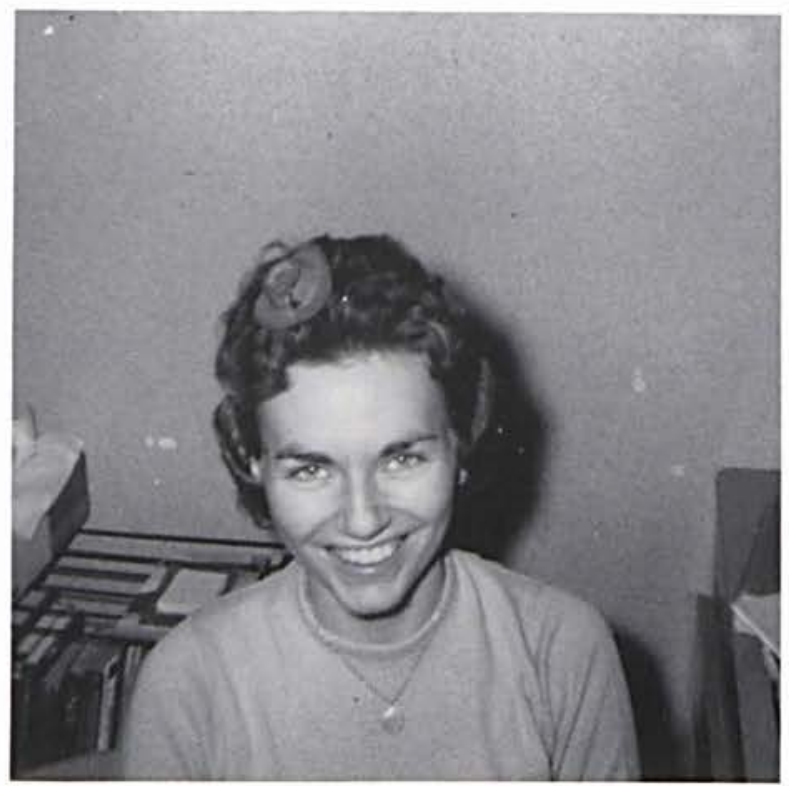

"Who says my head is big?" submitted by Nancy Warkentin

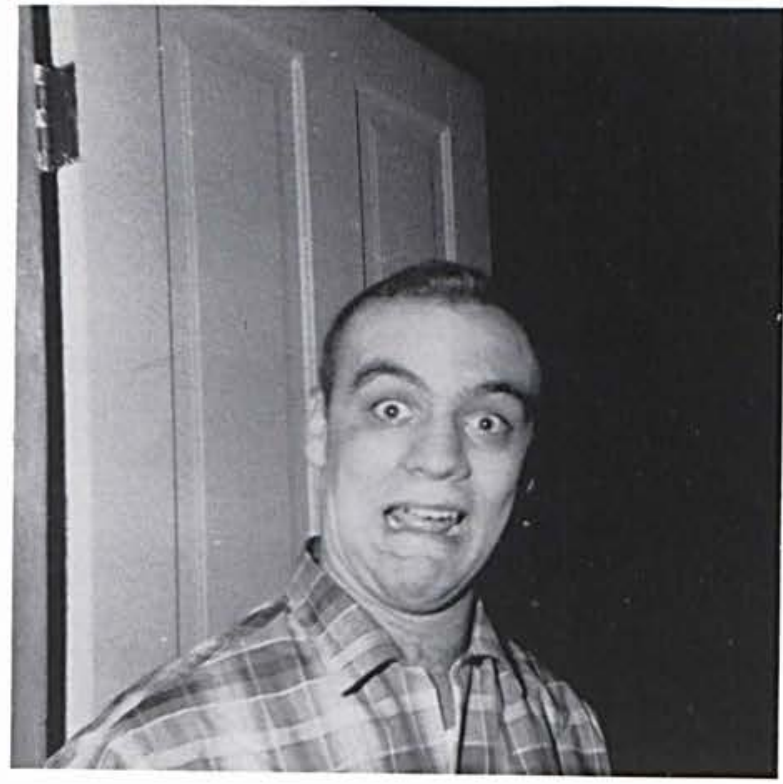

"Good morning, Dean" submitted by Irene Benson

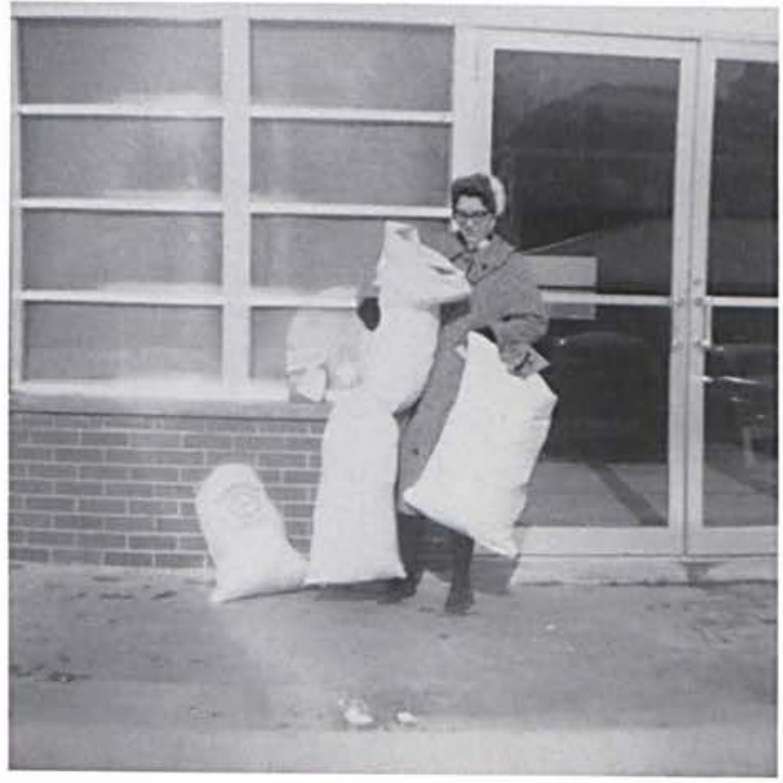

"You think you've got troubles!!" submitted by Amy Roe 


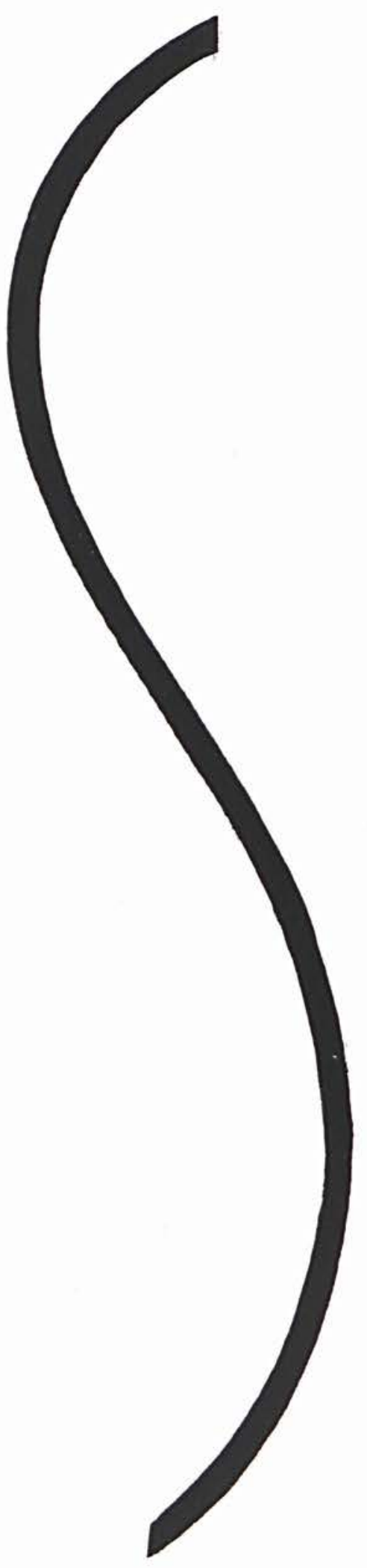

A look across the four hundred and fifty empty seats in Milner Chapel call to mind our classmates, the FRIENDS we have made this year. Again we are reminded that the ones who fill these seats, taking away the emptiness, are what makes this place what it is. Because we are "of the household of faith," we can rejoice that these FRIENDSHIPS are eternal.

\section{+.}

+.

s.

के

$+3$

06
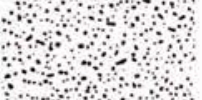

Seniors

Juniors

132

Sophomores

138

Freshmen

145

Second Semester Students

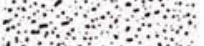

-

-

$\mathrm{r}$

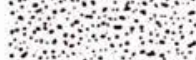

मा

\section{CONTENTS}

.
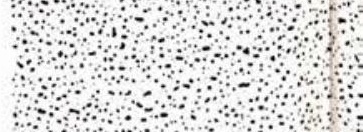

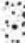
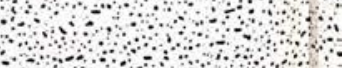

4
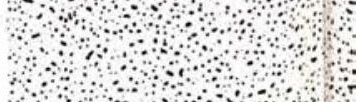

\section{\%}

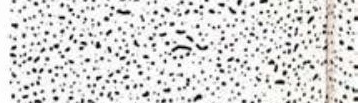

\section{.}
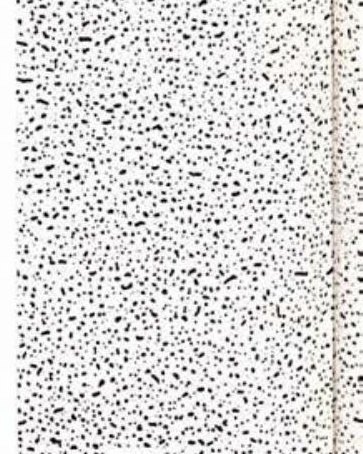

6
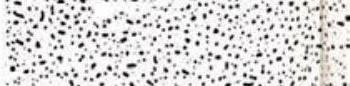

3
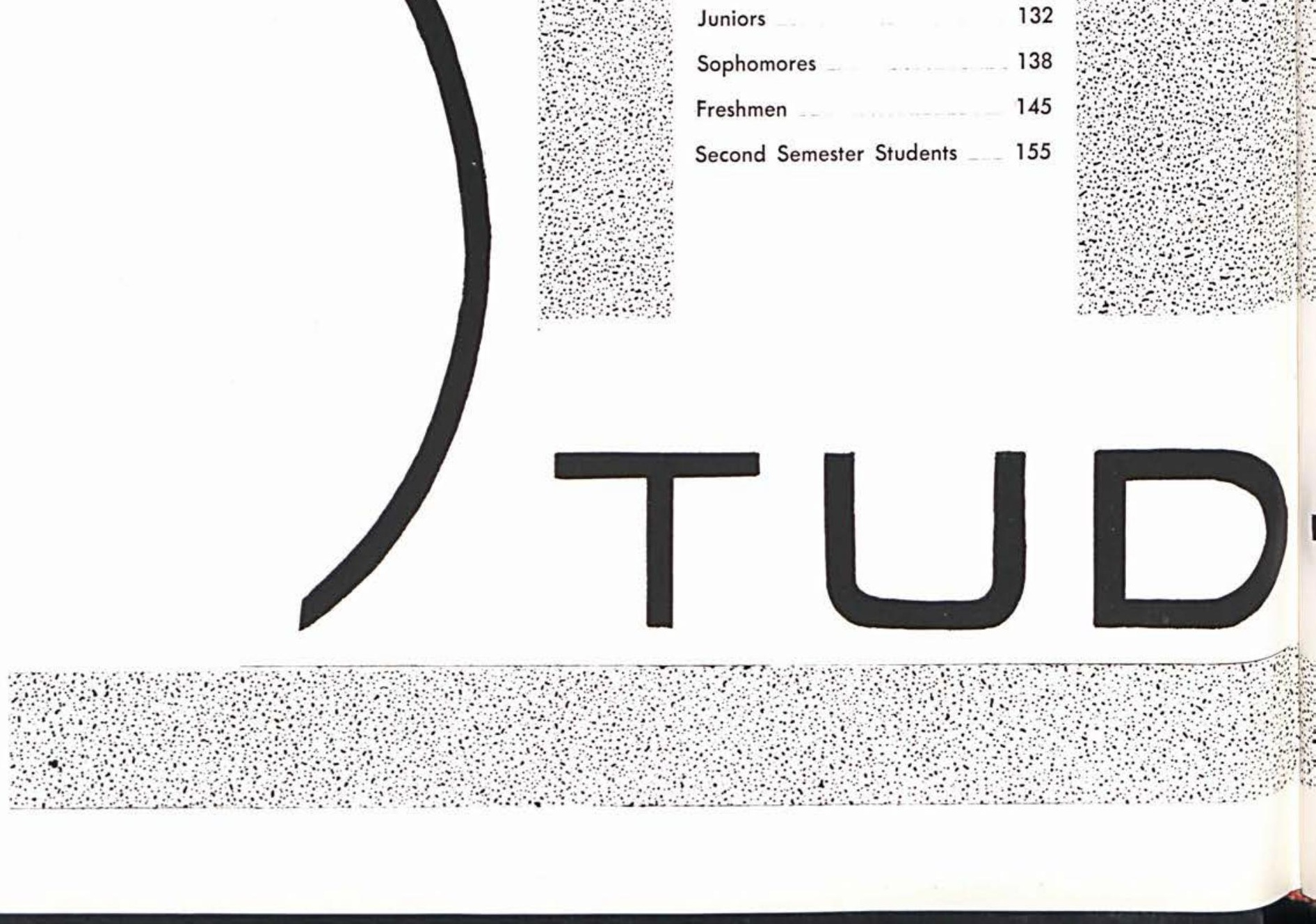

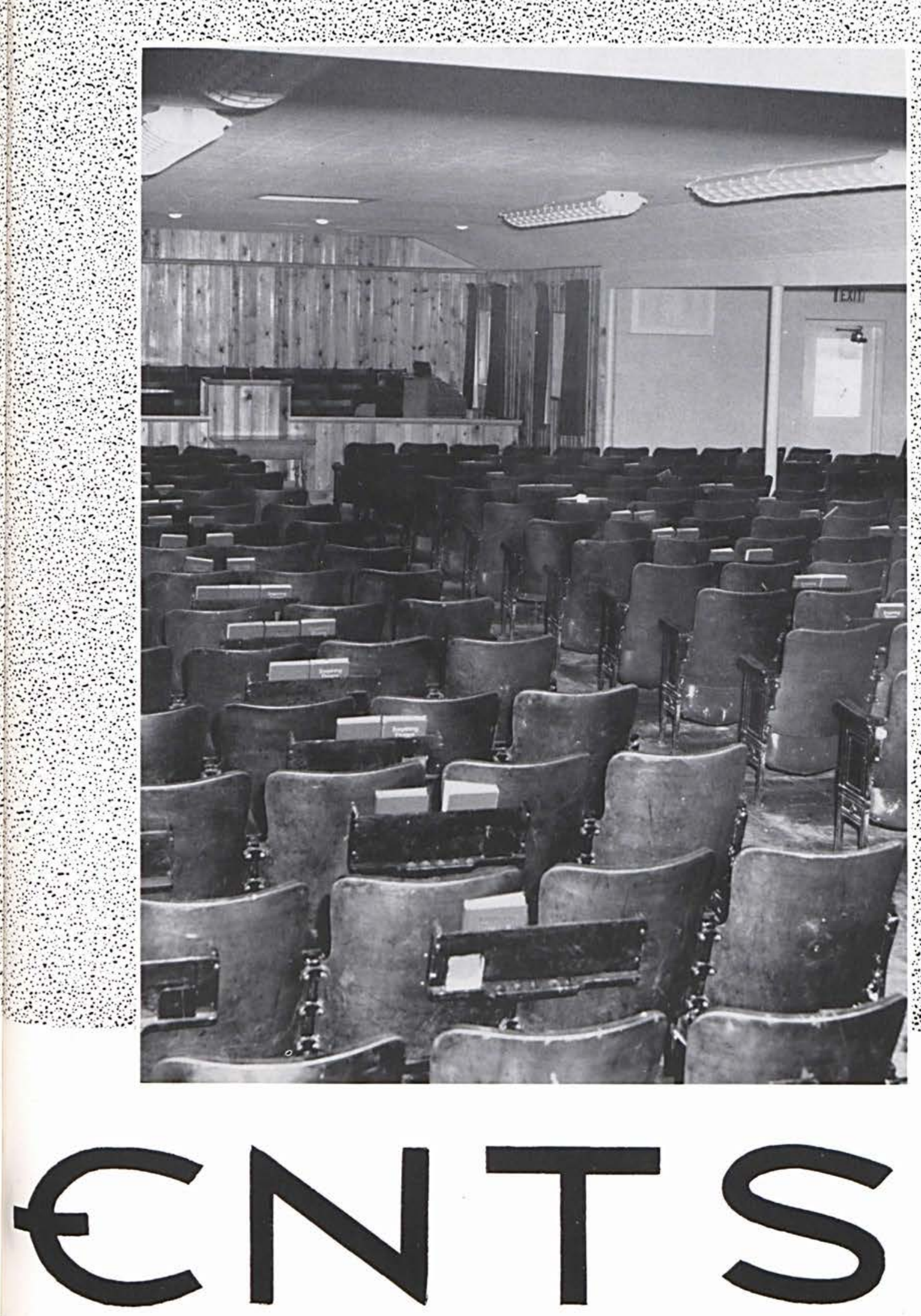

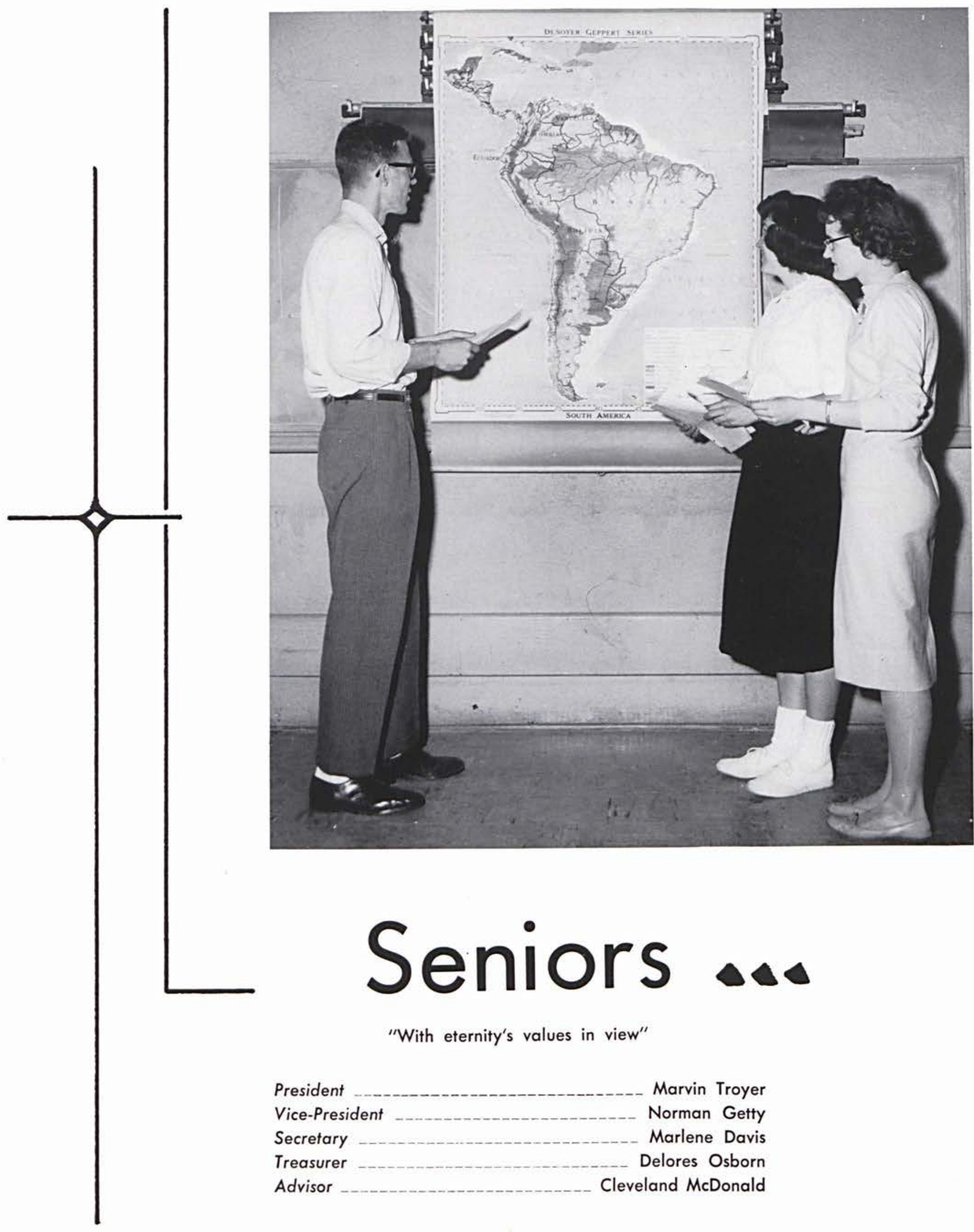

"With eternity's values in view"

President Marvin Troyer

Vice-President Norman Getty

Secretary Marlene Davis

Treasurer

Delores Osborn

Advisor

Cleveland McDonald 


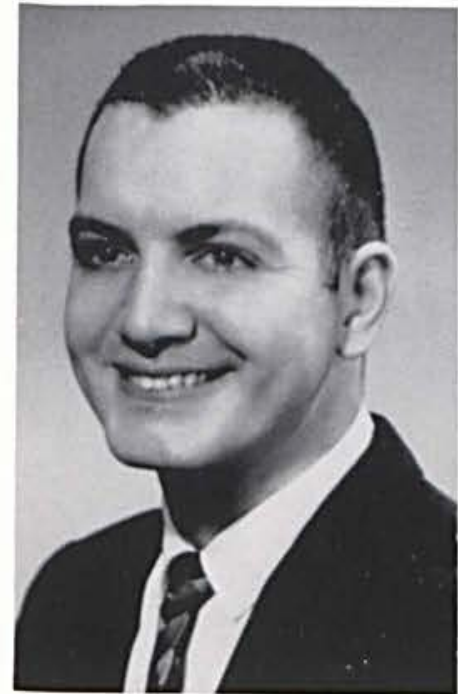

WARREN W. ALLEN

Blanchester, Ohio

First Baptist Church

A.B., History-Moody Bible Institute '55-'59.

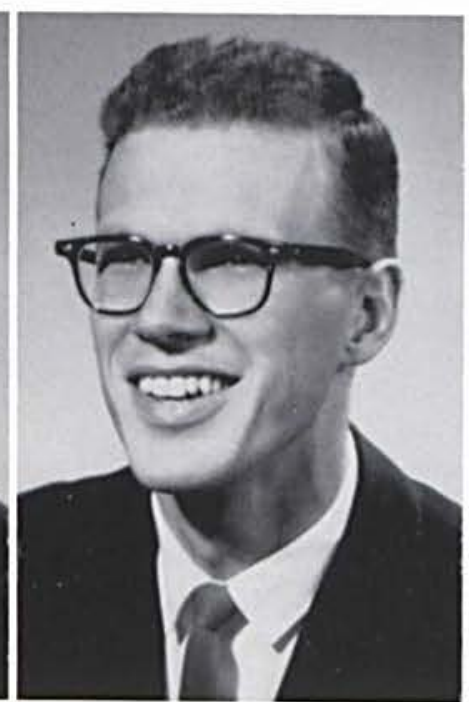

JOHN G. BUTLER

Greene, lowa

Alameda Baptist Church, Corpus Christie, Texas.

A.B., Bible - Tennessee Temple College '58; Class Vice-President 3; Basketball Team 2, 3; Choir 2, President 3; Quartette 2, 3; Student Body Project Co- Chairman 4.

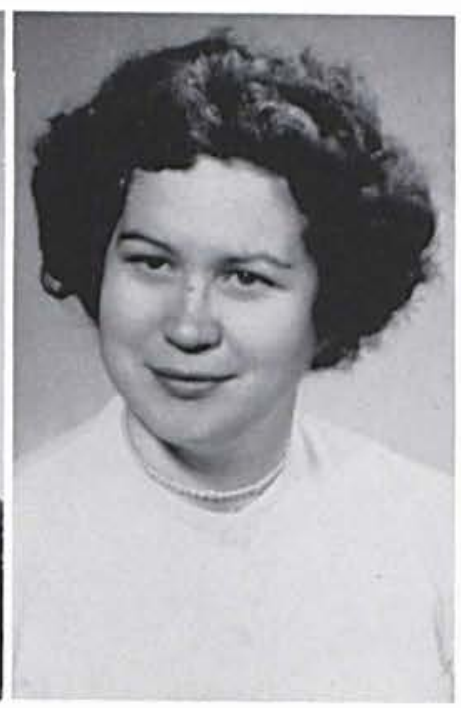

\section{NEVA VOSS CLAYPOOL}

Kittanning, Pennsylvania

Old Union Baptist Church

A.B., General Science-Sock-'nBuskin 3, 4; Homecoming Play $2,3,4$.

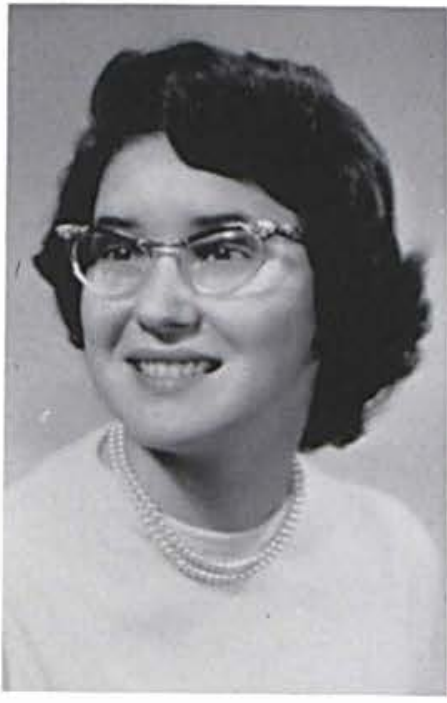

DONIS ERLENE COLLIER

Moweaqua. Illinois

Grace Baptist Church

A.B., Social Science-Homecoming Play 1; Yearbook Staff 3; Secretary New Girls' Dorm. 4; Pep Club 4.

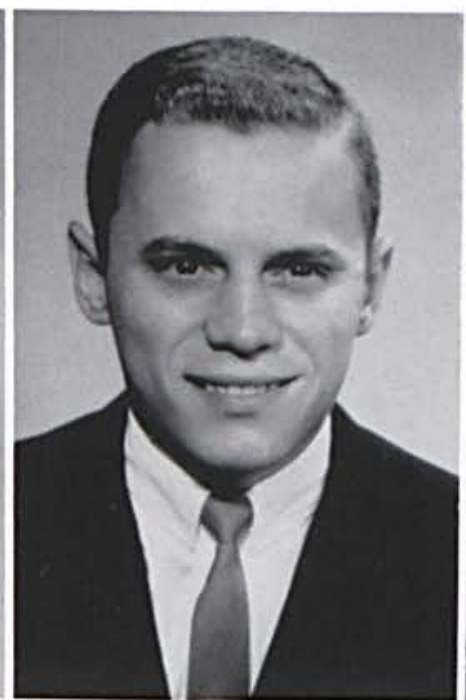

JAMES RICHARD COOK

Flint, Michigan

Riverside Baptist Church

A.B., Music - Alpha Chi 1, 2, 3; Yearbook Staff 3; F.W.M. 1, 2; Baseball Team 1, 2; Choir 1, 2 Student Director 3; Quartefte $1,2,3$.

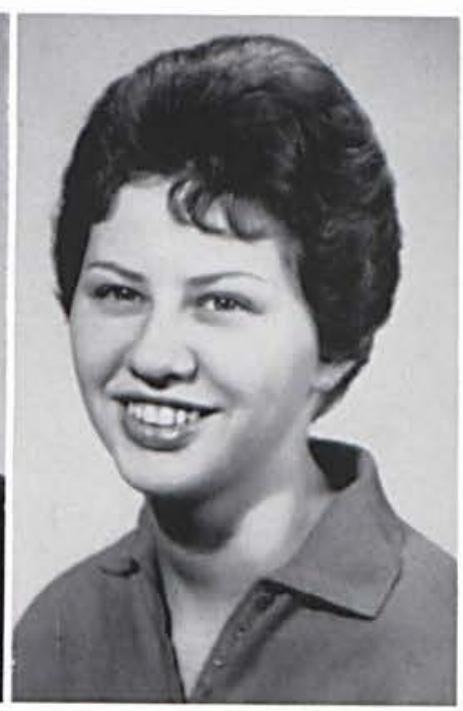

MARCIA GAIL CROTHERS

Lakeville, Indiana

First Baptist Church, Plymouth, Indiana

A.B., Social Science-Class So. cial Chairman 4; Student Council 1; Gamma Chi 1; Band 1, 2, 3; Trumpet Trio Pianist 1; Quartette Pianist 2, 3; Pep Club 4. 


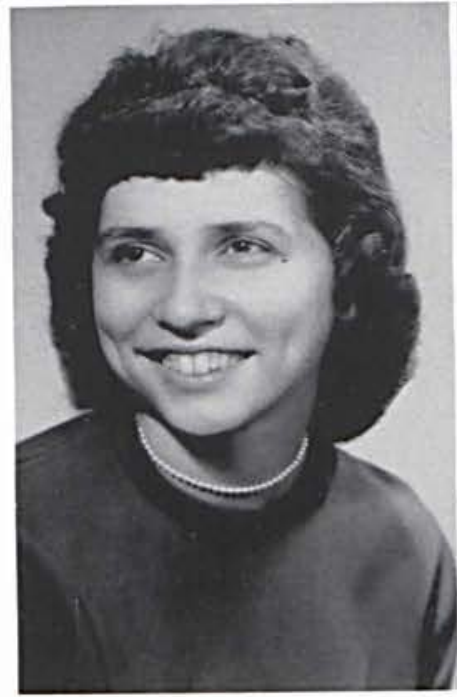

MARLENE DAVIS

Parma, Ohio

First Baptist Church

B.S., Christian Education - Class Secretary 1. 3, 4; Gamma Chi 1, 2, 4, Secretary 3; Homecoming Play 2, 3; Yearbook Staff 3: Whispering Cedars Staff 1, Editor 2; F.W.M. 1, 2, 3, Secretary 4; Choir 1, 2; Quartette Pianist 3; Cheerleader 1.

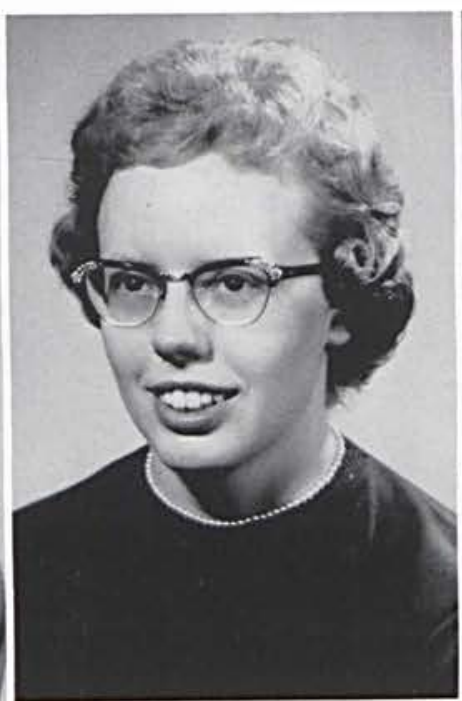

PHYLLIS ELAINE DOBBS

Kuna, Idaho

First Baptist Church

A.B., Elementary Education Central State '60-'61, Boise Junior College '59; Student Council 3; Student Government 3, 4; Gamma Chi 1; Sock-'nBuskin 3, Secretary 4; Homecoming Play 3.

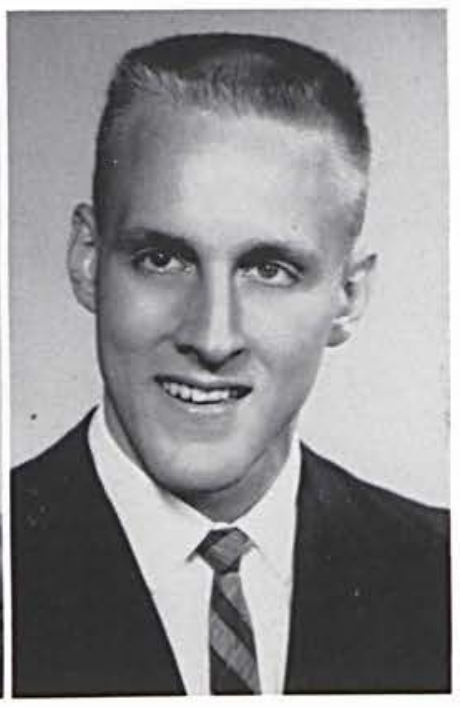

JAMES L. ENTNER

Connersville, Indiana

Community Baptist Church

A.B., General Science-Class President 1; Student Council 2, President 4; Discipline Committee 4; Yearbook Editor 3; F.W.M. 2, 3, 4; Varsity " $\mathrm{C}$ " 1, 2. 3, Vice-President 4; Basketball Team 1, 2, 3, Captain 4; Baseball Team 1, 2, 3, 4; Tennis Team 1.

\section{Seniors}

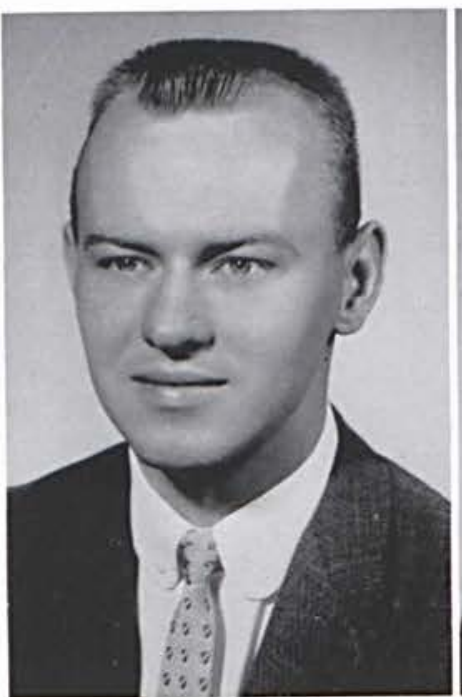

FORREST TERRY GOODRICH

Boise, Idaho

Baptist Temple

A.B., Social Science-Class Parliamentaian 2, 3; Class Intramural Representative 3, 4; Student Council Vice-President 4 Student Government 4; Alpha Chi 1, 4, Secretary-Treasurer 2 , 3; F.W.M. 1; Varsity "C" 3, Secretary 4; Basketball Manager 3, 4; Baseball Manager 3,4

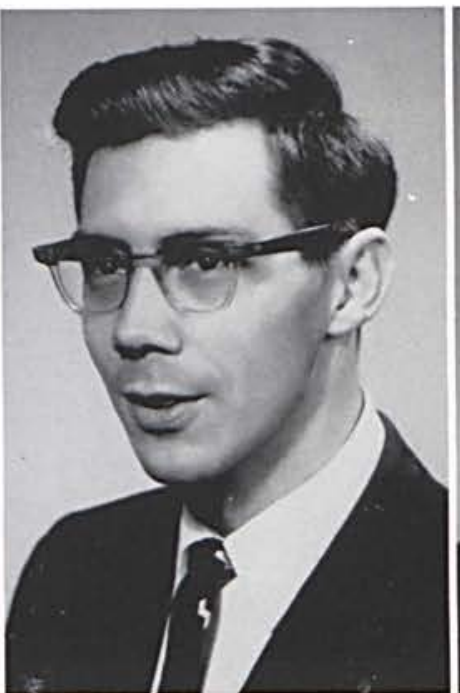

\section{RONALD HAROLD HALL}

Bedford, Ohio

Bible Baptist Church

A.B., Bible - Life Bible College, Los Angeles '52:'54.

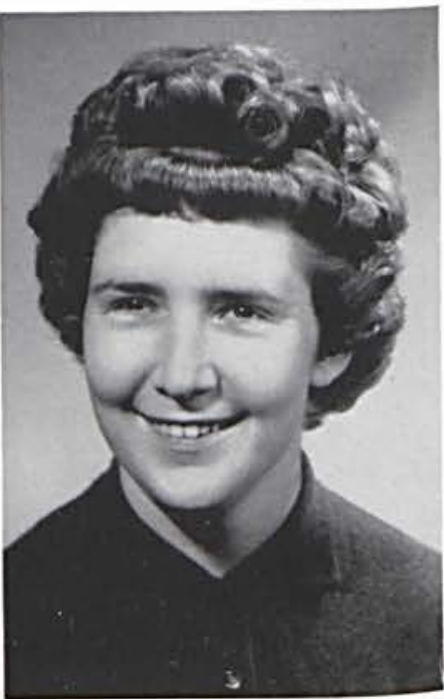

SHIRLEY ANN HARRINGTON Kankakee, Illinois

First Baptist Church, Watseka, Illinois

A.B.. Music - Student Council Treasuret 4; Student Government 3; Gamma Chi 1, 2; Homecoming Play 3 ; F.W.M. 4; Choir $1,2,3,4$; Band 2, 3; Music Masters 2, Historian 3, Treasurer 4; Trio 3, 4. 


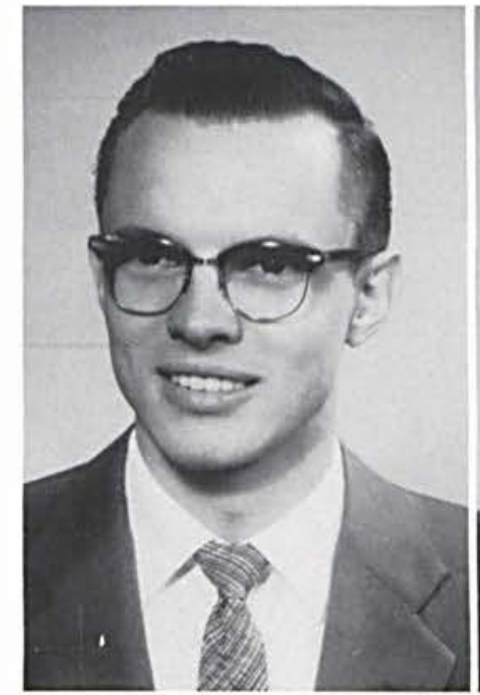

FRANK ALTON HOWARD

Cedarville, Ohio

Grace Baptist Church

A.B., History - Central Michigan University '57-59; F.W.M. 3; Youth for-Nixon, Lodge ViceChairman 4.

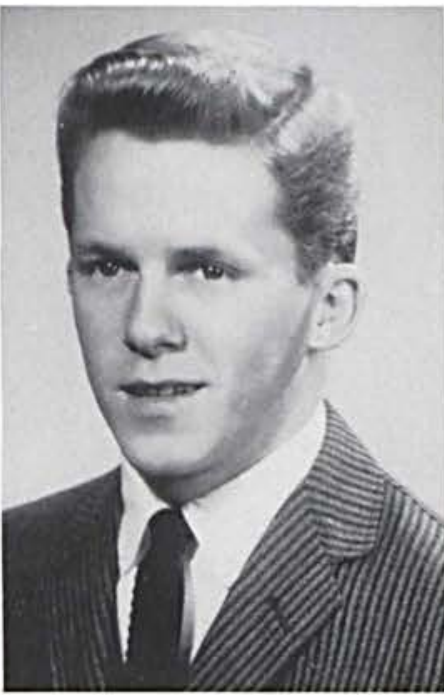

WILLIAM BRYAN JENNINGS

Cuyahoga Falls, Ohio

Graham Road Baptist Church

A.B., History - Bryan College, Dayton Tennessee '56-'59; Indiana University '59; Student Council 4; Yearbook Staff (Indiana) 3; Cross Country (Bryan) 1, 2, 3; Track (Bryan) 1, 2, (Cedarville) 4.

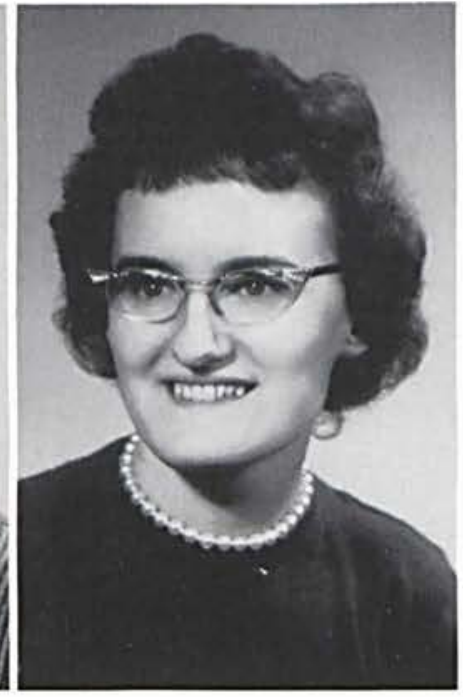

ERNAJEAN LOCKERBIE

Brooklyn, New York

Brooklyn Baptist Church

B.S., Nursing - Methodist Hospital of Brooklyn '55.'58; Student Council 4; Gamma Chi 2, 3, 4; Sock-'n-Buskin 4; Homecoming Play 3; F.W.M. 3, 4; Choir 2, 3, 4; Music Masters 3, Historian 4; Soloist with Trumpet Duet 3; Prospective Students' Day Play 3.

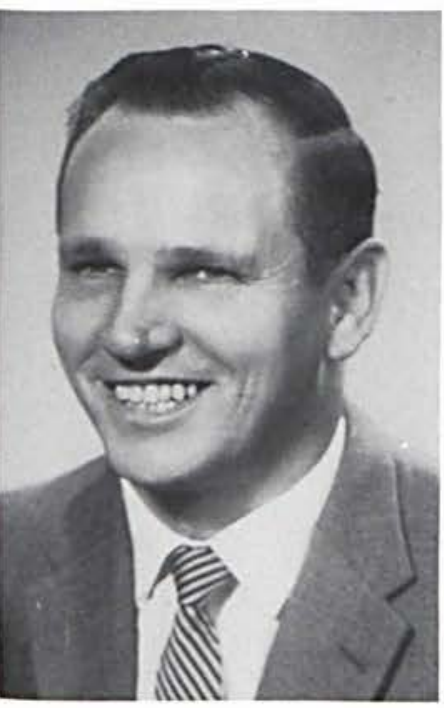

KARL W. LUYBEN

Fort Wayne, Indiana

Grandview Park Baptist Church, Des Moines, lowa

A.B., Bible - Wartburg College, Waverly, lowa '43-45; Class Chaplain 4.

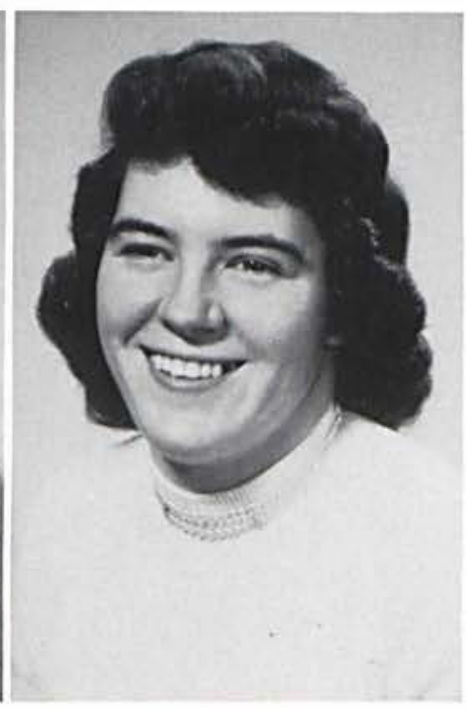

\section{NANCY MC DIVITT}

Garrettsville. Ohio

Troy Baptist Church

B.R.E., Christian Education Student Council 3; F.W.M. 2, 3 , 4; Girls' Basketball Team 4; Intramural Representative 3, 4; Dorm Counsellor 3, 4 .

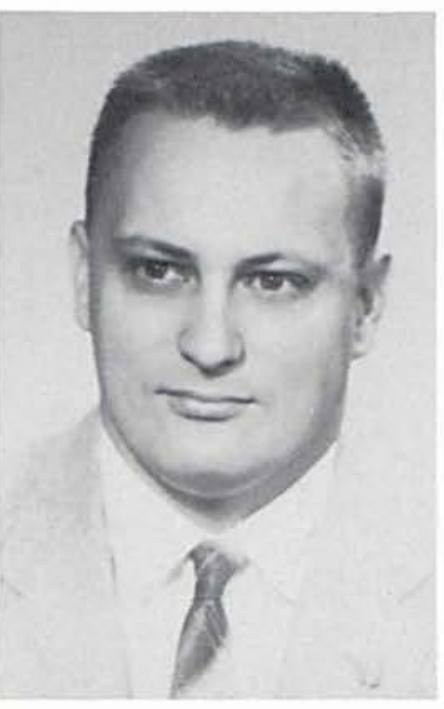

\section{JAMES RAY NEELY}

Westwood 'Baptist Church, Cincinnati, Ohio

A.B., Music - Union University, Jackson, Tennessee '51:'52, Indiana University '52.'53; Choir 1, 2; Music Masters Treasurer 2, 3, President 4; Music Director of Emmanuel Baptist Church, Xenia, Ohio '59-'60; Minister of Music, Westwood Baptist Church, Cincinnati, Ohio ' $600^{\prime} 61$. 


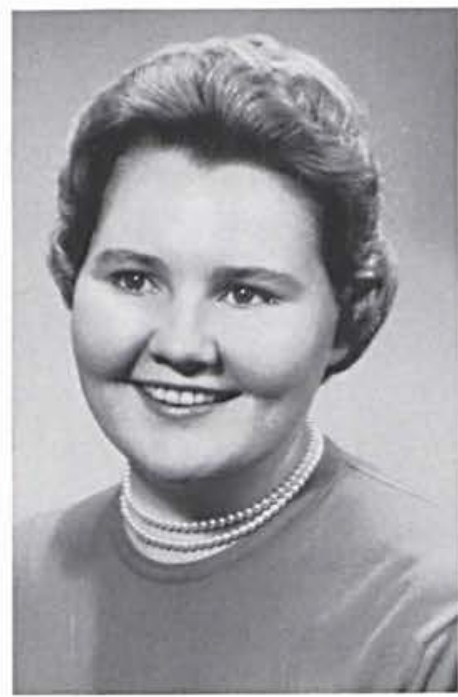

DELORES JUNE OSBORN

Westminister, Colorado

First Baptist Church

A.B. Social Studies - Class Secretary 2, Treasurer 3, 4; Sockn-Buskin 2, Historian 3, Program Chairman 4; Homecoming Play 1, 2, 3; Yearbook Staff 3; Whispering Cedars Staff 2, 3; Dorm Counselor 4

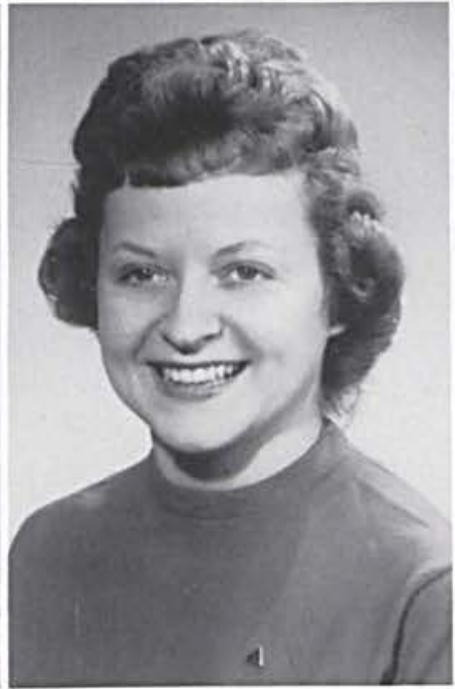

\section{PAT WANDA PETRY}

Arcanum, Ohio

Immanuel Baptist Church

A.B., History - Class Treasurer 3; Student Government 4; Gamma Chi 2, 3, Vice-President 4; F.W.M. 2, 3; Choir 1, 2, 3, 4; Sextette 1; Cheerleader 3, 4 Prospective Students' Day Play 3.

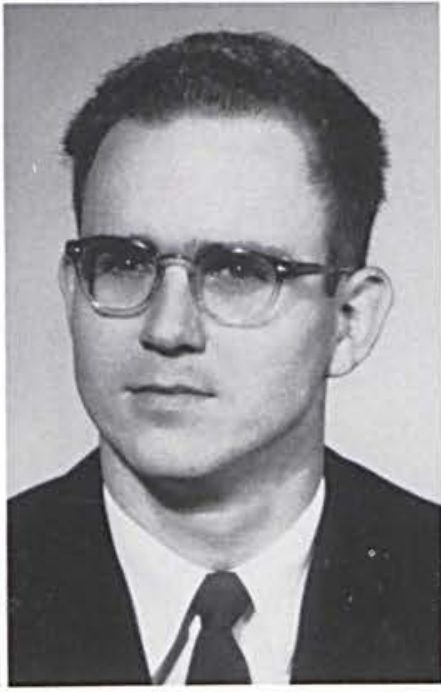

LON K. REISING

Chesterfield, Missouri

Lackland Road Baptist Church, Overland, Missouri

A.B., Biological Science-Class President 2; Future Pastors' Fellowship 4.

\section{Seniors}

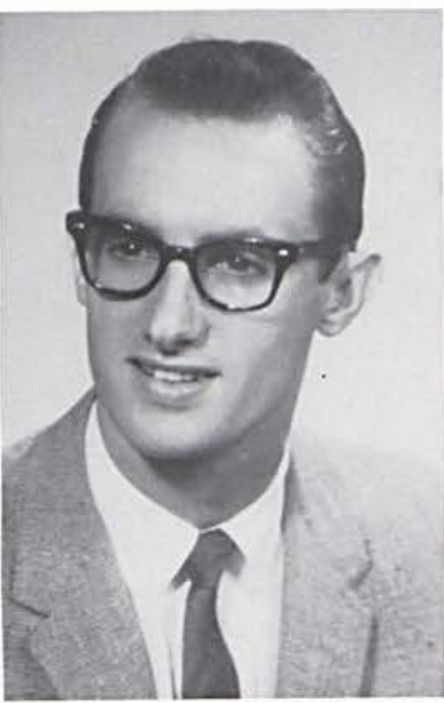

LEON C. ROWLAND

OHumwa, lowa

Blessed Hope Baptist Church

A.B., History - Class Chaplain 3, Future Pastors' Fellowship 4.

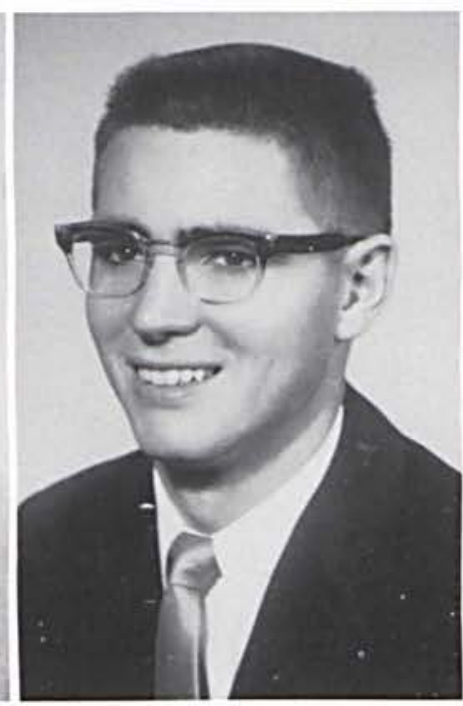

LOUIS JAY SCHRAMM

Armada, Michigan

First Baptist Church, Romeo, Michigan

A.B., History - Moody Bible In. stitute ' $56-59$.

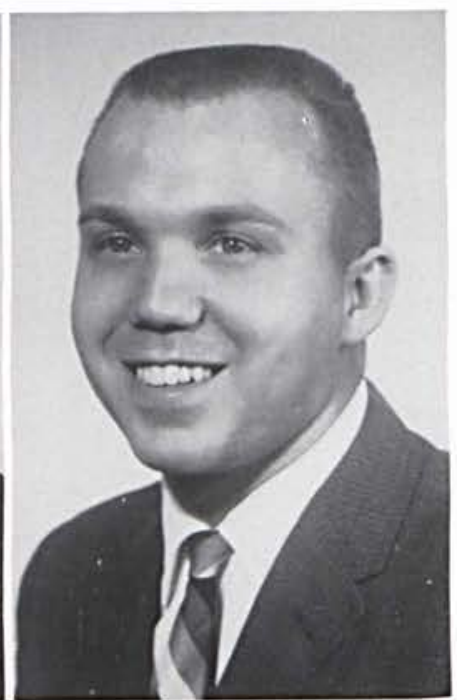

MARVIN B. TROYER

Fort Wayne, Indiana

Immanuel Baptist Church

A.B., Bible - Fort Wayne Bible College 1, 2; Central State 3, 4; Class President 4; Varsity Basketball (Fort Wayne) 2; Class Athletic Director (Fort Wayne) 2. Class Ensemble Director (Fort Wayne) 2; Intramural Sports 1, 2, 3, 4; Future Pastors' Fellowship 4; Student Pastor 2. 


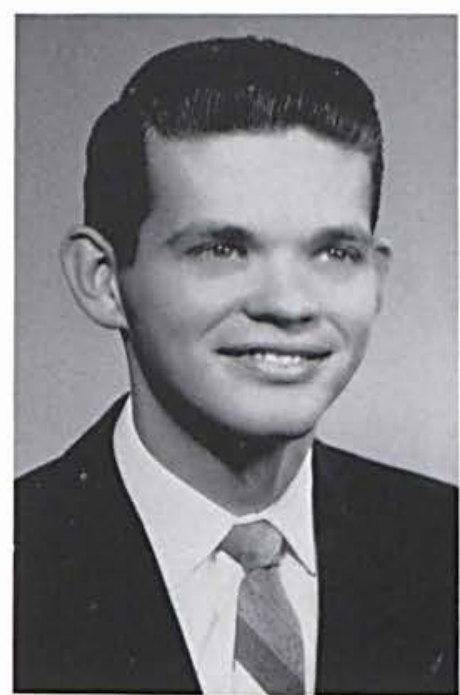

HORACE WARD, JR.

Cedarville, Ohio

Penecostal Church of Christ

A.B., Social Science-Southwestern Bible College '56.'57; Central State College '60-'61; Whispering Cedars Editor 3; Student Government 3; Homecoming Play 3; Student Pastor.

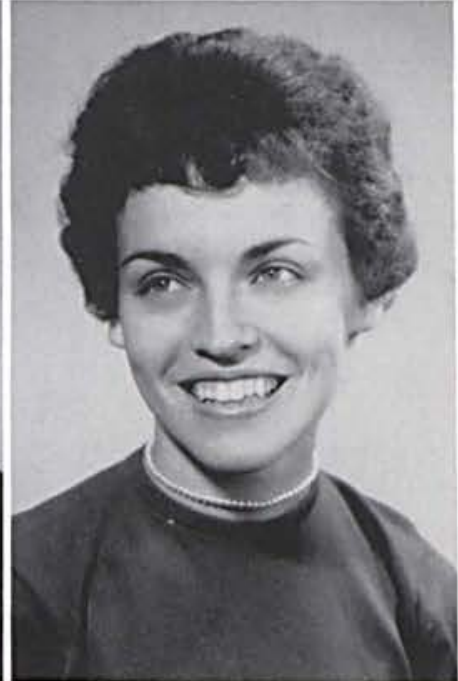

ESTHER RUTH WEISS

Fairview Park, Ohio

Berea Baptist Church

A.B., Elementary Education Central State 3, 4; Class Treasurer 1; Student Council 2. Treasurer 3, Secretary 4; Discipline Committee 4; Gamma Chi 1, Secretary-Treasurer 2, Parliamentarian 3, President 4; Sock-'n-Buskin 3, Vice-President 4; Homecoming Play 1, 2, 3; Yearbook Staff 2, 3; F.W.M. 1, 2, 3, 4; Girls' Basketball Team 1, 2, 3, 4; Choir 1, 2, 3, 4; Band 1, 4, Librarian 2, VicePresident 3; Sextette 1; Trumpet Trio 1, 2; Women's Chorus 1; Cheerleading 1, 2, 3, Captain 4.

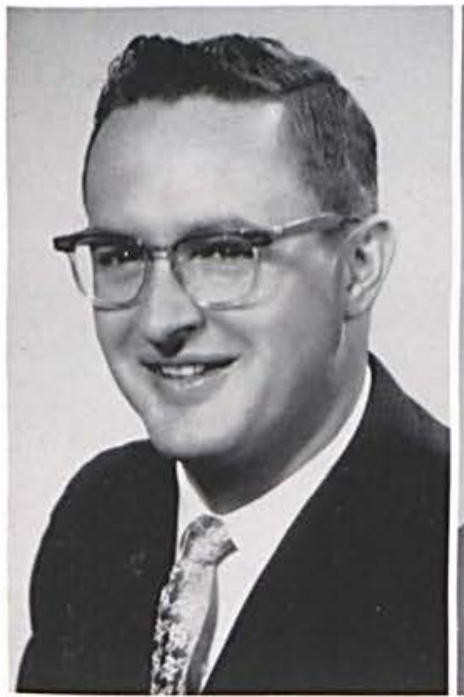

DEAN A. ZERBY

Berrien Springs, Michigan

Emmanual Baptist Church, Xenia, Ohio

A.B., Bible - Class Chaplain 2 .

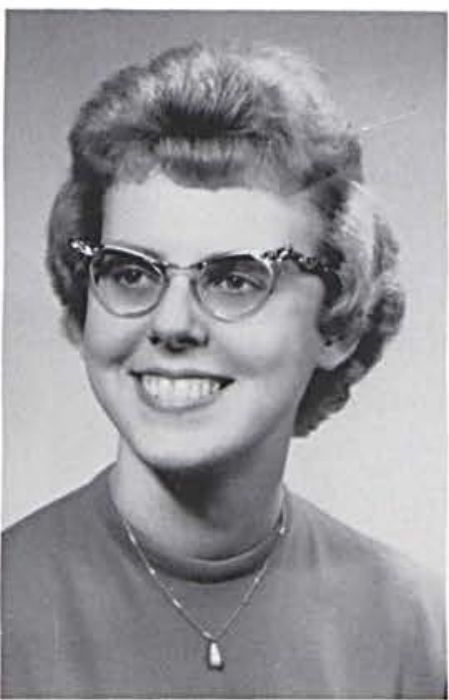

\section{CAROLE ANN ZOELLNER}

Sandusky, Ohio

Meadowbrook Baptist Church

A.B., Music-Gamma Chi 2, Treasurer 3, Program Chairman 4; Choir 1, 2, 3, Librarian 4; Band 1, 2, Librarian 3, President 4; Music Masters 1, Secretary 2, 3, 4; Sextette 1; Trio

2, 3, 4; Cheerleading 3; Prospective Students' Day Play 3. 


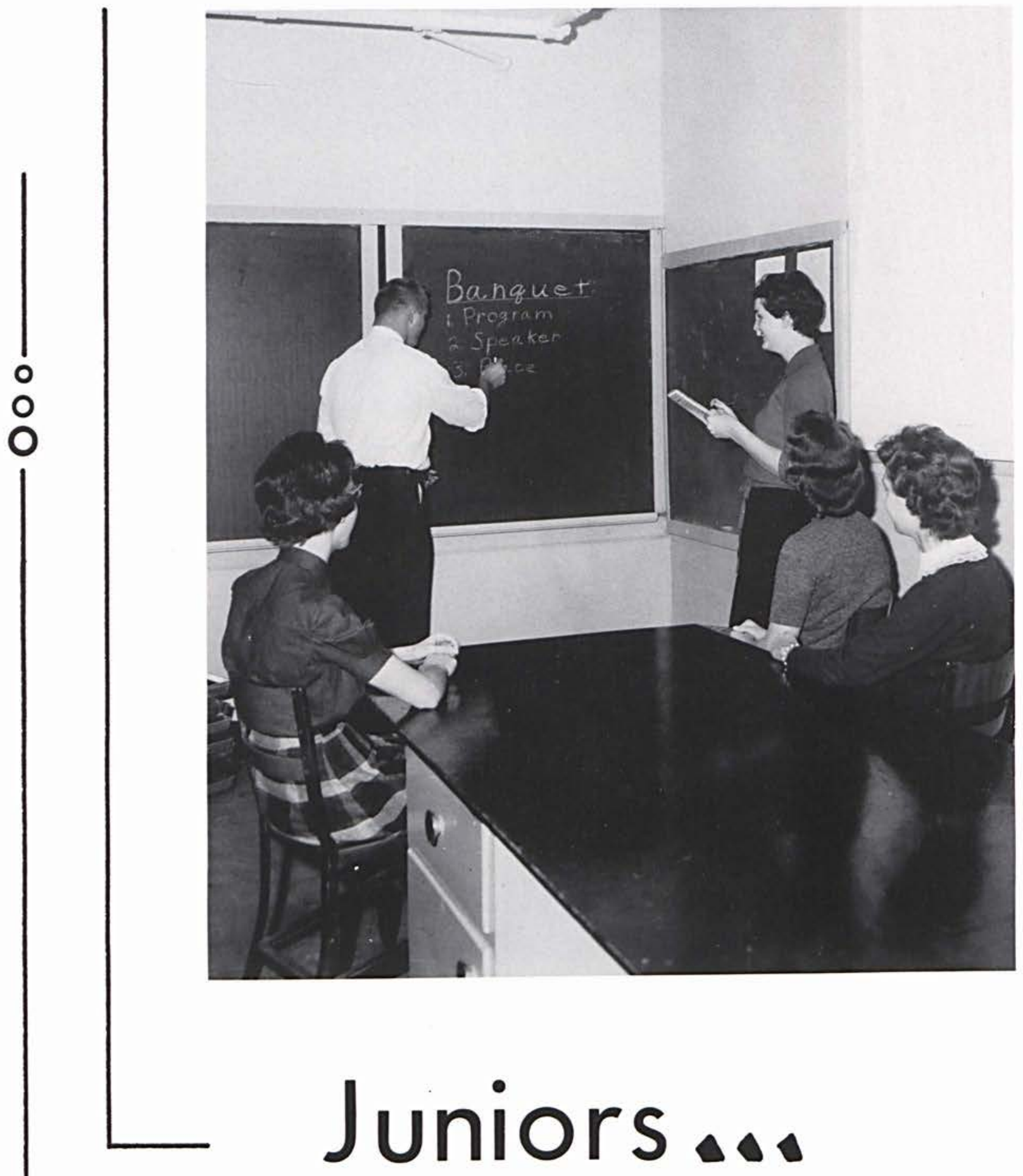

"We enter to learn and go forth to serve."

President

Vice-President

Secretary

Treasurer

Advisor
David Earnhart David Piper Carole Lanius

Charlene Ressler Paul Wyland 
ROSA LEE ALBRECHT

Calvary Baptist Church LaPaz, Indiana

Lakeville, Indiano

W. E. ALEXANDER

Shiloh Baptist Church

Shiloh, Ohio

Marion, Ohio

JUANITA ROSE ALLFORD

Heights Bible Baptist Church

East Liverpool, Ohio

Lisbon, Ohio

ALLEN BIDDLE

First Baptist Church

Gallipolis, Ohio

Rutland, Ohio

STEVE BOALT

Springfield, Ohio
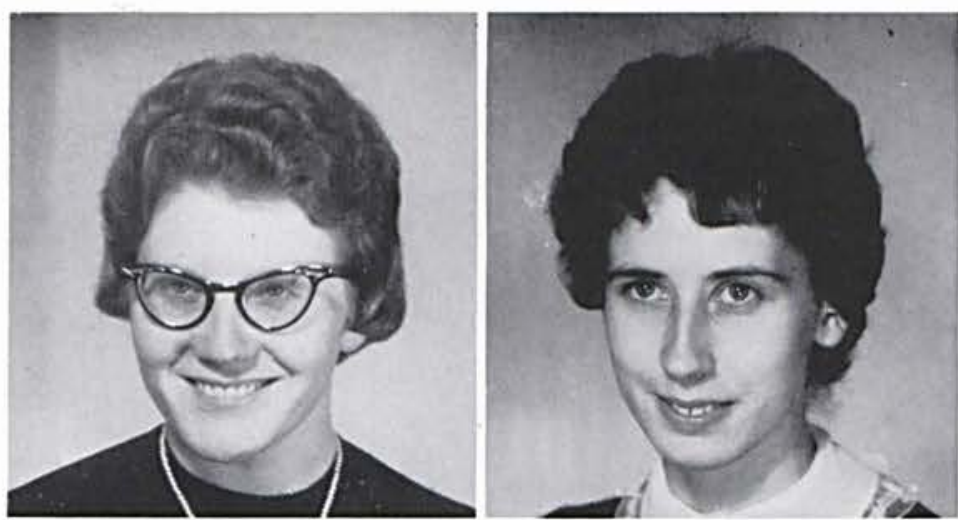

HAZEL M. BROVONT

First Baptist Church

Galion, Ohio
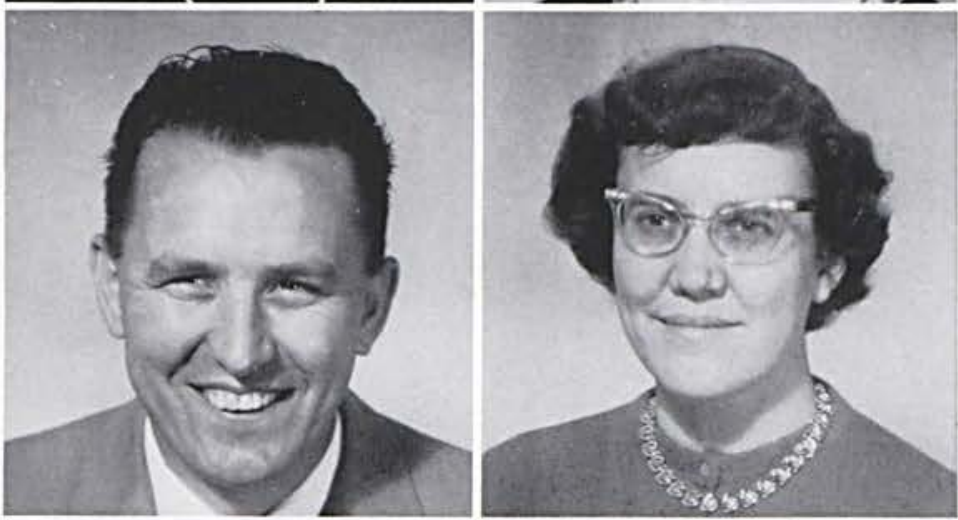

LORRAINE CARTWRIGHT

Grace Baptist Church

Cedarville, Ohio

\section{DAVE COCHRAN}

Grace Baptist Church

Cedarville, Ohio

Russell, lowa

\section{VIRGINIA COX}

Center Community Church Russell, lowa
ROBERT L. DOMOKOS

Huntsburg Baptist Church

Huntsburg, Ohio

Windsor, Ohio 
DAVE EARNHART

Emmanuel Baptist Church

Xenia, Ohio

Waynesville, Ohio

\section{ROBERT ELLIS}

First Baptist Church Boise, Idaho
CHARLES EDWARD FRY Grace Baptist Church

Fairborn, Ohio

Crawfordsville, Indiana

JOYCE GRANT

Third Street Baptist Church East Moline, Illinois

SANDRA HAMMERSTROM North Royalton Baptist Church North Royalton, Ohio
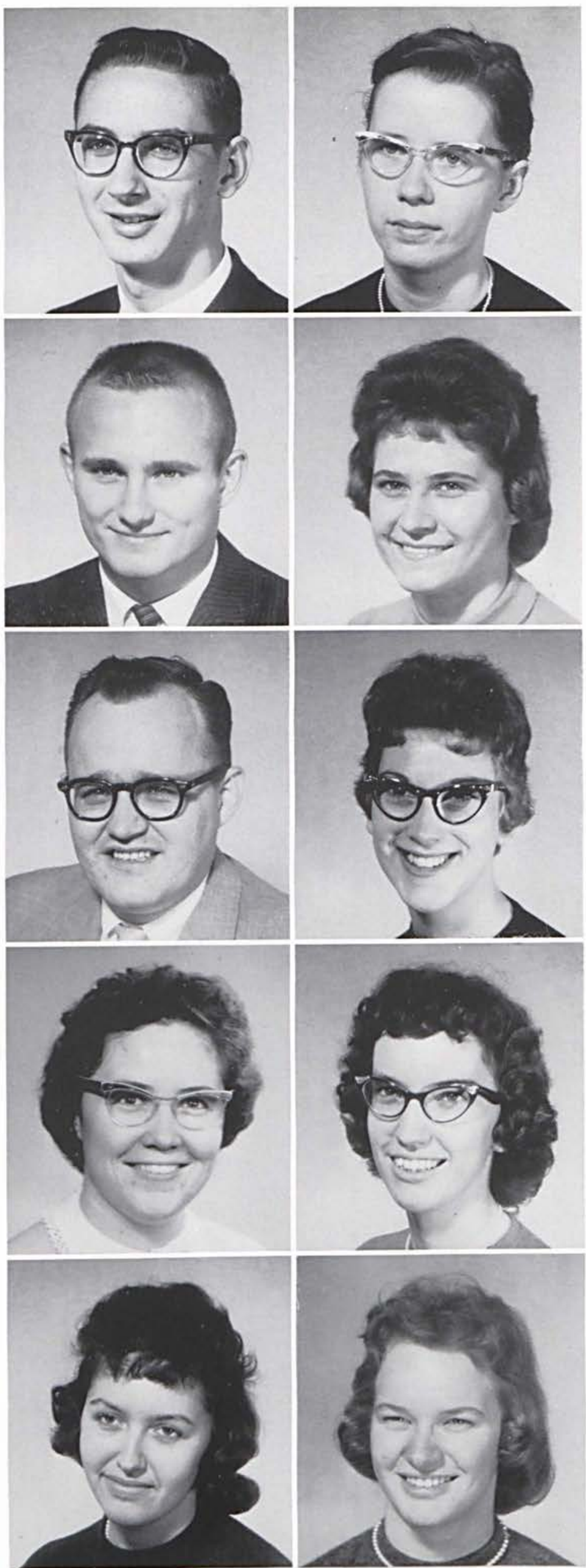

PAT HARRIS

Marietta Bible Center

Marietta, Ohio

Belpre, Ohio

CAROLE ANN HELL

Gladwin Baptist Church

Gladwin, Michigan

BARBARA HEMENWAY

Grace Baptist Church

Austin, Minnesota

PEGGY HOWARD

Calvary Baptist Church

Meadville, Pennsylvanio

DOLLY JESSE

First Baptist Chureh

Elyria, Ohio

\section{Juniors}


ELAINE JORDAN

Berean Baptist Church

Richmond, Virginia

KENNETH DEAN KELLER Silvercrest Baptist Church Drayton Plains, Michigan Clarkston, Michigan

TONY KILBOURN

Locust Corners Baptist Church Hudson, Michigan

WILLIAM O. LANE First Baptist Church Blanchester, Ohio Midland, Ohio

CAROLE SUE LANIUS Calvary Baptist Church Covington, Kentucky
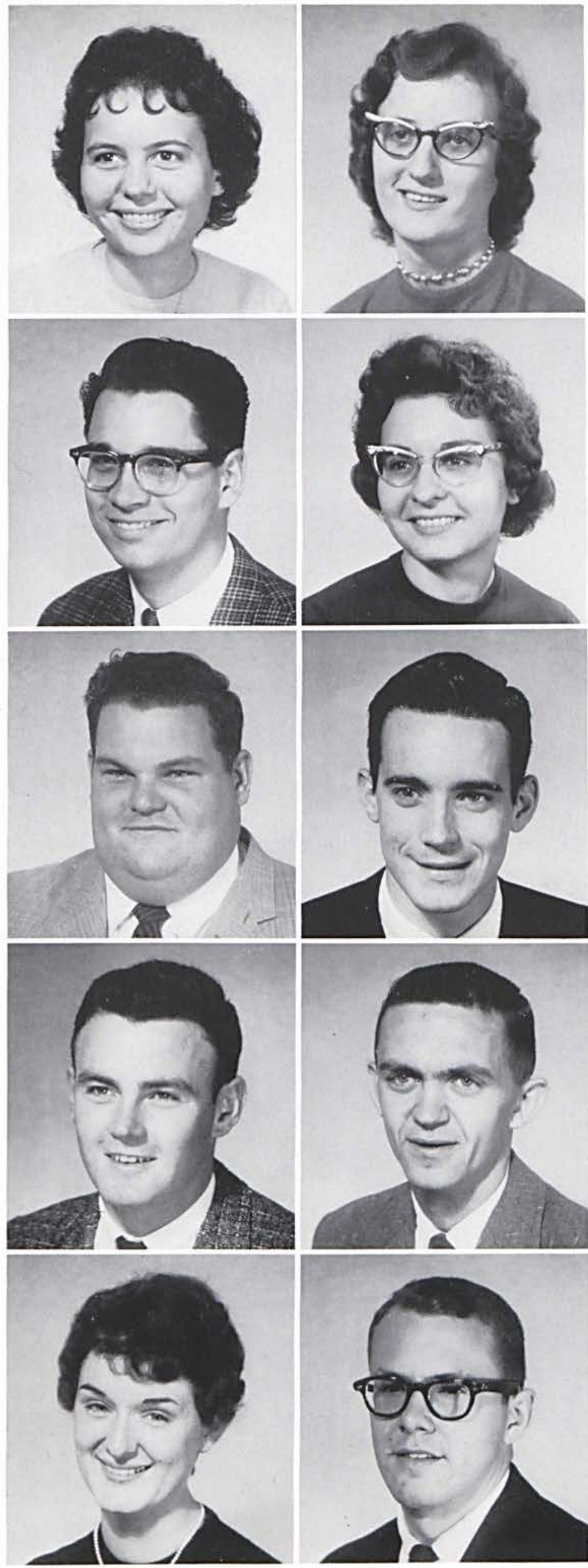

PAULINE LOWE

Locust Corners Baptist Church

Hudson, Michigan

Osseo, Michigan

\section{BEVERLY LYON}

Pleasant View Baptist Church Crawfordsville, Indiano

DON MIDDLETON

North Chester Baptist Church Chester, Pennsylvania

Media, Pennsylvania

DICK MINIER

Immanuel Baptist Church Fort Wayne, Indiana

JERRY L. PEIFER

Emmanuel Baptist Church Marion, Ohio

Mansfield, Ohio 
DAVID PIPER

Locust Corners Baptist Church

Hudson, Michigan

Pittsford, Michigan

DAN PURDY

Berea Baptist Church

Berea, Ohio

Cedarville, Ohio

HAROLD I. PYLE

Emmanuel Baptist Church

Xenia, Ohio

WAYNE E. RADER

First Baptist Church

Evans City, Pennsylvania

Renfrew, Pennsylvania

JOAN REITER

Bible Baptist Church

Greenport, L. I., New York

Southold, L. I., New York
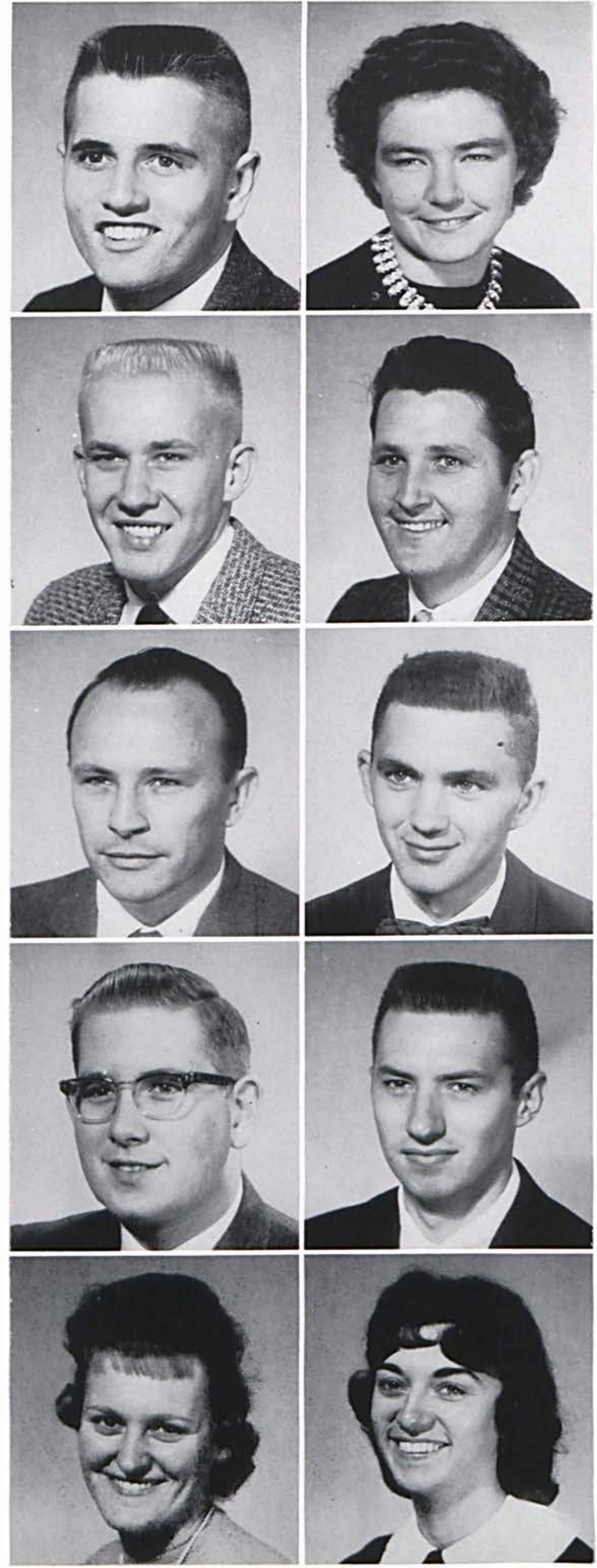

CHARLENE ALICE RESSLER

First Baptist Church

Shell Rock, lowo

\section{HAROLD RODIN}

Emmanuel Baptist Church Xenia, Ohio

Burlington, lowa

FREDERICK J. ROLFE

Tabernacle Baptist Church Ithaca, New York

MARVIN W. ROYSE

Crestline Conservative Baptist Church

Logansport, Indiano

CATHERINE SHELTON

Howell Baptist Church Howell, Michigan

\section{Juniors}


BETTY L. SMITH

Grace Baptist Church

Austin, Minnesota

BOGLE STANDIFER

First Baptist Church

Galion, Ohio

OTIS R. STONE

First Baptist Church

Rochelle, Illinois

\section{ELEANOR TAYLOR}

Hayden Avenue Baptist Church Cleveland, Ohio

\section{TOM THOMPSON}

Baptist Temple

Boise, Idaho
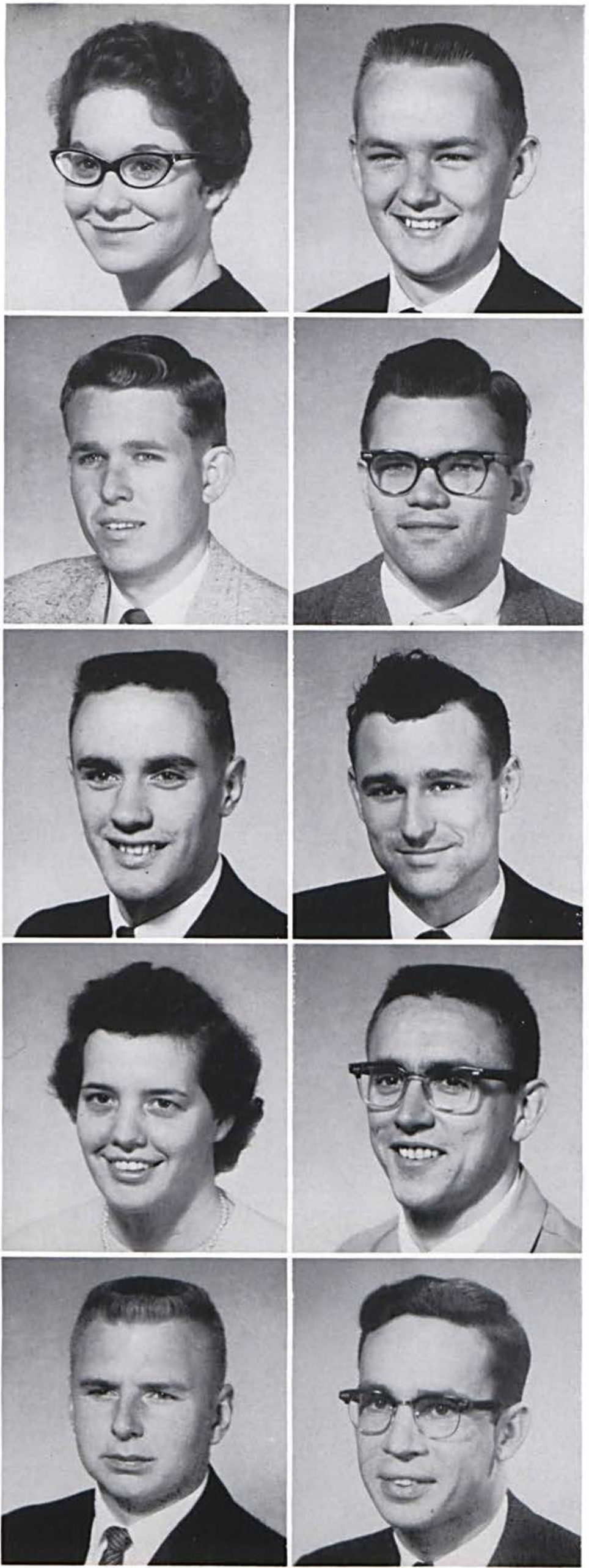

BILL WASHBURN

First Reformed Church

Xenia, Ohio

KEITH R. WEBSTER

Bible Baptist Church Bedford, Ohio

MARVIN B. WISEMAN

Blessed Hope Baptist Church Springfield, Ohio

\section{TERRY ZERBY}

Berrien Center Bible Church Berrien Springs, Michigan

SPECIAL STUDENT

VERNON D. MILLER Bible Baptist Church McClure, Illinois

NOT PICTURED

DAVE LEWIS

Temple Baptist Church

Portsmouth, Ohio

Cedarville, Ohio 

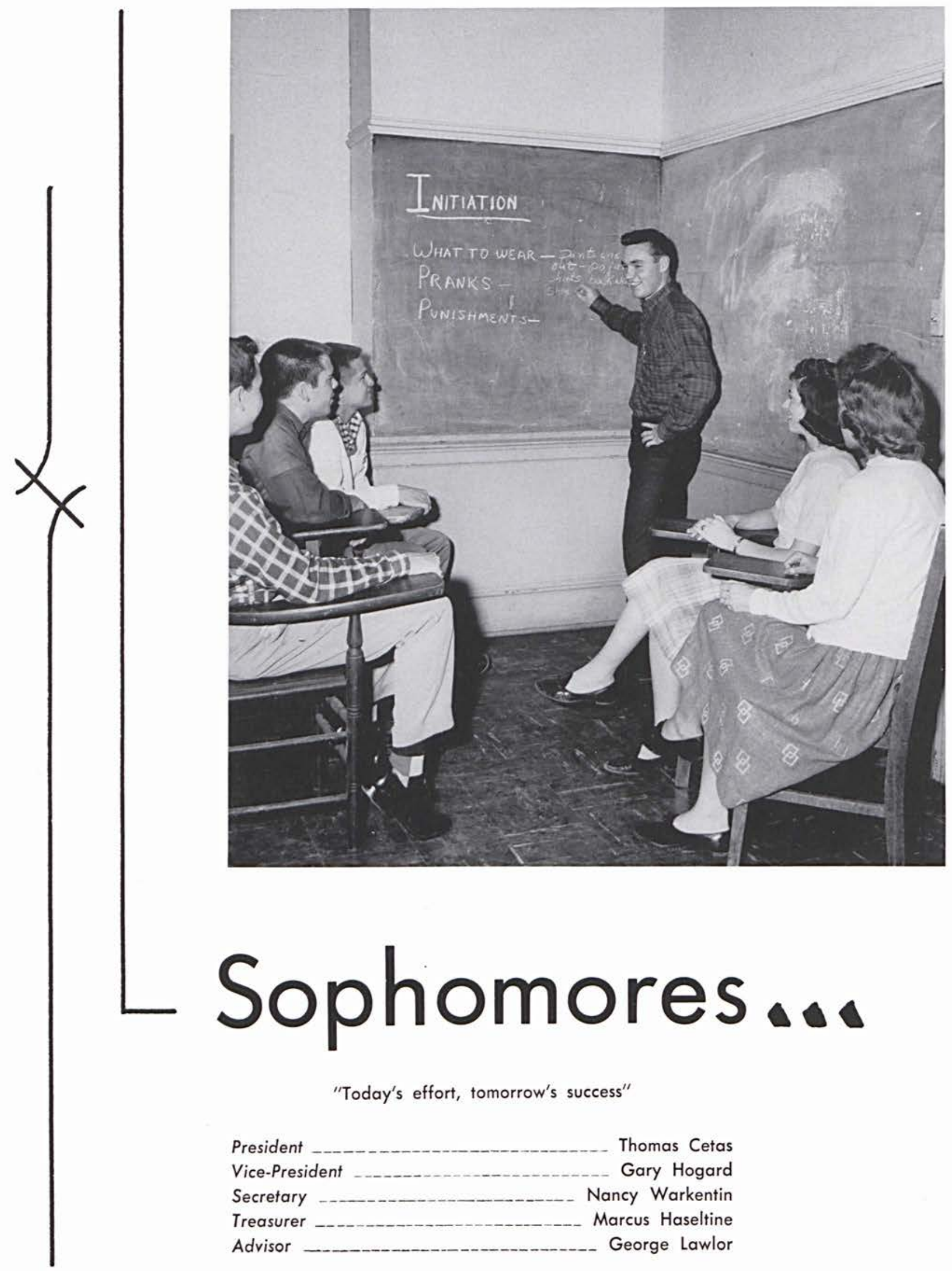

\section{Sophomores ...}

"Today's effort, tomorrow's success"

President

Thomas Cetas

Vice-President

Gary Hogard

Secretary Nancy Warkentin

Treasurer Marcus Haseltine

Advisor George Lawlor 
BARBARA ADAMSON

First Baptist Church

Perry, lowe

LOIS ALLEM

Calvary Baptist Chureh

Cresaptown, Maryland

\section{NEAL AMSTUTZ}

Trinity United Church of Christ Fairborn, Ohio

\section{A. LEE BENNETT}

Freeport, Pennsylvania

Calvary Baptist Church

Brackenridge, Pennsylvania

\section{IRENE BENSON}

Inland Mannor Baptist Church

Gary, Indiana

\section{JOHN BIGELOW}

West Chicago Baptist Church

Detroit, Michigan
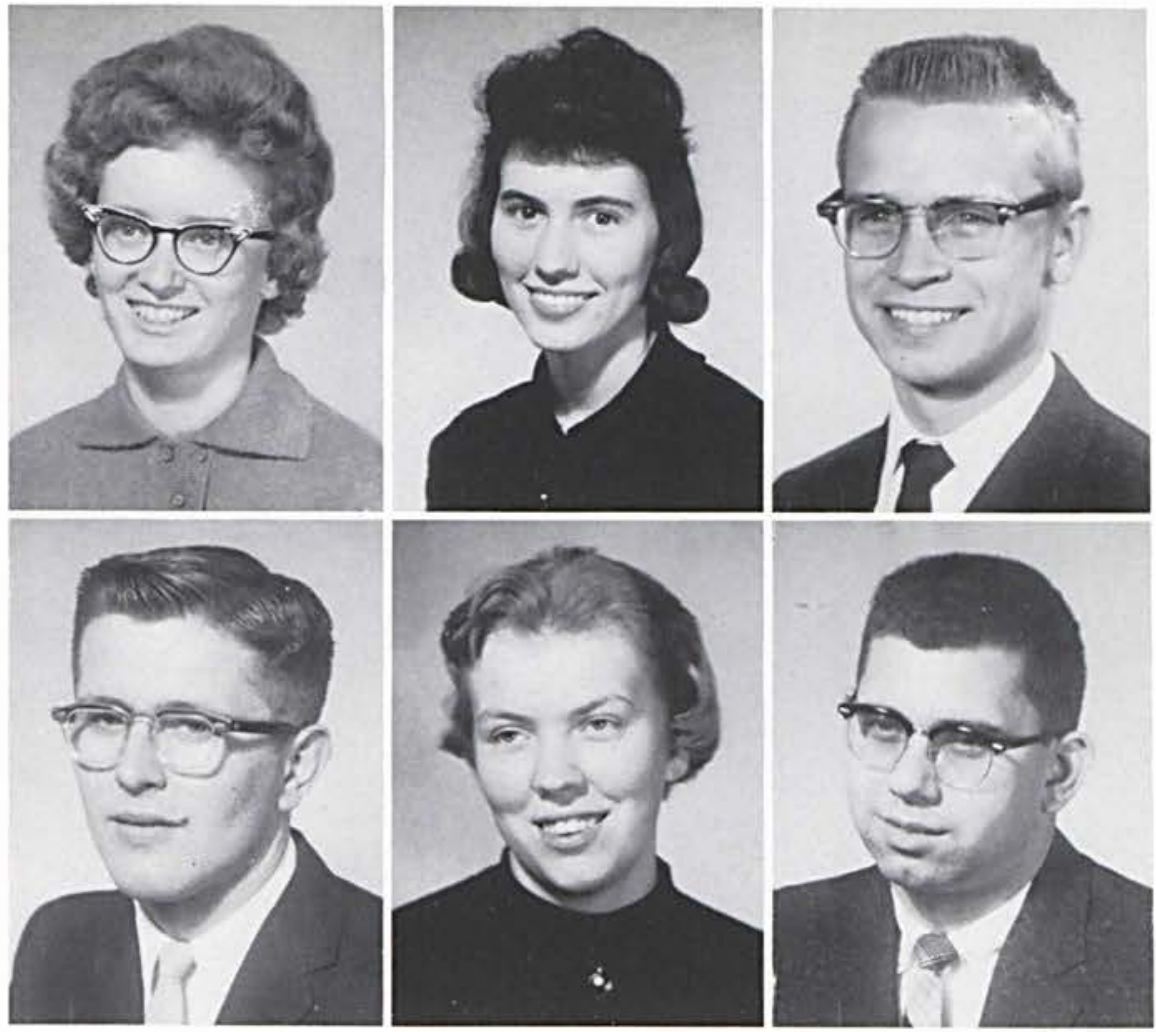

\section{Sophomores}

JULIA BIRD

Saline, Michigan

York Baptist Church

Milan, Michigan

DAN BROWER

Zeeland Baptist Church

Zeeland, Michigan
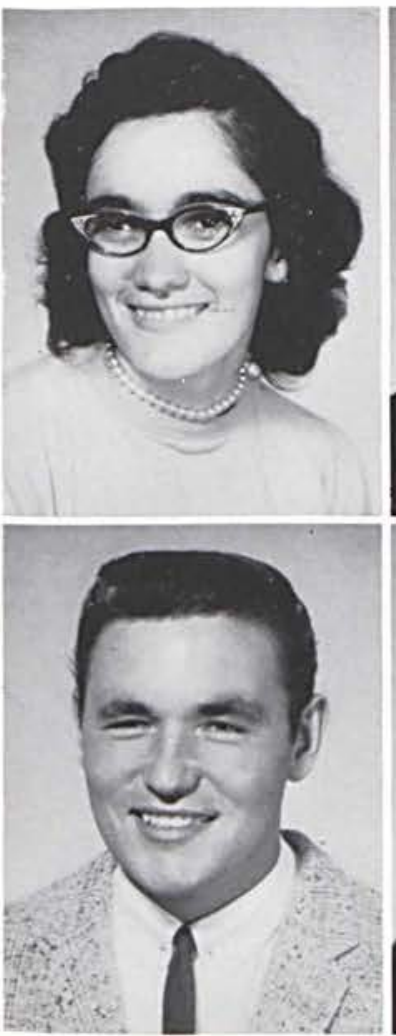

RICHARD ALAN

BLUMENSTOCK

Teaneck, New Jersey

First Baptist Church

Hackensack, New Jersey

PHIL BROWER

Kalkaska Baptist Church

Kalkaska, Michigan
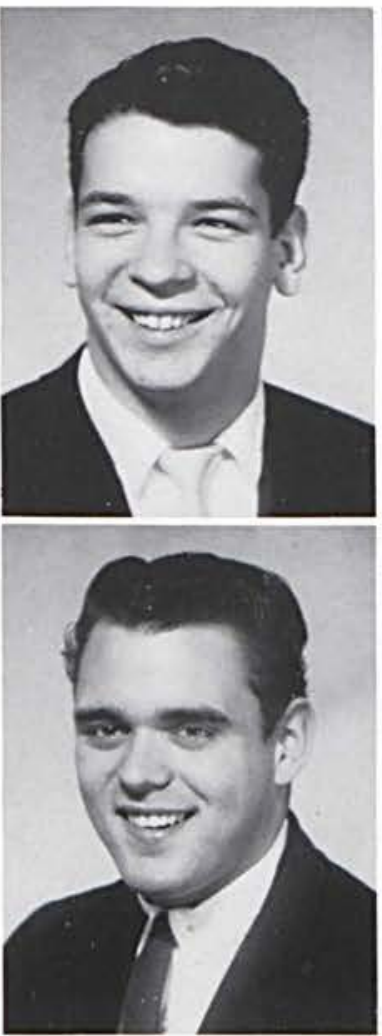

CAROLE ANN BOREN

First Baptist Church

Niles, Ohio

CAROL BROWN

Sycamore, Ohio

Calvary Baptist Church

Tiffin, Ohio
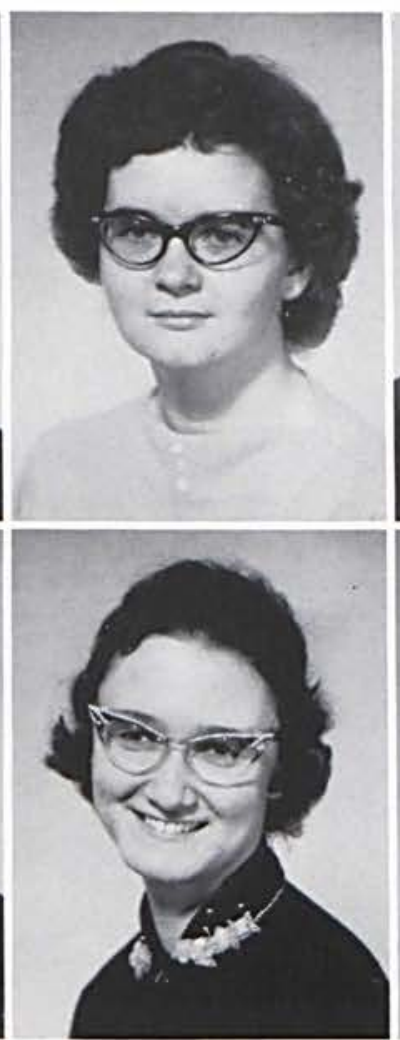

RICHARD BRESSON

Tippecanoe, Indiana

First Baptist Church

Menone, Indiana

PEGGY BUERER

First Baptist Church

Ceres, California
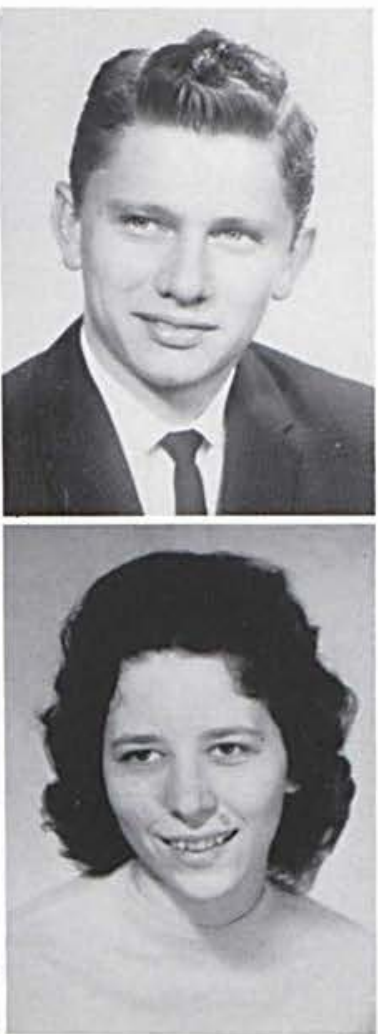


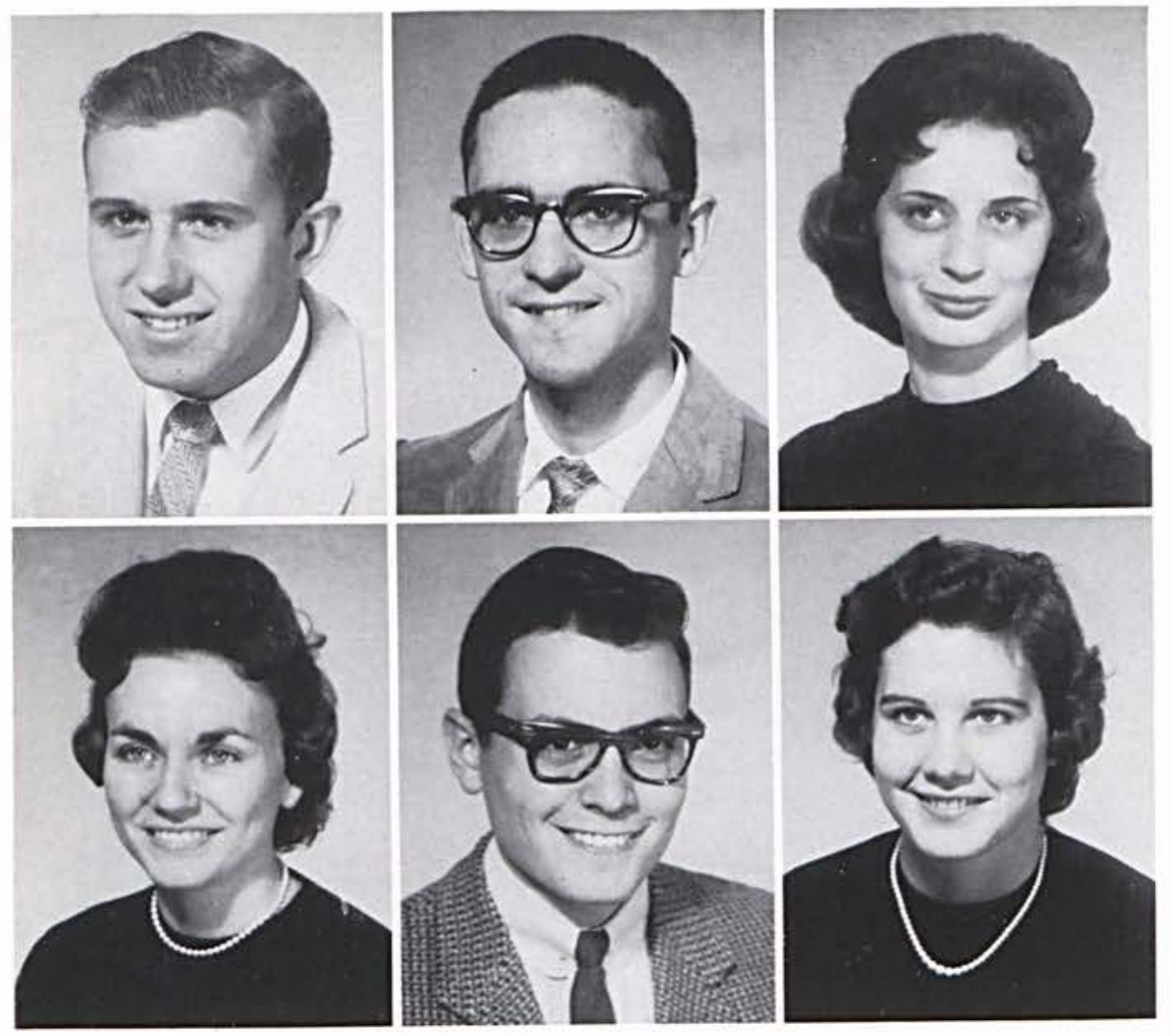

RONALD G. BUTLER

Emmanuel Baptist Church

Toledo, Ohio

\section{SAM CANINE}

First Baptist Church

Blanchester, Ohio

FLORA CANNON

Social Circle, Georgia

First Baptist Church

Parma, Ohio

\section{GAIL CARTER}

Evangel Baptist Church

Taylor, Michigan

\section{THOMAS C. CETAS}

First Baptist Church

Lapeer, Michigan

MARY ANN CLAUSEN

Riverside Baptist Church

Decatur, Illinois
LORETTA CUSHEY

Saxonburg, Pennsylvania

First Baptist Church

Butler, Pennsylvania

JEANNIE DU PRE

Capitol Baptist Church

Washington, D.C.
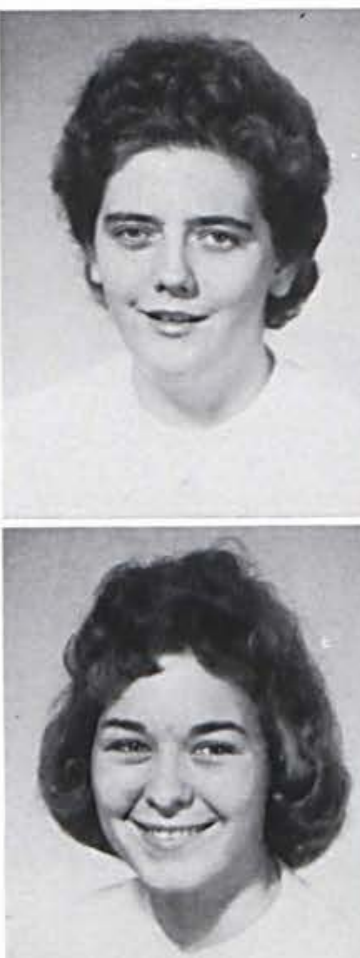

JUDY DADISMAN

Christian \& Missionary

Alliance Church

Warren, Ohio

EDWARD EASTMAN

Bible Baptist Church

Wiscasset, Maine
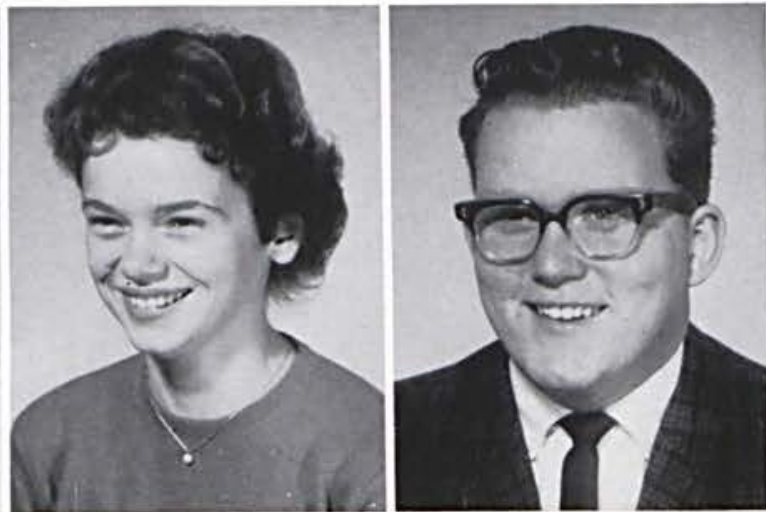

First Baptist Church

Harvey, Illinois

DONNA G. EVERETT

First Baptist Church

Caro, Michigan
EARL H. DUNLAP

Kalkaska, Michigan

BARNEY FARNSWORTH

Jerome, Michigan

North Adams Baptist

Church

North Adams, Michigan
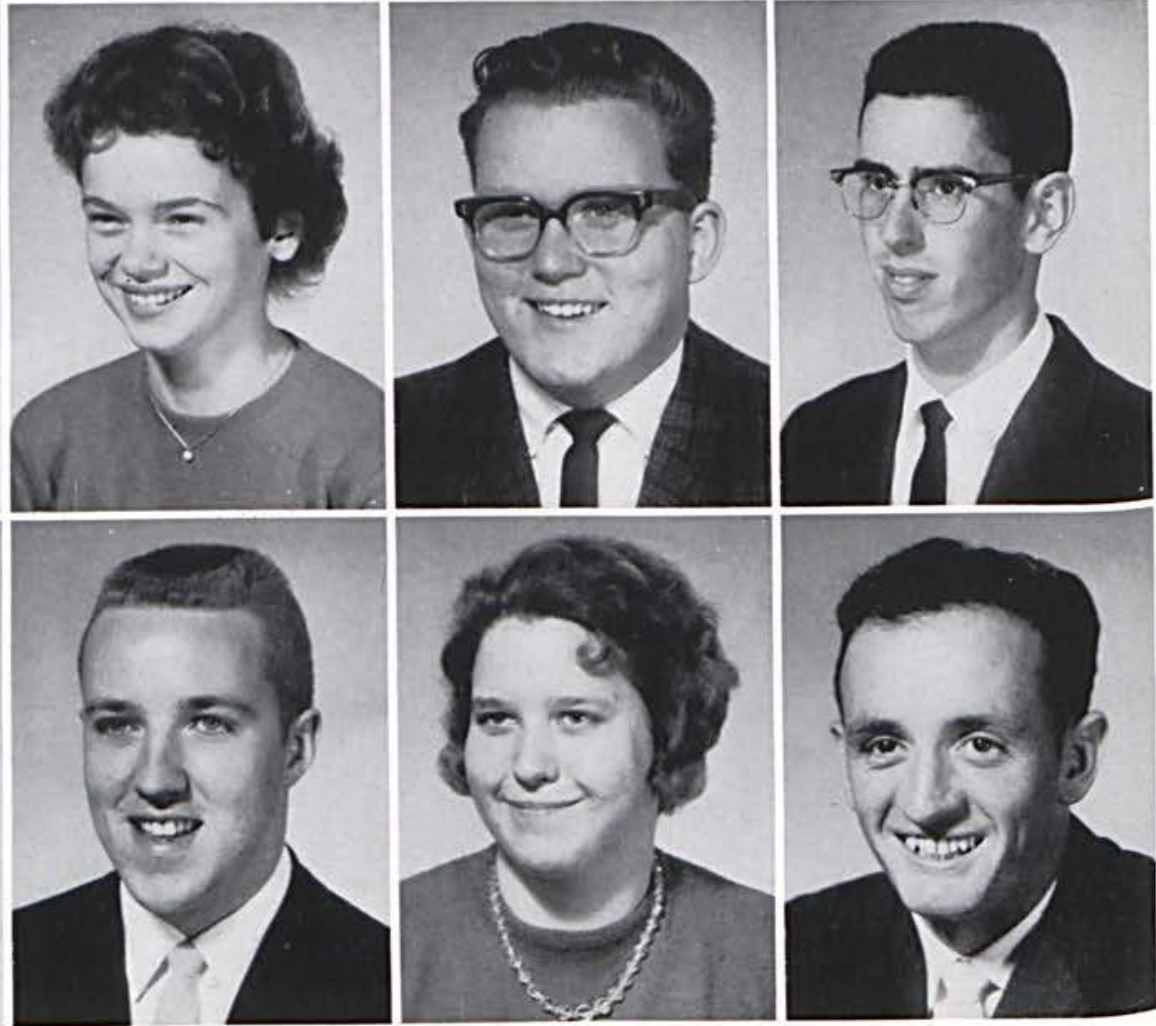
ROBERT BRUCE FIDLER

Glen Park Baptist Church

Gary, Indiana

DONNA JEAN FINLEY

First Baptist Church

Faribault, Minnesota

PRISCILLA FLEMING

Brunswick Baptist Church

Gary, Indiano
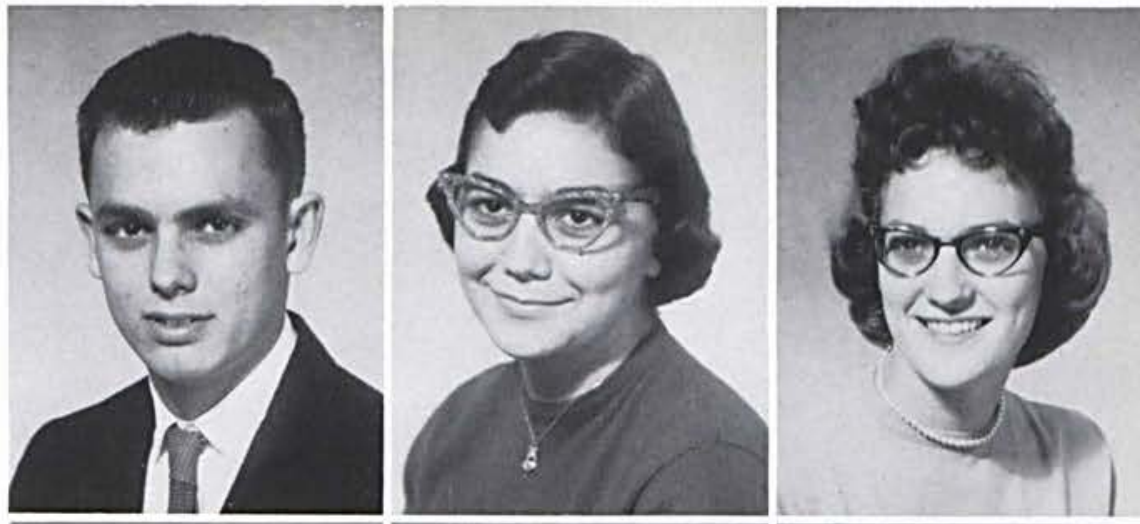

PAUL GATHANY

First Baptist Church

Randolph, New York

PEG GETTY

First Baptist Church of Elyria

Amherst, Ohio

JANE GINZ

Germantown Baptist

Church,

Peoria, Illinois
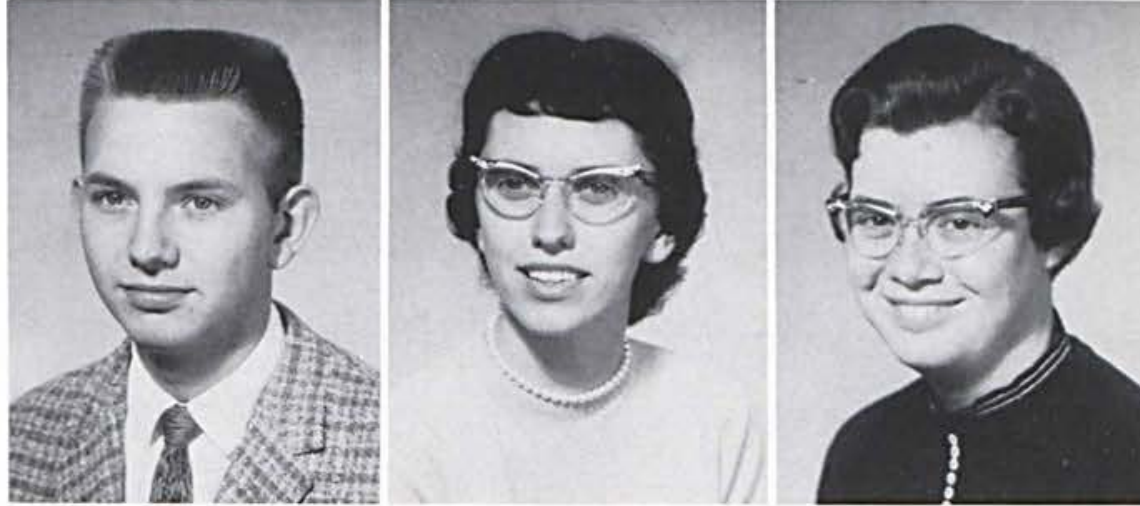

\section{Sophomores}

JUNE ELLEN GOLDEN

First Baptist Church

Stanton, Michigan

MARK HASELTINE

First Baptist Church of Butler

East Butler, Pennsylvania
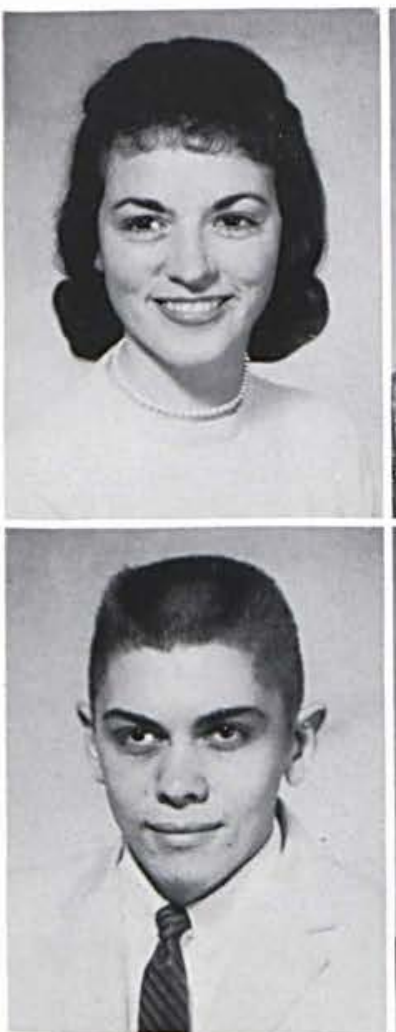

JAMES GRAFTON

First Baptist Church

Worthington, Pennsylvanio

LARRY HELMICK

Immanuel Baptist Church

Traverse City, Michigan
PHIL GRANT

Third Street Baptist Church

East Moline, Illinois

CAROL HENSON

Lackland Rd. Baptist

Church

Overland, Missouri
CHUCK HARTZELL

First Baptist Church of Butler

Butler, Pennsylvanio

ARTHUR HICKS

North Adams Baptist

Church

North Adams, Michigan
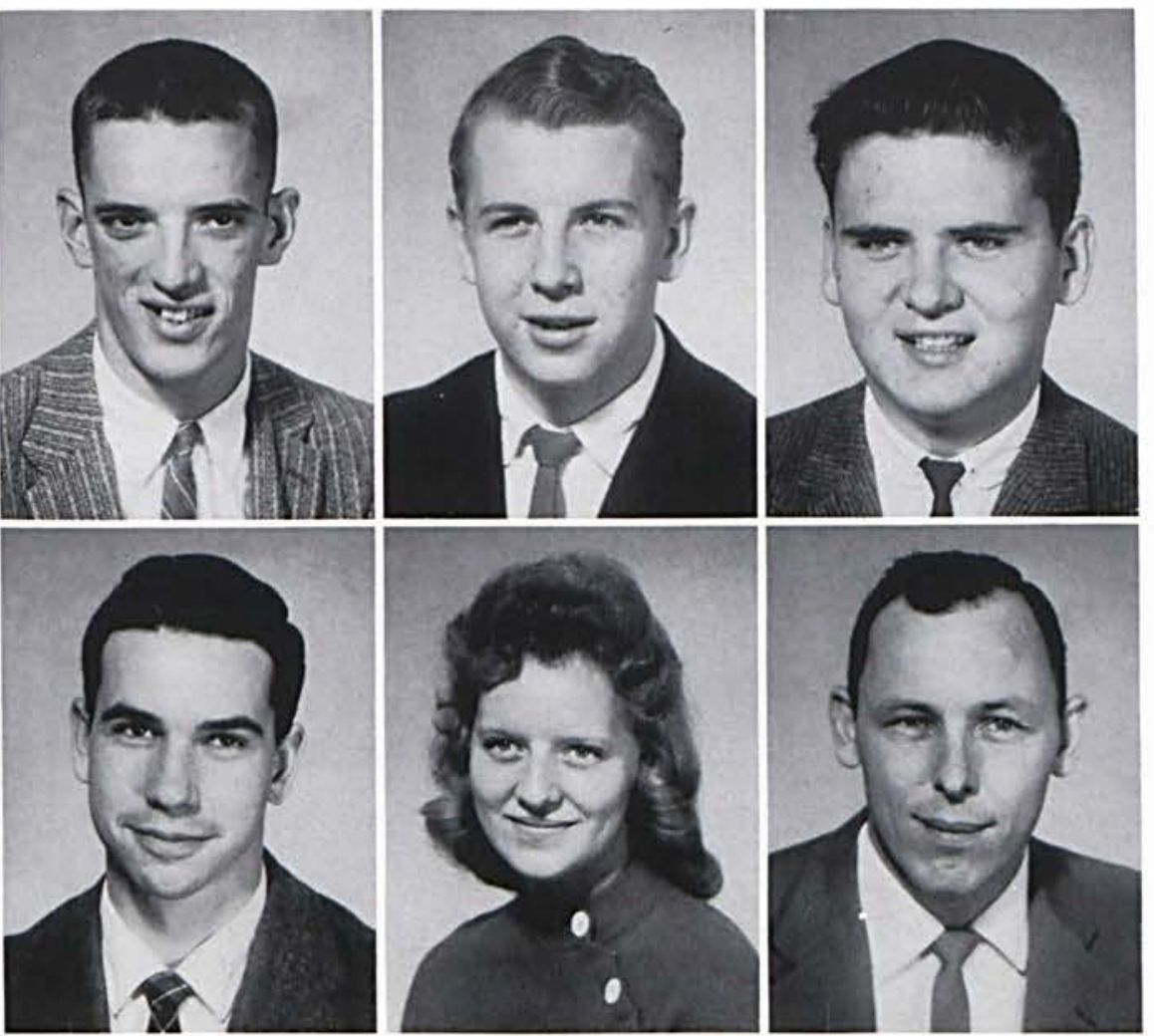

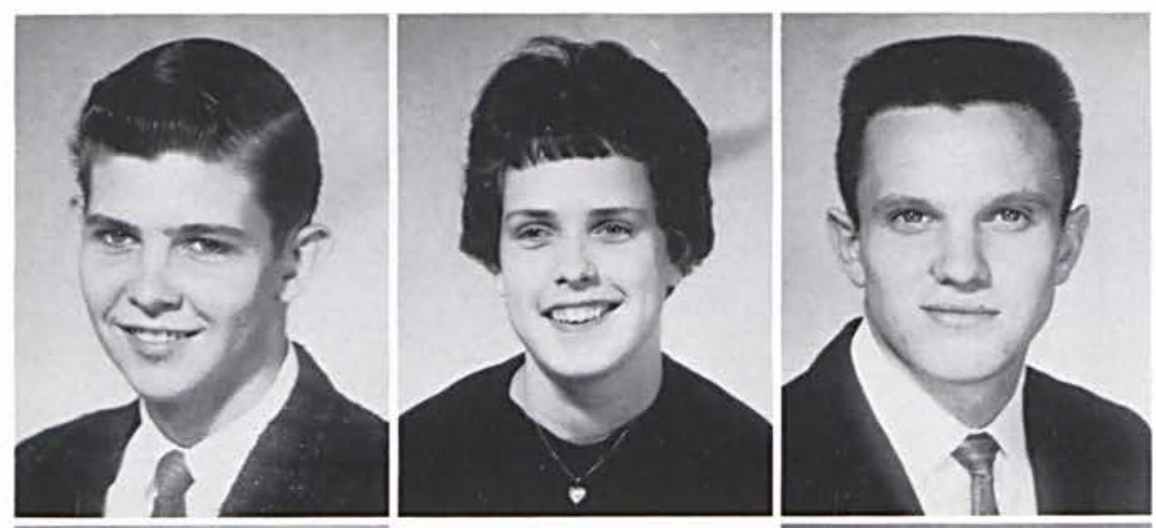

GARY HOGARD

Allen Park, Michigan

First Baptist Church

Lincoln Park, Michigan

\section{ELAYNE HOWARD}

Belden Avenue Baptist Church

Chicago, Illinois

\section{ELLIS M. HOWARD}

First Baptist Church

Williamston, Michigan

\section{LYNN JEFSON}

Calvary Baptist Church

Forest City, lowa

\section{PICTURE}

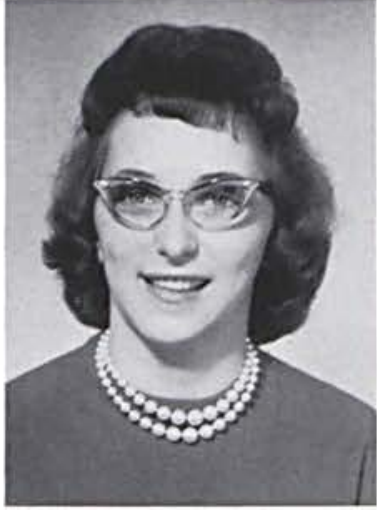

\section{DAVE JEREMIAH}

Grace Baptist Church

Cedarville, Ohio

WANDA LEE KENNEDY

First Baptist Church

Evans City, Pennsylvania

JUDY ANN LACHMAN

Penfield Junction Baptist Church

Lorain, Ohio

BOB MAYO

Kalkaska Baptist Church

Kalkaska, Michigan
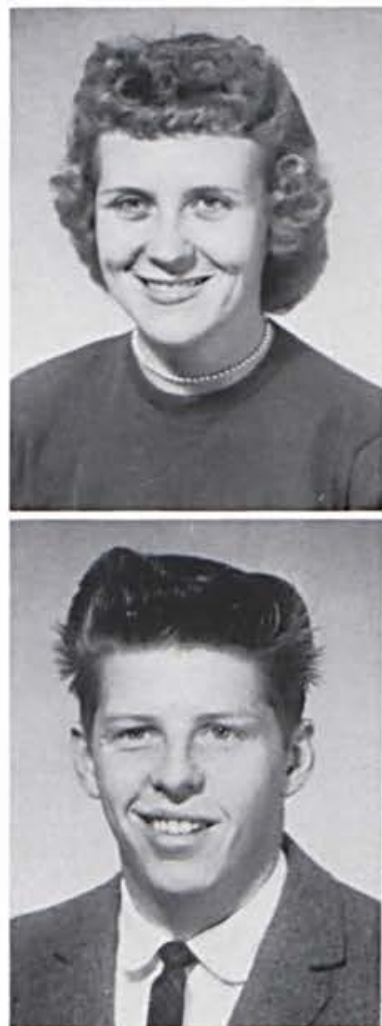

JOHN LAWLOR

Grace Baptist Church

Cedarville, Ohio

\section{JACK MOFFAT}

Grace Baptist Church

Cedarville, Ohio
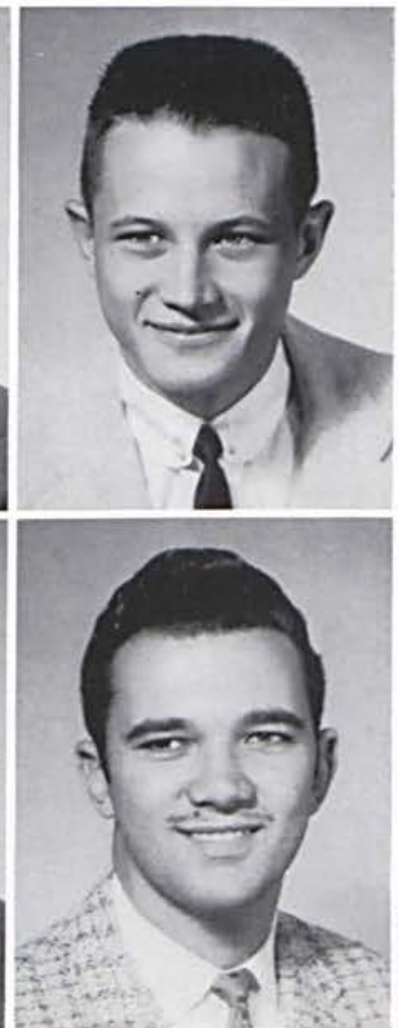

VIRGINIA LOWE

Wilder, Idaho

Roswell Baptist Church

Parma, Idaho

\section{TED OCHELTREE}

St. Albans, West Virginia

Randolph St. Baptist

Church

Charleston, West Virginia
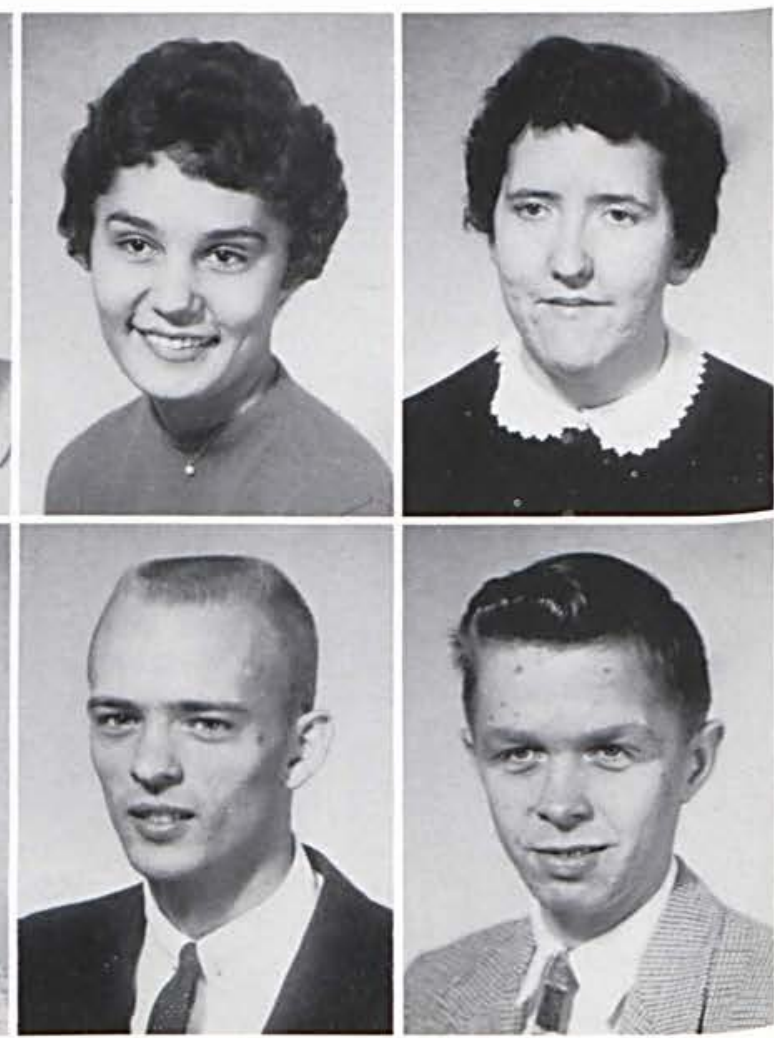

BETTY ANNE MC KEEHAN

First Baptist Church

Galion, Ohio

R. DEUR PARK

First Baptist Church

Vassar, Michigan

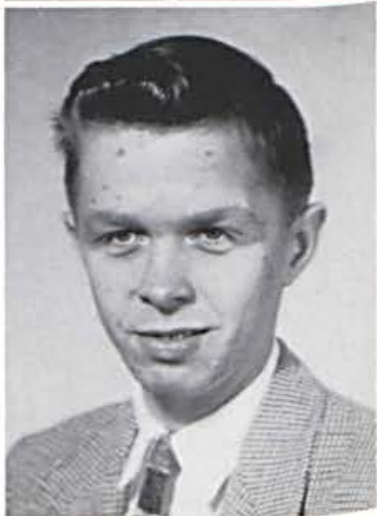


ALOHA PATCH

Grace Baptist Church

Austin, Minnesota

\section{CLARA QUITER}

Allen Baptist Church

Allen, Michigan

MARCIA LYNN RATCLIFF

Napoleon Baptist Church

Napoleon, Michigan

DAVID HAROLD RIFENBERICK

First Baptist Church

Spartansburg, Pennsylvania

\section{JUDY RITCHIE}

Riverdale Baptist Church

Flint, Michigan

\section{BETTY ROSE}

Pleasant View Baptist Church

Crawfordsville, Indiana
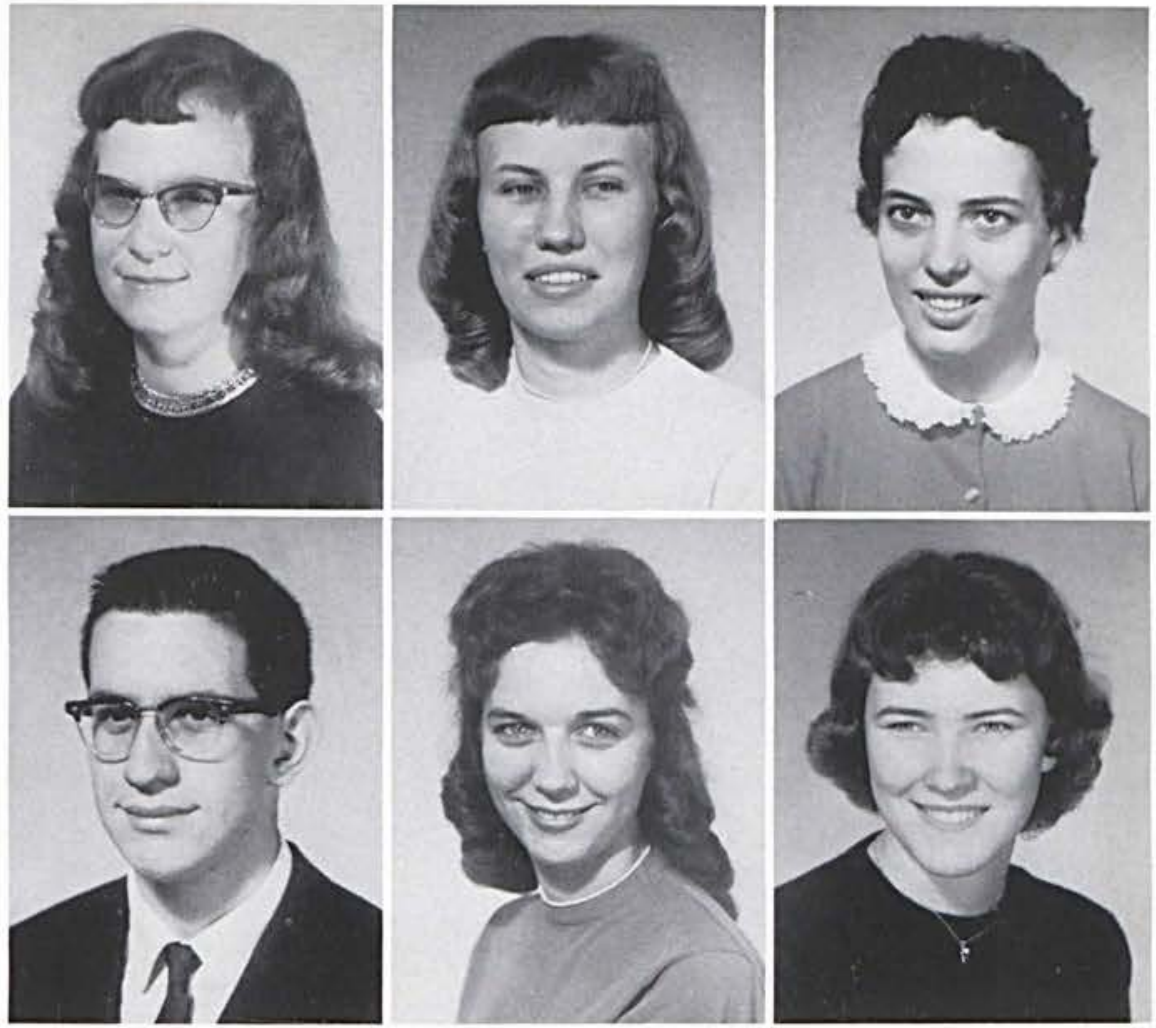

\section{Sophomores}

LAUREN H. SCHENCK

Cedarville, Ohio

Hayden Ave. Baptist

Church

E. Cleveland, Ohio

ELIZABETH SMYTHE

Calvary Baptist Church

Norwalk, Ohio
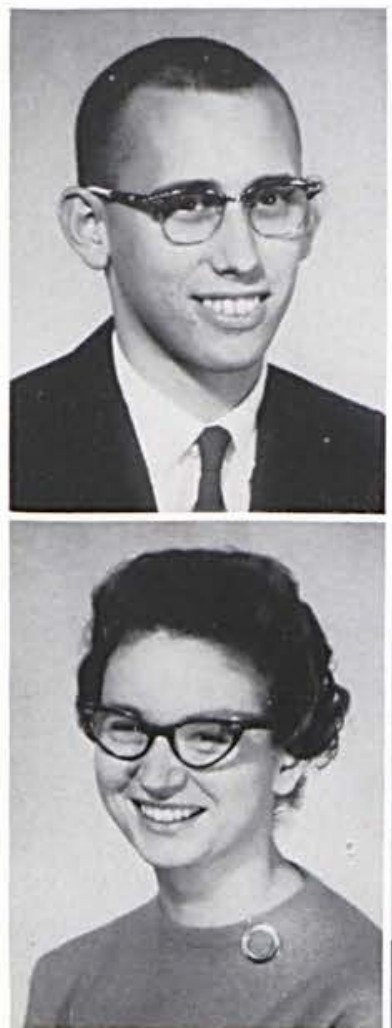

PATRICIA THELMA

SCHONSCHECK

Allen Park, Michigan

Evangel Baptist Church

Taylor, Michigan

ESTHER SPIETH

La Grange Baptist Church

La Grange, Ohio
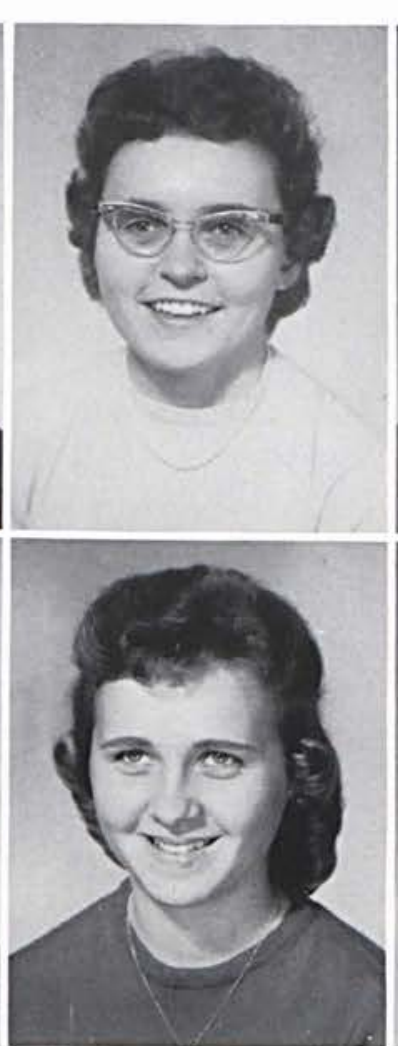

CAMILLA SHAMBAUGH

Church of Christ

Wilmington, Ohio

BARB SWERTFAGER

Bethany Baptist Church

Melbourne, Florida
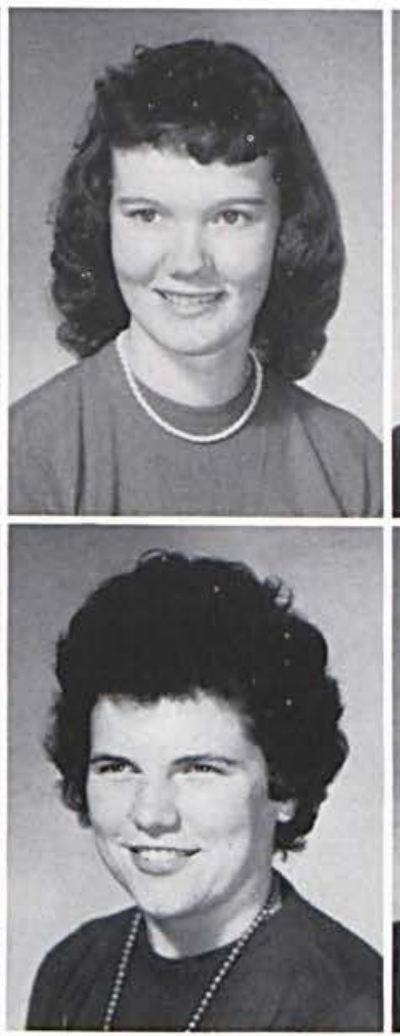

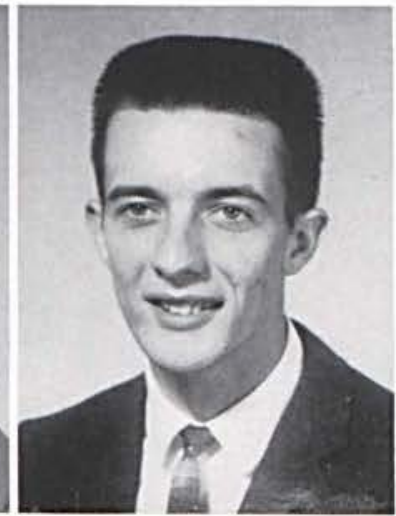

NORRIS SMITH

Kirkersville, Ohio

Bible Mission Baptist

Church

Reynoldsburg, Ohio

DON TENNANT

First Regular Baptist

Church

Bellefontaine, Ohio

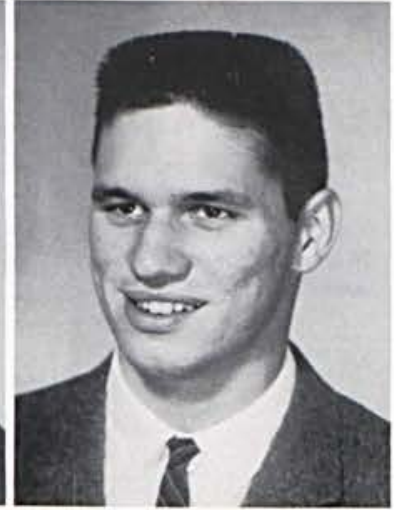



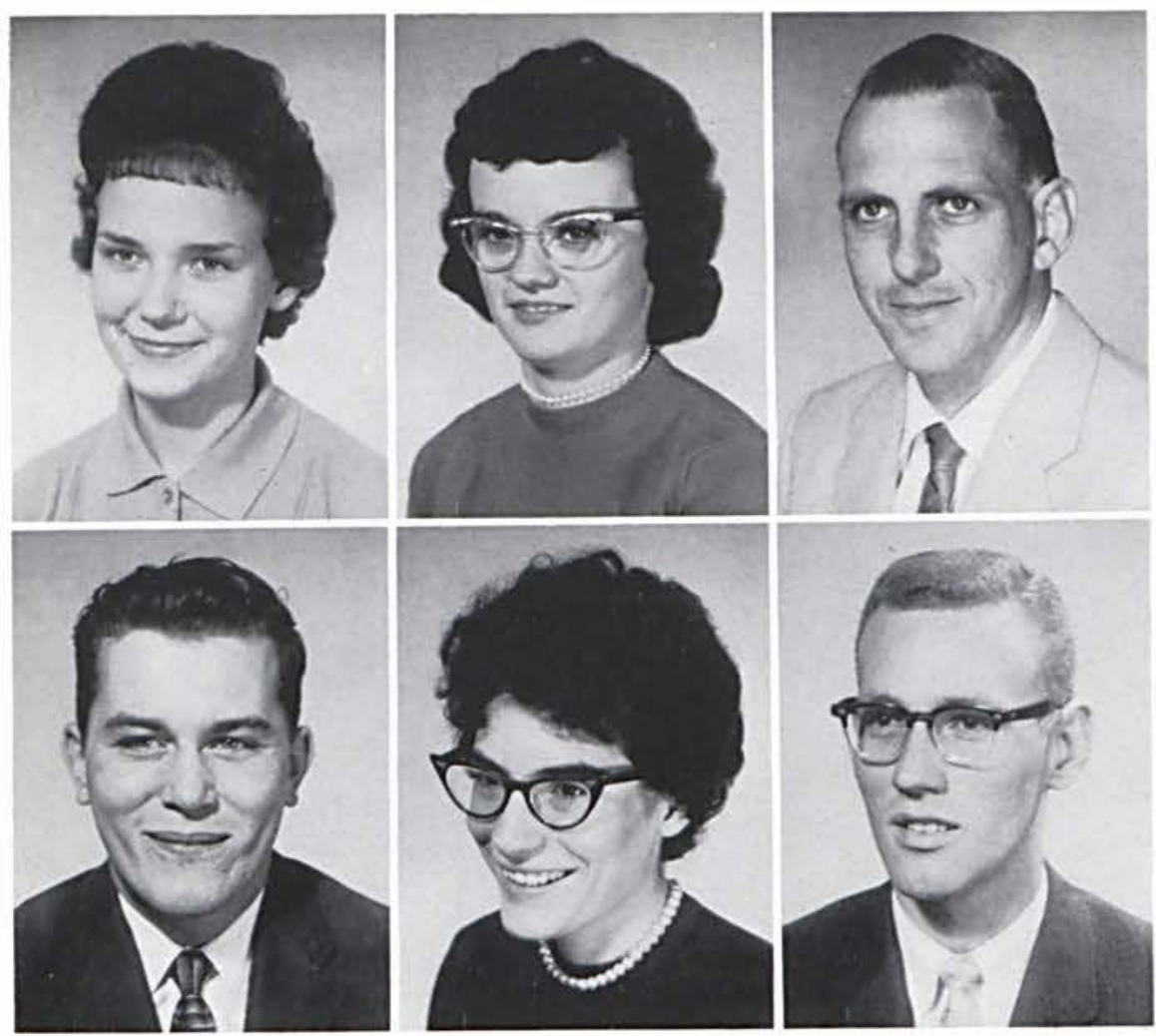

DONNA THOMPSON

North Solon Baptist Church

Bedford, Ohio

\section{LOUISE VARISCO}

Strongsville, Ohio

Beebetown Baptist Church

Brunswick, Ohio

\section{JERRY WAGNITZ \\ Milford, Michigan \\ Grace Baptist Church \\ Cedarville, Ohio}

TED WALBORN

First Baptist Church

Wauseon, Ohio

\section{CATHY WALMSLEY -}

Lake Ann, Michigan

Immanuel Baptist Church

Traverse City, Michigan

WILLIAM W. WARFIELD

Elmhurst, Illinois

Grace Baptist Church

Lombard, Illinois
Not pictured

BRIAN F. HALL

Kalkaska Baptist Church

Kalkaska, Michigan

LOIS R. KENNEDY

Pleasantville, New Jersey

Chelsea Baptist Church

Atlantic City, New Jersey

ROBERT E. ROBINSON

Third Avenue Methodist

Church

Columbus, Ohio

JAY WICKHAM

Kuna Baptist Church

Kuna, Idaho
N NCY WARKENTIN

W iverly, lowa

Walnut Street Baptist

Church

Waterloo, lowo

\section{BEVERLY WOODS}

Fostoria Baptist Church

Fostoria, Ohio
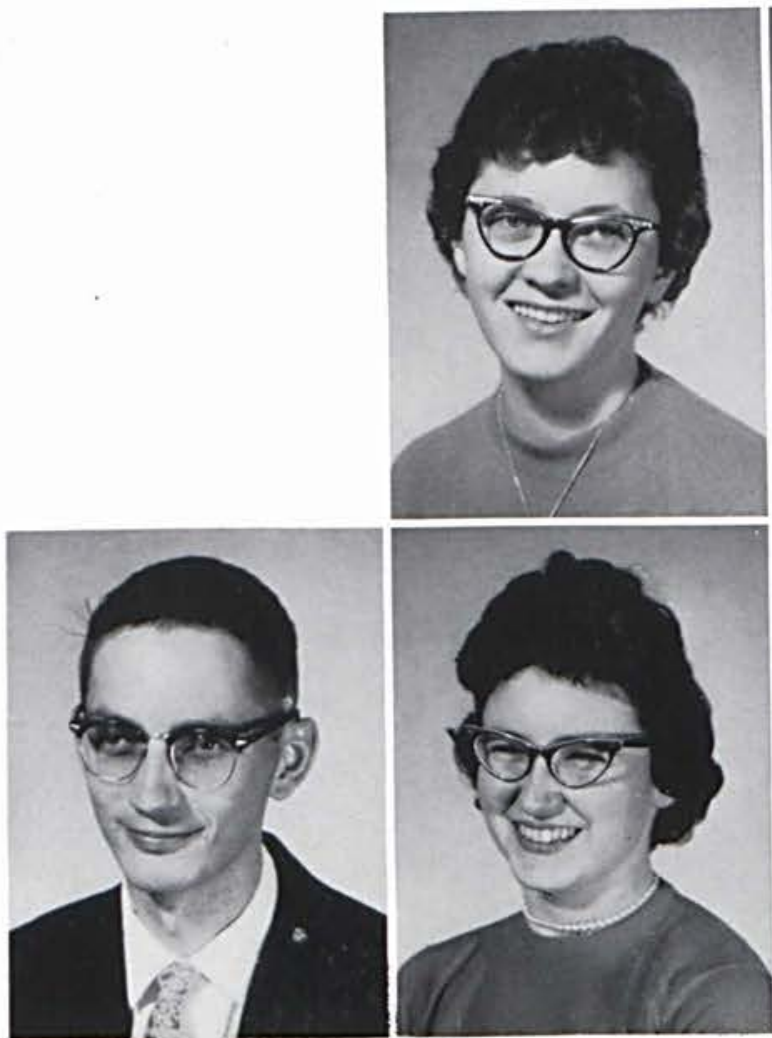

RALPH WERNER, JR.

First Baptist Church

Columbia Falls, Montane

GENE ARNOLD WRIGHT

First Baptist Church

Harrison, Michigan

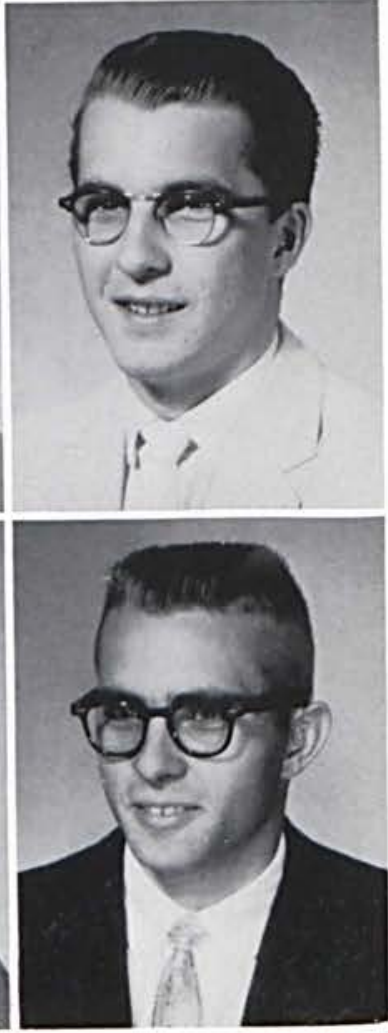

IRVING WOODARD

Chandler Street Baptist Jamestown, New York 


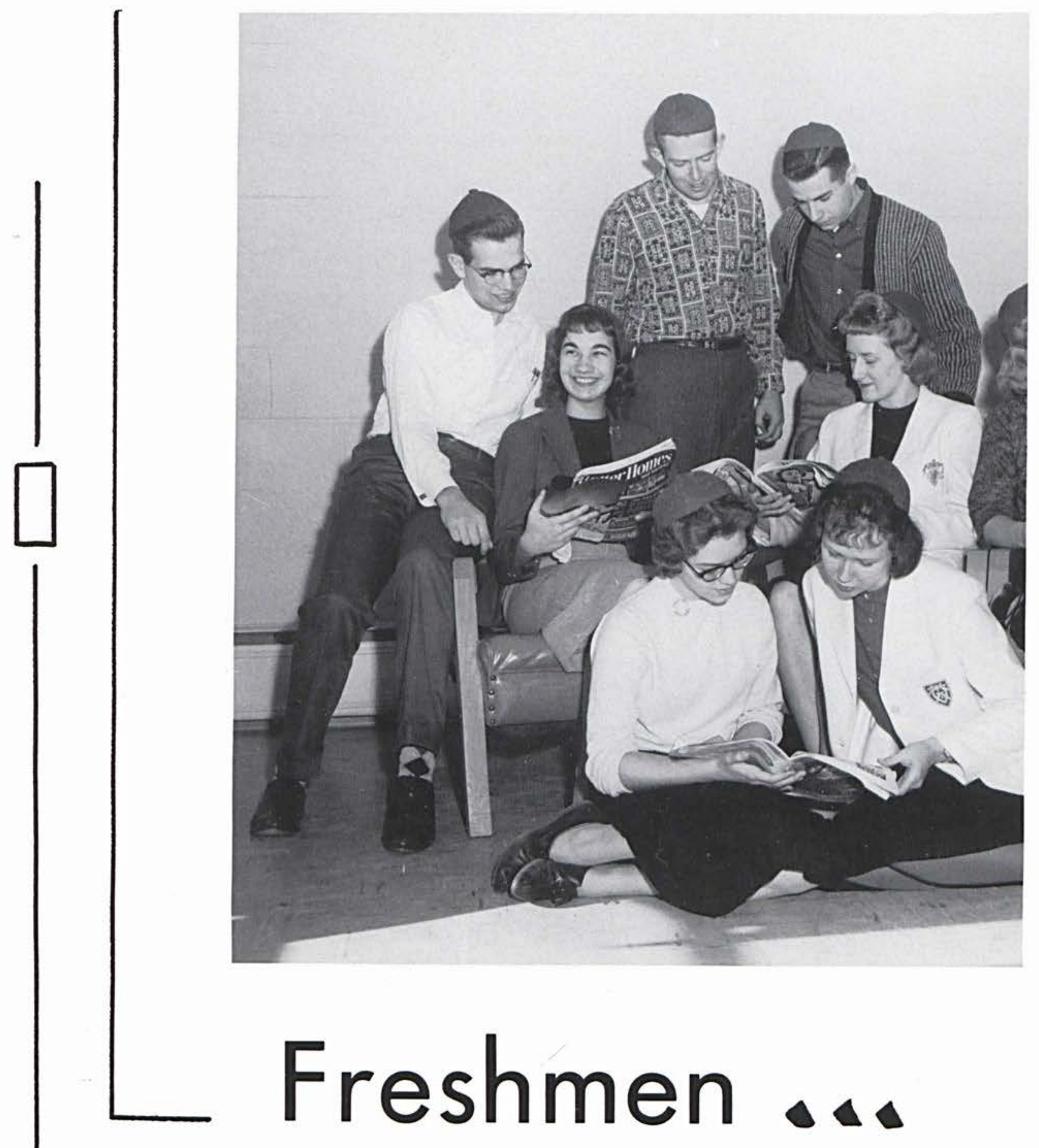

"Those who kneel before God, will stand before men."

President David Mills

Vice-President David Trumbull

Secretary Reava Krumrauf

Treasurer June Willington

Advisor Dale Thomson 

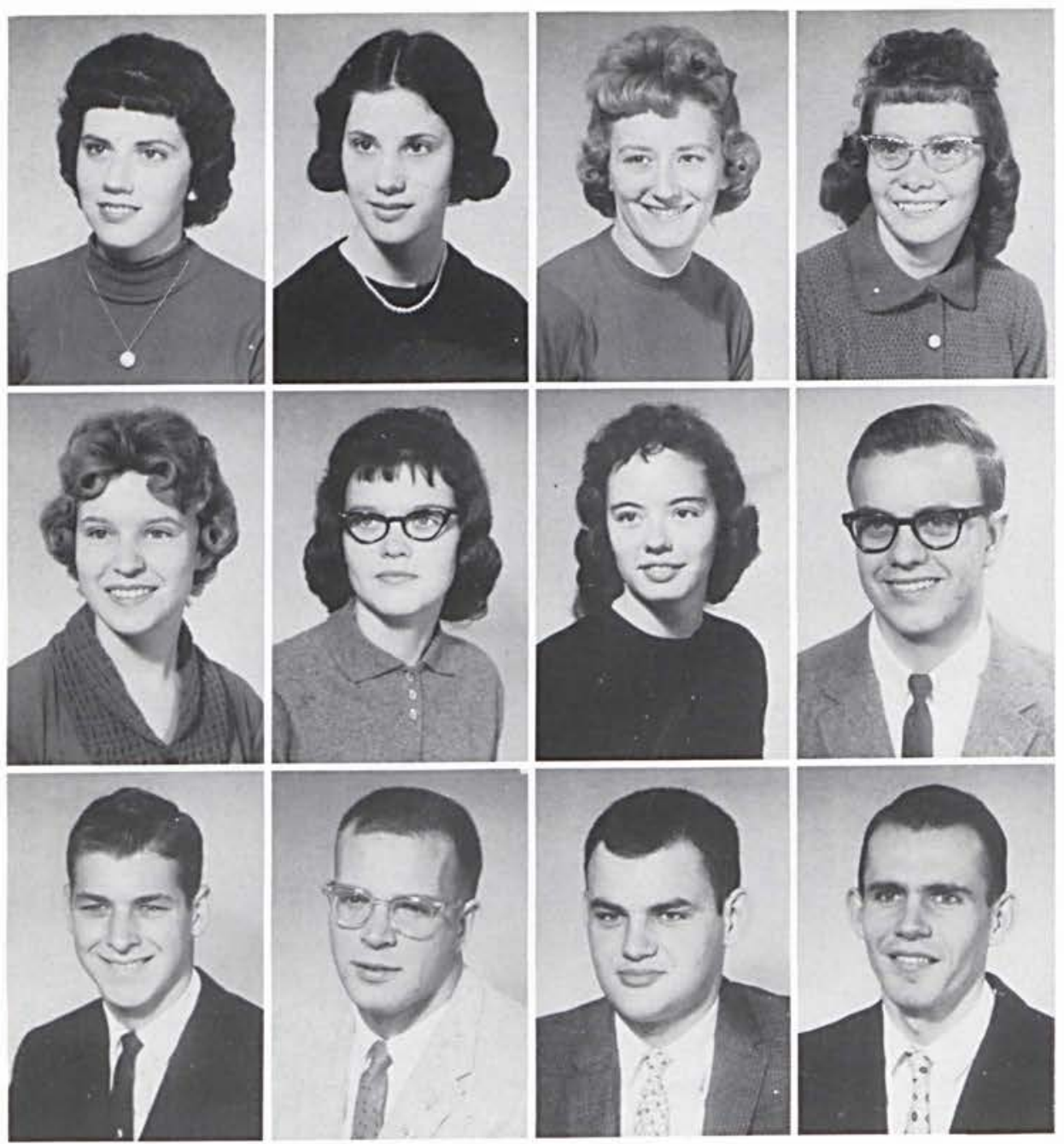

ELAINE ADAMS

Worthington First Baptist Church East Brady, Pennsylvania

PAT ADAMS

First Baptist Church

Silvis, Illinois

BETTE ADAMSON

First Baptist Church

Perry, lowa

SHARON KAY ADDLEMAN

Hillsdale, Michigan

North Adams Baptist Church

North Adams, Michigan

\section{SUE ADDLEMAN}

Worthington First Baptist Church Worthington, Pennsylvania BARBARA ALEXANDER

First Regular Baptist Church

Bellfontaine, Ohio

EUNICE ILYNNE ALLEM

Calvary Baptist Church

Cresaptown, Maryland

KEN ATKINS

Randolph Street Baptist Church

Charleston, West Virginia

\section{ROBERT G. AUFFORT}

Collingswood, New Jersey

Haddon Heights Baptist Church

Haddon Heights, New Jersey

THOMAS F. BABITT

First Baptist Church

Wellington, Ohio

LAWRENCE BAKER

First Baptist Church

Lincoln Park, Michigan

JOHN G. BARBER

Saylorville Baptist Church

Des Moines, lowa

\section{Freshmen}

PATRICIA BARRETT

Walnut Street Baptist Church Muscatine, lowa

LOIS BAYLESS

Baptist Bible Church

Yuma, Arizona

CAROLYN BEACH

First Baptist Church

Galion, Ohio

JAMES LOUIS BECK

Stanleyville Community Church Marietta, Ohio

\section{SALLY BENDER}

Calvary Baptist Church Clendenin, West Virginia ED BENSINGER

Calvary Baptist Church

Ionia, Michigan

NORMA JEAN BERTRAM

Fostoria Baptist Church

Fostoria, Ohio

MARY BLANN

Capital Heights Baptist Church

Bismarck, North Dakota
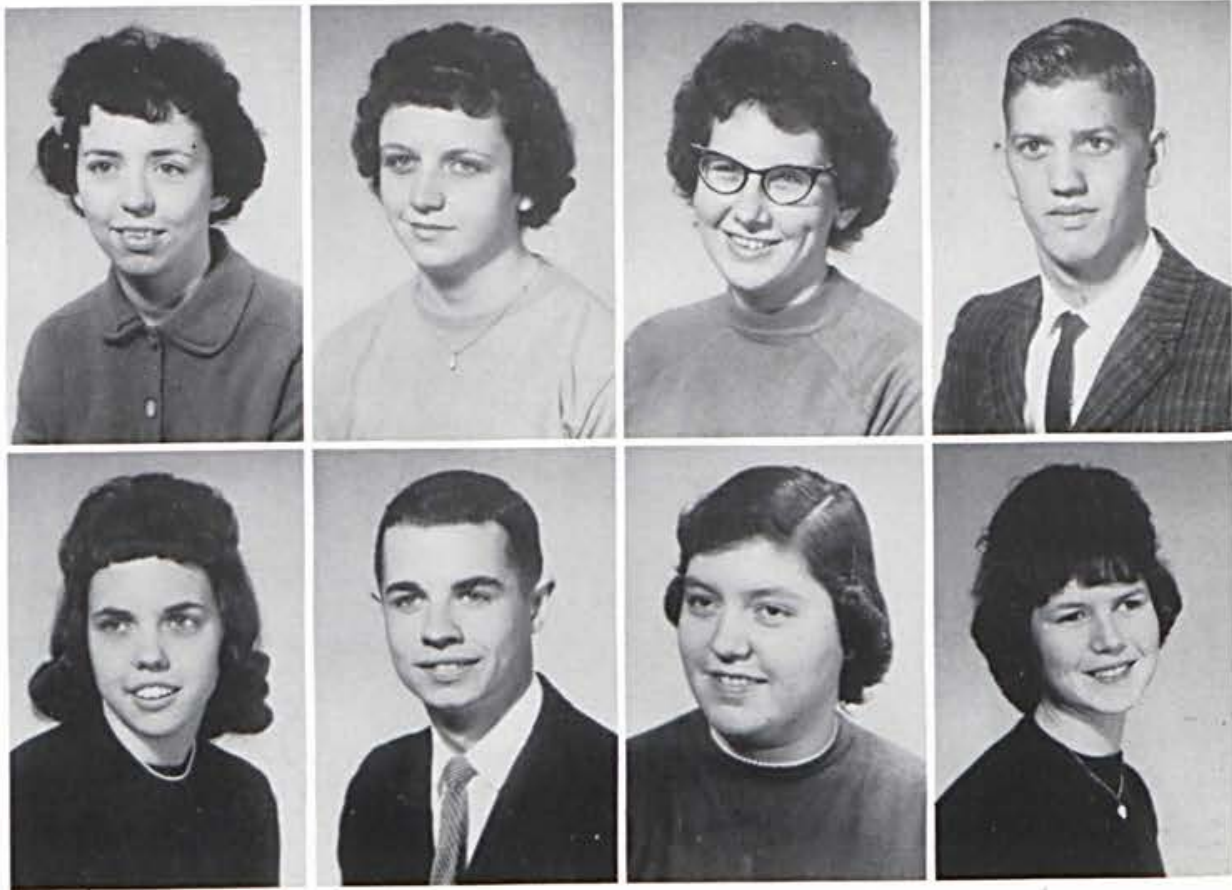
CHARLENE BLOEMER

South Fort Mitchell, Kentucky

Calvary Baptist Church

Covington, Kentucky

DAVE BLOSSOM

First Baptist Church

Vassar, Michigan

WARREN BURNSIDE

First Baptist Church

Randolph, New York

JOAN D. CARTER

First Baptist Church

Spartansburg, Pennsylvania

\section{WILLIAM CAULK}

Kittanning, Pennsylvanio

Worthington Baptist Church

Worthington, Pennsylvania

GORDON CHITTY

First Reformed Church

Xenia, Ohio

JOYCE CLEMENCE

Sandusky Street Baptist Church

Pittsburgh, Pennsylvania

DAVID LEWIS CLINE

First Baptist Church

Galion, Ohio

HANK COOK

Riverdale Baptist Church

Flint, Michigan

JOHN OMER COONS

Danville Baptist Church

Brownsburg, Indiana

BUD CONNELL

Springwells Baptist Church

Detroit, Michigan

HOWARD L. DAY

Temple Baptist Church

Portsmouth, Ohio
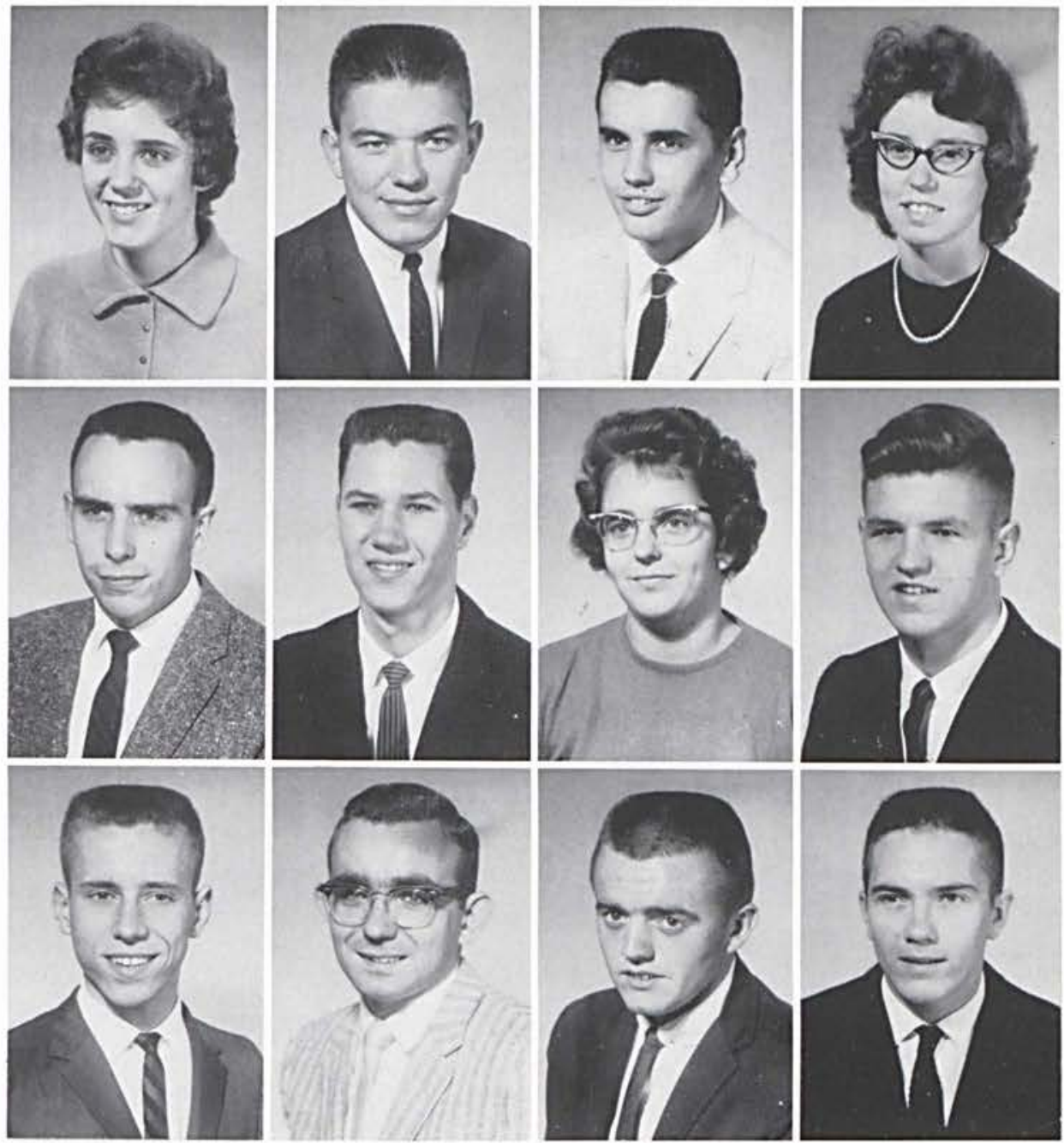
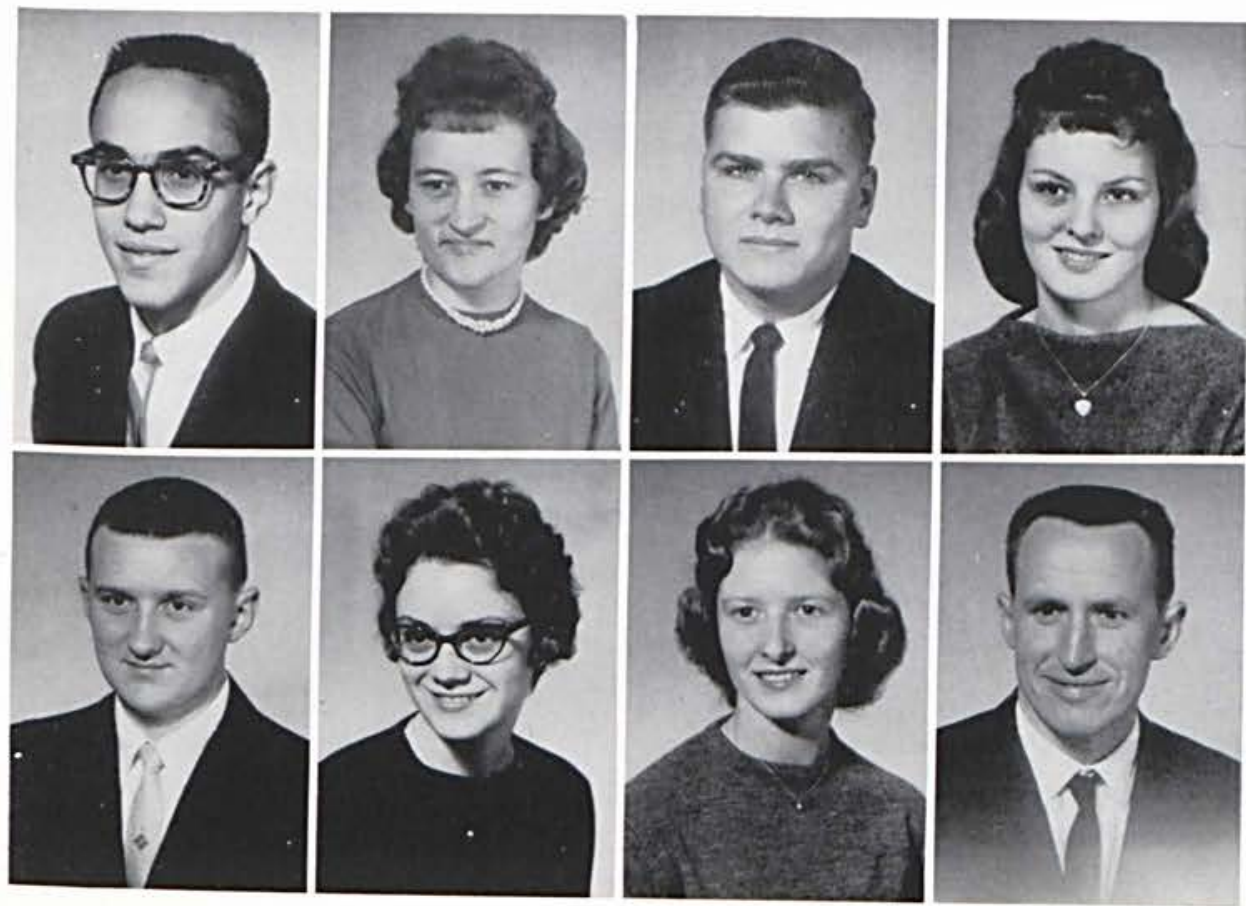

TOM DELANZO

Calvary Independent Church

New Castle, Pennsylvania

KARIN J. DE ROSSET

First Baptist Church

Evans City, Pennsylvania

NORMAN L. DEUGAN

Walnut Street Baptist Church

Lebanon, Indiana

NANCY DICKSON

Grace Baptist Church

De Queen, Arkansas

\section{GALE DODGE}

First Baptist Church

Caro, Michigan

BONNIE JEAN DUBOIS

First Baptist Church Mt. Pleasant, Michigan LOIS DUDDLESTON

Riverside Baptist Church

Decatur, Illinois

ROBERT E. EDWARDS

Sharon Springs, New York

Ames Baptist Church

Ames, New York 

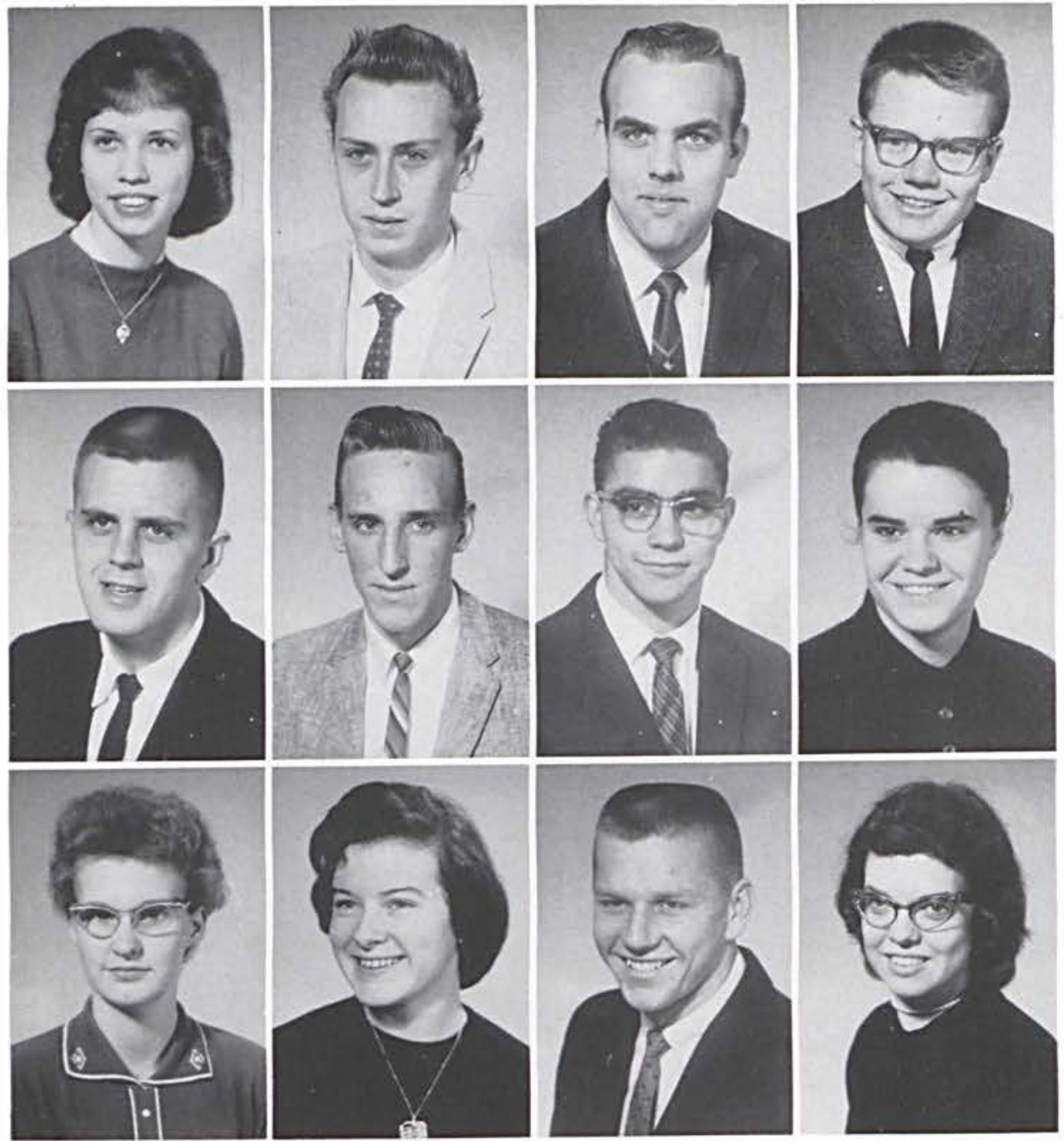

BETH ELMORE

Emmanuel Baptist Church Bloomington, Indiano

NORMAN EMERY

Calvary Independent Church

New Castle, Pennsylvania

MARK EVANS

Allen Park, Michigan

First Baptist Church

Lincoln Park, Michigan

TOM EVANS

Memorial Baptist Church

Columbus, Ohio

FRANK D. FARLEY, JR.

Temple Baptist Church

Portsmouth, Ohio

DAVE FETZER

Cedar Hill Baptist Church

Cleveland Heights, Ohio

GORDON FINLEY

First Baptist Church

Faribault, Minnesota

SUSAN LOUISE FULLHART

First Baptist Church

Perry, lowa

\section{SUZANNE GAY GEYSER}

Berea Baptist Church

Berea, Ohio

JUDITH MARIE GINGELL

Hunters Creek Independent Bible Church

Lapeer, Michigan

MELVIN A. GOODENOUGH

Grace Baptist Church

Saginaw, Michigan

SHIRLEY GOODMAN

First Baptist Church

Mentone, Indiana

\section{Freshmen}

MARY RAE GOODWIN

Tinley Park, Illinois

First Baptist Church

Harvey, Illinois

CAROLE M. GORTHEY

Broadalbin Baptist Church

Broadalbin, New York

FAYE MARIE HAAS

First Baptist Church

Randolph, New York

JOY HALBERG

Orchard Avenue Baptist Church

Vacaville, California

\section{DARLENE HALE}

Emmanuel Baptist Church

Toledo, Ohio

JIM HAMILTON

Wilmington, Delaware

Community Fellowship Church

Brookland Terrace, Delaware

KENNETH HAMILTON

Emmanuel Baptist Church

Traverse City, Michigan

JANET MARIE HAND

Midview Baptist Church

Grafton, Ohio
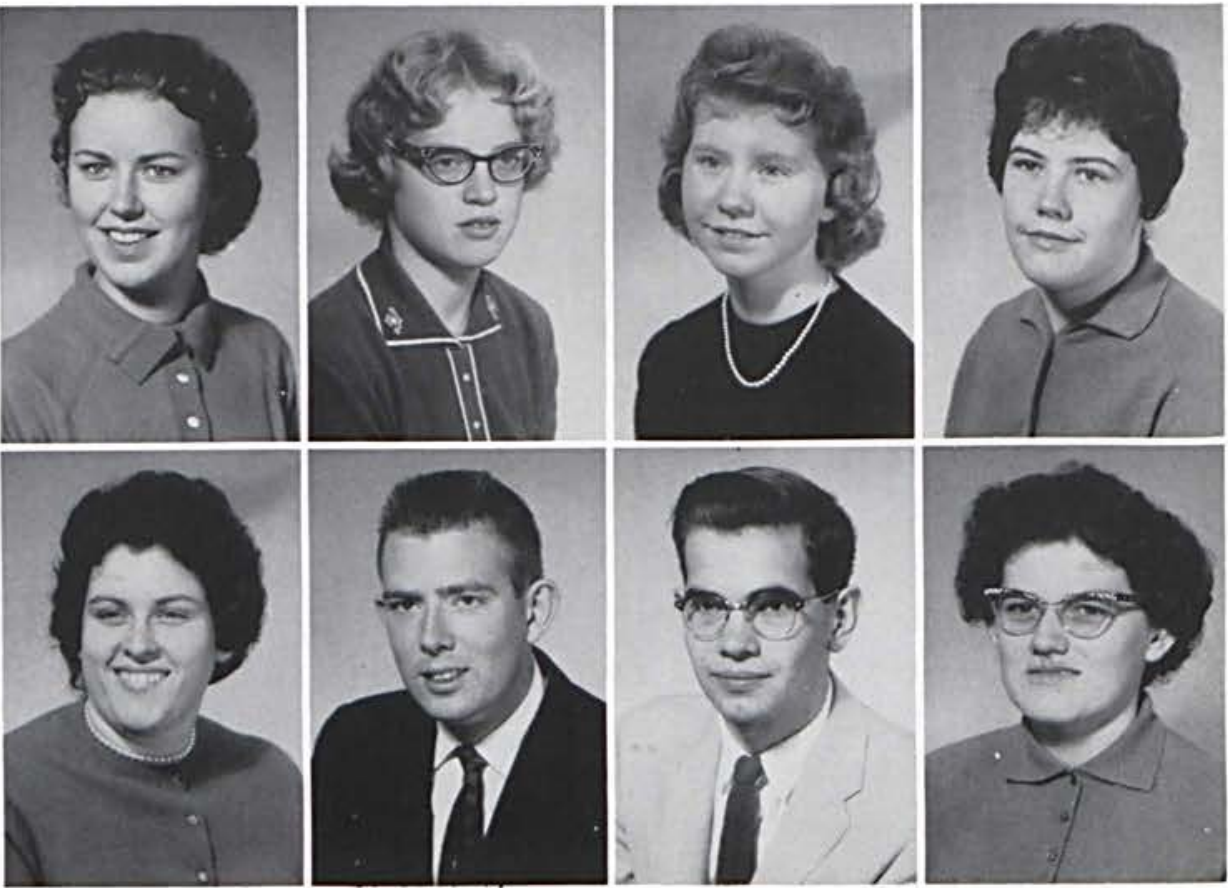
JEANE HARTSELL

North Adams Baptist Church

North Adams, Michigan

HARRY HARTZELL

First Baptist Church

Butler, Pennsylvania

LOUANN HAWKINS

Ravenna Baptist Church

Ravenna, Michigan

NORMA SMITH HICKS

South Bend, Indiana

Calvary Baptist Church

Quincy, Illinois

\section{ELSIE HIMSEL.}

Verona Memorial Baptist Church Verona, Wisconsin

BARRY LLOYD HODGES

Trotwood, Ohio

Westwood Baptist Church

Dayton, Ohio

JUDY F. HUFF

Locust Corners Baptist Church

Hudson, Michigan

JUDITH ANN HUMPHREYS

Calvary Baptist Church

Findlay, Ohio

\section{DIANA LOU HUNTER}

Fertile, lowa

Walnut Street Baptist Church

Waterloo, lowa

LAWRENCE R. ICE, JR.

Grace Gospel Church

Marietta, Ohio

VIRGINIA JACKSON

East Moline, Illinois

Silvis Baptist Church

Silvis, Illinois

LOIS M. JACOBSON

New Market Baptist Church

New Market, Ohio
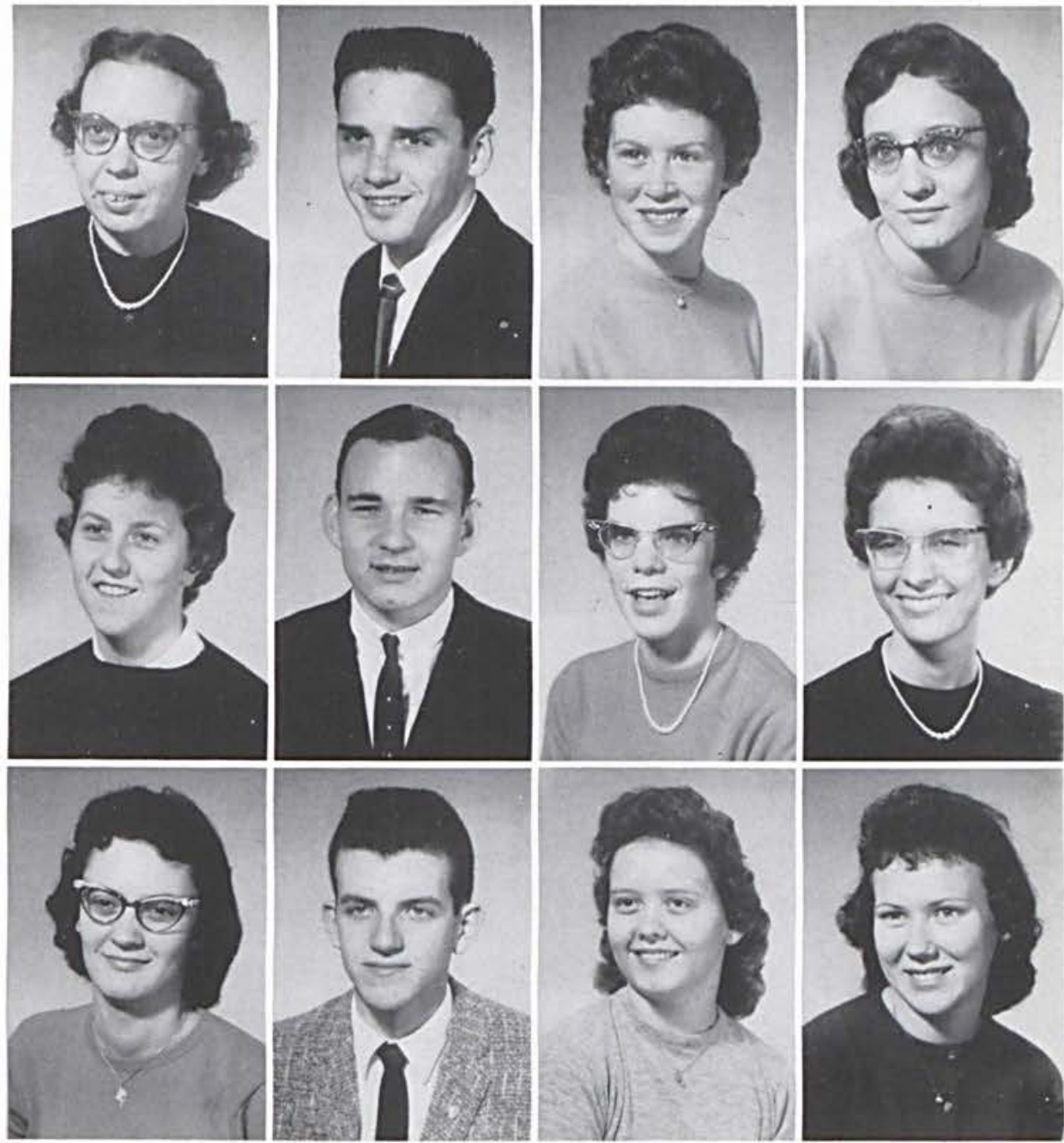
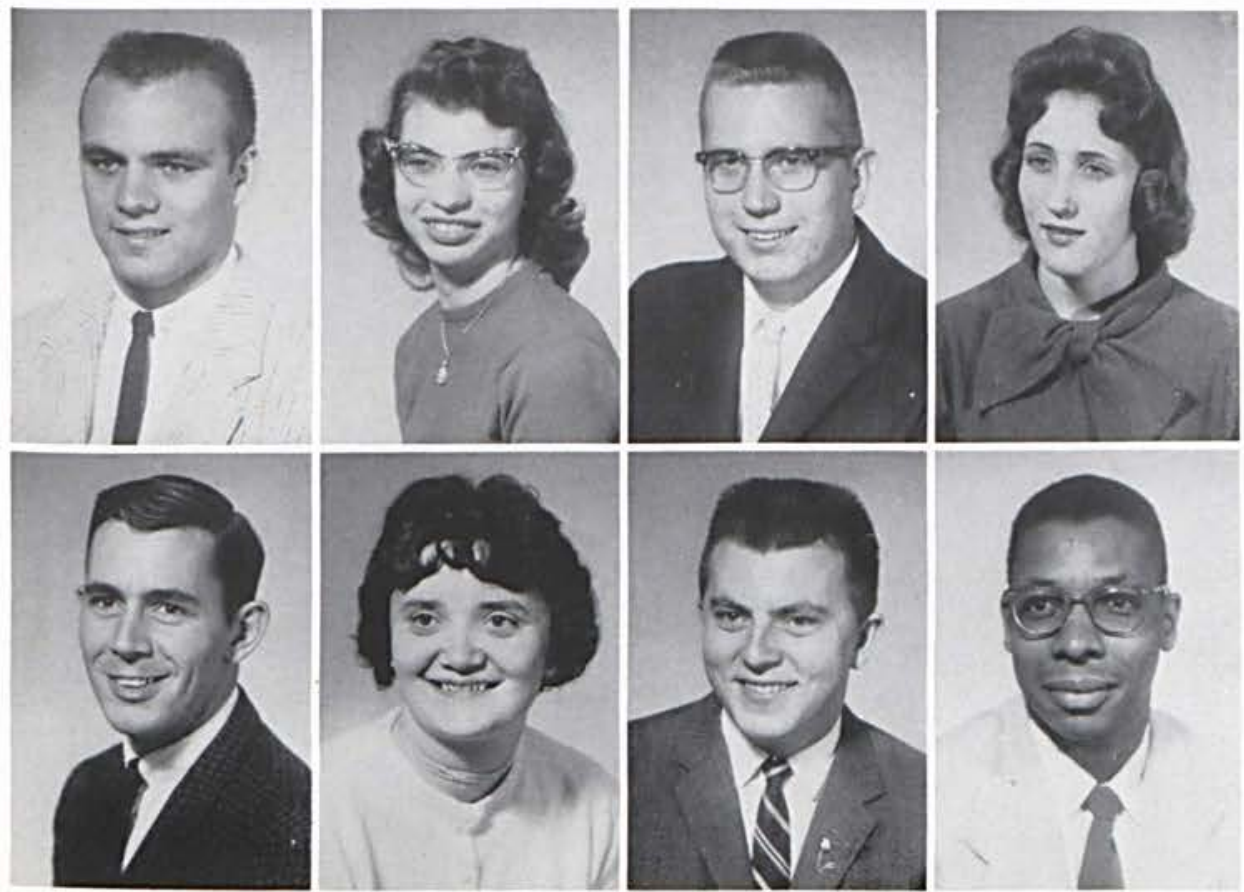

PHIL JEWETT

Rochester Baptist Church

Wellington, Ohio

DONNA LOU JOHNS

First Baptist Church

Grove City, Pennsylvania

GARY L. JOHNSON

Silvis Baptist Church

Silvis, Illinois

JOAN ELIZABETH JOHNSON

Cedar Hill Baptist Church

Cleveland, Ohio

\section{JAMES JOINER}

Central Baptist Church

Gary, Indiana

LOIS JOY

First Baptist Church

Elyria, Ohio

JAMES KEIM

Holsopple, Pennsylvania

Johnstown Bible Church

Johnnstown, Pennsylvania

WILLIAM A. KEYS

Pittsburgh, Pennsylvania

Mt. Olive Baptist Church

Rankin, Pennsylvania 

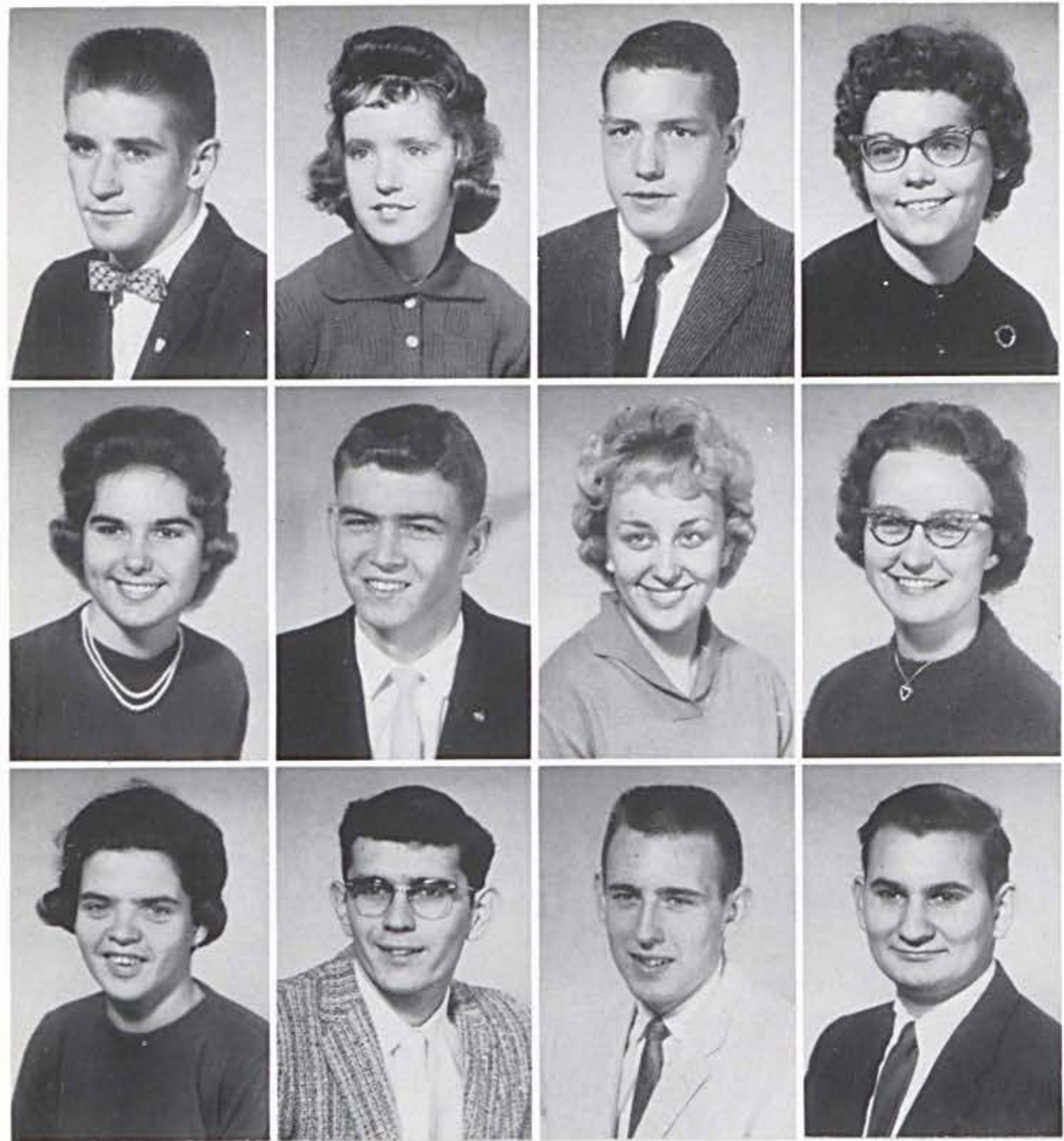

ELVIN KING

New London, Ohio

Rochester Baptist Church

Rochester, Ohio

KATHRYN M. KING

New London, Ohio

Rochester Baptist Church

Rochester, Ohio

C. L. KINGSLAND

Grace Bible Church

Owosso, Michigan

REAVA J. KRUMLAUF

St. Louis, Michigan

Emmanuel Baptist Church

Traverse City, Michigan

CAROLE A. KUNEY

Sheridan, Michigan

Stanton Baptist Church

Stanton, Michigan

ROD LANE

Midland, Ohio

First Baptist Church

Blanchester, Ohio

LINDA LARSON

Grove Avenue Baptist Church

Racine, Wisconsin

JOAN G. LEWISTON

First Baptist Church

Perry, lowa

JANET MC CLISH

Sharon Baptist Church

Sharon, Pennsylvania

CHARLES A. MC COMBER

St. Clair Baptist Church

St. Clair, Michigan

DENNIS MC DONALD

First Baptist Church

Lake Orion, Michigan

GEORGE MALIS

Columbia Station, Ohio

Berea Baptist Church

Berea, Ohio

\section{Freshmen}

JAMES PERRY MAPLE

Evangelical Free Church

Valparaiso, Indiana

JUDY MARCELLUS

West Chicago Baptist

Detroit, Michigan

SHERYL MARTIN

Emmanuel Baptist Church

Fort Wayne, Indiana

RONALD D. MICK

First Baptist Church

Monroe, lowa

PATRICIA ANNE MICKA

Ridgefield Park, New Jersey

First Baptist Church

Hackensack, New Jersey

RITA MILLIKIN

Kalkaska Baptist Church

Kalkaska, Michigan

DAVID R. MILLS

Berean Baptist Church

Grand Rapids, Michigan

JOHN K. MOODY

West Side Baptist Church

Lorain, Ohio
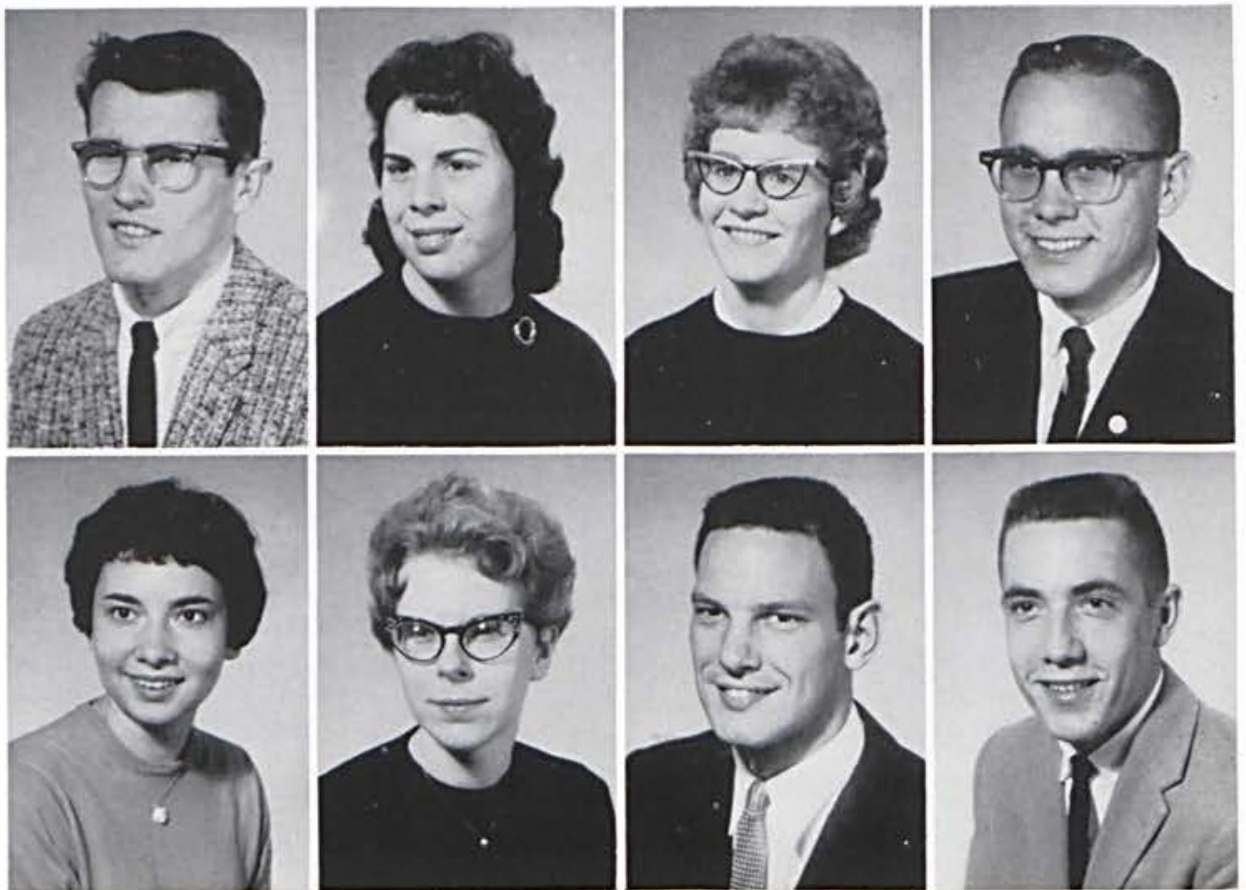
RONN MOONEY

Calvary Independent Church

New Castle, Pennsylvania

JAY W. MOORE

Memorial Baptist Church

Verona, Wisconsin

JOHN MORGAN

Dysart, lowa

Calvary Baptist Church

Traer, lowa

DAVE MORGANTI

St. Joseph Parish

New Castle, Pennsylvania

\section{ALLEN MUMFORD}

Apostolic Christian Church

Francesville, Indiana

BONNIE MAE NASH

Calvary Baptist Church

Midland, Michigan

NORMAN A. NICKLAS

Callery, Pennsylvania

First Baptist Church

Evans City, Pennsylvania

STEVE NIMMO

Cedar Hill Baptist Church

Cleveland Heights, Ohio

\section{ED NORRIS}

Rochester, Indiana First Baptist Church

Argos, Indiana

DARIUS D. NUTT

Wellington, Ohio

Letchfield Baptist Church

Letchfield, Ohio

ROGER O'BRYAN

First Baptist Church

Eldora, lowa

BETTY ELAINE PALMER

Emmanuel Baptist Church

Columbus, Ohio
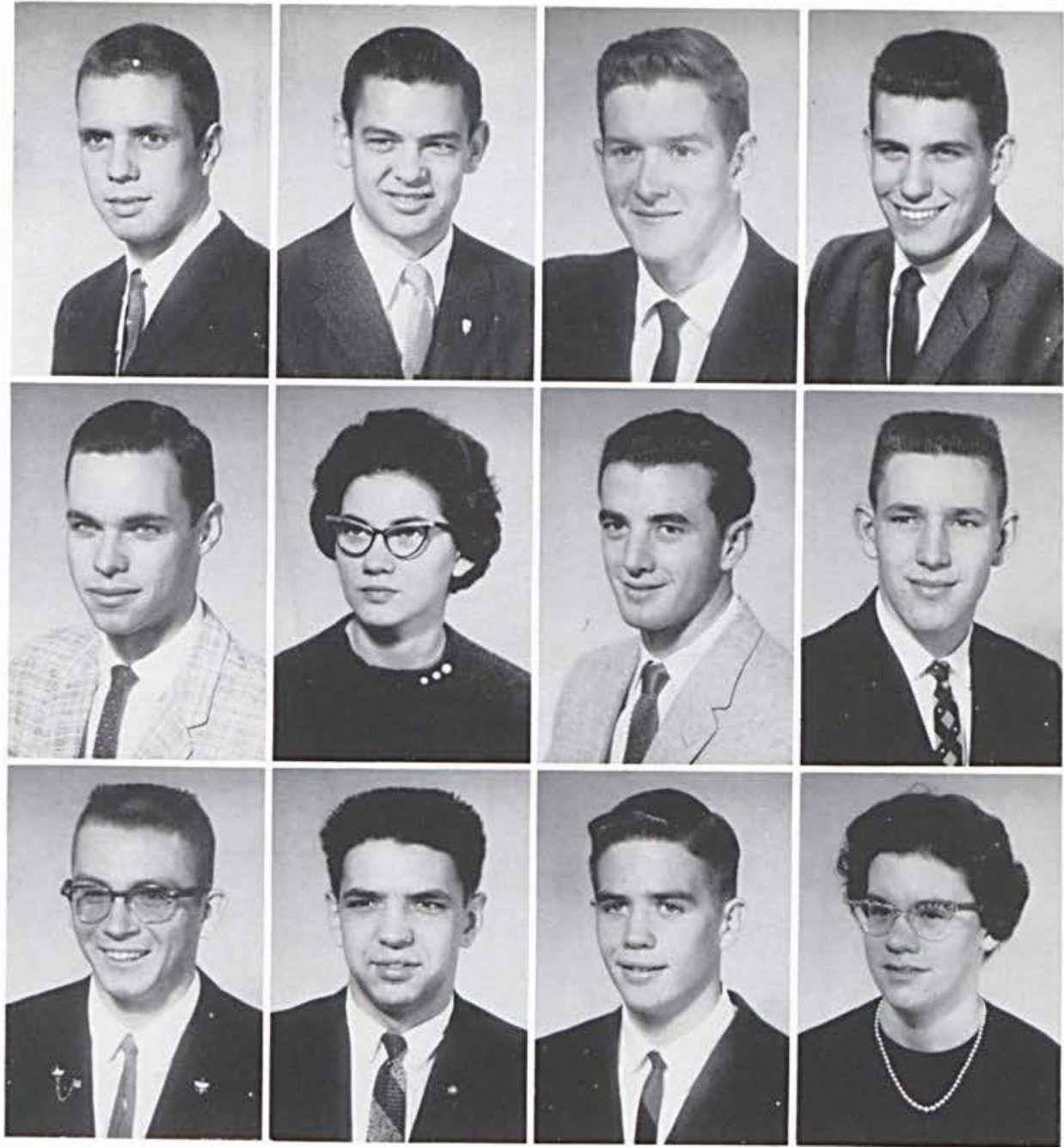
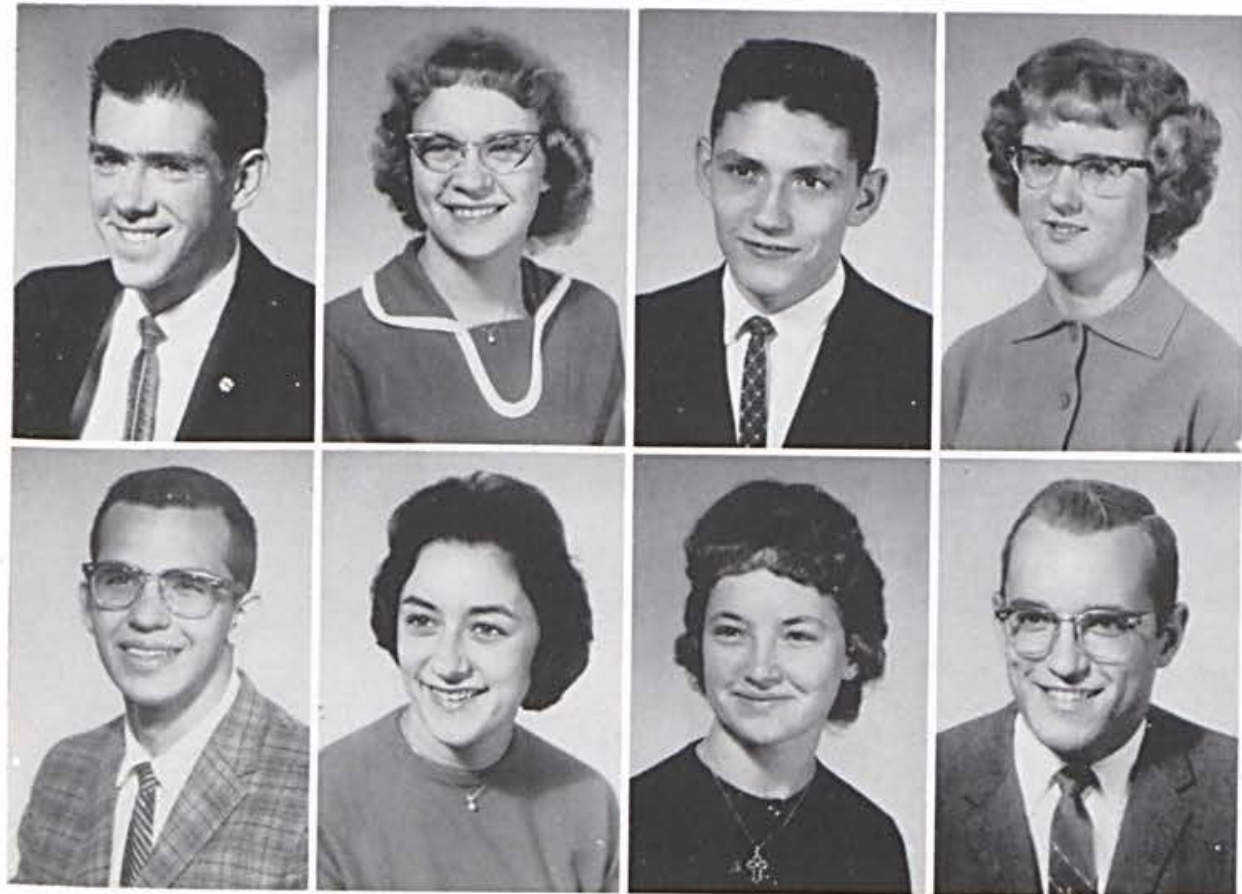

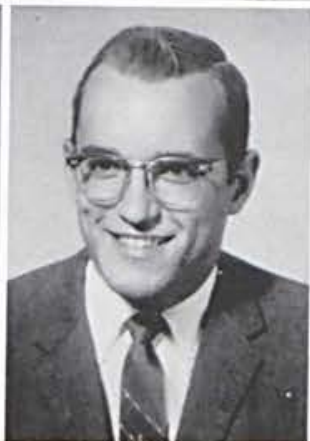

TOM PATTERSON

MARY ELLEN POWELL

Renfrew, Pennsylvania

First Baptist Church

Evans City, Pennsylvania

ROBERT D. REYNOLDS

First Reformed Church

Xenia, Ohio

SHARON DAWN RICHARDSON

Leonard Heights Baptist Church

Grand Rapids, Michigan

\section{WILLIAM RITER}

Community Baptist Church

Deerfield, Illinois

DOROTHY ROCKENSTEIN

Grace Baptist Church

Rocky River, Ohio

AMY ROE

Metamora, Michigan

First Baptist Church

St. Lovis, Michigan

LYLE D. ROSE

Grace Baptist Church

Moweaqua, Illinois 

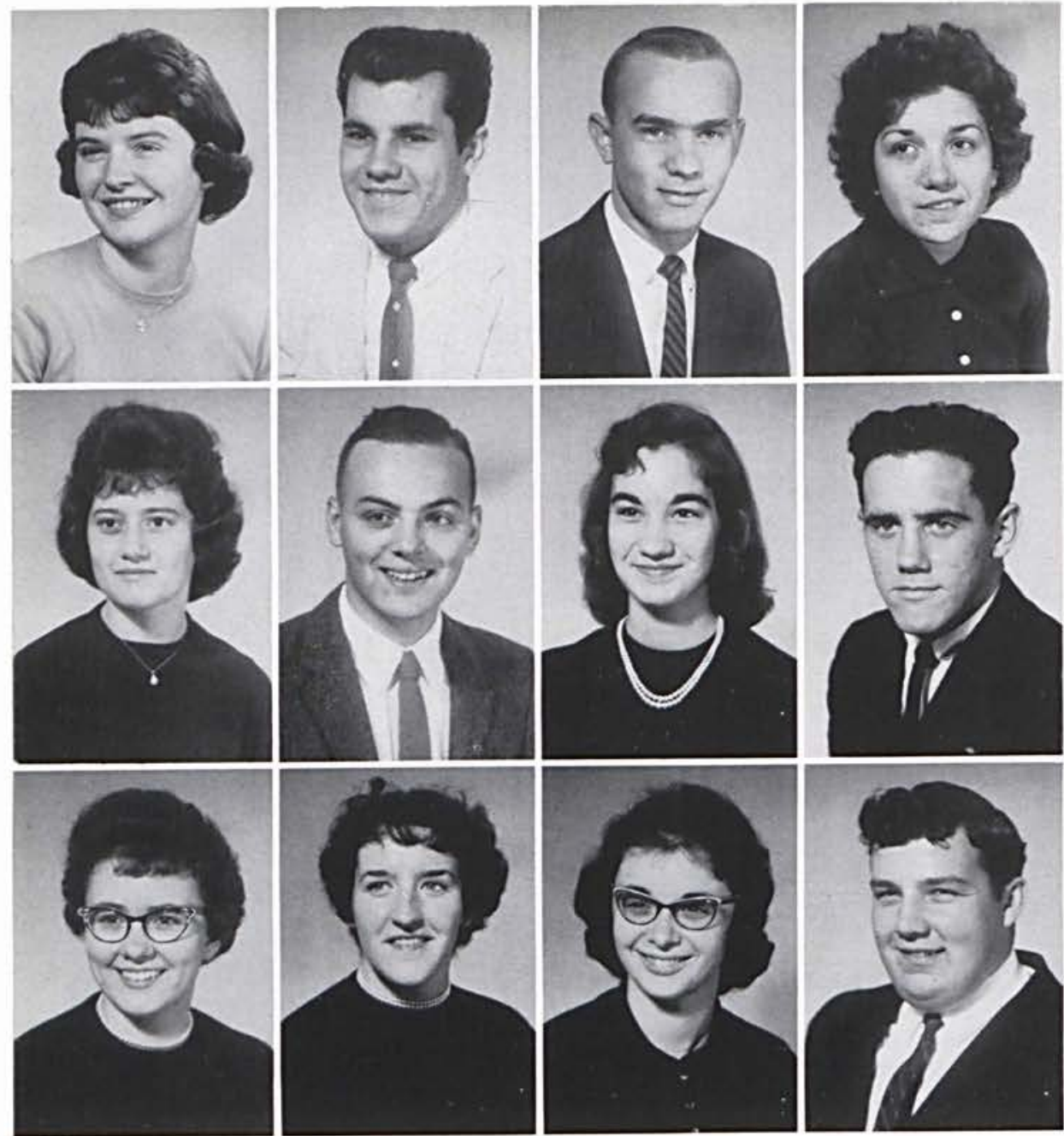

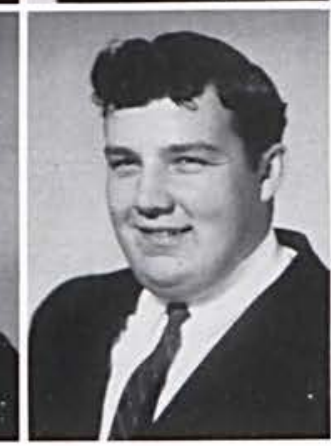

GLADYS ROSS

First Baptist Church of Hazel Park

Hazel Park, Michigan

TONY ROTONDI

Teaneck, New Jersey

First Baptist Church

Hackensack, New Jersey

CHESTER L. RUSSELL

East Side Baptist Church

Crawfordsville, Indiana

RUTH ANN SCHLOSSER

Calvary Baptist Church

Creasaptown, Maryland

BETTY LOU SCHULTZ

Hunters Creek Independent Bible Church Lapeer, Michigan

DAVID SEARLES

Camden Baptist Church

Wellington, Ohio

NANCIE ELLEN SHIMITS

Hayden Avenue Baptist Church

Cleveland, Ohio

LAYTON SHOEMAKER

Deanville Baptist Church

Deanville, Pennsylvania

\section{EDNA LOUISE SHRIDER}

Fostoria Baptist Church

Fostoria, Ohio

BARBARA SLAVENS

Pleasant View Baptist Church

Crawfordsville, Indiana

ELEANOR SMELSER

First Baptist Church

Medina, Ohio

DOUG SMITH

Bucyrus, Ohio

First Baptist Church

Galion, Ohio

\section{Freshmen}

\section{JUDIE SMITH}

Immanuel Baptist Church Traverse City, Michigan

NANCY SMITH

Kirkersville, Ohio

Bible Mission Baptist Church

Reynoldsburg, Ohio

SHARON LEE SMITH

First Baptist Church

Greenfield, Indiana

JANE SMOKER

McCoy Memorial Baptist Church

Elkhart, Indiana

\section{SHERRY SUE SOUTHWELL}

Mancelona, Michigan

Kalkaska Baptist Church

Kalkaska, Michigan

JAMES SPRAGUE

South Lyon, Michigan

Tri-Lakes Baptist Church

Brighton, Michigan

JERRY E. STAFFORD

Townsend Avenue Baptist Church

Baltimore, Maryland

WAYNE STANEHFIELD

Bangor, Maine

Emmanuel Baptist Church

Xenia, Ohio
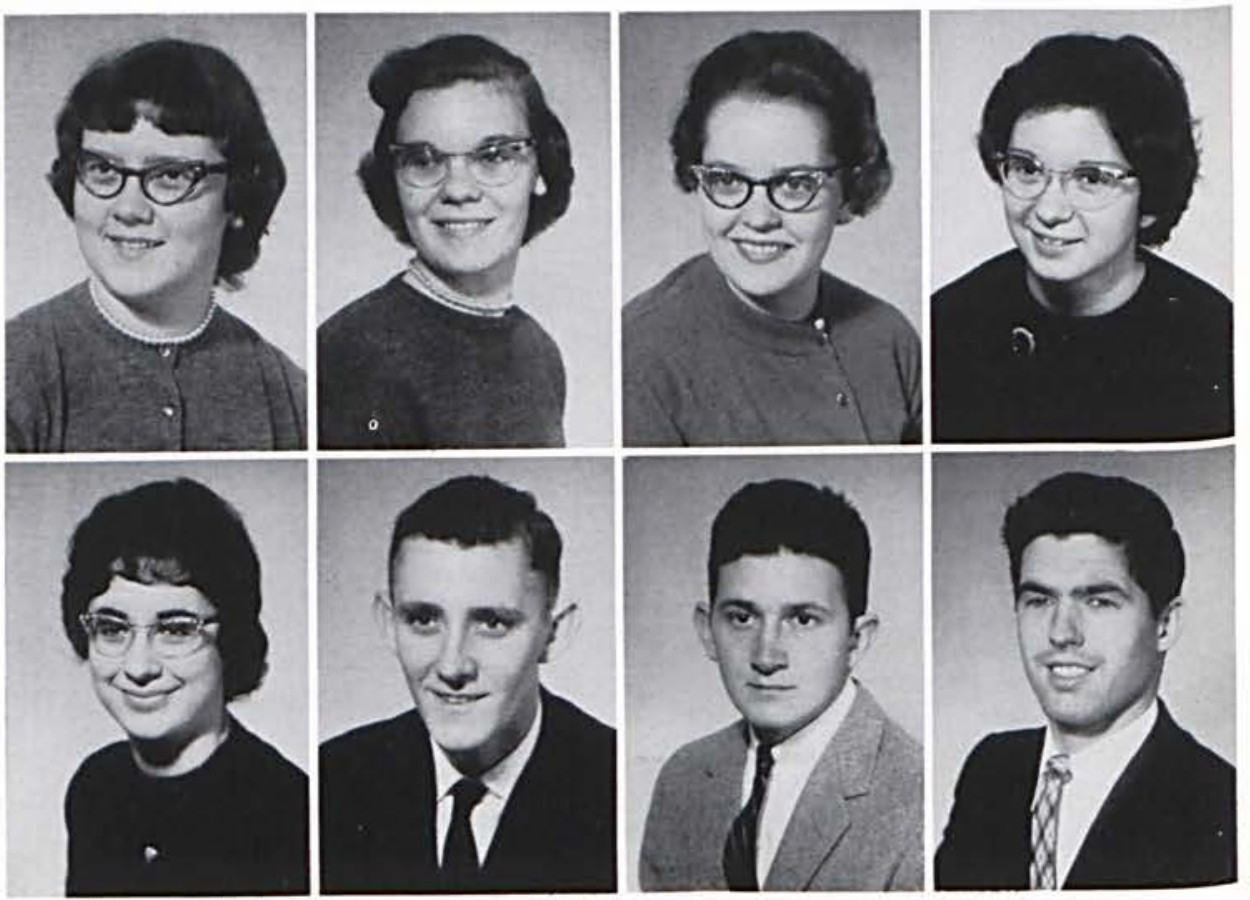
MARGARET ELIZABETH STOWELL

First Baptist Church

Hackensack, New Jersey

CARL SWANDER

Open Door Bible Church

Hudson, Michigan

JANICE SWANDER

Open Door Bible Church

Hudson, Michigan

KENNETH SWIGART

Dexter, lowa

Grace Baptist Church

Winterset, lowo

DAVID E. TAYLOR

First Baptist Church

Blanchester, Ohio

PATRICIA JANE TERRY

Calvary Baptist Church

Ypsilanti, Michigan

ANNA TITUS

Pleasant View Baptist Church

Crawfordsville, Indiana

DAVID BRUCE TRUMBULL

LaVale, Maryland

Calvary Baptist Church

Cresaptown, Maryland

BARBARA UNZICKER

Claypool, Indiana

First Baptist Church

Mentone, Indiano

SHIRLEY VAN ALLEN

Caro First Baptist Church

Caro, Michigan

SHARON VAN GORP

Calvary Baptist Church

Highland, Indiana

EDWARD C. VILLALBA

Trinity Baptist Church

Taylor, Michigan
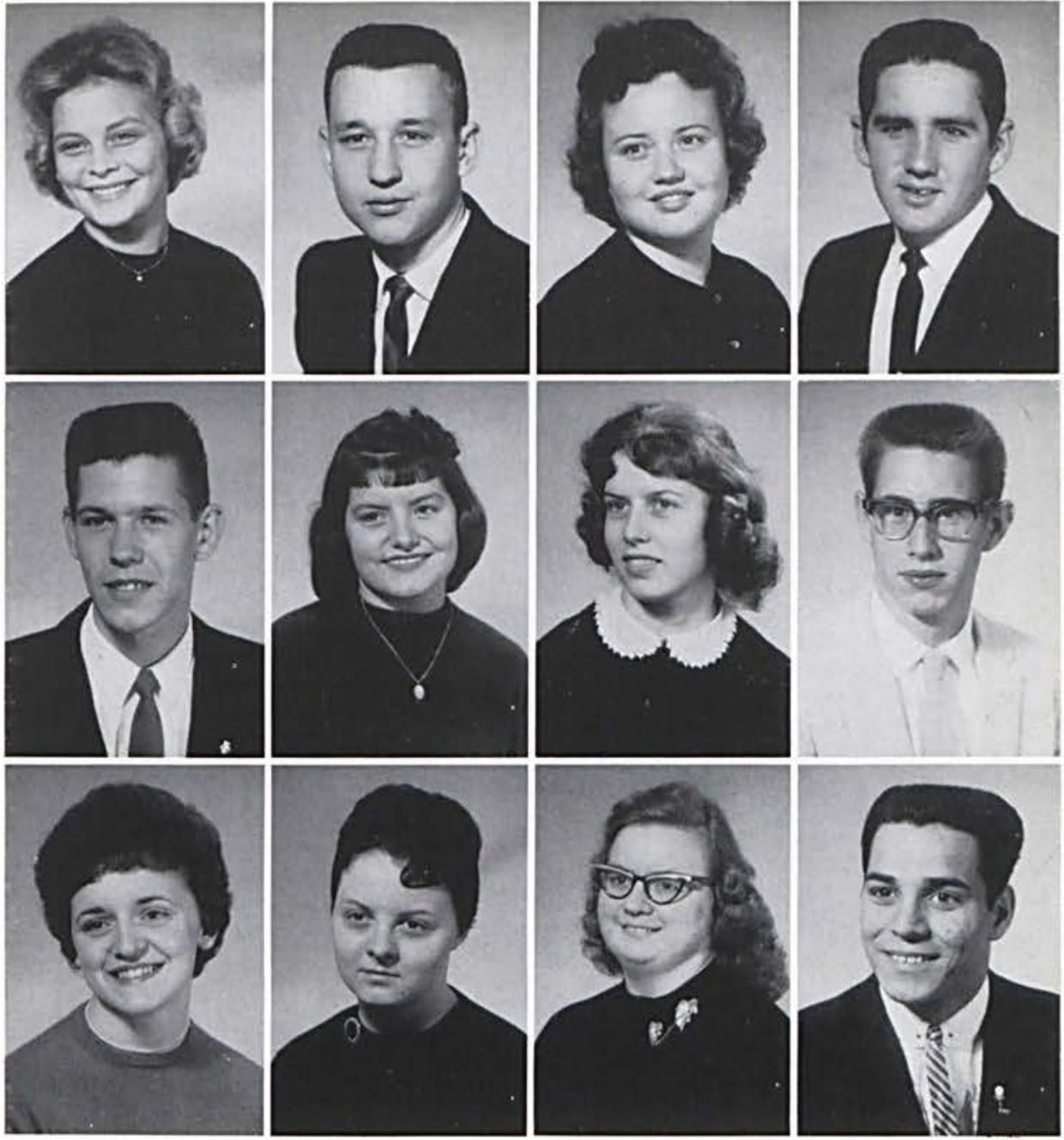
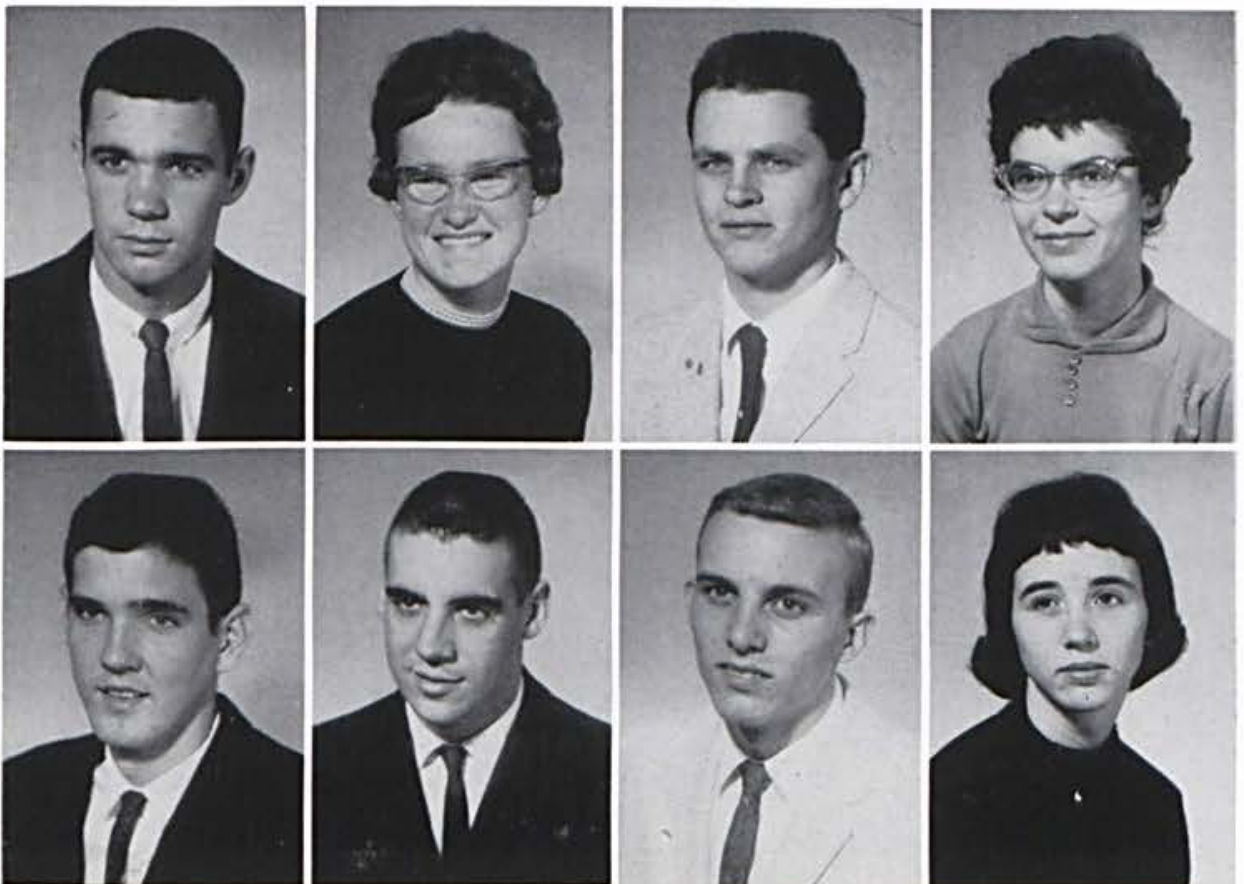
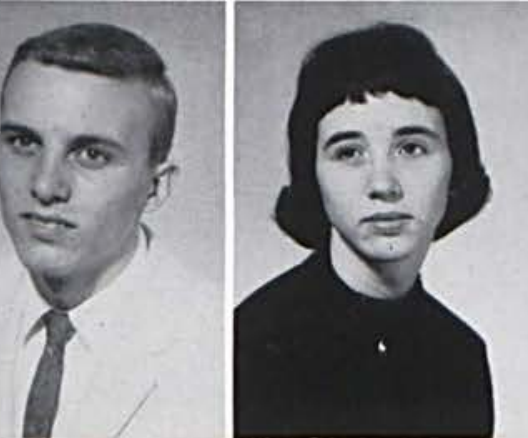

FRASER VIPOND

Kalkaska Baptist Church

Kalkaska, Michigan

JOYCE E. WALKER

First Baptist Church

Bowling Green, Ohio

T. JAMES WALKER

First Baptist Church

Soap Lake, Washington

BETTY WALL

Riverside Baptist Church Decatur, Illinois

\section{GARY WALTHALL}

Xenia Bible Church

Xenia, Ohio

PAUL WARNER

East Lenord Baptist Church

Grand Rapids, Michigan

DAVE WARREN

Trinity Baptist Church

Taylor, Michigan

SANDI WELCH

Bellbrook, Ohio

Dayton Baptist Temple

Dayton, Ohio 

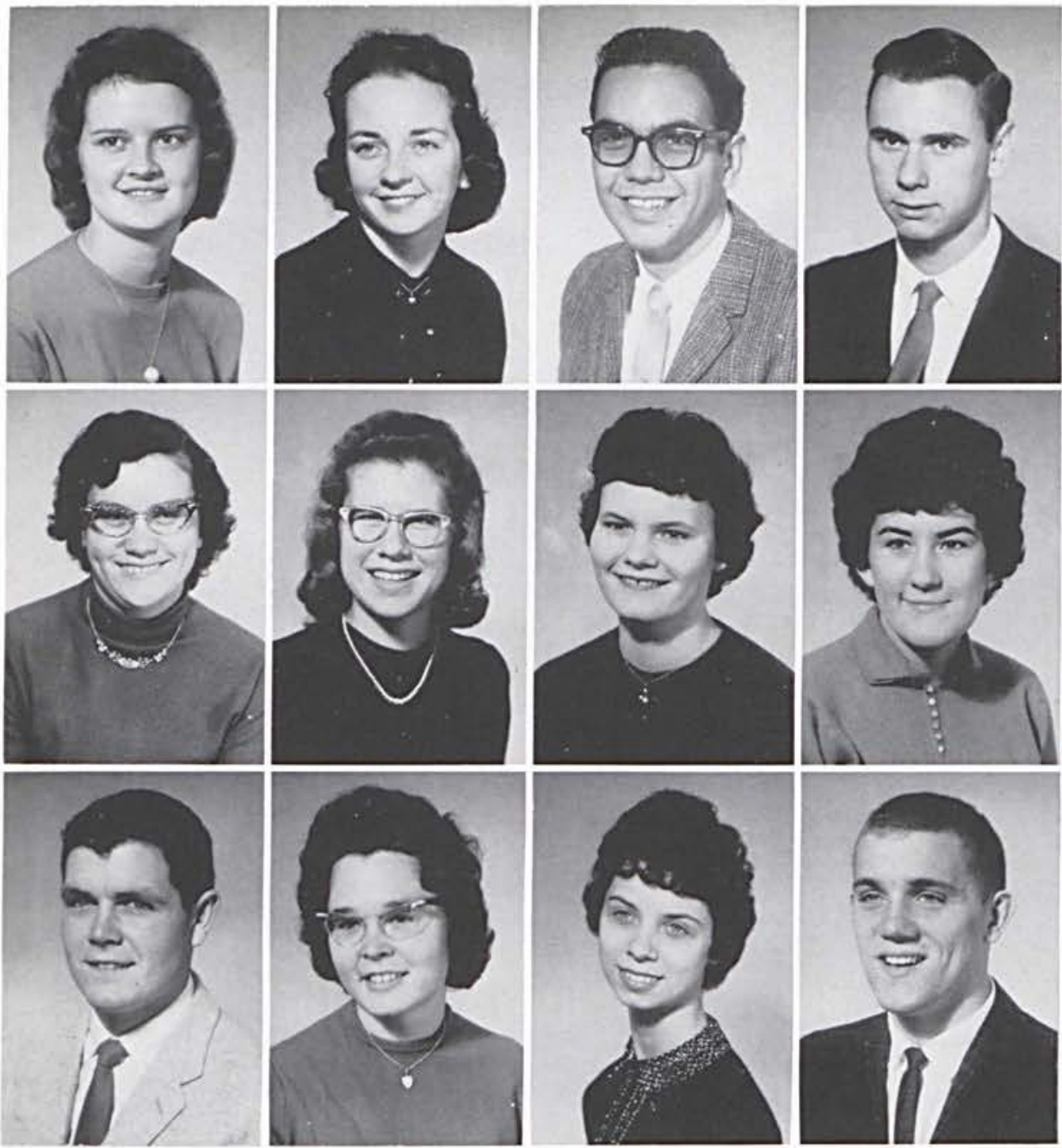

SPECIAL STUDENT

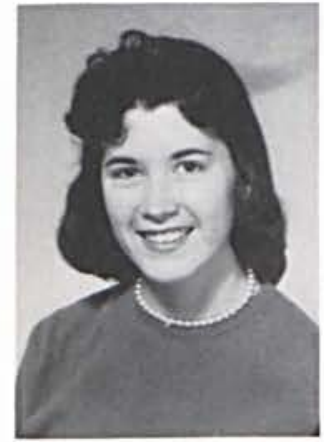

\section{Freshmen}

BONNIE MAYES

First Baptist Church

Hamilton, Ohio
Not pictured

GARY LEE FOGLE

St. Paul Methodist Church Dayton, Ohio

JOHN M. JUSTICE

Grace Gospel Church

Hayesville, Ohio

CARL STWEART

Central Baptist Church

Gary, Indiana
MARY ELLEN WEST

Bethel Baptist Church

Warren, Ohio

SANDRA L. WHITEKER

South Charleston, West Virginia

Randolph Street Baptist Church

Charleston, West Virginia

RICHARD WHITE

Crown Point, Indiana

First Baptist Church

Merrillville, Indiana

DALE WHITING

Grandview Park Baptist Church

Des Moines, lowa

\section{JERI WICKELL}

Calvary Baptist Church

Quincy, Illinois

HOPE MARIE WILLIE

First Baptist Church

Faribault, Minnesota

JUNE WILLMINGTON

Calvary Baptist Church

Quincy, Illinois

CARMEN WITT

Calvary Baptist Church

Quincy, Illinois

DAVID ALLEN WOODMAN

First Baptist Church

Bay City, Michigan

JUDY WALBORN

SALLY YODER

Grace Chapel Church

West Liberty, Ohio

RICHARD ZANDSTRA

Calvary Baptist Church

Grand Rapids, Michigan

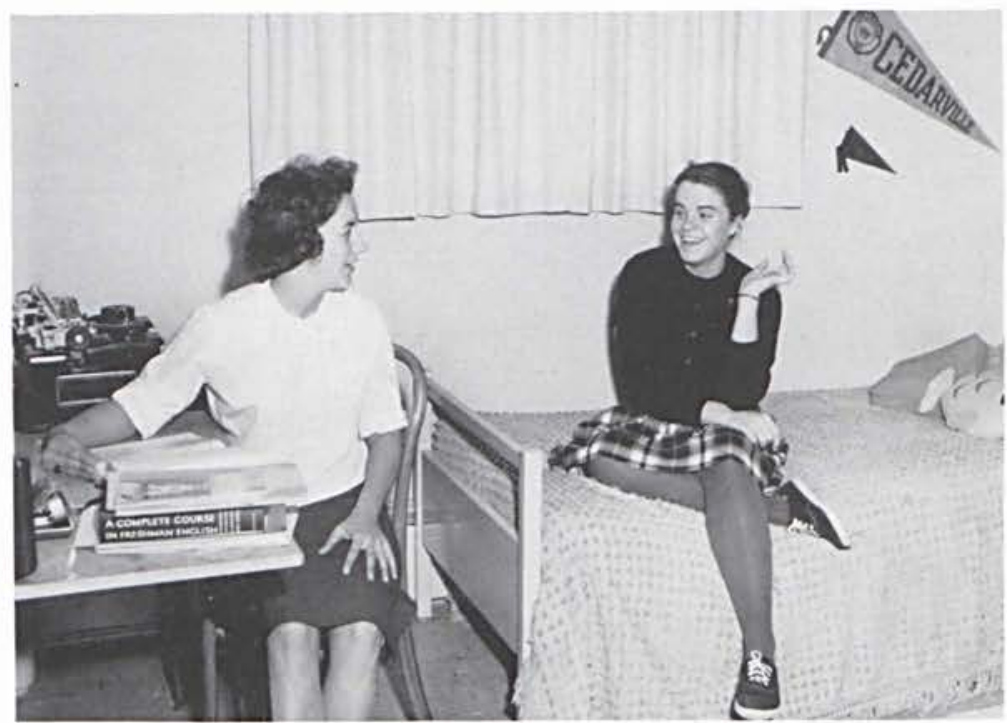

It's easier for Freshmen to gab than to study. 

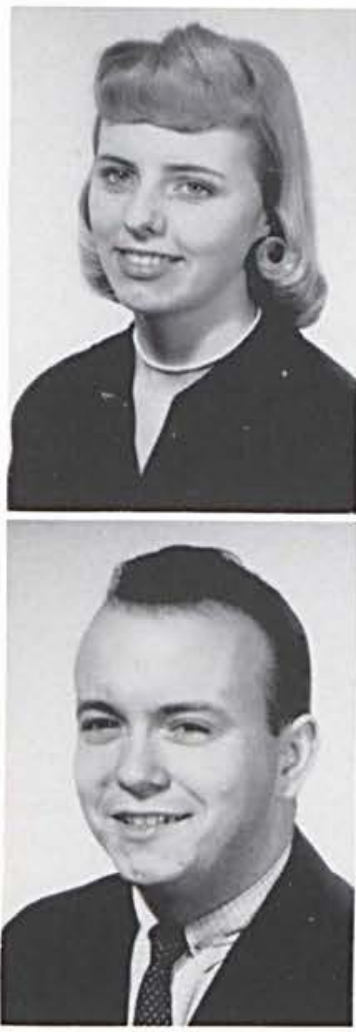

DONNA DAVIS

West Chicago Baptist Church

Detroit, Michigan

JOHN INGRAM

Emmanual Baptist Church

Columbus, Ohio
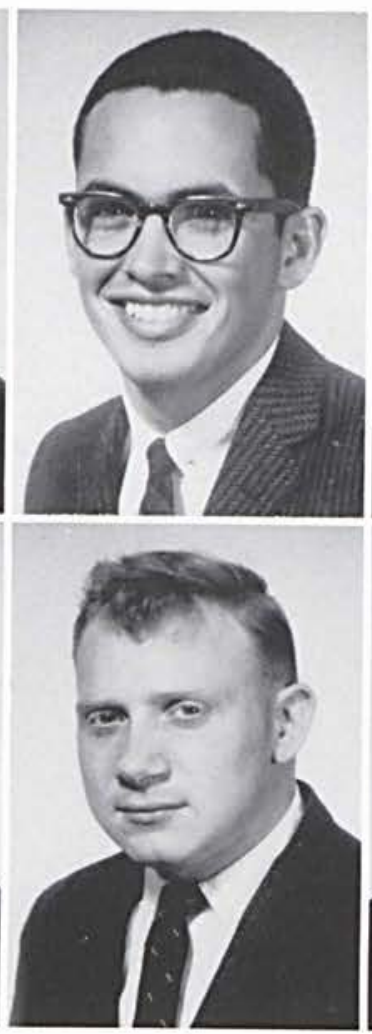

BILL ELDER

Emmanuel Baptist Church Marion, Ohio

RICHARD KENSINGER

Newhall Baptist Church Grand Rapids, Michigan
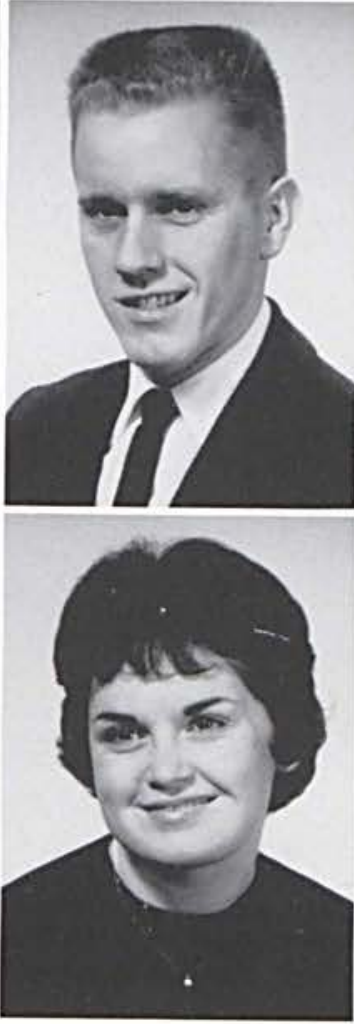

BILL EUBANK

Sharon Baptist Church Sharon, Pennsylvania

SANDY KIDDER

McCoy Memorial Baptist

Church

Elkhart, Indiana
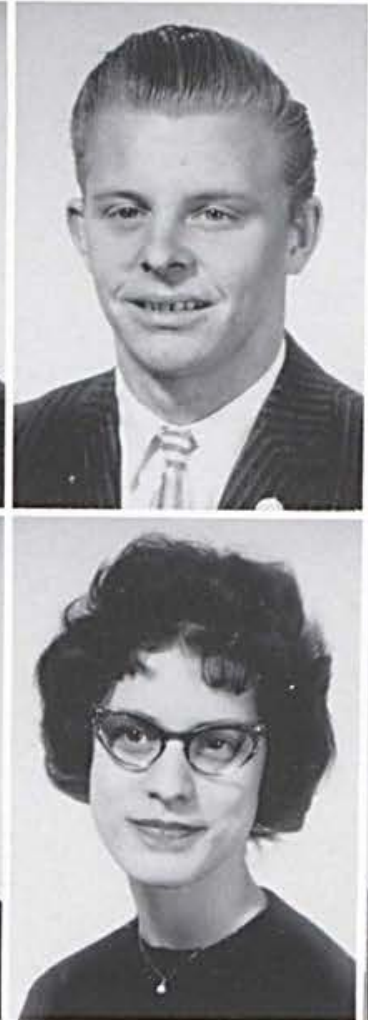

RICHARD FORSYTH

South Vermont Avenue Church

Los Angeles, Californio

JUDY LEIBY

Chelsea Baptist Church

Atlantic City, New Jersey
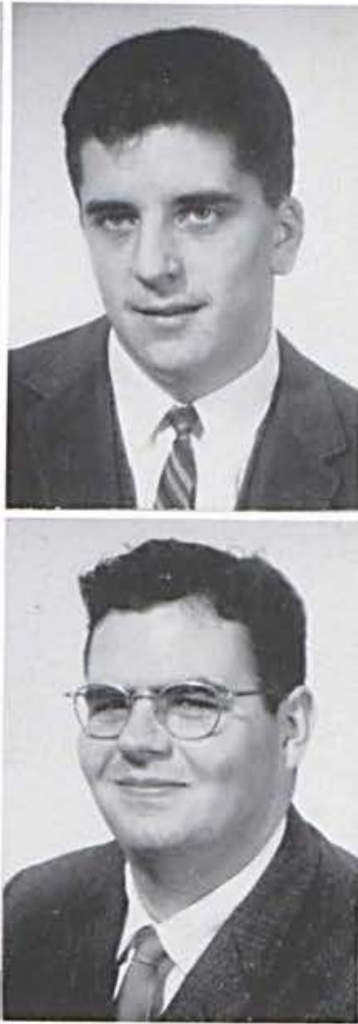

JOHN GAYER

First Baptist Church Medina, Ohio

JOSEPH LLOYD

First Baptist Church Elyria, Ohio

\section{Second Semester Students}

ELIZABETH PRICE

Memorial Baptist Church

Columbus, Ohio

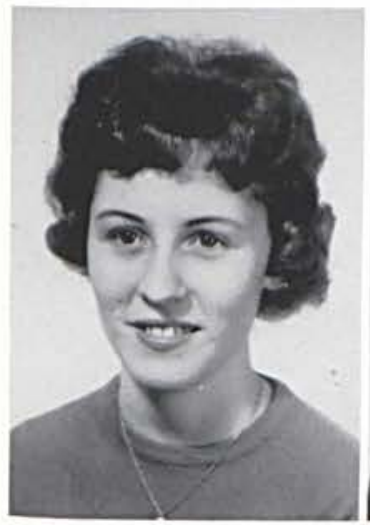

BEVERLY ROACH

Berean Baptist Church

Granada Hills, California

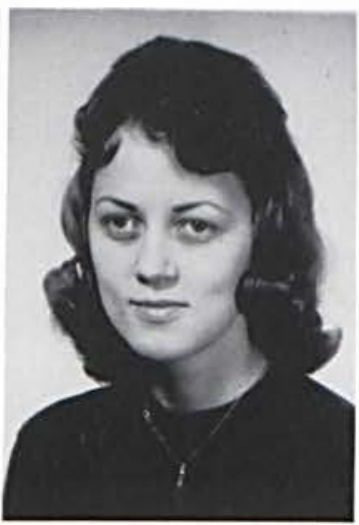

SANDRA SHANKS

Calvary Bible Church

Columbus, Ohio

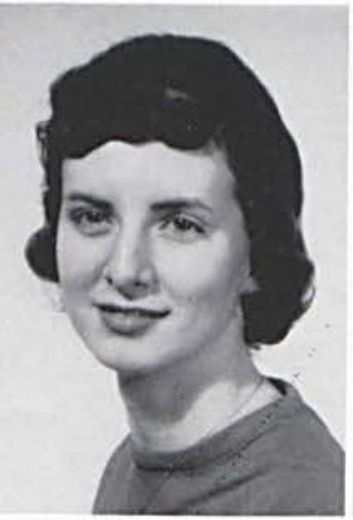

VIKI WOOSTER

Calvary Baptist Church

Bellefontaine, Ohio

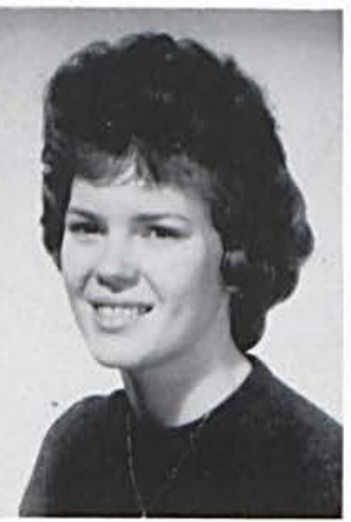

Not Pictured:

VANCE ASHLEY

WILLIAM EICKELBERG

RUTH NEPHEW

JAMES PARKER

DAVID PERRY 


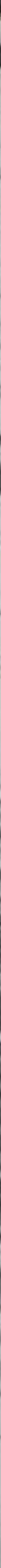

GETTING TO KNOW many Christian friends and growing to UNDERSTAND them and ourselves has filled our college life this year with WARMTH and BEAUTY through the times when "the cherished fields put on their winter-robe of purest white" to when our campus is clothed in "the gorgeous blooms of May." And so we finish another year of LOOKING TOGETHER. 


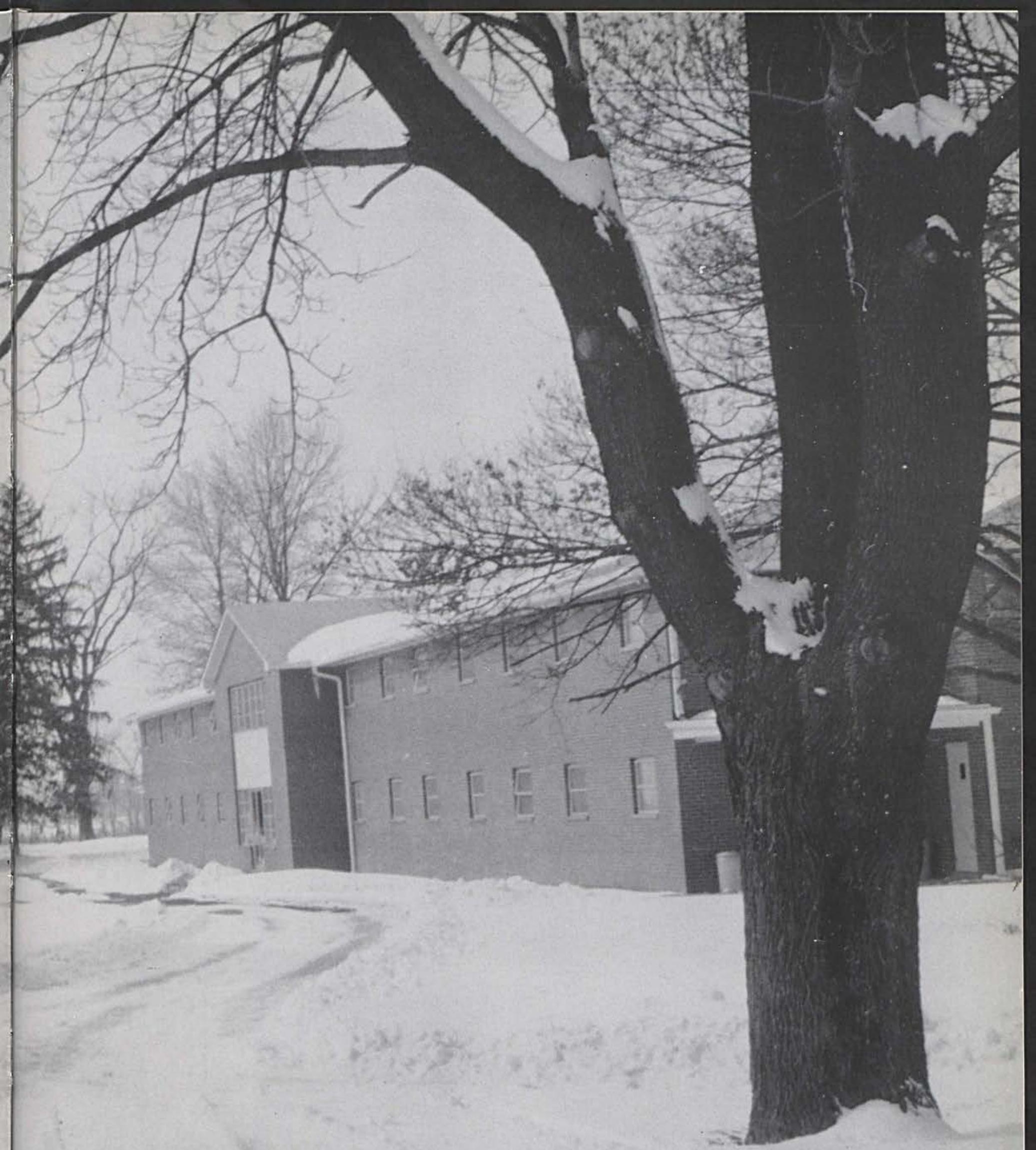




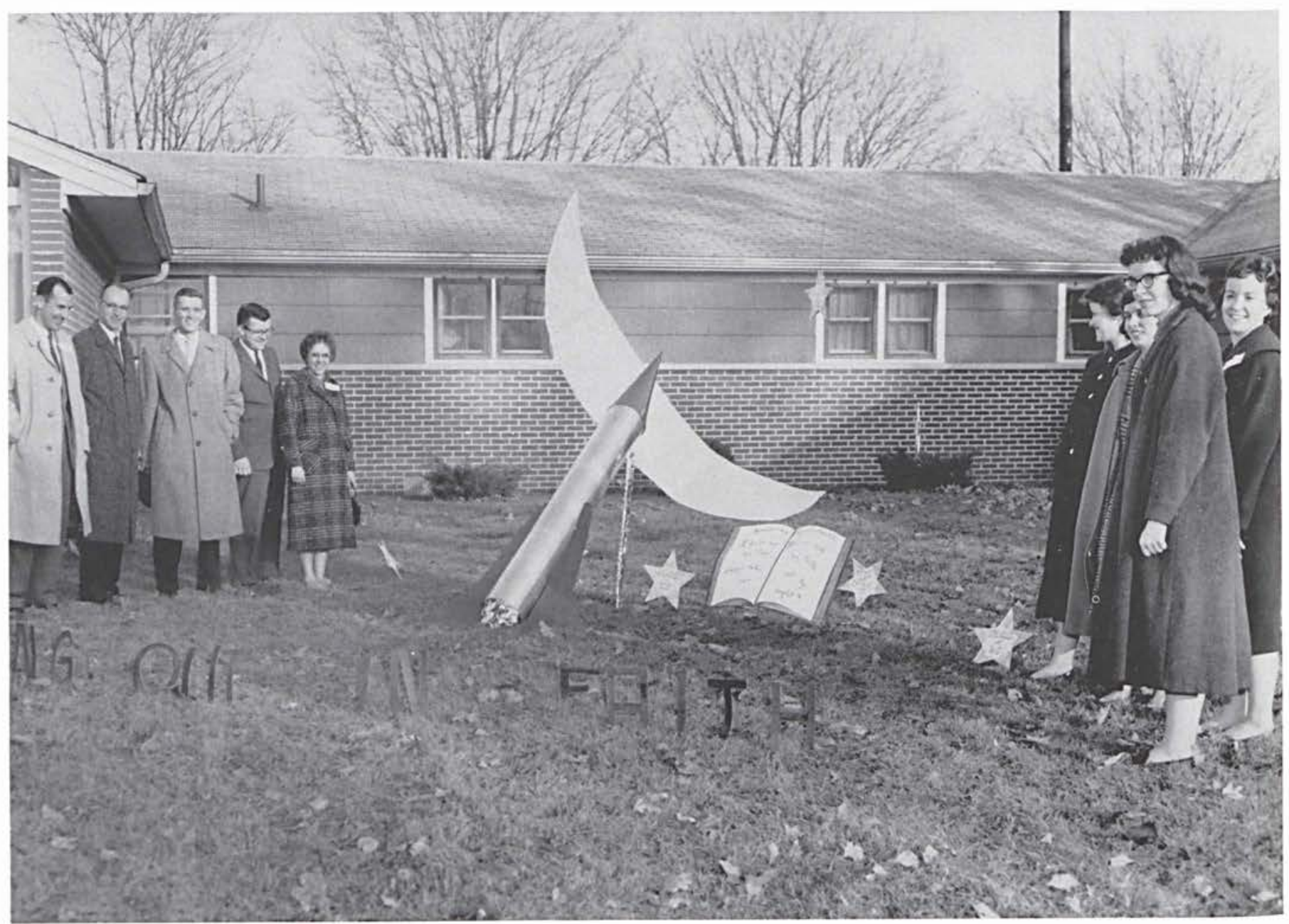

A recent group of alumni gather before the Faith Hall Homecoming display.

\section{Alumni Association}

OFFICERS
President
Vice-President_- Dale Thomson
Secrefary-Treasurer
Regional Vice-President:
$\quad$ Cleveland _
Grand Rapids

The enthusiastic and loyal alumni are always seeking to find ways to assist their alma mater. 


\section{Our Patrons ...}

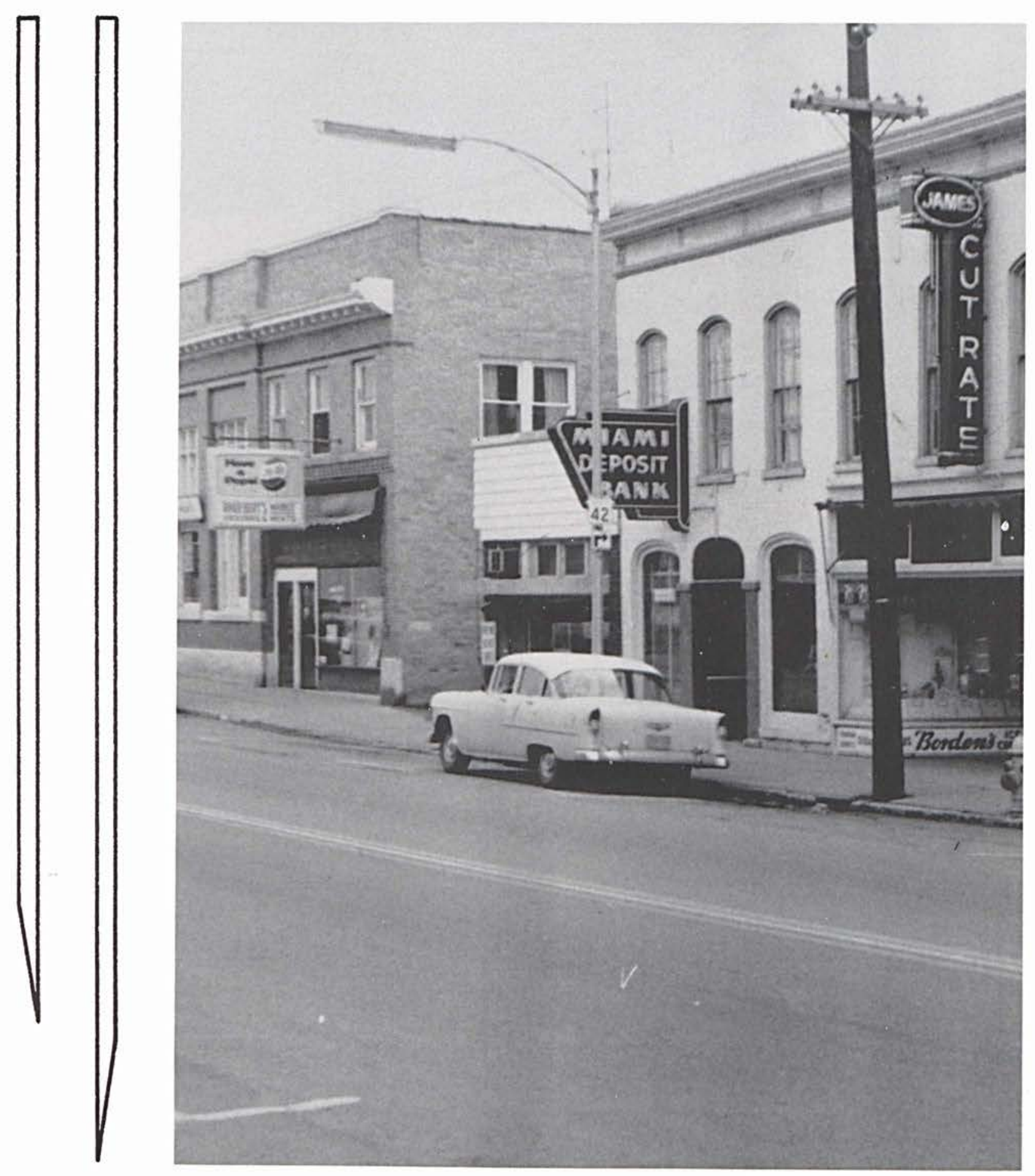




\section{WE DESIRE}

THE LORD'S BLESSING

TO BE UPON THE

GRADUATES OF 1961

AS THEY CONTINUE

FORWARD WITH CHRIST.

\section{HUNTSBURG BAPTIST CHURCH}

Route No. 322

Huntsburg, Ohio

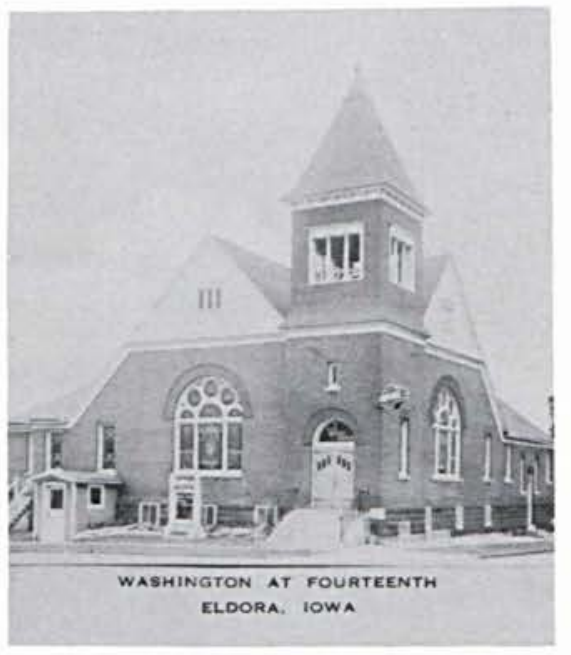

FIRST BAPTIST

\section{$\mathrm{CHURCH}$}

Eldora, lowa

H. C. Short, Pastor Lois Jingst, Director of Christian Education

A FULL PROGRAM OF Reaching, Teaching Preaching, Training For
FOSTORIA BAPTIST CHURCH

524 West Lytle St. Fostoria, Ohio

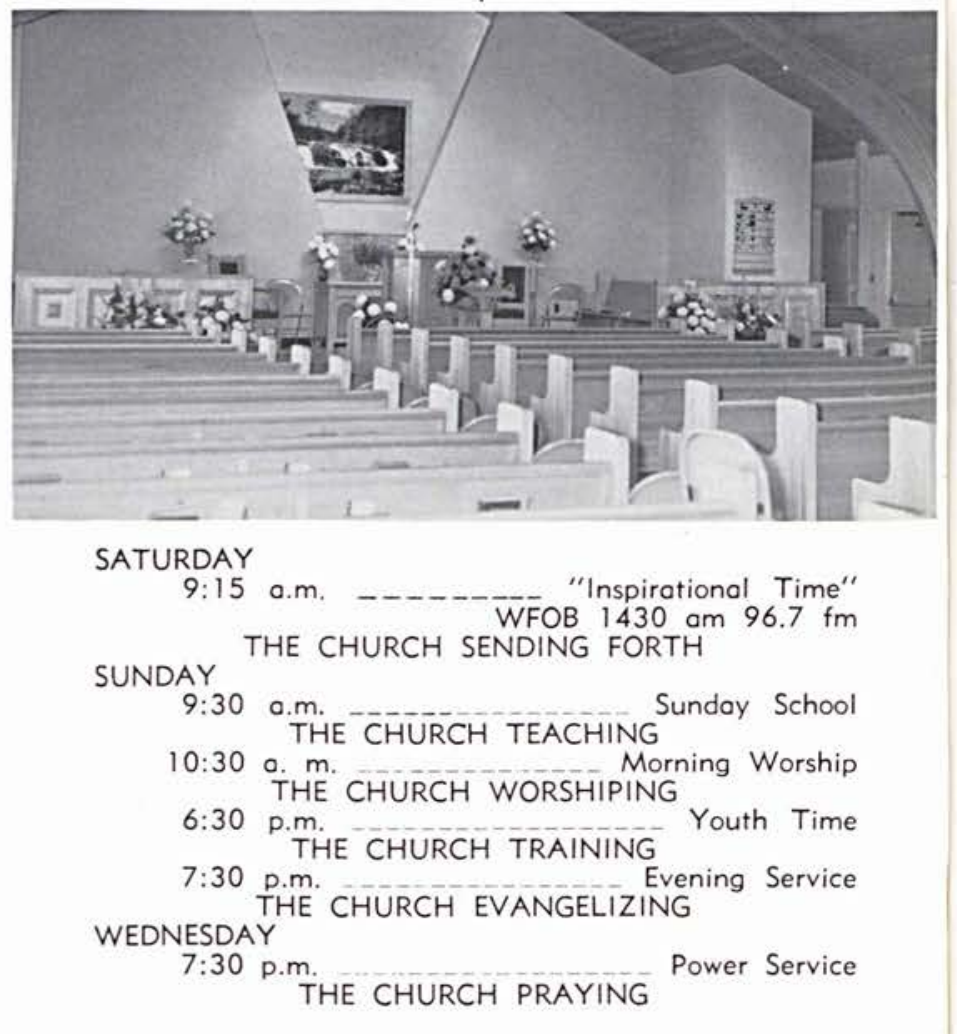

\section{FIRST \\ BAPTIST CHURCH}

W. Main and Center

Grove City, Pa.

\section{SERVICES}

9:45 a.m.

11:00 a.m.

6:30 p.m.

7:30 p.m.

Wed., 7:30 p.m.
Sunday School Morning Worship Young Peoples Evening Service Prayer Service

\section{Kenneth L. Andrus, Pastor}

"To know Him, and to make Him known." 


\title{
FIRST REFORMED $\mathrm{CHURCH}$
}

Detroit and Church Sts.

Xenia, Ohio

An Independent Bible Church

"Holding Forth the Word of Life"

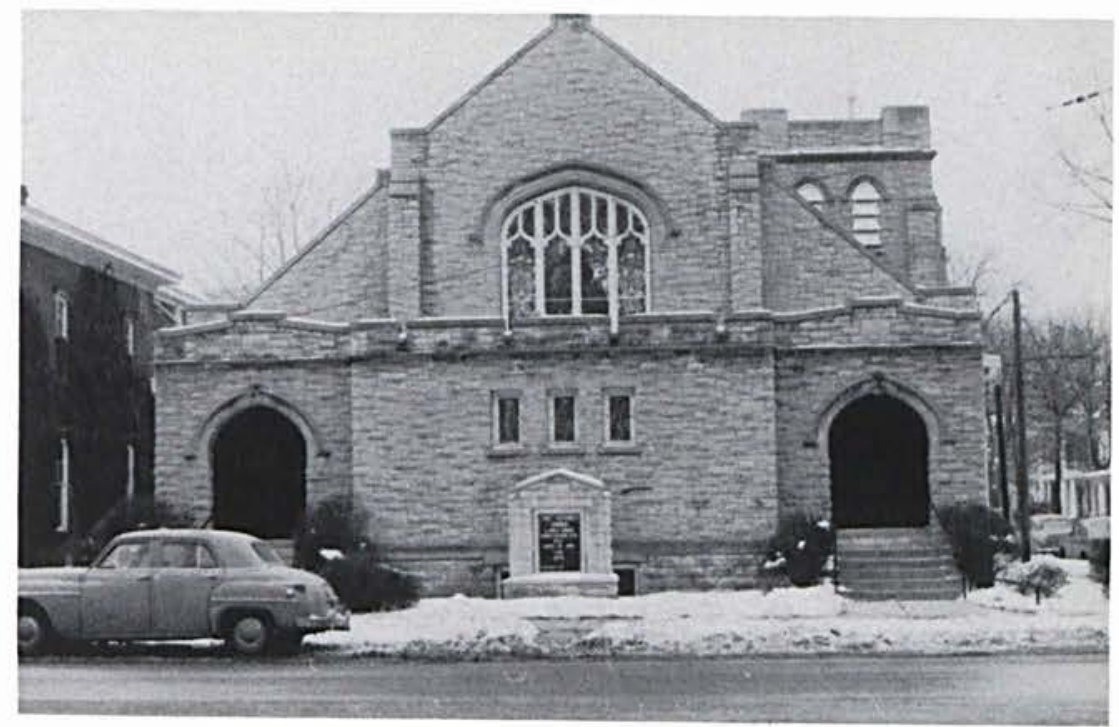

\author{
Russell Mayer, Pastor \\ Minister of Music - William Washburn \\ Cedarville College
}

When In The St. Louis Area Visit The

\section{LACKLAND ROAD BAPTIST CHURCH}

10308 Lackland Road, Overland, Missouri

"The Friendly Church

Where Visitors Are Always Welcome"

Sunday Bible School 9:30 a.m.

Sunday Preaching Services 10:45 a.m.

7:45 p.m.

Bible Training Union 6:30 p.m.

Mid-Week Bible Study \& Prayer Meeting 7:30 p.m.

Youth Meetings - Sunday 6:30 p.m. Mon., Tues., Wed. 7:00 p.m.

"Bus Transportation

Furnished To Those In Need"

C. S. Henson, Pastor

(Two Nurseries)

Phone HA 7-7455

\section{THE TABERNACLE}

\section{BAPTIST CHURCH}

"The friendly church on the corner"

East Lincoln at Utica Street Ithaca, New York

\section{Harold E. Cole, Pastor}

\section{SUNDAY}

Sunday School

9:45 a.m.

Morning Worship

11:00 a.m.

Baptist Training Union

6:30 p.m.

Evening Service

7:30 p.m.

WEDNESDAY

Mid-Week Devotional Service

7:30 p.m. 


\section{SHELL ROCK, IOWA}

\section{Congratulations}

To the '61 Graduates

From the Members and Friends of

\section{FIRST}

\section{BAPTIST CHURCH}

\section{Lexington Ave.}

Harvey, Illinois

\section{Henry Murdoch, Pastor}

J. G. Short Director Christian Education

"And God is able to make all grace abound toward you; that ye, always having all sufficience in all things, may abound to every good work."

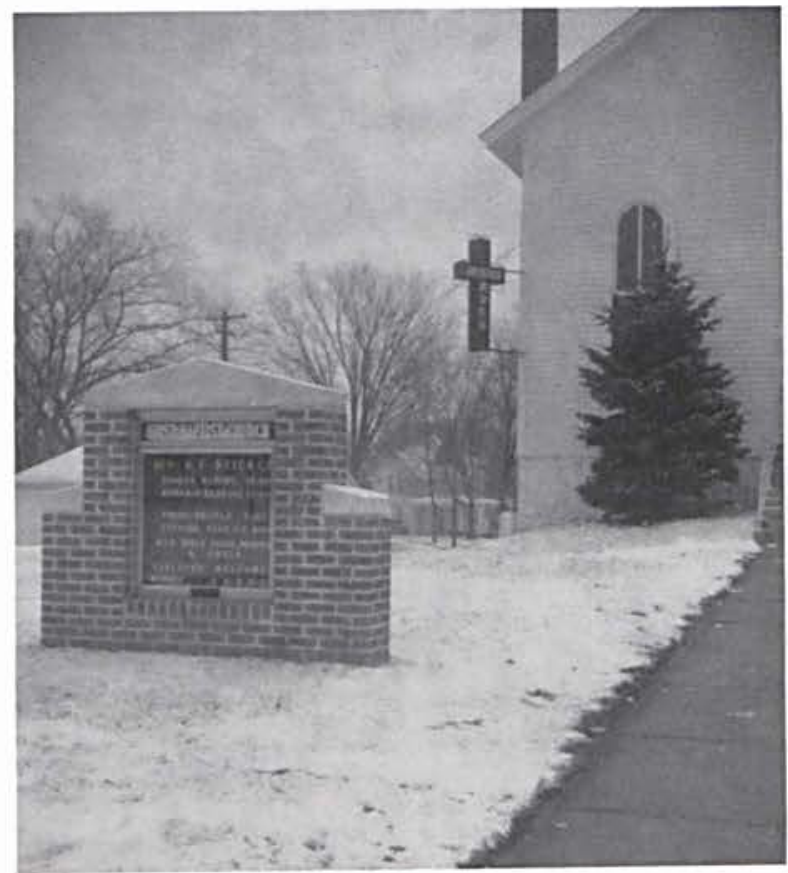

\section{FIRST}

BAPTIST CHURCH

\author{
5994 Ridge Road \\ Parma 29, Ohio
}

Elliott Horton, Pastor

Al Bowden, S. S. Supt.

Richard Hollen, Youth Director

\section{SERVICES}

Sun. - 10:00 A.M. - Sunday School

Sun. - 11:00 A.M. - Worship Services

Sun. - 6:30 P.M. - Youth Meeting

Sun. - 7:30 P.M. - Evangelistic Service

Wed. - 7:30 P.M. - Prayer \& Praise

"Every One Always Welcome"
Morning Worship

We invite you to worship with us when in Elyria.

Sunday School

$8: 30$ and $10: 50$ 9:45 A.M. 6:15 P.M.

$7: 30$ 


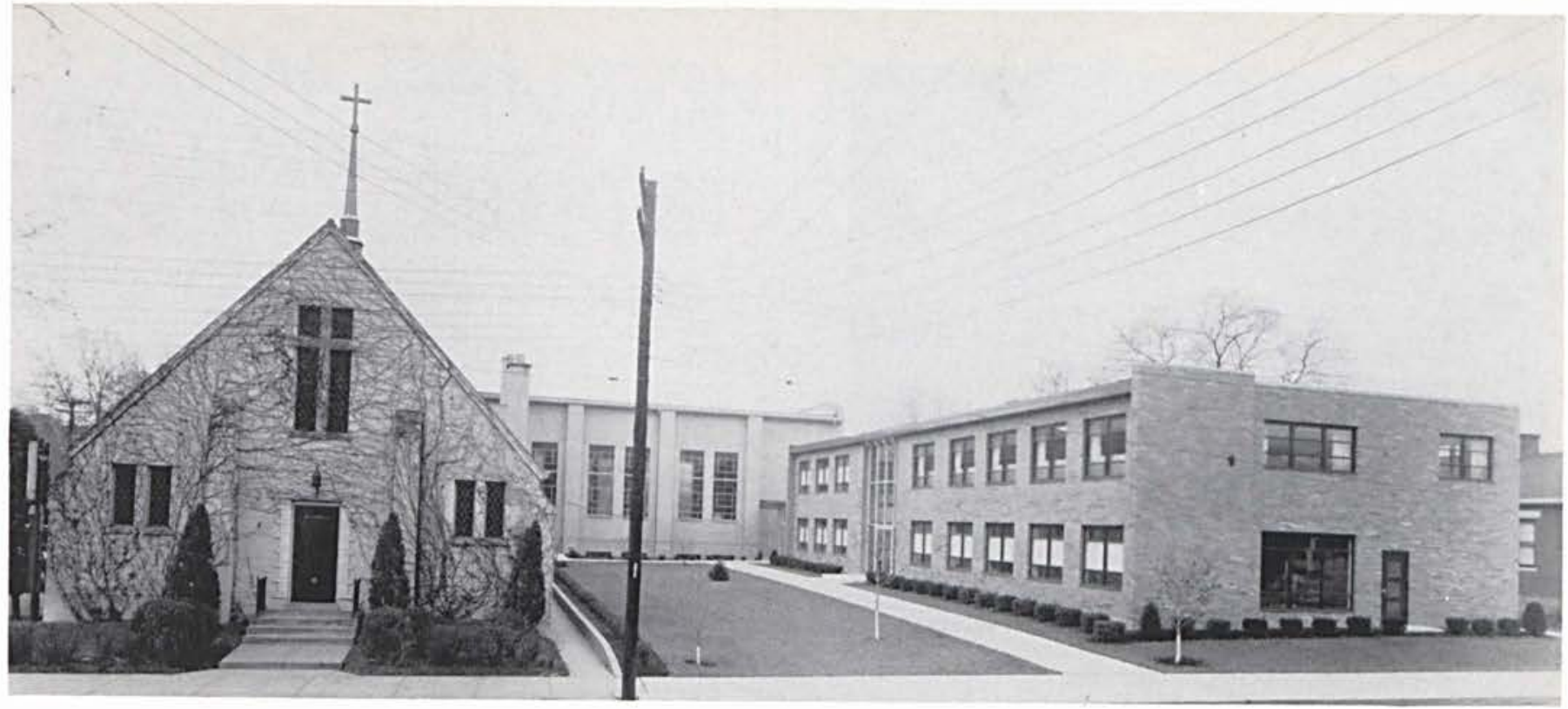

Welcome to

\section{CALVARY BAPTIST CHURCH}

"The Church With A Heart In The Heart Of Latonia"

Covington - Kentucky

D. B. Eastep - Pastor

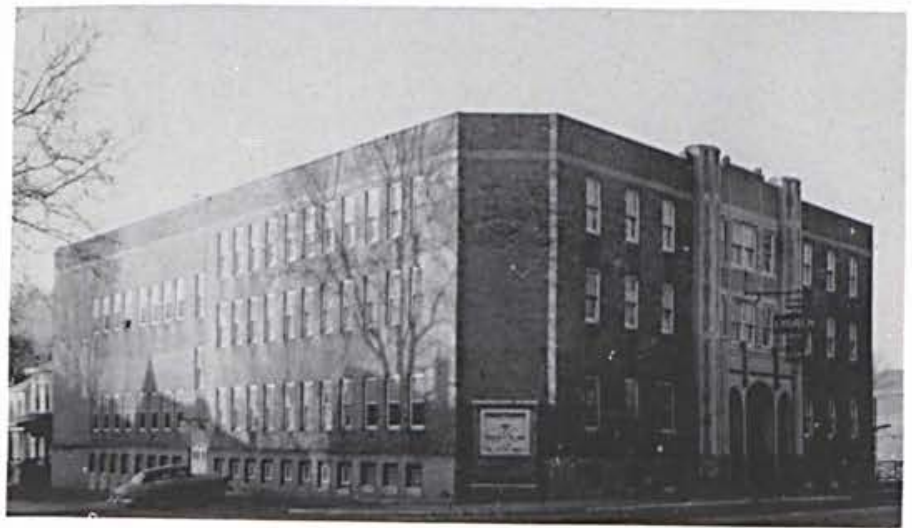

Sincere

Best Wishes

to the Class of ' 61

TEMPLE BAPTIST CHURCH

Portsmouth, Ohio

Rev. Hall Dautel, Pastor, Rev. Thomas D.

Bunyan, Minister of Music

Sunday Services

9:15 A.M. Bible School

10:30 A.M. Morning Worship

Broadcast over WNXT, Portsmouth (1260 on your dial)

5:30 A.M. Broadcast over WPKO, Waverly, Ohio

(1380 on your dial)

6:30 P.M. Youth Groups

7:30 P.M. Evening Service

9:30 P.M. Delayed broadcast of evening service WNXT, Portsmouth

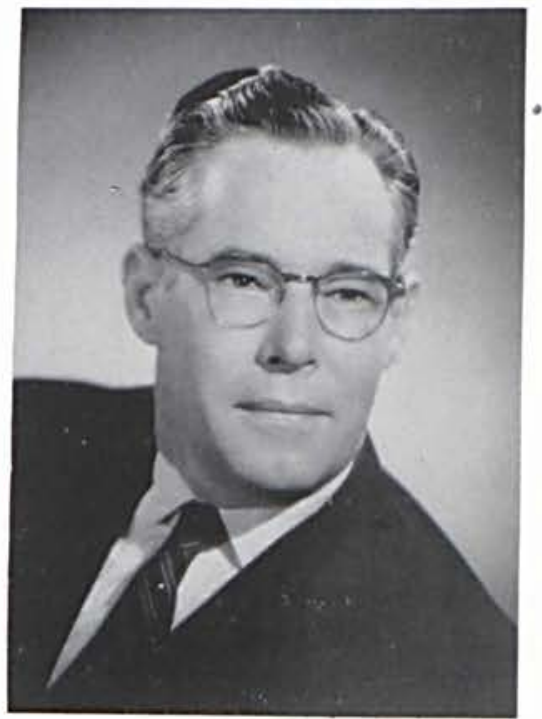




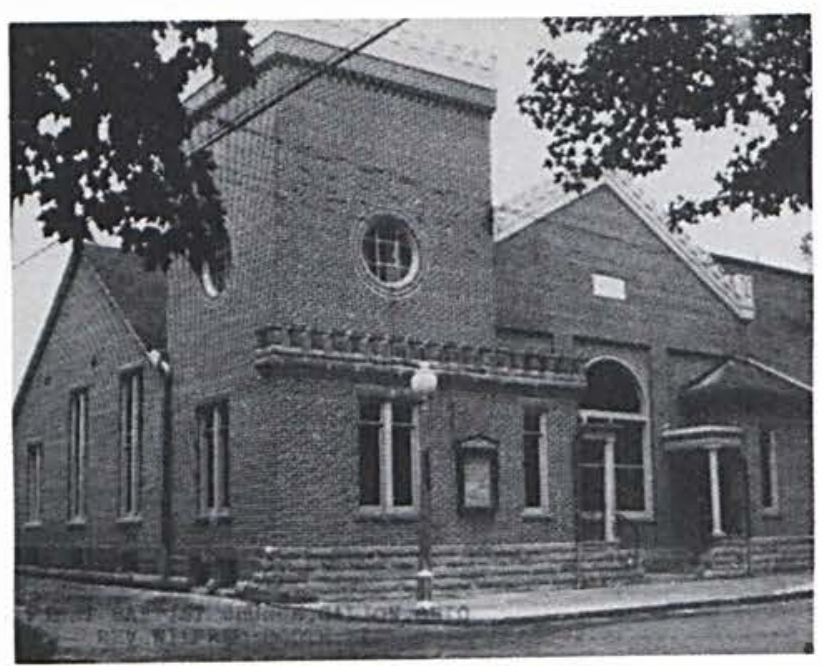

\section{FIRST BAPTIST $\mathrm{CHURCH}$}

Galion, Ohio

118 West Walnut Street

PASTOR - Wilfred Booth SUNDAY

Bible School 9:30 A.M.

Worship Service 10:30 A.M.

Baptist Youth Fellowship 6:30 P.M.

Gospel Service 7:45 P.M. WEDNESDAY

Prayer and Bible Study 7:30 P.M.

A Cordial Welcome to

\section{CALVARY BAPTIST $\mathrm{CHURCH}$}

Front \& Cory Streets

Findlay, Ohio

Services for the Lord:

Sunday

9:30 — Sunday School

10:30 - Morning Worship

6:30 - Training Union Adult Prayer Time

7:30 - Evening Gospel Hour

Thursday

7:30 - Hour of Power

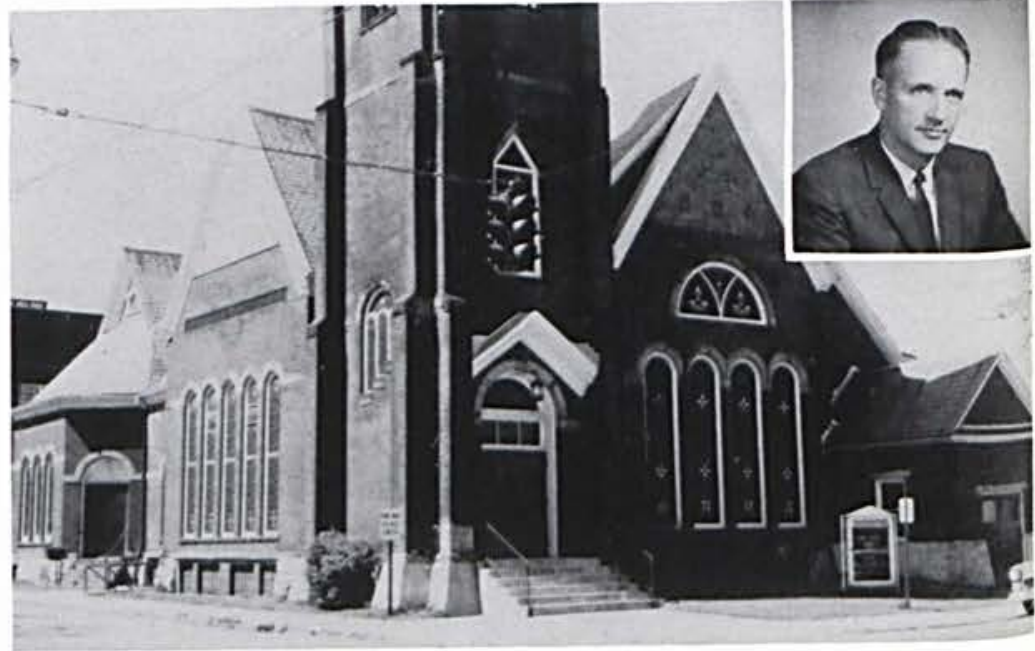

Pastor F. Donald Worden, TH.M.
Pastor H. O. Van Gilder, Jr. and Members of the MEMORIAL BAPTIST CHURCH

201 South Main Street

Verona, Wisconsin

(6 miles SW of Madison on US 18, 151) offer

CONGRATULATIONS to the

GRADUATES OF 1961

Sunday 10:00 a.m. Worship

11:00 a.m. Sunday School

8:00 p.m. Evening Service

Thurs. $\quad 8: 00$ p.m. Prayer Meeting

A WELCOME waits you and your family as you plan a vacation to AMERICA'S DAIRYLAND 


\section{HADDON HEIGHTS BAPTIST CHURCH}

Third and Station Aves. Haddon Heights, New Jersey

"Holding Forth The Word of Life"

Rev. Kenneth W. Masteller, Pastor

Sunday

Rev. Richard D. Christen, Ass't Pastor

9:45 A.M. - Bible School (Departmentalized and Graded for All)

11:00 A.M. - Morning Worship Service

6:30 P.M. - Six Thriving Youth Groups Convene

7:30 P.M. - Gospel Service

Monday

7:30 P.M. - Visitation Program

Wednesday

8:00 P.M. - Prayer Meetings (Youth and Adults)

Friday

Saturday

7:30 P.M. - Fun Night for Youth

All Day Recreation Program in Recreation Room

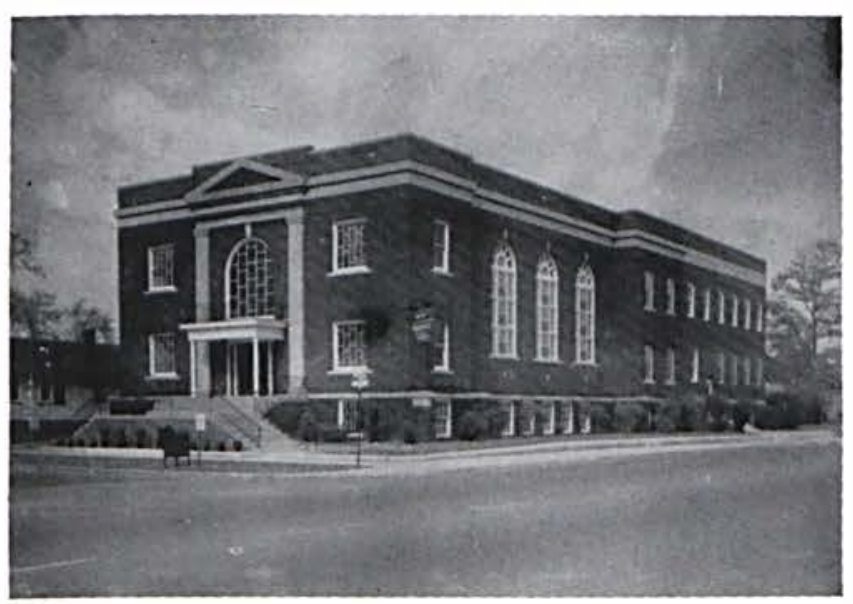

RIVERSIDE

BAPTIST CHURCH

Decatur, Illinois

George A. Bates - Pastor

Helen Lapp - Pastor's Secretary

Jim Christensen - Youth Director

"As my Father hath taught me, I speak these things ... for I do always those things that please Him."

\section{IMMANUEL BAPTIST CHURCH}

3417 Palmetto at Derrer Road

Columbus, Ohio

William A. Brock, Pastor 
NOW! Enjoy the Finest

in Dairy Products... Produced in

Springfield's Most Modern Self-Serve Home-Owned Dairy!

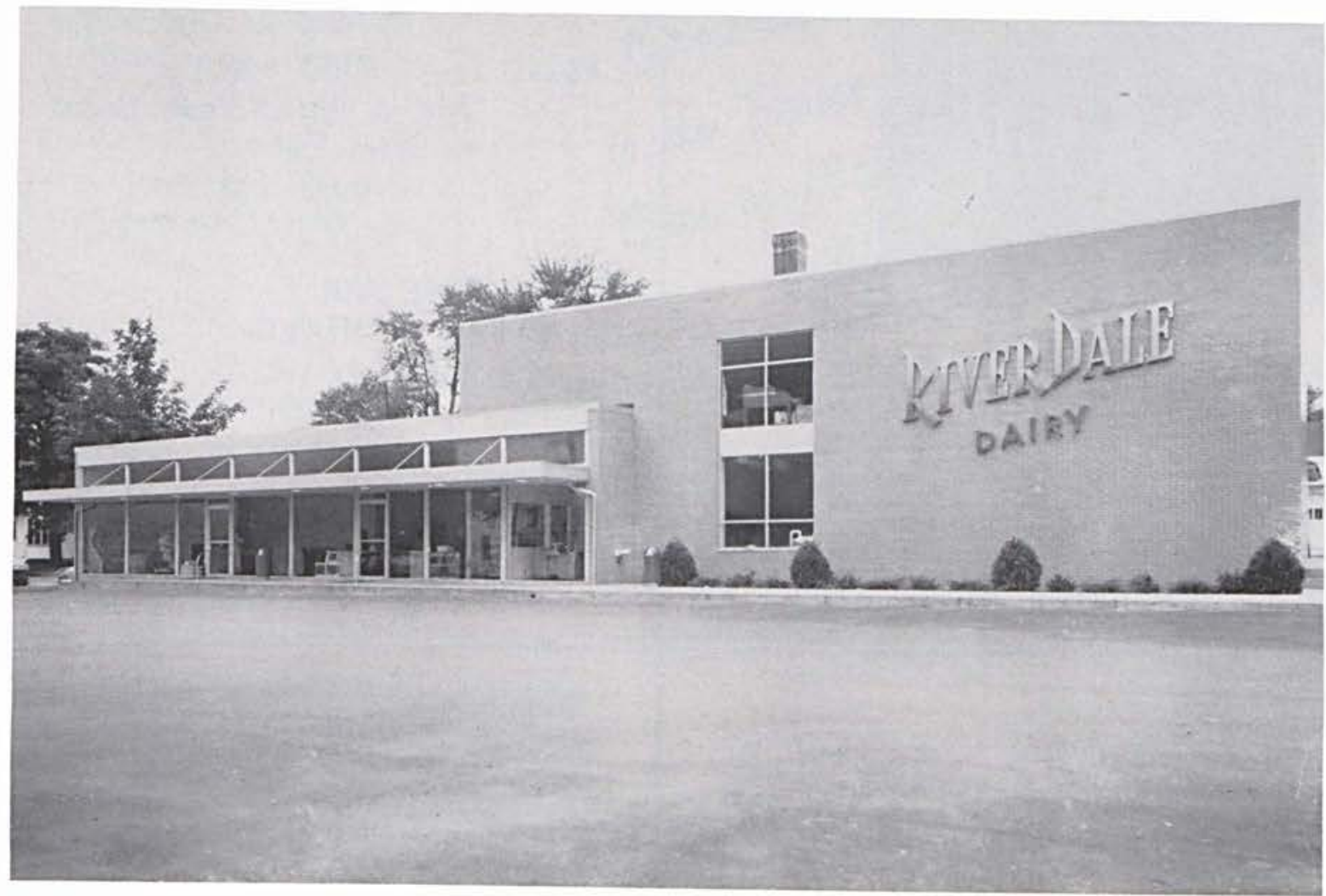

BUT WHERE YOU SAVE

Springfield's Home-Owned, Home-Operated

RIVER DALE

DAIRY

Corner Selma Road and Oak Street

Open Daily 8 A.M. Till 9 P.M.

Plenty of Parking Space 


\section{BLESSED HOPE BAPTIST CHURCH}

315 So. Kensington Place Springfield, Ohio

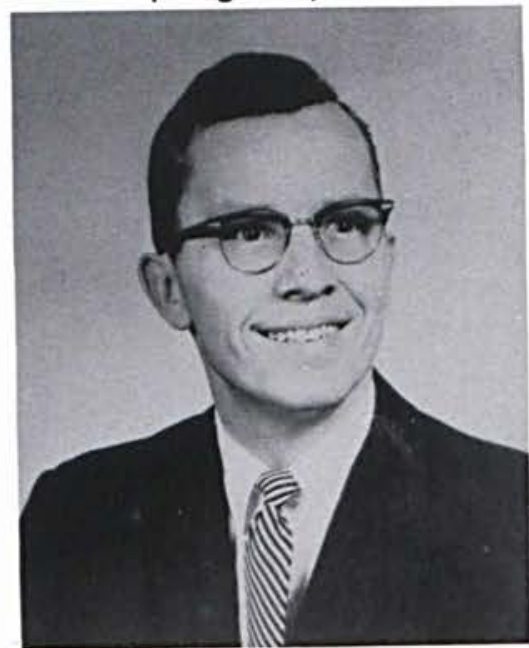

REV. GLENN GREENWOOD, PASTOR SUNDAY

Bible School 9:30 A.M. Morning Worship 10:45 A.M. Young Peoples 6:15 P.M. Evening Service 7:15 P.M. Broadcast - WIZE 7:30-8:00 P.M. Wednesday Prayer Meeting -_- 7:30 P.M. "Looking for that Blessed Hope"-Titus $2: 13$.

\section{CEDAR HILL \\ BAPTIST CHURCH}

12601 Cedar Road Cleveland 6, Ohio

Rev. John G. Balyo, Pastor

CHRIST CENTERED, BIBLE BASED, LIFE RELATED

Attending Cedarville

from Cedar Hill;

Mr. \& Mrs. Steve Boalt

Dave Fetzer

Joan Johnson

Steve Nimmo

ON THE AIR

EVERY SUNDAY

8:30 A.M. WGAR 1220 kc AM (and 99.5 Meg. FM)

7:30 P.M. WDOK 1260 kc AM

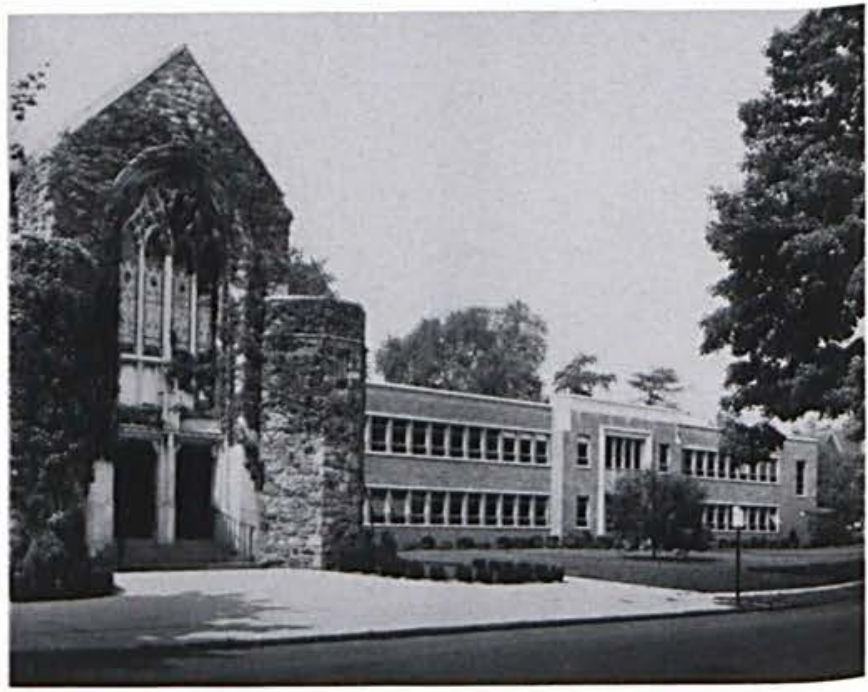

\section{GEYER'S}

15 W. Main

Xenia

DR 2-1511

\section{FIRST BAPTIST $\mathrm{CHURCH}$}

\section{Dr. Joseph M. Stowell, Pastor}

Anderson Park - Hackensack, N. J.

We believe in Cedarvilles' future. 


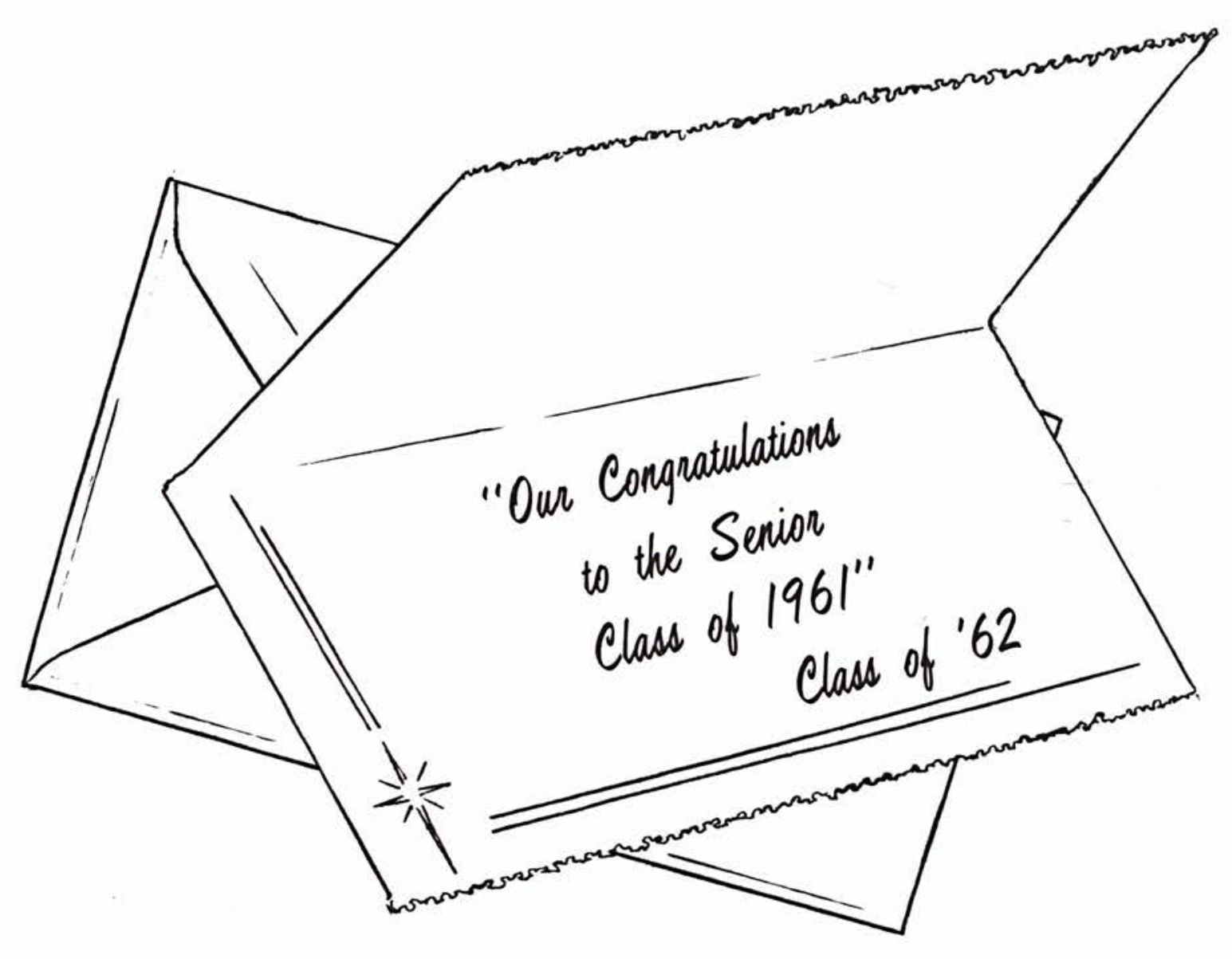

$$
\begin{gathered}
\text { Compliments } \\
\text { of }
\end{gathered}
$$

MORRIS BEAN

AND COMPANY

YELLOW SPRINGS, OHIO

CEDARVILLE, OHIO

169 


\section{MUSIC}

Is Our Business

\section{BAND BOX \\ MUSIC CENTER}

31 West Main Street

Xenia, Ohio

\section{CEDARVILLE LOCKER \& GROCERY \\ "Your Frozen Food Center" \\ 39 S. Main St. \\ Tel. SO. 6-1141}

\section{Randall} Stormont, Inc.

Phone SO 6-1031

CEDARVILLE

$\mathrm{OHIO}$

\section{DEPEND ON THE CAMERA SHOP}

for all your photographic needs

22 West Main Street

Xenia, Ohio

Tel. DR 2-1469

\section{BRAUN'S JEWELERS}

8 N. Detroit St. Xenia, Ohio

Registered Jeweler American Gem Society Exceptionally Fine Diamonds

Rolex - Omega - Logines - Bulova Watches
RECO

SPORTING GOODS

\author{
AND \\ GIFT STORE \\ Uniforms \\ Jackets \\ Sweaters
}

Sports Equipment

Come in and Browse Around

113 E. High St.

Springfield, Ohio 


\section{JAMES CUT-RATE}

THE REXALL STORE

Phone SO 6-1771

CEDARVILLE, OHIO

E. W. Greenwald, Proprietor

\section{RHEUBERT'S MARKET}

Groceries \& Meats

18 North Main Street

SO 6-2151

CEDARVILLE, OHIO

\section{HARNER'S \\ CEDARVILLE MARKET \\ Meats}

Produce Groceries

\author{
Phone SO 6-1201 \\ CEDARVILLE, OHIO
}

\title{
CHAPLIN CLEANERS
}

\section{HAROLD'S}

\section{SOHIO SERVICE}

Batteries

Lubrication

Harold Rodin, Proprietor
Laundry Service

Cleaning

Shoe Repair

Pressing

Tel. SO 6-3871

CEDARVILLE, OHIO

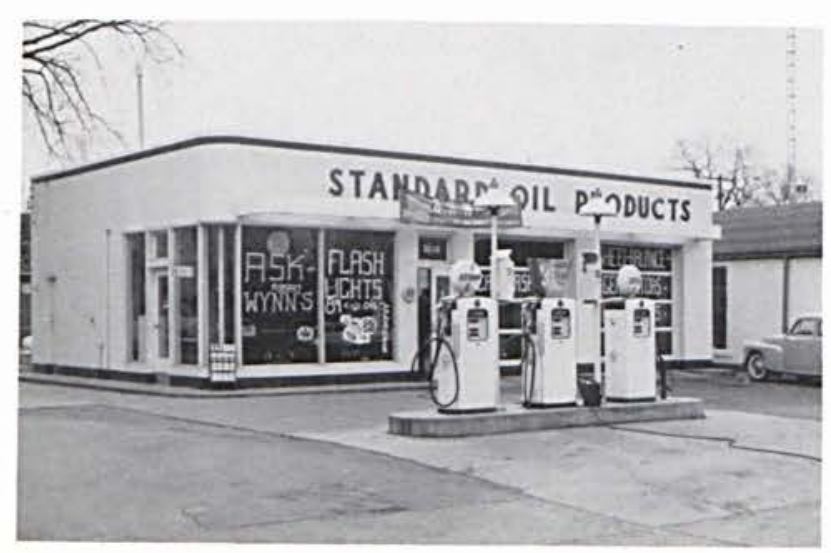

Compliments of

\section{CEDARVILLE HARDWARE}

Progressive Hardware Service

CEDARVILLE, OHIO

Phone SO 6-1941

Your GE Appliance Dealer 


\section{MIAMI DEPOSIT BANK}

Complete Facilities

Ready to Serve You

CEDARVILLE, OHIO and

YELLOW SPRINGS, OHIO

Member of the

FEDERAL DEPOSIT

INSURANCE CORPORATION

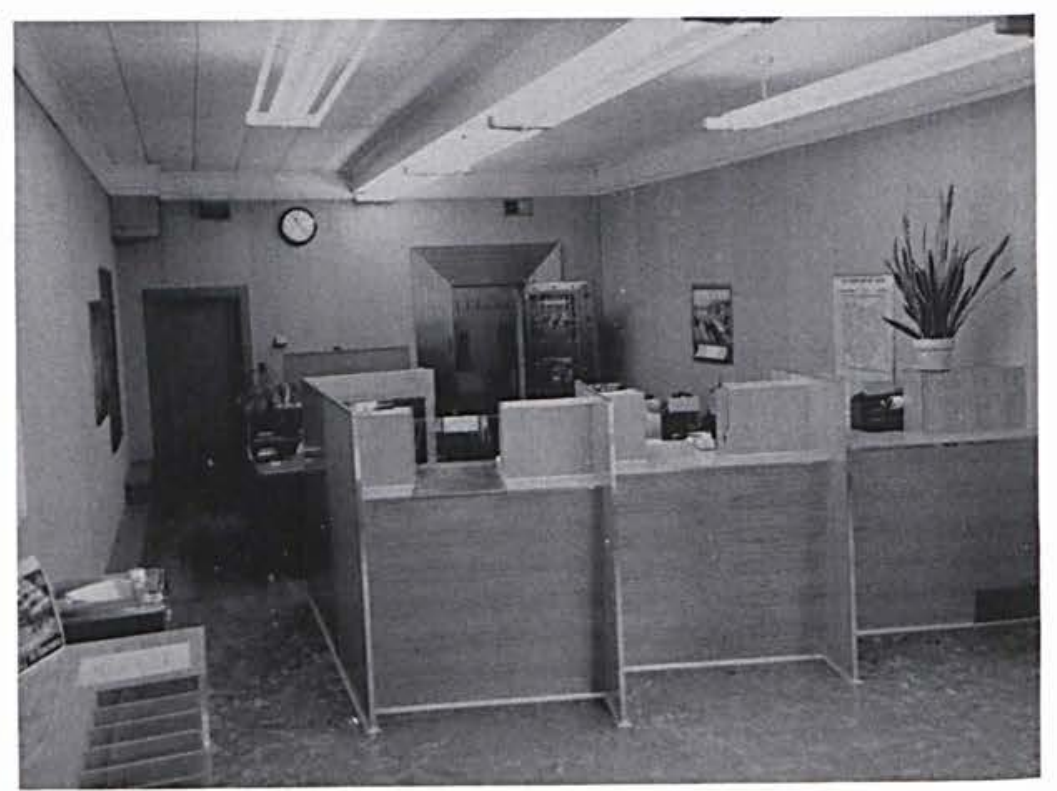

when out where the tall corn grows visit

\section{CALVARY BAPTIST CHURCH}

Forest City, lowa

\section{W. Stadt, Pastor}

Home Church of Lynn Jefson

Home Area of Dianne Hunter

Best wishes to the graduates and to all who have chosen Cedarville as their training center.
Short Orders Lunches Sandwiches

PIZZA AS YOU LIKE IT

\section{THE I-T PIZZA HOUSE}

Hours Daily: 11:00 A.M. to 1:00 A.M.

Except Saturday till 2 A.M., Sunday 12 to 12

Wednesday 5:00 P.M. to 1:00 A.M.

Irene and Ted (Dumas)

Phone: DR 2-3587
122 E. Main St. Xenia, Ohio
HOAK'S GREENHOUSE

Flowers

for

Everyone

Fairborn

Phone TR 8-8453 


\author{
Congratulations \\ and \\ Best Wishes \\ To The \\ Seniors \\ From Your Friends \\ MILNER ELECTRIC CO.
}

Cleveland 14, Ohio
Congratulations to the Class of '61

\section{CEDARVILLE COLLEGE BOOKSTORE}

Student Supply Center

Bernice Mick, Manager

\section{IRVINE DAIRY ISLE}

North Main St.

Ice Cream

Sandwiches

Sodas
Cedarville, Ohio

Soft Drinks

Candy

Sundaes
Shakes

Pizza Burgers

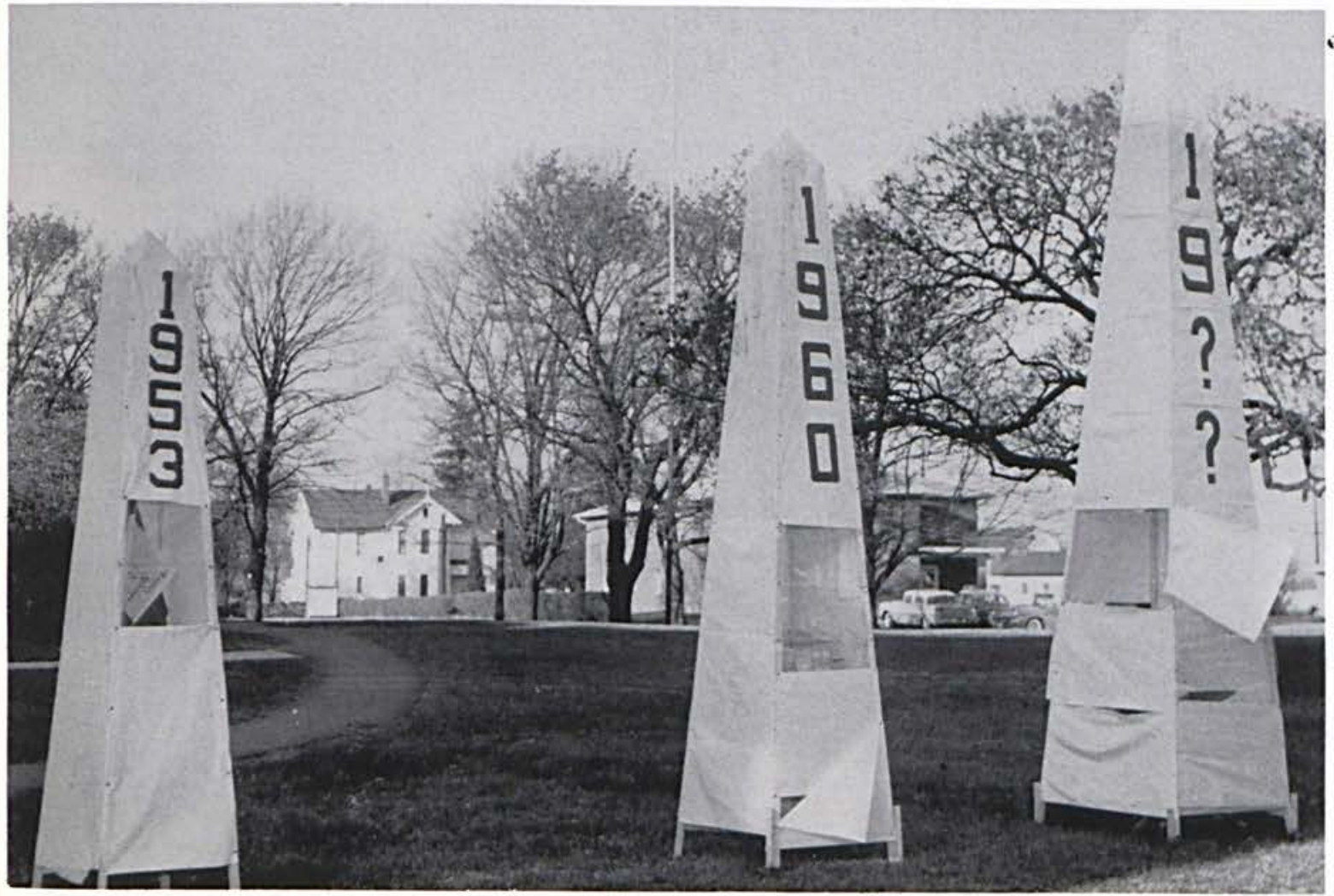

\section{from \\ the \\ Miracle \\ Staff}




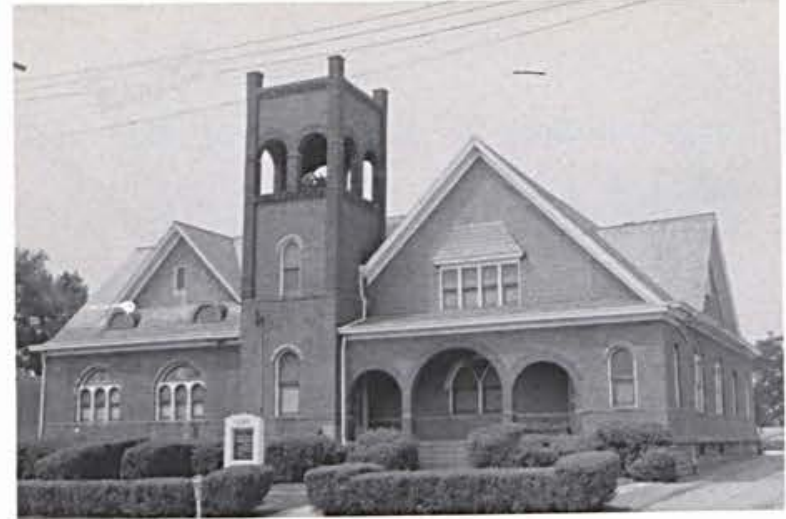

FIRST BAPTIST CHURCH

123 West Liberty Street Medina, Ohio

R. Kenneth Smelser, Pastor
Bible School

9:45

Worship

Youth Groups

Evening Service

Prayer Meeting (Wed.)
$10: 55$

$6: 30$

$7: 30$

$7: 30$

"That the trial of your faith, being much more precious than of gold that perisheth, though it be tried with fire, might be found unto praise and honour and glory at the appearing of Jesus Christ."

I Peter 1:7

You Are Always Welcome At The

\section{GRANDVIEW PARK BAPTIST CHURCH}

1701 E. 33rd Street
Des Moines 17, lowa

\section{Carl E. Elgena, D.D., Pastor}

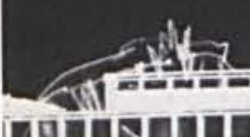

\section{$=$}

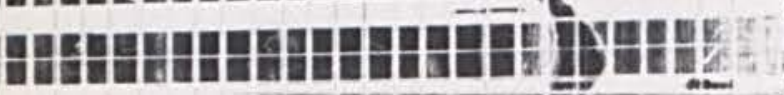
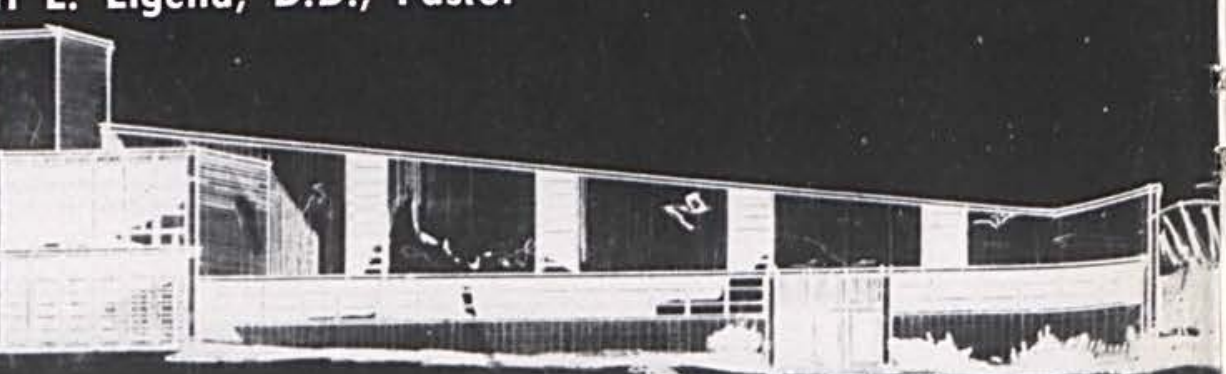

Jack Payne, B.Mu. M. Regular Services-r. Minister of Music and Youth w forlall eas Mary Jo Short, B.A. Lord's day. Director of Christian Education WETHERELL HARRISON WIA GNLE AECHITECTS

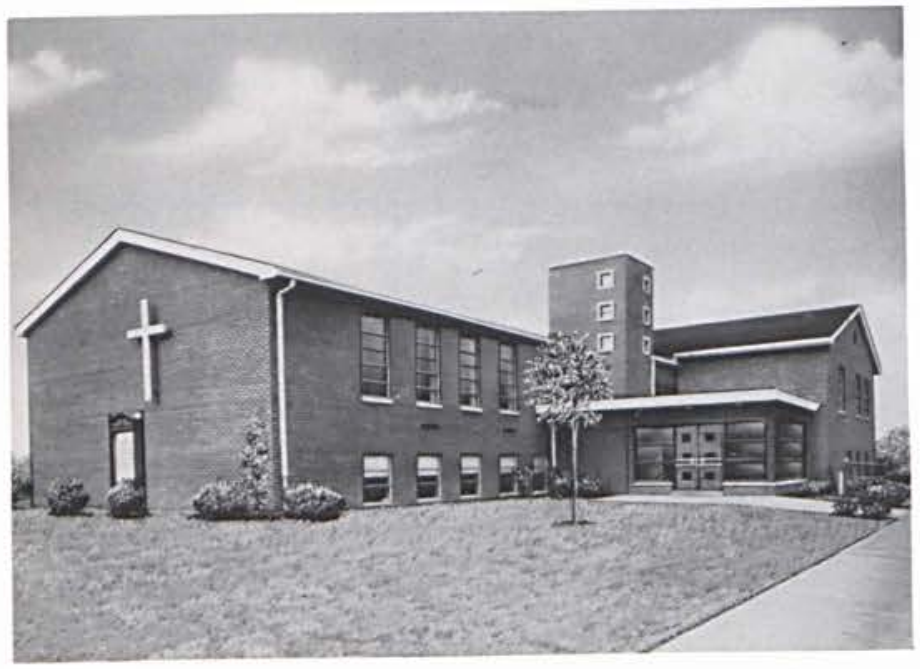

When in Cleveland we invite you to visit

\section{HAYDEN AVENUE BAPTIST CHURCH}

\section{Hayden Ave. UL. 1-0941}

\section{Donald B. Woodby - Pastor}

\author{
Sunday School \\ Worship Service \\ Youth Meetings \\ Evening Service \\ Prayer Meeting Wednesday
}

\begin{abstract}
9:45 A.M.
11:00 A.M.

6:00 P.M.

7:00 P.M.

7:30 P.M.
\end{abstract}




\section{Congratulations Seniors}

$$
\text { of }
$$

1961

\section{From \\ Class of '63}

"Today's Efforts - Tomorrow's Success"

"Stand fast therefore in the liberty wherewith Christ hath made us free."

Best Wishes

Class of '61

\footnotetext{
"Those who kneel before God will stand before men."

". . . that in all things $\mathrm{He}$ might have the preeminence..."

Col. 1:18b
}

THE FRESHMAN CLASS

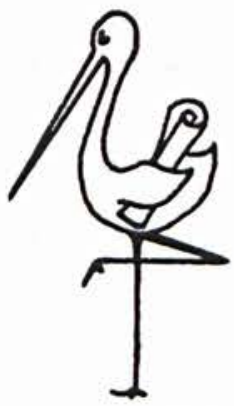




\section{FIRST BAPTIST $\mathrm{CHURCH}$}

Third Avenue at Locust Street Gallipolis, Ohio

Rev. Howard G. Young, D.D., Pastor Residence: 459 Third Ave.

In the HEART of the City with the City on its HEART."

When in our Area

You are cordially invited to attend our:

Bible School at

Morning Worship at

Young People's Meeting at

Evangel Hour Service at

Prayer Meeting Wednesday

We Preach Christ Crucified,

Risen and Coming Again!
Congratulations, Seniors From

\section{FIRST BAPTIST}

\section{$\mathrm{CHURCH}$}

Perry, lowa

\section{J. M. Kain, Pastor}

And this I pray, that your love may abound yet more and more in knowledge and in all judgment; That ye may approve things that are excellent; that ye may be sincere and without offence till the day of Christ; Being filled with the fruits of righteousness, which are by Jesus Christ, unto the glory and praise of God.

Philippians 1:9-11

\section{THE FIRST}

\section{BAPTIST CHURCH}

New Castle and Church Sts.

Butler, Pennsylvania

\section{Clayton Howard Gray, Pastor}

SUNDAY

9:45 A.M. The Church Studying

11:00 A.M. The Church Worshiping

(Broadcast on WISR, $680 \mathrm{Kcs}$.)

6:30 P.M. The Church Training

7:30 P.M. The Church Evangelizing TUESDAY

7:30 P.M. The Church Visiting WEDNESDAY

7:30 P.M. The Church Praying THURSDAY

7:00 P.M. The Youth of the Church

"The Whole Christ

in The Whole Bible

for The Whole World"

\section{CALVARY \\ BAPTIST CHURCH}

502 Cherry at Bayliss

Midland Michigan

William Suk, Pastor

Bible School

10:00 A.M.

Morning Service 11:00 A.M.

Evening Service 7:30 P.M.

Wednesday - Prayer and Bible Study 7:00 P.M. Always a Warm Welcome 


\section{BEREA BAPTIST}
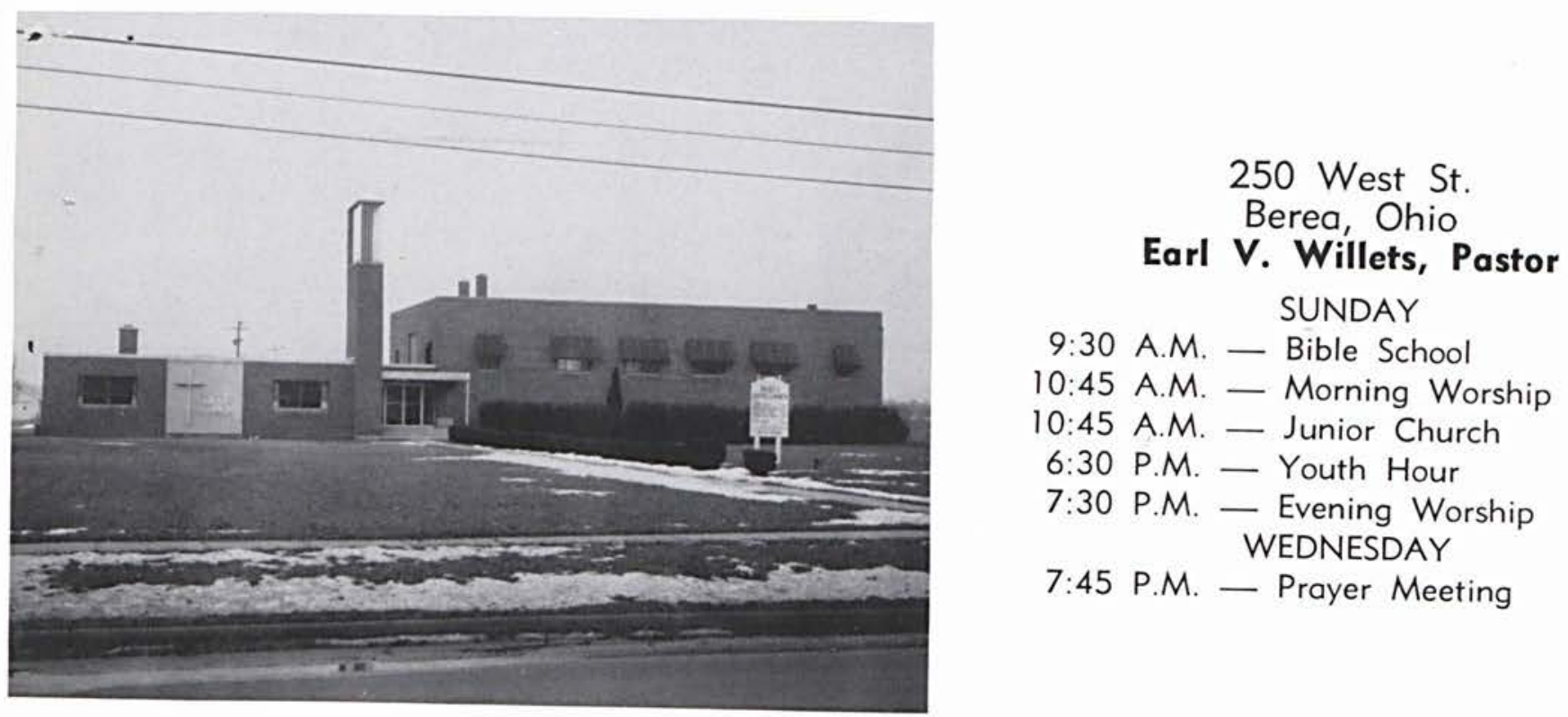

"That in All Things He Might Have the Pre-eminence"

Congratulations, Class of 1961

CALVARY BAPTIST CHURCH

Highland, Indiana

“With God nothing shall be impossible." (Luke 1:37) 


\section{Index}

\section{COLLEGE PERSONNEL}

Adams, Elaine - 27, 146

Adams, Patricia - 27, 77, 79, 81, 146

Adamson, Barbara - 67, 96, 139, 146

Adamson, Bette - 67, 80, 94, 96

Addleman, Sharon - 27, 61, 68, 69, 77, 79, 146

Addleman, Sue -27

Albrecht, Rosa Lee - 64,65,67,69, 72, 133

Alexander, Barbara - 146

ALEXANDER, Mrs. W. E. - 30

Alexander, W. E. - 133

Allem, Eunice - 146

Allem, Lois - 139

Allen, Warren -127

Allford, Juanita - 25, 29, 64, 67, 69, 72, 133

Amstutz, Neal - 139

Ashley, Vance - 84, 85, 97, 120, 155

Atkins, Kenneth $-27,146$

Auffort, Robert - 146

Babitt, Thomas - 146

Baker, Lawrence - 146

Barber, John - 146

Barrett, Patricia - 67, 111, 146

BARTHOLOMEW, Mr. Raymond - 44, 45, 72

Bayless, Lois - 69, 146

Beach, Carolyn - 146

Beck, James - 146

Bender, Sally - 43, 68, 77, 80, 146

Bennett, A. Lee - 139

Bensinger, Edward - 66, 79, 146

Benson, Irene - 60, 67, 68, 69, 139

BERGEN, Mr. Harmon - 14, 44, 46

Bertram, Norma Jean - 80, 146

Biddle, Allen - 66, 95, 133

Bigelow, John $-80,92,139$

Bird, Julia $-29,36,67,69,139$

Blann, Mary - 69, 146

Bloemer, Charlene - 67, 147

Blossom, David - 79, 92, 147

Blumenstock, Richard - 66, 139

Boalt, Steve $-77,133$

Boren, Carole - 77, 81, 118, 139

BOWSER, Mr. Sherwin - 39, 70, 83, 84

Bresson, Richard - 139

Brower, Daniel - 64, 139

Brower, Philip - 97, 139

Brovont, Hazel - 67,69, 72, 94, 133

Brown, Carol - 67, 68, 69, 74, 77, 81, 118 134

Buerer, Peggy - 30,61, 67, 69, 134

Burnside, Warren - 68, 147

Butler, John - 29, 65, 127

Butler, Ronn - 140

CALLAN, Mr. Donald - 39, 40, 70, 88, 92, 121

Canine, Sam - 43, 64, 70, 74, 79, 81, 88, $90,119,120,140$

Cannon, Flora - 94, 140

Carter, Gail - 140

Carter, Joan - 67, 80, 147

Cartwright, Lorraine - 133

Caulk, William - 147

Cetas, Thomas - 66, 140

CHAFFE, Mrs. S. L. $-30,50$

Chitty, Gordin - 119, 147

Clausen, Mary Ann - 140

Claypool, Neva - 71, 127

Clemence, Joyce - 147

Cline, David - 80, 147

Cochran, David - 70, 133

Collier, Donis - 68, 127

Cook, Henry - 147

Cook, Richard - 71, 74, 127

COOKE, Mr. Richard - 41, 79, 119

COOKE, Mrs. R. A. - 41

Coons, John $-27,147$

Connell, Bud - 147

Cox, Virginia - 133,

Crothers, Marcia - 127
Cushey, Loretta - 27, 68, 140

Dadisman, Judy - 140

Davidson, Richard - 79, 140

Davis, Donna - 155

Davis, Marlene - 80, 128

Day, Howard - 147

Delanzo, Thomas - 147

deRosset, Karin - 147

Deugan, Norman - 147

Dickson, Nancy - 147

Dobbs, Phyllis - 71, 128

Dodge, Gale - 147

Domokos, Robert - 29, 64, 69, 133

DuBois, Bonnie - 80, 147

Duddleston, Lois - 80, 147

Dunlap, Earl - 140

DuPre, Jeannie - 69, 117, 140

Earnhart, David - 62, 66, 77, 79, 120, 134

Eastman, Edward - 140

Edwards, Robert - 80, 147

Eickelberg, William - 155

Elder, William - 70, 155

Ellis, Robert - 134

Elmore, Beth - 30, 148

Emery, Norman - 58, 148

Entner, James - 5, 64, 69, 70, 84, 88, 90, 116 128

Eubank, William - 155

Evans, Mark - 148

Evans, Thomas - 88, 92, 148

Everett, Donna - 69, 72, 140

Farley, Frank - 148

Farnsworth, Leon - 69, 140

Fetzer, David - 61, 148

Fidler, Robert - 141

Finley, Donna $-28,67,68,74,79,81,118$,

Finley, Gordon - 66, 68, 69, 79, 148

FISHER, Miss Jean $-29,34$

Fleming, Priscilla - 141

Fogle, Gary - 154

Forsyth, Richard - 155

Frazier, Rush - 35

Fry, Charles - 134

Fullhart, Susan - 148

Gathany, Paul - 36, 141

Gayer, John - 155

Getty, Norm - 5, 27, 74, 101

Getty, Peg - 64, 67, 69, 141

Geyser, Suzanne - 27, 80, 148

Gingell, Judith - 148

Ginz, Jane - 29, 67, 68, 72, 75, 141

Golden, June - 68, 79, 81, 141

Goodenough, Melvin - 148

Goodman, Shirley - 148

Goodrich, Terry - 64, 70, 97, 128

Goodwin, Mary - 67, 148

Gorthey, Carol - 148

Grafton, James - 58, 70, 85, 97, 141

Grant; Joyce - 68, 77, 134

Grant, Phillip - 27, 64, 77, 119, 141

GROMACKI, Mr. Robert - 34, 35

Haas, Faye - 77, 80, 81, 148

Halberg, Joy $-67,148$

Hale, Darlene - 67, 148

Hall, Brian - 144

Hall, Ronald - 128

Hamilton, James - 148

Hamilton, Kenneth $-27,148$

Hammerstrom, Sandy -134

Hand, Janet - 148

Harrington, Shirley $-29,64,69,74,79,81$, 128

Harris, Patricia - 134

Hartsell, Jeane - 25, 149

Hartzell, Charles - 29, 64, 66, 69, 70, 88, 97,141

Hartzell, Harry - 149

Haseltine, Marcus - $66,69,70,88,141$

Hawkins, Louann - 149

Hell, Carole - 134
Helmick, Larry - 58, 141

Hemenway, Barbara - 67, 134

Henson, Carol - 60, 141

HES, Miss Marjorie - 25

Hicks, Arthur - 36, 141

Hicks, Norma - 149

Himsel, Elsie - 67, 80, 149

.Hodges, Barry - 149

Hogard, Gary - 38, 86, 87, 142

Howard, Elayne - 68, 74, 79, 142

Howard, Ellis - 66, 80, 142

Howard, Frank - 129

Howard, Peggy - 25, 29, 69, 134

Huff, Judy - 149

Humphreys, Judith $-67,149$

Hunter, Diana $-27,80,149$

Ice, Lawrence R. - 149

Ingram, John $-30,68,79,155$

Jackson, Virginia - 43, 77, 80, 81, 118, 149

Jacobson, Lois - 67, 77, 149

Jefson, Lynn $-79,120,142$

Jennings, William - 64, 129

Jeremiah, David - 79, 81, 88, 89, 90, 142

JEREMIAH, Mrs. J. -25

JEREMIAH, Mr. James T. - 11, 34, 107, 113, 122

Jesse, Dorothea - 134

Jewett, Philip $-42,58,117,149$

Johns, Donna - 80, 149

Johnson, Gary - 149

Johnson, Joan - 149

Joiner, James - 149

Jordan, Elaine $-30,67,135$

Joy, Lois - 149

Justice, John - 88, 91, 92, 154

KANTZER, Miss Ruth - 44, 45, 71, 75

KEEFER, Miss Elinor - 25

Keim, James - 30, 68, 79, 149

Keller, Kenneth - 135

Kennedy, Lois - 144

Kennedy, Wanda - 142

Kensinger, Richard - 155

Keys, William - 149

Kidder, Sandra $-80,155$

Kilbourn, Tony - 109, 135

King, Elvin - 66, 150

King, Kathryn - 150

Kingsland, Clifton - 66, 150

Krumlauf, Reava - 67, 150

Kuney, Carole $-77,150$

Lachman, Judy - 42, 67, 68, 79, 93, 94, 101, 142

Lane, Rodney - 88, 91, 92, 150

Lane, William - 135

Lanius, Carole $-28,67,68,79,121,135$

Larson, Linda - 150

LAWLOR, Mr. George - 34, 36,

Lawlor, John - 62, 64, 65, 142

Leiby, Judith $-81,155$

Lewis, David - 70, 88, 91

Lewiston, Joan -150

Lloyd, Joseph - 155

Lockerbie, Ernajean - 64, 67, 71, 74, 79, 129

Lowe, Pauline - 27, 135

Lowe, Virginia - 142

Luyben, Karl - 129

Lyon, Beverly - 67, 69, 135

MADDOX, Dr. Clifford - 15, 24, 37, 38

MADDOX, Mrs. C. $-44,46$

Malis, George - 150

Maple, James - 58, 150

Marcellus, Judith - 67, 150

MARSHALL, Mr. Gerald - 26

Martin, Sheryl - 67, 150

Mayes, Bonnie - 154

Mayo, Robert - 142

$\mathrm{McCl}$ ish, Janet - 96, 150

McComber, Charles - 150

McDivitt, Nancy - 29, 36, 96, 129

MC DONALD, Mr. Cleveland - 50, 51

McDonald, Dennis - 150 


\section{Index}

MC INTOSH, Mrs. R. $-47,48$

MC INTOSH, Mr. Richard - 24, 44, 57, 64

McKeehan, Betty - 27, 72, 142

MICK, Miss Bernice - 28

Mick, Ronald - 150

Micka, Patricia - 80, 150

Middleton, Don $-60,69,135$

Miller, Vernon - 137

Millikin, Rita $-67,68,79,94,150$

Mills, David - 150

Minier, Richard - 135, 86, 87

MOFFAT, Mrs. D. $-41,67$

Moffat, Jack - 70,86, 142

Moody, John - 150

Mooney, Ronald - 64, 151

Moore, Jay - 26, 66, 151

Morgan, John - 68,77, 79, 15

Morganti, David - $88,92,151$

Mumford, Allen - 66, 68, 79, 151

Nash, Bonnie - 42,67, 69, 79, 151

Neely, James - 74, 129

Nephew, Ruth - 155

Nicklas, Norman $-27,69,151$

Nimmo, Steve - 27, 80, 151

Norris, Ed - 88, 91, 92, 151

Nutt, Darius - 66, 77, 151

O'Bryan, Roger - 79,81, 151

Ocheltree, Ted $-70,88,91,92,98,108,142$

Osborn, Delores - 29, 36, 71, 130

Palmer, Elaine - 151

Park, R. Deur - 27, 68, 77, 79, 142

Parker, James - 155

Patch, Aloha - 67, 143

Patterson, Thomas - 151

Peifer, Jerry $-75,135$

Perry, David - 155

Petry, Pat - 67, 68, 79, 93, 101, 130

Piper, David - 136

Powell, Mary Ellen - 68, 151

Price, Elizabeth - 155

Purdy, Daniel - 136

Pyle, Harold - 136

Quiter, Clara - 143

Rader, Wayne - 136

Ratcliff, Marcia - $67,80,143$

Reising, Lon $-73,130$

Reiter, Joan - 136

Ressler, Charlene - 28, 29, 69, 136

Reynolds, Robert - 151

Richardson, Sharon - 151

Rifenberick, David - 26, 80, 143

Ritchie, Judy - 143

Riter, William - 77, 151

Roach, Beverly - 80, 155

Robinson, Robert - 144

Rockenstein, Dorothy - 151

Rodin, Harold - 136

Roe, Amy - 80, 151

Rolfe, Frederick - 136

Rose, Betty - 69, 143

Rose, Lyle - 27, 69, 77, 151

Ross, Gladys - 152

Rotondi, Tony - 66, 68, 152

Rowland, Leon - 73, 130

Royse, Marvin - 136

RUDER, Mrs. Esther - 30

Russell, Chester - 152

ST. CLAIR, Mrs. K. -30

ST. CLAIR, Mr. Kenneth -50

Schenck, Lauren - 69, 73, 143

Schlosser, Ruth - 152

Schonscheck, Patricia - 27, 143

Schramm, Lovis - 26, 130

Schultz, Betty - 152

Searles, David - 58, 68, 79, 152

Shambaugh, Camilla - 74, 143

Shanks, Sandra - 155

Shelton, Catherine $-69,96,136$

Shimits, Nancy - 64, 67, 72, 152

SHIRLEY, Mrs. J. -27

Shoemaker, Layton - 152
Shrider, Edna - 152

Slavens, Barbara - 69, 152

Smelser, Eleanor - 68, 79, 152

Smith, Betty - 69, 75, 80, 137

Smith, Douglas - 59, 66, 88, 92, 152

Smith, Judith $-27,67,80,152$

Smith, Nancy - 77, 80, 152

Smith, Norris - 70,83, 88, 89, 90, 143

Smith, Sharon - 152

Smoker, Jane $-80,152$

Smythe, Betty - 143

Southwell, Sherry - 152

Spieth, Esther - 27, 80, 143

Sprague, James - 92, 152

Stafford, Gerald - 152

Stanchfield, Wayne -152

Standifer, Bogle $-80,137$

Stewart, Carl - 154

Stone, Otis - 66, 70, 75, 80, 137

Stowell, Margaret - 67, 72, 153

Swander, Carl - 153

Swander, Janice - 153

Swertfager, Barbara $-29,67,68,79,143$

Swigart, Kenneth $-58,66,79,153$

TARTER, Mrs. C. -27

TARTER, Mr. Charles - 26

Taylor, David - 26, 153

Taylor, Eleanor - 75, 137

Tennant, Don - 66, 143

Terry, Patricia $-80,153$

Thompson, Donna - 67, 68, 79, 93, 94, 144

Thompson, Tom - 137

THOMSON, Mr. Dale - 47, 49

YHORNTON, Mr. William - 15, 77, 41, 43

THORNTON, Mrs. W. -30

Titus, Anna - 153

Troyer, Marvin - 73, 130

Trumbull, David - 80, 153

TURNBULL, Mr. Bruce - 47, 49,73

UNDERWOOD, Mrs. Ruth - 29

UNDERWOOD, Mr. Robert - 24, 37, 38, 51

Unzicker, Barbara - 153

Van Allen, Shirley - 153

Van Gorp, Sharon - 153

Varisco, Lovise - 67, 144

Villalba, Edward - 27, 68, 93, 94, 95, 153

Vipond, Fraser - 153

Wagnitz, Gerald - 73, 144

Walborn, Judy - 154

Walborn, Ted - 144

Walker, Joyce $-43,77,80,81,118,153$

Walker, Thomas $-68,77,153$

Wall, Betty $-80,153$

Walmsley, Cathy - 144

Walthall, Gary - 88, 89, 90, 116, 153

Ward, Horace - 131

Warfield, William $-27,144$

Warkentin, Nancy - 67, 144

Warner, Paul - 153

Warren, David - 27, 153

Washburn, William - 77, 80,119, 137

WEBBER, Mrs. W. $-50,52$

WEBBER, Mr. Warren - 41, 42, 106, 119

Webster, Keith - 29, 35, 69, 71, 137

Weiss, Esther - 64, 67, 68, 69, 71, 79, 93, 13

Welch, Sandi - 153

Werner, Ralph - 27, 77, 79, 81, 144

West, Mary Ellen - 154

Whitaker, Sandra - 80, 154

WHITE, Miss Gerry - 25

White, Richard - 80, 92, 154

Whiting, Dale $-77,80,154$

Wickell, Geraldine - 30, 154

Wickham, Jay - 144

WILLIAMS, Dr. Arthur - 34, 35

Willie, Hope $-27,72,154$

Willmington, June $-110,154$

Wiseman, Marvin - 137

Witt, Carmen - 110, 154

Woodard, Irving - 144

Woodman, David - 26, 154
Woods, Beverly - 27, 72, 75, 144

Wooster, Vicki - 79, 155

Wright, Gene - 26, 66, 69, 144

WYLAND, Mrs. P. -27

WYLAND, Mr. Paul - 20, 30, 50, 52

Yoder, Sally - 154

Zandstra, Richard - 154

Zerby, Dean - 131

Zerby, Terry - 70, 137

ZINN, Mr. George - 41, 80, 118

Zoellner, Carol $-67,68,74,77,79,81,118$

131

\section{PATRON INDEX}

Berea Baptist Church - 177

Butler First Baptist Church - 176

Cedarville

CC Alumni Association - 166

CC Bookstore - 173

Feed \& Grain - 172

Hardware - 171

Locker \& Grocery - 170

Chaplin Cleaners - 171

Freshman Class - 175

Grace Baptist Church - 166

Harner's Market - 171

Harold's Sohio Service - 171

Irvine Dairy Isle -173

James Cut Rate - 171

Junior Class - 169

Miami Deposit Bank - 172

Miracle Staff - 173

Morris Bean \& Co. -169

Randall \& Stormont, Inc. - 170

Rheuberts' Market - 171

Sophomore Class - 175

Cleveland Cedar Hill Baptist - 168

Cleveland Hayden Ave. Baptist - 174

Cleveland Milner Electric Co. - 173

Columbus Immanuel Baptist - 165

Covington Calvary Baptist - 163

Decatur Riverside Baptist - 165

Des Moines Grandview Pk. Baptist - 174

Eldora First Baptist Church -160

Elyria First Baptist Church - 162

Fairborn Hoak's Greenhouses - 172

Findlay Calvary Baptist - 164

Forest City Calvary Baptist - 172

Fostoria Baptist Church -160

Galion First Baptist Church - 164

Gallipolis First Baptist - 176

Grove City First Baptist - 160

Hackensack First Baptist - 168

Haddon Hts. Baptist Church - 165

Harvey First Baptist Church - 162

Highland Calvary Baptist - 177

Huntsburg Baptist Church - 160

Ithaca Tabernacle Baptist - 161

Medina First Baptist Church -174

Midland Calvary Baptist - 176

Parma First Baptist Church - 162

Perry First Baptist Church - 176

Portsmouth Temple Baptist - 163

St. Louis Lackland Rd. Baptist - 161

Shell Rock First Baptist - 162

Springfield

Blessed Hope Baptist Church - 168

Reco Sporting Goods - 170

Riverdale Dairy - 167

Verona Memorial Baptist - 164

Xenia

Art Cox Studios - 166

Band Box Music Center - 170

Braun's Jewelers - 170

Camera Shop, The - 170

First Reformed Church - 161

Geyer's Restaurant - 168

I-T Pizza House, The -172 








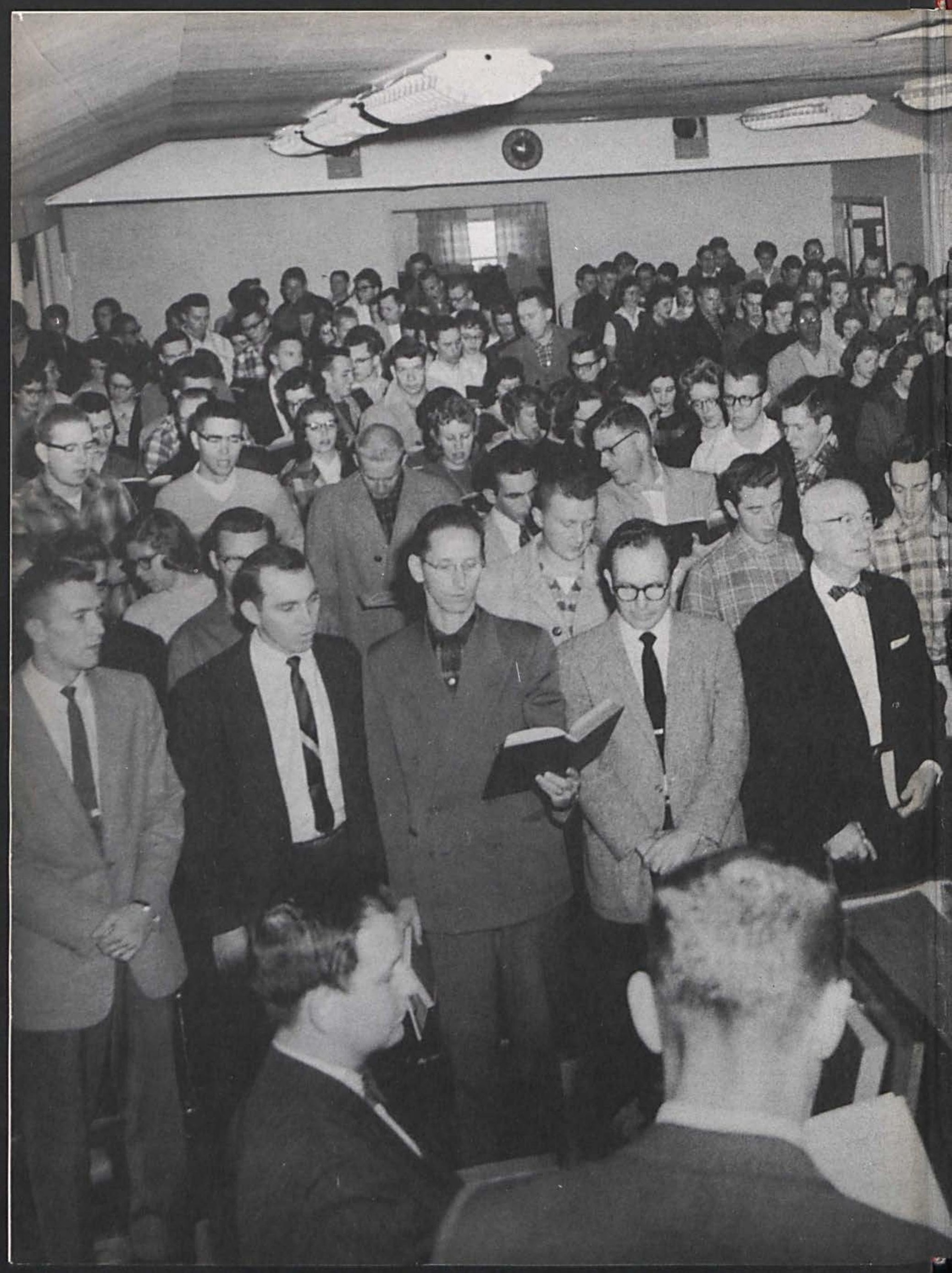




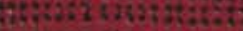

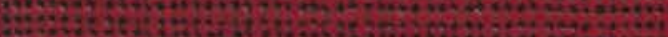

\section{trit:}

